UNIVERSIDADE DE SÃO PAULO e UNIVERSITE PARIS I PANTHEON SORBONNE

Doutorado em Direito Econômico e Direito Internacional Econômico

Departamento de Direito Econômico e Financeiro e CERDIN Paris 1

\title{
O INTERESSE PÚBLICO NO ANTIDUMPING
}

\author{
Leonor Augusta Giovine Cordovil \\ Orientadores : Prof. Dr. Hermes Marcelo Huck e \\ Profa. Dra. Hélène Ruiz-Fabri
}

São Paulo e Paris, 2009 
A tese é de autoria da doutoranda. Nenhuma responsabilidade, em relação ao seu conteúdo, pode ser atribuída às Universidades de Paris ou de São Paulo. 
Ao Marcos, meu companheiro em todas as teses desta vida. 


\section{AGRADECIMENTOS}

Cabe fazer um enorme e primeiro agradecimento aos meus orientadores. Profa. Hélène Ruiz Fabri, obrigada por acreditar nos alunos estrangeiros e aceitar compartilhar conosco seu profundo conhecimento. Ao Prof. Marcelo Huck, obrigada por me abrir as portas tão cerradas da USP, acreditando em minhas idéias, e pelos conselhos valiosos.

Obrigada à Profa. Paula Forgioni e ao Prof. João Grandino Rodas, por seus profícuos comentários na minha banca de qualificação, que em muito contribuíram para o período de reflexão que transcorreu posteriormente.

Ao Mauro Grinberg, por me ensinar tanto sobre antidumping e concorrência, por permitir que eu me ausentasse tanto do trabalho, por compreender tanto as minhas vontades, e, como se não bastasse, dar inúmeras boas sugestões à tese. Camilla Paoletti e Natália Figueiredo, obrigada por segurarem minhas mãos na caminhada, ajudarem direta e indiretamente no trabalho e por tanto me incentivarem. À Fundação Getúlio Vargas, Leandro Pereira e Raquel Favatto, por permitirem minha ausência e me apoiarem.

Aos queridos Leandro Rocha e Bárbara Oliveira, por me abrirem as portas de Genebra e me apresentarem a oportunidade que foi decisiva para a tese.

Obrigada, Jesse Kreier, por me acolher na OMC, discutir comigo tantas vezes os pontos principais do trabalho e por seu profundo conhecimento em antidumping.

Obrigada, Patrick Low, Souda Tandara-Stenier e Paulette Planchette, pela oportunidade de estadia na OMC. Obrigada Lauro Locks e Silvia, Victor do Prado, Vera Thorstensen, Ana Gerdau de Borja, Sílvio Tai, Rafael Direito e Tatiana Prazeres, pela doce recepção e amizade genevoise durante os mais duros momentos da tese. Mariya Teteryatnikova, obrigada por ter sido meu anjo da guarda na OMC, minha companheira de trabalho pesado.

Obrigada aos diplomatas Daniel Figueiredo (Brasil), Helio Silva (Brasil), Sérgio Balibrea (Comissão Européia), Jon Lyons (EUA), Sylvie Larose (Canadá), pelas oportunidades de bate-papo e por me ensinarem muito sobre a prática e negociações do antidumping.

Obrigada, Sras. Adinda Sinnaeve e Myrtho Zambarta, por me receberem na Comissão Européia e me explicarem tão bem o antidumping europeu.

Obrigada, Míriam Barroca, grande cabeça do antidumping brasileiro, Prof. Welber Barral, Roberto Sarmento, Ana Caetano, Rodrigo Pupo e equipe do DECOM, por acreditarem no antidumping e por compartilharem o tanto que sabem. 
Obrigada, Michele Françoise, por ser tão boa professora de francês, e Lucas Matheron, pela incrível atenção dispensada ao meu trabalho neste idioma.

Aos meus amigos Beatriz Pellegrino, Vanessa Fontenelle, Carmela Mayrink, Ana Paula Bedran, Raquel Dias da Silveira, Thaís e Evandro Siqueira, Elisa Ruozzi, Carla Junqueira, Fernando Barros, Lira Padovan, Gismari Miranda e Roberto Vasconcellos, pela super torcida, paciência e conselhos. Ao Paulo Mattos, pelo fundamental apoio na arrancada.

Com especial importância, obrigada, minhas duas famílias (Cordovil e Ferreira), por rezarem, acreditarem e torcerem.

Marcos, por ser sempre minha inspiração, por apoiar tudo que eu faço, por estar junto comigo, na alegria e na chatura, e por todos os outros motivos que dariam para escrever outra tese. Tenha certeza de que você é o co-autor deste trabalho. 


\section{LISTA DE ABREVIAÇÕES MAIS UTILIZADAS}

OMC - Organização Mundial do Comércio (WTO, em inglês)

GATT - General Agreement of Trade and Tariffs

OIC - Organização Internacional do Comércio

CAMEX - Câmara de Comércio Exterior

DECOM - Departamento de Defesa Comercial

SECEX - Secretaria de Comércio Exterior

MDIC - Ministério do Desenvolvimento, Indústria e Comércio Exterior

TEC - Tarifa Externa Comum

TN - Trade negotiations (negociações comerciais)

RL - Rules Division (divisão de regras)

TDI - Trade Defense Instruments (instrumentos de defesa comercial)

CNI - Confederação Nacional da Indústria

CNC - Confederação Nacional do Comércio

ONG - organização não governamental

ICN - International Competition Network (rede internacional sobre concorrência)

CITT - Canadian International Trade Tribunal (Tribunal canadense de comércio internacional)

SIMA - Special Import Measures Act (lei sobre medidas especiais de importação)

ALCA - Área de Livre Comércio das Américas

CEB - Coalização Empresarial Brasileira

CADE - Conselho Administrativo de Defesa Econômica

OIT - Organização Internacional do Trabalho

ITC - International Trade Commission (Comissão de comércio internacional) 


\section{SUMÁRIO}

INTRODUÇÃO 12

I. ASPECTOS FUNDAMENTAIS SOBRE O INTERESSE PÚBLICO NO ANTIDUMPING 16

1.1 A EVOLUÇÃO DO ANTIDUMPING 17

1.1.1 A construção jurídica do antidumping ………..................................................... 18

1.1.2 As negociações do Acordo Antidumping e o protecionismo ................................... 22

1.1.3 A aplicação do Acordo Antidumping....................................................................... 26

1.1.3.1 A aplicação de medidas antidumping pelos países desenvolvidos.................... 27

1.1.3.2 Aplicação do acordo pelos países em desenvolvimento ................................... 29

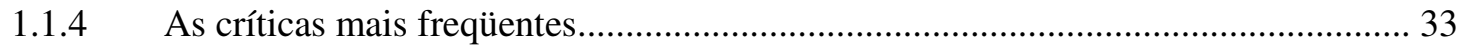

1.1.4.1 A difícil definição do produto similar .............................................................. 34

1.1.4.2 O problema do dano e sua ameaça .............................................................. 37

1.1.4.3 O uso da melhor informação disponível como disfarce da discricionariedade 40

1.1.4.4 A necessidade de transparência........................................................................ 43

1.2 A CONSIDERAÇÃO DO INTERESSE PÚBLICO NO ANTIDUMPING................... 48

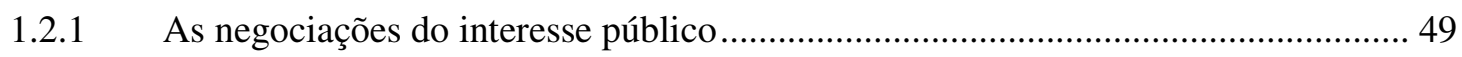

1.2.1.1 Negociações sobre interesse público no GATT …........................................... 50

1.2.1.2 Negociações sob a égide da OMC ................................................................ 54

1.2.1.3 As propostas de redação do teste e suas críticas .............................................. 61

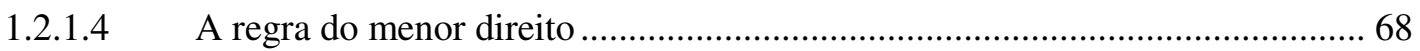

1.2.2 A aplicação pelos Membros que já adotam a cláusula............................................. 70

1.2.2.1 O teste do interesse público na Comunidade Européia ................................... 70

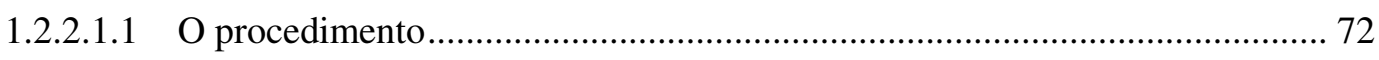

1.2.2.1.2 Posição da Comunidade Européia nas negociações sobre interesse público na $\mathrm{OMC}$ 78

1.2.2.1.3 A jurisprudência européia sobre interesse comunitário ................................. 80 


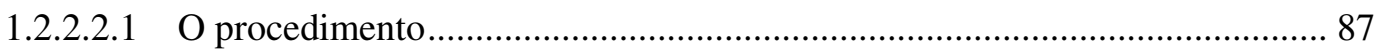

1.2.2.2.2 A opinião do Brasil nas negociações sobre interesse público na OMC .......... 90

1.2.2.2.3 A jurisprudência brasileira sobre interesse público no antidumping .............. 91

1.3 A INDETERMINAÇÃO DA NOÇÃO DE INTERESSE PÚBLICO ...............................94

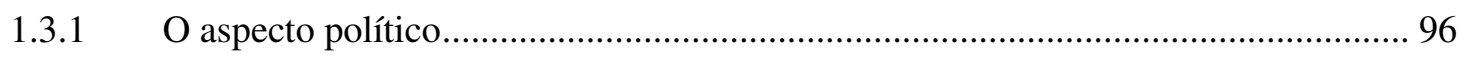

1.3.1.1 A vontade geral para Rousseau como limitadora do poder do Estado .............. 98

1.3.1.2 A formação do interesse público democrático em Tocqueville ...................... 102

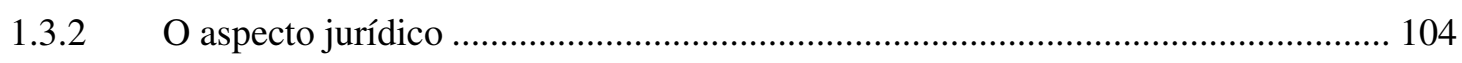

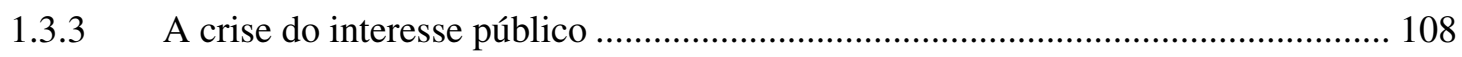

1.3.4 As pressões que influenciam a formação do interesse público ……………............ 112

1.3.4.1 O grupo de pressão na formação do interesse público .................................... 112

1.3.4.2 O comportamento dos grupos na União Européia............................................ 116

1.3.4.3 O comportamento dos grupos no Brasil .................................................... 120

1.3.5 A indeterminação do interesse público e protecionismo........................................ 124

1.3.5.1 O interesse protecionista no comércio internacional................................... 125

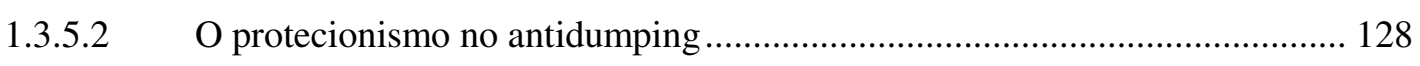

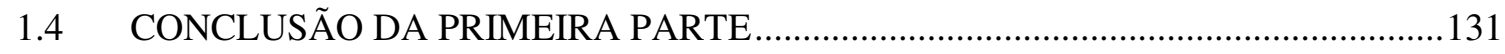

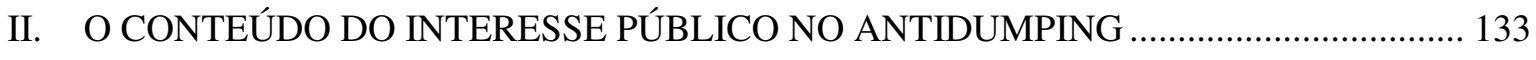

2.1 A IMPORTÂNCIA DA DEFINIÇÃO DOS CRITÉRIOS ………….............................134

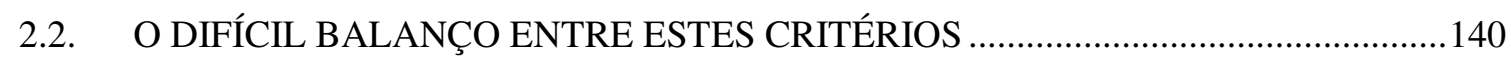

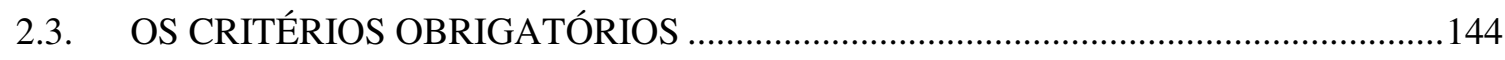

2.3.1 A concorrência como primeiro elemento do interesse público no antidumping .... 144

2.3.1.1 A análise do comércio internacional na defesa da concorrência..................... 145

2.3.1.1.1 As negociações multilaterais para a proteção da concorrência global .......... 146

2.3.1.1.2 Pontos a serem observados pelas autoridades de concorrência..................... 154

2.3.1.1.2.1 A delimitação do mercado relevante................................................... 155

2.3.1.1.2.2 A análise das barreiras à entrada..................................................... 158 
2.3.1.1.2.3 Cartéis e restrições verticais internacionais

2.3.1.1.2.4 Análise das concentrações econômicas que afetam o comércio internacional

2.3.1.2 As semelhanças e diferenças entre comércio internacional e concorrência ... 167

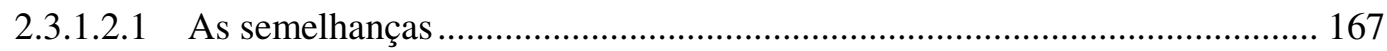

2.3.1.2.2 O conflito entre concorrência e defesa comercial ..................................... 169

2.3.1.2.2.1 O dumping não predatório (mera discriminação de preços) é procompetitivo 170

2.3.1.2.2.2 A insuficiência da teoria concorrencial para a realização dos objetivos do antidumping

2.3.1.2.3 A substituição do antidumping pela defesa da concorrência 177

2.3.1.3 A defesa da concorrência como interesse público no antidumping ................ 182

2.3.1.3.1 O direito da concorrência como instrumento para implementar políticas...... 183

2.3.1.3.2 Os objetivos da defesa da concorrência ....................................................... 187

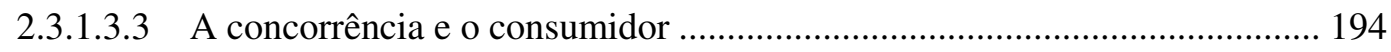

2.3.1.4 A análise concorrencial pelas autoridades de defesa comercial..................... 198

\subsection{A PROTEÇÃO AO EMPREGO COMO SEGUNDO ELEMENTO DO INTERESSE}

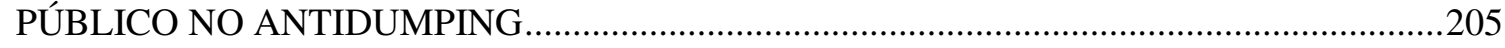

2.4.1 A relação entre comércio internacional e o emprego …………………................. 205

2.4.2 O emprego como preocupação no antidumping ................................................. 210

2.4.2.1 Por que não proteger os empregos da indústria doméstica ............................. 211

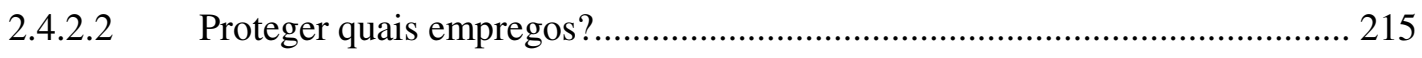

\subsection{O DESENVOLVIMENTO TECNOLÓGICO E INDUSTRIAL COMO TERCEIRO} ELEMENTO DO INTERESSE PÚBLICO NO ANTIDUMPING ……..................................220

2.5.1 A relação entre comércio internacional e desenvolvimento tecnológico e industrial ..

2.5.2 O desenvolvimento tecnológico e industrial como interesse público no antidumping

2.5.2.1 A indevida proteção dos setores estratégicos ................................................ 224

2.5.2.2 Como conjugar desenvolvimento e interesse público no antidumping .......... 228 
III. QUESTÕES PROCESSUAIS RELACIONADAS À ANÁLISE DO INTERESSE

PÚBLICO NO ANTIDUMPING.

3.1. QUEM SÃO AS PARTES INTERESSADAS EM SUBMETER CONSIDERAÇÕES DE

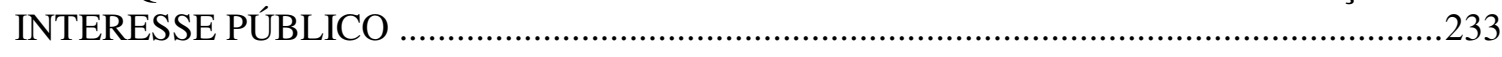

3.1.1 O interesse individual formador do interesse público no antidumping.................. 234

3.1.1.1 Interesses das empresas em uma investigação antidumping .......................... 235

3.1.1.2 A globalização das partes interessadas.......................................................... 240

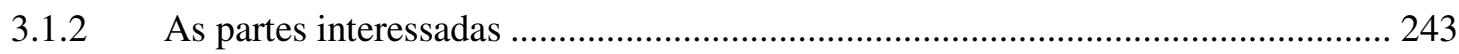

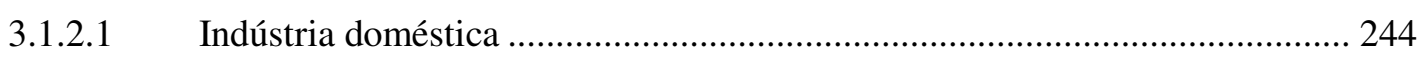

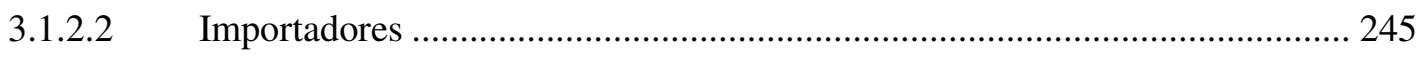

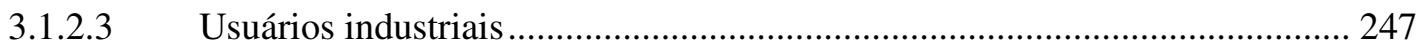

3.1.2.4 Consumidores e suas associações ............................................................. 250

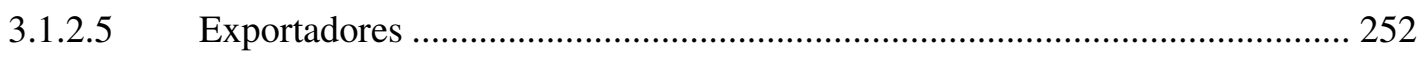

3.2. DIREITOS E DEVERES PROCESSUAIS DAS PARTES INTERESSADAS ..............254

3.3. QUAL O MOMENTO DA CONSIDERAÇÃO DO INTERESSE PÚBLICO ...............257

3.3.1 Antes da abertura da investigação ................................................................... 257

3.3.2 Na aplicação de medidas provisórias …………………….................................... 260

3.3.3 Na desistência do peticionário ....................................................................... 261

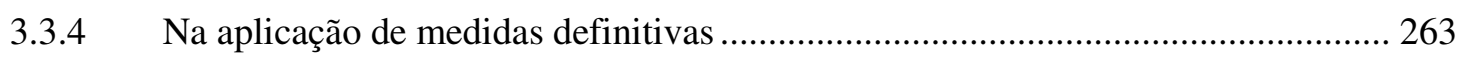

3.3.5 Na celebração de compromissos de preços .............................................................. 264

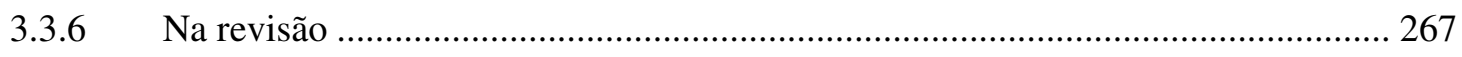

3.3.7 Consideração do interesse público para a aplicação de um direito mais flexível .. 268

3.4. A AUTORIDADE COMPETENTE PARA A ANÁLISE DO INTERESSE PÚBLICO271

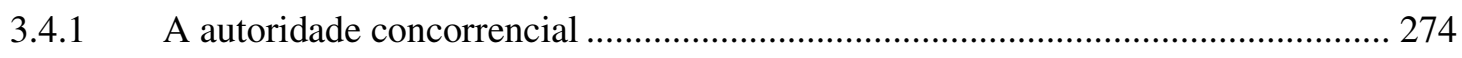

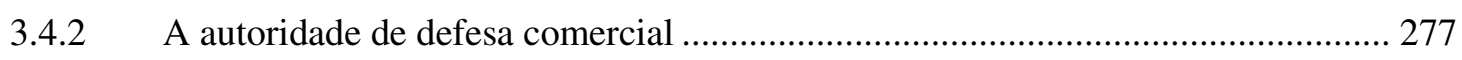

3.4.3 A necessária independência da autoridade .......................................................... 279

3.5. A POSSIBILIDADE DE REVISÃO DA DECISÃO ADMINISTRATIVA....................281

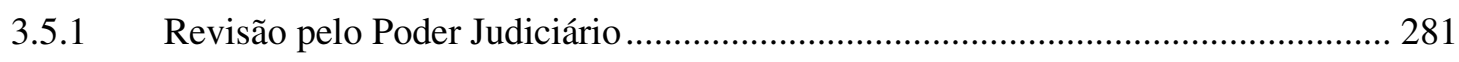


3.5.1.1 A revisão da decisão de interesse público pelo Poder Judiciário 283

3.5.1.2 A legitimidade ativa para recorrer ao Poder Judiciário no caso de conflito sobre o interesse público

3.5.2 Pelo mecanismo de solução de controvérsias da OMC............................................ 286

3.5.2.1 Critério de exame pelo órgão de solução de controvérsias da OMC .............. 287

3.5.2.2 Competência do órgão de solução de controvérsias para a análise de decisões nacionais de caráter político ............................................................................................. 291

3.5.2.3 Exame da decisão nacional sobre interesse público ........................................ 296

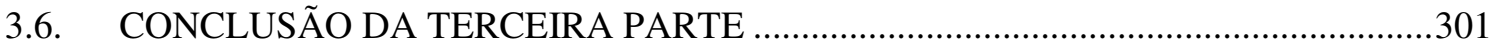

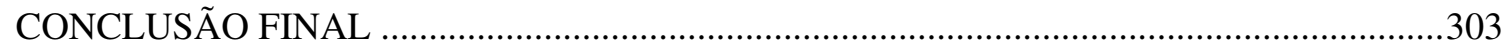

ANEXO 01 - PROPOSTAS DOS MEMBROS SOBRE INTERESSE PÚBLICO NO

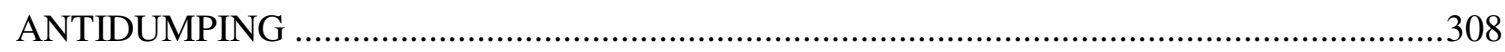

ANEXO 02 - DECISÕES RELEVANTES, NA COMUNIDADE EUROPÉIA, SOBRE

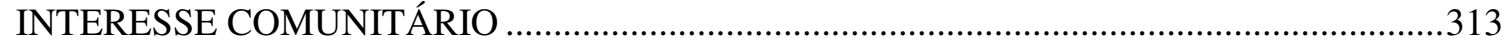

ANEXO 03 - DECISÕES RELEVANTES, NO BRASIL, SOBRE O INTERESSE PÚBLICO320

BIBLIOGRAFIA 


\section{INTRODUÇÃO}

Embora o número de investigações antidumping nos países Membros da OMC venha caindo, é possível observar, há alguns anos, uma mudança no comportamento destes países em relação ao assunto. Membros que eram conhecidos como alvos de medidas antidumping são hoje usuários freqüentes destas medidas, abrindo investigações, que, comumente, atingem importações provenientes dos antigos países usuários do antidumping. Este é o caso de alguns países asiáticos (Hong Kong, China, Japão), e de Membros como Austrália e Brasil, que abrem investigações contra bens de origem européia e norte-americana.

O comportamento das empresas também vem se modificando. Se antes os produtores buscavam alento quando estavam diante de um grande crescimento no volume de mercadorias importadas a preços muito baixos, hoje estes produtores buscam proteção a qualquer tipo de concorrência que os ameace. Cabe ao Membro fazer a distinção entre as duas hipóteses e observar se a sua decisão de abrir investigações não contraria o acordo multilateral assinado perante a OMC, o Acordo Antidumping.

Não há dúvidas de que a aplicação de medidas antidumping provoca controvérsia no país investigador. Se o objetivo real de tais medidas é frear as importações a baixo preço (no caso, a preço de dumping), não se pode negar que o antidumping pode barrar importações, provocando aumento dos preços, diminuindo a concorrência no país investigador, o número de ofertas aos usuários, e, muitas vezes, a qualidade e a variedade dos produtos. Por isso, independentemente da motivação da indústria doméstica e mesmo do país investigador, sempre haverá descontentes.

Um dos grandes dilemas do antidumping, na atualidade, é o desafio de saber dosar os efeitos negativos e efeitos positivos das medidas. Uma medida antidumping pode reduzir a concorrência, mas pode, por outro lado, salvar empregos (na indústria doméstica). Uma medida antidumping pode salvar empregos na indústria doméstica, mas pode, por outro lado, levar ao desemprego milhares de pessoas na indústria consumidora (usuária do produto). A não aplicação de uma medida antidumping pode salvar milhares de 
empregos na indústria consumidora, mas representar o fim da indústria doméstica, e, com isso, de uma indústria estratégica para o país.

Este trabalho objetiva discutir e propor critérios a serem considerados por uma autoridade investigadora diante do dilema "aplicar ou não aplicar" medidas antidumping. Antes mesmo da aceitação da atual redação do Acordo Antidumping, os Membros da OMC já vinham discutindo a consideração de certos aspectos que aconselhariam a não aplicação, em um debate ao qual foi dado o infeliz nome de "interesse público". ${ }^{1}$

A expressão "interesse público" carrega, entretanto, um peso muito grande, significa que a autoridade de defesa comercial deverá desvendar o interesse nacional, um interesse de todas as pessoas, um interesse maior e indiscutível que trará a resposta que o país busca em relação às importações. Além disso, "interesse público" remete o negociador e a autoridade nacional à esfera do bem comum, da discussão político-social, que ultrapassa as fronteiras de uma simples discussão antidumping (de natureza econômica). Seria mais fácil e apropriado se os países tivessem escolhido a expressão "balanço econômico", "teste de proporcionalidade", ou qualquer outra menos severa. $^{2}$

Contudo, já que a expressão foi escolhida e já é adotada por alguns Membros em suas legislações nacionais, cabe aceitá-la e contribuir para a definição e limitação de seu conteúdo. Acredita-se que a definição e limitação de seu conteúdo tornarão possível a sua aceitação pelos Membros e a sua aposição, de forma definitiva e obrigatória, no texto do Acordo Antidumping.

Como não se pretende sugerir a troca da expressão, o que pode obstacularizar ainda mais as negociações, é preciso entender como um Estado define o interesse público, certas discussões filosóficas envolvidas na acepção da expressão, bem como a influência de grupos de pressão na compreensão deste interesse. Para tanto, abordar-se-á aspectos políticos e jurídicos relacionados à formação de um interesse

\footnotetext{
${ }^{1}$ Cláusula do interesse público, ao se referir à previsão no Acordo Antidumping, e teste do interesse público, ao se referir ao estudo do interesse público.

${ }^{2}$ WENIG, Harald, The European Community's Antidumping System: Salient Features. Journal of World Trade, v. 39, n. 4, p. 2005, p. 791.
} 
público. É impossível falar de antidumping sem lembrar a pressão sofrida pelas autoridades nacionais, em todo o mundo, para a aplicação de medidas. No caso do interesse público no antidumping, tal pressão é ainda mais relevante.

O objetivo deste trabalho é indicar a importância da consideração do interesse público nas investigações antidumping, análise que não pode ser feita sem a definição prévia de critérios a serem utilizados por todos os Membros da OMC, evitando, assim, uma aplicação discriminatória. Se a definição do interesse público pretende ser obrigatória, como parece ser o resultado buscado pelos Membros da OMC no estado atual das negociações, é fundamental que sejam definidos parâmetros claros, que devem ser seguidos por todos os Membros. Caso contrário, a busca do interesse público pode aumentar, ainda mais, a insegurança e a imprevisibilidade que circundam as investigações antidumping, desmotivando partes interessadas a contribuir para a busca da verdade e da melhor solução para o contexto interno de cada país.

Além disso, para que a contribuição seja completa, cabe lembrar os aspectos procedimentais que envolvem uma investigação de interesse público, não menos importantes do que a definição de seus critérios. Escolheu-se desafiar os momentos apropriados, em uma investigação, para analisar o interesse público, qual é a autoridade mais adequada para o exame, quais partes podem contribuir, de forma mais eficiente, com a análise e, ainda, discutir a possibilidade revisão, judicial ou pelo mecanismo de solução de controvérsias da OMC, da conclusão da autoridade administrativa.

Esta tese foi dividida em três pilares fundamentais.

O primeiro capítulo foi dividido em três partes. Inicialmente, tratar-se-á da evolução do antidumping, de sua história e negociação, aplicação atual e críticas a este instrumento. Entendidos os principais objetivos do antidumping, explicar-se-á, em segundo lugar, o surgimento do tema interesse público nas negociações de antidumping, bem como a sua utilização pelo Brasil e pela Comunidade Européia. Finalmente, discorrer-se-á sobre os aspectos políticos e jurídicos relacionados à expressão, bem como sobre o interesse protecionista e o comportamento dos grupos de pressão na formação deste interesse.

O segundo capítulo trata do conteúdo do interesse público. Conforme será demonstrado, é essencial que as negociações concluam sobre os critérios que 
nortearão a definição deste interesse. Baseando-se na prática atual de alguns Membros da OMC e no que eles parecem buscar nas negociações, sugerir-se-á a consideração de três pontos de interesse público no antidumping: a concorrência (como fim o consumidor), o emprego e o desenvolvimento tecnológico e industrial.

O terceiro e último capítulo dissertará sobre os aspectos processuais envolvidos na discussão do interesse público. A definição de critérios para o interesse público e a decisão pela obrigatoriedade do teste pelas autoridades ficam comprometidos se não forem estipuladas - e tornadas obrigatórias - determinadas regras procedimentais a serem observadas pelos Membros. A acepção do interesse público por uma autoridade que não compreende os objetivos do antidumping compromete severamente o resultado do exame. Uma análise em momento inapropriado pode provocar erro na conclusão sobre o que parece ser interessante ao país. Além disso, este ponto tratará das partes interessadas, delimitando a contribuição que cada uma é capaz de dar à investigação e quais delas devem ser ouvidas pelas autoridades. Por fim, discutir-se-á a possibilidade de revisão da decisão administrativa pelo Poder Judiciário e pelo mecanismo de solução de controvérsias da OMC. 


\section{ASPECTOS FUNDAMENTAIS SOBRE O INTERESSE PÚBLICO NO ANTIDUMPING}

Para que se possa compreender o conteúdo do interesse público no antidumping, o que se fará na segunda parte deste capítulo, é essencial que, antes, seja estudada a evolução do instrumento antidumping, sua função inicial e sua aplicação pelos Membros da OMC. Realidade e prática se distanciaram muito, tornando o antidumping um instrumento exclusivamente protecionista, mesmo que esta proteção signifique privilegiar um competidor ineficiente, ou causar prejuízos aos consumidores e usuários, sem contrapartida que justifique este prejuízo.

Após conhecer o instrumento antidumping, sua aplicação por países desenvolvidos e países em desenvolvimento, e as principais críticas ao mecanismo, é possível estudar o tema interesse público. Para tanto, descrever-se-á a evolução das negociações, bem como a aplicação que já é feita por alguns deles, antes mesmo de se tornar obrigatória a regra no Acordo Antidumping (elegendo-se Brasil e Comunidade Européia como exemplos).

Ficaria vazio o exame se não fossem lembrados os aspectos filosóficos que deram origem e norteiam a definição de interesse público. A partir deste estudo, será possível definir qual o papel do Estado no exame pretendido, bem como o que ele deve considerar. Falar de interesse público sem falar de pressão de grupos é admitir um mundo ideal, que não existe. Parte deste interesse público é sempre formada por pressão, sendo muito importante que o decisor saiba apreciar e receber idéias de grupos de influência, que fornecem importantes subsídios sobre a aceitação, pelo grupo social, de determinada decisão pública. Por fim, estudar-se-á a relação entre o interesse público e o protecionismo. 


\subsection{A EVOLUÇÃO DO ANTIDUMPING}

As medidas antidumping são, ao lado das salvaguardas e das medidas compensatórias, chamadas de medidas de defesa comercial. Elas são exceções ao princípio do livre comércio, mas desempenham, ao mesmo tempo, o contraditório papel de instrumentos que permitem este comércio. A medida de defesa comercial é a garantia que um país tem de que, diante de uma abertura ao comércio leal, a preços esperados, em volumes razoáveis, ele terá armas para se proteger das exportações que constituírem exceções a estas regras. Desta forma, as medidas de defesa comercial servem de verdadeiras peneiras diante do fluxo de importações. ${ }^{3}$

Contudo, de peneiras a serem utilizadas diante de importações a preços de dumping, o antidumping passou a ser usado, exageradamente, como instrumento de proteção contra qualquer importação. Em alguns países, o objetivo principal da investigação deixou de ser evitar que as importações a preços de dumping possam afetar o comércio legal, passando a ser aplicar medidas antidumping para proteger a indústria doméstica, mesmo que as vantagens obtidas por estes produtores nacionais bem sejam menores do que as desvantagens para a economia.

Para utilizar indevidamente o instrumento antidumping, alguns Membros promovem interpretações duvidosas do texto do Acordo Antidumping, e, em alguns casos, ferem regras processuais. Este uso exagerado e inapropriado será discutido abaixo, para que se possa, depois, entender a importância do teste do interesse público como meio de evitar a aplicação abusiva de medidas antidumping.

\footnotetext{
${ }^{3}$ Barral classifica as medidas de proteção contra importações como exceções permanentes, exceções contingenciais e medidas de defesa comercial. As medidas permanentes seriam aquelas que podem ser impostas pelos Estados parte a qualquer tempo, para restringir as importações. São exemplos o waiver e a renegociação de concessões. As exceções contingenciais aplicam-se no caso de situações econômicas peculiares. Permite-se a restrição nas importações para reequilibrar a balança de pagamentos, por exemplo. (BARRAL, Welber. Dumping e Comercio Internacional: A regulamentação antidumping após a Rodada do Uruguai. Rio de Janeiro: Forense, 2000, p. 130.)
} 


\subsubsection{A construção jurídica do antidumping}

O processo de liberalização do comércio internacional foi sempre paralelo e estritamente dependente do processo normativo no mercado internacional. Os acordos da $\mathrm{OMC}$, que demoraram sete longos anos para serem finalizados e aprovados pelas Partes Contratantes do GATT-Acordo Geral sobre Comércio e Tarifas de 1947, estabeleceram o império do direito no comércio internacional. ${ }^{4}$

A história da legislação antidumping pode ser dividida em três períodos. ${ }^{5} \mathrm{O}$ primeiro deles começa no início do século $\mathrm{XX}$, com o surgimento de legislações espaças sobre o assunto, e chega à Segunda Guerra Mundial. O segundo começa logo após a guerra, com legislações nacionais enraizadas e países já buscando a negociação das primeiras legislações internacionais, e termina em 1995, com o Acordo Antidumping da OMC. O terceiro período começa com a assinatura do acordo e segue até os dias atuais.

O primeiro período se caracterizou pelo tratamento similar dado aos subsídios e ao dumping, sob o ponto de vista de seus efeitos para o mercado importador. ${ }^{6}$ Nesta época, os acordos bilaterais ou multilaterais eram raríssimos, e, quando existentes, tratavam de assuntos relacionados à situação passageira enfrentada por algum mercado.

O Canadá foi o primeiro país a adotar uma legislação específica de dumping (1904), seguido da Nova Zelândia (1905), Austrália (1906) e África do Sul (1914). A legislação do Canadá tinha objetivos extremamente curiosos, que lembram o anseio protecionista dos países investigadores no século XX. Concedia-se ao funcionário alfandegário a discricionariedade para aumentar, de forma extraordinária e passageira, o nível da tarifa cobrada de certas exportações, por reclamação dos produtores. Era uma forma adequada para evitar que fossem necessárias intervenções

\footnotetext{
${ }^{4}$ OMC FOCUS, Boletim de Informação da OMC, n. 1, 1995, p. 4.

5 Marta Rodrigues Fernández fala em dois períodos, mas é importante acrescentar um terceiro. (FERNANDEZ, Marta. Los Derechos antidumping en el derecho comunitário. Valladolid: Lex Nova, 1999. p. 47.)

6 A semelhança se resume a isso, pois o subsídio decorre de uma ação do governo em favor de determinada indústria ou produto agrícola, ao passo que o dumping está vinculado ao comportamento de uma empresa.
} 
permanentes e generalizadas, por parte do governo, para resolver problemas temporários e atípicos. ${ }^{7}$

Os Estados Unidos aprovaram sua primeira legislação antidumping em 1916, o Revenue Act of 1916 (Antidumping Act). Antes, normas como o Sherman Act, conhecido no âmbito antitruste, eram utilizadas para o combate ao dumping. ${ }^{8} \mathrm{O}$ Antidumping Act eliminou a necessidade de se caracterizar a conspiração ou combinação entre vendedores para atingir o fim comum, exigida pelo Sherman Act. Em 1921, a legislação passa a exigir a comprovação do dano. ${ }^{9}$

Período bastante difícil para as trocas comerciais internacional foi o entre-guerras. A grande preocupação da maioria das potências européias arrasadas pela Primeira Guerra Mundial, bem como os reflexos provocados nos outros países não afetados pela guerra, levou ao surgimento de legislações protecionistas, de movimentos em busca do bem-estar nacional e do desenvolvimento da indústria doméstica. Isso, sem dúvida, significava proteger os países contra as importações.

Após a Segunda Guerra Mundial, teve início o segundo período. A falta de transparência e o excesso de discricionariedade das autoridades nacionais na aplicação do antidumping provocaram as primeiras discussões sobre o antidumping em foros multilaterais. De forma geral, era necessário conter as interpretações, feitas por cada país, sobre os requisitos que autorizariam a aplicação dos direitos antidumping. Buscava-se algum tipo de sintonia na aplicação de medidas.

Com isso, somadas várias outras necessidades ligadas indiretamente ao contexto do comércio, surgiu a idéia da criação da Organização Internacional do

\footnotetext{
${ }^{7}$ Em 1907, a legislação canadense sofreu uma profunda reforma para acalmar os ânimos dos exportadores e importadores, insatisfeitos com o excesso de poder delegado à aduana. Também foram impostos limites às medidas, que não poderiam ultrapassar 15 por 100 ad valorem, de forma a evitar a formação de monopólios no mercado interno e impedir definitivamente as importações. (MOEN, Paul. Public interest issues in international and domestic Anti-dumping Law: the WTO, European Communities and Canada. Genebra: Intitut Universitaire de Hautes Etudes Internationales, 1998, p. 59.)

${ }^{8} \mathrm{O}$ ato de importar a preços muito baixos e discriminatórios era considerado uma restrição à ordem econômica.

9 JOHANNPETER, Guilherme Chagas Gerdau, Antidumping - prática desleal no comércio internacional. Porto Alegre: Livraria do Advogado, 1996, p. 63.
} 
Comércio $(\mathrm{OIC})^{10}$. As primeiras conversas entre Estados Unidos e Reino Unido resultaram na elaboração de um documento chamado Proposals for consideration by an International Conference on Trade and Employment. Várias negociações se seguiram até assinatura, em 1948, da Carta de Havana, que constituía o documento preparatório para o surgimento da OIC. Contudo, em 1950, os Estados Unidos declararam que não ratificariam a Carta. Com isso, o projeto havia sido rejeitado pelo seu próprio autor, o que levou à rejeição pelos outros países. Paralelamente, já se desenrolavam negociações para a redução de direitos aduaneiros, promovidas pelos Estados Unidos, que não seguiam as regras da Carta.

Nem tudo foi perdido. Os países, diante do fracasso da OIC, assinaram um acordo de caráter provisório, que esteve em vigor durante mais de quarenta anos. Este acordo foi chamado de GATT - Acordo Geral sobre Comércio e Tarifas de 1947. O artigo VI do GATT de 1947 previa que:

"As partes contratantes reconhecem que o dumping, pelo qual os produtos
de um país são introduzidos no comércio de outro país a um preço inferior
do que o valor normal destes produtos, é condenável se causa ou ameaça
dano a uma indústria estabelecida no território da parte contratante ou
materialmente retarda o estabelecimento da indústria doméstica."

Embora muito se falasse na necessidade de prover a indústria doméstica com meios para a sua defesa contra o dano provocado pelo dumping no comércio internacional, é certo que a função precípua do GATT 1947 era conter a discricionariedade das autoridades nacionais. O GATT 1947 não proibiu o dumping per $s e$, mas somente aquele que causasse o dano. Como notado por alguns autores, alguns países queriam defender o interesse de certas indústrias que sobreviviam se beneficiando dos preços baixos dos produtos importados. ${ }^{12}$ Surgem, neste ponto, as primeiras bases para uma discussão sobre interesse público.

O GATT 1947 não esgotou, porém, todas as controvérsias que circundavam o tema antidumping. Foram necessárias negociações até que, em 1967, foram efetivamente aprovadas modificações e emendas ao primeiro acordo (Código

\footnotetext{
${ }^{10}$ A OIC foi discutida logo após os Estados Unidos terem declarado, em 1944, o surgimento do Fundo Monetário Internacional e do Banco Internacional de Reconstrução e Desenvolvimento. Estas três iniciativas resultaram na assinatura dos acordos de Bretton Woods.

${ }^{11}$ Tradução livre do texto, em inglês, do artigo VI do GATT.

${ }^{12}$ VERMULST, Edwin; WAER, Paul, E.C. Antidumping Law and Practice. London: Sweet \& Maxwell, 1996, p. 3.
} 
Antidumping do GATT $1967^{13}$ ). Foi também criado um Comitê sobre Práticas Antidumping. Nova versão revisada foi publicada em 1979 (Código Antidumping do GATT 1979). Estas versões trataram, fundamentalmente, de questões procedimentais, do dano e do nexo causal.

Ciclos de negociação se seguiram, entre negativas de alguns países e a busca de soluções por outros, até que foi firmado, à época da criação da OMC, o Acordo para Implementação do Artigo VI do GATT 1994 (Acordo Antidumping da OMC). $\mathrm{O}$ artigo 2.1 do Acordo Antidumping previu que:

\begin{abstract}
"Para os fins deste Acordo, um produto é considerado a preço de dumping quando introduzido no comércio de um país por um preço menor do que o valor normal, se o preço de exportação do produto exportado de um país para outro é menor do que o preço comparável, no curso ordinário do comércio, para o produto similar quando destinado ao consumo no país exportador" 14
\end{abstract}

As dificuldades que marcaram as negociações até a Rodada do Uruguai, na qual foi celebrado o acordo mencionado, foram causadas, sobretudo, pelas constantes negativas da Comissão Européia e dos Estados Unidos. Estes países, além de firmarem um pacto de não agressão em $1989^{15}$, entendiam que os benefícios que ganhariam protegendo seus exportadores das arbitrariedades das autoridades nacionais não eram maiores do que as desvantagens de ter as suas próprias autoridades controladas por regras e por instrumentos multilaterais. ${ }^{16}$

\footnotetext{
${ }^{13}$ Assinado em 30 de junho de 1967, chamado de Agreement on the Interpretation of Article VI, ou também 1967 Antidumping Code.

${ }^{14}$ Tradução livre do artigo 2.1 do Acordo Antidumping.

15 Pacto em que ambos os lados se comprometerem a não atacar o outro com medidas antidumping ou abertura de investigações. Nos anos precedentes à Rodada Uruguai, os exportadores americanos foram a segunda vítima de medidas antidumping na Europa e os exportadores europeus foram o primeiro alvo de investigações dos Estados Unidos. A explicação para esta aliança era o fato de que ambos (governo americano e Comissão Européia) se auto-intitulavam mais utilizadores da legislação antidumping do que exportadores, um raciocínio criticado, já que os dois eram os maiores exportadores do mundo. (United States General Accounting Code, Use of the GATT Antidumping Code, GAO/NSIAD-90 - 238FS, July 1990, p. 19) Para Horlick and Shea, os norte-americanos e europeus perceberam que eles teriam mais a perder com o aumento do controle internacional sobre seus métodos de investigação do que a ganhar com a segurança gerada aos seus exportadores investigados em outros países. Com isso, ambos se comprometeram a não aprovar medidas e a tentar bloquear algumas das negociações da Rodada Doha. (HORLICK, Gary e SHEA, Eleanor. The World Trade Organization Anti-dumping Agreement. Journal of World Trade, v. 29, n. 1, 1995, p. 5-31.)

${ }^{16}$ HORLICK, Gary e SHEA, Eleanor. Op cit, p. 5-31.
} 


\subsubsection{As negociações do Acordo Antidumping e o protecionismo}

O Comitê Antidumping da Rodada Tóquio foi responsável por exaustivos trabalhos, entre 1980 e 1986, que incluíam questões teóricas e práticas. As Partes Contratantes do GATT entendiam que, entre as funções do comitê, estava a de analisar a interpretação do Acordo Antidumping feita pelos países, julgando se as regras estavam sendo aplicadas de maneira correta e esperada. O grupo foi responsável por uma série de recomendações relacionadas à forma de aplicação das regras antidumping, tais como regras relativas ao procedimento, regras sobre respostas a questionários e regras sobre investigação in loco. ${ }^{17}$

Em 1986, passou a ser negociada a chamada Rodada Uruguai, inicialmente prevista para terminar em 1990, finalizada somente em abril de 1994. Embora a questão antidumping não estivesse entre as maiores preocupações, o comitê antidumping continuou desenvolvendo normalmente suas atividades, elaborando relatórios sobre suas principais conclusões.

Os Estados Unidos, principais responsáveis pela Declaração Ministerial que lançou a Rodada do Uruguai em setembro de 1986, estavam no ápice da aplicação de medidas antidumping, como um instrumento de política industrial, e, também, como uma válvula de escape para responder às crescentes pressões vindas da alta do dólar no início dos anos 1980 e dos conseqüentes problemas gerados por este fato entre setores importadores e exportadores. A administração americana argumentava que altas medidas antidumping contra importações "desleais" eram necessárias para preservar o mercado. Por exemplo, no caso conhecido como US-Japão: Semicondutores $^{18}$, foram impostos altíssimos preços mínimos para importações de semicondutores provenientes do Japão, mas nem dumping, nem dano, foram suficientemente comprovados (ou mesmo investigados). ${ }^{19}$

\footnotetext{
17 Recomendação concernente à transparência de procedimentos antidumping, adotada em 15 de novembro de 1983, GATT Doc. N. ADP/17, reprinted in GATT, BISD 30th Supp, at. 24; Recomendação sobre procedimentos para uma investigação in loco, adotada em 15 de novembro de 1983, GATT Doc. N. ADP/18, reprinted in GATT, BISD 30th, Supp, at 28.

${ }^{18}$ Japão - Comércio de semicondutores, BISD 34S/116.

${ }^{19}$ HORLICK, Gary; SHEA, Eleanor. Op cit, p. 6.
} 
Outra dificuldade encontrada, na época, era a terrível crença de que antidumping era uma matéria a ser discutida entre empresas privadas, ao passo que medidas compensatórias (aplicadas para neutralizar os subsídios) interessavam aos governos. O primeiro país a clamar pela inclusão do antidumping na Rodada Uruguai foi a Coréia do Sul, por pressão de suas indústrias privadas. Produtores coreanos haviam sido alvos freqüentes de medidas antidumping nos períodos anteriores, como é o caso da Hyundai Motor $\mathrm{Cars}^{20}$, o maior exportador coreano, que sofrera com medidas impostas pelo Canadá. ${ }^{21}$

As complexidades de cada mercado, as diferenças, a forma com que cada país interpretava o antidumping, bem como a disposição de cada país em aplicar medidas antidumping mais ou menos rígidas, faziam com que fossem vários os interesses em jogo e profundas e delicadas as discussões. Contudo, o aumento dos procedimentos para solução de controvérsias, em especial na última fase das negociações, contribuiu para o consenso de que, mesmo complexa, a discussão e formulação de propostas de mudança eram necessárias. ${ }^{22}$

Nos Estados Unidos, a intensa batalha de lobbies foi sempre responsável pelo posicionamento deste país perante as negociações de um acordo antidumping. Tanto Estados Unidos quanto países europeus eram extremamente vulneráveis aos grupos de interesse, pois nenhum deles possuía um governo com uma maioria parlamentar garantida. $^{23}$ Entre 1987 e 1988, o país esteve focado na modificação de sua própria legislação. Após batalhas de lobbies, as modificações foram consideradas insatisfatórias, restando a promessa de que os assuntos estavam sendo discutidos na Rodada Uruguai. Contrastavam duas forças: a dos importadores, que acreditavam que a imposição de medidas duras impedia as importações e o progresso, e, de outro lado, os produtores domésticos, prezando pela competitividade de seus produtos.

Foi elaborado o texto chamado de Carlisle I (julho 1990), em homenagem ao Diretor Geral do GATT, Charles Carlisle, presidente do grupo de

\footnotetext{
${ }^{20}$ Cars Produced By or on Behalf of Hyundai Motor Company, CIT-13-87, C.I.T. No. 15, 1988.

${ }^{21}$ HORLICK, Gary; SHEA, Eleanor. Op. cit p. 7.

${ }^{22}$ FERNANDEZ, Marta Rodríguez. Op. cit. p. 86.

${ }^{23}$ HORLICK, Gary; SHEA, Eleanor. Op. cit. p. 13.
} 
negociação responsável pela revisão do Código Antidumping. Logo depois, foi redigida uma nova versão, a Carlisle II (agosto 1990), que também não foi aceita pelos países como base da negociação, mas foi aceita como instrumento de trabalho para a redação de outro texto. ${ }^{24}$ Em novembro de 1990, foi escrito o texto Nova Zelândia I, seguido por Nova Zelândia II (uma semana depois) e Nova Zelândia III (duas semanas depois). A preparação das redações foi liderada pela delegação neozelandesa e negociada sob a direção de Arthur Dunkel, bilateralmente. ${ }^{25}$

Ao final de 1990, foi proposto o texto Ramsauer (Rudi Ramsauer). Não aprovado pela Comunidade Européia e pelos Estados Unidos, coube a Arthur Dunkel elaborar outro. ${ }^{26}$ Nesta época, o antidumping já havia atraído a atenção do "Grupo dos Oito" e de todos os países negociadores, especialmente os países em desenvolvimento e os exportadores médios, devido às intransigências da Comunidade Européia e dos Estados Unidos, vistos como sistemas claramente protecionistas e que exigiam, por outro lado, a abertura comercial dos demais.

Em 20 de dezembro de 1991, o chamado Documento Dunkel foi publicado. As negociações continuaram, em formato bilateral, até a elaboração de um acordo final. Seu conteúdo é basicamente o incluído no Acordo Relativo à Aplicação do Artigo VI do Acordo Geral sobre Aduana e Comércio de 1994, o Acordo Antidumping de 1994, em vigor desde janeiro de 1995, início da terceira fase. ${ }^{27}$

Sem dúvida, o novo Acordo Antidumping é uma evolução em relação ao Código Antidumping. O instrumento da OMC serviu para trazer transparência em relação à forma de aplicação das medidas, bem como (e principalmente), ao controle

\footnotetext{
${ }^{24}$ Ambos os textos foram elaborados a partir de propostas de alguns Membros, tais como Singapura, Hong Kong e Canadá que propunham o reexame de bases fundamentais das regras antidumping. Tais propostas não foram aceitas pela maioria.

${ }^{25}$ HORLICK, Gary; SHEA, Eleanor. Op cit. p. 13.

${ }^{26}$ Estados Unidos e Comunidade Européia exerceram profunda pressão sobre o Diretor Geral Dunkel para a aprovação de regras antidumping mais restritivas. Fala-se que os Estados Unidos teriam telefonado para Dunkel dizendo que o Congresso não aceitaria medidas pouco protecionistas. Ele não poderia ignorar as pressões dos dois maiores membros do GATT. Foi construído um documento acusado de incoerente, com pelo menos uma seção desconexa com o restante.

27 Aprovado pela Comunidade Européia mediante a Decisão do Conselho n. 94/800/CE, de 22 de dezembro de 1994, DOCE n. 336/1, de 23 de dezembro de 1994. No Brasil, foi aprovado pelo Decreto Legislativo n. ${ }^{\circ} 30$, de 15.12 .94 e promulgado pelo Decreto n. ${ }^{\circ} 1.355$, de 30.12.94.
} 
desta aplicação pela OMC. Ficou definido o papel do mecanismo de solução de controvérsias no caso de má interpretação, por um Membro, das normas do Acordo.

O terceiro período tem sido marcado por discussões a respeito do procedimento adotado nas investigações e conceitos contidos no Acordo. Há diversas propostas sendo negociadas no seio da OMC desde 1995 e, recentemente, foi proposto um novo texto de acordo pelo presidente do grupo de negociações na matéria. ${ }^{28} \mathrm{O}$ Acordo Antidumping, embora seja considerado um instrumento eficaz e bem aceito pelos Membros, peca, em alguns momentos, pela extrema margem de discricionariedade concedida às autoridades nacionais. Também há diversas dúvidas sobre alguns conceitos apostos, tais como produto similar, melhor informação disponível, entre outros. Tal discricionariedade e obscuridade têm permitido certa influência política ou mesmo erros técnicos em sua aplicação, seja pelos países desenvolvidos, seja pelos países em desenvolvimento.

A interpretação destes termos tem ficado sob a responsabilidade do órgão de solução de controvérsias da OMC, que é criticado por alguns países pelo extremo rigor no entendimento sobre alguns pontos do acordo.

O terceiro momento é também caracterizado pelo aumento das investigações contra a China, aceita como Membro da OMC em 2000, mas não reconhecida como economia de mercado por alguns países. Os países que não a reconhecem como economia de mercado, como é o caso do Brasil ${ }^{29}$, recorrem ao artigo 2.2 do Acordo Antidumping, que permite a escolha de um terceiro país como base de comparação para o cálculo da margem de dumping. ${ }^{30}$ A China é o terceiro maior

\footnotetext{
${ }^{28}$ Draft Consolidated Chair Texts of the AD and SCM Agreements, TN/RL/W/213, 30 de novembro de 2007.

${ }^{29}$ Em 2004, em visita do Chefe de Estado chinês ao Brasil, o presidente brasileiro Luis Inácio Lula da Silva reconheceu o status da China como economia de mercado. O Brasil foi o $23^{\circ}$ Membro da OMC a tomar esta decisão. Contudo, para que tenha validade jurídica, a decisão do presidente deverá ser analisada e aprovada pela CAMEX, que é composta pelos Ministros da Casa Civil, Fazenda, Planejamento, Orçamento e Gestão, Relações Exteriores e Agricultura. Ainda não há decisão (Resolução) da CAMEX que reconheça juridicamente este status.

${ }^{30}$ Artigo 2.2. Caso inexistam vendas do produto similar no curso normal das ações de comércio no mercado doméstico do país exportador ou quando, em razão de condições específicas de mercado ou por motivo do baixo nível de vendas no mercado doméstico do país exportador tais vendas não permitam comparação adequada, a margem de dumping será determinada por meio de comparação com o preço do produto similar ao ser exportado para um terceiro país adequado, desde que esse preço seja representativo
} 
exportador do mundo (968 bilhões de dólares em 2006), perdendo apenas para Estados Unidos (1.038 bilhões de dólares) e União Européia (1481 bilhões de dólares). ${ }^{31}$ Devido ao grande volume exportado pela China, sem discutir aqui se as importações são feitas a preços de dumping ou não, vem aumentando o número de investigações contra bens provenientes deste país. ${ }^{32}$ Alguns países, por esta razão, tem se distanciado da discussão de uma nova redação do Acordo Antidumping, preferindo a redação atual, com suas lacunas, a qualquer redação que dificulte a aplicação de medidas. ${ }^{33}$

\subsubsection{A aplicação do Acordo Antidumping}

Conforme relatado, não foram poucas as discussões que circundaram a elaboração de um instrumento legal antidumping, seja pela pressão de alguns países, seja pela opressão de outros. Mas será que os países que o defenderam tiveram a intenção de criar um documento que desse alento ao intuito protecionista? Não. Pelo menos aparentemente, os protecionistas de hoje parecem ter defendido a elaboração de um texto que hamonizasse a prática antidumping e impedisse que o uso abusivo da medida pudesse ir de encontro aos objetivos de liberalização. A Comunidade Européia, por exemplo, defendeu que "a intenção dos redatores do Artigo [Artigo VI] não é condenar o dumping ele mesmo, mas limitar a possibilidade de medidas contra o dumping e subsídios. "34

Teoria e prática, contudo, distanciaram-se. Países desenvolvidos ou em desenvolvimento incorporaram o antidumping a suas legislações ou modificaram regras existentes, no sentido a se conformar com o novo ambiente multilateral de crescimento do volume do comércio. Este mesmo aumento no número de trocas aguçou o espírito protecionista dos parceiros comerciais, que passaram a ver nos textos recém

ou com o custo de produção no país de origem acrescido de razoável montante por conta de custos administrativos, comercialização e outros além do lucro.

${ }^{31}$ Dados obtidos no site oficial da OMC, www.wto.org, na seção Trade Statistics, Leading Traders.

${ }^{32}$ Ver MEDEIROS, Evan. Chasing the dragon: assessing China's system of export controls for WMDrelated goods and technologies. Santa Monica: Rand, 2005, 112 p. CHAN, Thomas. China's export miracle: origins, results and prospects. London: McMillan, 1999, 180 p.

${ }_{33}$ Conclusões após entrevistas nas Missões Permanentes do Brasil, Comunidade Européia, Estados Unidos e Canadá, em Genebra, em setembro de 2008.

${ }^{34}$ PALMETER, David. A commentary on the WTO Anti-Dumping Code. Journal of World Trade. v. 30, n. 4, 1996, p. 43. 
adotados uma boa forma de se defender contra as importações. $\mathrm{O}$ volume de medidas aplicadas foi incrivelmente aumentado e várias regras do acordo, que permitiam estas medidas, passaram a ser contestadas.

As contestações envolvem, na maioria dos casos, a alegação de que os países investigadores interpretam de forma equivocada algum dispositivo do Acordo Antidumping, ou ampliam demais certas possibilidades de aplicação do acordo, em proteção à indústria doméstica. Por isso, grande parte das discussões envolve propostas para o esclarecimento de termos do acordo, de forma a reduzir ou dificultar arbitrariedades.

1.1.3.1 A aplicação de medidas antidumping pelos países desenvolvidos

No passado, os países desenvolvidos eram, indiscutivelmente, os principais usuários do antidumping. Entre 1980 e 1989, 395 novas investigações antidumping foram iniciadas nos Estados Unidos. Na mesma década, 421 tiveram origem na Austrália, 294 no Canadá e 271 na Comunidade Européia. Neste período, estas quatro jurisdições eram responsáveis por 98,8\% dos casos reportados pelos signatários do Código Antidumping do GATT. ${ }^{35}$

Algumas experiências nacionais são relevantes. Uma delas é a evolução do antidumping nos Estados Unidos. O número de investigações para a aplicação de medidas antidumping, neste País, até 1980, foi incrivelmente maior do que o número após esta data, mas a redução pode ser explicada, entre outros fatores, pelo aumento do número de países demandados em um só processo (ou seja, o número de produtos caiu, mas, a cada investigação, são mais numerosos os países investigados). ${ }^{36}$

\footnotetext{
${ }^{35}$ ANDERSON, Keith. Antidumping Laws in the United States: use and welfare consequences. Journal of World Trade, 1993. v. 27. n 2. p. 100.

${ }^{36}$ As primeiras idéias de antidumping nos Estados Unidos surgiram ainda no início do século XIX, com a proibição, pelo Clayton Act de 1914, de discriminação de preços. O Antidumping Act de 1916 trouxe as primeiras bases de uma legislação sobre a matéria, mas a lei que realmente trata o antidumping tal como conhecido atualmente só veio em 1921 (Antidumping Act of 1921). Segundo este ato, as medidas devem ser impostas se o preço de venda é menor do que o preço de mercado no mercado exterior e este dumping deve estar relacionado ao dano sofrido pela indústria doméstica. Contudo, durante as décadas de 1920 e 1930, embora várias investigações tenham sido iniciadas, não há um número expressivo de medidas
} 
Na Comunidade Européia, até a elaboração do Acordo Antidumping, as regras sobre antidumping e subsídios eram dispostas pelo mesmo documento. ${ }^{37} \mathrm{O}$ Conselho Europeu decidiu separá-las. O princípio continuou o mesmo: quando exportadores venderem seus produtos no território da Comunidade e causarem dano à indústria doméstica européia, as autoridades devem aplicar medidas antidumping se considerarem que estas sejam de interesse da Comunidade.

O Acordo Antidumping foi reformulado e transposto à legislação

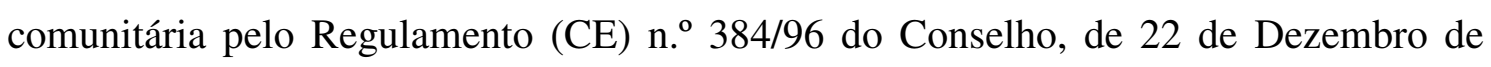
1995 (Regulamento Básico). Este documento legal propôs princípios gerais, procedimentos e diretrizes, tais como a definição de dumping e de seus fatores (valor normal, produto similar), determinação de dumping, dano e indústria doméstica, procedimento de consulta, verificações, etc.

Não é possível dizer que o volume de investigações iniciadas pelos países desenvolvidos, entre 1995 e 2007, tenha sido semelhante. O número apresentado por alguns países sugere uma redução no número de investigações após 2005, mas ela não é observada nos maiores usuários de forma parecida (Austrália, Canadá, Comunidade Européia e Estados Unidos).

\begin{tabular}{|c|c|c|c|c|c|c|c|c|c|c|c|c|c|}
\hline $\begin{array}{l}\text { Membro da } \\
\text { OMC }\end{array}$ & $\ddot{\alpha}$ & $\stackrel{2}{2}$ & $\hat{\sigma}$ & $\stackrel{\infty}{2}$ & $\hat{\sigma}$ & હ્సి & હิ & 气ิ & હે & ఫ્సે & ֻิ๊ & હั่ & 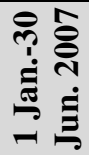 \\
\hline Austrália & 5 & 17 & 42 & 13 & 24 & 15 & 23 & 16 & 8 & 9 & 7 & 10 & 0 \\
\hline Canadá & 11 & 5 & 14 & 8 & 18 & 21 & 25 & 5 & 15 & 11 & 1 & 7 & 0 \\
\hline $\begin{array}{c}\text { Comunidade } \\
\text { Européia }\end{array}$ & 33 & 25 & 41 & 22 & 65 & 32 & 28 & 20 & 7 & 30 & 25 & 35 & 0 \\
\hline Israel & 5 & 6 & 3 & 7 & 0 & 1 & 4 & 0 & 0 & 1 & 4 & 0 & 0 \\
\hline Japão & 0 & 0 & 0 & 0 & 0 & 0 & 2 & 0 & 0 & 0 & 0 & 0 & 4 \\
\hline $\begin{array}{c}\text { Nova } \\
\text { Zelândia } \\
\end{array}$ & 10 & 4 & 5 & 1 & 4 & 9 & 1 & 2 & 5 & 5 & 0 & 1 & 6 \\
\hline
\end{tabular}

aplicadas. Isto porque as tarifas de importações eram bastante altas, a penetração das importações não era expressiva e os produtores domésticos podiam invocar outras leis para obter sua proteção. Em 1970, a demanda por medidas antidumping aumentou, fazendo com que o Congresso editasse nova lei sobre a matéria. Por exemplo, a definição de antidumping foi ampliada e foram incluídas as vendas abaixo do preço de custo. A estrutura dos órgãos investigativos também foi alterada, passando a análise do dano a ser feita pelo U.S. Tariff Commission (hoje International Trade Commission) (IRWIN, Douglas. The rise of U.S. antidumping activity in historical perspective. IMF Working Paper: Research Department, WP/05/31, 2005, p. 7).

${ }^{37}$ Regulamento (CE) n. 2423/88 do Conselho, J.O. 1988 L 209/1. 


\begin{tabular}{|c|l|l|l|l|l|l|l|l|l|l|l|l|l|}
\hline $\begin{array}{c}\text { Estados } \\
\text { Unidos }\end{array}$ & 14 & 22 & 15 & 36 & 47 & 47 & 75 & 35 & 37 & 26 & 12 & 7 & 2 \\
\hline
\end{tabular}

Fonte: Investigações iniciadas, por Membro, entre 01/01/95 e 30/06/07. Organização Mundial do Comércio

\subsubsection{Aplicação do acordo pelos países em desenvolvimento}

A partir da década de 90, um movimento iniciado pelo México seguiuse por vários países em desenvolvimento, que começaram a descobrir nas medidas antidumping importantes armas para a negociação comercial. $^{38}$ Como lembra Narayanan, desde a imposição das primeiras medidas antidumping pela Índia, em 1992, ela rapidamente se tornou a maior usuária deste remédio nos últimos anos. Para ele, existe uma perfeita relação entre o número de investigações iniciadas no país, o aumento das restrições quantitativas na importação de bens e a redução das tarifas. ${ }^{39}$

Com a Rodada Uruguai e as reduções tarifárias proporcionadas pelos compromissos assumidos pelos países, desapareceram fronteiras, mas, ao mesmo tempo, atribuiu-se maior atenção ao direito antidumping como freio a esta liberalização.

Os países em desenvolvimento, que eram os maiores defensores das negociações de regras claras e detalhadas para a aplicação de medidas antidumping, descobriram, posteriormente, que, quanto mais detalhadas e precisas estas regras, mais difícil seria utilizá-las, se desejassem aplicar as medidas. Estes países enfrentam três dificuldades na aplicação do antidumping: i) falta de conhecimento especializado; ii) falta de recursos financeiros e iii) falta de mão de obra qualificada. Geralmente, tais países desejam manter sua legislação simples, sem deixar de se conformar com o Artigo VI do GATT $1994 .^{40}$

\footnotetext{
${ }^{38}$ Uma explicação possível para o fenômeno simultâneo é a abertura comercial destas economias, tais como Índia, México, Brasil e África do Sul. Vários países em desenvolvimento adotaram políticas de abertura às importações e concessões, após 1990.

39 A maioria das investigações iniciadas no início da década de 90 já demonstra que os maiores interessados na aplicação de medidas são indústrias que detêm poder de mercado nos países investigadores. Também pode se falar em uma alta taxa de medidas aplicadas, em relação às investigações abertas, no início desta década. (NARAYANAN, Prakash. Anti-dumping in India - present state and future prospects. Journal of World Trade, v. 40, n. 6, 2006, p. 1081.)

40 VERMULST, Edwin. Adopting and Implementing Anti-Dumping Laws: some suggestions for developing countries. Journal of World Trade, v. 31, n. 2, 1997, p. 7.
} 
Vermulst sugere algumas idéias para a prática antidumping em países em desenvolvimento. ${ }^{41}$ Em primeiro lugar, deve haver preocupação na escolha entre uma ou duas autoridades para a análise de dumping e de dano. Como há um grande volume de informações que são, ao mesmo tempo, utilizadas para as duas análises (dumping e dano), é melhor e mais econômico que a mesma equipe cuide de ambos os estudos. Devem existir tribunais especializados para rever decisões relacionadas à matéria, devido à excessiva especialização exigida pelo tema (como acontece nos Estados Unidos). Contudo, o autor reconhece que isso é extremamente oneroso aos países em desenvolvimento, sendo pelo menos interessante que a mesma jurisdição que se ocupa das questões aduaneiras trate também do antidumping.

Por fim, entre outras recomendações, o autor lembra o interesse público, objeto deste trabalho. Pode ser difícil a constituição de um sistema de análise específica do interesse público, mas deve haver, pelo menos, a previsão da possibilidade de não aplicar as medidas antidumping se as autoridades estão convencidas de que elas não são interessantes ao país importador.

Independentemente de qualquer sugestão, os países em desenvolvimento adotaram formas distintas de procedimento, de acordo com as características de cada um deles e à adequação às necessidades de cada país. No Brasil, foi criado, em 1995, o Departamento de Defesa Comercial (DECOM), que tem a competência investigativa e reporta suas conclusões para a aprovação da Secretaria de Comércio Exterior (SECEX). ${ }^{42} \mathrm{Na}$ Argentina, foram criados dois departamentos, um

\footnotetext{
${ }^{41}$ VERMULST, Edwin. Op cit. p. 9-23.

${ }^{42}$ Em 1990, foi feita uma ampla reforma na estrutura da Administração Pública brasileira, tendo a gestão governamental do comércio exterior sido atribuída ao Departamento de Comércio Exterior (DECEX), subordinado à Secretaria Nacional de Economia (SNE) do Ministério da Economia, Fazenda e Planejamento (MEFP). Posteriormente, foi criado o Ministério da Indústria, Comércio e Turismo (MICT), ao qual foi subordinada a Secretaria de Comércio Exterior (SECEX) que assumiu as funções anteriormente atribuídas ao DECEX/SNE/MEFP. Em 1994, o Congresso Brasileiro aprovou a Ata Final que Incorpora os Resultados da Rodada Uruguai de Negociações Multilaterais do GATT, incluindo os novos Acordos Antidumping, de Subsídios e Medidas Compensatórias e de Salvaguardas, bem como o Acordo de Marrakeche, que cria a OMC. Em 1995, com o objetivo de aumentar a capacitação técnica e operacional para a atuação governamental na aplicação da legislação antidumping, de subsídios e medidas compensatórias e de salvaguardas, foi criado no, âmbito da SECEX, o Departamento de Defesa Comercial (DECOM), como órgão especializado para a condução das investigações da espécie (art. 18 do Decreto 4632/2003). Naquele mesmo ano, foi aprovada a União Aduaneira no âmbito do Mercado Comum do Sul (Mercosul) e adotada uma Tarifa Externa Comum (TEC) pelos quatro países que o integram. A competência para aplicação de medidas de defesa comercial, que inicialmente era comum dos Ministros da Indústria, Comércio e Turismo (posteriormente Desenvolvimento, Indústria e Comércio
} 
responsável pela análise do dano, a Comisión Nacional de Comercio Exterior (CNCE), e outro responsável pela análise do dumping, a Direccion de Competencia Desleal (DCD). Não se conhece nenhum país em desenvolvimento que tenha designado jurisdição especial para a análise e revisão das investigações e medidas antidumping. Por fim, o interesse público é previsto em raras legislações, como a brasileira.

Sobre a abertura de investigações antidumping e a aplicação de medidas, é possível afirmar que ambos os números foram crescentes a partir de 1995. O quadro abaixo mostra a situação descrita:

\begin{tabular}{|c|c|c|c|c|c|c|c|c|c|c|c|c|c|}
\hline $\begin{array}{l}\text { Membro } \\
\text { da OMC }\end{array}$ & $\hat{\sigma}$ & ลั & $\hat{2}$ & $\stackrel{2}{2}$ & $\hat{\sigma}$ & ฮิ & ฮิ & สิ่ & ๕ิ & ఫิે & 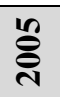 & สั่ & ฐ \\
\hline Argentina & 27 & 22 & 14 & 8 & 23 & 43 & 26 & 14 & 1 & 12 & 12 & 15 & 3 \\
\hline Brasil & 5 & 18 & 11 & 18 & 16 & 11 & 17 & 8 & 4 & 8 & 6 & 12 & 4 \\
\hline Chile & 4 & 3 & 0 & 2 & 0 & 5 & 0 & 0 & 0 & 0 & 0 & 1 & 1 \\
\hline $\begin{array}{c}\text { R.P. } \\
\text { China }\end{array}$ & 0 & 0 & 0 & 0 & 0 & 6 & 14 & 30 & 22 & 27 & 24 & 11 & 4 \\
\hline Colômbia & 4 & 1 & 1 & 6 & 2 & 3 & 6 & 0 & 0 & 2 & 2 & 5 & 1 \\
\hline Egito & 0 & 0 & 7 & 14 & 5 & 1 & 7 & 3 & 1 & 0 & 12 & 8 & 1 \\
\hline Índia & 6 & 21 & 13 & 28 & 64 & 41 & 78 & 81 & 46 & 21 & 28 & 34 & 13 \\
\hline Indonésia & 0 & 11 & 5 & 8 & 8 & 3 & 4 & 4 & 12 & 5 & 0 & 5 & 0 \\
\hline Jamaica & 0 & 0 & 0 & 0 & 0 & 1 & 1 & 1 & 1 & 0 & 0 & 0 & 0 \\
\hline Coréia & 4 & 13 & 15 & 3 & 6 & 2 & 4 & 9 & 18 & 3 & 4 & 7 & 5 \\
\hline Malásia & 3 & 2 & 8 & 1 & 2 & 0 & 1 & 5 & 6 & 3 & 4 & 8 & 0 \\
\hline México & 4 & 4 & 6 & 12 & 12 & 6 & 6 & 10 & 14 & 6 & 6 & 6 & 2 \\
\hline Peru & 2 & 8 & 2 & 3 & 8 & 1 & 8 & 13 & 4 & 7 & 4 & 3 & 0 \\
\hline Filipinas & 1 & 1 & 2 & 3 & 6 & 2 & 0 & 1 & 1 & 0 & 0 & 0 & 0 \\
\hline $\begin{array}{c}\text { África do } \\
\text { Sul }\end{array}$ & 16 & 33 & 23 & 41 & 16 & 21 & 6 & 4 & 8 & 6 & 23 & 3 & 3 \\
\hline $\begin{array}{c}\text { Trinidad e } \\
\text { Tobago }\end{array}$ & 0 & 1 & 0 & 4 & 3 & 1 & 1 & 0 & 2 & 0 & 0 & 0 & 0 \\
\hline Turquia & 0 & 0 & 4 & 1 & 8 & 7 & 15 & 18 & 11 & 25 & 12 & 8 & 0 \\
\hline Uruguai & 0 & 0 & 1 & 0 & 0 & 1 & 4 & 0 & 0 & 0 & 0 & 0 & 0 \\
\hline Venezuela & 3 & 2 & 6 & 10 & 7 & 1 & 1 & 1 & 0 & 0 & 0 & 0 & 0 \\
\hline
\end{tabular}

Exterior) e da Fazenda, foi transferida, a partir de 2001, para a Câmara de Comércio Exterior (CAMEX). Dessa forma, com a promulgação da Lei 9.019/95, e com as alterações introduzidas pela Medida Provisória 2.158-35, de 24 de agosto de 2001, e o Dec. 4.732, de 10 de junho de 2003, ficaram estabelecidas as seguintes competências da CAMEX, em termos de medidas de defesa comercial: aplicação de medidas provisórias; homologação de compromissos de preços; encerramento da investigação com aplicação de medidas definitivas; suspensão, alteração ou prorrogação de medidas definitivas; encerramento de revisão dos direitos definitivos ou compromissos de preços. Vale ressaltar que todas as decisões acima elencadas serão tomadas com base em parecer elaborado pelo DECOM.

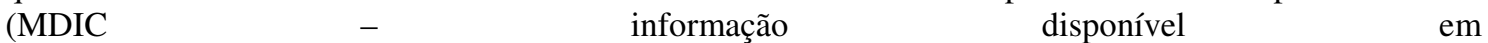
http://www.mdic.gov.br/sitio/interna/interna.php?area=5\&menu=312\&refr=228, consultada em 13 de fevereiro de 2008). 
Fonte: Investigações iniciadas, por Membro, entre 01/01/95 e 30/06/07. Organização Mundial do Comércio $^{43}$

O Kommerskollegium - National Board of Trade da Suécia estudou, em outubro de 2005, o uso do antidumping por Brasil, China, Índia e África do Sul, que corresponderam, entre 2003 a 2004, a 32\% das investigações iniciadas. O estudo relata o aumento indiscutível no número de investigações iniciadas e no volume de medidas aplicadas por estes países desde 1995. A Índia foi apontada como a maior usuária do antidumping. Para todos os quatro países, a rápida redução das tarifas observada nas negociações da Rodada Uruguai foi a principal causa do aumento na utilização do antidumping. Os autores observaram, também, que, na Índia e na África do Sul, empresas em situação próxima ao monopólio foram as que mais solicitaram a aplicação de medidas antidumping. Na Índia, a maioria das petições era de produtores que representavam mais de $90 \%$ da produção nacional. A retaliação também foi apontada como causa da abertura de investigações. ${ }^{44}$

No Brasil, dois fatores foram determinantes para o aumento na aplicação de medidas. O primeiro deles foi a liberalização do comércio no início dos anos 90. O País assinou diversos acordos com outros países, bem como ratificou os acordos da OMC. O segundo fator foi a paridade com o dólar norte-americano, observada entre 1994 e 1998, um grande incentivo às importações. A indústria doméstica passou a se organizar politicamente na busca da aplicação de medidas urgentes. Esta pressão levou à criação de uma burocracia federal treinada para investigar antidumping e subsídios. ${ }^{45}$ Os produtos mais investigados foram os produtos químicos, seguidos pelo aço. O maior alvo do Brasil foram os Estados Unidos, seguidos pela China.

\footnotetext{
${ }^{43}$ Os dados fornecidos pelos Membros à OMC devem ser vistos com cautela. Como só há a obrigação de reportar as investigações que estão sendo iniciadas, estas informações são mais confiáveis do que aquelas que se referem às medidas aplicadas.

${ }^{44} \mathrm{O}$ estudo da retaliação como motivação para petições de abertura de investigação antidumping é estudado por PRUSA, Thomas; SKEATH, Susan. The Economic and Strategic Motives for Antidumping Filings. NBER Working Paper Series, Working Paper 8424, 2001.

${ }^{45}$ Comentários de Welber Barral e Gilvan Brogini no Kommerskollegium, National Board of Trade of Sweden, The use of antidumping in Brazil, China, India, South Africa, - rules, trends and causes. p. 11, disponível

em http://www.kommers.se/upload/Analysarkiv/Arbetsomr\%C3\%A5den/Antidumpning/National_Board_of Trade-_Antidumping_in_Four_Developing_Countries.pdf, disponível em 20 de janeiro de 2008.
} 
É possível dizer que os países em desenvolvimento deixaram de ser alvos para serem usuários do instrumento antidumping. ${ }^{46}$ Sem dúvida alguma, isso refletiu nas negociações para modificação do acordo existente, conforme será exposto no capítulo 0. Alguns destes países, que eram defensores de revolucionárias mudanças no texto, passaram a se posicionar de forma menos agressiva nas negociações.

\subsubsection{As críticas mais freqüentes}

Existem vários pontos controvertidos no Acordo Antidumping, que abrem espaço à discricionariedade do país investigador. Cada Membro da OMC faz sua leitura sobre o texto, bem como sua avaliação da sobreposição de alguns aspectos sobre outros. Por exemplo, o Acordo determina a avaliação, pela autoridade investigadora, dos fatores que podem ter causado o dano, que não as importações investigadas. Não raro, alguns Membros não analisam todos os elementos, entendendo serem alguns critérios mais importantes do que os outros. ${ }^{47}$

Com tamanha margem para decisão, é certo que os países utilizam o Acordo de uma maneira mais ou menos protecionista, havendo diferenças na aplicação das medidas antidumping até mesmo entre uma investigação e outra (no mesmo país). Tais imprecisões e a insegurança gerada por elas fazem com que sejam ainda maiores as reclamações dos Membros e a vontade de renegociar uma nova redação para o acordo.

O resultado destas interpretações são medidas que protegem um setor ou determinada empresa, mas prejudicam todos os outros setores e a economia em geral. Os críticos da imposição exagerada de medidas antidumping enumeram vários

\footnotetext{
${ }^{46}$ Lembra Prusa que, uma vez impostas as primeiras medidas antidumping, é muito difícil para o Membro negar a aplicação a outras indústrias. Para ele, é improvável que os novos usuários conheçam os custos de se abraçar a política antidumping. (PRUSA, Thomas. On the Spread and Impact of Antidumping. NBER Working Paper Series, Working Paper 7404, 1999, disponível em www.nber.org/papers/w7404, p. 5.) Sobre os custos macroeconômicos do antidumping, ver AGGARWAL, Aradhna. Macro Economic Determinants of Antidumping: A comparative analysis of developed and developing countries. World Development, v. 32, n. 6, 2004, p. 1043-1057.

${ }^{47}$ A consideração de todos os fatores que podem ter influído para o dano é obrigatória, segundo decisão do grupo especial no caso Índia. Roupa de cama, WT/DS141/R, 30 de outubro de 2000. "O uso da expressão 'deve incluir'no artigo 3.4 nos sugere que a avaliação dos fatores listados neste artigo é propriamente interpretada como mandatória em todos os casos. Isso significa, em nossa visão, que o sentido ordinário desta previsão é que o exame do impacto das importações a preços de dumping devem incluir a avaliação de todos os fatores listados no art. 3.4" (tradução livre do parágrafo 6.154 da decisão).
} 
efeitos negativos desta aplicação. Além disso, fazem um estudo apurado do que chamam de custos do protecionismo. ${ }^{48}$

Esta flexibilidade tem gerado inconformismos nas investigações nacionais. Por vezes, conceitos como produto similar, dano e sua ameaça são usados em favor dos produtores nacionais, com o claro intuito de privilegiar a demanda interna. Uma interpretação falseada destes conceitos elementares afasta a investigação de seus objetivos iniciais, tornando os resultados cada vez mais distintos do que é o interesse público. Ocorre, também, a utilização indevida de procedimentos previstos no Acordo Antidumping, que são usados como válvulas de escape, permitindo que a investigação seja concluída segundo o desejo de grupos de pressão. A transparência nas investigações também não é, por vezes, respeitada, constituindo-se em um problema adicional a ser desafiado pelos exportadores em sua defesa.

\subsubsection{A difícil definição do produto similar}

A definição de produto similar é de extrema importância em uma investigação antidumping, pois ela permitirá a comparação entre o produto da indústria doméstica e o importado, bem como entre o produto importado e o vendido no mercado de origem. A boa acepção do produto similar permitirá a boa identificação do mercado afetado pela investigação e, assim, do interesse público naquela aplicação de medidas antidumping.

A determinação do que é o produto similar é estratégica, dependendo tão somente do interesse da indústria doméstica. ${ }^{49}$ Tende-se a definir o produto similar de uma forma muito ampla, para que um maior número de produtos seja incluído no escopo da investigação e contra este leque sejam aplicadas medidas. Por outro lado, esta

\footnotetext{
${ }^{48}$ Ver PANAGANYA, Arvind. Cost of protection: where do stand. American Economic Review, v. 92, n. 2, 2002, p. 176-179.

${ }^{49}$ E da margem de discricionariedade da autoridade nacional em aceitar esta definição ampla. Sobre este ponto, HOEKMAN, Bernard; MAVROIDIS, Petros. Dumping, Antidumping and Antitrust. Journal of World Trade, v. 30, n. 1, p. 27-52.
} 
estratégia torna mais difícil, à indústria doméstica, a prova do dano e da efetiva produção de toda a gama de produtos sob investigação. ${ }^{50}$

No caso Ácido Sulfônico, investigação antidumping aberta pela Comunidade Européia contra as importações provenientes da Índia, a Comissão Européia tratou os vários graus técnicos do ácido como sendo um só produto. Os exportadores argumentaram que há diversos tipos de propriedade e aplicações para o ácido, sendo incorreto tratá-los como um produto único. A autoridade, em sua análise, deve investigar se a indústria doméstica produz toda a gama de produtos investigada e se o dano alegado a atingiu integralmente. Contudo, as autoridades européias argumentaram que as propriedades e o processo de purificação do ácido não alteram as propriedades moleculares, sendo, portanto, um mesmo produto. ${ }^{51}$

No caso europeu do Filme PET (filme de polietileno, produzido pela Índia), argumentaram as partes que o filme metalizado não poderia ser considerado da mesma forma que os demais, pois possuía características físicas e técnicas diferentes, sendo vendido a um preço mais elevado. As autoridades européias novamente consideraram que a metalização não alterava as características principais do filme e, que, por isso, ele poderia ser considerado como um só. Na investigação conduzida pelos Estados Unidos, contra o PET indiano, entendeu a autoridade norte-americana que o produto metalizado não poderia ser considerado como mesmo produto, já que sua aplicação e desempenho eram diferentes. ${ }^{52}$

Existem vários níveis de similaridade no direito da $\mathrm{OMC}$, expressados por palavras como identical goods, similar goods, like products. O artigo 15 do Acordo de Valoração Aduaneira define como idênticas as mercadorias que são iguais em todos os sentidos, incluindo características físicas, qualidade e reputação. $\mathrm{O}$ mesmo artigo define mercadorias similares como sendo aquelas que, embora não sejam semelhantes em todos os aspectos, têm características semelhantes e componentes materiais que as

\footnotetext{
${ }^{50}$ São freqüentes as investigações nas quais os importadores ou exportadores alegam que a indústria doméstica não será capaz de suprir a demanda do produto. Vários exemplos serão relatados adiante, no capítulo 1.2.2.1.

${ }^{51}$ Acido Sulfânico. Regulamento (EU) n. 1339/2002 do Conselho, de 22 de julho de 2002, OJ L 196, 25/07/2002, p. 11 in AGGARWAL, Aradhna. The WTO Antidumping Code: issues for review in postDoha negotiations. Working Paper n. 99, New Delhi: Indian Council for Research on International Economic Relations. 2003, p. 2.

${ }^{52}$ Regulamento (CE) n. 193/2007 do Conselho, de 22 de Fevereiro de 2007, JO L 59 de 27.2.2007.
} 
permitam desempenhar as mesmas funções e serem comercialmente intercambiáveis. ${ }^{53}$ A qualidade dos produtos, a sua reputação e a existência de uma marca são, entre outros, fatores a serem considerados na similaridade. ${ }^{54}$

O artigo 2.8 do Acordo Antidumping define como like products ${ }^{55}$ os produtos que são idênticos em todos os aspectos ao produto em consideração, ou, na ausência destes produtos, outro produto que, embora não seja igual em todos os aspectos, tenha características próximas ao produto em consideração. ${ }^{56}$

Muito se discutiu sobre a similaridade em Japão - Bebidas alcoólicas. O Grupo Especial ${ }^{57}$ deveria definir se o sistema japonês de taxação do álcool, que taxava uísque e vodka mais pesadamente do que o produto doméstico shochu, violava a determinação do GATT de não discriminação. ${ }^{58}$ Neste caso, o Órgão de Apelação decidiu que a similaridade tinha a imagem de um acordeão. A abertura ou fechamento de um acordeão demonstraria as possibilidades de análise da similaridade do produto posto à análise, bem como do contexto analisado.

\section{Em outro caso, Comunidades Européias - Amianto ${ }^{59}$, o Canadá} alegou que um decreto francês impôs proibição à venda de amianto e produtos contendo esta substância, mas não proibiu a venda de substâncias similares, como a celulose e fibra de vidro. O mecanismo de solução de controvérsias da OMC decidiu que a

\footnotetext{
${ }^{53}$ Art. 15.2 En el presente Acuerdo: a) se entenderá por "mercancías idénticas" las que sean iguales en todo, incluidas sus características físicas, calidad y prestigio comercial. Las pequeñas diferencias de aspecto no impedirán que se consideren como idénticas las mercancías que en todo lo demás se ajusten a la definición; b) se entenderá por "mercancías similares" las que, aunque no sean iguales en todo, tienen características y composición semejantes, lo que les permite cumplir las mismas funciones y ser comercialmente intercambiables. Para determinar si las mercancías son similares habrán de considerarse, entre otros factores, su calidad, su prestigio comercial y la existencia de una marca commercial.

${ }^{54}$ GOCO, Jonell. Non-discrimation, Likeness, and market definition in World Trade Organization Jurisprudence. Journal of World Trade: v. 40, n. 2, 2006, p. 315-340.

55 "Produit similaire", na versão oficial do Acordo Antidumping em francês, e "producto similar", em espanhol.

${ }^{56}$ Art 2.8. Ao longo deste Acordo o termo produto similar (like product - produit similaire) deverá ser entendido como produto idêntico, i.e., igual sob todos os aspectos ao produto que se está examinando ou, na ausência de tal produto, outro produto que embora não exatamente igual sob todos os aspectos apresenta características muito próximas às do produto que se está considerando.

57 Embora alguns autores brasileiros prefiram traduzir a expressão americana, encontrando a palavra "painel", prefere-se, aqui, adotar a tradução literal da versão francesa dos acordos, a expressão "grupo especial".

58 Japan - Taxes on Alcoholic Beverages, WT/DS8/AB/R, WT/DS10/AB/R, WT/DS11/R, 1 de novembro de 1996.

${ }^{59}$ EC - Asbestos, WT/DS135/AB/R, 12 de março de 2001.
} 
determinação da similaridade entre os produtos dependeria da relação de competitividade entre eles. ${ }^{60}$

A comparação entre os produtos de acordo com o nível de concorrência entre eles é correta, pois o objetivo das medidas antidumping é exatamente corrigir uma situação de não competição por prática desleal. Pode ocorrer de produtos similares não serem considerados diretamente concorrentes, embora fisicamente similares. Neste caso, estar-se-á impondo medidas antidumping para produtos que não são efetivamente concorrentes e que não foram, por isso, os causadores do dano.

Risco também há em se definir que produtos não são concorrentes, pois não foram classificados da mesma forma pela autoridade aduaneira, mas que, de fato, são. Nesta hipótese, por ser a medida antidumping aplicada de acordo com a nomenclatura técnica aduaneira adotada pelo país ou bloco econômico, é possível que outros produtos escapem do antidumping, mesmo sendo os causadores do dano. Por exemplo, uma escova de cabelo e um pente podem ser classificados de forma diferente do conjunto que contém escova e pente. O exportador, para não sofrer as medidas antidumping, passa a exportar o conjunto, não os produtos em separado. ${ }^{61}$

Por todas estas razões, é o conceito de similaridade criticado, sendo necessária e urgente a definição de critérios que tornarão os produtos comparáveis. Somente desta forma será reduzida a margem de discricionariedade da autoridade e a amplitude de imaginação e argumentação da indústria doméstica.

\subsubsection{O problema do dano e sua ameaça}

O dano e sua ameaça já foram o alvo de discussões. ${ }^{62}$ Diversas são as questões, merecendo destaque as mais controversas, que interferem no resultado das

\footnotetext{
${ }^{60}$ Outros casos analisados pelo mecanismo de solução de controvérsias da OMC podem ser citados como exemplos de discussão sobre a definição de produto similar:

${ }^{61}$ Tal discussão ocorreu no Brasil, em 2007, no caso Processo MIDIC/SECEX 52500.012357/2006-38, importação de escovas de cabelo, Circular n. 62, de 14 de setembro de 2006, publicada no D.O.U em 15.09.2006.

${ }^{62}$ Exemplos. Thailand - Anti-Dumping Duties on Angles, Shapes and Sections of Iron or Non-Alloy Steel and H Beams from Poland, WT/DS122/AB/R, 12 de março de 2001, sobre a não consideração de todos os fatores dispostos no art. 3.4.; Bed Linen from India, WT/DS141/R, 30 de outubro de 2000, no
} 
investigações. A má interpretação do dano e de sua ameaça pode ser usada como instrumento para a proteção indevida de uma indústria doméstica, que ocorre mesmo quando não há comprovação de dano, dumping ou nexo. Se isso acontecer, o balanço que de ser feito para o exame do interesse público ficará comprometido, pois a razão da indústria doméstica para a aplicação do antidumping será duvidosa.

Na Europa, critica-se o cálculo da margem de dano. Esta margem é igual à diferença entre o preço na União Européia do produto importado e o preço na União Européia do produto doméstico similar. O que parece um cálculo objetivo tem sido afetado por algumas variáveis. Em primeiro lugar, o preço de revenda é usualmente usado como um preço base, calculado acrescendo-se os custos do peticionário doméstico (não se considerando sua situação de competitividade) e um lucro teórico que garanta um retorno suficiente (ex. remuneração de capital, reservas para futuros desenvolvimentos, etc). Deve-se, contudo, verificar se este retorno é realmente alcançável, de acordo com as circunstâncias do mercado, o que não acontece. Além disso, outros fatores não são considerados nesta diferença de preços, tais como melhores políticas dos exportadores, menores custos, diferenças em qualidade, reputação e, principalmente, depreciação da moeda. ${ }^{63}$

Que aspectos considerar para definir o dano? Conforme o art. 3.1 do Acordo Antidumping, a autoridade investigadora deve avaliar, de forma objetiva, a) o volume das importações objeto de dumping e o seu efeito sobre os preços dos produtos similares no mercado interno e b) a repercussão destas importações sobre os produtores nacionais de tais produtos. Cabe à autoridade verificar se houve um aumento sensível no volume destas importações em comparação com a produção nacional e, ao mesmo tempo, se houve subvalorização nos preços das importações objeto de dumping em relação aos preços no mercado interno. Nenhuma destas análises pode ser feita de forma separada.

qual as Comunidades Européias não teriam agido de acordo com o art. 3.4, investigando todos os fatores relacionados ao dano; Guatemala - Definitive Anti-Dumping Measure on Grey Portland Cement from Mexico, WT/DS156/R, 24 de outubro de 2000, a Guatemala teria falhado em considerar dois dos fatores relacionados ao dano (retorno de investimentos e habilidade para produzir capital).

${ }^{63}$ VERMULST, Edwin. The 10 Major Problems with the Anti-Dumping Instrument in the European Community. Journal of World Trade, v. 39, n. 1, 2005, p. 108. 
Para examinar os efeitos das importações sobre os produtores, a autoridade deve, de acordo com o art. $3.4^{64}$, avaliar a diminuição real e potencial das vendas, o volume de produção, a participação de mercado, a produtividade, o rendimento dos investimentos ou utilização da capacidade, os fatores que afetam os preços internos, a magnitude da margem de dumping, os efeitos negativos reais ou potenciais sobre o fluxo de caixa, estoques, emprego, salários, crescimento, capacidade para contrair empréstimos. Ressalta o artigo que nenhum destes fatores deve ser considerado separadamente e que a lista não é exaustiva. Mesmo que os quesitos sejam bastante objetivos, caberá ao Membro investigador determinar a importância de uns sobre os outros. Desta discricionariedade nascem a arbitrariedade e a possibilidade de uma comparação inadequada.

Embora não exista previsão no Acordo Antidumping, defende-se que as autoridades devam exigir que a indústria doméstica interessada na aplicação das medidas apresente um plano de reestruturação para ser colocado em prática se as medidas antidumping forem aplicadas. ${ }^{65}$ Isto porque há diversos casos de indústrias domésticas que deixam o mercado mesmo quando a proteção do antidumping lhes é garantida, seja por deficiências em seu planejamento, seja por incapacidade de atender a demanda. Pedido comparável já é feito no Acordo de Salvaguardas, no artigo 7.2, para a prorrogação das salvaguardas. ${ }^{66}$

As investigações sobre a existência de ameaça de dano são ainda mais criticadas. Devem ser investigados o aumento significativo das importações, uma suficiente capacidade disponível do exportador e a probabilidade de dedicação desta capacidade à exportação, o fato de que os preços das importações causem queda nos preços internos, de forma que a importação passe a ser mais demandada, e os estoques

\footnotetext{
64 Art. 3.4. O exame do impacto das importações a preços de dumping sobre a indústria nacional correspondente deverá incluir avaliação de todos os fatores e índices econômicos relevantes que tenham relação com a situação da referida indústria, inclusive queda real ou potencial das vendas, dos lucros, da produção, da participação no mercado, da produtividade, do retorno dos investimentos ou da ocupação, da capacidade instalada, fatores que afetem os preços internos, a amplitude da margem de dumping, efeitos negativos reais ou potenciais sobre o fluxo de caixa, estoques, emprego, salários, crescimento, capacidade para aumentar capital ou obter investimentos. A enumeração acima não é exaustiva, nem poderão tais fatores isoladamente ou em conjunto ser tomados necessariamente como indicação decisiva.

${ }^{65}$ Este ponto será discutido no capítulo 2.5 .

66 DIDIER, Pierre. The WTO Anti-Dumping Code and EC Practice: issues for review in trade negotiations. Journal of World Trade, vol. 35, n. 1, 2001, p. 47.
} 
do produto objeto de investigação. ${ }^{67}$ Embora o acordo diga claramente que a autoridade não pode se basear em meras alegações, conjecturas ou possibilidades remotas, esta regra nem sempre é respeitada. ${ }^{68}$

No caso Madeira de $\operatorname{Lei}^{69}$, o órgão da OMC concluiu que o grupo especial deve fazer um exame profundo para saber se as explicações fornecidas pelo Membro mostram como a autoridade encarregada da investigação tratou os fatos e os elementos de prova contidos no processo. O grupo deve observar, também, se a autoridade levou em consideração a complexidade dos dados que lhe foram apresentados e se ela explicou porque rejeitou algumas explicações e elementos. No caso, o Grupo Especial, depois de examinar as constatações feitas pela autoridade investigadora norte-americana, não examinou os elementos que contribuíram para a constatação final de ameaça importante, contrariando o art. $3.7 .^{70}$

\subsubsection{O uso da melhor informação disponível como disfarce da discricionariedade}

\footnotetext{
${ }^{67}$ Mais sobre ameaça, ver CLOSE, Patricia. The ABCs of discretion in antidumping injury decisions. International Trade and Regulation, v. 13, n. 5, 2007, p. 104-108.

${ }^{68}$ Mexico - Corn Syrup, WT/DS132/R. As autoridades mexicanas cometeram um erro ao não avaliar o impacto das importações sobre a indústria doméstica e, além disso, ao não examinar e considerar todos os aspectos do art. 3.4 do Acordo Antidumping.

${ }^{69}$ United States - Investigation of the International Trade Commission in Softwood Lumber from Canada, WT/DS277/AB/RW, 13 de abril de 2006.

70 3.7. A determinação de ameaça de dano material deverá basear-se em fatos e não meramente em alegações, conjecturas ou possibilidades remotas. Mudanças circunstanciais capazes de gerar situação em que o dumping causaria dano devem ser claramente previsíveis e iminentes 10. Na determinação de existência de ameaça de dano material, as autoridades deverão considerar, inter alia, os seguintes fatores: (a) significativa taxa de crescimento da disponibilidade no mercado interno de produtos importados a preços de dumping, indicativa de provável aumento substancial nas importações; (b) suficientes quantidades disponíveis ou iminente aumento substancial na capacidade do exportador que indiquem a probabilidade de significativo aumento das exportações a preços de dumping para o mercado do Membro importador, considerando-se a existência de outros mercados de exportação que possam absorver o possível aumento das exportações; (c) se as importações são realizadas a preços que terão significativo efeito em deprimir ou suprimir preços internos e que provavelmente aumentarão a demanda por novas importações; (d) estoques do produto sob investigação. Nenhum desses fatores tomados isoladamente poderá fornecer orientação decisiva, mas a totalidade dos fatores considerados deverá necessariamente levar à conclusão de que mais importações a preços de dumping são iminentes e que, a menos que se tomem medidas de proteção, ocorrerá dano material. (RUIZ FABRI, Hélène; MONNIER, Pierre. Chronique du règlement des différends 2005-2006. Journal du Droit International, juilet-aout-septembre 2006, p. 1237.)
} 
O artigo $6.8^{71}$ e o Anexo II do Acordo Antidumping autorizam o país investigador a fazer uso dos fatos disponíveis (facts available), também chamados de “melhor informação disponível”. Esta hipótese está limitada aos casos em que a parte se recusa ou, de outra forma, não oferece acesso à informação necessária, em um período razoável de tempo, ou quando a parte significativamente impede a investigação. Isso significa que a autoridade poderá usar as informações de que dispõe até aquele momento, ou as informações fornecidas pela indústria doméstica quando da elaboração da petição, para formular suas conclusões. ${ }^{72}$

O volume de informações requerido pelas autoridades nacionais geralmente é muito grande, sendo necessário que a parte interessada, seja ela o importador ou o exportador, tenha incentivos para fornecer o que lhe é solicitado. Um bom incentivo é a expectativa de que suas informações irão alterar o panorama da investigação, em seu favor. Da mesma forma, se constatado que a melhor informação disponível é mais benéfica do que a informação que poderiam apresentar, as partes deixarão de apresentar qualquer dado real. ${ }^{73}$

Se o não fornecimento significa que a autoridade pode fazer uso da informação da indústria doméstica, que, por sua vez, está interessada na aplicação de medidas antidumping, é esperado que os importadores e exportadores temam esta opção. A indústria doméstica colecionará os dados que mais lhe forem mais convenientes. Este é o incentivo aos importadores e exportadores: evitar a utilização de informações que lhe serão prejudiciais.

A utilização das informações disponíveis é motivo de diversas discussões na doutrina e em casos concretos, desde a Rodada Tóquio. Para tentar reduzir a discricionariedade da autoridade do país investigador, o Anexo II, do Acordo Antidumping da OMC, trouxe algumas condições para a utilização desta melhor informação. As condições são: i) os investigados devem ser avisados do entendimento

\footnotetext{
71 Art. 6.8. Salvo nas circunstâncias previstas no parágrafo 10, as autoridades deverão, no curso das investigações, certificar-se de que são corretas as informações fornecidas pelas partes sobre as quais aquelas autoridades basearão suas conclusões.

${ }_{72}$ Conforme Anexo II do Acordo, as autoridades são livres para tomar suas decisões baseadas em informações contidas no questionário do início da investigação, apresentado pela indústria doméstica.

73 MOORE, Michael. Facts available dumping allegations: when will foreign firms cooperate in antidumping petitions? European Journal of Political Economy. v. 21. 2005, p, 188.
} 
sobre o não fornecimento da informação solicitada; ii) nas questões em que forem solicitados dados de sistemas, as empresas não serão obrigadas a usar outros sistemas que não os seus; iii) toda a informação apropriadamente submetida deve ser considerada; iv) toda informação que for menos do que o ideal deve ser, de qualquer forma, considerada, se a parte fez o melhor que estava ao seu alcance para provê-la; v) se a informação não for aceita, a parte deve ser informação sobre as razões da rejeição e deve ser data oportunidade para que ela promova esclarecimentos em um período razoável de tempo; vi) se a informação que não a fornecida pela parte for utilizada, as autoridades devem checá-la com fontes independentes. ${ }^{74}$

Tais diretrizes nem sempre são observadas. Um Membro que possui certo interesse protecionista não fará grandes esforços para aguardar o envio de toda a informação solicitada ao exportador e, mesmo que este a envie, poderá ser mais rigoroso no que se refere à sua consideração. ${ }^{75} \mathrm{~A}$ autoridade pode acabar por desconsiderar outras informações já enviadas pelo exportador, reconhecendo as informações fornecidas pela indústria doméstica como úteis à investigação. As conclusões serão certamente desfavoráveis, neste caso, ao interesse dos exportadores, privilegiando-se facilmente a indústria doméstica.

Moore critica a prática norte-americana neste sentido. Os questionários solicitados pela autoridade são, segundo ele, excessivamente grandes, o que torna muito difícil a resposta das partes no tempo solicitado, que não é facilmente prorrogável. Além disso, as autoridades demandam dados no formato norte-americano a empresas em países que não utilizam este formato em sua atividade diária. Os norteamericanos também são extremamente criteriosos em suas verificações in loco,

\footnotetext{
${ }^{74}$ PALMETER, David. A commentary on the WTO Anti-Dumping Code, Journal of World Trade, v. 30, n. 4 1996, p. 57. No caso Egypt - Rebar from Turkey, WT/DS211/R, 8 de agosto de 2002, foi discutido, entre outros aspectos, o fato de a autoridade investigadora não ter concedido tempo suficiente para a resposta das informações solicitadas, e, por isso, teria considerado a melhor informação disponível.

${ }^{75}$ No caso Papéis (Korea - Certain Paper, WT/DS312/R, 28 de novembro de 2005), a indonésia sustentou que, na determinação do valor normal, a autoridade coreana deveria ter levado em consideração os dados relativos às vendas no mercado interno, apresentados por dois exportadores, nas respostas a seus questionários. A autoridade coreana sustentou que os dados financeiros e registros contáveis de um intermediário, por meio do qual os produtos eram colocados no mercado interno, não foram puderam ser verificados, o que a impediu de considerar os dados confiáveis. O Grupo Especial deu razão à coréia. Ele entendeu que as empresas não forneceram dados pedidos, em um prazo razoável, e que a autoridade teve que recorrer aos fatos disponíveis. Sem estes dados, os números das exportadoras não eram confiáveis. (RUIZ FABRI, Hélène ; MONNIER, Pierre. Chronique du règlement des différends 2005-2006. Journal du Droit International, juilet-aout-septembre 2006 , p. 1263).
} 
exigindo a demonstração de quase tudo o que foi questionado nos formulários. Se todas as exigências não são cumpridas, o Departamento de Comércio acaba considerando que a empresa foi apenas "parcialmente cooperativa", não levando em consideração nenhum dos dados que foram informados com perfeição. Já sabendo de todas estas dificuldades, as empresas norte-americanas tendem a requerer mais investigações, contando, muitas vezes, com a desconsideração total da informação fornecida pelos importadores e exportadores. $^{76}$

A melhor informação disponível é um mecanismo facilmente usado por países que desejam proteger a indústria doméstica. Sua utilização pode não ser derivada de má-fé, mas sim de um procedimento extremamente rígido adotado por aquele país. A desconsideração das informações fornecidas pelas partes interessadas, quando completas ou parcialmente completas, distorce os resultados da investigação em favor daqueles que a requereram, o que pode significar o afastamento, por estas autoridades, dos objetivos que permeiam a observância do interesse público, que serão vistos adiante.

\subsubsection{A necessidade de transparência}

Uma das principais reclamações nas controvérsias levadas ao mecanismo de solução de controvérsias da OMC é a falta de transparência nas investigações conduzidas pelas autoridades nacionais. O número de investigações sofreu um relativo aumento, mas não acompanhado pela evolução, nestes países, das regras sobre transparência, tanto em relação às informações fornecidas pelas partes, quanto em relação às decisões das autoridades.

A falta de transparência nos procedimentos e informações gera a insegurança em relação às decisões tomadas e ao que se pode esperar. É usual as partes estrangeiras contratarem representantes legais locais para os auxiliarem na defesa de seus interesses, mas nem mesmo estes representantes conseguem, por vezes, compreender determinadas ações ou suas justificativas.

76 MOORE, Michael. Facts available dumping allegations: when will foreign firms cooperate in antidumping petitions? European Journal of Political Economy. v. 21, 2005, p, 186. 
Como lembrado pelos Estados Unidos, as partes interessadas precisam da transparência em três momentos: 1) para conhecer os procedimentos da autoridade e se preparar para estes procedimentos; 2) para examinar a similaridade entre seu caso e casos anteriores; 3) para defender seus interesses no curso das investigações. Outros interessados também precisam ter amplo acesso a estas informações, tais como consumidores, sociedade civil, acadêmicos, etc. ${ }^{77}$

Em alguns Membros, brechas nas legislações contribuem para esta insegurança. Em muitos casos, não é possível saber se uma autoridade irá ou não proceder a uma verificação in loco, como irá reagir à ausência de vendas domésticas ou até mesmo conhecer o método de cálculo da margem de dumping. Com isso, algumas partes interessadas podem deixar de colaborar com as autoridades, deixando de fornecer dados importantes, por exemplo, quando não se sabe se haverá a verificação posterior destes dados.

Em alguns países em desenvolvimento, é visível a falta de recursos financeiros para que se proceda à verificação de determinadas informações e, em muitos casos, a autoridade investigadora conta com poucas pessoas, o que dificulta o desenvolvimento da investigação, o estudo de todos os dados e, com isso, a transparência. Esta não verificação torna o procedimento menos transparente, e a falta de pessoal faz com que a autoridade tenha dificuldades em divulgar todos os seus passos (o que demanda o dobro de trabalho).

Yu critica a prática chinesa neste sentido. Para ele, não há transparência em diversos procedimentos. Os resumos não confidenciais necessários, que são apresentados pelas próprias partes que desejam a confidencialidade de suas informações, são muito superficiais. Além disso, a autoridade não fornece resumos não confidenciais de suas decisões, para que as partes consigam entender como foi calculada a margem de dumping. Não há qualquer livro ou documento oficial que permita

77 Access to non-confidential information: paper from the United States. TN/RL/GEN/90, 17 de novembro de 2005. 
entender a prática do Ministério de Comércio da China. A maioria das decisões da autoridade são tomadas de forma confidencial. ${ }^{78}$

Problema semelhante é apontado por Vermulst na prática das Comunidades Européias. Procurações dos representantes legais são tratadas como confidenciais, os questionários estão disponíveis somente para as partes interessadas, o público não tem acesso às informações não confidenciais, os relatórios de verificação in loco não são fornecidos às partes, os Estados Membros são informados antes das partes interessadas sobre a aplicação de medidas antidumping provisórias e as diretrizes para aplicação da legislação são consideradas de uso interno e confidenciais. ${ }^{79}$

O procedimento para a determinação do interesse público nas investigações antidumping na Comunidade Européia também é criticado pela falta de transparência. Os consumidores e usuários industriais, por exemplo, não tem o mesmo direito das partes interessadas de acesso aos documentos não confidenciais. Desta forma, fica cerceado o direito de manifestação destes interessados em relação aos fatos apresentados no processo. Em 1989, o European Office of Consumer Unions (BEUC) desafiou a questão perante o Tribunal de Justiça. Contudo, a corte entendeu que as medidas não poderiam trazer prejuízos aos consumidores, ignorando a realidade econômica das partes diversamente afetadas pelas investigações, no caso dos consumidores, a possibilidade do aumento no preço e redução na escolha. ${ }^{80}$

Com base em tais constatações, alguns países membros da OMC propuseram modificações ao Acordo Antidumping. Em 17 de novembro de 2005, os Estados Unidos sugeriram um texto versando sobre transparência, para ser incluído no Acordo Antidumping (art. 6) e no Acordo de Subsídios (art. 12):

"Os Membros devem manter suas instalações abertas por um específico e
razoável período de tempo durante as horas normais de trabalho, quando
qualquer pessoa pode, sem custo ou agendamento, revisar todos os
documentos não confidenciais submetidos ou obtidos pela autoridade
durante as investigações. Estes documentos devem estar organizados de

${ }^{78} \mathrm{Yu}$, Tian. The 10 Major Problems with the Anti-Dumping instrument in the People's Republic of China. Journal of World Trade, v. 39, n. 1, 2005, p. 99.

79 VERMULST, Edwin. The 10 Major Problems with the Anti-dumping Instrument in the European Community. Cit. p. 107.

${ }^{80}$ Caso 170/89, Bureau Europeen des Unions de Consommateurs v. Commission, 1991, E.C.R I-5709. (WELLHAUSEN, Marc. The Community Interest Test in Antidumping Proceedings of the European Union. American University International Law Review, v. 16. p. 1037.) 
forma facilmente acessivel a qualquer pessoa, com um índice completo que devem ser disponibilizado ao interessado. É desejável que estes documentos estejam disponíveis na internet. Também devem manter disponível um arquivo com todas as notificações, em ordem cronológica, de acordo com o art. 12, e também cópias de todos os documentos submetidos ao Comitê de Práticas Antidumping. Os Membros devem permitir que qualquer documento não confidencial seja copiado por uma despesa razoável pelo interessado. " 81

Em 20 de abril de 2006, a Comunidade Européia propôs o documento TN/RL/GEN/110 ${ }^{82}$, no qual enfatizou a necessidade de revisão do sistema de aplicação das regras antidumping por cada membro, revisão que seria feita pelo Comitê de Regras. Tal revisão seria conduzida com base na análise dos relatórios submetidos por cada membro, que deveriam descrever suas ações visando à maior transparência nos procedimentos e prática antidumping. O Comitê deveria, então, elaborar um relatório dos fatos e estatísticas apresentadas. A freqüência deste relatório dependeria da freqüência de investigações antidumping por cada membro. Por exemplo, membros mais ativos enviariam este relatório a cada três anos.

A proposta da Comunidade Européia traz alguns exemplos de procedimentos que poderiam ser descritos no relatório dos membros, como método para determinação do preço de exportação e do valor normal, uso de país terceiro e método de construção de valor normal, métodos de comparação (ajustes), métodos para cálculo da margem de dumping, métodos para cálculo da margem de dano (subcotação, depressão ou supressão de preços), se o país aplica ou não a regra mínima (lesser duty), consideração do interesse público, procedimentos em investigação in loco, etc.

A revisão proposta pela Comunidade Européia, embora custosa, contribuiria para a redução da insegurança dos agentes econômicos em relação aos procedimentos nacionais. De certa forma, o Membro, tendo reportado todas as suas práticas, ficaria preso ao que já foi reportado à $\mathrm{OMC}$, não alterando sensivelmente seu desempenho nas próximas investigações.

A existência de transparência nas investigações antidumping é fundamental para a busca da verdade e da melhor solução para o país investigado. A

\footnotetext{
81 Access to non-confidential information: paper from the United States. TN/RL/GEN/90, $17 \mathrm{de}$ novembro de 2005.

${ }^{82}$ Transparency on antidumping activity: submission from the European Communities. TN/RL/GEN/110, 20 de abril de 2006.
} 
transparência facilita a ação das partes interessadas e permite o esclarecimento da opinião das autoridades, em todos os momentos em que isso for necessário. Nesse condão, a existência de transparência é essencial na investigação do interesse público, à busca do que é mais importante e recomendado para a economia do país investigador. 


\subsection{A CONSIDERAÇÃO DO INTERESSE PÚBLICO NO ANTIDUMPING}

Mesmo que sejam propostas soluções para definir métodos de cálculo, para se conferir maior transparência, melhor exame da situação da indústria doméstica, do dano e outros mecanismos para diminuir o arbítrio das autoridades locais, certa liberalidade sempre pertencerá àqueles que investigam. Por exemplo, uma autoridade deve investigar, ao avaliar o dano, a perda de participação de mercado, a diminuição na massa salarial e o fluxo de caixa, mas definir qual o valor será dado a estas variáveis é uma decisão discricionária.

Desta forma, se a autoridade for capturada, ou seja, assumindo a autoridade uma posição mais simpática a uma das partes envolvidas, seja por um contexto de mercado, seja por influência de lobby, seja por um senso quase natural de proteção ao mercado doméstico, a aplicação do antidumping sempre correrá o risco de uma decisão arbitrária e menos técnica.

No sentido contrário à proteção da indústria doméstica, como válvula de escape para a consideração de outros interesses que não o interesse dos produtores nacionais, alguns Membros propuseram a consideração do interesse público nas investigações antidumping. ${ }^{83} \mathrm{O}$ interesse público serve de justificativa para a não aplicação das medidas quando se entender que os benefícios gerados, por estas medidas, à industria doméstica, são menores do que os prejuízos provocados aos agentes diversamente afetados (consumidores, usuários industriais do produto, importadores, sociedade em geral, etc.).

A atual redação do Acordo Antidumping dispõe que, após analisados todos os requisitos para a aplicação do antidumping (sendo identificados o dumping, o dano e o nexo causal), a autoridade pode (e não deve) aplicar a medida. Fica a critério do Membro a aplicação da medida. Mas por que não aplicaria? Porque a aplicação seria contrária ao interesse público, segundo as propostas apresentadas pelos Membros.

\footnotetext{
${ }^{83}$ A consideração dos efeitos adversos do antidumping sobre importadores, consumidores, usuários do produto e outras partes é discutida desde 1923, no capítulo VIII da famosa obra de Jacob Viner. (VINER, Jacob: Dumping: a problem in international Trade. Chicago: The University of Chicago Press, 1923).
} 
Sendo facultativa a aplicação da medida, conforme a redação atual do Acordo Antidumping, alguns Membros já adotam, em suas legislações, o teste do interesse público. ${ }^{84} \mathrm{Em}$ alguns países, não é sequer necessária apuração do dano, dumping ou nexo causal se a autoridade entender, já no início da investigação, ou mesmo antes de sua abertura, que a aplicação não é interessante.

\subsubsection{As negociações do interesse público}

As negociações sobre o teste do interesse público no antidumping são antigas, não se trata de um tema novo. Contudo, pouco se avançou no sentido de tornála obrigatória, ou, de alguma forma, tentar harmonizar os entendimentos e a aplicação pelos Membros. Alguns deles já prevêem esta cláusula em seus ordenamentos, trazendo contribuições relevantes às discussões nos grupos de negociação do GATT e OMC. ${ }^{85}$ Outros, contudo, seguem afirmando que a imposição de uma cláusula que obrigue o Membro a observar o interesse público, definindo o que é este interesse, seria uma violação à soberania, já que a definição do que é interesse público cabe ao próprio Membro. ${ }^{86} \mathrm{O}$ Acordo Antidumping da OMC já permite a participação de partes interessadas no processo antidumping, ou seja, faculta alguma participação às empresas ou grupos de pessoas não pertencentes à indústria doméstica, tais como os importadores do produto sob investigação ${ }^{87}$, mas que possam contribuir com o entendimento da autoridade investigadora sobre os benefícios ou desvantagens da aplicação da medida. ${ }^{88}$

A primeira proposta sobre interesse público foi apresentada em 1989, por Hong Kong. As negociações alternaram momentos de euforia, no que diz respeito à aplicação da cláusula, e momentos de dúvida acerca de sua extensão e possibilidade de aplicação pelos Membros. A última proposta de rascunho para o Acordo Antidumping,

\footnotetext{
${ }^{84}$ São exemplos o Brasil, a Comunidade Européia, o Canadá e Hong Kong.

${ }^{85}$ Como exemplo, as contribuições trazidas por Hong Kong, Comunidade Européia e Canadá, que serão relatadas adiante.

${ }^{86}$ Como exemplo, que também será mencionado à frente, o Egito.

${ }^{87}$ Conforme art. 6.12 do Acordo Antidumping.

${ }^{88}$ Contudo, embora o Acordo Antidumping permita a manifestação de outros atores que não aqueles diretamente envolvidos na investigação (indústria doméstica, importador, exportador), o texto legal não tratou de definir a importância que seria dada a estas manifestações.
} 
apresentada aos Membros do Grupo de Negociações em Regras em 2007, prevê a realização obrigatória do teste do interesse público.

\subsubsection{Negociações sobre interesse público no GATT}

Segundo os países que defendem a cláusula do interesse público, outros elementos, além dos interesses dos produtores, devem influenciar a decisão da autoridade investigadora sobre a aplicação de uma medida antidumping. $\mathrm{O}$ interesse público é um fator que deve ser considerado no processo antidumping em geral e na aplicação de medidas antidumping particularmente. $\mathrm{O}$ interesse público deve envolver uma análise global dos efeitos das medidas para, se for o caso, não autorizar a aplicação de medidas antidumping.

Para que isso se torne obrigatório aos Membros da OMC, é necessário mudar a redação do art. 9.1. ${ }^{89}$ Alguns propuseram reformas, tais como Cingapura, Japão, Canadá, Hong Kong e Brasil. As negociações trazem este tema desde 1989, quando a questão foi debatida pela primeira vez no Grupo de Negociações sobre Bens. Analisando-se as atas do Grupo de Negociações sobre Bens ou do Comitê de Práticas Antidumping, disponíveis no sítio internet da OMC, é possível reviver, em parte, a história das negociações do interesse público.

Em julho de 1989, Hong Kong submeteu, ao grupo de negociações, um documento bastante instigante, que propunha a revisão de diversos pontos do Código Antidumping, reunidos em quatro pilares: i) a necessidade de melhor entender a racionalidade do antidumping no GATT; ii) a necessidade de remover certas ambigüidades no código, que trazem diferenças nos pontos de vistas dos Membros; iii) um maior detalhamento e precisão a certas obrigações, especialmente aquelas relacionadas aos procedimentos nas legislações nacionais; e iv) a obrigação de

\footnotetext{
${ }^{89}$ Art. 9.1. São da competência das autoridades do Membro importador a decisão sobre a imposição ou não de direito anti-dumping, quando estiverem preenchidos os requisitos necessários, e a decisão, sobre se o montante do direito anti-dumping a ser imposto será a totalidade da margem de dumping ou menos do que esse valor. E desejável que o direito seja facultativo no território de todos os Membros e que seu montante seja menor do que a margem de dumping, caso tal valor inferior seja suficiente para eliminar o dano à indústria nacional.
} 
transparência nas decisões das autoridades, que devem seguir critérios mais rígidos na aplicação das medidas. ${ }^{90} \mathrm{O}$ mesmo Membro, em um documento imediatamente posterior, apresentado em setembro de 1989, propôs que os produtores domésticos deixassem de ser a única preocupação dos investigadores. Os interesses da indústria importadora e os custos das medidas deveriam ser levados em consideração. ${ }^{91}$

Com a discussão do Código Antidumping iniciada, foram enviadas diversas propostas, com relação a diversas modificações no Acordo Antidumping.

Cingapura propôs, em outubro de 1989, a consideração dos interesses dos consumidores e usuários industriais dos produtos também quando da decisão de iniciar uma investigação. Alguns procedimentos deveriam ser estabelecidos para levar em consideração interesses públicos mais amplos do que os interesses das partes afetadas. Este documento enfatizou a necessidade da instituição de uma cláusula de interesse público, pela primeira vez assim nomeada, porque a) as leis antidumping protegem os interesses dos produtores domésticos à custa dos consumidores e, b) as práticas antidumping atuais têm causado efeitos adversos à economia nacional e custos à indústria importadora. Assim: "o objetivo da cláusula de interesse público é assegurar que as autoridades investigadoras considerem as demandas de antidumping em um contexto amplo, levando em consideração não somente o interesse das indústrias afetadas, mas também os interesses dos usuários industriais e os custos de uma intervenção antidumping para a economia nacional." 92

O documento de Cingapura lembrou que o tema não seria completamente estranho a algumas legislações. Contudo, vários elementos, como o conceito de interesse público, deveriam ser estudados e debatidos pelo grupo

\footnotetext{
${ }^{90}$ Principles and Purposes of Anti-dumping provisions: communication from the delegation of Hong Kong, MTN.GNG/NG8/W/46, 3 de julho de 1989 e Amendments to the Anti-dumping code: communication from the Delegation of Hong-Kong - Addendum, MTN.GNG/NG8/W/51/Add.1, 22 de dezembro de 1989.

${ }^{91}$ Amendments to the Antidumping Code, Communication from the Delegation of Hong Kong, MTN. GNG/NG8/W51 12 September 1989

${ }^{92}$ O documento tem início com a descrição: "o objetivo deste trabalho é sugerir uma base principiológica e dos objetivos das regras de antidumping. Esta submissão ressalta os princípios básicos e os objetivos, incluindo os assuntos que serão tratados para que as regras antidumping não sejam usadas como instrumento protecionista, disfarçando salvaguardas ou de forma não condizente com o interesse público" Tradução literal de Proposed Elements for a Framework for Negotiation, principles and objectives for antidumping rules, communication for the delegation of Singapore, GATT Doc, n. MTN, GNG/NG8/W/55 (13 de outubro de 1989), p. 3.
} 
negociador. Alguns procedimentos poderiam ser adotados, como conceder a importadores e consumidores maior acesso às investigações, estabelecendo a obrigatoriedade de as autoridades levarem em consideração os interesses destes grupos. A autoridade poderia, também, examinar o comportamento competitivo dos produtores domésticos e determinar se eles estão envolvidos em práticas restritivas de comércio. Se eles estiverem, as petições de indústrias anticompetitivas deveriam ser rejeitadas, já que uma medida antidumping pode apenas reforçar o poder de mercado destas empresas.

Em 22 de dezembro de 1989, o Canadá expôs sua preocupação. Segundo o texto, a crescente interdependência entre as economias fez com que a questão da avaliação do dano provocado pelo dumping fosse inserida em um contexto mais amplo. O objetivo da discussão deve ser permitir a consideração de fatores econômicos maiores. A aplicação do antidumping provoca efeitos sentidos pelos consumidores, por outras indústrias e pela economia em geral. As partes devem acordar procedimentos para a consideração formal de quando a imposição do antidumping é uma medida de interesse público. Esta consideração deve ter lugar após a determinação do dano. ${ }^{93}$

É da mesma data um documento coreano que defende a consideração de fatores como produção, competitividade e lucratividade das firmas importadoras. $\mathrm{O}$ interesse dos consumidores, o grau de concentração e o nível competição na indústria doméstica foram fatores apresentados pela Coréia para serem incluídos na proposta de interesse público. ${ }^{94}$

Em 29 de janeiro de 1990, o Japão enviou sua manifestação. Para o Membro, as medidas antidumping afetariam não somente os produtores domésticos, mas toda a indústria nacional, incluindo consumidores. Então, antes de impor medidas antidumping, a autoridade investigadora deveria levar em consideração estes efeitos. $\mathrm{O}$ Japão sugeriu um rodapé ao artigo 8.1: “Antes de impor medidas antidumping, as

\footnotetext{
${ }^{93}$ Amendments to the Anti-dumping Code - Submission by Canada. MTN.GNG/NG8/W/65, 22 dezembro de 1989.

94 Submission by the Republic of Korea on the Antidumping Code, Addendum, MTN. GNG/NG8/2/40/Add.2 20 December 1989.
} 
autoridades devem levar em consideração seus impactos sobre toda a economia nacional." $" 95$

O grande opositor à inclusão de cláusulas sobre o interesse público foi os Estados Unidos, para quem tais considerações deveriam ser discutidas pelas legislações domésticas, não devendo ser uma imposição multilateral. Além disso, os Estados Unidos argumentaram que considerar o interesse público seria abrir espaço para a ação de grupos lobistas que tenderiam a interferir na análise objetiva dos fatos. $O$ documento proposto pelos Estados Unidos lembrou que, em alguns países (sem mencionar quais), cabe à autoridade administrativa decidir quando e se será analisado o interesse público. Alguns Membros da OMC que aplicam a cláusula reportaram que ela tem funcionado de forma aceitável, mas que este teste pode dar menor atenção aos aspectos técnicos, jurídicos e à objetividade esperada da investigação. ${ }^{96}$

A indeterminação do conceito de interesse público sempre foi um grande empecilho à sua consideração. Além disso, o fato de que ele não fora definido pelo Direito Internacional, o que deixaria as legislações nacionais como responsáveis por sua definição, foi um dos obstáculos mencionados pelos Estados Unidos.

Em abril de 1990, os países nórdicos elaboraram proposta que defendia a observância do interesse público como critério para definir se a autoridade abrirá ou não a investigação. Também foi lembrada a necessidade de observar o interesse em outras fases da investigação, como na decisão de aplicação de medidas provisórias. Estes países propuseram uma nota de rodapé ao artigo 8:

\begin{abstract}
"Ao decidir sobre a abertura de uma investigação, se aplicáveis ou não medidas provisórias ou definitivas, e sobre o valor de tais medidas, a autoridade deve considerar se elas serão de interesse público. Considerações de interesse público devem estar relacionadas a questões como a situação competitiva, os interesses dos consumidores e usuários industriais do produto e outras circunstâncias econômicas relevantes. "97
\end{abstract}

\footnotetext{
${ }^{95}$ Submission of Japan on the Amendments to the Antidumping Code, MTN.GNG/NG8/W/48/Add.1, 29 de janeiro de 1990.

96 Meetings of January 31 - February 2 and February 19-20, 1990, GATT Doc n. MTN.GNG/NG8/15 (19 de março de 1990) pp 38-39.

${ }^{97}$ Drafting proposals of the Nordic Countries Regarding Amendments of the Anti-dumping Code. GATT Doc. N. MTN.GNG/NG8/2/76.(11 de abril de 1990), p. 5.
} 
Em 17 de abril de 1991, a Coréia, esclareceu que, naquele país, "os fatores relativos ao interesse público no antidumping são também (mas não somente) considerados ao fim das investigações. Entre os aspectos a serem considerados, estão os preços domésticos, o impacto sobre as importações, o impacto em outras indústrias. A consideração do interesse público poderá ser feita quando da decisão de se iniciar uma investigação antidumping, ou aplicar medidas provisórias. Contudo, isso não é a regra. O Governo Coreano nunca rejeitou a abertura de uma investigação ou a aplicação de medidas provisórias com base no interesse público."98

\subsubsection{Negociações sob a égide da OMC}

Debates não menos interessantes se desenrolaram a partir de 1995, já no âmbito da OMC. Naquele momento, já havia sido aprovado o Acordo Antidumping, de observação obrigatória por todos os Membros, prevendo a possibilidade de aplicação ou não de medidas, a critério do Membro. Não há, contudo, artigo que especifique que estas medidas não serão aplicadas se sua aplicação não for de interesse público.

Entre 1995 e 2002, observou-se um período de familiarização, pelos Membros, com as novas disposições. Alguns deles, que não possuíam legislação antidumping, adotaram-na. Outros, que já aplicavam medidas antidumping, adaptaram suas leis às novas exigências multilaterais. Somou-se a esta fase o momento de abertura comercial relevante, com o aumento da participação dos países desenvolvidos nas exportações, bem como com a abertura de vários mercados desenvolvidos aos países em desenvolvimento.

Em 2002, o primeiro documento registrado pelo Grupo de Negociações em Regras, uma Comunicação do Canadá, registrou que, entre as áreas que devem ser beneficiadas pelo esclarecimento das regras e disciplinas nas negociações ${ }^{99}$, está, entre outras, a consideração do interesse público. ${ }^{100}$

\footnotetext{
${ }^{98}$ Responses by the Republic of Korea to Questions Raised by the European Commission, GATT Doc. N. ADP/W/287 (17 de abril de 1991), p. 2.

${ }^{99} \mathrm{O}$ art. 28 da Declaração de Doha dispõe que os Membros se propõem a negociar, para esclarecer e melhorar as regras do Acordo sobre a Implementação do Artigo VI do GATT 1994. As expressões
} 
Em 26 de abril do mesmo ano, o Brasil, Chile, Colômbia, Costa Rica, Hong Kong, China, Israel, Japão, Coréia, México, Noruega, Singapura, Suíça, Tailândia e Turquia $^{101}$ enviaram um documento no qual ressaltaram os pontos, no Acordo Antidumping, que acreditavam ser de urgente consideração e estudo pelo Grupo de Negociações em Regras. Entre eles, foi mencionada a consideração mais ampla do interesse público. Como exemplo, citaram:

\begin{abstract}
"Imagine-se uma petição submetida contra importadores no intuito de proteger 1.000 empregos de determinada indústria. Os importadores se opõem frontalmente a esta petição. Eles alegam que não poderão competir se o preço do produto importado subir significativamente e que 5.000 empregos desta indústria serão perdidos se as medidas forem aplicadas. Além disso, uma associação de consumidores também expressa sua preocupação de que os preços irão subir vertiginosamente se as medidas forem impostas. Esta associação demonstra que o custo para os consumidores é quatro vezes maior que o ganho para os produtores domésticos. A autoridade administrativa ignora todas as manifestações e impõe altas medidas antidumping. São estas medidas racionais? Devem as autoridades levar em consideração os interesses dos outros setores afetados pela medida?" 102
\end{abstract}

$\mathrm{Na}$ primeira submissão da Comunidade Européia ao Grupo de Negociações em Regras da OMC, o bloco econômico ilustrou as disciplinas que julgava merecedoras de estudo profundo, sobre as quais gostaria de compartilhar as suas experiências. Entre elas, o que chamou de teste do interesse público, ou exame do impacto sobre os operadores econômicos. Ela ressaltou que este teste, embora seja em sua natureza discricionário, é capaz de fornecer uma larga e completa análise da situação do mercado doméstico importador. ${ }^{103}$

originais usadas, no idioma inglês, são "clarifying and improving disciplines". (WTO, Ministerial Declaration adopted on 14 November 2001, WT/MIN(01)/DEC/1.)

${ }^{100}$ Improved Disciplines under the Agreement on Subsidies and Countervailing Measures and the AntiDumping Agreement, TN/RL/W/1, 15 de abril de 2002.

${ }^{101}$ Chamados de Friends of Antidumping (FANs), ou amigos do antidumping. Este grupo foi formado na década de 80 , quando os países em desenvolvimento, sobretudo no sudeste asiático, eram surpreendidos por medidas antidumping semanais contra seus produtos. Com a mudança desta conjuntura, o grupo foi dividido entre aqueles Membros mais radicais, que não aplicam medidas, apenas as sofrem, e Membros mais flexíveis, como o Brasil

${ }_{102}^{102}$ Anti-Dumping: illustrative major issues, TN/RL/W6, 26 de abril de 2002.

${ }^{103}$ Submission from the European Communities concerning the Agreement on Implementation of Article VI of GATT 1994 (Antidumping Agreement), TN/RL/W13, 8 de julho de 2002. 
Diante de tais primeiros questionamentos, a primeira ata de conclusões do grupo negociador de regras manifestou a inexistência e necessidade de uma metodologia clara sobre interesse público. ${ }^{104}$

Em um próximo documento da Comunidade Européia, ela questionou ao grupo: i) quais são as idéias dos proponentes (Membros da OMC) sobre interesse público e como construir um teste do interesse público? ii) deve ser o interesse público um requisito procedimental para coletar certas informações, ou deve ser ele um teste com critérios substantivos a serem considerados pela autoridade investigadora? iii) já existem idéias para estes critérios substantivos? ${ }^{105}$

Em resposta aos questionamentos, Brasil, Chile, Colômbia, Costa Rica, Hong Kong, China, Israel, Japão, Coréia, México, Noruega, Singapura, Suíça, Tailândia e Turquia apresentaram sua contribuição. Para eles, o art. 6.2 do Acordo Antidumping ${ }^{106}$ deveria ser aperfeiçoado, introduzindo-se um critério mais substantivo. O objetivo de uma medida de interesse público deveria ser diminuir ou eliminar direitos antidumping em razão de considerações de um interesse público mais amplo. Seria necessário examinar, durante o curso das investigações, os outros interesses (consumidores, importadores, etc.) também afetados se a medidas forem impostas no todo ou em parte. ${ }^{107}$

Segundo o mesmo grupo de Membros, há vários momentos durante uma investigação em que interessados podem se manifestar (consumidores, usuários industriais, autoridades antitruste) sobre quando (em qual estágio da investigação) e como o interesse público deve ser considerado (quais fatores). Respondendo-se a estas

\footnotetext{
${ }^{104}$ Summary Report of the Meeting Held on 8 and 10 July 2002, TN/RL/M/3, 1 de agosto de 2002.

${ }^{105}$ Questions from the European Communities on Documents TN/RL/W/6 AND TN/RL/W/10, de 10 de outubro de 2002.

${ }^{106}$ Art. 6.2. Ao longo das investigações anti-dumping, todas as partes interessadas devem dispor de completa possibilidade de defesa de seus interesses. Para essa finalidade, as autoridades deverão, caso assim requeridas, propiciar oportunidade para que todas a partes interessadas possam encontrar-se com aquelas partes que tenham interesses antagônicos, de forma a que interpretações opostas e argumentação contrárias possam ser expressas. O propiciamento de tais oportunidades deverá levar em consideração a necessidade de ser preservada a confidencialidade e a conveniência das partes. Não deverá existir qualquer obrigatoriedade de comparecimento a tais encontros e a ausência de qualquer parte não poderá ser usada em prejuízo de seus interesses. As partes interessadas deverão ter o direito, se devidamente justificado, de apresentar informações adicionais oralmente.

${ }_{107}$ Replies to questions to our first contribution (TN/RL/W/6), Paper from Brazil, Chile, Colombia, Costa Rica, Hong Kong, China, Israel, Japan, Korea, Norway, Singapore, Switzerland and Thailand, TN/RL/W/45, 27 de janeiro de 2003.
} 
questões (quem, quando e como), estariam respondidas questões sobre procedimentos e sobre as questões substantivas relacionadas ao interesse público. Se nenhum acordo for alcançado sobre como considerar o interesse público, é possível que os efeitos negativos das medidas para consumidores e usuários industriais sejam maiores do que os efeitos positivos para a indústria doméstica. Neste caso, o impacto total para o país como um todo é negativo e, conseqüentemente, contrário aos objetivos da $\mathrm{OMC}$ de melhorar o bem-estar coletivo por meio do comércio e sua disciplina.

A Austrália, em 15 de outubro de 2002, manifestou-se contrariamente à inclusão do teste do interesse público nas considerações fundamentais do Grupo de Negociações em Regras, por entender que a consideração do interesse público depende da maneira como cada Membro se relaciona com sua própria lei. ${ }^{108}$

Em dezembro de 2002, os Estados Unidos apresentam questões dirigidas à Comunidade Européia, relacionadas à sua prática. Eles acrescentam alguns questionamentos, como: i) é o Membro livre para determinar quais critérios irá utilizar na determinação do interesse público? ii) a Comunidade Européia faz este teste? iii) em caso positivo, qual metodologia utilizada? iv) este teste está sujeito à revisão judicial? v) se sim, quais são os resultados desta revisão? ${ }^{109}$

Tal manifestação é quase simultânea à nova manifestação canadense, para quem "estas negociações devem objetivar atingir a efetividade da legitimidade das medidas antidumping e limitar inconsistentes, algumas vezes ilegais, medidas antidumping." 110 Para este Membro, o artigo 6.2 instrui as autoridades a fornecerem oportunidades para a representação de consumidores e usuários industriais sobre dumping, dano e nexo causal. Enquanto esta obrigação é limitada em seu escopo, alguns membros tomaram medidas para permitir que estas partes submetam argumentos relevantes sobre um leque de assuntos econômicos relacionados à imposição das medidas antidumping. Aspectos fundamentais, relacionados ao interesse público, podem incluir incapacidade de fornecimento, aumentos dos preços para usuários comerciais e

\footnotetext{
${ }^{108}$ Comments on Document TN/RL/W/6 on Anti-Dumping Measures, Paper from Australia, TN/RL/W/22, 15 de outubro de 2002.

${ }^{109}$ Second set of questions from the United States on papers submitted to the Rules Negotiation Group, TN/RL/W/34, 2 de dezembro de 2002.

${ }^{110}$ Submission from Canada respecting the Agreement on Implementation of Article VI of the GATT 1994 (The Antidumping Agreement), TN/RL/W/47, 28 de janeiro de 2003.
} 
industriais, preocupações concorrenciais. Então, concluiu o Canadá que os esforços para melhorar o Acordo Antidumping precisam incluir um exame dos fatores indesejáveis do antidumping e esforços para reforçar as previsões do acordo que considerassem as conseqüências do antidumping para a economia, comércio e competição.

No início de 2003, os Estados Unidos questionaram se é necessário que todos os países usem os mesmos critérios na definição do interesse público, ou se há certa flexibilidade para que os Membros definam o que é interesse público. ${ }^{111}$

Em fevereiro do mesmo ano, o Canadá, em sua manifestação, comentou a proposta australiana de que cada país deve ser livre para definir o que entendesse como interesse público. O Canadá enfatizou a necessidade de previsibilidade, transparência e respeito ao devido processo. O Acordo Antidumping reconhece o conceito de interesse público por meio da regra de que a margem de dumping não pode ser imposta em sua totalidade e, como o Canadá acrescentou, reconhece o direito dos usuários industriais dos produtos e dos consumidores. ${ }^{112}$

Comentário contrário ao interesse público pode ser encontrado na manifestação do Egito. Para este Membro, a decisão de iniciar a investigação, baseandose ou não neste interesse, deve ser deixada à escolha do país, que é livre para decidir qual peso dar a estas considerações em sua determinação. ${ }^{113}$ Em outra manifestação, no mesmo ano, o Egito esclareceu que as atuais previsões do Acordo Antidumping são claras o suficiente e dão à autoridade a opção de determinar quando o interesse público irá se beneficiar das medidas antidumping. O Egito considerou que o teste do interesse público deveria continuar sendo uma questão de política doméstica, deixada à decisão de cada um, pois a decisão de conduzir tal teste demandaria uma complexa e detalhada

\footnotetext{
111 Third set of questions from the United States on papers submitted to the Rules Negotiation Group, TN/RL/W/54, 6 de fevereiro de 2003.

112 Comments from Australia on Canada's submission on the antidumping agreement. (DOCUMENT TN/RL/W/47), TN/RL/W/62, 11 de fevereiro de 2003.

${ }^{113}$ Preliminary comments and questions by the Arab Republic of Egypt on the contributions submitted in the framework of the Doha Negotiations on the antidumping agreement and on the agreement on subsidies and countervailing measures, TN/RL/W/79, 24 de março de 2003.
} 
análise dos vários aspectos e setores de uma economia e consumiria uma desarrazoada quantidade de tempo e recursos. ${ }^{114}$

O presidente do Grupo de Negociação de Regras apontou um resumo das medidas postuladas envolvendo o interesse público: a) esclarecer as regras e disciplinas relacionadas à consideração de um interesse público mais amplo; b) reforçar regras para garantir que informações mais relevantes considerando o interesse público sejam levadas em consideração de uma maneira mais substantiva; c) discutir quando as autoridades devem levar em consideração os interesses de outros setores econômicos afetados pelas medidas; d) discutir o estabelecimento de um teste do interesse público como uma condição adicional para a imposição de medidas; e e) examinar os efeitos indesejados do antidumping e esforços para se considerar as conseqüências das medidas para a economia como um todo, comércio e competição. ${ }^{115}$

Em 29 de março de 2005, Costa Rica, Hong Kong, China, Israel, Japão, Coréia, Noruega, Suíça, Taiwan, Penghu, Kinmen, Matsu e Tailândia apresentaram manifestação. Logo no primeiro parágrafo, lembraram que uma medida antidumping afeta o fluxo de comércio entre o Membro importador e o Membro exportador. Esta medida provoca efeitos diretos sobre a indústria doméstica, mas o seu custo é suportado pela economia do Membro importador como um todo, chegando àqueles que pagam os tributos. O Acordo Antidumping não obriga o Membro a considerar estes efeitos adversos. Dizer que a aplicação de medidas é compatível com a economia do país importador não limita o direito dos membros de aplicá-las, mas assegura que o uso do antidumping tenha uma base econômica e ajude a afastar a preocupação de que alguns membros estão usando o antidumping como uma ferramenta conveniente para reduzir o acesso aos seus mercados. Isto provoca um efeito positivo na promoção do comércio do membro importador e em seu desenvolvimento econômico, o que se adéqua ao propósito do sistema multilateral de comércio.

Estes países lembraram que sua proposta se encontra apoiada em quatro fatores: 1) o acordo deve incluir uma previsão para que as autoridades, antes de

\footnotetext{
${ }^{114}$ Egyptian paper containing replies to questions posed by Australia in document number TN/RL/W/73, $T N / R L / W / 101$, de 6 de maio de 2003.

${ }^{115}$ Negotiating Group on Rules: note by the Chairman. TN/RL/W/143, 22 de agosto de 2003.
} 
aplicar a medida antidumping, determinem se ela faz parte do interesse econômico mais amplo do Membro. Esta medida pode ser aplicada, não aplicada ou mitigada ${ }^{116}$; 2) o acordo deve escolher fatores mínimos para consideração da autoridade, como o custo de tais medidas para os consumidores industriais, consumidores finais, importadores, atacadistas e varejistas, efeito sobre a produtividade na cadeia de produção, competição e escolha dos consumidores. Esta lista não deve ser exaustiva e os membros devem ser livres para levar em consideração outros fatores; 3) deve ser dado o direito de manifestação a qualquer interessado, manifestação que pode ser a apresentação de fatores ligados à consideração do interesse público ${ }^{117}$; 4) transparência: as autoridades devem revelar suas conclusões e explicar quais fatos relevantes foram considerados na sua determinação (sobre o interesse público). ${ }^{118}$

O interesse público, a partir da proposta apresentada e acima mencionada, foi um dos assuntos da reunião de 11, 13 e 15 de abril de $2005 .{ }^{119}$ Alguns Membros (o documento não diz quais) aduziram preocupações em relação à aplicação da cláusula, tais como 1) o conceito de interesse público é muito subjetivo, devendo ser deixada aos Membros a tarefa de definir critérios; 2) a proposta permite a consideração de aspectos não-econômicos e isso traz preocupações em relação à obrigação de não discriminação; 3) a aplicação do teste consume tempo, é custosa e demanda ônus às partes interessadas e às autoridades investigadoras; 3 ) a proposição do teste do interesse público não tem como o objetivo o mesmo escopo da regra do direito mínimo? 4) não haverá sobreposição entre as tarefas da autoridade investigadora e das autoridades antidumping? 5) por que não fazer do teste apenas diretrizes, não um teste obrigatório? 5) até que ponto o mecanismo de solução de controvérsias da OMC está autorizado a determinar se os Membros fizeram o julgamento correto sobre o interesse público? e, por fim, 6) será que suportar preços de dumping é de interesse público mais amplo?

\footnotetext{
${ }^{116}$ Os FANs abrem a discussão sobre como seria a medida antidumping mitigada. Por exemplo, pode-se reduzir o nível da medida, o período da aplicação ou pela sua suspensão.

${ }^{117}$ Deve ser dada a ciência, a todos os possíveis interessados, sobre a existência de uma investigação, assim como prazo suficiente para a sua manifestação.

118 Public Interest: paper from Chile, Costa Rica, Hong Kong, China, Israel, Japan, Korea, Norway, Switzerland, Separate Customs Territory of Taiwan, Penghu, Kinmen and Matsu and Thailand. TN/RL/W/174, 29 de março de 2005.

${ }^{119}$ Summary Report of the Meeting held on 11, 13 \& 16 April 2005, TN/RL/M/26, 11 de maio de 2005.
} 
Os amigos do antidumping responderam, na mesma oportunidade, a alguns destes questionamentos. Disseram que o teste é primariamente econômico, a aplicação do teste é de tal interesse econômico que nenhum membro tem dificuldades de aplicá-lo como uma obrigação. Responderam, sobre o mecanismo de solução de controvérsias, que uma controvérsia relativa à aplicação do teste não é muito distinta de nenhuma outra controvérsia já julgada. Explicaram, também, que o teste do interesse público se difere totalmente da regra do direito mínimo. Isto porque esta última analisa até que ponto uma medida é adequada para sanar o dano da indústria doméstica, ao passo que o teste do interesse público estuda efeitos da medida sobre outros setores da economia.

A África do Sul, em manifestação de 29 de maio de $2006^{120}$, reconheceu a importância da consideração do interesse público, mas defendeu que isto pode trazer um custo maior à autoridade e o cometimento de recursos administrativos. Por isso, para os sul-africanos, a inclusão ou não desta previsão nas legislações nacionais deve ser uma prerrogativa do Membro, especialmente em países em desenvolvimento. ${ }^{121}$

\subsubsection{As propostas de redação do teste e suas críticas}

Além das propostas discutidas nas inúmeras reuniões realizadas no GATT e no período após a criação da OMC, cabe destacar as propostas de redação para a cláusula, já indicando, a partir de 2005, um momento mais avançado da discussão.

Em 1 de julho de 2005, os Amigos do Antidumping propuseram um texto para a cláusula do interesse público: ${ }^{122}$

\section{Artigo [x] Interesse Público}

[x.1] Antes de aplicar uma medida definitiva, as autoridades devem dar ampla oportunidade aos agentes que podem ser afetados pela medida para

\footnotetext{
120 Proposals on issues relating to the anti-dumping agreement: paper from South Africa. TN/RL/GEN/137, 29 de maio de 2006.

${ }_{121}$ Quadro com o resumo de todas as propostas foi apresentado como Anexo 1 a este trabalho.

${ }^{122}$ Further Submission on Public Interest: communication from Hong Kong, China, Israel, Japan, Korea, Norway, Switzerland, Separate Customs Territory of Taiwan, Penghu, Kinmen and Matsu and Thailand, TN/RL/GEN/53, 1 de julho de 2005.
} 
comentá-la. Para este fim, a autoridade deve divulgar publicamente e mandar notificações para os agentes relevantes conhecidos, dando a eles pelo menos [ ] dias para se manifestar em referência ao parágrafo segundo abaixo.

[x.2] Agentes relevantes podem tecer comentários sobre os efeitos da medida antidumping, entre outros:

(i) Custos para os usuários industriais, consumidores, importadores, atacadistas e varejistas do produto em consideração;

(ii) Competição no mercado do produto considerado no membro importador $^{123}$;

(iii) Escolha ou disponibilidade do produto similar em preços competitivos aos usuários industriais e consumidores;

(iv) Lucratividade e competitividade ${ }^{124}$ dos usuários industriais, importadores, atacadistas e varejistas do produto em consideração.

[x.3] A oportunidade para tecer comentários em relação ao parágrafo primeiro deve ser dada na primeira oportunidade em que tais agentes relevantes sejam capazes de fornecer comentários interessantes. Quando a oportunidade for dada antes que sejam fornecidos os detalhes da medida antidumping a ser aplicada (incluindo razões do dumping e dano), aos agentes relevantes deve ser dado [ ] dias para complementar seus comentários quando tais detalhes forem conhecidos.

[x.4] Para os fins deste artigo, agentes relevantes que não forem já partes interessadas devem gozar dos mesmos direitos das partes interessadas de acordo com o parágrafo primeiro, (exceto 1.1 e $1.3^{125}$ ), parágrafos $2^{126}$ e $5^{127}$ e parágrafos $9^{128}$ e $13^{129}$ do artigo 6 .

[x.5] Os comentários recebidos relativos a este artigo devem ser levados em consideração pelas autoridades em uma análise objetiva e imparcial. Quando nenhuma informação for recebida ou a informação for incompleta, as autoridades devem levar em consideração a melhor informação disponível de fontes públicas, se for razoável obtê-las. Se o Membro importador concluir que não é de seu interesse econômico impor as medidas antidumping definitivas, as medidas não deverão ser impostas. ${ }^{130}$

A expressão "agentes relevantes” está definida, no rodapé da proposta, como importadores, varejistas, atacadistas, usuários industriais, consumidores, que tenham um elo econômico com o produto sob investigação. Contudo, menciona também o rodapé que os países são livres para estender estes direitos a outras categorias, até mesmo ao público em geral, de acordo com a legislação nacional.

\footnotetext{
${ }^{123}$ Segundo explicado mais adiante, na mesma proposta, um destes fatores pode ser a aplicação de medidas antidumping que tem como efeito expulsar os exportadores do mercado e, com isso, reforça uma posição dominante da indústria doméstica.

${ }^{124} \mathrm{~A}$ lucratividade ou competitividade são severamente afetadas pelo aumento dos preços à montante, ou pela dificuldade em obtenção do produto.

${ }_{125}$ Ampla oportunidade para apresentar informação e acesso à informação apresentada pela outra parte.

${ }^{126}$ Ampla oportunidade para defender seus interesses.

${ }^{127}$ Tratamento a ser dado a uma informação oral.

${ }^{128}$ Fatos essenciais, disponíveis no final da investigação.

${ }^{129}$ Assistência a partes interessadas, especialmente pequenas empresas.

${ }^{130}$ Tradução livre do inglês.
} 
Após divulgada a proposta de texto, a Jamaica foi a primeira a sugerir que fosse considerada uma outra versão. Defendeu a Jamaica que os Amigos do Antidumping não estariam defendendo a observação de um interesse público mais amplo, um interesse público nacional, mas sim a observância de fatores que estão muito mais relacionados à competição e à possibilidade de escolha do que propriamente a um contexto maior. Por isso, considerando-se tais fatores restritos, podem surgir outros, mais amplos e não necessariamente econômicos, que desmotivem a aplicação do teste ou cláusula do interesse público. ${ }^{131}$

Hong Kong lembrou que a proposta dos amigos do antidumping coaduna com os objetivos de boa governança e transparência. Isto porque os países, ao aplicarem o teste, seriam obrigados a discutir os custos e benefícios do antidumping. Além disso, o próprio Acordo Antidumping prevê a possibilidade de que as medidas não sejam aplicadas ${ }^{132}$, sendo a proposta do interesse público perfeitamente compatível com o sentido do acordo. ${ }^{133}$ Hong Kong também apresentou resposta à opinião da Jamaica acima exposta. Para a Jamaica, outros fatores, que não sejam econômicos, devem ser considerados, autorizando-se, assim, a não aplicar as medidas. Para Hong Kong, isso não teria sentido, já que o mecanismo antidumping é eminentemente econômico e não se prestaria a fazer considerações de natureza não econômica.

Hong Kong fez sugestões acerca da implementação da cláusula. O Membro lembra, por exemplo, que o texto sugerido menciona "autoridades", sem determinar quais são. Isto deve ficar a cargo de cada Membro. Como método, Hong Kong propõe que sejam aplicados métodos quantitativos, já que grande parte da informação fornecida será quantitativa (ex. aumento do custo). Informações qualitativas podem ser utilizadas na apreciação da disponibilidade e escolha, por exemplo. Sobre a análise concorrencial, Hong Kong defendeu que a proposta não obriga as autoridades investigadoras a pedir auxílio às autoridades concorrenciais, se existentes, nem obriga tais autoridades a fazerem uma análise concorrencial. Para o Membro, as autoridades investigadoras já têm competência para tratar a questão, já que os elementos a serem

${ }^{131}$ Comments by Jamaica on Proposals to the Negotiating Group on Rules discussed at the Group's Meeting on 26-30 September 2005. TN/RL/W/188, 10 de outubro de 2005.

${ }^{132}$ Artigo 9.1 do Acordo Antidumping.

${ }^{133}$ Further Explanation of the Public Interest Proposal: Paper from Hong Kong, China. TN/RL/W/194, 17 de novembro de 2005. 
analisados (custo, disponibilidade no mercado, lucratividade e competição) não são estranhos ao texto do acordo em vigor. Além disso, o artigo 3.5 já determina o exame de todos os fatores concorrenciais que podem estar provocando dano à indústria doméstica, incluindo práticas restritivas de mercado e competição entre produtores domésticos e estrangeiros. ${ }^{134}$

Outra preocupação está relacionada ao fato de que a aplicação da cláusula pode aumentar o período de duração de uma investigação. Alguns Membros sugeriram que a consideração do interesse público se dê antes mesmo do início da investigação e, assim, não haveria prejuízo ao prazo determinado pelo acordo. Defendeu Hong Kong que os membros troquem experiências sobre esta prática, mas lembrou que outros procedimentos muito demorados também são conduzidos durante as investigações e que os membros vêm se adaptando a eles. No final de sua manifestação, Hong Kong mencionou que a aplicação da cláusula seria ainda mais benéfica aos países em desenvolvimento, que a teriam como um instrumento para balancear os interesses da indústria doméstica e indústria importadora, aumentando o volume das exportações em detrimento das importações, por exemplo.

O Canadá, em manifestação de 17 de novembro de 2005, defende diretrizes para a inclusão da cláusula do interesse público. Qualquer nova obrigação em relação a este assunto deve guardar certa flexibilidade para permitir acomodar diferentes pontos de vista dos Membros e dos seus sistemas legais nacionais e as decisões de interesse público não devem ser analisadas pelo mecanismo de solução de controvérsias.

\footnotetext{
${ }^{134}$ Art. 3.5. É necessário demonstrar que as importações a preços de dumping, por meio dos efeitos produzidos por essa prática, conforme estabelecido nos parágrafos 2 e 4, estão provocando dano no sentido em que este último termo é adotado neste Acordo. A demonstração de nexo causal entre as importações a preços de dumping e o dano à indústria nacional deverá basear-se no exame de todos os elementos de prova relevantes à disposição das autoridades. Estas deverão, igualmente, examinar todo e qualquer outro fator conhecido, além das importações a preços de dumping que possam estar causando dano à indústria nacional na mesma ocasião e tais danos, provocados por motivos alheios às importações a preços de dumping, não devem ser imputados àquelas importações. Fatores relevantes nessas condições incluem, inter alia, os volumes e os preços de outras importações que não se vendam a preços de dumping, contração na demanda ou mudanças nos padrões de consumo, práticas restritivas ao comércio e concorrência entre produtores nacionais e estrangeiros, progresso tecnológico, desempenho exportador e produtividade da indústria nacional.
} 
O Canadá defendeu a aplicação da cláusula, mas não a fixação das modalidades precisas de implementação pelos Membros.

\section{O Canadá propôs o texto:}

"9.1 bis Cada Membro deve estabelecer procedimentos apropriados em sua lei para permitir que suas autoridades analisem se a aplicação de medidas antidumping ou a sua aplicação na sua totalidade é de interesse público. estes procedimentos devem requerer que as autoridades considerem as representações feitas por qualquer parte doméstica cujos interesses possam ser afetados pela imposição das medidas, incluindo, mas não se limitando a, usuários industriais do produto em consideração, organizações de consumidores representativas e as autoridades de concorrência do Membro. Ao conduzir tal investigação, a autoridade deve considerar toda informação relevante, incluindo o Anexo III deste Acordo. Como resultado, as autoridades podem decidir aplicar ou reduzir o nível das medidas que seriam de outra forma aplicadas. As decisões de interesse público não podem dar ensejo a discussões de violação de acordo com o mecanismo de solução de controvérsias.

Anexo III

Para os fins do art. 9: 1 bis, os fatores a serem levados em consideração incluem:

a) Os produtos similares aos produtos em consideração são realmente disponíveis em outras origens às quais a medida não será aplicada;

b) Quando a medida antidumping deve ser aplicada em sua quantidade máxima porque:

i) Quando a medida elimina ou substancialmente reduz ou pode eliminar ou substancialmente reduzir a competição no mercado doméstico do produto;

ii) Causa ou pode causar dano substancial aos produtores domésticos que usam o produto para produção ou de prestação de serviços;

iii) Prejudica substancialmente ou podem prejudicar substancialmente a concorrência por:

a. Limitar acesso aos produtos que são usados como insumos para a produção de outros produtos ou prestação de serviços;

b. Limitar o acesso à tecnologia.

iv) Restringe significantemente ou pode restringir a escolha ou disponibilidade de produtos a preços competitivos pelos consumidores ou de outra forma causaram ou podem causar-lhes prejuízos.

c) Quando a imposição ou não imposição da medida em sua quantidade total pode causar dano aos produtores domésticos de insumos, incluindo commodities primárias, usadas na manufatura doméstica ou produção de produtos similares;

d) Outros fatos que forem relevantes em determinadas circunstâncias. "135

Alguns dos Amigos do Antidumping, preocupados com a repercussão provocada por sua proposta de texto, especialmente no que se refere à soberania dos

${ }^{135}$ Public Interest - Paper from Canada, TN/RL/GEN/85, 17 de novembro de 2005. 
Membros, sugeriram pequenas modificações à sua idéia inicial. Para eles, a cláusula ou teste deveria ser aplicada também nas revisões de antidumping, quando o dano estiver sendo novamente investigado. As autoridades que examinam o interesse público podem ser determinadas pelo Membro investigador. ${ }^{136}$

Em novembro de 2007, o presidente do Grupo de Negociações em Regras propôs, pela primeira vez, um rascunho da nova redação do Acordo Antidumping. Segundo ressalta, não se trata de uma proposta para ser aprovada ou reprovada pelos Membros, mas tão somente uma compilação das propostas que já foram apresentadas e a tentativa de negociar, a partir daquele momento, sobre um texto anunciado.

Sobre o interesse público, o rascunho prevê a inclusão da cláusula 9.1, com a seguinte redação:

Cada Membro que possui legislação antidumping deve estabelecer procedimentos em sua lei ou regulamento que permita que suas autoridades, ao tomar as decisões descritas no artigo 5 [initiation and subsequent investigation] levem em consideração a representação feita pelas partes domésticas interessada ${ }^{137}$ s que podem ter seu interesse afetado pela imposição de medida antidumping. A aplicação destes procedimentos, $e$ as decisões tomadas em relação a ele, não devem ser sujeitas ao mecanismo de solução de controvérsias, ao art. 17 deste Acordo ou qualquer outra previsão de acordo da OMC. $^{138}$

Vários membros fizeram críticas ao texto proposto. ${ }^{139}$ É necessário mais do que permitir que as autoridades levem em consideração os comentários das partes domésticas, já que algumas autoridades podem simplesmente escolher deixar de fazê-lo. Além disso, o conceito de partes domésticas é muito limitado, aplicando-se somente para os consumidores imediatos do produto, deixando de fora os importantes consumidores finais.

\footnotetext{
136 Economic Effects of Anti-dumping Measures: paper from Hong Kong, China, and the Separate Customs Territory of Taiwan, Penghu, Kinmen e Matsu, TN/RL/GEN/142, 6 de junho de 2006.

${ }^{137}$ Partes domésticas interessadas são consideradas, segundo o rodapé sugerido, como usuários industriais do produto importado ou do produto similar doméstico, fornecedores da indústria doméstica e, se o produto for vendido no varejo, organizações representativas de consumidores.

${ }^{138}$ Draft Consolidated Chair Texts of the ADA and SCM Agreements TN/RL/W/213, 30 de novembro de 2007.

139 Public Interest: Communication from Colombia, Hong Kong, China, Israel, Japan, Norway, Singapore, Switzerland, the Separate Customs Territory of Taiwan, Penghu, Kinmen and Matsu, and Thailand. 12 de março de 2008.
} 
Outro ponto que chama a atenção é a impossibilidade de discussão da decisão da autoridade relativa ao interesse público no mecanismo de solução de controvérsias ou mesmo a revisão judicial. Para os Amigos do Antidumping, deve haver ambas as revisões. Eles sugeriram as seguintes inclusões ao texto: 1) as autoridades devem considerar todos os comentários feitos pelas partes, mas são livres para incorporá-los em suas decisões; 2) o texto não é claro sobre se o art. 11 (revisões) é aplicável à cláusula do interesse público, o que sugerem esclarecer positivamente; 3) ampliar o conceito de partes domésticas interessadas para quaisquer interessados que podem ser afetados pela imposição dos direitos; 4) a implementação e aplicação da cláusula sujeitam-se à revisão pelo mecanismo de solução de controvérsias da OMC e deverá haver a possibilidade de revisão judicial. Entretanto, a revisão pelo órgão de solução de controvérsias deve ser limitada aos aspectos procedimentais, isentando-se o mérito, já que cabe a cada um dos Membros determinar o que é o interesse público. ${ }^{140}$

Em 28 de maio de 2008, o Presidente do Grupo de Negociações em Regras trouxe a versão consolidada de todas as propostas já apresentadas pelos Membros após o primeiro rascunho. O texto foi dividido em: i) consolidação das propostas dos Membros, ii) texto do presidente e iii) comentário dos Membros. ${ }^{141}$

O texto proposto está distante da proposta dos Membros. Em primeiro lugar, ele não esclarece quais aspectos devem ser considerados pelos Membros na análise do interesse público. A previsão de que todos os Membros considerem o interesse público em suas decisões, sem que quaisquer critérios sejam sugeridos, representa, para alguns, um grande risco. Haverá grande margem para a discriminação, com investigações encerradas e direitos não aplicados, apoiados no teste do interesse público, em relação a importações provenientes de pais que, por alguma razão, momentânea ou permanente, estão entre os favorecidos por aquele Membro investigador. Em outros casos, os importadores farão o seu melhor para conseguir demonstrar que há uma grande desvantagem para o interesse público e, mesmo assim, o

\footnotetext{
${ }^{140}$ Tal proposta, no que concerne à possibilidade de revisão pelo órgão de solução de controvérsias, parece conflitar com a proposta apresentada por este grupo - com a diferença de alguns países - três anos antes. Na reunião de abril de 2005, conforme narrado pelo documento TN/RL/M/26, este grupo defendeu a possibilidade de reexame de toda a decisão (não somente aspectos procedimentais) pelo órgão de solução de controvérsias.

${ }^{141}$ Negotiating Group on Rules - Working Document from the Chairman, TN/RL/W232, 28 de maio de 2005.
} 
Membro desconsiderará esta desvantagem em nome do interesse de um grupo de pressão. Não se poderá fazer muito em relação a estas práticas se o acordo não definir diretrizes, aspectos substantivos ou a forma como será conduzida a investigação do interesse público.

\section{As negociações, felizmente, prosseguem.}

\subsubsection{A regra do menor direito}

Outra discussão correlata ao interesse público é a regra do direito menor, ou lesser duty rule.

De acordo com o que foi pactuado pelos diversos Membros da OMC, as medidas restritivas do comércio, seja na forma de medidas compensatórias, salvaguardas ou antidumping, serão aplicadas em circunstâncias excepcionais, previstas claramente por seus respectivos instrumentos jurídicos e mediante a apuração por meio de investigação. O art. 9.1 do Acordo Antidumping prevê que a decisão sobre o valor da medida a ser imposta deve ser tomada pela autoridade de cada Membro, mas é desejável que a medida seja menor do que a margem de dumping, se esta medida menor for adequada para remover o dano à indústria doméstica.

Contudo, mesmo com diversas previsões dispondo sobre o caráter excepcional das medidas antidumping e com a previsão de sua aplicação em patamar mínimo necessário para a remoção do dano, a experiência demonstra que não são muitos os Membros que adotam este nível mínimo suficiente para neutralizar o dano.

O Acordo Antidumping não prevê a metodologia para cálculo do nível de dano, a chamada margem de dano. A chamada mandatory lesser duty rule, proposta por alguns Membros ${ }^{142}$, seria responsável pela inclusão desta preocupação com o nível

\footnotetext{
${ }^{142}$ As propostas de mudança na dinâmica da lesser duty rule são mais recentes do que as propostas que versam sobre a cláusula de interesse público. Illustrative Major Issues, Paper from Brazil, Chile, Colombia, Costa Rica, Hong Kong, China, Israel, Japan, Korea, Mexico, Norway, Singapore, Switzerland, Thailand and Turkey, TN/RL/W/6, 26 de abril de 2002; Submission from the European Communities concerning the Agreement on Implementation of Article VI of GATT 1994, TN/RL/W/13, 8 de julho de 2002; General Contribution to Discussion of Negotiating Group on Rules on Anti-dumping Measures, Paper from Brazil, Chile, Colombia, Costa Rica, Hong Kong, China, Israel, Japan, Korea,
} 
de dano no regulamento antidumping. Segundo defendido por estes países, a autoridade deve (não apenas pode) impor uma medida menor do que a margem antidumping quando esta medida menor já for suficiente e adequada para impedir o dano.

O Acordo de Salvaguardas prevê que o nível da salvaguarda aplicada deva se basear no nível do dano causado pelo aumento das importações. ${ }^{143}$ Mas qual seria a razão desta preocupação de imposição da medida neste limite? Na decisão USLine Pipe, o órgão de apelação da OMC entendeu que uma medida de salvaguarda é imposta em um comércio justo (fair) e que este comércio justo não pode ser sujeito a uma medida restritiva de comércio de natureza punitiva. ${ }^{144}$

Outro exemplo da aplicação deste effect-based approach $^{145}$ são as consequiências previstas para o caso de não cumprimento, por um Membro, de uma disposição do mecanismo de solução de controvérsias da OMC. O Membro que teve seu entendimento examinado, saindo perdedor, deve cumprir as recomendações do órgão. Se ele falha no cumprimento da decisão, aquele que saiu vitorioso tem o direito de suspender suas concessões ou deixar de cumprir outras obrigações em relação ao primeiro. O nível desta suspensão de concessões ou outras obrigações é limitado ao nível de medidas apropriadas, proporcional ao efeito do dano causado. ${ }^{146}$

No caso do antidumping, poderia se sustentar o argumento de que a natureza injusta do dumping justifica uma medida punitiva. Contudo, deve-se lembrar que mesmo as medidas punitivas do órgão de solução de controvérsias são limitadas ao

Mexico, Norway, Singapore, Switzerland, Thailand and Turkey, TN/RL/W/28/Rev.1, 22 de novembro de 2002 (Índia e Brazil propuseram the a regra deveria ser obrigatória para investigações de países desenvolvidos contra exportações de países em desenvolvimento. Outras propostas foram mais longe, prevendo já a metodologia de cálculo da regra. A Austrália propôs a importância da distinção entre quando a regra deve ser de consideração obrigatória e quando a regra deve ser de aplicação obrigatória. (FUKUNAGA, Yuka. A Effect-Based Approach to Anti-Dumping: why should we introduce a mandatory lesser duty rule? Journal of World Trade, v. 38, n. 3, 2004, p. 492).

143 "Art. 5.1 As medidas de salvaguarda só serão aplicadas na proporção necessária para prevenir ou remediar prejuízo grave e facilitar o ajustamento. Se é utilizada restrição quantitativa, tal medida não reduzirá a quantidade das importações abaixo do nível de um período recente, que corresponderá à média das importações efetuadas nos três últimos anos representativos para os quais se disponha de estatísticas, a menos que se demonstre claramente a necessidade de se estabelecer um nível diferente para prevenir ou remediar o prejuízo grave. Os Membros deverão escolher as medidas que mais convenham à consecução daqueles objetivos."

${ }^{144}$ United States - Definitive safeguard measures on imports of circular welded carbon quality line pipe from Korea, WT/DS202/AB/R, 8 de março de 2002.

145 FUKUNAGA, Yuka. Op cit, p. 492.

${ }^{146}$ Entendimento no caso Brazil - Aircraft, WTO/DS46/ARB, 28 de agosto de 2000. 
dano. ${ }^{147} \mathrm{O}$ dumping pode ser injusto, mas não é uma violação, em si, do Acordo da OMC. ${ }^{148}$

As propostas atuais no âmbito das negociações no grupo de regras parecem convergir para a existência de uma regra do direito menor, desde que este direito seja suficiente para neutralizar (remover) o dano. Alguns membros enfatizaram, de forma bem apropriada, que o interesse público e a regra do direito mínimo são conceitos distintos e não deve haver a substituição de um pelo outro. ${ }^{149} \mathrm{O}$ teste do interesse público tem como objetivo investigar os efeitos da medida sobre o bem-estar, enquanto a regra do direito menor tem como escopo a aplicação de uma medida mais baixa. Contudo, o teste do interesse público pode ser aplicado para justificar a imposição de um direito mais baixo, como é feito no Canadá. ${ }^{150}$

\subsubsection{A aplicação pelos Membros que já adotam a cláusula}

Mesmo sem qualquer previsão no Acordo Antidumping sobre a consideração do interesse público, alguns Membros já prevêem o teste, em suas legislações. Este é o caso do Brasil e da Comunidade Européia. Contudo, o que se nota é que, embora exista previsão legal, estes países têm entendimentos erráticos sobre a aplicação do dispositivo, seja por falta de regulamentação, seja por falta de apoio nas regras multilaterais.

\subsubsection{O teste do interesse público na Comunidade Européia}

\footnotetext{
${ }^{147}$ Segundo mencionado no parágrafo 120 da decisão US-Cotton Yarn, WT/DS192/AB/R, "nossa visão está fundamentada pelas regras de direito internacional sobre responsabilidade do Estado, que dispõem que as contramedidas em resposta à violação de obrigações internacionais pelos Estados devem ser mensuradas de acordo com o dano sofrido. No mesmo sentido, nós sustentamos que o artigo 22.4 do DSU estipula que a suspensão das concessões deve ser equivalente ao nível da anulação ou redução das vantagens. Esta previsão do DSU tem sido interpretada consistentemente como não justificando medidas punitivas." (tradução literal da versão inglesa)

${ }^{148}$ FUKUNAGA, Yuka. Op. cit, p. 505.

${ }^{149}$ Lesser Duty Rule, Communication from Brazil, Chile, Colombia, Costa Rica, Hong Kong, China, Israel, Japan, Korea, Norway, Singapore, Switzerland, Taiwan, Penghu, Kinmen and Matsu and Thailand, TN/RL/W/224 (12 de março de 2008).

${ }^{150}$ Art. 45 (5) do SIMA.
} 
A Comunidade Européia é um dos poucos Membros que aplica o teste do interesse público, mesmo que se conclua que as importações a preço de dumping estão causando dano à indústria doméstica. ${ }^{151} \mathrm{O}$ artigo 21.1 do Regulamento Básico europeu. ${ }^{152}$ diz que as medidas antidumping podem não ser aplicadas se a autoridade concluir que não é do interesse comunitário aplicá-las. ${ }^{153}$ Há vasta jurisprudência sobre

${ }^{151}$ SINNAEVE, Adinda. The Community Interest Test in Anti-dumping Investigations: time for reform? Global Trade and Customs Journal, v. 2, n. 4, 2007, p. 157.

152 "Art. 21. Interesse da Comunidade.

1. A fim de se determinar se o interesse da Comunidade requer ou não uma intervenção, deve ter-se em conta uma apreciação dos diversos interesses considerados no seu conjunto, incluindo os interesses da indústria comunitária, dos utilizadores e dos consumidores, só podendo ser efetuada uma determinação a abrigo do presente artigo se todas as partes tiverem tido oportunidade de apresentar os seus pontos de vista nos termos do n. 2. Nesse exame, deve ser concedida especial atenção à necessidade de eliminar os efeitos de distorção do comércio provocados por dumping que cause prejuízo bem como à necessidade de restabelecer uma concorrência efetiva. Não podem ser aplicadas medidas, tal como determinadas com base no antidumping e no prejuízo verificados, se as autoridades, com base nas informações facultadas, concluírem claramente que não é do interesse da comunidade a aplicação de tais medidas.

2. A fim de que as autoridades disponham de uma base sólida que lhes permita tomar em consideração todos os pontos de vista e informações, para decidir se o interesse da Comunidade requer ou não a criação de medidas, os autores da denúncia, os importadores e as suas associações representativas, os utilizadores representativos e as organizações de consumidores representativas podem, no prazo previsto no anúncio de início do inquérito anti-dumping, dar-se a conhecer e fornecer informações à Comissão. Tais informações, ou um resumo adequado das mesmas, devem ser postas à disposição das outras partes mencionadas no presente artigo, que terão a possibilidade de apresentar as suas observações.

3. As partes que tenham atuado em conformidade com o $n^{\circ} 2$ podem solicitar uma audição. Estes pedidos podem ser aceitos se tiverem sido apresentados no prazo fixado no $n^{\circ} 2$ e se especificarem as razões, em termos do interesse da Comunidade, pelas quais as partes devem ser ouvidas.

4. As partes que tenham atuado em conformidade com o $n^{\circ} 2$ podem apresentar as suas observações sobre a aplicação de quaisquer direitos provisórios criados. Para serem tomadas em consideração, estas observações devem ser recebidas no prazo de um mês a partir da data de aplicação de tais medidas. As observações, ou um resumo adequado das mesmas, devem ser postas à disposição das outras partes que terão a possibilidade de responder a essas observações.

5. A Comissão examinará as informações devidamente comunicadas e determinará em que medida são representativas, devendo os resultados dessa análise, juntamente com um parecer sobre o seu fundamento, ser transmitidos ao comitê consultivo. Os diferentes pontos de vista expressos no comitê serão tomados em consideração pela Comissão em qualquer proposta apresentada nos termos do artigo $9^{\circ}$.

6. As partes que tenham atuado em conformidade com o $n^{\circ} 2$ podem solicitar que lhes sejam facultados os fatos e as considerações com base nos quais poderão ser tomadas as decisões finais. Tais informações serão divulgadas na medida do possível e sem prejuízo de qualquer decisão posterior adotada pela Comissão ou pelo Conselho.

7. As informações só serão tomadas em consideração se se basearem em elementos de prova concretos que confirmem a sua validade."

${ }^{153} \mathrm{O}$ interesse comunitário no antidumping foi introduzido pela primeira vez, na legislação do bloco, em 1988, no Regulamento (EC) n. 2423/88 do Conselho, J.O L. 209/1, de 2 de agosto de 1988). Nenhum ato ou decisão de uma instituição européia é considerado válido se não for identificado o interesse da Comunidade. Por esta razão, ao Tribunal Europeu são levadas numerosas discussões em que se pede a apreciação da validade de atos que, aparentemente, não se coaduam com este interesse. A expressão interesse comunitário não é, geralmente, definida, somente declarada. O interesse público é um instrumento jurídico com objetivo único: contribui para reforçar a ordem jurídica comunitária. (ver HAMONIAUX, Thomas. L'intérêt general et le juge communautaire. Paris: L.G.D.J. 2001, p. 14-33). 
o assunto, permitindo delinear aspectos que são fundamentais no exame da Comissão Européia. $^{154}$

\subsection{O procedimento}

Para a análise do interesse comunitário, é conduzido um procedimento especial, ao qual é dado peso equivalente àquele da análise do dumping, dano e nexo causal. Aqueles que desejam se manifestar preenchem questionários, que são analisados pelas autoridades. A experiência européia tem demonstrado que a coleta de informações é uma das maiores dificuldades na análise do interesse comunitário. Em vários casos, as partes não colaboram, ou submetem suas informações já em um estágio muito avançado da investigação.

O teste do interesse comunitário pode ser feito não somente antes da aplicação de medidas definitivas, mas também antes da aplicação de medidas provisórias. No segundo caso, o estudo é normalmente menos detalhado, devido à pouca informação já disponível.

As partes que têm ouvidas suas considerações foram elencadas em uma lista não exaustiva no próprio artigo 21 , sendo elas os peticionários ${ }^{155}$, os usuários industriais, os importadores e suas associações representativas, e as organizações representativas dos consumidores. Esta lista compreende os agentes que possuem ou podem possuir algum interesse econômico sobre o produto em investigação. Ela é meramente exemplificativa e, por isso, os fornecedores da indústria doméstica também podem ter suas opiniões consideradas. Os interesses dos exportadores não são necessariamente considerados (pois são interesses estranhos ao bloco econômico), mas como podem trazer informações e fatos relevantes ao processo, podem ser analisados

154 SINNAEVE, Adinda. The Community Interest Test in anti-dumping investigations: time for reform? Global Trade and Customs Journal. Kluwer Law International, v. 2, n. 4, 2007. p. 157.

155 A Corte de Justiça européia confirmou que a representatividade da indústria doméstica para fins de interesse público não está ligada diretamente à sua participação de mercado, mas sim ao fato de que representam um bom exemplo das empresas do setor. (Case T-132/2001 Euroalliages et. al. v. Commission [2003] ECR II - 2359 (90). 
para um entendimento mais amplo. ${ }^{156}$ Os interessados trazem informações acompanhadas por provas dos fatos alegados e, se for o caso, a demonstração de alguma experiência no passado ${ }^{157}$. As suas alegações não podem ser meras especulações. ${ }^{158}$

Deve haver um equilíbrio entre os benefícios para a indústria doméstica e para a União Européia, e os impactos negativos das medidas. Por isso, se as medidas antidumping não trouxerem qualquer vantagem à indústria doméstica, elas serão claramente desproporcionais. Esta interpretação permite concluir que, se não houver indícios de que a indústria doméstica pode ser recuperar do dano (mesmo que o dumping seja seu causador), ou que a indústria doméstica não é viável por alguma razão, não são impostas as medidas. Contudo, não há como se fazer uma perfeita equação entre os fatores. ${ }^{159}$

A maior crítica em relação à consideração do interesse comunitário é a insegurança e opacidade de seu conteúdo, bem como a dificuldade em analisar e sopesar os benefícios da indústria doméstica em relação a consumidores, importadores e outros interessados. Tais dificuldades podem abrir demasiado espaço à politização do instrumento antidumping. ${ }^{160}$ Alguns defendem que não é grande o espaço para pressões de grupos interessados na consideração do interesse comunitário, pois a definição deste interesse não deve ser confundida com o interesse nacional dos Membros. Assim, a Comissão não poderá ouvir somente o interesse de grupos isolados, pois interesses contrários aos destes grupos podem estar localizados em qualquer parte da Comunidade, em 27 países.

\footnotetext{
${ }^{156}$ Aqueles que exportam para a Europa não podem se manifestar a respeito dos interesses comunitários. Para alguns, isto seria uma violação ao princípio de que a todas as partes será dada ampla oportunidade de defender seus interesses (art. 6.2 do Acordo Antidumping). Se os exportadores e o governo do país exportador possuem o direito de expressar sua opinião em relação a todos os aspectos da aplicação da medida, porque não poderia trazer elementos ao contraditório sobre os interesses da Comunidade? Este tema foi tratado no caso do Regulamento n. 2997/95, de 20 de dezembro de 1995, em que se discutiu a aplicação de direito provisório sobre as importações de magnésio bruto originário da Rússia e Ucrânia. DOCE n. L 312 de 23 de dezembro 1995. (DIDIER, Pierre. The WTO Anti-Dumping Code and EC Practice: issues for review in trade negotiations. Journal of World Trade, v. 35, n. 1, 2001, p. 47.)

${ }^{157}$ Por exemplo, informação sobre aumento no custo da matéria prima no passado pode servir para demonstrar que os usuários industriais poderão repassar o custo da medida antidumping aos consumidores. (SINNAEVE, Adinda. Op. cit. p. 159)

${ }^{158}$ Art. 21.7 do Regulamento Básico europeu.

${ }^{159}$ SINNAEVE, Adinda, Op. cit p. 160.

${ }^{160}$ FERNANDEZ, Marta Rodríguez. Op cit. p. 261.
} 
A análise do interesse comunitário também pode ocorrer no procedimento de revisão. Se ficar demonstrado que os efeitos reais das medidas aplicadas são substancialmente diferentes daqueles imaginados quando da primeira decisão da autoridade, esta mudança nas circunstâncias justifica a revisão.

Discute-se, na Comissão Européia, se aspectos são econômicos são relevantes para a análise do interesse comunitário, tais como meio ambiente, direitos do trabalho, desenvolvimento, entre outros. Em sua jurisprudência, a Comissão sempre recusou estes aspectos, por estarem em conflito com a natureza legal e técnica do antidumping. Além disso, tais aspectos mais amplos são tratados por legislação especial. As medidas de defesa comercial não podem ser usadas como meio de reforçar legislações ou resolver problemas particulares de determinadas áreas.

Um documento lançou a discussão, na União Européia, sobre o interesse comunitário na imposição dos TDI ("Trade Defence Instruments" ou Instrumentos de Defesa Comercial). O seu objetivo não era questionar o valor fundamental dos instrumentos de defesa comercial, mas convidar o mercado comum a refletir sobre como a União Européia pode continuar usando estes instrumentos para a realização do interesse europeu. ${ }^{161}$ Foi lançada, em julho de 2006, uma consulta a alguns operadores do direito antidumping, com o objetivo de colher suas opiniões. Como resultado, foram delineados pontos a serem ainda discutidos, compilados em um Livro Verde. ${ }^{162}$

Estes são os principais questionamentos do Livro Verde que se referem ao teste do interesse comunitário:

1) Qual é o papel dos instrumentos de defesa comercial em uma economia globalizada? São as medidas de defesa comercial

\footnotetext{
${ }^{161}$ Segundo Cliff Stevenson, um dos colaboradores para a elaboração do Livro Verde, autor do documento Evaluation of EC Trade Defence Instruments, TDI é uma política comunitária que provoca paixões fortes e sobre a qual as pessoas têm posicionamentos firmes. STEVENSON, Cliff. Mayer, Brown, Rowe \& Maw LLP. Evaluation of EC Trade Defence Instruments. December 2005.

${ }^{162}$ COMISSION OF THE EUROPEAN COMMUNITIES. Global Europe: Europe's trade defence instruments in a changing global economy. A Green Paper for public consultation. Brussels, 6 December 2006 COM (2006) final.
} 
necessárias para assegurar o respeito às regras de comércio internacional e para proteger interesses europeus? ? $^{163}$

2) Deve a União Européia rever o balanço dos interesses entre os vários operadores econômicos na aplicação do teste do interesse comunitário nas investigações antidumping? Ao lado dos interesses dos produtores e de seus empregados na Europa, como devem ser julgados os interesses das empresas que mantêm suas operações mais significativas e seus empregados na Europa, mesmo que tenham levado parte de sua produção para fora da União Européia? ${ }^{164}$

3) Precisa a União Européia rever a forma com que os interesses dos consumidores estão sendo considerados em investigações antidumping? Como o impacto das medidas de defesa comercial sobre os consumidores está sendo considerado e monitorado?

4) Com o alargamento da União Européia, observou-se que as indústrias continuaram concentradas em certos países, ao passo que os consumidores estão cada vez mais espalhados. Com isso, a atividade de lobby está cada vez mais intensa, com o objetivo de aproximar os interesses destes consumidores distantes. Como lidar com ele?

\footnotetext{
${ }^{163}$ Em primeiro lugar, o Livro Verde questiona qual é o papel dos instrumentos de defesa comercial em uma economia global. A justificativa para o antidumping deriva do fato de que a competição nos mercados internacionais é imperfeita: não existe uma autoridade concorrencial para regular o comportamento anticoncorrencial entre os países. Por outro lado, também há poucas regras na Europa sobre o comportamento em mercados internacionais. Por isso, de acordo com o Livro Verde, alguns países defendem que os instrumentos de comércio são necessários por não existirem regras concorrenciais internacionais. Outros acreditam as regras de defesa comercial não são economicamente justificáveis do ponto de vista do bem-estar geral de um país. Outros argumentam que os instrumentos de defesa comercial se justificam se um exportador se beneficia de uma fraca ou inexistente regra concorrencial interna.

${ }^{164}$ A aplicação de medidas de defesa comercial abarca o interesse econômico da União Européia, incluindo o interesse de seus produtores e trabalhadores. Deve-se refletir sobre os produtores europeus que terceirizam sua produção em outros países afetados por medidas antidumping. Neste ponto, o documento lembra o caso Sapatos de Couro importados da China e Vietnã, de 2006, no qual foram impostas medidas antidumping contra alguns sapatos de couro importados pela União Européia. Neste caso, apenas os produtores que mantinham sua produção na Europa foram considerados no teste do interesse comunitário. Por esta razão, Peter Bernet propõe, em sua monografia sobre o tema, um conceito mais amplo de indústria comunitária (doméstica). A proposta é que o interesse comunitário seja considerado como pré-requisito para a abertura da investigação. (BERNERT, Peter. Thoughts in response to the list of issues considered by the Commission. Eurocommerce: Preparatory Paper for the Seminar on Trade Defence Instruments. 11 de julho de 2006.). Do lado oposto de Bernet está Bethke, que também contribuiu para a discussão contida no Livro Verde. Para ele, os trabalhadores e cidadãos europeus não iriam entender uma política de comércio favorecendo a terceirização do trabalho para outros países. (BETHKE, R. Note concerning a short written contribution with regard to the EU trade defence instruments and its application in a globalized economy. Issues under reflection. 11 de julho de 2006)
} 
5) Deve a União Européia incluir considerações amplas de interesse comunitário nas negociações de defesa comercial?

6) Que tipo de análise econômica pode ajudar nestas considerações?

7) Deve ficar explícito que o nível das medidas propostas deve ser rebaixado, seguindo os resultados do teste do interesse comunitário? Deve a União Européia permitir a exclusão de certos produtos das considerações de interesse comunitário? Que critério deve ser aplicado?

8) Deve a União Européia promover mudanças no teste do interesse comunitário para permitir a sua aplicação nos primeiros estágios do procedimento, antes mesmo da abertura da investigação? Em quais outras situações ele pode ser apropriado (exemplo: antes do início da revisão)?

9) Serão as barreiras à entrada consideradas nas decisões sobre instrumentos de defesa comercial? ${ }^{165}$

10) Deve a União Européia considerar os planos de reestruturação da indústria doméstica antes de aplicar o antidumping? ${ }^{166}$

11) Deve a União Européia facilitar a participação de pequenas empresas nas investigações? ${ }^{167}$

12) Considerando que qualquer redução no tempo para o encerramento das investigações pode levar a prejuízos na condução e transparência dos procedimentos, deve a União Européia considerar esta possibilidade ${ }^{168}$

\footnotetext{
${ }^{165}$ Em alguns setores, as barreiras à entrada de novos competidores podem ser tão altas que acabam por influir na aplicação das medidas.

${ }^{166}$ Segundo o Livro Verde, os planos de reestruturação são importantes para se conhecer a possibilidade de recuperação da empresa durante a aplicação das medidas. Para outros, isso é irrelevante, já que o dano é decorrente do dumping e promete ser sanado com a aplicação do antidumping.

${ }^{167}$ As pequenas empresas têm se mostrado muito importantes para a análise do interesse comunitário. Contudo, a sua participação nas investigações traz custos com os quais elas não podem arcar. Deve-se facilitar sua atuação? "o interesse comunitário também pertence às pequenas e médias empresas. Estes operadores, que constituem um fator chave na economia européia, requerem consideração específica no que se refere ao interesse comunitário. Eles são particularmente vulneráveis nos casos de exportações desleais exercidas por indústrias fortes e parcialmente dominantes e outros países." (BETHKE, R. Op cit. p. 3)

${ }^{168}$ Uma boa análise do interesse comunitário poderá significar um aumento no tempo das investigações.
} 
13) A Comissão deve publicar todas as suas atas, agenda ou trabalhos relacionados ao comitê antidumping? ${ }^{169}$

Outra questão lembrada em alguns dos comentários que antecederam o Livro Verde está relacionada à competitividade na indústria doméstica. Se existir, previamente à investigação, uma situação não competitiva no mercado interno (exemplo, uma das empresas detém posição dominante), uma análise deve ser conduzida para evitar que as medidas aplicadas só sirvam como obstáculo para proteger a indústria. ${ }^{170}$ Contudo, não seria a função das autoridades de comércio internacional fazer comentários sobre a competição. Isso não é determinado pela legislação européia e elas não possuem qualificação ou recursos para fazer esta análise. Não há menção expressa a este assunto no Livro Verde. ${ }^{171}$

A questão política também é lembrada, como sendo um importante divisor de águas nas decisões da Comissão. Alguns Estados Membros defendem que a influência política dos governos nacionais é importante para se definir apropriadamente o interesse daquele Membro (já que o governo está mais próximo aos interesses da indústria doméstica). ${ }^{172}$ Outros Estados defendem que a interferência política deve ser considerada ilegal, sendo o TDI um instrumento eminentemente técnico. ${ }^{173}$

Por fim, cabe lembrar a questão do emprego. A relação entre a utilização de medidas antidumping e a criação de empregos não é tão evidente. "A utilização das TDI não salva a Europa do problema da competitividade". A solução está no campo da pesquisa, reestruturação e inovação. Deve-se fazer uma boa análise sobre

\footnotetext{
${ }^{169}$ Isso significaria maior publicidade à definição do interesse comunitário.

${ }^{170}$ Como ressaltado no comentário de Peter Bernet, a competição cria competitividade. Exemplo: a Suécia protegeu, por muitos anos, sua indústria têxtil, usando, sobretudo, medidas de defesa comercial. Sua indústria automotiva, ao contrário, nunca recebeu nenhuma proteção. Hoje, a Suécia não tem mais nenhuma indústria têxtil, mas tem uma muito bem sucedida indústria automobilística. (BERNERT, Peter. Op cit. p. 6)

${ }^{171}$ STEVENSON, Cliff. Op cit, p. 30.

${ }^{172}$ Também lembra a crítica de Cliff Stevenson que os Estados Membros tendem a defender o interesse nacional (já que, muitas vezes, a indústria doméstica está naquele país, mas os consumidores estão em outros, ou espalhados pela União). O interesse comunitário, por sua vez, é completamente distinto do interesse nacional, e também não é sua soma simples.

${ }^{173}$ A existente cláusula do interesse público (na União Européia) contém claras, apolíticas e previsíveis regras. (BETHKE, R. Op cit . p. 4.)
} 
os empregos criados ou aumentados na Europa com a aplicação de medidas de defesa comercial. $^{174}$

Uma das maiores dificuldades na análise do interesse comunitário é a influência dos Estados Membros da Comunidade nas decisões da Comissão ou do Conselho. As tentativas de interferência não são tão expressivas perante a Comissão, embora existam, mas são bem relevantes diante do Conselho. Isto porque o Conselho é formado por representantes dos Estados Membros, que são a voz dos interesses nacionais. Se a indústria doméstica está localizada em um Estado, por exemplo, mas todos os importadores e usuários domésticos estão localizados em outro, haverá uma acirrada disputa para a imposição dos interesses nacionais.

Como decidir diante deste conflito de interesses nacionais? A Comunidade Européia deve realizar o interesse comunitário, não o interesse dos Membros. Neste sentido, deve ela observar que há um interesse maior, que não coincide com a simples soma dos interesses nacionais, ou seja, não basta apenas provocar uma votação perante o Conselho, decidindo-se pela maioria. Os representantes de um Estado Membro, por vezes, desconhecem a realidade de outro Estado Membro que busca a não aplicação das medidas. Deve haver discussão no sentido de se descobrir qual solução melhor se adéqua aos propósitos do ente maior, dotado de personalidade jurídica, que é a Comunidade Européia. Por exemplo, se a preocupação com o emprego, naquele momento, for maior do que a preocupação com o consumidor final europeu, privilegiase a política socioeconômica. ${ }^{175}$

\subsection{Posição da Comunidade Européia nas negociações sobre interesse público na $O M C$}

A Europa sempre desempenhou relevante papel nas transformações do comércio internacional, o que pode ser explicado por seu peso econômico e sua

\footnotetext{
${ }^{174}$ BERNERT, Peter. Op cit. p.3.

${ }^{175}$ Embora a observância deste maior interesse, o interesse comunitário, seja a prática recomendável, não é esta a realidade observada nas decisões mais recentes sobre antidumping. Na maioria dos casos, ganha o voto da maioria dos Membros, sem qualquer consideração sobre este interesse maior. (Conclusões formuladas após discussões na Comissão Européia, em entrevista com membros da DG Comércio Exterior, em 29 de setembro de 2008.)
} 
experiência em matéria de liberalização econômica. ${ }^{176}$ Quando da criação da OMC, a Comunidade Européia e cada um dos seus Membros ganhou o estatuto de Membro. ${ }^{177}$ Ela participa da OMC com fundamento no art. 133 do Tratado da Comunidade Européia (antigo art. 113) e tem competência para concluir acordos multilaterais relativos ao comércio de bens. As outras formas de liberalização, como regras sobre serviços e propriedade intelectual, têm sua competência dividida entre a Comunidade Européia e seus Membros (o que lhes impõe cooperação estreita).

A posição da Comunidade Européia nas negociações não parece acompanhar a prática da Comissão Européia nas investigações. Enquanto a Comissão discute, no mencionado Livro Verde, a possibilidade de consideração de aspectos mais amplos, como o meio ambiente e preocupações sociais do trabalho, a posição da Comunidade Européia nas investigações sobre o interesse público é muito diferente.

Em suas duas manifestações relevantes ${ }^{178}$, em 2002, a Comunidade Européia defende o exame do impacto das medidas antidumping sobre os diversos operadores econômicos, mas alertando que ele será, sempre, um teste de natureza discricionária. A Comunidade também questiona os outros Membros, buscando definir o que é o interesse público, se o texto deve incluir apenas um teste obrigatório, ou deve impor critérios substantivos.

A Comunidade Européia aplica o teste do interesse público, que se chama, para ela, interesse comunitário, não somente porque se preocupa com os interesses dos usuários, ou dos importadores. Há, na Comunidade, um problema muito maior, que é a consideração de interesses de diversos Estados Membros. Alguns Estados são mais ativos perante a Comissão Européia, tentando fazer prevalecer sua opinião, mas as decisões não podem ceder a estas pressões, e sim encontrar um interesse

\footnotetext{
${ }^{176}$ BLIN, Olivier. La stratégie communautaire dans l'Organisation Mondiale du Commerce. Journal du Droit International, janvier-fevrier-mars 2006, n. 1, 2006, p. 87.

${ }^{177} \mathrm{O}$ artigo XI do Acordo que institui a OMC dispõe que as Partes Contratantes do GATT 1947 e a Comunidade Européia, quando aceitarem o Acordo Instituindo a OMC, bem como os acordos multilaterais sobre comércio, bem como os anexos sobre concessões e compromissos, serão considerados Membros originais da OMC.

${ }^{178}$ Submission from the European Communities concerning the Agreement on Implementation of Article VI of GATT 1994, TN/RL/W/13, 8 de julho de 2002 e Negotiating Group on Rules - Questions from the European Communities on Documents TN/RL/W/6 and TN/RL/W/10, TN/RL/W/20, 10 de outubro de 2002.
} 
que é maior do que a soma dos interesses dos Estados Membros e dos grupos privados interessados.

Diante de tamanha particularidade na interpretação do interesse comunitário, a Comunidade Européia não encontra outra solução senão defender, perante as negociações, que os Membros apliquem o teste, mas observem certa flexibilidade na aplicação. A observação do interesse público é interessante, porque é o único mecanismo que permite que as autoridades não recomendem a aplicação de medidas. Contudo, segundo defendem, a definição do interesse público é bastante particular e é distinta em cada Membro.

A Comunidade Européia também não parece estar interessada em defender aspectos não econômicos na consideração do interesse comunitário em investigações antidumping. Ao contrário do questionamento feito no Livro Verde, os negociadores não acreditam que estes aspectos devam ser incluídos na prática multilateral.

Mas qual seria o ideal, na opinião da Comunidade Européia: a aprovação de um texto amplo e que apenas obrigue a consideração obrigatória do interesse público pelos Membros, ou a aprovação de um texto que contenha regras ou diretrizes? A Comunidade Européia acredita que a sua prática, ou a prática de outros países que aplicam o teste ${ }^{179}$, não deve ser imposta aos demais Membros da OMC, sobretudo em países em desenvolvimento. O ideal seria o estabelecimento de critérios ideais a serem aplicados e da possibilidade de revisão judicial. Desta forma, cada Membro gozaria de liberdade para definir o seu conceito de interesse público, mas poderia sofrer revisão judicial, aparentemente independente de qualquer influência política.

\subsection{A jurisprudência européia sobre interesse comunitário}

${ }^{179}$ Como exemplo, o Canadá, freqüentemente criticado por impor suas práticas nas investigações de interesse público nas negociações multilaterais. 
Embora haja a previsão legal, são poucos os casos em que este dispositivo foi aplicado para a não imposição de medidas antidumping. ${ }^{180}$

No caso Bolsas de Plástico e Tecido da China ${ }^{181}$, a Comissão entendeu que a vantagem gerada a um produtor nacional, que tinha apenas $2 \%$ do mercado, não compensaria a desvantagem sofrida pelos importadores. Além disso, se as medidas fossem aplicadas, havia sérios indícios de um possível desabastecimento no mercado.

No outro caso, Sistemas de Leitura Ótica a Laser para carros, provenientes do Japão, Coréia, Malásia, China e Taiwan (LORS) ${ }^{182}$, a Comissão considerou que o produto investigado deveria ser subdivido em três, cada um investigado separadamente: sintonizadores com leitor de discos compactos (sintonizadores com leitor de CD), leitores com carregador de discos e auto-rádios com um dispositivo de controle de discos (auto-rádio). Em relação ao leitor com carregador, a Comissão Européia entendeu que não haveria nenhum interesse comunitário para que a investigação continuasse, nem houve pedido expresso das partes. No caso dos sintonizadores com leitores, entendeu a Comissão que outras importações também contribuíam para o dano sofrido pela indústria doméstica. O entendimento para os dispositivos de controle de discos foi baseado no interesse comunitário.

Ao examinar os aspectos do caso relacionados a este interesse, a Comissão analisou os custos e benefícios que a imposição de medidas teria sobre os operadores econômicos interessados. Descobriu-se que a participação de mercado dos produtores domésticos havia aumentado de 0\% em 1996 para 1,4\%, no período de investigação. Isso significava que a indústria doméstica era muito incipiente, não sendo

\footnotetext{
180 "Entretanto, apesar do pequeno número de casos que terminam sem a aplicação de direito antidumping por falta de interesse comunitário, não se pode automaticamente concluir que o interesse comunitário não é um teste importante. Os peticionantes tentam redesenhar seus casos se eles percebem que a investigação pode ser encerrada por falta de interesse comunitário. Além disso, não faz sentido ao peticionário começar um caso se ele sabe que, ao final, as medidas podem não ser impostas por falta de interesse comunitário. Então, apesar do interesse comunitário não ser um critério para a admissibilidade de uma petição, ele é, sim, considerado em um primeiro estágio. Por isso, o número pequeno de investigações que terminam por falta de interesse não representa a situação total." (tradução livre de STEVENSON, Cliff. Mayer, Brown, Rowe \& Maw LLP. Evaluation of EC Trade Defence Instruments. December 2005. Section 2, p. 28.)

${ }^{181}$ J.O L 20/8 de 2/08/1997.

182 J.O. L18/62 de 23/01/1999.
} 
claras as perspectivas futuras e viabilidade da indústria nacional. ${ }^{183}$ Já era exigido um tributo de importação de $20 \%$ sobre este produto. Assim, mesmo se considerado que a indústria doméstica alcançaria o desenvolvimento sustentado, a produção não seria suficiente. $80 \%$ das vendas no mercado doméstico eram originárias dos países em investigação. Assim, "as vantagens a serem obtidas pela indústria doméstica nesta situação particular seriam mínimas, considerando-se o nível do emprego imediatamente afetado, e seriam menores do que as desvantagens, especialmente para os consumidores finais do produto. $\mathrm{O}$ produto em questão tem um grande potencial de crescimento, mas a imposição de medidas poderia afetar severamente os consumidores". ${ }^{184}$

O mesmo raciocínio foi empregado no caso Discos Versáteis Digitais Regraváveis (DVD +/- R). ${ }^{185}$ A indústria comunitária era embrionária se comparada aos exportadores. Após cinco anos de existência, ela havia alcançado apenas 0,8\% de participação de mercado. Havia poucas chances de desenvolvimento e a parcela das importações afetadas pelo dumping seria, se fossem impostas as medidas, substituída por importações de outros países. Dumping, dano e nexo causal não foram sequer analisados neste caso. ${ }^{186}$

Neste caso, também foi alegado que a situação da indústria comunitária era resultado de um comportamento abusivo por certos exportadores com poder dominante, consistente em utilizar estratégias de venda abaixo do custo, o que teria impedido a indústria de se firmar no mercado. A Comissão observou, em relação a este argumento, que não haveria investigação sobre abuso de poder dominante e não teria apontado o peticionário nenhuma investigação correspondente. Além disso, a

\footnotetext{
${ }^{183}$ Deve ser analisada, na União Européia, a capacidade da indústria de se recuperar do eventual dano provocado pelas importações investigadas. No caso Bicicletas. Regulamento (EU) n. 1095/2005, de 12 de julho de 2005, OJ L 183, 14/07/2005, P. 1., a Comissão decidiu, após ampla análise, pela viabilidade da recuperação da indústria doméstica.

${ }^{184}$ Tradução livre do parágrafo 18, página 18, O.J. L18/62 de 23 de janeiro de 1999.

185 Discos Versáteis Digitais Regraváveis (DVD +/- R). Decisão da Comissão n. 713/2006 de 20 de outubro de 2006, OJ L. 293/07, 14/10/2006.

186 "Parece evidente que a produção de DVD+/-Rs pela indústria comunitária começou tardiamente, se comparada com a produção dos exportadores nos países investigados. É muito improvável que a imposição de medidas irá permitir à indústria comunitária aumentar seus preços para alcançar um nível de produtividade que os permitam sobreviver, ou, alternativamente, aumentar as vendas reduzindo o custo de produção e se beneficiando de economias de escala. O desenvolvimento durante o período de investigação demonstra que a indústria comunitária nunca foi capaz de obter uma parcela substancial de participação de mercado. Diante destas circunstâncias, é improvável que a indústria doméstica se mostre viável e possa se beneficiar da imposição de medidas." (Discos Versáteis Digitais Regraváveis (DVD +/R). Decisão da Comissão n. 713/2006 de 20 de outubro de 2006, OJ L. 293/07, 14/10/2006).
} 
investigação comprovou a existência de diversos competidores neste mercado, o que inibiria qualquer comportamento abusivo. Também não comprovaram, os investigadores, qualquer indício de venda abaixo do preço de custo.

Um caso bastante citado, que espelha uma aplicação interessante do interesse comunitário, é o caso Sapatos de Couro, de $2006^{187}$. Nele, alguns importadores e consumidores argumentaram que i) a produção doméstica era insuficiente, o que faria com que as importações investigadas fossem substituídas por importações de outras origens; ii) o dano não foi causado pelo dumping, mas sim por outros fatores que não relacionados a ele. Foram aplicadas medidas provisórias e a discussão sobre o interesse comunitário se deu após esta aplicação.

A Comissão dividiu sua análise em quatro pontos: interesse dos consumidores, interesse dos distribuidores, interesse dos importadores não relacionados, outros interesses. Sobre o interesse dos consumidores, não houve representações de entidades ou organizações que pudessem trazer elementos sobre o prejuízo sofridos por este grupo. Além disso, alguns importadores declararam que não repassariam as medidas antidumping aos consumidores, por ser um mercado competitivo, no qual os consumidores migrariam para outros mercados em caso de preços excessivos. Ademais, a argumentação dos importadores de que a aplicação de medidas limitaria a escolha dos consumidores, porque alguns sapatos só seriam produzidos na China e Vietnã, não foi adequadamente comprovada.

Sobre o interesse dos distribuidores, nenhuma informação econômicofinanceira foi trazida de modo a apurar a situação em que se encontravam e os efeitos econômicos das medidas. Os importadores argumentaram que não teriam como suportar as medidas antidumping, a não ser que pudessem dividir seu custo com atacadistas e varejistas, que não iriam aceitá-las. Esta afirmação seria controversa, segundo a Comissão, pois não seria condizente com a afirmação de algumas partes de que o custo seria repassado aos consumidores.

Outras considerações foram trazidas, tais como o fato de ser o Vietnã um país em desenvolvimento e que precisaria exportar sua produção. Os trabalhadores

187 Sapatos de couro. Regulamento (EU) n . 1472/2006, de 4 de outubro de 2006, OJ L. 275/34 6/10/2006. 
vietnamitas, segundo os importadores, sofreriam diretamente com as medidas. A Comissão respondeu categoricamente que "de acordo com o artigo 21 (1) da Regulação básica, bem como em consistência com a prática das instituições deste o início das análises, este tipo de argumento não faz parte do interesse comunitário". ${ }^{188}$ Apenas são considerados os efeitos econômicos para o espaço comunitário.

No caso Lâmpadas ${ }^{189}$, o interesse comunitário foi analisado em sede de revisão. Foi enfatizado pela Comissão que, embora se tratasse de uma revisão de medidas aplicadas, o interesse público deveria ser novamente examinado, pois novas práticas ou situações poderiam ter provocado mudanças na situação da época da aplicação. Os fornecedores da indústria doméstica novamente argumentaram que teriam grandes prejuízos se a representante comunitária viesse a falir. Os importadores informaram que as medidas os impediriam de oferecer diferentes tipos do produto, reduzindo sua produtividade, investimento, pesquisa, entre outros aspectos. Por fim, foi também lembrado que a aplicação de medidas antidumping sobre as lâmpadas seria contrária à política de redução do gasto de energia na União Européia, já que os consumidores voltariam a comprar lâmpadas mais baratas, mas que consomem mais energia. Sobre este caso, concluiu a Comissão Européia que havia suficientes indícios de que a aplicação de medidas seria contra o interesse comunitário. A indústria doméstica precisava das importações para conseguir suprir toda a demanda doméstica, alguns produtores domésticos eram contra a aplicação, e a aplicação de medidas teve como efeito o aumento dos preços aos consumidores. $\mathrm{O}$ único argumento não aceito foi o relacionado ao gasto de energia, por não ser uma preocupação econômica.

No caso do PSF (Fibras Sintéticas de Poliéster) ${ }^{190}$, importado da Malásia e Taiwan, o interesse comunitário foi considerado para a não aplicação de medidas. Entendeu a Comissão que as desvantagens com a aplicação seriam superiores às vantagens à indústria doméstica. $\mathrm{O}$ volume e variedade dos produtos oferecidos pela indústria doméstica estariam se reduzindo, haveria problemas no fornecimento de

\footnotetext{
${ }_{188}^{189}$ Parágrafo 279 da decisão.

189 Lâmpadas. Regulamento (EU) n 1470/2001, de 16 de julho de 2001, OJ L 195 19/07/2001, p. 8.

${ }^{190}$ Fibras sintéticas de poliéster. Regulamento (EU) n . 428/2005 de 10 de março de 2005, OJ L 71, 17/03/2005, p. 1 .
} 
algumas fibras aos produtores comunitários e estava claro que a imposição de medidas ocasionaria aumento dos preços ao consumidor.

Outro caso de bastante relevância é o caso Euroalliages (importação de ferro silício do Brasil, China, Cazaquistão, Rússia, Ucrânia e Venezuela), levado a julgamento pela Corte de Primeira Instância. A Comissão decidira que "enquanto o impacto do fim das medidas antidumping para a indústria comunitária é incerto, a experiência tem demonstrado que não é garantido que a manutenção das medidas será benéfica ao interesse comunitário. A indústria do aço sofre prejuízos constantes, que serão indevidamente prorrogados caso a medida seja mantida." O Tribunal de Justiça europeu criticou a inércia da Comissão e realçou a necessidade de a Comissão buscar dados sobre o interesse comunitário. A Corte citou o artigo 21 (2) do Regulamento Básico europeu, entendendo que:

\begin{abstract}
"As peticionárias, importadores e suas representativas associações, usuários representativos e organizações de consumidores representativas podem, nos prazos especificados no início da investigação, saber e fornecer informação para a Comissão. Esta informação, e seus sumários apropriados, deve ser disponibilizada a todas as partes interessadas.

Está claro, nos termos do artigo 21(2), que o propósito da regra é assegurar que a decisão sobre o interesse comunitário seja tomada com base em informações as mais completas possíveis, representativas e críveis, sobre as quais todas as partes tenha tido a oportunidade de se manifestar. Contudo, isso não significa que a Comissão não procure outras informações que possam ser relevantes para se concluir sobre o interesse comunitário e que não tenham sido trazidas sob a luz do artigo 21(1).,"191
\end{abstract}

Diante destes exemplos e dos exemplos descritos no Anexo 2 a este trabalho, pode-se delinear os pontos analisados pela Comunidade Européia na consideração do interesse comunitário:

1. A incapacidade da indústria doméstica de suprir a demanda. Se a indústria não tem capacidade de oferecer produtos a todos os consumidores, o mercado depende de importação, não sendo do interesse comunitário a aplicação de medidas;

2. A incipiência da indústria doméstica, ainda no início de seu desenvolvimento, ou seja, não há evidências de que a indústria irá se desenvolver com a aplicação das medidas;

3. As barreiras à entrada na indústria, tais como custos de entrada e tributos na importação, já demonstram que i) a indústria

${ }^{191}$ Euroalliages v. Commission. Judgment of the Court of First Instance, 8 de julho de 2003, p. 8. 
doméstica goza de posição favorecida; ii) a entrada de outro fornecedor, caso seja necessário, é improvável;

4. O nível de emprego afetado na indústria doméstica e sua comparação com as demais indústrias afetadas, ou seja, a análise de qual parte interessada perderá mais com a aplicação ou não das medidas;

5. Se a parcela das importações a preço de dumping será simplesmente substituída por importações de outras origens, ou seja, não haverá qualquer aproveitamento, por parte da indústria doméstica, das barreiras aplicadas;

6. Se houve manifestação de associações de consumidores, considerando falta de interesse a não manifestação;

7. A capacidade tecnológica e industrial dos produtores, ou seja, se a indústria doméstica será capaz de se desenvolver durante a aplicação das medidas;

8. Setor estratégico para a economia ou defesa nacionais, impondo a sua proteção;

9. Diminuição das opções de escolha aos consumidores e aumento dos preços, como, por exemplo, bloqueio de produtos que não são oferecidos pela indústria doméstica ${ }^{192}$;

10. No caso de revisão, a verificação do aproveitamento, pela indústria doméstica, durante a fase em que existiu proteção.

Alguns argumentos foram trazidos pelas partes interessadas, mas não foram considerados pela Comissão. Entre eles estão argumentos concorrenciais, tais como o fato de que o dano não foi conseqüência das importações, mas sim do comportamento da indústria doméstica, praticando preços muito altos devido à sua posição dominante, ou alegações de que a aplicação de medidas poderia aumentar o poder de mercado da indústria doméstica. Argumentos ligados ao meio ambiente e ao desenvolvimento também não foram considerados. A Comissão não se rendeu ao fato de que as medidas antidumping poderiam ser contrárias às políticas ambientais da União Européia, nem tampouco ao fato de que os países investigados eram países em

\footnotetext{
${ }^{192}$ Aqui, poder-se-ia falar em erro da autoridade investigadora ao considerar os produtos similares. Se a indústria doméstica não fabrica toda a gama de produtos importada, então estes produtos não produzidos devem ser excluídos da investigação e sobre eles não pode ser aplicada medida. Contudo, a prática pode se distinguir da teoria, de forma fácil, neste caso. Como as medidas são aplicadas segundo a nomenclatura de comércio exterior, são freqüentes as aplicações de medidas sobre todos os produtos registrados sob aquele número, incluindo, por isso, produtos não similares. Tal crítica foi feita em capítulo anterior, sobre a definição de produto similar.
} 
desenvolvimento (e que a aplicação de medidas poderia trazer prejuízos aos países em desenvolvimento).

\subsubsection{A aplicação pelo Brasil}

A experiência brasileira nesta matéria não permite alcançar conclusões acerca do entendimento das autoridades brasileiras sobre o interesse público no antidumping. Em apenas cinco investigações o tema foi debatido, o que não significa dizer que ele não tenha sido aventado nos demais casos. ${ }^{193}$ Contudo, não houve, ainda, um posicionamento uniforme, a formação de um precedente importante, nas decisões brasileiras, que indicasse a posição do País.

\subsection{O procedimento}

De acordo com a legislação brasileira, a CAMEX pode, diante de circunstâncias excepcionais, decidir em favor do interesse nacional, deixando de aplicar medidas antidumping mesmo quando demonstrado o dano, o dumping e o nexo causal. ${ }^{194}$

O teste não é obrigatório e não é feito em todos os casos. Além disso, a CAMEX não é a autoridade que conduz a investigação (e sim o DECOM), havendo um distanciamento substancial entre os responsáveis pela definição do interesse público e aqueles que pesquisaram o mercado, investigaram os produtos e verificaram as

193 O Departamento de Defesa Comercial promove audiência final em todas as investigações antidumping. Nestas oportunidades, é frequiente a presença de importadores, consumidores ou interessados não habilitados como partes no processo. Contudo, como a análise do interesse público, pelo art. 64.3, do Decreto n. 1.602/95, é de competência da CAMEX, limita-se o DECOM a instruir os interessados para, se desejarem, manifestar-se perante o órgão competente. (Art. 18 do Decreto $n$. 4.632/2003.)

${ }^{194}$ Decreto n. 1602/95, artigo 64.3. "Em circunstâncias excepcionais, mesmo havendo comprovação de dumping e do dano dele decorrente, as autoridades referidas no art. 2 poderão decidir, por razões de interesse nacional, pela suspensão da aplicação do direito ou pela não homologação de compromissos de preços, ou, ainda, respeitando o disposto no parágrafo único do art. 42, pela aplicação de direito em valor diferente do que o recomendado, e, neste caso, o ato deverá conter as razões que fundamentaram a decisão." As autoridades do art. 2 são os Ministros de Estado da Indústria, do Comércio e do Turismo e o Ministro da Fazenda, com base em parecer da Secretaria de Comércio Exterior - SECEX. 
informações. Por não existirem critérios, há dificuldade em se analisar o interesse público no caso concreto, havendo muita pressão de grupos interessados e poucas condições para uma boa decisão pela câmara. ${ }^{195}$

Poucos artigos acadêmicos foram publicados, no país, sobre o tema. Contudo, a totalidade destes artigos apresenta críticas e se posiciona a favor de uma aproximação entre os instrumentos de defesa da concorrência e os instrumentos de defesa comercial.

Monteiro e Galvão, em texto publicado sob os auspícios da Secretaria de Acompanhamento Econômico do Ministério da Fazenda brasileiro ${ }^{196}$, mencionam a existência, no seio dos governos nacionais, de um movimento em busca de uma aplicação mais racional do instrumento de defesa comercial, consubstanciado no esforço de evitar conflitos internos entre o antidumping e a defesa da concorrência. As autoras elaboraram um trabalho cujo objetivo é a "harmonização das políticas de defesa da concorrência e de defesa comercial, buscando o objetivo comum de beneficiar o consumidor."197

Monteiro e Galvão sugerem a análise do interesse público após a determinação do dumping, incorporando-se conceitos utilizados na esfera concorrencial. A avaliação pode ser feita com a verificação de: i) disponibilidade de produtos iguais ou substitutos $^{198}$; ii) impactos da imposição da medida antidumping (no ambiente concorrência, na cadeia produtiva, na acessibilidade a insumos e tecnologia, na

\footnotetext{
${ }^{195}$ Aguarda votação pelo Senado Federal brasileiro um projeto de lei que prevê a criação de um Conselho de Defesa Comercial, que tem como objetivo combater práticas desleais de comércio exterior, como o dumping. Segundo o senador que o propôs, a criação deste conselho daria mais celeridade às investigações, que atualmente, critica, são muito lentas e raramente permitem a aplicação de direitos provisórios. Além disso, a influência que sofre a CAMEX, por representantes de outros Ministérios, não é saudável, já que cada Ministério parece estar preocupado com a sua política, e não com princípios do comércio internacional. (mais informações em PLS715/07, www.senado.gov.br)

${ }^{196}$ Um dos três órgãos, no Brasil, responsáveis pela análise concorrencial.

${ }^{197}$ MONTEIRO, Carmen Diva Beltrão; GALVÃO, Letícia Andreoli. Interesse público: critérios para a consideração em processos de investigação antidumping. SEAE/MF Documento de trabalho $n$. SEAE/MF Documento de trabalho n. 44, Dezembro de 2006. p. 6.

${ }^{198}$ Pela análise do fluxo de importações de outras origens durante o prazo de análise de dumping, análise do fluxo de importação antes do período de dumping (por um mesmo tempo considerado), levantamento de possíveis fornecedores nas origens não investigadas e de regimes preferenciais de importação (acordos bilaterais ou regionais) e mapeamento das barreiras à importação de origens não investigadas.
} 
acessibilidade de consumidores) ${ }^{199}$; iii) impactos da eliminação/redução da medida antidumping $^{200}$; e iv) outras análises ${ }^{201}$.

Araújo Jr. é um dos maiores críticos da aplicação do instrumento antidumping no Brasil. Ele defende a reflexão sobre quatro pontos: i) os custos altos da proteção antidumping; ii) os procedimentos são facilmente apropriados por empresas domésticas envolvidas em condutas anticompetitivas (colusão, manutenção dos cartéis e abuso de posição dominante); iii) as medidas de salvaguarda são mais apropriadas para alcançar o mesmo objetivo, que é a proteção seletiva e temporária a indústrias incapazes de enfrentar a concorrência dos bens importados; iv) pode-se substituir as normas antidumping por normas antitruste. ${ }^{202} \mathrm{O}$ autor propõe, como solução para os problemas do antidumping, a utilização de dois testes já adotados nas análises concorrenciais: a verificação do grau de concentração no mercado exportador e das barreiras à entrada no mercado importador. Segundo ele, não devem ser abertas investigações contra produtos provenientes de mercados pulverizados - em que não seria possível a prática de preços predatórios - ou contra exportadores que não possuem posição dominante.

\footnotetext{
${ }^{199}$ I - NO IMPACTO CONCORRENCIAL: Definição do mercado relevante, sob dimensão geográfica e do produto, determinação do grau de concentração vis-à-vis o mercado internacional, análise da evolução de preços no mercado interno e externo no período investigado, exame da probabilidade de exercício de poder de mercado (barreiras à entrada, rivalidade, possibilidade de colusão), análise do impacto provável nas condições de concorrência de operações estruturais (fusões e aquisições) e análise do histórico da participação das empresas domésticas em processos de investigação antitruste. II - NA CADEIA PRODUTIVA: avaliação do grau de integração, determinação do percentual de influencia da medida aplicada no custo de produção, determinação do percentual de repasse do custo provocado pela medida ao longo da cadeia produtiva. III - NA ACESSIBILIDADE A INSUMOS/TECNOLOGIA: dterminação de produtos usados como insumos e tecnologia ligados ao produto, análise da estrutura da demanda e oferta dos produtos usados como insumo e tecnologia, análise das eficiências econômicas e dos efeitos da medida antidumping sobre o bem-estar do consumidor e IV - NA ACESSIBILIDADE DOS CONSUMIDORES: análise na estrutura da demanda e oferta (elasticidades), análise nas eficiências econômicas sobre o bem-estar do consumidor e possíveis danos decorrentes da aplicação da medida na logística de distribuição dos produtos aos consumidores.

${ }^{200}$ Avaliação do grau de integração da cadeia produtiva de produtos similares (dependência entre os elos, integração, localização dos insumos), determinação do percentual de influência da redução da medida no custo de produção, determinação do percentual de repasse que um menor aumento no custo acarretará ao preço final, possíveis vantagens que a não aplicação da medida ensejaria para a cadeia produtiva.

${ }^{201}$ Quaisquer outras informações ou dados que não se enquadrem nas hipóteses acima mas que sejam relevantes à análise. As autoras esclarecem que a análise dos itens acima depende da existência e disponibilidade dos dados e informações, bem como do tempo que as autoridades disporão para analisálos.

${ }^{202}$ ARAÚJO Jr., José Tavares. As normas antidumping da ALCA e a agenda multilateral. Sistema de Informação sobre Comércio Exterior/Organização dos Estados Americanos - SICE/OEA, Dezembro de 2001, disponível em HTTP://www.sice.oas.org/compol/articles/cpant.asp, acessado em 27 julho de 2008.
} 
Tais críticas e sugestões, embora oportunas e construtivas, parecem distantes da realidade da defesa comercial no mundo. Tal detalhamento nas análises tornaria inviável a consideração do interesse público e o encerramento das investigações no prazo de dezoito meses.

\subsection{A opinião do Brasil nas negociações sobre interesse público na OMC}

Aqueles que analisam as manifestações do Brasil nas negociações antidumping na OMC não conseguem compreender facilmente o posicionamento do País. O Brasil assinou as propostas dos Amigos do Antidumping de 2002 e $2003^{203}$, mas não é um dos signatários das propostas posteriores deste grupo.

A explicação para uma aparente mudança de opinião é o fato de que o Brasil deixou de estar entre aqueles Membros da OMC conhecidos como alvos de medidas antidumping, para figurar, também, entre os Membros conhecidos como usuários do antidumping. Os países usuários tendem a ser mais restritivos em suas negociações, pois temem que as regras fiquem ainda mais rígidas e isso torne difícil a aplicação do antidumping. O Brasil encontra-se em posição intermediária. É um dos países que aplica mais medidas antidumping ${ }^{204}$, mas também é um dos países que mais sofre medidas antidumping ${ }^{205}$.

Há uma grande preocupação, segundo os negociadores brasileiros, em relação ao tempo de duração das investigações e o custo. O Brasil teme que seja

\footnotetext{
203 Negotiating Group on Rules - Report by the Chairman to the Trade Negotiations Committee, TN/RL/W/6, de 2 de julho de 2003 e Negotiating Group on Rules - Replies to Questions to our First Contribution (TN/RL/W/6) - Paper from Brazil; Chile; Colombia; Costa Rica; Hong Kong, China; Singapore; Switzerland and Thailand, TN/RL/W/45, de 27 de janeiro de 2003.

204147 investigações iniciadas pelo Brasil (6 da lista), 75 medidas aplicadas pelo Brasil (9 da lista), entre 01/01/95 e 31/12/07, segundo dados da OMC disponíveis em www.wto.org, consulta em 24 de setembro de 2008;

20594 investigações iniciadas contra o Brasil (9 da lista), 72 medidas aplicadas contra o Brasil (8 da lista) entre 01/01/95 e 31/12/07, segundo dados da OMC disponíveis em www.wto.org, consulta em 24 de setembro de 2008.
} 
aprovada uma proposta que vá dificultar a aplicação do antidumping, com mais requisitos a serem observados, tornando mais oneroso o procedimento. ${ }^{206}$

O Brasil discorda de alguns pontos do texto proposto pelo Presidente do Grupo de Negociações de Regras. ${ }^{207}$ O ponto mais controverso é a impossibilidade de revisão judicial das decisões sobre interesse público. Sustenta o Brasil que esta cláusula é contrária ao princípio da inafastabilidade do Poder Judiciário, disposto no art. 5, inciso XXXV, da Constituição Federal. ${ }^{208}$

\subsection{A jurisprudência brasileira sobre interesse público no antidumping}

$\mathrm{Na}$ investigação de antidumping sobre as importações de barrilhas densas (carbonato dissódico) provenientes da Bulgária, Polônia e Romênia, o interesse público foi lembrado sob o argumento de que a imposição do antidumping poderia afetar dramaticamente as indústrias de vidro e limpeza, dependentes das importações. $\mathrm{O}$ direito antidumping não foi imposto e a indústria doméstica acabou falindo. ${ }^{209}$

$\mathrm{Na}$ investigação de antidumping sobre as importações de pneus de bicicleta da China, Índia, Taipe Chinês e Tailândia, a aplicação da medida contra a China foi reconsiderada, aparentemente sob a idéia de que não era do interesse publico. Contudo, a motivação foi claramente política, e não de apreciação de qualquer interesse público tal como a preservação dos importadores ou consumidores. O Brasil viu-se em meio a fundamentais negociações comerciais com a China, passando a ser desinteressante a aplicação de uma medida contra as importações provenientes daquele

\footnotetext{
${ }^{206}$ Segundo entrevistas realizadas na Missão Permanente do Brasil, em Genebra, em setembro de 2008.

${ }^{207}$ Embora o Brasil não tenha se manifestado formalmente acerca do texto, as opiniões dos Membros sobre a redação podem ser colhidas nos corredores da OMC. No caso do Brasil, a opinião foi colhida na Missão Permanente em Genebra.

${ }^{208}$ Art. $5^{\circ}$ Todos são iguais perante a lei, sem distinção de qualquer natureza, garantindo-se aos brasileiros e aos estrangeiros residentes no País a inviolabilidade do direito à vida, à liberdade, à igualdade, à segurança e à propriedade, nos termos seguintes: XXXV - a lei não excluirá da apreciação do Poder Judiciário lesão ou ameaça a direito;

209 Processo MDIC/SECEX 52100-000016/1996-11, importação de carbonato dissódico (barrilha), Circular n. 23, de 29 de junho de 1998, publicada no D.O.U em 30.06.98.
} 
país. Posteriormente, a aplicação do direito foi revista e o valor elevado, pois a não aplicação provocou efeitos imediatos na indústria doméstica, acentuando-se o dano. ${ }^{210}$

$\mathrm{Na}$ investigação de antidumping no ferro cromo, proveniente da África do Sul, Cazaquistão e Rússia, houve muita discussão entre o Ministério da Fazenda e o Ministério do Desenvolvimento. O primeiro defendia a não aplicação da medida antidumping, sob o argumento de que a indústria doméstica era extremamente concentrada, e a aplicação levaria a um aumento do poder econômico. São as palavras da Resolução CAMEX n. 36, de 13 de dezembro de 2004: "O Conselho de Ministros da Câmara de Comércio Exterior, reunido em 25 de novembro de 2004, com fundamento no $\S 3^{\circ}$ do art. 64 do Decreto n. 1.602/95, e considerando o interesse do país em preservar a estabilidade de preços no setor siderúrgico, decide suspender, por prazo indeterminado, a aplicação de direitos antidumping definitivos sobre a importação de ferro cromo alto carbono (...) monitorando-se as importações do produto em questão." 211 Posteriormente, o Brasil decidiu aplicar as medidas contra a África do Sul. $^{212}$

$\mathrm{Na}$ investigação de antidumping no produto cimento portland, originário da Venezuela e México, o interesse público também foi discutido. De acordo com o Ministério da Fazenda brasileiro, o Estado de Roraima, ao norte do Brasil, enfrentava um sério problema concorrencial, que tornava o produto mais caro naquela região do que no sul do país. Diante deste fato, a CAMEX decidiu suspender os direitos, para as importações desembaraçadas em Roraima e destinadas ao consumo neste Estado, "considerando o interesse do País em preservar a estabilidade dos preços do cimento portland no Estado de Roraima". Esta decisão foi bastante criticada, pois não parece possível controlar e impedir que o cimento importado em Roraima permaneça no Estado. $^{213}$

\footnotetext{
210 Processo MDIC/SECEX 52100.085489/2002-27, importação de pneus novos para bicicletas, Resolução CAMEX n. 37, de 11 de dezembro de 2003, publicada no D.O.U em 19.12.03.

${ }^{211}$ Processo MDIC/SECEX 52100-017966/2003-11, importação de ferro cromo, Resolução CAMEX n ${ }^{\circ}$ 31, de 05 de outubro de 2004, publicada no D.O.U. de 11 de outubro de 2004.

${ }^{212}$ Resolução CAMEX n. 13, de 25 de abril de 2007.

${ }^{213}$ Processo MDIC/SECEX 52500.007154/2005-16, importação de cimento portland, Resolução CAMEX n. 36, de 22 de novembro de 2006, publicada no D.O.U em 27.11.06.
} 
Em uma decisão bem recente, no processo de revisão de medidas antidumping aplicadas para o nitrato de amônio proveniente da Rússia e Ucrânia, o Brasil alterou os direitos vigentes, determinando sua aplicação por mais um ano, e imediatamente suspendeu esta aplicação, por também um ano. O fundamento para tal suspensão foi o "interesse do país em preservar a estabilidade dos preços do produto e sua importância nas principais culturas brasileiras". Neste caso, houve muita pressão do setor agrícola brasileiro. Como o Ministério da Agricultura participa das decisões da CAMEX, ele se manifestou sobre os prejuízos que a continuidade da aplicação do direito poderia gerar ao setor. Ao contrário da Comunidade Européia, em que os direitos antidumping não são aplicados, no caso brasileiro é determinada sua aplicação e posterior suspensão. Não são claras as razões deste procedimento adotado, mas, ao que parece, ele evitaria a abertura de uma nova investigação ou revisão caso alguma situação de fato obrigasse o fim da suspensão. ${ }^{214}$

Não é possível determinar o entendimento brasileiro sobre o interesse público, apenas se podem delinear os aspectos considerados pelas autoridades investigadoras nas investigações mencionadas, sendo eles: i) efeitos negativos para a indústria à jusante; ii) concentração da indústria doméstica e aumento do poder econômico; e iii) necessidade de preservar a estabilidade no setor.

${ }^{214}$ Processo MDIC/SECEX/RJ 52500.017967/2007-78, importação de nitrato de amônio, Resolução n. 71, de 4 de novembro de 2008, publicada no D.O.U em 07.11.08. 


\subsection{A INDETERMINAÇÃO DA NOÇÃO DE INTERESSE PÚBLICO}

Uma das principais dificuldades nas negociações do interesse público no antidumping é, sem dúvida, a definição do interesse público. Parte desta dificuldade se deve à própria expressão. Nenhuma outra poderia trazer mais apelo ao clamor de soberania dos países do que "interesse público". Se os países tivessem optado por negociar apenas aspectos econômicos relativos aos efeitos provocados pelas medidas, por exemplo, seria mais fácil chegar a um acordo.

Contudo, não foi por acaso que a expressão "interesse público" foi escolhida pelos primeiros Membros que a propuseram. ${ }^{215}$ A maioria dos países adota o termo, ou alguma outra semelhante, em suas legislações nacionais. Em todos eles, há um interesse ou vontade maior do que as vontades individuais, que forma o caminho pelo qual deve seguir o Estado na realização de suas políticas e princípios.

No Brasil, assim como em outros países do mundo, em especial os de tradição civilista, são comuns, em textos legais, expressões de conteúdo impreciso, de acepção indefinida. A imprevisibilidade de significado destas locuções possui uma razão de ser. Elas são responsáveis pela adaptação do texto, elaborado para uma longa vigência, no tempo em que ele é lido e interpretado. Por esta razão, estas expressões não têm o seu conteúdo delimitado, estático.

O interesse público possui conteúdo indeterminado por natureza. ${ }^{216} \mathrm{~A}$ sua vitalidade e a possibilidade de ele prevalecer por vários anos e décadas são explicadas por esta indeterminação, que permite que ele se adapte à realidade. Se lhe é dada uma definição rígida e preestabelecida, ou é certo que esta definição deverá ser revista de tempos em tempos, ou ela não será adequada à sua própria finalidade, de

\footnotetext{
${ }^{215}$ Hong Kong, proposta MTN.GNG/NG8/W/46, e Singapura, MTN.GNG/NG8/W/55.

${ }^{216} \mathrm{Na}$ definição de Eros Roberto Grau: "São indeterminados os conceitos cujos termos são ambíguos ou imprecisos - especialmente imprecisos - razão pela qual necessitam ser completados por quem os aplique. Neste sentido, talvez pudéssemos referi-los como conceitos carentes de preenchimentos com dados extraídos da realidade (...) os parâmetros para tal preenchimento - quando se trate de conceito aberto por imprecisão - devem ser buscados na realidade, inclusive na consideração das concepções políticas predominantes, concepções estas que variam conforme a situação das forças sociais" (GRAU, Eros Roberto. Direito, Conceitos e Normas Jurídicas. São Paulo: Editora RT, 1988, p. 72.)
} 
instrumento de legitimação de decisões, de normalização de comportamentos e de unificação de regras de direito. Ser indeterminado não é, portanto, um defeito do conceito, pois lhe permite a exata adequação à realidade de cada momento.

Ser indeterminado é diferente de ser indeterminável. É possível interpretar seu significado de acordo com a história e seu contexto. Por exemplo, no século XVI, não era exagero afirmar que o interesse público coincidia com o interesse do soberano. Apenas com o desenvolvimento social e político tornou-se possível identificar interesses públicos não estatais (exemplo de entidades não governamentais que agem em prol da sociedade). Contudo, não se pode construir o conceito de interesse público a partir de seu titular, pois o Estado é apenas o instrumento de realização destes interesses, que são anteriores à sua existência. O interesse é público não porque cabe ao Estado defini-lo, mas sua definição é atribuída ao Estado por ser público. ${ }^{217}$ É importante lembrar, também, que o Estado não atua necessariamente de modo semelhante aos particulares, eles não possuem interesses qualitativamente similares. ${ }^{218}$

Contudo, mesmo não se lhe sendo atribuída uma definição rígida ${ }^{219}$, a interpretação do que é interesse público deve respeitar princípios, no Brasil detalhados

217 "Sem dúvida, as demais funções estatais também são vinculadas ao interesse público. Mas à função administrativa incumbe, em nosso ordenamento jurídico, a responsabilidade especifica e precípua de prover a respeito, em caráter concreto, direto, contínuo, imediato, cotidiano. Caberá à Administração Pública, no seu dia-a-dia, interpretar interesse público, para aplicá-lo às hipóteses da realidade viva." (BORGES, Alice Gonzáles. Interesse Público: um conceito a determinar. Revista de Direito Administrativo, Rio de Janeiro, v. 205, jul/set. 1996, p. 109-116). Nas palavras de Marçal Justen Filho: "O interesse público não se confunde com o interesse do Estado, com o interesse do aparato administrativo ou do agente público. É imperioso tomar consciência de que um interesse é reconhecido como público porque é indisponível, porque não pode ser colocado em risco, porque suas características exigem a sua promoção de modo imperioso. Afirma-se que o princípio da supremacia e indisponibilidade do interesse público é o alicerce fundamental do Direito Público, o que seria suficiente para legitimar as decisões adotadas pelos administradores. Ora, juridicamente, o titular do interesse público é o povo, a sociedade. Mas os governantes refugiam-se neste princípio para evitar o controle de seus atos pela sociedade." (JUSTEN FILHO, Marçal. O Direito Administrativo Reescrito: problemas do passado e temas atuais. Revista Negócios Públicos, ano II, n. 6, p. 39-41.)

${ }^{218}$ São conhecidos casos em que o Estado fornece drogas a viciados, ou assume atividades ou empresas moralmente reprováveis, seja porque sabe que é impossível eliminá-las, seja para evitar prejuízos ainda maiores. Nestes casos, ele não age de forma similar aos particulares. (JUSTEN FILHO, Marçal. Conceito de Interesse Público e a personalização do direito administrativo. Revista Trimestral de Direito Público, v. 26, 1999, p. 117).

${ }^{219}$ Justen Marçal Filho defende que não há conceito definitivo. A determinação de seu conteúdo se faz ao longo do processo de produção e aplicação do Direito. A concretização do Direito produz a seleção dos interesses, com a identificação do que se chamará de interesse público em face das circunstâncias. E isso não é negativo, mas positivo, pois representa a superação de soluções formalistas, de forma a propiciar a realização dos valores fundamentais da comunidade. Para ele, o processo de democratização conduz à 
na Constituição Federal, e, na União Européia, no Tratado de Roma. Eles garantem o respeito aos valores essenciais. Conforme lembra Maria Lúcia Valle Figueiredo, o fato de não haver uma concepção fixa e imutável de interesse público não impede que ele tenha um "núcleo mínimo de compreensão". Sua conotação e denotação deverão ser extraídas dos princípios informadores do ordenamento. Seu conceito será dado à luz do próprio instituto que se examina, do próprio sistema. ${ }^{220}$

Duas grandes questões serão respondidas a partir deste momento. A primeira delas é quem deve determinar o interesse público no caso concreto, quem desvendará este "núcleo mínimo de compreensão". Será o Estado ou os cidadãos, em uma contribuição democrática e participativa? Para isso, estudar-se-á as contribuições de Rousseau e Tocqueville, respectivamente, contratualista e individualista. Rousseau e Tocqueville, em seus estudos sobre a formação do interesse público e a sua definição por um soberano ou pelo cidadão, podem fornecer parâmetros para a acepção do interesse público nas investigações antidumping.

O interesse público pode ser estudado sob dois aspectos: o político e o jurídico. Cada um destes aspectos pode fornecer subsídios interessantes à utilização da expressão como requisito a ser analisado em uma decisão administrativa.

\subsubsection{O aspecto político}

É sob o aspecto político que ele aparece mais freqüentemente, na palavra dos governantes, que buscam a realização do interesse público da nação. Não raro, a expressão é utilizada sem que haja qualquer preocupação com sua dimensão. Por vezes, ela significa a soma dos interesses individuais. Em outras, ela parece ser a vontade de uma coletividade, destacada da soma das vontades individuais.

Outra dúvida é se o interesse público é o interesse do povo ou o interesse do Estado. Ele será do Estado se este estiver comprometido com a

necessidade de verificar, em cada oportunidade, o que se configura como interesse público. (Op. cit. p. 133.)

${ }^{220}$ VALLE FIGUEIREDO, Maria Lúcia. Curso de Direito Administrativo. São Paulo: Ed. Malheiros, p. 32. 
representação dos interesses de seu povo. ${ }^{221}$ Pode ser que o interesse público se reduza a uma decisão dos governantes imposta aos seus governados. ${ }^{222} \mathrm{O}$ conflito se encontra exatamente neste ponto, ou seja, pode ser que o Estado defina o conteúdo do interesse público de forma diferente ao que seria definido se os cidadãos o interpretassem.

Para François Rangeon, o interesse geral ${ }^{223}$ cumpre uma tripla função de legitimação de decisões, de normalização de comportamentos e de unificação de regras de direito. Para que possa exercer estas três funções, a norma de interesse geral deve ser clara, ordenada e autêntica, qualidades conferidas pela codificação pelo Estado. $^{224}$ É o Estado que, ao prever a observância do interesse geral em seu ordenamento jurídico, traça linhas que permitem interpretar o que pode ser o conceito da expressão.

Dois filósofos, separados por uma centena de anos, contribuíram para o estudo do interesse público. Em primeiro lugar, Rousseau (1712-1778), com sua glorificação da coletividade (teoria da soberania popular e insistência na idéia da vontade geral), é o primeiro filósofo do pensamento liberal a recorrer à noção de vontade geral como fundamento de democracia. Tocqueville (1805-1859), em perfeita contraposição - embora em certos momentos também em apoio - a Rousseau,

\footnotetext{
${ }^{221}$ Toda teoria democrática defende que o povo seja a verdadeira fonte de interesse público. Uma concepção de interesse público que seja oposta à vontade popular será contrária a todo princípio democrático. É desta forma que o Estado consegue a aprovação para várias políticas que vinculam o setor privado às orientações do setor público. Porém, mesmo quando o Estado consegue a participação do setor privado na realização do interesse público, este interesse público não pode ser confundido com o interesse privado. As privatizações no Brasil, na década de 90, com a conseqüente delegação aos particulares de atividades antes desempenhadas pelo Estado, em prol do interesse público, são um bom exemplo.

${ }^{222}$ Para evitar que o Estado seja chamado de autoritário, concebe-se o discurso de que ele atua como garantidor do interesse público. Embora se saiba que o monopólio da definição do que seja este interesse é deste Estado, transmite-se a idéia de que ele apenas garante a sua realização. (RANGEON, François. L'ideologie de l'intérêt général. Paris : Economica,1986, p. 17.)

${ }^{223}$ Luigi Graziano defende a distinção entre interesse público e intérêt général. "Interesse público e intérêt général correspondem a duas concepções diferentes do que é público. Na primeira expressão, "público" se refere ao que existe de comum numa coletividade e, também, a um espaço público (como um jardim público). Designa, então, uma arena que pertence tanto ao Estado quanto à sociedade. O conceito de esfera pública em Habermas tem uma conotação semelhante: corresponde ao que não é privado na sociedade civil (opinião pública, imprensa, mercado, profissões). Em contraste, o intérêt général não pode ser outra coisa senão uma prerrogativa do Estado e de suas instituições. Não pode ser pluralizado e pressupõe uma visão conjunta da sociedade e de suas necessidades. Embora os atores sociais tenham liberdade para procurar realizar seus vários objetivos, tudo o que é comum, público, de importância suprema para a nação, pertence ao âmbito exclusivo do Estado." (GRAZIANO, Luigi. $O$ lobby e o interesse público. Revista Brasileira de Ciências Sociais. V. 12, n. 35, fev. 1997. p. 21). Neste trabalho, não faremos a distinção entre interesse público e intérêt general, adotando as expressões como sinônimas. ${ }^{224}$ Op. cit. p. 21.
} 
reconhece a existência de uma diversidade de interesses, mas não aceita soluções contratualistas para a pacificação do conflito entre eles, mas sim a cidadania como única garantia da superação do predomínio do auto-interesse.

Não se pode estudar o interesse público no direito antidumping sem conhecer a sua origem e os argumentos de Rousseau e Tocqueville. Na aplicação do interesse público no tempo e no espaço, o operador estará sempre diante do conflito entre aplicar os interesses por meio da solução contratualista ou da solução democrática. Além disso, Tocqueville e Rousseau lembram a força das pressões públicas na definição deste interesse. É impossível estudar o interesse público no direito antidumping sem reconhecer a força dos grupos de pressão.

\subsubsection{A vontade geral para Rousseau como limitadora do poder do Estado}

A partir do momento em que a sociedade passou a se preocupar com o interesse do individuo, com o homem racional, nasceu a inquietação do homem em relação à formação de uma organização social capaz de assegurar o Bem Comum. ${ }^{225}$

Rousseau defende que o ato de associação encerra o compromisso do público com os particulares e dos particulares com o todo, não podendo, assim, aplicarse a máxima do direito civil de que ninguém é obrigado aos compromissos assumidos consigo mesmo (pois há grande diferença entre obrigar-se consigo mesmo ou com um todo do qual se faz parte).

\footnotetext{
${ }^{225}$ Aristóteles ressaltou a defesa do bem comum como forma boa de governo e o descreve como objetivo a ser seguido por todos os membros da comunidade. $\mathrm{O}$ homem, como animal social, mesmo que não necessite de assistência mútua, deseja viver junto, reunindo-se pela existência de um interesse comum, na medida em que cada um deles pode participar de uma vida melhor. Seriam estruturadas todas as constituições cujo objetivo maior é o bem comum. Quando o governante decide pensando em seu bem próprio, há um governo desviado. (Aristóteles, Política, Universidade de Brasília, Trad. Maria da Gama Kury, p. 89.) A questão também chamou a atenção dos filósofos dos séculos XVII e XVIII. A Maquiavel se deve a intenção de libertar a política dos conceitos morais e religiosos, em busca de um Bem Público pela noção da estatização. Hobbes deixa claro que o Bem Comum não é um reflexo da ordem natural exterior aos indivíduos, mas uma criação da vontade humana. O Leviatã, personagem criado por ele, ilustra o Estado Social, criado para salvar o homem do Estado do Terror e manter a ordem e a paz. Para Locke, Montesquieu e Rousseau, o bem comum é uma limitação ao poder do Estado, ele existe somente para proteger os interesses particulares.
} 
O Estado é o representante, por contrato, do interesse que é distinto da soma dos interesses particulares. O contrato institui a formação de um terceiro interesse, baseado na vontade geral, mas que não é a sua simples soma. Ao mesmo tempo, este Estado está vinculado a esta vontade geral, não podendo atuar além dela, o que seria considerado como tirania.

Rousseau tornou-se o grande entusiasta da teoria da "vontade geral", justificando que o homem perderia, pelo contrato social, sua liberdade natural e o direito ilimitado, ganhando a liberdade civil e a propriedade de todos os bens que possui. $\mathrm{O}$ pacto social reduz-se, para ele, nos seguintes termos: "Cada um de nós reúne sua pessoa e todo o seu poder sob a suprema direção da vontade geral; e nós recebemos num corpo cada membro, como parte indivisível do todo."226

Uma vez postos os princípios (o homem busca seu interesse particular, o interesse comum não tem existência natural) e o projeto definido (construir um interesse comum a partir dos interesses particulares e garantir ao homem sua liberdade natural), começam as verdadeiras dificuldades. Como passar do interesse particular ao interesse comum? ${ }^{227}$ Por qual miraculoso mecanismo as vontades individuais poderão se fundir na "vontade geral", aquela do corpo político, do Estado? ${ }^{228}$

A solução é, em princípio, contratual. A ordem social é fundada em convenções. É exatamente da existência de interesses individuais conflitantes que surge a necessidade do estabelecimento das sociedades. O homem nasce livre, porém está acorrentado em todos os lados. A realização do interesse individual depende da existência de um contrato social, uma livre associação de seres humanos inteligentes, que por vontade própria decidem formar um tipo de sociedade à qual passam a obedecer. Assim, comprometem-se a não se opor individualmente à vontade do Estado (a primazia da vontade geral). O "Contrato Social" de Rousseau explica que os homens têm, por natureza, direitos que lhes permitiriam viver bem sem a sociedade.

\footnotetext{
${ }^{226}$ ROUSSEAU, Jean-Jacques. Do Contrato Social: Princípios do Direito Político. Trad. J. Cretella Jr. e Agnes Cretella. São Paulo: Editora Revista dos Tribunais, 2002, p. 32.

${ }^{227}$ Esta é um dos principais questionamentos na aplicação do interesse público no antidumping. Haverá sempre pelo menos dois interesses opostos: o interesse da indústria doméstica e o interesse do exportador. Embora o Estado não deva considerar, mas apenas ouvir, o interesse do exportador, este interesse pode ser coincidente com o interesse daquele que compra seus produtos dentro do país investigador. Como passar destes dois interesses distintos a um só interesse?

${ }^{228}$ ROUSSEAU, Jean-Jacques. Op. cit, p. 111.
} 
Rousseau também assume que, muitas vezes, há diferenças entre a vontade de todos e a vontade geral, entendida a vontade de todos como a soma de vontades particulares. Contudo, estas vontades se destruirão entre sim, nas deliberações, restando, para a soma das diferenças, a vontade geral. ${ }^{229}$

Para Rousseau, "a vontade geral dirige as forças do Estado segundo os fins de sua instituição, que é o bem comum: porque se a oposição de interesses particulares se tornou necessária para o estabelecimento das sociedades, foi o acordo destes mesmos interesses que a tornou possível. É o que há de comum entre os diferentes interesses que forma o elo social, e se não existe qualquer ponto sobre o qual estes interesses concordam, nenhuma sociedade existirá. Ou é unicamente sobre este interesse comum que a sociedade deve ser governada. "230

Rousseau distingue a "vontade geral" (que necessariamente vislumbra o interesse público) da "vontade de todos" (que pode ser composta da soma dos interesses particulares). A partir desta distinção, situa-se o soberano, na assembléia, como realizador da vontade geral, nunca da vontade de todos. ${ }^{231}$

\footnotetext{
${ }^{229}$ ROUSSEAU, Jean-Jacques. p. 49.

${ }^{230}$ J. Rousseau. Du Contrat Social (1762), livre II, cap 1, Paris, Gallimard, citado por Guylain Clamour, Intérêt Général et concurrence, Dalloz, Nouvelle Bibliothèque de Thèses, p. 167.

231 Poucos autores se preocupam com as nuances de vocabulário, distinguindo interesse comum de interesse público e, ambos, de interesse geral. François Rangeon faz a leitura de tais diferenças em Rousseau. O interesse comum é a soma dos interesses particulares. Para que exista interesse comum, é necessário que exista um elo entre as pessoas que compõem aquela coletividade, que faz com que os interesses sejam coincidentes. É necessário que os interesses tenham a mesma força, sob pena de o interesse mais forte dominar o mais fraco. O interesse comum nada mais será do que o interesse destas pessoas. O interesse público deve ser compreendido como o interesse próprio da coletividade criada. Uma vez instituído, o corpo político adquire um interesse que lhe é específico, o interesse público. Assim, o contrato social significa um compromisso recíproco do público com os particulares. Embora o público seja composto dos particulares, ele possui uma existência própria. O público tem uma vontade pública e, como toda vontade, tem um objeto, o interesse público. Não é possível dizer que o interesse público se resuma à soma dos interesses particulares. A comunidade é muito mais do que o conjunto de interesses dos seus membros, ela adquire uma existência distinta destes. A formação de uma comunidade pressupõe um processo de institucionalização política e o surgimento de organismos de vida própria, alheia à existência das vontades individuais que o constituíram. O processo de formação desta comunidade passa pela transformação do interesse comum em interesse público. O interesse público não é formado a partir dos interesses particulares. Ao contrário, ele os ultrapassa e passa a lhes ser superior. Os interesses individuais passam a ser observados, nesta coletividade, a partir dos interesses públicos. Já a vontade geral, para Rousseau, é a soma de interesses que podem ser diferentes, a favor e contra, positivos e negativos, nascendo a vontade geral da associação destas diferenças. Quanto mais diferentes as vontades, mais geral é o interesse. ${ }^{231}$ (RANGEON, François. L'ideologie de l'intérêt général. Paris : Economica,1986, p. 119.)
} 
Não é necessário sequer que as cláusulas deste contrato sejam escritas, enunciadas formalmente, bastando que sejam tacitamente admitidas e reconhecidas. Contudo, se tais cláusulas exagerarem o proposto, deverão ser consideradas nulas. $\mathrm{O}$ soberano faz parte da assembléia de associados, não podendo se esquecer de que deve velar pelo poder que lhe foi delegado para a função específica: a preservação da vontade geral. Isso previne o totalitarismo ${ }^{232}$

A concepção de Rousseau de contrato social não abarca, contudo, a discussão da luta de classes e do conflito de interesses. Sua utopia de igualdade e liberdade é inspirada na democracia vivida por ele na cidade de Genebra e pressupõe uma unidade pequena, uma comunidade homogênea com uma diversidade limitada de interesses. $^{233}$

A Revolução Francesa marca o fim de um período em que o interesse público era confundido com o interesse do rei. As aspirações individuais passam a ser base da sociedade e o individualismo domina sob dois postulados: a igualdade e a liberdade. A idéia do bem comum como fonte do interesse público é substituída pela idéia de que a vontade individual constitui a base da soberania. O Estado Liberal caracteriza-se como defensor dos interesses individuais ${ }^{234}$, mas, ao mesmo tempo, é insuficiente para conter alguns vícios, como a exagerada acumulação de poder e o crescimento da desigualdade social. ${ }^{235}$

Surge, pois, a fase democrática, em que a necessidade de participação do povo na organização do Estado, na formação e na atuação do governo torna-se essencial para garantir a sua vontade e resguardar a liberdade e a igualdade. ${ }^{236}$

\footnotetext{
${ }^{232}$ CARRACEDO, Jose Rubio. Democracia y legitimacion del poder em Rousseau. Revista de Estudios Politicos, n. 58, Outubro-dezembro, 1987.

${ }^{233}$ FREY, Klaus. Descentralização e Poder Local em Alexis de Tocqueville. Revista de Sociologia Política, Curitiba, n. 15, p. 83, Nov. 2000.

${ }^{234}$ A noção de interesse público no Estado Liberal estava ligada à de ordem pública, traduzindo-se em uma missão exclusivamente política. A justiça, a polícia e as finanças estavam entre os domínios de ação do Estado, sendo a segunda a principal. (LINOTTE, Didier; MESTRE, Achille. Services Publics et Droit Public Économique. Paris: Librairies Techniques, 1982, t. 1, p. 52).

${ }^{235}$ VIDIGAL, Geraldo de Camargo. Teoria Geral do Direito Econômico. São Paulo: Revista dos Tribunais, 1977, p. 14.

${ }^{236}$ ABREU DALLARI, Dalmo. Elementos de Teoria Geral do Estado, 16 ed. Saraiva, São Paulo, 1991, p. 128.
} 
Neste contexto, transparecem as idéias de Tocqueville. O jovem magistrado francês embarca para os Estados Unidos, em busca de aventuras e conhecimento, e se depara com uma sociedade ancorada em ideais diferentes daqueles nos quais se inspirava seu país. Decide, então, observar a democracia norte-americana e escrever sobre ela, defendendo que o Estado, o "delegado" da vontade geral, não seria capaz de conter o individualismo moderno, sendo necessária a instituição de um sistema participativo.

\subsubsection{A formação do interesse público democrático em Tocqueville}

Alexis de Tocqueville vê com desconfiança a consolidação da sociedade pequeno-burguesa caracterizada pela atividade comercial e industrial, por temer a perda da grandeza, da glória e da liberdade que o ancien regime ofereceu e proporcionou aos integrantes da aristocracia dirigente. Com uma expectativa bastante pessimista, Tocqueville previu a difusão do individualismo, o isolamento social dos homens, a prática de atitudes alheias à virtude cívica e ao engajamento público, causados pelo economicismo e pelo consumismo.

A grande esperança, para ele, é a ação política de homens dotados de espírito cívico, perseguindo o ideal de liberdade. Para tanto, ele se apóia na abordagem democratizante da descentralização político-administrativa. Enquanto a liberdade para Rousseau se baseia na igualdade social e na efetivação da vontade geral, a liberdade para Tocqueville independe da condição social e corresponde ao agir político. Mas é certo que, na sociedade moderna, a visão de uma sociedade harmoniosa e integrada se torna cada vez menos convincente, face às reivindicações sociais da população. ${ }^{237}$

Para Tocqueville, a chave para a pacificação dos conflitos de interesses não está no contrato social, posto que este sacrifica, de modo artificial, a vontade individual, mas sim dentro da própria sociedade. A solução não está em se constituir um fator externo, o Estado, para a realização do interesse público, mas sim a formação de uma sociedade democrática, aproximando o público ao privado pela

${ }^{237}$ VELASCO, Demetrio. Tocqueville (1805-1859), dos siglos despues. Estudios de Deusto. Revista de La Universidad de Deusto. v. 53/1, Janeiro-junho 2005. Bilbao: Deusto, 2005. p. 185. 
aproximação das esferas pública e privada. Sempre haverá certo descontentamento de um grupo, mas este será pontual e isolado.

A chave para a solução dos conflitos encontra-se não na busca da força externa, o Estado, mas sim dentro da própria sociedade. Inspirando-se na observação da prática norte-americana, ele sustenta que a conciliação entre o público e o privado só pode ser alcançada por meio de uma prática social educadora, transformando o egoísmo em um interesse bem compreendido. Ele não aposta nos interesses que as pessoas têm em comum, que não seriam, em longo prazo, suficientes, mas no estabelecimento de uma ordem que seja apoiada no agir e nos costumes de cidadãos. A liberdade manifesta-se, para ele, no exercício da cidadania. ${ }^{238}$

Neste sentido, sustenta Tocqueville que o sistema político perde estabilidade em uma sociedade de massa e em um território vasto, criando inimizades com o poder central. Em um território vasto, poucas pessoas terão acesso à esfera pública, ao passo de que, em uma sociedade descentralizada, a sociedade civil pode controlar melhor seus governantes. ${ }^{239}$

Dentro da idéia de que a solução para o problema do conflito de interesses não está na constituição de um fator externo - o Estado - mas sim na própria sociedade, Tocqueville ressalta a importância de os cidadãos passarem a identificar o exercício da liberdade política na esfera pública com seus próprios interesses privados.

O problema, todavia, é como aproximar as esferas pública e privada sem submeter o indivíduo a um Estado, à representação da vontade geral da sociedade. Para tanto, ele propõe a conciliação, somente alcançada por meio de uma prática social educadora que leva à transformação do egoísmo em um “interesse bem compreendido". Ele ressalta que só se pode esperar um maior comprometimento da população na vida política se o público integrar-se aos interesses privados.

Observando a prática norte-americana, descobriu Tocqueville que a liberdade pode ser explicada por fatores históricos, presente em suas instituições, costumes, práticas políticas e sociais. É presente, também, a idéia de que esta liberdade

${ }^{238}$ TOCQUEVILLE, Alexis de. A Democracia na América. T.1. São Paulo: Martins Fontes, 2005, p. 125. ${ }^{239}$ TOCQUEVILLE, Alexis. Op cit, p. 265. 
não pode ser derivada do Estado, imposta por leis ou instituições. O associativismo norte-americano é resultado de uma necessidade contínua de reunião. Os americanos, para Tocqueville, vêem na liberdade a maior garantia do seu bem estar, estando no seio das associações a realização desta liberdade. O processo participativo é visto como fundamental para criar ou salvaguardar a liberdade e alcançar o bem comum. Nesta realidade, a descentralização e o poder local tornam-se elementos importantes para a reconquista da autonomia da ação política pelo cidadão. ${ }^{240}$

Apesar de acreditar que as instituições serão capazes de conter o impulso de seres uniformes e iguais (que abdicarão da liberdade em nome de uma extremada igualdade), ele não deixa de reconhecer a existência da força de uma maioria sobre uma minoria desprovida de quaisquer condições para resistir. O poder da maioria tende a se tornar, na América, não somente predominante, mas irresistível. ${ }^{241}$

Mas, neste ponto, Tocqueville reconhece a existência de grupos intermediários que exprimem o espírito da sociedade, uma associação de cidadãos que, ao defender seus direitos particulares contra as exigências do poder, salva as liberdades comuns. ${ }^{242}$ São estes grupos sérios empecilhos ao abuso de poder por parte da maioria. Mas não se pode dizer que estes grupos estejam totalmente insatisfeitos ou não tenham as suas liberdades garantidas. A democracia atinge a todos indistintamente, fazendo com que seu descontentamento seja pontual e setorial. ${ }^{243}$

\subsubsection{O aspecto jurídico}

\footnotetext{
${ }^{240}$ FREI, Klaus. Op cit. P. 83-95.

${ }^{241} \mathrm{O}$ receio da existência da tirania da maioria confirma-se em John Kenneth Galbraith (1992), que relata a existência nos Estados Unidos, hoje, de uma Ditadura dos Ricos ou da Cultura do Contentamento. Vivese o pesadelo de uma "ditadura da classe satisfeita", aquela que recebe os benefícios de bem-estar e está satisfeita porque diz ser a maioria. (GALBRAITH, John Kenneth. A cultura do contentamento. São Paulo: Pioneira, 1992, p. 63).

${ }^{242}$ TOCQUEVILLE, Alexis. Op cit, p. 652.

${ }^{243}$ MAGALHÃES, Fernando. O passado ameaça o futuro: Tocqueville e a perspectiva da democracia individualista. Tempo Social, Revista de Sociologia da USP, São Paulo, 12 (1), maio 2000, p. 141-164.
} 
Sob o ponto de vista jurídico, o interesse público é um princípio que justifica uma obrigação ou uma proibição. Ele permite justificar a aplicação de uma regra precisa, ou, ao contrário, revogar uma regra precisa. ${ }^{244}$

Um princípio pode assumir três formatos: ser um axioma, um postulado ou uma norma. O interesse público assumiu a forma de postulado, observado na experiência, ou seja, não é concebido como uma vontade geral inquestionável, nem tampouco é claro o suficiente para ser chamado de norma.

Embora seja aposto em várias legislações, e em outras tantas seja considerado, o princípio do interesse público é questionado. Discute-se se, diante de tantos interesses privados conflitantes e egoístas, diante do próprio interesse do Estado, muitas vezes tirânico, ainda existe a possibilidade de se delimitar e encontrar um interesse público. Tal fato fez com que alguns autores entendessem existir uma crise no conceito, marcada pelo choque de individualismos e pela dificuldade do Estado de compreender a noção da expectativa pública.

Humberto Bergmann Ávila faz uma breve e útil introdução sobre a definição de princípios, que cabe aqui ser mencionada para a melhor compreensão do interesse público explicado, no antidumping chamado de "cláusula" ou "teste", mas que se trata de um princípio. O problema na definição e utilização de um princípio surge quando fenômenos distintos são explicados mediante o uso de denominações equivalentes, ou quando serve um princípio para explicar fenômenos descobertos em um mesmo objeto do conhecimento. Assim, eles passam a significar tudo, e, ao mesmo tempo, coisa alguma. A dogmática jurídica passa, ao invés de explicar enunciados, a encobri-los sob o manto dos princípios.

Para entender o que seja um princípio, o autor sugere fazer distinções quanto à sua finalidade e o objeto de conhecimento ao qual ele é extraído e ao qual deve manter referência. Consideram-se três as formas assumidas pelos princípios. Eles

\footnotetext{
${ }^{244} \mathrm{Na}$ Constituição Federal brasileira, por exemplo, o interesse público é mencionado diversas vezes (Art. 19 , sobre cultos religiosos, art. 37, sobre contratação de servidores públicos, art. 57, sobre a convocação do Congresso Nacional, art. 66, sobre projetos de lei, art. 93, sobre a magistratura brasileira e sobre os julgamentos, art. 95, sobre as garantias dos juízes, art. 114, sobre a Justiça do Trabalho e no art. 231, sobre a exploração de domínios indígenas). Além dele, pode-se lembrar também que as expressões interesse coletivo (Art. 5 e art. 173) e interesse geral (Art. 5) são usadas também, embora sem definição precisa, no texto constitucional.
} 
podem se comportar como axiomas (verdade inquestionavelmente aceita), postulados (obtido da observação da realidade) e normas (depende de positivação). Cabe definir, portanto, o que é o interesse público, defendido pelos Membros da OMC como uma cláusula a ser aposta em um acordo sobre antidumping, derivado da experiência, que permite a compreensão do fenômeno jurídico.

Um axioma é uma proposição cuja veracidade é aceita por todos, não sendo possível nem necessário prová-la. Ele é auto-demonstrável ou óbvio. O axioma serve como ponto inicial para dedução e inferências de outras verdades. A palavra axioma significa o que é considerado válido, adequado, auto-evidente. ${ }^{245}$ Trata-se de um valor incontestável. Um bom exemplo de axioma no sistema jurídico dos povos civilizados é a dignidade humana. Ela é espelhada em cartas constitucionais ou leis diversas, mas nem precisaria ser. Ela é lógica e sua observância é esperada.

Postulados são possibilidades de conhecimento de determinados objetos. Ao contrário dos axiomas, os postulados são estabelecidos por meio de experiências reais, do senso-comum. Assim há os postulados normativos, que são a possibilidade do conhecimento do fenômeno jurídico. Eles não são suficientes para fundamentar uma decisão, mas explicam como pode ser obtido o conhecimento do Direito (princípios de hermenêutica). São exemplos o postulado da coerência e o postulado da integridade. ${ }^{246}$

Por fim, há a norma-princípio. Norma é o conteúdo de determinada prescrição, em função do qual o ordenamento jurídico determina, proíbe ou permite. A norma-princípio tem seu fundamento no Direito Positivo e é concretizável. A normaprincípio não pode ter caráter abstrato, mas, ao contrário, deve-se aplicar a um determinado grupo de indivíduos, uma sociedade. A regra do artigo $5^{\circ}$, da Constituição Federal brasileira, é um princípio-norma: todos são iguais perante a lei. Não é uma verdade universal, algo óbvio como um axioma. Tampouco é algo que se possa abstrair

\footnotetext{
${ }^{245}$ São axiomas: Duas coisas iguais a uma terceira são iguais entre si. O todo é maior do que a parte.

${ }^{246}$ São postulados: Uma reta pode ser traçada de um ponto para outro qualquer. Qualquer segmento finito de reta pode ser prolongado indefinidamente para construir uma reta.
} 
da experiência da sociedade. Ao contrário, é uma norma imposta a um determinado grupo, deve ser positivada. ${ }^{247}$

Diante das definições acima trazidas, cabe elucidar se o princípio do interesse público seria um axioma, um postulado ou uma norma-princípio.

Seria uma norma-princípio? A resposta é negativa. A Teoria Geral do Direito não permite a classificação do princípio do interesse público como uma normaprincípio. Seu significado abstrato não permite a positivação e compreensão desejável a uma norma-princípio. Além disso, ele não pode ser colocado em grau de hierarquia com outros princípios: se houver princípio a ser observado acima do interesse público, este deixará de existir, não sendo possível a sua minimização.

Também não se pode falar que o princípio do interesse público seja auto-explicável como os axiomas. Não há qualquer obviedade em seu conteúdo, não lhe é possível delimitar, muitas vezes, nem mesmo conhecendo sua finalidade ou motivação.

O interesse público é um postulado ético-político. Freqüentemente apresentado como pressuposto da ordem social, ele é visto como a realização da vontade geral, entregue a um ser externo a todos os indivíduos - o Estado - encarregado da sua realização. Sua validade não depende de qualquer positivação, vai existir mesmo se o ordenamento jurídico não o trouxer em qualquer previsão. Ao mesmo tempo, ele é fruto da observação, da experiência.

O interesse público no antidumping não é óbvio, mas, pela observação da realidade, pela experiência, mostrou-se presente e necessário. A necessidade de positivação pode trazer alguma discussão, já que um postulado não depende de positivação para ser reconhecido pela experiência. Alguns dirão que, para que sua aplicação seja respeitada por todos os Membros da OMC, ele deve estar claro no texto do Acordo Antidumping e nas legislações nacionais.

Defende-se, aqui, que a observação do interesse público é inerente à ação do Estado, como contratualista ou fruto de uma democracia, sendo impossível

247 ÁVILA, Humberto Bergmann. Repensando o princípio da supremacia do interesse público sobre o particular. Revista Trimestral de Direito Público, n. 24, 1998. 
dizer que ele não exista. Ele é anterior a qualquer lei antidumping, qualquer acordo internacional.

O postulado é obtido do senso comum e permite o conhecimento do fenômeno jurídico, da lei. Ele não pode, por si, fundamentar a decisão, mas sim explicar como pode ser obtido o conhecimento do Direito. Por isso, está sempre atrelado ao interesse público uma justificativa, a explicação de como ele é interpretado naquele contexto ou momento. Esta explicação pode e deve ser positivada, sobretudo em um contexto multilateral, para que não se torne desculpa para a discricionariedade acima referida, inviabilizando, assim, a aplicação do referido instrumento (antidumping).

\subsubsection{A crise do interesse público}

Para que se possa compreender o interesse público no antidumping, é importante estudar a relação entre o desejo público e o que é interessante aos atores privados. Existe hierarquia, ou estes interesses são realmente distintos?

Alguns autores defendem que o Estado deve espelhar os desejos dos particulares, sendo-lhes fiel. O interesse público é a soma dos interesses privados, não existindo sobreposição do primeiro sobre o segundo. Outros autores defendem que os interesses privados são interesses de tal forma egoístas, que seria impossível falar em reunião destes interesses, ou em formação de um interesse diverso que seguisse as diretrizes emanadas dos interesses particulares, passando o interesse público por uma crise.

Celso Antônio Bandeira de Mello esclarece que diferenciar interesse público do interesse privado é um grande equívoco. Para ele, interesse público é uma forma, um aspecto, uma função qualificada do interesse das partes, não podendo se conceber que o interesse público seja contraposto e antinômico ao interesse privado. Não são os indivíduos que servem ao Estado, mas sim o inverso, ou seja, o interesse 
público é que deve espelhar o conjunto de vontades, o conjunto dos interesses individuais. $^{248}$

Hector Escola sustenta que o interesse público não é de nenhuma forma uma entidade superior ao interesse privado, não havendo contraposição entre eles. Eles são qualitativamente iguais, somente se distinguem quantitativamente, por ser o interesse público nada mais do que um interesse individual que coincide com o interesse individual da maioria dos membros da sociedade. ${ }^{249}$

Alexandre Santos de Aragão estuda o interesse público a partir da noção de Estado de Direito. A idéia de Estado de Direito parte de uma concepção estruturante de Estado e do Direito Público, que racionaliza e sistematiza as relações entre Estado e indivíduos, submetendo estes a uma estrutura hierarquicamente construída, que parte da Constituição e chega até as decisões concretas do Poder Judiciário e da Administração Pública. Ele lembra a concepção alemã de Estado de Direito, para a qual não importa o conteúdo das leis, são todas impostas pelo Estado e ao Estado (compreendidas aí como sua autolimitação), ou seja, o Estado só se subordina ao que ele próprio estabelece, o que era considerado por Duguit como a "institucionalização da barbárie" 250 .

Conclusão necessária, para Aragão, é a de que todo Direito é estatal, ou seja, não há valor, regra ou costume que possa ser imposto ao Estado, já que ele tem o monopólio da definição do interesse público, somente se estes valores, regras ou costumes já tiverem sido encampados pelo próprio Estado. Todavia, é necessária uma metodologia adequada para limitar a subjetividade do julgador e do administrador na aplicação do Direito Público, já que eles não são mais os garantidores do interesse público titularizado no Estado, mas sim um instrumento da garantia, pelo Estado, dos direitos fundamentais.

Justen Marçal Filho resume as diferentes concepções de interesse público a partir do interesse privado. Em primeiro lugar, ele lembra a existência do

\footnotetext{
${ }^{248}$ BANDEIRA DE MELLO, Celso Antonio. Curso de Direito Administrativo. 11 ed. São Paulo: Malheiros, 1999, p. 28.

${ }^{249}$ ESCOLA, Hector. El interes público como fundamento del derecho administrativo. Buenos Aires: Depalma, 1989, p. 236.

${ }^{250}$ Op cit. p. 1140-1165.
} 
interesse público como somatório dos interesses privados, que corresponderia ao interesse comum e homogêneo da totalidade ou da maior parte do povo. Não haveria diferença qualitativa entre interesse público e privado, mas sim e apenas uma diferença quantitativa. Em segundo lugar, ele apresenta a concepção de interesse público como somatório de determinados interesses privados. Existiriam alguns interesses privados egoístas que não poderiam se transformar em públicos.

No antidumping, há sempre um grande conflito entre as classes, como será visto adiante, mas isso não impede, em teoria, que o Estado encontre o interesse público. Quando aprovada a obrigatoriedade da observância do interesse público no Acordo Antidumping, os Membros da OMC deverão, sem qualquer interferência da maioria ou da somatória dos interesses individuais, formular uma concepção do interesse público no caso estudado. Este interesse público deverá transcender os interesses individuais e lhes ser superior.

Para explicar a relação entre o público e o privado, alguns autores falam da "crise do interesse público" e entendem que há vários interesses públicos, não somente um. Odete Medauar lembra que

\begin{abstract}
"a uma concepção de homogeneidade de interesse público segue-se, assim, uma situação de heterogeneidade; de uma idéia de unicidade, passou-se à concreta existência de multiplicidade de interesses públicos. A doutrina contemporânea refere-se à impossibilidade de rigidez na prefixação do interesse público, sobretudo na relatividade de todo padrão de comparação. Menciona-se a indeterminação e dificuldade na definição de interesse público, a sua difícil e incerta avaliação e hierarquização, o que gera crise na sua própria objetividade." 251
\end{abstract}

A conseqüência mais indesejável desta pluralidade de interesses públicos é a subjetividade na interpretação e na ponderação dos interesses. Em consequiência, muito poder é dado à decisão administrativa ou judicial, que se torna fonte principal de valores metajurídicos como segurança nacional, preservação da saúde pública, liberdade de expressão, entre outros conceitos. Como solução, Alexandre Aragão propõe que seja dada prioridade aos argumentos jurídicos que possam ser objetivamente condivididos coletivamente, em detrimento das afirmações genéricas mais ligadas às concepções pessoais e ao perfil psicológico de cada julgador. Para ele,

${ }^{251}$ MEDAUAR, Odete. O Direito Administrativo em Evolução, São Paulo, Revista dos Tribunais, 1992, pp. 181/182. 
isso permite que sejam mais prestigiados argumentos ligados ao texto da regra a ser aplicada do que aos argumentos de caráter não estritamente jurídico. ${ }^{252}$

Alice Gonzáles Borges critica a visão de obras mais modernas, segundo as quais se estaria diante de uma desconstrução da supremacia do interesse público. Para ela, não há que se falar em desconstrução, mas sim em uma necessária reconstrução da noção. Ela sugere recorrer à justa e imparcial ponderação entre os diversos interesses, norteada pela obediência ao princípio da proporcionalidade. Releva a importância e pleno conhecimento dos fatos em jogo e a participação do cidadão. ${ }^{253}$

Certamente, o momento é marcado pela valorização de comportamentos individualistas e uma descrença na existência de um interesse público existente, já que os indivíduos estão mais preocupados com a proteção de seus interesses próprios do que com a defesa de ideais coletivos. O Estado, dentro desta realidade, tem dificuldade de se posicionar como defensor do interesse geral, face à diversidade de interesses da sociedade. Há também dificuldade de o Estado se posicionar tendo sua própria estrutura descentralizada. A criação de diversos órgãos e institutos, com o objetivo de conseguir atender às demandas crescentes de uma sociedade numerosa, faz com que o poder seja dividido entre diversas instâncias administrativas e, com isso, também é dividido o poder de definir o que é o interesse público daquela sociedade. Diante da contestação do papel do Estado como garantidor do interesse público, há um enfraquecimento de sua legitimidade. Isso ocorre, sobretudo, no domínio econômico.

Entretanto, embora vários autores apontem para uma crise no conceito de interesse público, seja ela marcada pela supervalorização dos interesses individuais, seja ela marcada pela existência de vários interesses públicos, prefere-se defender a necessária reconstrução desta noção. Há, sim, vários interesses em conflito. Há, sim, muito individualismo na sociedade moderna. Contudo, cabe ao Estado, como legítimo representante do interesse, tanto como titular do contrato, quanto como representante

\footnotetext{
${ }^{252}$ Ele lembra que isto não significa descartar a possibilidade de interpretações evolutivas das leis, mas estas devem seguir minimamente a sua letra, que constitui "o início e o limite, negativo e positivo, de toda interpretação". Op cit. p. 1143.

${ }^{253}$ BORGES, Alice Gonzáles. Supremacia do Interesse Público: desconstrução ou reconstrução? Interesse Público. v. 37, ano 2006, p. 37.
} 
democrático, ditá-lo de acordo com as diretrizes que lhe são postas no caso concreto. Como se defendeu anteriormente, ele não é a soma nem o interesse da maioria, é independente. Como postulado ético-político, ele é entregue a este Estado, para que este, com base na experiência e observação, bem como no poder que lhe foi concedido, delimite seu conteúdo.

\subsubsection{As pressões que influenciam a formação do interesse público}

As concepções de Rousseau e Tocqueville sobre interesse público apontam que o caminho ideal é a definição de um interesse que vai além dos interesses individuais. A diferença entre as duas compreensões reside na possibilidade de definição deste interesse pelo Estado, ou por uma instituição necessariamente democrática.

Entretanto, embora o interesse resultante seja o interesse maior do que as vontades individuais, elas agem como peças fundamentais para a engrenagem. A pressão exercida por estas peças provoca efeitos na definição do interesse final. As peças que não se manifestarem no jogo tendem a ser consideradas não interessadas. ${ }^{254}$

1.3.4.1 O grupo de pressão na formação do interesse público

Não há uma expressão correta para designar as forças sociais organizadas que exercem uma "atividade de pressão" direta ou indireta sobre o comportamento dos órgãos decisórios. Até 1958, os cientistas anglo-saxões utilizavam a expressão pressure group e os franceses groupe d'intêrét. Após, porém, houve uma inversão de papéis. Os anglo-saxões passaram a utilizar tanto a expressão pressure group quanto interest group, e os autores franceses cuidam dos groupes de pression. ${ }^{255}$

\footnotetext{
${ }^{254}$ Lembra-se, aqui, o entendimento da Comissão Européia, manifestado no item 1.2.2.1.3, de que a não manifestação de organizações de consumidores, distribuidores ou usuários industriais no antidumping permite concluir que não há um interesse significativo a ser defendido por estas partes.

${ }^{255}$ Meynaud define os grupos de interesse como sendo "o conjunto de indivíduos que a partir de uma comunidade de atitudes, exprimem reivindicações, alegam pretensões e tomam posições que afetam,
} 
Durante o estudo do interesse público, desenvolvido nos capítulos anteriores, foi possível concluir que não é possível estudá-lo sem analisar os efeitos dos interesses individuais, que, para alguns autores, formam o interesse geral, e, para outros, reúnem-se para criar um interesse novo, que lhes transcende.

Para desenvolver o tema objeto da tese, delimitando o conceito de interesse público, é importante analisar a posição dos grupos na formação deste interesse. Os grupos de pressão podem influenciar as políticas econômicas e sociais das democracias. É preciso, por isso, entender o significado de grupos de pressão e sua participação no processo de formação e compreensão do interesse público.

Independentemente da existência de uma cláusula do interesse público, alguns destes grupos já possuem certo espaço nas investigações em determinados Membros da OMC. Quanto mais democrática e organizada a estrutura administrativa de um Membro, maior é o espaço para participação destes grupos.

Com a criação do poder político e, com ele, a criação dos Estados, tornou-se institucionalizado o modelo de comando, que passou das mãos do indivíduo para a instituição-Estado. Embora se possa identificar, por vezes, a projeção de uma figura expressiva ou absorvente, a ordem estatal é a estrutura maior. Contudo, este Estado atua entre fases de tranqüilidade e crise, de acordo com o prestígio de sua autoridade e a produtividade ou eficiência de sua administração. Cabe a ele o papel de equilíbrio, devendo agir com imparcialidade, o que nunca ou quase nunca ocorre, já que a própria constituição deste Estado é dotada de interesse. ${ }^{256}$

Defende Marinho que a constelação dos grupos de pressão reflete rigorosamente as estruturas econômico-sociais e querelas ideológicas de um país considerado, sendo estruturas típicas de sistemas democráticos. Em cada país, assumem

\footnotetext{
direta ou indiretamente, os atores da vida social. Os grupos de interesse tornam-se grupos de pressão, para ele, quando seus responsáveis utilizam a ação sobre a máquina governamental para alcançar suas aspirações e reivindicações. O elemento diferenciador entre grupos de pressão e grupos de interesse é o fato de que os grupos de pressão adotam um processo específico para defender as reivindicações ou pressões do grupo." (MEYNAUD, Jean. Les Groupes de Pression. Presses Universitaires de France. 1965 Que sais-je? n. 985 p. 13.)

${ }^{256}$ MARINHO, Josaphat. Grupos de Pressão na Sociedade. Revista Trimestral de Direito Público, n. 1, 1993, p. 16-20. Editora Malheiros.
} 
feições singulares, de acordo com as peculiaridades da estrutura cultural, social e econômica.

A palavra lobby significa, em inglês, ante-sala, vestíbulo, saguão. Lembra o lugar onde ficam as pessoas que procuram influenciar as autoridades e ou políticos e que acabou por designar a atividade dos profissionais ou grupos que buscavam exercer pressões, muitas vezes legais, para a aprovação de projetos ou medidas em benefícios de seus representados. O lobbying surgiu como processo de diálogo entre grupos de interesses econômicos e o governo, apropriado por organizações que não tinham motivos econômicos, de cunho social ou idealístico, comprovando a validade do processo para representar interesses perante os agentes governamentais. ${ }^{257}$

O objetivo do lobby é influenciar burocratas e políticos na tomada de decisões que beneficiem um grupo social ou empresarial, programa econômico ou linha de atuação de determinado segmento sócio-econômico, mediante uma legislação específica ou medidas especiais. Para isso, ele fornece aos burocratas e políticos informações que supostamente eles não detêm e que são essenciais para a maior clareza do tema em questão. ${ }^{258}$

Para tratar a questão, Pincus tem fundamental importância. Ele descreve diferentes grupos de pressão e seu poder de influenciar, de forma distinta, a fixação de um tributo sobre a importação. O texto descreve como as características de cada grupo influem no resultado e seu poder sobre a atividade legislativa. ${ }^{259}$ Pequenos grupos industriais coesos podem reagir melhor do que grupos maiores e diversos; proprietários são mais vitoriosos do que trabalhadores assalariados; indústrias geograficamente concentradas, mais ativas do que as dispersas pelo território. Todavia, perante o Congresso, a habilidade de um grupo industrial para conseguir melhores

\footnotetext{
${ }^{257}$ OLIVEIRA, Andréa Cristina de Jesus. Breve histórico sobre o desenvolvimento do lobbying no Brasil. Revista de Informação Legislativa. Brasília: Senado Federal, Outubro/Dezembro 2005, ano 42, n. 168, p. 31.

258 BORIN, Jair. O lobby na imprensa: tipificação e formas de atuação. Cadernos de jornalismo e Editoração, São Paulo, n. 22, 1998.

${ }^{259}$ PINCUS, J. J. Pressure Groups and the Pattern of Tariffs. Journal of Political Economy. n. 4, 1983, p. 757-78.
} 
benefícios não está associada somente à sua força, mas também às dificuldades em formar a coalizão de seus representantes e senadores. ${ }^{260}$

Uma tarifa de importação vai afetar os fatores domésticos de produção empregados na indústria de tal forma desigual que criará um comum, mas não necessariamente idêntico, interesse em obter esta tarifa de importação. Por outro lado, haverá também os que nada irão fazer em prol da obtenção daquela tarifa (deixando que outros o façam) e irão dela se beneficiar. Em outras palavras, haverá "free riders" que nada contribuirão para a obtenção ou discussão da tarifa em busca do bem comum, mas dela poderão se aproveitar.

Para o autor, quanto menor o número de indivíduos a se beneficiar e, independentemente do tamanho do grupo, quanto mais concentrados forem os benefícios, maior é a razão do grupo para agir. Além disso, a intensidade da pressão do grupo depende de sua dispersão no território, porque os custos da obtenção da informação sobre a ação do outro e a coordenação e monitoramento dos esforços aumentam com a distância.

É importante diferenciar os grupos de pressão de acordo com seu objeto. O interesse e a forma de ação dos grupos que defendem interesses sociais não são equivalentes ou sequer semelhantes ao interesse e à forma de ação dos grupos de interesse econômico ou político.

Nos Estados Unidos, há os conhecidos “citizen groups”, que possuem um especialíssimo grau de credibilidade junto ao público e à imprensa, acreditando, sinceramente, que o interesse público que representam é benéfico a toda a nação. Por ser distinto de qualquer interesse de caráter econômico ou comercial, seu interesse aproximar-se-ia dos objetivos das políticas públicas do próprio Estado. ${ }^{261}$

E como se dá o lobby no antidumping? O antidumping é, originalmente, uma discussão despolitizada. Sua idéia inicial, todas as previsões dos acordos antidumping até hoje firmados demonstram a prevalência do tecnicismo sobre

\footnotetext{
260 Op. Cit. p.. 206.

261 BERRY, Jeffrey. Citizen Groups and the Changing Nature of Interest Groups Politics in América. Annals of The American Academy of Political and Social Science, v. 528, 1993, p. 34.
} 
qualquer teor político. Contudo, na prática, o antidumping tem se mostrado um terreno fértil para a atividade dos lobbies, da influência política, abrindo este espaço nas políticas comerciais de uma forma geral. Por exemplo, ameaças críveis feitas por grupos de interesse de pedido de abertura de uma investigação pode ser a causa de uma redução imediata de importações daquela origem. Leis antidumping claras e fortes podem reduzir, por outro lado, a atividade dos grupos de interesse. Também é interessante aos governos democráticos a existência de suporte democrático. Promovendo a abertura de seus mercados, eles atrairão a rivalidade dos importadores e consumidores. Assim, podem negociar a liberalização dos mercados com parceiros internacionais e, ao mesmo tempo, satisfazer os interesses nacionais com a aplicação das justificadas e solicitadas medidas de defesa comercial. ${ }^{262}$

Os lobistas podem influenciar uma ou duas camadas da cadeia produtiva. Em determinados casos, será necessário investir certa pressão sobre as classes indiretamente relacionadas, mas que exercem algum poder sobre a investigação. Também são variadas as formas pelas quais os lobistas se relacionam com os seus rivais. $^{263}$

\subsubsection{O comportamento dos grupos na União Européia}

O estudo do interesse comunitário é necessário por duas razões. Primeiramente, por ter sido este trabalho produzido em uma instituição francesa. Em segundo lugar, por prever a legislação da União Européia a observação deste interesse público na aplicação de direitos antidumping contra países não membros (Regulamento

\footnotetext{
262 "O antidumping abre um espaço para o lobby estratégico, segundo o qual os compromissos do lobby podem produzir efeitos favoráveis sobre as decisões das firmas exportadoras, sendo a política antidumping encorajadora do lobby. Então, uma instituição apolítica pode ser perversamente responsável pela politização das políticas de comércio de uma forma geral." (ANDERSON, James. Strategic Lobbying and Antidumping. Journal of Economic Integration, v. 9, n. 2, 1994, p. 129.)

${ }^{263}$ Broek critica a formação de lobbys no antidumping. Para ele, não há muita razão em se defender determinada posição, em prejuízo de outra, se, no comércio, o indivíduo nunca está de um lado só. Ele aparentemente recebe sua remuneração de sua atividade da indústria doméstica, mas gasta esta remuneração sendo um consumidor. (BROEK, Naboth. Legal Persuasion, political realism, and legitimacy: The European Court's recent treatment of the effect of WTO Agreements in the EC legal order. Journal of International Economic Law, v 4, n 2, 2001, p. 428.
} 
Básico europeu). Este modelo de aplicação do interesse público pode ser lembrado como exemplo para a aplicação que se pretende no âmbito da OMC.

$\mathrm{Na}$ construção comunitária, os Estados Membros tomaram para si determinadas competências, deixando para as instituições comunitárias o exercício de outras. Esta delegação de competências está apoiada em um "contrato social fundador", assim chamado por Denys Simon, que pressupõe que seja reconhecida a existência de um interesse comum que não significa necessariamente a soma algébrica dos interesses individuais, e também a prevalência de um interesse geral autônomo da Comunidade que não se reduz à soma dos interesses particulares de cada um de seus componentes. ${ }^{264}$

O conceito de interesse comunitário deve ser resguardado pelo Tribunal de Justiça Europeu como sendo o pressuposto do Tratado a ser observado pelos Estados Membros. A perfeição e eficácia das instituições européias estão estreitamente ligadas à observação dos objetivos realizados pelas disposições do direito comunitário material. ${ }^{265}$

O Tratado de Roma de 1957 traz diversas disposições que prevêem a observância do interesse comunitário. Entre os vários exemplos, menciona-se que o capítulo destinado às empresas encarregadas da gestão de serviços de interesse econômico geral. ${ }^{266}$

Além de uma previsão ao interesse comunitário, fala-se, também, em interesse comum europeu, que parece ser um sinônimo do interesse comunitário. Assim, o art. 99 prevê que os Estados-Membros consideram suas políticas econômicas uma questão de interesse comum e coordená-las-ão no Conselho, de acordo com o disposto no art. 98. Dispõe o art. 87 que pode ser considerado compatível com o mercado comum os auxílios destinados a fomentar a realização de um projeto importante de interesse europeu comum.

\footnotetext{
${ }^{264}$ SIMON, Denys. Le système juridique communautaire, Paris, PUF, 2001.

${ }^{265}$ HAMONIAUX, Thibau. L'intérêt general et le juge communautaire, Paris, LGDJ, Systèmes, 2001, p. 12.

266 “Art. 86. As empresas encarregadas da gestão de serviços de interesse econômico geral ou que tenham a natureza de monopólio fiscal ficam submetidas ao disposto no presente Tratado, designadamente às regras de concorrência, na medida em que a aplicação destas regras não constitua obstáculo ao cumprimento, de direito ou de fato, da missão particular que lhes foi confiada. O desenvolvimento das trocas comerciais não deve ser afetado de maneira que contrarie os interesses da Comunidade."
} 
Contudo, assim como acontece em outros países, não há, na União Européia, qualquer legislação que traga um conceito definido e estático para o interesse público, ou, no caso, o interesse comunitário. Sua avaliação não é menos intuitiva, de acordo com o caso concreto posto sob análise, levando-se em consideração o momento histórico, o país envolvido e o que pode ser considerado como a vontade geral da comunidade.

Os grupos de pressão e a atividade conhecida como lobbying são profundamente estudados e difundidos na Europa e nos Estados Unidos. Contudo, sua ação depende de diversas variáveis, entre elas, a necessidade de uma opinião convergente e a existência de recursos financeiros que propiciem a ação destes grupos.

$\mathrm{Na}$ Europa, há inúmeros grupos de pressão, atuando sobre as diversas instâncias e procedimentos. Há sempre diversos interesses em jogo, diversas posições, e, conseqüentemente, diversas reações. Há um interesse comunitário, mas há, também, diferentes territórios, fronteiras, idiomas, climas, diferenças sociais, aspectos que caracterizam a ação diferenciada dos grupos. Embora sejam diversos os interesses, eles são vistos, a partir do trabalho de Ernst Haas, como os motores da integração econômica européia, capazes de influenciar os mecanismos e os atores políticos em um processo de integração. $^{267}$

Luigi Graziano cita Andy Smith para lembrar que o que ele chama de "porosidade" da União Européia ao lobby deve-se ao fato de se tratar de um Estado in fieri, no qual não houve desenvolvimento de uma sociedade civil que abranja toda a Europa, onde não se conhecem greves que se estendam a todo o conjunto de países, onde não há uma opinião pública propriamente européia. Por outro lado, há imensos poderes da Comissão.

"Desconfio de que o relativo vazio político em que essa poderosa burocracia
opera, e a insegurança política que ela provoca, estejam entre os fatores
responsáveis pela porosidade da Comissão aos interesses organizados e pela
ansiedade com que se busca e se estimula a organização e a manifestação
das opiniões desses interesses. Redes de influência (networking), mais do que

${ }^{267}$ GROSSMAN, Emiliano. Les groupes d'intérêt économiques face à l'intégration européenne: Le cas Du secteur bancaire. Revue Française de science politique, v. 53, n. 5, 2003, p. 737. 
lobbies, seria a designação mais adequada dessa modalidade de interação com grupos de pressão."268

As trocas econômicas são o fundamento da integração européia, a integração econômica é, para a maioria, a base da construção européia. Assim, os representantes econômicos, os grupos de interesse, são os maiores responsáveis por esta integração. ${ }^{269}$

Os grupos se organizam de diversas formas jurídicas na Europa, tais como grupo de interesse econômico europeu, fundação, sociedade, entre outros. Também é bastante comum a forma de associação de direito belga, em razão da grande flexibilidade deste direito nacional sobre associações e diante da inexistência de um estatuto europeu de associações. ${ }^{270}$ Grande parte destes grupos são variações de grupos nacionais que se desenvolveram em torno de um tema pontual e estabeleceram bases em Bruxelas, mais próximos à Comissão Européia. Este movimento se deveu, em parte, à atitude da Comissão de permitir uma maior participação dos grupos.

Os grupos de interesse podem ocupar uma posição nos comitês ou grupos nomeados pela Comissão como organização sócio-econômica e nomeando seus próprios especialistas. Assim é o caso da BEUC perante o Conselho Consultivo de Consumidores e Representantes de Fabricantes de Beterrabas no Comitê Consultivo do

\footnotetext{
${ }^{268}$ GRAZIANO, Luigi. O lobby e o interesse público. Revista Brasileira de Ciências Sociais. v. 12, n. 35, fev. 1997.

${ }^{269}$ Após a assinatura do Ato Único Europeu, observou-se o surgimento dos chamados Eurogrupos. Este foi o termo encontrado para designar as federações européias de grupos de interesses nacionais como, por exemplo, a UNICE, que reúne os sindicatos patronais da Europa. Além destes grupos, surgiram outros tipos de empresas de lobbying, de consultores em "negócios públicos" e "relações públicas", bem como diversos escritórios em Bruxelas interessados na representação de empresas ou grupos. Os grupos de interesse representaram um papel de extrema relevância na definição do interesse na origem da Comunidade Européia. Os grupos nacionais sócio-econômicos adotaram, em função dos Estados envolvidos e de seus interesses representados, atitudes ora favoráveis à construção européia, ora demasiadamente hostis.

${ }^{270}$ O surgimento da CECA (Comunidade Econômica para o Carvão e Aço) mobilizou cerca de quinze grupos de interesse representando interesses do carvão e aço diante da autoridade luxemburguesa. A criação da CEE (Comunidade Econômica Européia) e do EURATOM (Comunidade Européia da Energia Atômica) provocou posteriormente um desenvolvimento considerável no fenômeno (entre 1957 e 1963 , estima-se que foram criados 34 grupos por ano). O Ato Único Europeu registra a participação de cerca de 300 grupos interessados, que sugeriram textos e alterações. A resposta da Comissão foi sempre provocar um diálogo aberto e estruturado entre comissão e grupo de interesses. Em 1993, Joël Rideau estimou a participação de 10.000 pessoas empregadas em trabalhos de lobbying perante Bruxelas. (RIDEAU, Joël. Les Groupes d'intérêt dans le système institutionnel communauaire. Revue des Affaires Européennes. n. 3. LGDJ, 1993, p. 49.)
} 
Açúcar. A Comissão também consulta os grupos ao publicar os Livros Verdes, Livros Brancos, Memorandos. ${ }^{271}$

\subsubsection{O comportamento dos grupos no Brasil}

Não existe, na Constituição Federal brasileira, um artigo que diga claramente que o interesse público é um princípio de Direito. Contudo, ele aparece não realçado em si mesmo, como lembra Celso Antônio Bandeira de Mello, mas em suas repercussões no ordenamento jurídico em geral. Ao interesse público não é atribuído valor absoluto, mas importância de ponto fundamental de Direito Administrativo. ${ }^{272}$

O art. 37 da Constituição Federal não cita o interesse público ao lado da legalidade, impessoalidade, moralidade, publicidade e eficiência, que são os princípios da Administração Pública. Todavia, isso não quer dizer que ele não tenha sido contemplado, pois, em todos os momentos, está claro que o administrador público deve ter como motivação principal o respeito ao interesse da coletividade.

Uma sociedade politicamente organizada demanda uma Constituição que a estruture, defina atores internos e suas funções. Também serve a Constituição como relevante instrumento de limitação do poder, fixando freios ao governante na realização e na própria definição do interesse público.

A Constituição, segundo Celso Bastos, é um conjunto de forças políticas, econômicas, ideológicas que conforma a realidade social a um determinado

${ }^{271}$ Os Livros Verdes são documentos de reflexão publicados pela Comissão sobre um domínio de atividade específico. Trata-se, fundamentalmente, de documentos destinados às partes interessadas, organizações e particulares, chamadas a participar num processo de consulta e debate. Em alguns casos, podem dar origem a textos legislativos posteriores. Os Livros Brancos são documentos que apresentam propostas de ação comunitária num domínio específico. São muitas vezes elaborados na sequiência de um Livro Verde publicado para lançar um processo de consulta a nível europeu. Enquanto os Livros Verdes expõem uma série de idéias para análise e debate público, os Livros Brancos apresentam um pacote oficial de propostas em áreas políticas específicas e contribuem para o seu desenvolvimento. (COMISSÃO EUROPÉIA. http://europa.eu/documents/comm/index_pt.htm)

272 “...não por porque possuam em si mesmos a virtude de se imporem como fontes necessárias do regime, mas porque, investigando o ordenamento jurídico-administrativo, acredita-se que eles hajam sido encampados por ele e nesta condição validados como fonte-matriz do sistema. Logo, não se lhes dá um valor intrínseco, perene e imutável. Dá-se-lhes importância fundamental porque se julga que foi o ordenamento jurídico que assim os qualificou. "BANDEIRA DE MELLO, Celso Antonio. Curso de Direito Administrativo. 11 ed. São Paulo: Malheiros, 1999, p. 28. 
Estado, configurando a sua particular maneira de ser. ${ }^{273}$ E sua particular maneira de ser é refletida pelos valores firmados pela sociedade, que, "dotados de originalidade e superioridade material sobre todos os conteúdos que formam o ordenamento constitucional são transformados pelo direito em princípios." 274

O povo, por meio de seus representantes, escolhe os valores fundamentais que irão fundamentar a sua própria organização, ou seja, os princípios. Por isso, muitos autores afirmam que mais grave que o desrespeito à lei é o desrespeito ao princípio. $^{275}$

$\mathrm{Na}$ Constituição Federal brasileira, os primeiros valores a serem perseguidos pelo Estado encontram-se descritos já no art. $3^{\circ}$. Estes valores são desdobramentos do interesse público no rol de objetivos fundamentais a serem perseguidos pelos poderes. Também a representação popular e a separação de poderes são a manifestação da necessária intervenção popular na escolha do que será considerado interesse público.

O interesse público é anterior à Constituição e ao Direito, pois consiste em um valor desejado pela maioria da sociedade. ${ }^{276}$ Celso Antonio Bandeira de Mello lembra que, diferentemente do que ocorre no mundo físico, no campo do Direito os princípios são livremente escolhidos pelos homens. Assim, pode o legislador, pouco a pouco, fixar inconscientemente um conjunto de princípios que estarão informando o sistema, desde que as normas postas traduzam sua acolhida. Estes cânones estariam sempre à disposição do legislador, que pode modificá-los ou substituí-los. Por isso, cabe

\footnotetext{
${ }^{273}$ BASTOS, Celso Ribeiro. Curso de Direito Constitucional, 11 ed. Saraiva, 1989, p. 3 e 4.

${ }^{274}$ ROCHA, Carmen, p. 25.

275 BANDEIRA DE MELlO, Celso Antonio. Elementos de Direito Administrativo, 2 ed. São Paulo: Revista dos Tribunais, 1981, p. 32.

${ }^{276}$ Assim, de acordo com SUELI CAPITULA "Para que cada indivíduo conserve plenamente a sua aspiração de usufruir efetivamente de direitos e liberdades, impõe-se o reconhecimento de que o interesse público é princípio implícito nas fórmulas que prescrevem os princípios fundamentais relacionados em nosso Texto Constitucional. (...) Assim, como princípio implícito nos comandos dos princípios fundamentais, o interesse público constitui uma peça essencial para a correta e razoável interpretação constitucional" (CAPITULA, Sueli Solange. Interesse Público - Princípio Constitucional Implícito. Cadernos de Direito Constitucional e Ciência Política. Revista dos Tribunais, ano 5, n. 17, out/dez 1996, p. 186.)
} 
ao jurista interpretá-los de acordo com o regime. Os legisladores dão identidade, perante o Direito, às noções que lhe serviram de estribo. ${ }^{277}$

Um ponto de comunhão entre todos os possíveis conceitos de interesse público é a conclusão de que ele se perfaz com a satisfação de necessidades de segmentos da população, em um momento concreto, para realizar valores fundamentais. ${ }^{278}$ Mesmo que ele esteja em consonância com o interesse especial de um grupo determinado, ele deve estar em conformidade com os valores fundamentais daquela sociedade. Cabendo ao Estado a sua realização, torna-se imediato garantidor destes valores. Assim, nenhum governante pode fundamentar suas decisões na pura invocação ao interesse público. Deve demonstrar como a sua decisão contribuirá para a realização dos princípios fundamentais daquele grupo social. ${ }^{279}$

Contudo, o que deve fazer o Estado se precisar decidir entre dois valores fundamentais antagônicos? Aqui se evidencia a necessidade de ponderação dos interesses relacionados, por meio da aplicação do princípio da razoabilidade ${ }^{280}$, na sua vertente da proporcionalidade ${ }^{281}$.

No Brasil, ao contrário do que ocorre em países como os Estados Unidos, os grupos de pressão não são organizados como tal, não se identificam como grupos de pressão, mas sim sob a forma de corporações profissionais, organizações setoriais, militantes da defesa do meio ambiente, entre outros.

277 BANDEIRA DE MELlO, Celso Antonio. Elementos de Direito Administrativo, 2 ed. São Paulo: Revista dos Tribunais, 1981, p. 29.

${ }^{278}$ MARÇAL FILHO, Justen. Op. Cit. p. 129.

${ }^{279}$ Este argumento será bastante útil no capítulo 3, em que se discutirá se o país investigador deve definir ou não o que seja interesse público, ou seja, deve ou não motivar sua decisão relativa ao interesse público. 280 Segundo Celso Antonio Bandeira de Mello, "a razoabilidade é compreendida como princípio constitucional da Administração Pública a prescrever que a Administração, ao atuar no exercício de discrição, terá de obedecer a critérios estáveis do ponto de vista racional, em sintonia com o senso normal de pessoas equilibradas e respeitosas das finalidades que presidiram a outorga da competência exercida (...) condutas dezarrazoadas, bizarras, incoerentes ou praticas com desconsideração de situações e circunstâncias que seriam atendidas por quem tivesse atributos normais de prudência, sensatez e disposição de acatamento às finalidades da lei atributiva da discrição manejada." (BANDEIRA DE MELLO, Curso de Direito Administrativo, cit, p. 97.

281 “A proporcionalidade implica, afirma a doutrina mais abalizada e atual, o dever de adequação, necessidade e equilíbrio da ação administrativa. Impõe que a limitação de bens ou interesses privados por ato do Poder Público seja adequada e necessária aos fins concretos colimados, bem como seja tolerável quando verificadas as implicações jurídicas resultantes da medida." (OLIVEIRA, José Roberto Pimenta. Os princípios da razoabilidade e da proporcionalidade no Direito Administrativo Brasileiro. São Paulo: Malheiros, 2006, p. 190.) 
A existência destas organizações no Brasil também não é tão difundida, mas aumenta de acordo com o grau de instrução da população, bem como com a abertura dos canais de comunicação entre os grupos. Por exemplo, não são raros os casos de abertura de consultas públicas para aprovação de leis, para a criação de órgãos, agências, entre outros, que podem ser comentados e sofrer influência destes grupos.

Poucos autores estudaram a prática do lobbying no Brasil. Em 1978, o regime militar perdeu a capacidade de arbitrar o conflito entre empresários e não pode evitar o aumento da pressão econômica e política causada pela crise econômica. Estes fatos contribuíram não só para abertura política, mas também para o retorno das discussões de organizações e abertura dos canais de comunicações (fim do período conhecido como Milagre Econômico).

Com as eleições de 1982, os empresários passaram a se preocupar com a oposição no Congresso Nacional, surgindo entidades como a CNI (Confederação Nacional das Indústrias), CNC (Confederação Nacional do Comércio), entre outras. ${ }^{282}$ No período pré-constitucional (Constituição de 1988), a demonstração do poder destes grupos já se torna novamente visível por meio de declarações à imprensa.

A luta pela redemocratização no Brasil levou ao fortalecimento do Congresso Nacional como poder político e, ao seu lado, dos grupos de pressão. Muitos dos textos legais desta época se deveram a estes movimentos, tais como os direitos da mulher, o pátrio poder, os direitos dos aposentados, o Estatuto da Microempresa e o Código de Defesa do Consumidor.

Hoje, embora não exista a regulamentação desejada à atividade, ela é crescente, sendo bem procurados os cursos de formação no setor e aceita a prestação de serviço de escritórios de lobbying perante autoridades brasileiras. Há um dispositivo no Regimento da Câmara dos Deputados que admite a representação corporativa perante o Poder Legislativo, as chamadas confederações. Há 62 registradas.

282 ARAGÃO, Murillo. Grupos de pressão no Congresso Nacional: como a sociedade pode defender licitamente seus direitos no Poder Legislativo. São Paulo: Maltese, 1994. 
Há quatro tipos de lobbying no Brasil, assim classificados: i) assessoria de assuntos parlamentares ou Departamentos de Comunicação Social dos Ministérios (lobbying público); ii) executivos de relações governamentais, alocados em departamentos de assuntos corporativos de empresas (lobbying institucional); iii) entidades de classe, como CNI e DIAP (lobbying classista) e iv) escritórios de lobbying e consultoria (lobbying privado). ${ }^{283}$

Um bom exemplo, com participação bastante expressiva nos assuntos relacionados aos interesses comerciais é a Coalização Empresarial Brasileira (CEB). Ela foi criada em 1996 como resposta a uma necessidade de maior participação dos empresários brasileiros na definição de estratégias brasileiras no mercado internacional. Sua Secretaria Executiva é coordenada pela CNI e ela é aberta à participação de organizações empresariais (hoje, mais de 170) e companhias de setores diversos. ${ }^{284}$

Não se conhece nenhum estudo, no Brasil, sobre a influência do lobby nas investigações antidumping. Contudo, é impossível negar que ela ocorra, ou que pelo menos não seja tentada. Isto porque o sistema de análise comercial no Brasil, embora conte com um departamento encarregado da análise técnica, conta também grande margem para discussão envolvendo outras políticas, na CAMEX. ${ }^{285}$ Neste momento, é relativamente aberto o espaço aos grupos de pressão que, com freqüência, procuram o Ministério mais relacionado à sua causa para buscar proteção aos seus interesses.

\subsubsection{A indeterminação do interesse público e protecionismo}

No comércio internacional, embora se possa falar em um conflito de interesses, há espaço para a formação de um único interesse público, que representa os olhos do Estado sobre o que é mais relevante e satisfatório à sociedade naquele momento. Nos próximos capítulos, serão fornecidos critérios para a definição deste

\footnotetext{
${ }^{283}$ OLIVEIRA, Andréa Cristina de Jesus. As muitas faces do lobbying no Brasil: corrupção, tráfico de influência ou um instrumento democrático de representação de interesses? Revista Espaço Acadêmico. N. 47, Abril 2005.

${ }_{284}$ CONFEDERAÇÃO NACIONAL DAS INDÚSTRIAS. http://www.negociacoesinternacionais.cni.org.br/negocia.nsf/ceb.htm, consultado em 26 de fevereiro de 2008.

${ }^{285}$ Conforme criticado no ponto 1.2.2.2.1 e será novamente comentado no item 3.4.2.
} 
interesse. Todavia, antes de se alcançar a discussão dos critérios para se identificar o interesse público no antidumping, deve-se estudar o protecionismo no comércio internacional e nas investigações antidumping e a participação das partes interessadas na definição do interesse público.

\subsubsection{O interesse protecionista no comércio internacional}

Um país pode decidir proteger um determinado setor por várias razões. Estes motivos podem estar ligados ao interesse público, mas também podem estar relacionados a pressões individualistas, que representam tão-somente a vontade de um pequeno grupo. Esta proteção pode se dar de várias formas, como pela imposição de quotas para importação, de licenças, ou de medidas antidumping.

Para que se possa entender adequadamente o protecionismo no comércio internacional, um rápido resgate histórico é necessário.

Na Conferência de Bretton Woods, em 1944, foram traçadas as linhas dos três pilares da nova ordem econômica internacional, segundo a qual o liberalismo, entendido sob três aspectos, era essencial. O primeiro pilar a ser construído era o Fundo Monetário Internacional, capaz de promover o equilíbrio macroeconômico esperado à nova ordem. O segundo pilar, o Banco Mundial, tinha como principais desafios conseguir recursos para as nações em desenvolvimento, para que estas pudessem se tornar parte do contexto liberal. Por fim, restou o comércio internacional como terceiro pilar, a expectativa de que o aumento das trocas entre as nações seria a solução para evitar conflitos entre elas. Após o fracasso da Organização Internacional do Comércio, coube ao GATT a dura tarefa de encabeçar a negociação de concessões entre os países, tarefa que durou oito rodadas até que fosse criada a OMC.

O protecionismo que interessa a este trabalho começou no momento em que os países passaram a negociar estas concessões. Bhagwati defende que as nações dominantes perseguem acesso aos mercados mundiais enxergando nas políticas 
de comércio, a serem adotadas multilateralmente, o seu próprio interesse nacional. ${ }^{286}$ Contudo, o crescimento do comércio revelou seu instinto, que é a conquista de mercados de outros países. A reação era prevista: pressões protecionistas aumentaram significativamente. ${ }^{287} \mathrm{O}$ autor se apóia na doutrina Darwiniana para defender que, psicologicamente, o comércio é a idéia e a preferência política de um país quando ele está forte, quando há uma crença firme de que o país irá sobreviver ao combate com outros países. Assim, os surtos de apoio e repulsa ao desenvolvimento do comércio - e, conseqüentemente, protecionismo - alternam-se em momentos de força e fraqueza do próprio país.

O aumento do comércio entre os países foi substancial nos primeiros anos de negociação, gerando maior riqueza, arrecadação e bem-estar. Bem-estar, arrecadação e riqueza motivaram, por sua vez, mais cortes tarifários, formando um círculo de prosperidade observado nos anos 50 e 60. Em 1970, o surto positivo foi severamente golpeado ${ }^{288}$ pelo surgimento das barreiras não-tarifárias ao comércio $^{289}$, a proteção administrativa, já que tais barreiras não necessitam de um longo processo legislativo para aplicação e podem encobrir mais facilmente a ação de grupos de interesse. $^{290}$ Observou-se uma diminuição moderada na expansão do comércio entre 1973 e 1983.

Mesmo com a difusão dos mecanismos de proteção, grande crescimento do comércio foi observado. A explicação de Baldwin para este cenário é que a proteção é sempre menor do que ela sugere, pois os exportadores sempre encontrarão uma forma de continuar aumentando seus ganhos em exportação, seja

\footnotetext{
${ }^{286}$ Este argumento individualista foi construído com a observação de que a liberalização do comércio mundial seguiu o crescimento da Grã-Bretanha, no século XIX, e dos Estados Unidos, no século XX.

${ }^{287}$ BHAGWATI, Jagdish. Protectionism. Massachusetts: The MIT Press, 1988, p. 25-38.

${ }^{288}$ Este golpe pode ser explicado pela crise financeira atravessada por vários países, nesta época, relacionada à crise do petróleo da década de 70 . O déficit da oferta do petróleo causou a recessão nos Estados Unidos e na Europa e grande instabilidade ao redor do mundo.

${ }^{289}$ As barreiras não-tarifárias são restrições de quantidades, composição e destino dos produtos no comércio internacional, podendo ser citadas as quotas, contingenciamentos, as licenças de importação, as medidas sanitárias e fitossanitárias, entre outras. (VIEGAS, Isabel; JANK, Marcos; MIRANDA, Silvia. Barreiras não-tarifárias dos Estados Unidos e União Européia sobre as exportações agrícolas brasileiras. Informações Econômicas, v. 37, n. 3, março 2007, p. 27.) Barreiras não-tarifárias são definidas como qualquer restrição, despesas ou política que não seja uma tarifa, que limite o acesso dos produtos importados, como quotas, sistemas de licenciamentos, regulamentos sanitários, proibições. (ORGANIZAÇÃO MUNDIAL DO COMÉRCIO, Glossário, disponível em WWW.wto.org).

${ }^{290}$ BHAGWATI, Jagdish. Op cit. p. 49.
} 
exportando os componentes, não o produto pronto, seja encontrando substitutos para a demanda dos importadores. ${ }^{291}$

Em 1970, outro fator elevou a preocupação das nações: a entrada, no comércio mundial, de países como Japão e os tigres asiáticos (já assim chamados, Singapura, Hong Kong, Coréia do Sul e Taiwan). Tal fato causou um efeito psicológico relevante, sobretudo nos Estados Unidos, onde propagandas protecionistas passaram a incomodar os norte-americanos com a idéia de que seus filhos trabalhariam, no futuro, em fábricas dos japoneses. Criou-se a falsa idéia de que o sucesso dos japoneses seria explicado pela prática do comércio desleal. Esta preocupação acelerou a ação das estruturas de pressão, dos grupos de lobby, que passaram a atuar diretamente perante as instituições na busca de socorro.

Lafay enumera dois tipos de proteção. A primeira é a proteção ofensiva, que tem como escopo obter vantagens comparativas e melhorar sensivelmente a competitividade de um setor determinado. Ela atua para sanar uma deficiência temporária da indústria doméstica. Ela é justificada para proteger indústrias nascentes, por exemplo, em países em desenvolvimento. Este tipo de protecionismo deve decrescer com o tempo. Ela deve fixar objetivos concretos e realistas ao país. O segundo tipo é o protecionismo defensivo, que age para defender uma posição ameaçada. É menos ambicioso do que o protecionismo ofensivo, mas é mais perigoso porque pode facilmente se generalizar, atingindo diversos setores sem explicação lógica. ${ }^{292}$

Corden cita três importantes razões para que um país decida proteger: a defesa do emprego; o que ele chama de "pauper labor"; e a lealdade. ${ }^{293}$

A primeira razão nasce da incompleta noção de que a proteção preserva empregos. Em primeiro lugar, a proteção pode beneficiar um setor, mas provocar efeitos adversos em outro: a proteção à indústria do aço, nos Estados Unidos, causou o desemprego na indústria automobilística norte-americana. Em segundo lugar, nem sempre o desemprego é causado pelo dano gerado pelo dumping: a remuneração

\footnotetext{
${ }^{291}$ BALDWIN, Robert. Inefficacy of protection in promoting social goals. World Economy, v. 8, p. 110.

${ }^{292}$ LAFAY, Gérard. Peut-on se proteger de la crise? Le protectionnisme. Paris: Economica. 1985, p. 148-149.

${ }^{293}$ CORDEN. W. The revival of protectionism. Occasional papers. New York: Group of Thirty. 1984, p.17- 19 .
} 
dos empregados (fruto da proteção aos direitos sociais) pode ser tão alta que leva ao desemprego, por exemplo.

Sob o argumento chamado "pauper labor", alguns países protegem sua indústria contra mercadorias originárias de países em que a remuneração é baixa ou não há respeito aos direitos sociais, com o intuito de boicotar tais importações e, assim, provocar a reflexão dos países exportadores. Com base nesta teoria, algumas uniões de trabalhadores norte-americanos pediram ao governo que impusesse barreiras à importação de mercadorias de Hong Kong. Contudo, a queda das importações pelos Estados Unidos fez com que os produtores de Hong Kong abaixassem ainda mais seus preços, ou investir em outros mercados, demitindo um grande número de empregados, sem qualquer conseqüência positiva para os empregados de Hong Kong.

Por fim, alguns países defendem que, se os exportadores conseguem vender em terceiros mercados por um preço muito baixo, seja por meio de corte nos custos ou pagamento de salários menores a seus empregados, esta prática é desleal e autoriza qualquer ação protecionista.

O problema do protecionismo está na avaliação dos seus efeitos pelos governos. Para Long, o escopo da liberalização do comércio internacional depende da capacidade dos governos nacionais de se informar e prever, antecipadamente, os futuros efeitos de suas decisões sobre proteção. Em momentos de crise, esta previsão não é tão fácil, e, por isso, deve ser feita antes mesmo que ela seja realmente necessária. Em segundo lugar, as políticas nacionais para promover setores domésticos e, com isso, mudanças no ambiente econômico, não podem ser postas em prática sem a concordância da comunidade. ${ }^{294}$

\subsubsection{2 $\mathrm{O}$ protecionismo no antidumping}

A entrada de países em desenvolvimento no círculo do comércio internacional, nos anos 70, causou um violento surto protecionista. A principal

${ }^{294}$ LONG, Olivier. Public Scrutiny of Protection: domestic policy transparency and trade liberalization. Special report n. 7, Londres: Trade Policy Research Centre. 1989, p. 12. 
manifestação foi o aumento do número de investigações antidumping. Como nunca houve punição às petições desarrazoadas, as medidas de defesa comercial passaram a ser meios rápidos e interessantes de protecionismo. ${ }^{295}$

O protecionismo no antidumping se manifesta em diversas fases de uma investigação antidumping. Pode envolver a decisão sobre a abertura da investigação - se estiver envolvido um setor considerado estratégico, por exemplo como pode ocorrer durante o procedimento, na aplicação de termos, regras ou instrumentos (ex. no reconhecimento de um dano que não existe, de um nexo causal que não é real, na interpretação da melhor informação disponível e na apuração da margem de dumping). ${ }^{296}$

Por que uma empresa afetada por importações decide buscar socorro nas medidas antidumping? Sabe-se que, ao lado das medidas antidumping, o país protecionista pode optar por aplicar salvaguardas. Contudo, o número de investigações antidumping e, conseqüentemente, medidas aplicadas, é absolutamente maior do que o número de investigações e salvaguardas aplicadas. A explicação, segundo Leidy e Hoekman, é o fato de que, em comparação com as salvaguardas, o acesso ao procedimento de antidumping é mais fácil, os requisitos mais transparentes, e há baixa probabilidade de ocorrência de um resultado inesperado. É muito mais simples obter uma decisão positiva - para a aplicação de medidas antidumping - do que no caso das salvaguardas, já que estas envolvem retaliação, decisão que é tomada pelo governo. ${ }^{297}$

\footnotetext{
295 Segundo Panagariya, as medidas foram inventadas pelos países desenvolvidos, nas negociações do artigo VI do GATT. Até os anos 90, apenas quatro países desenvolvidos eram responsáveis por $80 \%$ do volume de medidas: Austrália, Canadá, Comunidade Européia e Estados Unidos. Contudo, a partir desta época, a situação se inverteu. $\mathrm{O}$ autor ressalta que os países em desenvolvimento representam dois terços das medidas aplicadas, sendo a maioria delas aplicadas contra países em desenvolvimento. Agindo desta forma, o protecionismo dos países em desenvolvimento está usando o antidumping para ferir eles mesmos. (PANAGARIYA, Arvind. Anti-dumping: Let us not shoot ourselves in the foot. Economic Times, June 30, 1999).

296 "Para uma autoridade nacional menos preocupada com o espírito da OMC do que com os interesses da indústria doméstica, há um campo de oportunidades nas quais a alternativa menos favorável aos exportadores pode ser sempre escolhida, com o objetivo de provar que há dumping, dano, e a justificativa para a aplicação dos remédios." (HINDLEY, Brian. MESSERLIN, Patrick. Antidumping Industrial Policy: legalized protectionism in the WTO and what to do about it. Washington: The AEI Press, 1996, p. 2.)

${ }^{297}$ HOEKMAN, Bernard; LEIDY, Michael. Dumping, Antidumping and Emergency Protection. Journal of World Trade. v. 23, n. 5, Outubro 1989, p. 38.
} 
Nelson ressalta que a maior parte do comércio que satisfaz a definição de dumping na regulamentação atual (Acordo Antidumping e respectivas leis nacionais) não traz prejuízos. O mecanismo antidumping, ao contrário, está mais ligado à lealdade do que à predação. A proteção antidumping é, contudo, uma má proteção, não baseada na maximização do bem-estar social, é produto de um processo distorcido.

Para explicar a distorção neste processo, o autor divide o modelo de política econômica em dois: o modelo do voto e o modelo do lobby. No primeiro caso, a decisão pode se dar por meio de referendo ou de competição eleitoral. O primeiro, o referendo, está ligado a um equilíbrio de política macroeconômica, que não interessa a apenas uma classe ou setor, mas à economia de forma geral. O segundo está relacionado também ao modelo macroeconômico, mas abre espaço para defesas microeconômicas. $\mathrm{Na}$ aplicação do antidumping, na regulamentação doméstica, cada setor é tratado separadamente, sendo um exemplo de política microeconômica, mais próximo (embora não coincidente) ao modelo de competição eleitoral, que está mais vulnerável às tentativas de proteção.

No modelo de lobby, seja no caso de um estado passivo ou no caso de um estado politicamente ativo, os recursos são alocados para a política e balanceados segundo a margem que poderiam ter produzido na atividade diretamente produtiva. $\mathrm{O}$ lobby no antidumping envolve o pagamento (primeiramente aos advogados, posteriormente investimentos em geral) para acessar o sistema administrativo em que os resultados serão a aplicação de medidas, um acordo ou a desistência (por exemplo, conseguindo negociar acordos com firmas estrangeiras). O lobby pode ser indireto ou direto. O primeiro surge no simples desejo de instauração de um mecanismo antidumping, que é capaz de forçar o comportamento das indústrias ou setores contrários à medida. Alguns autores chamam esta estratégia de dano espúrio (spurious injury). ${ }^{298}$ Lobby direto é a atividade relacionada diretamente à proteção administrativa. A indústria doméstica ou sua associação contrata advogados e economistas para abrir

${ }^{298}$ HOEKMAN, Bernard; Leidy Michael. Spurious injury as indirect rent seeking: free trade under the prospect of protection. Economics and Politics, v. 3, n. 2, 1991, p. 111-137. 
uma investigação e envolve esforços em relações públicas perante os órgãos envolvidos, para terem seus interesses ouvidos. ${ }^{299}$

Contrários aos lobbies ansiosos pela proteção, há também aqueles que não a desejam. As orientações de uma política de comércio devem levar em conta estes interesses contraditórios sobre a proteção. A proteção não é o único objeto da política comercial, reflexão feita pelos Estados Unidos, onde se discute uma reorientação do reflexo protecionista em direção a uma política voluntarista de abertura dos mercados, buscando catapultar a indústria norte-americana em direção ao círculo vicioso do crescimento pelas exportações. Esta orientação consiste em satisfazer os interesses de grupos favoráveis às trocas. O método utilizado é agora mercantilista, pois as autoridades comerciais buscam promover as exportações de seus produtores nacionais e não somente uma troca livre de exportações e importações. ${ }^{300}$

\subsection{CONCLUSÃO DA PRIMEIRA PARTE}

O estudo das negociações para a elaboração do Acordo Antidumping, feito no primeiro capítulo, demonstrou o quanto foi difícil a aceitação, pelos Membros da OMC, de um texto que espelhasse as pretensões de todos, os desejosos de proteção e os que temiam certo controle supra-estatal sobre suas decisões.

Aprovado o Acordo Antidumping, foram os primeiros usuários os países desenvolvidos, substituídos pelos países em desenvolvimento. Atualmente, todos os Membros parecem estar extremamente interessados em aplicar medidas antidumping. Esta sede de aplicação provoca interpretações não desejadas ao Acordo. Termos e expressões complexas, não totalmente elucidadas pelo texto, tornam-se motivo de discórdia entre os aplicadores. As investigações também são criticadas por sua pouca transparência, que leva à insegurança daqueles que as pedem ou que as sofrem.

\footnotetext{
${ }^{299}$ NELSON, Douglas. The political economy of antidumping: a survey. European Journal of Political Economy, v. 22, 2006, p. 554-557.

300 JAVELOT, Sylvie. La loyauté dans le commerce international. Paris: Economica. 1998, p. 145.
} 
O Acordo Antidumping não obriga que, identificados dumping, dano e nexo causal, os Membros apliquem medidas. Ao contrário, o objetivo da redação é permitir certa margem para a não aplicação. Contudo, o texto não é claro sobre quais razões permitiriam ao Membro tal julgamento, e a ausência de uma disposição específica, somada à ânsia protecionista da maioria, fez com que esta possibilidade fosse muito pouco aplicada.

Aproveitando a permissão do Acordo, alguns Membros previram, em suas legislações, uma importante razão para a não aplicação do antidumping: o respeito ao interesse público. Embora o sentido da expressão seja extremamente amplo e traga controvérsias ligadas a uma necessária soberania para a definição do que seja seu conteúdo, estes Membros que já experimentam o "teste do interesse público" decidiram propor sua inserção, como obrigatória, em uma nova redação do Acordo Antidumping.

A sugestão de inclusão do teste no acordo multilateral trouxe conflito. Grande parte dos países concorda com a sua necessidade, em busca de uma investigação antidumping que satisfaça, de forma mais clara, as necessidades nacionais. Entretanto, esta grande parte acredita que deve caber ao governo do Membro investigador a definição do que seja este interesse.

Para que se possa sugerir, no próximo capítulo, critérios objetivos para o exame deste interesse público, percorreu-se, no primeiro momento, os aspectos políticos e jurídicos que envolvem a formação e a definição de um interesse público nacional. Rousseau propõe uma definição de interesse público contratual, na qual o Estado deve se esforçar para dizer a vontade da nação, que é um interesse distinto da soma dos interesses privados. Tocqueville propõe um interesse formado na manifestação do povo, na democracia, no exercício da cidadania.

A consideração do interesse público para Rousseau e Tocqueville permitiu vislumbrar a importância da ação dos grupos de pressão na definição deste interesse. Se o povo deve ser ouvido, a participação de grupos nas investigações antidumping é bem-vinda. A abertura que será dada a estes grupos será discutida no último capítulo. 


\section{O CONTEÚDO DO INTERESSE PÚBLICO NO ANTIDUMPING}

Faz parte dos debates, entre os Membros da OMC, a discussão de critérios para a definição do interesse público. Alguns Membros, como é o caso da Austrália e dos Estados Unidos, defendem que cabe aos governos nacionais a escolha do que será considerado como interesse público no julgamento de cada caso. Outros Membros, como é o caso dos Amigos do Antidumping, postulam que o Acordo Antidumping já preveja tais critérios.

Também se discute a consideração de aspectos não econômicos como parte do interesse público que justificará a não aplicação de medidas antidumping. Estes aspectos não econômicos seriam o respeito aos direitos sociais, a defesa do meioambiente, o apoio ao desenvolvimento de países terceiros, entre outros. Embora alguns Membros que já aplicam o teste entendam que o antidumping é, por natureza, um instrumento econômico e que, por isso, o interesse público no antidumping também deva ter natureza econômica, nem mesmo aqueles que têm mais experiência no assunto conseguem escapar totalmente deste debate. ${ }^{301}$

Critérios econômicos ou não econômicos, é importante que o Acordo Antidumping não deixe aos Membros a possibilidade ilimitada de escolhê-los e o amplo arbítrio para considerá-los. Caso isso ocorra, poderá o teste servir, facilmente, de arma de discriminação entre exportadores, ou de utilização do antidumping para discriminar mercadorias importadas de mercadorias nacionais.

Além disso, o Acordo Antidumping, caso o teste seja aprovado, deve ser claro sobre a necessidade de transparência e previsibilidade do procedimento de avaliação deste interesse. Caso contrário, as partes interessadas na discussão do interesse público, assim como as partes interessadas na própria investigação antidumping, deixarão de participar e contribuir se souberem que a decisão final pode ser extremamente arbitária e desconexa das informações e dados apresentados.

\footnotetext{
301 A Comunidade Européia considera apenas aspectos econômicos como interesse público que justifica a não aplicação de medidas. Contudo, em 2006, este assunto foi amplamente discutido e deu origem ao Livro Verde, conforme exposto no capítulo 1.2.2.1.1.
} 


\subsection{A IMPORTÂNCIA DA DEFINIÇÃO DOS CRITÉRIOS}

O teste do interesse público é útil para reduzir o protecionismo do Membro em relação a sua indústria doméstica. Ele permite aos Membros adotar um mecanismo, uma válvula de escape, para fugir da pressão exercida pela indústria doméstica. Contudo, se o texto do Acordo Antidumping apenas obrigar a aplicação do teste, sem que sejam definidos critérios, ${ }^{302}$ pode ser o interesse público usado como instrumento discriminatório, ou aumentar a insegurança nas investigações antidumping. ${ }^{303}$ Um Membro poderá aplicar o teste em favor dos importadores, apoiando-se nas mais exóticas justificativas, tais como a vontade de manter boas relações com o país investigado, e não aplicar o teste em favor de outros importadores, em casos em que havia razões muito menos exóticas para não se aplicar medidas, tais como a necessidade de se manter a competitividade na indústria doméstica. ${ }^{304} \mathrm{O}$ teste do interesse público deixa grande margem para a discricionariedade, mas a definição de critérios formais de análise e a obrigação de transparência no processo podem diminuir esta margem, tornado a análise mais técnica e objetiva. ${ }^{305}$

\footnotetext{
${ }^{302}$ Assim como é feito no texto elaborado pelo Presidente do Grupo de Negociações em Regras da OMC, em 2007.

${ }^{303}$ Bernert é claro ao se manifestar neste sentido. Questionando-se sobre como melhorar a eficiência das medidas de defesa comercial, ele responde que se deve assegurar um balanço mais eficiente entre os interesses dos afetados: importadores, consumidores, produtores. Para isso, é fundamental que existam regras mais claras. (BERNERT, Peter. Op cit. p. 9.)

${ }^{304}$ Uma medida antidumping pode ser aplicada por razões econômicas e razões políticas. Ambas as razões podem surgir de acordo com a orientação política ou sistema econômico do Membro. Em um total de 229 casos antidumping na Comunidade Européia, entre 1981 e 1985, 47\% foram abertos contra importações provenientes de economias planificadas. A tendência de aplicação de acordo com a orientação do Membro investigado foi chamada, por alguns autores, de "O problema do Japão", devido ao enorme número de medidas abertas contra indústrias japonesas na década de 70 e 80 . Assim, é provável que determinados Membros ajam de acordo com tais orientações, sendo maiores as chances de discriminação contra estas origens "escolhidas". (CZINKOTA, Michael; KOTABE, Masaaki. A marketing perspective of the US International Trade Commission's Antidumping Actions - an empirical inquiry. Journal of World Business, v. 32, i. 2, 1997, p. 177)

305 "Na Índia, a realização de um teste de interesse público não é obrigatória. Esta omissão não passa desapercebida. Especialistas têm sustentando a inclusão do teste na lei. Eles argumentam, entretanto, que não é suficiente que a lei dê às partes adversamente afetadas a possibilidade de apresentar seus argumentos. Para que uma cláusula de interesse público seja efetiva, o termo interesse público deve ter uma definição operacional clara e os fatores que formam o interesse público devem ser claramente definidos." (tradução livre de AGGARWAL, Aradhna. Antidumping Law and practice: an Indian Perspective. Working Paper 85. Indian Council for Research on International Economic Relations, Abril 2002, p. 55.)
} 
Além da utilização do antidumping como instrumento de discriminação, a imprevisibilidade na aplicação do teste, pela inexistência de critérios substantivos a serem observados pelas autoridades, será um freio à participação das diversas partes em uma investigação. ${ }^{306} \mathrm{O}$ Acordo Antidumping atual não prevê a aplicação obrigatória do teste do interesse público. Assim, as partes, ao participarem de uma investigação, sabem quais serão as fases e quais os possíveis resultados. Diante de um teste do interesse público obrigatório, mas sem critérios definidos, as partes contam com a possibilidade de, mesmo após uma investigação dos critérios técnicos e objetivos definidos pelo Acordo Antidumping, decidir a autoridade de forma totalmente contrária à conclusão da investigação, pelas mais diversas e possíveis razões. Certamente, passarão as partes a considerar este fator de incerteza antes de se habilitarem para cooperar com investigações antidumping.

Este problema já ocorre na China. O Regulamento Antidumping de 2004 prevê que medidas antidumping não podem ser aplicadas se forem contrárias ao interesse público. Contudo, não há qualquer critério que defina o que é este interesse e o que farão as autoridades para efetuar um correto balanço entre este interesse e o interesse da indústria doméstica. Tal falta de definição gera imensa insegurança para aqueles que participam das investigações. ${ }^{307}$

O antidumping é um instrumento essencialmente econômico, que tem como objetivo frear a causa de dano à indústria doméstica e tornar possível a recuperação dos produtores nacionais. Atribuir objetivos não econômicos a este instrumento é ampliar exageradamente suas funções. Assim, utilizar o antidumping para a realização de objetivos de política ambiental, política social ou política desenvolvimentista é descaracterizar o objetivo principal das medidas de defesa comercial. Além disso, A negociação de objetivos mais amplos parece ser contrária aos objetivos da Rodada Doha para o antidumping. De acordo com o artigo 28 da Declaração de Doha, os Membros se comprometeram a negociar para "esclarecer e

\footnotetext{
${ }^{306} \mathrm{E}$ até mesmo da indústria doméstica. Se as regras permitirem ampla discricionariedade às autoridades, os produtores domésticos deverão fazer esta avaliação antes de pedirem a abertura de uma investigação. Não há nenhum sentido em pedir aplicação de medidas antidumping se for óbvio que, ao final do processo, as medidas não serão impostas devido ao interesse comunitário. (STEVENSON, Cliff. Evaluation of EC Trade Defense Instruments. Cit. p. 28).

${ }^{307}$ YU, Tian. Op cit. p. 102.
} 
melhorar" a aplicação do Acordo Antidumping ("clarifying and improving" ou "aclarar y mejorar"). ${ }^{308}$ Não há poderes para o alargamento do objetivo das medidas de defesa comercial. Desta forma, as negociações e uma proposta de uma nova redação não poderiam abarcar critérios não econômicos.

A avaliação de aspectos não diretamente relacionados ao interesse econômico das partes afetadas seria de tal forma demorada e complexa, que poderia comprometer os avanços já alcançados na Rodada Doha. ${ }^{309}$ Ademais, o exame destes aspectos poderia alargar a margem de discricionariedade da autoridade e o espaço para a pressão e lobby, sendo ainda mais difícil evitar arbitrariedades na aplicação do teste do interesse público. ${ }^{310}$

A concorrência é um fator raramente analisado pelas autoridades investigadoras. O Membro deve ser capaz de avaliar a competitividade da indústria doméstica antes e depois da aplicação de medidas antidumping. O exame da competitividade no mercado antes da aplicação das medidas permitirá concluir se os

\footnotetext{
${ }^{308}$ Art. 28. A la luz de la experiencia y de la creciente aplicación de estos instrumentos por los Miembros, convenimos en celebrar negociaciones encaminadas a aclarar y mejorar las disciplinas previstas en el Acuerdo relativo a la Aplicación del Artículo VI del GATT de 1994 y el Acuerdo sobre Subvenciones y Medidas Compensatorias, preservando al mismo tiempo los conceptos y principios básicos y la eficacia de estos Acuerdos y sus instrumentos y objetivos, y teniendo en cuenta las necesidades de los participantes en desarrollo y menos adelantados. En la fase inicial de las negociaciones, los participantes indicarán las disposiciones, incluidas las disciplinas sobre prácticas que distorsionan el comercio, que pretenden aclarar y mejorar en la fase siguiente. En el contexto de estas negociaciones, los participantes también procurarán aclarar y mejorar las disciplinas de la OMC con respecto a las subvenciones a la pesca, teniendo en cuenta la importancia de este sector para los países en desarrollo. Observamos que también se hace referencia a las subvenciones a la pesca en el párrafo 31. (WTO, Doha Development Agenda, WT/MIN(01)/DEC/W/1(14 november 2001), parágrafo 25, disponível em http://www.wto.org/english/thewto_e/minist_e/min01_e/mindecl_e.htm\#interaction, consultado em $13 \mathrm{de}$ agosto de 2008.)

${ }^{309}$ Quase dez anos de discussão sobre a redação do Acordo Antidumping e a elaboração de uma proposta de texto.

${ }^{310}$ Bernert defende opinião contrária, mas, ao mesmo tempo, contraditória. Em monografia elaborada à época das discussões para a produção do Livro Verde sobre medidas de defesa comercial na União Européia, ele defende que, se a Europa pretende realizar política séria de auxílio a países em desenvolvimento, muitas vezes com suporte financeiro direto, permitindo que estes países tenham indústrias que possam competir com as indústrias européias, ela será totalmente contraditória à medida de defesa comercial que prejudica importações provenientes destes países. Contudo, o autor não faz sugestões para a harmonização destes interesses (proteção da indústria doméstica x proteção de países em desenvolvimento). No que se refere à incompatibilidade entre a aplicação de medidas de defesa comercial e preocupações ambientais, ele se manifesta contrariamente à inclusão do tema como interesse comunitário. Para ele, política de comércio não é uma panacéia. Nenhuma política comercial conseguirá resolver problemas ambientais na medida desejável. Contudo, políticas ambientais podem muito bem ser usadas para propósitos protecionistas que podem deturpar a política comercial. (BERNERT, Peter. Op cit. p. 7).
} 
preços praticados pela indústria doméstica podem ter sido influenciados por práticas anticompetitivas, tais como cartel ou abuso de posição dominante (para discriminação de preços ou imposição de preços elevados ao mercado doméstico) ou, ainda, pesquisar se os produtores domésticos estão buscando na prática abusiva do antidumping a redução da competição. ${ }^{311}$ Para tanto, o Membro pode se apoiar em investigações passadas, feitas pelas autoridades antitruste, neste setor, ou pode proceder a uma simples análise do número de competidores e das barreiras à entrada no mercado. Nos casos em que são poucos os competidores, deve ser dada maior atenção.

Os importadores, exportadores e consumidores podem contribuir para esta análise. Por vezes, os importadores fornecem dados sobre preços praticados pela indústria doméstica e sobre preços praticados em outros países não investigados, publicados por revistas do setor, que gozam de credibilidade. Será o primeiro passo para que a autoridade investigue que o dano sofrido pela indústria doméstica pode ser a conseqüência de suas próprias práticas. Até aqui, não é necessária qualquer modificação no Acordo Antidumping atual. Esta análise já é prevista para a conclusão do nexo de causalidade, pelo artigo 3.5 .

Embora descrita no artigo 3.5, concernente ao exame do nexo causal, esta análise também é relevante para os fins da determinação de interesse público. Se a indústria doméstica estiver praticando atos anticompetitivos, não é difícil concluir que estes atos serão continuados após a aplicação de medidas. Como será explicado em capítulo dedicado ao tema ${ }^{312}$, as medidas antidumping são barreiras à entrada de novos competidores. Se, antes, a contestabilidade do mercado era possível, razão pela qual não era necessária a intervenção da autoridade concorrencial, após a aplicação do antidumping as importações podem se reduzir ou deixar de existir, ficando a indústria doméstica livre para a prática de seus atos. Nos casos em que há somente um país exportador, a preocupação deve ser ainda maior.

Esta análise não deve ser profunda ao ponto de se transformar na análise das autoridades concorrenciais, nem tampouco é necessário que as autoridades

\footnotetext{
${ }^{311}$ VERMULST, Edwin; DRIESSEN, Bart. New Battles in the Anti-dumping War: recent movements on the European Front. Journal of World Trade, v. 31, n. 3, 1997, p. 155.

312 Tópico 2.3.1.1.2.2.
} 
concorrenciais participem do trabalho. Assim como o artigo 3.5 do acordo já permite que as autoridades de comércio adentrem superficialmente na análise da concorrência existente na indústria, não parece haver nada, no texto do acordo ou em outros documentos da OMC, que impeça às autoridades de defesa comercial de analisarem, superficialmente, os pontos expostos nos parágrafos anteriores.

O consumidor parece ser a segunda preocupação das autoridades de defesa comercial que aplicam o teste do interesse público. Se há risco de elevação dos preços, fruto do aumento dos custos dos importadores e/ou usuários industriais, bem como se houver risco de diminuição da oferta ou da diversidade da oferta, são os interesses dos consumidores elemento a ser considerado pelas autoridades investigadoras. Entretanto, tais preocupações, ou seja, preços e opções aos consumidores, já são preocupações contidas na análise concorrencial proposta. Se o mercado doméstico será menos contestado, ou seja, se os produtores domésticos terão mais liberdade para impor suas práticas (anticompetitivas ou não), nasce, neste ponto, o risco de uma menor oferta ao consumidor e de preços mais elevados. Por isso, a boa análise sob o elemento concorrencial já trará a segurança desejada de proteção aos consumidores. Além disso, é bastante difícil a participação ativa de associações de consumidores nas análises antidumping, entendendo algumas autoridades que a não manifestação implica o desinteresse dos consumidores e a provável inexistência de desvantagens na aplicação de medidas antidumping. ${ }^{313}$ Uma boa análise concorrencial superará a necessidade de participação dos consumidores nas investigações.

O emprego e os salários, previstos no art. 3.4 do Acordo Antidumping como fatores a serem verificados para a conclusão sobre o dano na indústria doméstica, são observados para definir o impacto das medidas antidumping para os importadores, os usuários industriais e os fornecedores da indústria doméstica. Far-se-á um balanço: nos casos em que o emprego e salários estão mais ameaçados nos importadores e nos usuários industriais, verificado que os benefícios a serem obtidos pela indústria doméstica com a imposição de medidas são menores, pode-se privilegiar a salvação dos empregos e salários daqueles que são contrários às medidas.

\footnotetext{
${ }^{313}$ Entendimento da Comissão Européia em várias decisões, como Sapatos de Couro. Regulamento (EU) n . 1472/2006, de 4 de outubro de 2006, J.O L. 275/34 6/10/2006 e Carbonato de Bário Regulamento (EU) n 1175/2005 de 18 de julho de 2005, J.O L 189, 21/07/2005, p. 15.
} 
Por fim, elemento não menos importante é o desenvolvimento industrial e tecnológico. Um governo pode decidir impor medidas antidumping acreditando que tais medidas irão facilitar o desenvolvimento da indústria doméstica, no que diz respeito ao aumento das plantas fabris e investimento em tecnologia. Contudo, alguns aspectos podem contribuir para que este desenvolvimento não seja observado, não ocorrendo, então, benefícios para a indústria doméstica. Neste caso, o balanço será totalmente desfavorável à aplicação, que não deverá ser considerada de interesse público. 


\subsection{O DIFÍCIL BALANÇO ENTRE ESTES CRITÉRIOS}

A aplicação de medidas antidumping certamente fará descontentes. As medidas podem aumentar o custo de produção dos usuários industriais e podem aumentar os preços aos consumidores. As medidas antidumping podem diminuir a oferta de produtos, bem como a sua qualidade. As medidas antidumping podem colocar em risco a indústria consumidora e importadora, levando à demissão de empregados. Medidas antidumping podem ameaçar indústrias e setores considerados tecnologicamente estratégicos. Por outro lado, medidas antidumping satisfazem os interesses da indústria doméstica que busca a competição saudável, com produtos a preços de mercado, competição esta que lhe permitirá recuperar certa participação de mercado, aumentar seus lucros, salvar empregos e investir no seu próprio desenvolvimento. Estes interesses precisam ser, de alguma forma, balanceados. A pergunta a ser feita pela autoridade investigadora é: os benefícios da aplicação da medida antidumping para a indústria doméstica são maiores do que as desvantagens causadas aos outros operadores econômicos diversamente afetados pelas medidas? $?^{314}$

O impacto negativo da imposição da medida antidumping não pode ser maior do que os impactos positivos à indústria doméstica. Alguns autores sugerem a avaliação, no caso dos importadores e usuários industriais, dos mesmos critérios utilizados para o exame do dano à indústria doméstica, descritos no art. 3.4 do Acordo Antidumping. ${ }^{315}$

Em primeiro lugar, este balanço depende da colaboração das partes interessadas. É importante, também, que as autoridades responsáveis pelo teste busquem elementos para a formação de seu convencimento, mas não é factível exigir que estas autoridades, dado o curto prazo para as investigações, tenham que buscar todos estes elementos. Na Comunidade Européia, embora a Comissão tenha modificado seu

\footnotetext{
${ }^{314}$ Os operadores a serem considerados serão discutidos no próximo capítulo, mas já se pode adiantá-los: i) importadores; ii) fornecedores da indústria doméstica; iii) usuários industriais; iv) consumidores.

${ }^{315}$ AGGARWAL, Aradhna. The WTO Anti-dumping Agreement: possible reform through the inclusion of a public interest clause. Working Paper n. 142, Indian Council for Research on International Economic Relations, Setembro 2004, p. 5.
} 
entendimento nos últimos $\operatorname{anos}^{316}$, a manifestação das partes ainda possui um peso fundamental para a decisão. Estas manifestações não podem ser meras alegações, mas serem acompanhadas de provas inequívocas e dados econômicos que comprovem o risco na aplicação das medidas antidumping. Estes dados podem ser verificados durante investigação in loco a ser feita pelas autoridades e as partes que colaboraram com a investigação devem ter acesso aos documentos públicos e poder solicitar audiências.

Não há, entre os Membros que já aplicam o teste, nenhuma legislação que disponha a hierarquia de consideração dos interesses manifestados. Em alguns casos, há menção a alguns critérios, como interesses dos usuários, consumidores, assim como a competitividade no mercado. ${ }^{317}$ Contudo, não é claro o peso destes fatores em relação aos interesses da indústria doméstica.

A forma de balanço entre os critérios concorrentes na definição do interesse público não pode ser imposta por uma organização internacional ou por instrumentos multilaterais. Nem mesmo as legislações nacionais podem estipular qual valor será atribuído a cada elemento, tendo em vista que ele varia em cada caso. Como já discutido, o interesse público é um conceito indeterminado, sendo esta indeterminação a chave para que ele seja utilizado em diversos momentos e contextos. $^{318}$ Pode-se e se deve, no máximo, estabelecer quais critérios deverão ser observados e seus limites, mas o resultado final ficará por conta e risco do Membro avaliador.

Não há nenhum impedimento a que um dos critérios sugeridos seja menosprezado por outro critério também sugerido. Por exemplo, no caso Gravadores de

\footnotetext{
${ }^{316}$ Passando a ser mais proativa na busca dos elementos de convencimento, sobretudo no que se refere aos prejuízos aos consumidores, tendo em vista que estes dificilmente se manifestam espontaneamente em investigações. A mudança do comportamento da Comissão Européia ocorreu após o julgamento do caso Algodão, no qual os importadores e usuários industriais, estritamente dependentes do produto asiático, solicitaram mais de 250 questionários. A ação dos importadores mostrou às autoridades o valor de suas contribuições. "Em conjunto com o novo procedimento introduzido em 1994, a Comissão Européia adotou métodos mais consistentes para investigar precisamente o interesse comunitário nos casos de antidumping." (Algodão. Regulamento (EU) n. 2208/96 de 18 de novembro de 1996. WELlHAUSEN, Marc. The Community Interest Test in Antidumping Proceedings of the European Union. American University International Law Review, v. 16, p. 1028)

${ }^{317}$ Ver Anexo 02 para diversos exemplos na Comunidade Européia.

${ }^{318}$ Não seria possível exigir das autoridades uma análise de custo-benefício estrita em cada caso, uma fórmula matemática que pudesse ser utilizada em todas as hipóteses. Estes interesses em jogo não são quantificáveis matematicamente. (BRONCKERS, Marco. Rehabilitating Antidumping and other Trade Remedies through cost-benefit analyses. Journal of World Trade, v. 30, n. 5, 1996, p. 11.)
} 
Vídeo Cassete, as autoridades comunitárias entenderam que nada garantia que os consumidores continuassem a se beneficiar das vantagens de preço resultantes da competição desleal. Uma possível desvantagem para os consumidores, no caso de um aumento dos preços causado pela imposição de medidas antidumping, será menor do que os benefícios de salvar empregos e se manter neste setor tão importante tecnologicamente. ${ }^{319}$ Contudo, é importante que a autoridade avalie de forma completa tais critérios, questionando, por exemplo, se este setor será sempre importante tecnologicamente, se os empregados salvos poderão consumir o produto após o aumento dos preços, entre outras reflexões.

A preservação do emprego e o desenvolvimento tecnológico e industrial são, também, em alguns países, objetivos da defesa da concorrência. Por esta razão, poder-se-ia argumentar que bastaria a análise da concorrência para que os outros interesses fossem contemplados. Contudo, esta afirmação não seria verdadeira e não conseguiria ser aplicada, com sucesso, por todos os Membros da OMC. Alguns deles enxergam na concorrência um valor em si mesmo, e não a realização de outros objetivos. ${ }^{320}$ Por isso, se a sugestão deste trabalho fosse a defesa da concorrência como único elemento do interesse público no antidumping, alguns países poderiam deixar de buscar esta concorrência como meio de preservação do emprego ${ }^{321}$ e busca de desenvolvimento industrial e tecnológico, que são valores fundamentais no balanço do interesse público no antidumping. Ter-se-ia, então, uma análise incompleta.

A influência política sempre será um temor para as partes em investigações de interesse público. São comuns as pressões de entidades especializadas na defesa dos interesses da indústria nacional, muitas vezes exercidas diretamente sobre as autoridades encarregadas da decisão. Na Comunidade Européia, estas entidades

\footnotetext{
${ }^{319}$ Video Cassete Recorders, J.O 1988 L 204/15.

${ }^{320}$ Como se discutirá adiante (2.3.1.4.2), a Comunidade Européia adota a concorrência meio, que a busca da concorrência como meio de realização de outros fins, tais como o progresso econômico, a preservação do meio ambiente, a busca do pleno emprego, entre outros. O Brasil segue o mesmo caminho, determinado a observação, pela autoridade concorrencial, de alterações no nível de emprego (art. 58, parágrafo $1^{\circ}$, da Lei n. 8.884/94) e desenvolvimento tecnológico (art. 54, parágrafo $1^{\circ}$, c). Nos Estados Unidos, ao contrário, adota-se a concorrência-fim, segundo a qual a concorrência é um fim em si mesma, não sendo meio para a realização de outros objetivos e políticas.

321 Sobre os escopos sociais do direito antitruste e a preservação do emprego nas discussões concorrenciais, ver GOMES, Carlos Jacques Vieira. Os Escopos Sociais do Direito Antitruste. Revista do IBRAC, v. 11, n. 2, 2004, p. 129-139.
} 
dirigem-se diretamente aos seus governos para que estes votem a seu favor perante o Conselho Europeu, a quem cabe a decisão final sobre a aplicação das medidas antidumping. Sobre este ponto, caberá à autoridade administrativa a correta apreensão do que seja o interesse público, que deve ser diferente da soma dos interesses particulares e, no caso europeu, diferente da soma do interesse dos Estados Membros. Acredita-se que a discricionariedade e o risco político podem ser mitigados pela adoção de critérios substanciais e pela necessidade de motivação das decisões e transparência na condução do processo. 


\subsection{OS CRITÉRIOS OBRIGATÓRIOS}

Três critérios são objeto de análise freqüente pelas autoridades que aplicam o teste do interesse público e exprimem o desejo de buscar a decisão mais adequada e que melhor espelhe o interesse público nacional: i) a concorrência, incluindo os interesses do consumidor por preços baixos e opções de compra; ii) o emprego e a redução dos salários; e iii) o desenvolvimento tecnológico e industrial. ${ }^{322}$

\subsubsection{A concorrência como primeiro elemento do interesse público no antidumping}

As autoridades de defesa da concorrência brasileiras têm discutido uma possível interação entre as análises concorrencial e antidumping, já que um dos efeitos do antidumping é a redução da competitividade no mercado do Membro importador. ${ }^{323}$ As análises da concorrência e dos efeitos das medidas antidumping sobre ela fazem parte do interesse público e precisam ser feitas antes da imposição de medidas Contudo, são os objetos da análise concorrencial e da análise antidumping bastante distintos e cada autoridade tem seu espaço de ação, dentro de sua esfera de competência, para evoluir em direção ao ponto de intercessão entre suas áreas.

Autoridades concorrenciais podem e devem observar a concorrência internacional, ao passo que autoridades antidumping podem e devem observar a situação competitiva do produto sob consideração. Contudo, cada autoridade deve restar limitada à sua competência e aos objetivos que lhe foram atribuídos pelo Direito.

\footnotetext{
${ }^{322}$ No Canadá, o teste do interesse público deve incluir a análise dos seguintes critérios: i) possibilidade de aquisição dos produtos de outras origens; ii) se a imposição de medidas causará: a) diminuição na competição; b) significativo prejuízo aos produtores que usam o produto no Canadá; c) limitação de acesso a matéria prima ou tecnologia; d) restrição à escolha do consumidor; iii) prejuízo aos fornecedores da indústria doméstica; iv) outros fatores julgados relevantes. (artigo 42 do SIMA).

${ }^{323}$ MONTEIRO, Carmen Diva Beltrão; GALVÃO, Letícia Andreoli. Op cit.
} 


\subsubsection{A análise do comércio internacional na defesa da concorrência}

Há uma relevante interação entre comércio internacional e defesa da concorrência: com o aumento das trocas internacionais, cresce a oferta de produtos e serviços ao consumidor, e, com ela, observa-se a redução do preço destes produtos e serviços. Contudo, o aumento do comércio traz benefícios imediatos e diretos apenas aos países e agentes privados que estão preparados para aproveitá-los. Os demais agentes, em primeiro momento, buscam formas de se proteger. Entre estas formas, pode-se citar os meios dependentes da ação dos Estados, como a imposição de medidas de proteção ao comércio. Contudo, se existem a expectativa e o receio de que o Estado não corresponderá aos anseios dos agentes privados, deixando de protegê-los, estes agentes privados buscam a auto-proteção.

Esta auto-proteção pode se manifestar sob a forma de restrições impostas pelos próprios agentes econômicos ao comércio, restrições horizontais, impostas a agentes privados que operam em um mesmo mercado relevante (ex. cartéis), ou restrições verticais, impostas a agentes privados à montante ou à jusante (ex. recusa de venda). Neste caso, deve-se frisar, estar-se-á descrevendo uma situação cujos efeitos envolvem mais de um país. ${ }^{324}$

As autoridades de defesa da concorrência de todo o mundo têm demonstrado maior preocupação em relação ao contexto internacional, desenvolvendo suas análises por meio de acordos com outras autoridades, por meio da observação da ação de agentes privados nacionais nos mercados internacionais, ou da observação da ação de agentes internacionais nos mercados nacionais. ${ }^{325}$ Contudo, esta tendência ainda está bem distante do desejado. Alguns destes exames têm sido apenas parciais, considerando a concorrência internacional visível no momento da análise, deixando de contemplar eventuais possibilidades de restrição à concorrência internacional que

\footnotetext{
${ }^{324}$ Não se considera, aqui, uma restrição vertical imposta a um fornecedor de peças aos seus clientes industriais, dentro do território, que não provoca qualquer efeito fora do território, a país ou a empresa estrangeira. Serão discutidas neste tópico tão somente as restrições entre empresas em uma mesma localização geográfica - pais, ou empresas de dois países distintos, mas que causarão prejuízos a outros mercados ou a outros agentes, que com ela comercializam ou compram/fornecem produtos.

${ }^{325}$ A interação entre autoridades concorrenciais vem se desenvolvendo com mais sucesso perante a ICN International Competition Network, um ponto de encontro para autoridades concorrenciais, uma organização que realiza seminários e permite a troca de experiências entre as autoridades.
} 
podem ocorrer em um curto prazo. ${ }^{326}$ Uma boa análise concorrencial, preocupada com a influência do comércio internacional sobre a concorrência, e vice-versa, já é o primeiro passo para a realização do interesse público, entendido como a busca do bem-estar para consumidores e concorrentes em esfera mundial.

\subsection{As negociações multilaterais para a proteção da concorrência global}

Notando a intrínseca relação com o comércio internacional, decidiram os Membros da OMC incluir a concorrência na pauta de debates multilaterais da OMC. Assim como acesso aos mercados, a não discriminação, entre outros temas, a concorrência é também um assunto de relevância nas discussões multilaterais.

A maioria dos países do mundo entende que suas leis concorrenciais são aplicáveis apenas em relação aos atos praticados, pelos agentes econômicos, em seus territórios, ou que nele produzam efeitos. ${ }^{327}$ Contudo, muitas das conseqüências não se restringem a um só território. Algumas escapam do exame dos Membros. Para evitar que isso ocorra, muito se clama pela instituição de uma organização multilateral de concorrência, ou, pelo menos, pela negociação de regras mínimas a serem aplicadas por vários países no combate ou controle a estes atos transnacionais.

Há muitos anos, vários países vêm tentando assinar um acordo multilateral sobre concorrência, sem êxito. Já foram propostas a criação de uma organização internacional especializada e a unificação dos critérios adotados pelas diversas autoridades nacionais. Nenhuma das propostas obteve êxito. $\mathrm{O}$ máximo alcançado foi a celebração de alguns acordos bilaterais ou regionais, versando sobre pontos controversos relativos ao direito da concorrência e a troca de experiências entre as autoridades concorrenciais de diversos países.

\footnotetext{
${ }^{326}$ Um exemplo muito simples, extremamente relacionado à esta tese: as autoridades de defesa da concorrência não costumam considerar, em suas análises, a existência de medidas antidumping contra as importações concorrentes. Assim, autoridades como a brasileira consideram apenas o valor do tributo cobrado na importação e o volume de importações no momento da investigação, análise bastante limitada e que não contempla o antidumping ou a qualquer outro aspecto que pode vir a diminuir ou falsear concorrência com o mercado internacional.

${ }^{327}$ A aplicação das leis concorrenciais de acordo com a produção de efeitos será discutida adiante.
} 
O primeiro instrumento firmado entre países sobre a concorrência foi a já mencionada Carta de Havana ${ }^{328}$, que tinha como objetivos instituir as primeiras medidas para um comércio livre e, ao mesmo tempo, obrigar os países signatários a adotar regras de concorrência que proibissem práticas anticompetitivas de seus agentes econômicos e dos próprios governos. ${ }^{329}$ Entretanto, este documento não foi aceito por alguns Membros ${ }^{330}$, que se recusavam a conferir autoridade concorrencial à Organização Internacional do Comércio. Do outro lado do Atlântico, os governos europeus decidiram firmar o Tratado de Paris, que trazia previsões específicas sobre a concorrência e tinha como objetivo evitar práticas anticompetitivas nos setores de aço e carvão. Posteriormente, em 1957, tais previsões foram repetidas no Tratado de Roma, que trouxe disposições relativas à concorrência aplicáveis em vários setores.

Em 1960, as Partes Contratantes do GATT decidiram nomear um grupo de especialistas para reexaminar a Carta de Havana. Contudo, sempre pareceu bastante difícil encontrar um ponto em comum entre países que não tinham a mesma experiência concorrencial e se encontravam em níveis distintos de desenvolvimento de suas políticas concorrenciais. ${ }^{331}$

\footnotetext{
${ }^{328}$ Havana Charter for an International Trade Organization of 1949, mencionada no tópico 1.1.1.

329 "1.Cada Membro deve tomar providências apropriadas para cooperar com a Organização na prevenção de práticas de negócios no comércio internacional, por parte de empresas públicas ou privadas, que possam restringir a concorrência, limitar o acesso a mercados, ou permitir o controle monopolístico, sempre que estas práticas tenham efeitos prejudiciais à expansão da produção ou do comércio.2. Para que a Organização possa decidir quando uma prática tem como efeito algumas das consequiências enumeradas no item 1., os Membros acordam que qualquer reclamação relacionada a qualquer das práticas assinaladas no parágrafo 3 deve estar sujeita à investigação conforme o procedimento previsto nos arts. 48 e 50 , sempre que: (a) esta prática for apresentada à Organização, e (b) se trate de prática de empresas públicas ou privadas, ou de qualquer acordo ou combinação entre estas empresas, e (c) estas empresas, individualmente ou em grupo, possuam efetivo controle do mercado entre um número de países em um ou mais produtos. 3. As práticas referidas acima são: (a) fixação de preços, prazos e condições a serem observados na venda, compra ou empréstimo de um produto; (b) exclusão de empresas por meio de alocação ou divisão de territórios ou consumidores ou fixação de quotas para compra e venda; (c) discriminação entre empresas particulares; (d) limitação da produção ou fixação de quotas; (e) proibindo, por meio de acordo, o desenvolvimento ou aplicação de tecnologia ou invenção, patenteada ou não; (f) estender o uso de direitos sobre patentes, marcas e direitos outorgados por Membros, de acordo com normas e regulamentações que não o prevejam, ou sobre produtos ou condições de produção, uso ou venda que não estejam estipulados nos acordos; (g) qualquer prática que a Organização declarar, por dois terços dos membros votantes ou presentes, ser uma prática restritiva de comércio. (Tradução livre de Havana Charter, 24 de março de 1948, United Nations. E/C. 2/78, reprinted in Dep't St., Pub. N. 3206, Commercial Policy Series 114, art. 46. Disponível em http://www.wto.org/english/docs_e/legal_e/prewto_legal_e.htm)

${ }^{330}$ Especialmente os Estados Unidos, temerosos de perder sua soberania nas análises concorrenciais.

${ }^{331}$ MARSDEN, Philip. A competition policy for the WTO. Londres: Cameron May, 2003, p. 50.
} 
A OCDE (Organização para o Desenvolvimento Econômico e Cooperação) mostrou-se interessante palco para as discussões sobre a criação de regras multilaterais. Uma das principais recomendações desta organização é a cooperação entre seus membros para a notificação de práticas abusivas, consultas e formas de conciliação de procedimentos. ${ }^{332}$

Algumas regras versam sobre a concorrência internacional, embora não seja possível falar em um regulamento multilateral efetivo. O artigo XVII:3 do GATT, por exemplo, dispõe que cabe aos Membros assegurar que os monopolistas baseiem suas decisões em considerações comerciais e não discriminem importações. Segundo as regras do GATS, os Membros se comprometeram a eliminar práticas restritivas e a reduzir o poder de empresas que, agindo como monopólios, possam restringir o comércio. ${ }^{333} \mathrm{O}$ TRIPS também dispõe que os Membros precisam estar atentos às práticas restritivas cometidas por aqueles que possuem direitos de propriedade intelectual. ${ }^{334}$ Embora o acordo não disponha sobre como o Membro deve agir em relação a estas práticas, ele prevê que outros Membros podem criticar os atos de seus parceiros comerciais e que a OMC tem o direito de revisar a ação dos Membros em relação a práticas concorrenciais.

Em 1997, alguns Membros da $\mathrm{OMC}^{335}$ delinearam pontos que deveriam ser negociados e examinados, referentes à concorrência, em um grupo de discussões conhecido como Grupo de Trabalho na Interação entre Política da Concorrência e Comércio Internacional. Entre estes pontos, estão: (a) o relacionamento entre as políticas concorrenciais e de comércio internacional como meio de desenvolvimento e crescimento dos Membros; (b) análise da prática dos Membros em relação à defesa da concorrência, tais como instrumentos de investigação, conceitos, medidas tomadas, diretrizes, etc; (c) análise dos acordos bilaterais, regionais e multilaterais existentes ou incentivados, versando sobre o tema; (d) interação entre as políticas de concorrência e comércio internacional, especificamente o estudo dos

\footnotetext{
332 OCDE, Coherences et incoherences entre les politiques des echanges et de la concurrence. COM/TD/DAFFE/CLP(98)25/FINAL, p. 7.

${ }^{333}$ General Agreement on Trade in Services, Art. VIII.1.

${ }_{334}$ Agreement on Trade Related Aspects of Intellectual Property Rights, Seção 8.

${ }^{335}$ Austrália, Canada, Egito, Comissão Européia, Hong Kong, India, Japão, México, Noruega, Paquistão, Suíça e Estados Unidos.
} 
monopólios nacionais e seus efeitos sobre o comércio, os efeitos das práticas anticompetitivas das empresas sobre o comércio entre Membros, os impactos da liberalização sobre a concorrência. ${ }^{336}$

Na Conferência Interministerial de Doha, em 2001, foi finalmente aprovada a inclusão de um parágrafo sobre os princípios a serem observados pelos Membros nas próximas negociações sobre concorrência. A Declaração de Doha prevê, em seu artigo 25, a discussão e o esclarecimento dos princípios fundamentais da concorrência a serem adotados pelos Membros, incluindo transparência, não discriminação e procedimentos justos, além de regras duras e claras sobre o combate aos cartéis, cooperação entre os Membros, progressivo desenvolvimento das autoridades de concorrência nos países em desenvolvimento. ${ }^{337}$ Contudo, ela não traz nenhuma certeza sobre a continuidade das negociações, quando elas serão desenvolvidas, ou qual é a obrigação dos Membros. ${ }^{338}$

Poucos pontos são convergentes entre os Membros, no que diz respeito à sua preocupação concorrencial. O primeiro deles é, como lembra Marsden, o combate a cartéis ${ }^{339}$ e às restrições verticais ${ }^{340}$. O segundo é uma mínima convergência sobre as regras nacionais de notificação de concentrações, para evitar que alguns países

\footnotetext{
${ }^{336}$ WTO, Report of the WTO Working Group to the General Council, Annex I Chairman's Checklist (25 de novembro de 1997).

337 WTO, Doha Development Agenda, WT/MIN(01)/DEC/W/1(14 november 2001), parágrafo 25, disponível em http://www.wto.org/english/thewto_e/minist_e/min01_e/mindecl_e.htm\#interaction, consultado em 13 de agosto de 2008.

${ }^{338}$ Um dos pontos mais difíceis nas negociações sobre o tema concorrencial é a definição de conceitos. Os relatórios da OCDE apontam, por exemplo, a dificuldade de se convencer os países desenvolvidos, que já aplicam suas leis anticoncorrenciais há vários anos, a definir de forma uniforme o que são os cartéis. Os Membros da OCDE elaboraram uma definição de cartel, mas deixaram margem para manobra e reinterpretação por suas autoridades concorrenciais. Seria um cartel um acordo anticompetitivo ou uma prática anticompetitiva, pela qual os competidores fixam preços, acordos em licitação, estabelecem restrições de produção ou quotas, dividem mercados alocando consumidores, fornecedores, territórios e linhas de comércio. A definição não inclui acordos, práticas concertadas que i) são razoavelmente a realização de redução de custos ou melhoria na eficiência; ii) são excluídas da legislação do Membro e iii) estão de acordo com a legislação do Membro. Entretanto, na prática, há várias diferenças entre os Membros. Alguns condenam os cartéis per se, outros aplicam a regra da razão. OECD, Recommendation Concerning Effective Action Against Hard-Core Cartels, C(98) 35/FINAL, citado por Philip Marsden, op. cit. p. 69, disponível em www.oecd.org/dataoecd/39/4/2350130.pdf, consultado em 14 de agosto de 2008. 339 "Cartéis de importação prejudicam os consumidores internos ao bloquear a entrada de produtos estrangeiros. Cartéis de exportação prejudicam mercados por inflarem os preços de outros mercados. Cartéis internacionais prejudicam diversos mercados." Op cit. p. 68.

340 "É prática comum a aplicação da regra da razão à maioria das restrições verticais, mas uma lista de fatores a serem considerados pelas diversas autoridades ao balancear os efeitos anti e procompetitivos de uma restrição vertical devem ser desenvolvidos." (KENNEDY, Kevin. Competition Law and the World Trade Organisation: the limits of multilateralism. Londres: Sweet \& Maxwell. 2001, p. 187.)
} 
tenham regras muito superficiais, ao passo que outros tenham regras exageradamente intervencionistas. Todos os Membros parecem concordar que estas são prioridades. ${ }^{341}$

Entretanto, cabe lembrar que, entre os objetivos dos Membros da OMC, não está a criação de uma lei única, ou mesmo de uma organização que verse sobre concorrência e julgue as ações dos governos no que se refere à concorrência. A OMC continua e continuará sendo uma organização que tem como objetivo a liberalização do comércio de bens e mercadorias. Assim, somente os fatores concorrenciais ligados a este comércio interessam às discussões entre os Membros, o Grupo de Trabalho da OMC deve se restringir à interação entre comércio e concorrência. $^{342}$

Outro importante ponto é a conduta insatisfatória de algumas autoridades concorrenciais. ${ }^{343}$ Alguns países possuem leis concorrenciais rígidas, que prevêem regras claras, mas não as aplicam adequadamente, permitindo a formação de monopólios inexplicáveis ou ineficientes, que dominam mercados e reduzem a competição. Estas estruturas certamente tentarão se preservar, no mercado doméstico, por meio da imposição de medidas de defesa comercial, bem como poder-se-ão lançar

\footnotetext{
${ }^{341}$ Segundo Frédéric Jenny, sempre houve menos interesse das fusões internacionais do que nos cartéis, pois as fusões não trazem tantos problemas ao comércio quanto estes últimos. (JENNY, Frédéric. Competition, Trade and Development Before and After Cancun. International Antitrust Law \& Policy: Fordham Corporate Law 2003, p. 540)

${ }^{342}$ Sobre este ponto, Marsden ressalta a existência de um documento produzido pelos Estados Unidos para ser apresentado ao Grupo de Trabalho, sob o nome "Em que ponto comércio e concorrência interagem". Uma seção específica foi dedicada ao tema, sob o título "Nem todos os problemas concorrenciais são problemas de comércio internacional". (International Competition Policy Advisory Committee of the Attorney General and Assistant Attorney General for Antitrust, Final Report (Washington 2000), disponível em www.usdoj.gov/atr/icpac). Eleanor Fox ressalta que os problemas não relacionados a comércio-concorrência são urgentes e devem ser analisados, porém estes assuntos pertencem definitivamente ao direito da concorrência, não ao comércio internacional, e devem ser mantidos no espaço destinado àquele. (Op. cit. p. 675). Frédéric Jemmy ressalta o conteúdo da proposta multilateral: (i) um compromisso dos Membros sobre os princípios a serem observados na aplicação da lei concorrencial, incluindo transparência, não discriminação e devido processo legal; (ii) um compromisso paralelo entre os governos para a ação contra cartéis; (iii) o desenvolvimento de medidas de cooperação entre Membros, de natureza voluntária; (iv) ajuda ao desenvolvimento da prática nos países em desenvolvimento e (v) o estabelecimento de um comitê permanente para o estudo da matéria e identificação das necessidades dos membros. (JENNY, Frédéric. Op cit. p. 645.)

${ }^{343}$ A conduta insatisfatória das autoridades concorrenciais pode permitir a inadequada concentração dos agentes econômicos e, com ela, abuso de poder econômico. Este abuso, como será visto adiante, pode levar à prática de dumping, em outros mercados.
} 
no mercado internacional por meio de cartéis, discriminação de preços, entre outras práticas. ${ }^{344}$

Independente da evolução das discussões sobre comércio internacional e concorrência, a relação já foi trazida, direta ou indiretamente, em três casos, ao mecanismo de solução de controvérsias da OMC. No primeiro deles, os Estados Unidos alegaram que o Japão teria violado as regras do GATT por não ter imposto uma agressiva política de combate às barreiras privadas ao comércio. ${ }^{345}$ No segundo caso, o Japão e a Comunidade Européia alegaram que os Estados Unidos teria violado o artigo VI:1 do GATT e o Acordo Antidumping da OMC, em seu Antidumping Act of $1916 .{ }^{346}$ No terceiro caso, já mais recente, o México foi acusado, pelos Estados Unidos, de não tomar medidas contra práticas anticompetitivas na

\footnotetext{
344 "A política concorrencial interage com a política de comércio internacional quando uma conduta anticompetitive exclui uma empresa estrangeira do mercado nacional de forma tão efetiva quanto se uma alta tarifa fosse imposta, e quando as autoridades concorrenciais daquele país tenham falhado em reprimir aquela prática." (tradução livre de Tarullo, Daniel. Norms and Institutions in Global Competition. in MARSDEN, Philip. op cit. p. 94) e "O mais grave problema entre concorrência e comércio internacional da atualidade é o bloqueio do acesso aos mercados por práticas anticompetitivas. Entretanto, o que mais preocupa não é a inexistência de leis concorrenciais nacionais, mas sim a não utilização das leis concorrenciais nacionais." (Tradução livre de FOX, Eleanor. Should competition join the WTO?, in MARSDEN, Philip. op cit. p. 94).

${ }^{345}$ A reclamação partiu da empresa Eastman Kodak Company. De acordo com suas afirmações, algumas práticas toleradas pelo governo japonês, tais como descontos anticompetitivos, imposição de preços de revenda e fixação de preços horizontal impediriam as empresas norte-americanas de exportar para naquele país. Além disso, as práticas da empresa japonesa Fijifilm, toleradas pela autoridade, teriam criado um canal de distribuição exclusive à empresa. A decisão do mecanismo de solução de controvérsias da OMC versou sobre a administração da lei concorrencial japonesa. O painel acolheu a alegação de que a reclamação dos Estados Unidos versava sobre a conduta de empresas privadas, não do governo do Japão. Sendo assim, a OMC não seria o foro apropriado para a discussão. Além disso, concluiu o painel que as importações não estariam sendo prejudicadas por certas medidas tomadas pelo governo japonês. Por fim, não haveria indícios de um tratamento discriminatório do Japão em relação às importações e os produtos nacionais. (Japan - Measures affecting Consumer Photographic Film and Paper, WT/DS44/R).

${ }^{346}$ O Antidumping Act of 1916 era o instrumento norte-americano utilizado para a defesa da concorrência e antidumping. Previa a imposição de medidas, multas e até mesmo prisão nos casos de infração à ordem econômica e antidumping (o texto trazia uma mistura dos dois institutos). As penalidades previstas pela lei nunca foram aplicadas, de fato, nos Estados Unidos, mas vários processos foram iniciados. Comunidade Européia e Japão protestaram contra a previsibilidade de punições para medidas antidumping que não estavam previstas no GATT. Basicamente, os dois reclamavam contra o tratamento não igualitário conferido aos produtos importados e os produtos nacionais (já que os produtos importados poderiam ser submetidos às punições previstas tanto na lei antitruste quanto na lei concorrencial). (AntiDumping Act of 1916, WT/DS136/AB/R and WT/DS162/AB/R)
} 
prestação de serviços de telecomunicações e de não conferir o mesmo tratamento aos prestadores de serviços norte-americanos e mexicanos. ${ }^{347}$

A legislação multilateral versando sobre concorrência ainda é uma realidade muito distante. Para os Estados Unidos, não há problema concorrencial que não possa ser resolvido pela legislação nacional e alguma cooperação entre autoridades $^{348}$, não sendo necessária a elaboração de um acordo internacional sobre o assunto. ${ }^{349} \mathrm{O}$ máximo possível de ser alcançado seriam princípios ou regras mínimas, com disciplinas contra o tratamento discriminatório e garantindo a transparência nos procedimentos nacionais. $^{350}$

Frédéric Jenny entende que são quatro as possíveis soluções a serem negociadas. A primeira seria um movimento de compreensão e adoção de algumas disposições das leis norte-americana e européia de defesa da concorrência. Segundo o autor, estas leis já são aplicadas há muito tempo e gozariam de uma maior credibilidade. A segunda solução seria a cooperação voluntária entre autoridades nacionais, como a International Competition Network $(\mathrm{ICN})^{351}$, para a discussão de medidas a serem tomadas e repressão de condutas que afetam mais de um país. A terceira solução seria a

\footnotetext{
${ }^{347}$ O México foi acusado de praticar discriminação entre os prestadores de serviços de telecomunicações mexicanos e norte-americanos, no que se refere às tarifas de interconexão internacionais e a outros serviços. Além disso, o México não teria se esforçado para aumentar o acesso, por prestadores estrangeiros, a seus serviços de telecomunicações. Por fỉm, o México incentivaria a existência de um monopolista em alguns serviços e nada faria para tentar aumentar a concorrência. (Telecoms WT/DS204/R).

${ }^{348}$ Sobre cooperação entre autoridades, ver FOX, Eleanor. International Antitrust and the Doha Dome. Virginia Journal of International Law, v. 43, 2003, p. 911-932.

349 Em 1980, o representante norte-americano para o comércio observou que, se um mercado não é suficientemente aberto às empresas norte-americanas e nenhuma restrição soberana pode ser identificada, certamente existe uma restrição imposta pelos agentes econômicos privados. O Advogado Geral para assuntos concorrenciais, nos Estados Unidos, acentuou que, se a lei de comércio internacional não consegue abrir uma economia de um mercado estrangeiro, então a lei antitruste norte-americana pode e deve fazer seu trabalho. (FOX, Eleanor. Competition Law and the Millennium Round. Journal of International Economic Law, 1999, p. 668.) Este raciocínio é bastante incompleto. Alguns países em desenvolvimento não possuem legislação antitruste, ou sua legislação não é suficientemente forte, ou não possuem recursos para a aplicação dos dispositivos legais. Há também uma enorme dificuldade, nestes países, de desafiar empresas multinacionais, já que são os receptores do investimento direto estrangeiro. Outra dificuldade se refere à coleta de provas, quando os infratores estão localizados fora do território. A autoridade nacional enfrentará dificuldades em concluir a sua investigação.

350 JOEL Klein, Anticipating the Millenium: international Antitrust Enforcement at the End of the Twentieth Century. in FOX, Eleanor. Op cit. p. 669.

${ }^{351}$ A experiência da ICN demonstra que é possível a cooperação entre diversas autoridades. A ICN nada mais é do que uma rede de contatos, reuniões e discussões entre autoridades de defesa da concorrência de vários países, que tem como objetivo discutir práticas, promover revisões de ações entre autoridades e encontrar soluções para os problemas encontrados nos diversos países. (ICN, www.internationalcompetitionnetwork.org).
} 
criação de um organismo supranacional, com poderes maiores do que os poderes das autoridades nacionais, tal como ocorre na União Européia. Tal solução tem se mostrado impossível diante das diferenças acentuadas entre as atividades nacionais e as necessidades de cada país. ${ }^{352}$ Por fim, a quarta solução seria a celebração de um acordo multilateral em concorrência, também complicado em virtude das mesmas dificuldades encontradas na criação de uma autoridade supranacional. ${ }^{353}$

Eleanor Fox resume os pontos que poderiam ser tratados. São eles: i) as nações devem reforçar sua legislação proibindo condutas comerciais que restringem desarrazoadamente o acesso aos mercados; ii) as nações devem reforçar suas leis ligadas à não discriminação; iii) deve-se assegurar que as análises anticoncorrenciais sejam feitas separadamente de qualquer outra análise e de forma transparente; iv) devem ser instituídas amplas oportunidades para que qualquer interessado - país ou indivíduo leve ao conhecimento das autoridades nacionais qualquer violação concorrencial; v) o país importador deve prover amplo acesso ao seu sistema de controvérsias, preservando o direito das pessoas e nações afetadas; vi) as leis nacionais do país importador devem ser aplicadas; vii) os Membros não podem restringir os benefícios e aplicabilidade das leis e das boas regras já alcançadas nas negociações; viii) as controvérsias devem ser limitadas às prováveis violações a estas obrigações. ${ }^{354}$

No que interessa a este trabalho, cabe concluir que, diante das dificuldades que impedem a convergência das regras concorrenciais entre os Membros da OMC, é importante que exista, pelo menos, certa preocupação, pelas autoridades concorrenciais, em relação à realidade e demanda do comércio internacional. Não deve ser aceito, pelos Membros, que uma autoridade concorrencial nacional fique reste completamente alheia à conjuntura do mercado internacional. Mesmo que não existam regras multilaterais, a prática nacional deve incluir procedimentos que permitam a avaliação das concentrações e restrições no que se refere aos seus produzidos, por elas, ao comércio entre países.

\footnotetext{
352 Como o próprio autor ressalta, não existe uma lei ou autoridade que se enquadre no conceito de "one size fits all".

${ }^{353}$ JENNY, Frédéric. Op cit. p. 642.

${ }^{354}$ Op. cit. p. 672.
} 


\subsection{Pontos a serem observados pelas autoridades de concorrência}

Mesmo inexistindo uma organização internacional e sendo pouco provável a harmonização das regras concorrências entre países, é importante que as autoridades concorrenciais nacionais estejam dispostas a analisar alguns aspectos de comércio internacional que afetam a concorrência nacional. Quatro momentos específicos do trabalho das autoridades concorrenciais demandam maior atenção no que se refere à conjuntura internacional: i) a análise do mercado relevante geográfico; ii) a análise de barreiras à entrada de novos concorrentes; iii) a análise de cartéis ou restrições verticais internacionais; e iv) a análise de concentrações econômicas transfronteiriças.

Conforme mencionado, a prática insatisfatória das autoridades concorrenciais pode permitir concentrações excessivas ou o abuso do poder econômico. Tais falhas na análise concorrencial e o acúmulo do poder privado podem encorajar práticas discriminatórias em outros mercados em que estes agentes privados desempenhem alguma atividade. Este é o caso do dumping. A falha no controle de concentrações pode ocasionar acúmulo de poder econômico e posterior abuso. Este abuso pode ocorrer no mercado externo, por meio da exportação a preço de dumping. Neste caso, o país de destino das mercadorias será afetado pela prática, sem que as autoridades concorrenciais deste país importador possam agir. De outra forma, as concentrações indevidas no território importador também podem fazer com que as empresas nacionais concentradas pratiquem preços elevados. A autoridade concorrencial, neste caso, entenderá esta prática como temporária, já que as baixas barreiras à entrada de competidores trarão, rapidamente, contestadores. Estes competidores internacionais aparecem, mas os produtores nacionais podem solicitar às autoridades de defesa comercial a aplicação de medidas antidumping contra estas importações. Caberá às autoridades de defesa comercial negar a aplicação, justificando a negativa no fato de que estas importações são importantes para a concorrência no mercado interno, garantindo preços e ofertas ao consumidor? Sim, elas poderão fazê-lo, mas é essencial que as autoridades de defesa da concorrência tenham, antes, cumprido sua função. 


\subsection{A delimitação do mercado relevante}

A definição do mercado relevante, geralmente feita no início do processo de exame de concentrações entre agentes econômicos ou da prática de restrições econômicas por estes agentes, é o primeiro momento em que as autoridades concorrenciais são chamadas a observar a conjuntura internacional do produto ou serviço analisado. As autoridades de defesa da concorrência não podem julgar determinada concentração ou restrição provocada por um agente do mercado, se não delimitarem a concorrência do produto ou serviço ${ }^{355}$, ou se não entenderem a amplitude geográfica de atuação desta concorrência.

Antes de definir o âmbito geográfico de uma concentração ou restrição, a autoridade precisará determinar se este produto ou serviço compete com outros produtos ou serviços que, mesmo que não idênticos ou similares, podem lhe substituir. A partir do momento em que a autoridade define que molho de tomate não compete com polpa de tomate, ketchup ou sopa de tomate, ela deverá buscar o mercado relevante geográfico do molho de tomate, se nacional ou internacional. ${ }^{356} \mathrm{Em}$ sua análise, a autoridade conclui que um aumento mínimo no preço do molho de tomate, de $\mathrm{R} \$ 0,50$, não fará com que os produtores de molho de tomate da França comecem a exportar para o Brasil. Contudo, se este aumento for maior que $\mathrm{R} \$ 1,00$, as marcas francesas começarão a ser encontradas no Brasil.

A análise da dimensão geográfica abarca, entre outros fatores, as condições de transporte, a existência de barreiras sanitárias, barreiras artificiais, etc. Por exemplo, se o preço do molho de tomate sofrer aumento de $\mathrm{R} \$ 1,00$, mas o governo decidir aplicar medidas antidumping contra o molho de tomate proveniente da França, no valor de $\mathrm{R} \$ 1,00$, haverá nova resposta ao questionamento do parágrafo anterior, e os produtos franceses não mais entrarão no Brasil. Será necessário um aumento maior do

\footnotetext{
355 Para ultrapassar o primeiro degrau da análise, ou seja, a definição do produto, ou o mercado do produto, a autoridade deve identificar todos os substitutos disponíveis para seus vendedores e compradores. Deve-se questionar o quanto um produto de um vendedor compete com outros produtos e se estes produtos limitam a sua capacidade de aumentar os preços. Se não substitutos são incluídos, significa que o mercado não é bem definido, pois estes produtos dificilmente irão afetar o poder deste vendedor de elevar os preços. (GELLHORN, Ernest; KOVACIC, William; CALKINS, Stephen. Antitrust Law and Economics in a nutshell. Saint Paul: Thompson West. 1994, p. 117.)

${ }^{356}$ Não se considera, nesta análise, os mercados regionais ou de menor âmbito geográfico.
} 
que $\mathrm{R} \$ 1,00$ para que a importação ocorra. Da mesma forma, se existir um cartel internacional que combine que os produtores franceses não irão exportar molho de tomate para a América do Sul, o aumento nos preços do produto brasileiro deverá ser infinitamente maior para compensar a traição ao cartel e a exportação ao Brasil.

A autoridade antitruste deve realizar uma profunda análise do mercado geográfico, considerando a competitividade do produto com seus similares estrangeiros $^{357}$ e a competitividade do próprio produto fora do país ${ }^{358}$. Muitas vezes, a análise de mercado relevante se resume à sua definição e não abrange preocupações relacionadas à situação do mercado internacional. Por exemplo, as autoridades concorrenciais não analisam a existência de investigações antidumping, o que pode determinar o fechamento artificial, por cinco anos, do mercado nacional. Assim, se a autoridade contava com a concorrência internacional, pode ser obrigada a deixar de contar poucos dias após a autorização de uma super concentração entre empresas nacionais.

Jonell Goco esclarece que as definições do mercado relevante no contexto da OMC e de similaridade no antitruste estão relacionadas, mas são distintas. ${ }^{359}$ As legislações antitruste e da OMC desempenham funções diferentes. A legislação da OMC visa remover barreiras governamentais à livre circulação de bens e serviços. A legislação antitruste visa disciplinar os atos de agentes econômicos que restrinjam a concorrência. Intuitivamente, o mercado relevante no contexto da OMC deve ser mais amplo do que no contexto da legislação antitruste, de forma que a

\footnotetext{
${ }^{357}$ No Brasil, a Resolução n.20 do CADE dispõe que: "mediante o teste do monopolista hipotético, o mercado relevante é definido como o menor grupo de produtos (ou a menor área geográfica) no qual um suposto monopolista poderia manter seu preço acima do nível competitivo por um período significativo de tempo. (CADE. Resolução n. 20, de 09 de junho de 1999. A Portaria Conjunta SEAE/SDE n. 50 define que "o mercado relevante se constituirá no menor espaço econômico no qual seja factível a uma empresa, autando de forma isolada, ou a um grupo de empresas, agindo de forma coordenada, exercer o poder de mercado." SEAE e SDE. Portaria Conjunta SEAE/SDE n. 50, de 1 de agosto de 2001.

${ }^{358}$ Uma autoridade pode aprovar, por exemplo, uma concentração, em determinado mercado, que possibilitará a um competidor deter $90 \%$ deste mercado. Uma das justificativas para esta aprovação pode ser a necessidade de desenvolvimento do setor no mercado internacional, já que o competidor será forte o suficiente para competir com outras empresas em outros países. (neste sentido, ver casos brasileiros Sadia/Perdigão AC n. 08012.003123/2001-64 e Petroquímica União AC n. 08012.014599/2007-16) Não se sugere, aqui, que a autoridade concorrencial possa verificar a possibilidade de que as empresas pratiquem dumping em outros mercados, mas a sua análise deve ser de tal forma completa que uma autoridade de defesa comercial, nacional ou estrangeira, será capaz de utilizá-la, no futuro, em uma investigação para aplicação de medidas antidumping (contra ou a favor da empresa).

359 GOCO, Jonell. Non discrimination, Likeness, and Market Definition in World Trade Organization Jurisprudence. Journal of World Trade, v. 40, n. 2, 2006, p. 315-340.
} 
aplicação do princípio da não discriminação será mais extensa no âmbito da legislação da OMC e a disciplina do poder de mercado será mais rigorosa no âmbito da legislação antitruste $^{360}$. Este entendimento foi confirmado no caso Coréia-Bebidas Alcoólicas. ${ }^{361}$

Desta forma, ao se convencer de que o mercado é internacional porque existem medidas antidumping aplicadas em relação às importações daquele produto, a autoridade concorrencial pode estar se baseando em uma análise falha, levando-a defender a substuibilidade de produtos que não podem ser incluídos em um mesmo mercado relevante. Por isso, embora o antidumping possa ser considerado uma barreira artificial à entrada de novos competidores, não é a sua existência suficiente para afirmar que o mercado é internacional.

A política da concorrência privilegia os fatos, o caso-a-caso, em uma análise normalmente ex post (sendo o controle de concentrações uma exceção), ao passo que a política comercial internacional possui um objetivo mais setorial e macroeconômico, geralmente aplicada ex ante (sendo a defesa comercial uma exceção). A primeira preocupa-se mais com os aspectos localizados em determinados mercados, ao passo que a política comercial se concentra em problemas de concorrência potencial, com o objetivo de preservar as perspectivas concorrenciais. Por isso, a definição dos mercados analisados, no direito da concorrência e no comércio internacional, pode ter dimensões distintas, sendo a segunda geralmente mais ampla. ${ }^{362}$

Conclui-se, então, que as autoridades concorrenciais não podem deixar de analisar o contexto internacional e, dentro deste contexto, a possibilidade de

\footnotetext{
${ }^{360} \mathrm{O}$ autor lembra os casos United Brands v. Commission (Caso 27/76, 1978) e Commission v. Italy (Caso 184/85, 1987). No primeiro,as bananas forma consideradas um mercado separado de outras frutas sob o âmbito da lei antitruste. No segundo, o Tribunal de Justiça europeu entendeu que bananas e outras frutas eram produtos similares no contexto da integração negativa.

361 "A definição de mercado não tem que ser idêntica. O direito do comércio, geralmente, e o artigo III em particular, focam na promoção de oportunidades econômicas para importadores, mediante a eliminação de medidas que atrapalham o comércio internacional. A lei do comércio internacional defende a potencialidade para competir. A lei antitruste geralmente se concentra na prática das firmas e nas modificações estruturais que podem impedir, restringir ou eliminar a competição. Não é ilógico que mercados sejam definidos mais largamente quando as leis são desenhadas para proteger as oportunidades de competição do que quando as leis são desenhadas para proteger mecanismos atuais de competição. Em nossa visão, é mais apropriado utilizar uma visão mais ampla de mercado com respeito ao art. III.2 do que quando usado no conceito da lei antitruste." (WT/DS75, 17 de setembro de1998, para. 10.8.1).

362 OCDE, Coherences et incoherences entre les politiques des echanges et de la concurrence. COM/TD/DAFFE/CLP(98)25/FINAL, p. 7.
} 
restrições artificiais provocadas pelas medidas antidumping. Porém, por outro lado, não podem se apoiar na existência de algum comércio internacional para caracterizar o mercado como internacional. As análises ocorrem de forma independente, comunicando-se apenas as conclusões finais.

\subsection{A análise das barreiras à entrada}

Um segundo momento no qual as autoridades de defesa da concorrência devem analisar o mercado internacional é na análise das barreiras à entrada. Em seu conceito básico, "barreiras à entrada são fatores de um mercado que permitem que as firmas já estabelecidas ganhem lucros de monopolista, enquanto impedem firmas de fora do mercado a nele entrar."

Há diversos exemplos de barreiras à entrada. Entre eles, as barreiras absolutas, custos irrecuperáveis, custos de troca, restrições à importação, reputação, custo de capital, preços predatórios, capacidade excedente, entre outros.

Barreiras absolutas são aquelas que impedem, em definitivo, a entrada de concorrentes no mercado. São elas os monopólios decorrentes de patentes e limitação na quantidade de matéria prima essencial à produção. Custos irrecuperáveis são os custos para se iniciar um novo negócio, investimentos essenciais de capital, irreversíveis. São eles equipamentos cujo valor de revenda é muito baixo se comparado ao preço de aquisição. São custos irrecuperáveis os custos com desenvolvimento da marca e investimentos em distribuição. São barreiras à entrada os custos de troca, entendidos como os custos que o agente econômico deve arcar para convencer o consumidor a trocar o produto ao qual está habituado pelo seu. A reputação é uma barreira à entrada. Os agentes arcam com um valor para que o consumidor acredite em sua qualidade, durabilidade, pontualidade, etc. As restrições à importação também pode afetar a entrada no mercado, como, por exemplo, a imposição, pelo governo, de altas tarifas à importação do produto. Preços predatórios são também barreiras quando o

\footnotetext{
${ }^{363}$ J. Bain. Barriers to New Competition: Their Character and Consequences in Manufacturing Industries (1962) in HOVENKAMP, Herbert. Federal Antitrust Policy: the Law of Competition and its Practice. Second Edition. Saint Paul: West Group, 1999, p. 39.
} 
agente estabelecido é capaz de impor um lucro negativo às firmas do setor. Para competir, o entrante deve contar com recursos substancialmente altos. ${ }^{364}$

As barreiras à entrada podem ser naturais ou artificiais. As primeiras são as barreiras decorrentes de uma condição inerente ao mercado. As barreiras artificiais são aquelas produzidas pelas firmas já instaladas para, propositadamente, tornar a entrada mais difícil. Como exemplo destas, cita-se a barreira regulatória imposta pelo governo a pedido do lobby de determinada indústria.

Medidas antidumping podem ser, em seus efeitos, comparadas às barreiras à entrada artificiais. Uma indústria pede a sua imposição, pelo governo, que deverá fazê-lo, em concordância ao ordenamento jurídico, quando encontrar preços de dumping, o dano causado à indústria doméstica, e o nexo causal. Contudo, deve-se lembrar que não haverá mais barreiras à entrada quando o governo constatar que não há mais preços de dumping. ${ }^{365}$

Seria aumentar desnecessariamente a tarefa das autoridades de defesa comercial exigir que elas fizessem a análise das barreiras à entrada no mercado, antes de aplicar medidas antidumping. Como já explicado no primeiro capítulo, o instrumento antidumping serve como proteção contra um preço praticado por empresas localizadas em outro mercado, preço que esteja causando dano no mercado nacional. Se ficar constatada tal prática de dumping, o dano e a relação entre eles, a autoridade de defesa comercial está autorizada a criar a barreira à entrada no mercado e, com isso, criar a barreira à entrada de novos competidores, mesmo que tal prática seja totalmente contrária aos objetivos da análise concorrencial. Por outro lado, deve a autoridade concorrencial observar a imposição de antidumping ou a probabilidade de imposição, no caso de existir investigação em curso.

\footnotetext{
364 SCHYMURA, Luiz Guilherme. Barreiras à entrada: o caso do setor de creme dental brasileiro. MATTOS, César (org.). A Revolução do Antitruste no Brasil. São Paulo: Editora Singular, p. 71-77.

${ }^{365}$ Isso acontecerá após a aplicação dos 5 anos previstos no Acordo Antidumping (artigo 11), ou em um ano após a aplicação das medidas, pela existência de circunstância nova. Em alguns casos, o governo pode deixar de aplicar medidas antidumping se, mesmo durante o período de 5 anos, os preços não estiverem abaixo de um determinado patamar. Assim ocorreu no Brasil, em medida inovadora, no setor de PVC, em que o Brasil aplica medidas antidumping somente se os preços da importação forem mais reduzidos do que um patamar fixado trimestralmente (Processo MDIC/SECEX n. 52100.-027088/200333)
} 


\subsection{Cartéis e restrições verticais internacionais}

A análise de cartéis e restrições verticais internacionais exige das autoridades concorrenciais ampla pesquisa sobre o mercado internacional.

Empresas de países distintos podem celebrar acordos para fixar preços, condições de produção, ou mesmo dividir mercados. Se os preços são fixados pelos concorrentes nos diversos países, o movimento destes produtos de um país a outro não é incentivado. Se as empresas dividem mercados, o fluxo de comércio internacional é obviamente penalizado. ${ }^{366}$

Mesmo com o desenvolvimento das legislações concorrenciais nacionais e da atividade de cooperação entre as autoridades, algumas práticas que prejudicam o fluxo de comércio escapam da análise das autoridades.

Em 1999, com a privatização e desregulamentação da indústria de cimento no Egito, formou-se um pequeno grupo de empresas capaz de suprir a alta demanda do mercado interno. Estas empresas, Suez Cement Company (31\% do mercado), Lafarge e Blue Circle (25\%) e Cemex (México, com 14\% do mercado) concentravam uma enorme parcela do mercado. Com a queda na demanda, a primeira empresa decidiu exportar seu excedente às Ilhas Canárias, mas foi surpreendida pela prática de preços muito baixos, neste mesmo mercado, pelas duas outras empresas. Repentinamente, as três empresas decidiram colocar fim à guerra de preços e fixar níveis a serem praticados nas Ilhas Canárias. Embora a competição nas Ilhas Canárias fosse regulamentada pelas rígidas normas européias de concorrência, pouco puderam fazer as autoridades de Bruxelas, já que o acordo foi realizado no Egito e sua prova era impossível. O acordo também provocou o efeito de aumentar substantivamente os preços no Egito, mas aquele país não possuía, à época, uma lei de defesa da concorrência. Além disso, pouco pode ser feito pelo Governo do Egito ou pela Comissão Européia, já que não havia acordo de cooperação entre os dois países. ${ }^{367}$

\footnotetext{
366 MATSUSHITA, Mitsuo; SCHOENBAUM, Thomas e MAVROIDIS, Petros. The World Trade Organization: Law, Practice and Policy, The Oxford International Law Library, 2003, p. 541.

367 JENNY, Frédéric. Competition, Trade and Development Before and After Cancun. International Antitrust Law \& Policy: Fordham Corporate Law, 2003. p. 632-635.
} 
O segundo caso envolveu o alumínio. Com o fim da União Soviética, a demanda pelo alumínio caiu sensivelmente, assim como seu preço. Uma das empresas, a Alcoa, advogava a criação de um cartel no setor, enquanto pedia ao governo norte-americano a aplicação de medidas antidumping nas importações provenientes da Rússia. O governo, por sua vez, hesitava em aplicar as medidas antidumping, já que a Rússia era um país que devia muito aos Estados Unidos e o fim das importações iria provocar um grave problema à economia russa. Os grandes produtores de alumínio norte-americanos e europeus decidiram então, como conhecimento do governo, reduzir sua produção, com o objetivo de aumentar os preços. Exigiram do governo norteamericano providências para evitar que a Rússia aproveitasse a oportunidade para exportar a valores muitos baixos para os Estados Unidos. O governo, em resposta, decidiu conceder um grande empréstimo aos russos, com o objetivo de alavancar sua indústria e demanda interna por alumínio. Como conseqüência, o mercado mundial de alumínio foi severamente afetado, o comércio internacional passou a ser artificial e os consumidores do mundo todo passaram a pagar preços mais elevados. ${ }^{368}$

Em geral, as legislações proíbem cartéis e restrições verticais quando eles afetam a concorrência interna, nacional. Assim, por exemplo, ocorre na União Européia e no Brasil, onde os cartéis internacionais são punidos se produzirem seus efeitos no mercado comunitário ou doméstico. Em alguns casos, os cartéis internacionais são punidos por ambas as legislações: do país importador e do país exportador. Um bom exemplo é o caso do carbonato de sódio, em que a Comissão Japonesa de Comércio investigou, a pedido dos Estados Unidos, um cartel que buscava controlar a quantidade de carbonato de sódio importado da América do Norte. O cartel foi punido nos Estados Unidos (local da ação) e no Japão (local de produção dos efeitos). ${ }^{369}$

Uma restrição vertical pode também afetar o comércio internacional. Por exemplo, uma venda casada em que o exportador determina que o importador compre um determinado produto químico vinculado a outro impede que o exportador daquele segundo produto tenha oportunidades no país de importação. A venda casada é

\footnotetext{
${ }^{368}$ JENNY, Frédéric. Op cit. p. 632-635.

${ }^{369}$ Asahi Glass Co. Decision of Fair Trade Commission of Japan, 31 March 1983.
} 
considerada ilegal em muitos países, quando é comprovado que o fornecedor tem poder de mercado. ${ }^{370}$

Quem tem competência para monitorar e reprimir as práticas internacionais que produzem efeitos em territórios nacionais? Apenas uma organização internacional da concorrência, nos moldes da OMC, com poderes delegados pelos Estados Membros, ou cada país pode, na medida em que tais infrações em âmbito internacional produzem efeitos em seu território ${ }^{371}$

Os critérios do direito internacional público que levam um país a reivindicar a aplicação de sua legislação nacional são, em resumo: i) princípio da territorialidade do comportamento: o Estado tem competência para regular o que acontece em seu território; ii) princípio da nacionalidade do autor do comportamento: o Estado tem competência para aplicar suas leis aos seus nacionais; iii) princípio da territorialidade dos efeitos: o Estado no território onde se produziu o efeito do comportamento tem competência para aplicar suas próprias leis àquele comportamento; iv) princípio da proteção da segurança pública: o Estado tem competência para aplicar sua legislação quando a segurança pública está em perigo; v) princípio da universalidade: o Estado pode aplicar as suas normas em caso de excepcional gravidade, mesmo que os comportamentos tenham se verificado fora do território nacional. ${ }^{372}$

A lei brasileira de defesa da concorrência, Lei n. 8.884/94, em conformidade com o seu art. $2^{\text {o373 }}$, é aplicável às práticas cometidas no todo ou em parte em território nacional ou que nele produzam ou possam produzir efeitos. Logo, a lei abarca práticas que produzirem seus efeitos em território brasileiro, independentemente da nacionalidade das empresas envolvidas ou de sua localização geográfica. ${ }^{374}$

\footnotetext{
370 Jefferson Parish Hospital District n.2 v Hyde, 466 U.S. 2 (1984) mencionado por MATSUSHITA, Mitsuo; SCHOENBAUM, Thomas e MAVROIDIS, Petros, op cit., p 541.

371 A este tema têm sido dedicadas teses de doutorado e livros, mas, por sua importância para a compreensão deste trabalho, ele será abordado resumidamente.

372 ALMEIDA, João Gabriel Assis. A aplicação extraterritorial do direito da concorrência brasileiro. Revista do Ibrac, vol. 8, número 3, 2001, p. 69.

373 Art. $2^{\circ}$ Aplica-se esta lei, sem prejuízo de convenções e tratados de que seja signatário o Brasil, às práticas cometidas no todo ou em parte no território nacional ou que nele produzam ou possam produzir efeitos.

${ }^{374}$ Diferenciam-se, também, a hipótese em que duas empresas, brasileiras ou não, estando fora do Brasil, praticam comportamento que visa a distorcer a concorrência no mercado brasileiro, mas, por um motivo alheio à vontade, acaba não produzindo seus efeitos no país. Este comportamento estaria fora da
} 
A União Européia segue o mesmo princípio. O fato de um ou mais participantes de um cartel estar sediado fora do território do bloco não impede a aplicação das normas de concorrência se o efeito do acordo produzir-se no território do mercado comum europeu. ${ }^{375}$ Aplica-se a effects-doctrine. ${ }^{376}$

Um caso a ser mencionado é o caso do cartel franco-japonês sobre a comercialização de rolamentos no mercado comum europeu. Produtores franceses e japoneses reuniram-se para discutir a política japonesa de vendas de rolamentos. $\mathrm{O}$ objetivo era reduzir as exportações de rolamentos para a França e aumentar os preços. A Comissão Européia processou todos os membros do cartel. Eles argumentaram que o objetivo era proteger a produção interna do mercado comum contra a concorrência japonesa. Os empresários japoneses alegaram que estavam imunes à aplicação do direito europeu.

A Comissão Européia estabeleceu os seguintes parâmetros na decisão, que condenou todos os participantes do cartel: i) medidas tomadas de acordo com tratados comerciais da União Européia com terceiros países estão relacionadas à política de comércio exterior, não se aplicando os artigos 81 e 82 do Tratado de Roma; ii) medidas resultantes de acordos entre empresários estrangeiros, sujeitas à aprovação das autoridades de seus países, estão também sujeitas ao Tratado de Roma (já que os empresários estavam livres para não as concretizar); iii) medidas resultantes de acordos

competência da lei brasileira ou do CADE. (ALMEIDA, João Gabriel Assis. Op cit. p. 77). Deve-se lembrar, contudo, que o art. 20 dispõe que "constituem infração à ordem econômica, independentemente de culpa, os atos, sob qualquer forma manifestados, que tenham por objetivo ou possam produzir os seguintes efeitos, ainda que estes não sejam alcançados..." Uma leitura simples permitiria concluir que qualquer ato que visasse a produção dos efeitos, mesmo que não alcançados, seria condenável. Contudo, a regra do art. 2 desta lei impede a condenação destes atos se eles não produziram seus efeitos no Brasil.

375 Arrêt de la Cour du 25 novembre 1971. Béguilin Import v. S.A.G.L Export, affaire 22-71, apud FARIA, José Ângelo Estrella. Aplicação Extraterritorial do Direito da Concorrência. Revista Informação Legislativa. A. 27, n. 105, Jan/mar, 1990, p. 40.

376 "A regra é a de que o direito comunitário não se preocupa com a localização no território da CE de todos os elementos de um comportamento não concorrencial, mas parte da localização dos efeitos concorrenciais destes comportamentos. Assim, por exemplo, se uma coligação se destina a produzir efeitos fora da $\mathrm{CE}$, as regras comunitárias não se lhe aplicam mesmo que as empresas intervenientes estejam localizadas no espaço comunitário. A situação será, porém, diferente se tais acordos, por ricochete, fizerem sentir nestes espaço os seus efeitos anticoncorrenciais. Neste caso haverá um efeito anticoncorrencial indireto, fato que pode justificar a aplicação do direito comunitário. Questão porventura mais complexa é a de saber se o acordo ou práticas anticoncorrenciais levadas a cabo por empresas sediadas fora do território da $\mathrm{CE}$, mas com reflexos neste, caem ou não na alçada do direito comunitário. A jurisprudência e a prática administrativa apontam em sentido afirmativo." (SANTOS, António; GONÇALVES, Maria Eduarda; LEITÃO MARQUES, Maria Manuel. Direito Económico. Coimbra: Almedina, 1997, p. 363). 
celebrados entre empresários estrangeiros ou após entendimentos com seus concorrentes europeus estão sujeitas à aplicação do direito europeu da concorrência; iv) estão excluídas medidas resultantes de acordos entre empresários estrangeiros se forem impostas pelas autoridades de seus países. ${ }^{377}$

Os cartéis nacionais ou internacionais, vistos como vilões na maioria dos ordenamentos jurídicos, nem sempre receberam este tratamento. São vários os casos em que a política econômica corroborou os interesses das empresas privadas, realizando ou simplesmente permitindo a realização de seus objetivos de colusão. No domínio internacional, esta interação pode se dar de algumas formas: i) acordos internacionais ou acordos entre governos que estabelecem regras regulatórias em determinados mercados; ii) a coordenação de medidas por vários governos relacionadas ao comércio internacional (intencional ou não) ${ }^{378}$; iii) medidas unilaterais dos governos afetando o comércio internacional ${ }^{379}$ e iv) acordos bilaterais ou multilaterais afetando princípios gerais de comércio. ${ }^{380}$

Percebe-se, diante do relato dos parágrafos anteriores, que a prática de cartéis e restrições verticais produz efeitos negativos sobre o mercado internacional, efeitos que prejudicam diretamente o comércio entre os países envolvidos (país da prática, país dos efeitos). Muitos destes atos escapam da análise das autoridades nacionais, sendo urgente, para evitar que isso ocorra, o desenvolvimento da prática doméstica e, ao mesmo tempo, da cooperação entre as autoridades concorrenciais.

\footnotetext{
${ }^{377}$ FARIA, José Ângelo Estrella. Op Cit. p. 41-42.

378 Estes acordos internacionais entre governos podem regular apenas alguns elementos do mercado, como preço, produção, consumo, ou o mercado como um todo. No caso de regularem apenas alguns elementos, uma estrutura de regulação privada pode surgir ao redor deste acordo. Isso pode ocorrer, por exemplo, nos mercados de commodities, como o açúcar, café, algodão. Estes acordos podem auferir a cada país uma cota fixa no mercado internacional e penalidades no caso de ultrapassar esta cota. Seus efeitos prováveis serão a colusão entre os produtores nacionais, para a distribuição destas cotas, e a colusão para impedir o surgimento de outros produtores.

${ }^{379}$ Ações unilaterais dos Estados podem influenciar cartéis internacionais quando decidem pela redução de uma tarifa de importação, por exemplo, permitindo que o cartel passe a exportar mais para aquele mercado, ou mesmo o contrário, permitindo que a combinação internacional se fortaleça e a divisão de mercados (redução das importações) se favoreça. Outra medida pode ser a autorização unilateral para a formação de um cartel de exportação. Um país autoriza que dois produtores nacionais se fortaleçam ao se unir em um acordo para exportação.

${ }^{380}$ Dois países decidem pela não utilização do Tratamento Geral da Nação Mais Favorecida por um determinado período, para favorecer a produção interna de um deles, que atravessa dificuldades econômicas. Para um estudo mais aprofundado desta matéria, recomenda-se a obra de KRONSTEIN, Heinrich. The Law of International Cartels. London: Cornell University Press. 1973, p. 9-46., de onde foram retirados a maioria dos exemplos citados.
} 


\subsection{Análise das concentrações econômicas que afetam o comércio internacional}

Concentrações econômicas também afetam o comércio internacional. Uma empresa em um país pode adquirir outra empresa em outro país para impedir as exportações do segundo país em direção ao primeiro. Por exemplo, no caso norteamericano Gillette, o Departamento de Justiça entendeu que a Gillete adquiriu uma empresa alemã concorrente para evitar as exportações da Alemanha para os Estados Unidos e considerou a aquisição uma violação à Seção 7 do Clayton Act. ${ }^{381}$ Esta prática impeditiva de exportações pode acontecer não somente por meio de uma aquisição, mas também por meio de uma joint venture. Isso ocorreu no caso Brunswick, no qual a companhia americana celebrou uma joint venture com uma japonesa para impedir as exportações da empresa japonesa para os Estados Unidos. ${ }^{382}$

Luiz Olavo Baptista menciona a grande polêmica no julgamento do caso dos fabricantes de relógios suíços. ${ }^{383}$ A associação The Watch Makers foi acusada de incentivar um conjunto de acordos e práticas entre os fabricantes de relógios suíços, alguns filiais de empresas suíças instaladas nos Estados Unidos, e empresas instaladas na Suíça. A indústria suíça exportava 95\% de sua produção, sobretudo para os Estados Unidos. Uma lei suíça de 1951 só previa a concessão de autorização para exportação para embarques que não violassem os interesses comuns das indústrias de relógios, amplamente protegida pela política econômica suíça. Grande parte dos acordos demonstrava o objetivo de reduzir a exportação de relógios para os Estados Unidos. Decidiu o tribunal norte-americano que a ação governamental não deveria perdoar atos ou contratos que tivessem um efeito substancial e material sobre o comércio interno ou externo dos Estados Unidos.

Contudo, a celebração de atos ou contratos nos Estados Unidos, para a produção de efeitos em outros países, não recebe o mesmo tratamento e preocupação. No caso Grace-Pan American, as empresas se reuniram para constituir uma empresa de

\footnotetext{
${ }^{381}$ United States v. Gillete Co. 406 F. Supp. 713, 1 Trade Reg. Rep. Para 4.

${ }^{382}$ Brunswick Corp. 94, FTC 1174 (1979).

383 United States v. The Watch Makers, SDNY, 1963. Apud BAPTISTA, Luiz Olavo. Empresa Transnacional e Direito. São Paulo: Editora Revista dos Tribunais, 1987, p. 116-119.
} 
aviação comercial na costa oeste da América do Sul. Anteriormente, ambas operavam separadamente no território. A acusação era de que, por meio da criação da subsidiária, buscavam restringir a competição e garantir seus lucros. A decisão, contudo, foi a de que não se poderia restringir o interesse legítimo de duas empresas norte-americanas de se desenvolver, mesmo que o resultado fosse a divisão de territórios. ${ }^{384}$

No Brasil, um dos casos em que mais se discutiu a aplicação territorial da Lei n. 8884/94 foi a fusão entre os grupos ASEA e BBC-Brown Boveri, que ocorreu no exterior, mas teve como efeito a criação de uma subsidiária comum no Brasil. O caso foi noticiado por uma revista e o CADE notificou as empresas para esclarecerem o fato. Elas se manifestaram no sentido de que se tratava de um caso "perfeito e acabado a nível mundial" e que comunicariam ao CADE apenas para efeito de "conhecimento do fato". O CADE entendeu que, à luz do artigo 74 da Lei n. 4.137/62 vigente, o acordo entre as subsidiárias brasileiras estava sujeito à análise. ${ }^{385}$

Aplicando a mesma teoria dos efeitos citada no capítulo anterior, as autoridades da maioria dos países só terão competência sobre as práticas que ocorrerem em seu território ou que nele produzirem efeitos. Entretanto, qualquer concentração pode gerar efeitos negativos ao comércio internacional. Tanto podem ocorrer concentrações para impedir o fluxo de comércio, como a concentração pode incentivar seus participantes à prática de dumping. Por isso, é essencial que a boa defesa da concorrência possa se desenvolver no sentido a analisar tais concentrações e ser capaz de prever seus efeitos sobre o comércio. Da mesma forma, se a concentração for inevitável, ficarão mais confortáveis as autoridades de defesa comercial diante da petição de abertura de uma investigação elaborada por um produtor nacional monopolista. Estas autoridades, confiantes na análise concorrencial prévia já realizada pelas autoridades competentes, poderão se limitar cada vez mais ao exame dos aspectos relacionados à prática internacional do dumping.

\footnotetext{
${ }^{384}$ BAPTISTA, Luiz Olavo. Empresa Transnacional e Direito. São Paulo: Editora Revista dos Tribunais, 1987, p. 116-119.

${ }^{385}$ VAZ, Isabel. Legislação de Defesa da Concorrência e Extraterritorialidade. Revista do IBRAC, vol. 4, número 6, 1997, p. 266.
} 
2.3.1.2 As semelhanças e diferenças entre comércio internacional e concorrência

O capítulo anterior estudou os quatro momentos em que as autoridades concorrenciais são convidadas a examinar aspectos relacionados ao comércio internacional, com o intuito de fundamentar suas decisões. A partir deste tópico, passar-se-á à discussão dos pontos de convergência entre a análise da autoridade concorrencial e da autoridade de defesa comercial. Com isso, será possível concluir sobre o espaço reservado às autoridades de defesa comercial em uma investigação antidumping, no que diz respeito a aspectos concorrenciais.

Comércio internacional e concorrência possuem objetivos convergentes e complementares. Ambos visam à liberalização dos mercados, ao aumento das trocas, ao aumento do número de participantes em um mercado. São também complementares, pois a liberalização do comércio internacional tem como escopo o aumento das trocas fora das fronteiras, assim como a defesa da concorrência tem como objetivo a competitividade no mercado interno.

Há um ponto em que as discussões de comércio internacional se chocam com os objetivos da defesa da concorrência: a defesa comercial.

\subsection{As semelhanças}

O direito do comércio internacional e o direito da concorrência aproximam-se em vários pontos.

O principal ponto de contato entre as duas ciências é a busca pelo maior acesso aos mercados. ${ }^{386}$ Kevin Kennedy enfatiza que, assim como o objetivo da liberalização dos mercados, o objetivo da política de concorrência é, em geral, promover a eficiente alocação dos recursos, assegurando que os mercados sejam livres e competitivos. O objetivo da política de liberalização dos mercados coincide e complementa o objetivo da política da concorrência. A redução das barreiras

386 OCDE, Coherences et incoherences entre les politiques des echanges et de la concurrence. COM/TD/DAFFE/CLP(98)25/FINAL, p. 6. 
governamentais ao comércio que protegem indústrias domésticas - objetivo da política de liberalização do comércio - complementa o escopo da política de concorrência de proteger os consumidores das empresas que, unilateralmente ou coletivamente, fixam altos preços. As empresas são capazes de cobrar preços mais altos quando elas possuem poder de mercado, mas elas não terão esta mesma capacidade se as barreiras à entrada neste mercado forem baixas. ${ }^{387}$

Dois dos principais efeitos da liberalização do comércio coincidem com os objetivos da política da concorrência. O primeiro deles é a especialização e economias de escalas, possíveis em um contexto em que é assegurado o fluxo comercial a um determinado mercado. Se os produtores sabem que aquele mercado consumidor faz parte de sua demanda, eles irão produzir conforme os desejos daquele mercado, e em maior quantidade, proporcionalmente à segurança que lhes é conferida pelo fluxo. Em segundo lugar, o aumento da competição internacional faz com que as empresas busquem qualidade, inovação, redução dos custos e aumento das opções ao consumidor. Estes são, sem dúvida, objetivos da política de defesa da concorrência.

Os responsáveis pela política de comércio e os legisladores podem sacrificar o bem-estar do consumidor para o bem de outros objetivos, como a proteção aos produtores e trabalhadores da indústria doméstica. ${ }^{388} \mathrm{O}$ mesmo é válido para os operadores do antitruste. A concorrência é freqüentemente tida como um instrumento para a realização de outros princípios. Desta forma, ela poderá ser direcionada para a realização de determinado objetivo, em detrimento de outro. Por exemplo, uma concentração poderá ser autorizada porque permitirá o desenvolvimento industrial, mesmo se, no curto prazo, isso significar um prejuízo ao consumidor.

As leis concorrenciais nacionais podem isentar determinados setores estratégicos da aplicação de suas regras, se isso for necessário à segurança nacional, segurança alimentar e soberania sobre recursos naturais. Similarmente, as leis de comércio internacional podem permitir a imposição de salvaguardas temporárias para

\footnotetext{
${ }^{387}$ KENNEDY, Kevin. Op cit. p. 3.

${ }^{388}$ Simples conclusão de que, trabalhando, poderão consumir.
} 
proteger a indústria doméstica se esta proteção for necessária pelas mesmas razões (segurança, soberania, etc.). ${ }^{389}$

Políticas de comércio e políticas de concorrência são, também, complementares. As políticas de liberalização do comércio só obtêm êxito se o poder da indústria doméstica for monitorado por leis de concorrência eficazes. De nada adiantará reduzir as barreiras artificiais ao comércio entre os países, por meio de difíceis negociações, se as empresas do mercado doméstico praticam infrações, abusam de seu poder de mercado, ou praticam comportamento colusivo (por exemplo, impõem a exclusividade desarrazoada a todos os distribuidores). ${ }^{390}$

Embora tenham objetos similares e sejam, por vezes, complementares, as duas políticas - de defesa da concorrência e de comércio internacional - possuem pelo menos um ponto de conflito: a defesa comercial. Ao proteger produtores contra determinados competidores internacionais (aqueles que praticam dumping ou são subsidiados, por exemplo), a política de comércio internacional está na contramão da defesa da concorrência, reduzindo o número de competidores.

\subsection{O conflito entre concorrência e defesa comercial}

A defesa comercial possui objetivos contrários aos objetivos da defesa da concorrência. A aplicação do antidumping tende a desmotivar a venda dos bens naquele país ou região, provocando a saída ou redução de participação daquele concorrente (exportador) do mercado. ${ }^{391}$ A defesa da concorrência tem como objetivo a proteção da competição (que leva à eficiência econômica), ao passo que as medidas

\footnotetext{
389 OCDE, Coherences et incoherences entre les politiques des echanges et de la concurrence. COM/TD/DAFFE/CLP(98)25/FINAL, p. 6.

390 "Assim como a política de liberalização dos mercados remove as barreiras governamentais à competição nas fronteiras, a política da concorrência remove as barreiras privadas à competição dentro das fronteiras." (Tradução do texto em língua inglesa, KENNEDY, op cit. p. 4)

${ }^{391}$ Embora, em alguns casos, observe-se o aumento das importações de outros países não investigados e aos quais não foi aplicada medida.
} 
antidumping têm como objetivo a proteção do competidor (ou dos fatores de produção). ${ }^{392}$

A prática do dumping, embora desleal, pode ser procompetitiva. As medidas antidumping são consideradas, por outro lado, anticompetitivas. ${ }^{393}$

A razão pela qual o dumping é considerado desleal é que a empresa, ao exportar seu excedente a preços mais baixos do que os preços praticados em seu mercado, maximizando seus lucros domésticos, pode se beneficiar de eficiências que as demais empresas não conhecem (tanto as empresas domésticas quanto as empresas do país importador). Contudo, o fato de ser uma prática desleal não significa que ela seja anticompetitiva. As vendas acima do preço de custo não são predatórias, ao contrário, são procompetitivas. Vendas acima do preço de custo geram competição no mercado importador, mesmo que desleais. ${ }^{394}$

Para diferenciar o dumping procompetitivo do dumping anticompetitivo, deve-se estudar as razões pelas quais ele é praticado. Para tanto, é útil a distinção entre o preço predatório e a discriminação de preços, emprestada do direito da concorrência. Este breve estudo auxiliará a compreensão do item 2.3.1.2.3, no qual se discutirá a substituição do antidumping pela defesa da concorrência.

\subsection{O dumping não predatório (mera discriminação de preços) é procompetitivo}

Sempre que há dumping, há discriminação de preços. Contudo, a discriminação de preços entre países nem sempre tem como objetivo eliminar

\footnotetext{
${ }^{392}$ HOEKMAN, Bernard; MAVROIDIS, Petros. Dumping, Antidumping and Antitrust. Journal of World Trade, v. 30, n. 1, February 1996, p. 29.

${ }^{393}$ Para Bernard Hoekman e Petros Mavroidis, no caso do dumping predatório, que será discutido a seguir, as medidas podem ser consideradas procompetitivas, sendo a única exceção, pois elas terão como objetivo restaurar o ambiente competitivo e preservar a existência de competidores no mercado. (HOEKMAN, Bernard; MAVROIDIS, Petros. Dumping, Antidumping and Antitrust, p. 29.)

${ }^{394}$ Por estas razões, as autoridades de concorrência não condenam a discriminação entre países como sendo anticompetitiva. Bierwagen lembra que a discriminação de preços não é um "malum per se" no direito da concorrência, mas um aspecto da própria competição em mercados com diferentes condições. $\mathrm{O}$ art. 85 do Tratado de Roma não proíbe a discriminação de preços ou o preço predatório, da mesma forma que não proíbe o dumping em si, mas sim aquele que causa um dano. (BIERWAGEN, Rainer. Op cit., p. 126-127.)
} 
competidores na localidade importadora ou conquistar o mercado com preços baixos. A discriminação no comércio internacional pode ser fruto da necessidade de vender um grande volume produzido pelo exportador, volume que seria descartado caso não fosse vendido a preços muito baixos. A discriminação pode também ocorrer na entrada de um novo competidor no mercado. Por exemplo, um competidor deseja conquistar clientes no novo país e, por esta razão, vende seus produtos por um preço mais baixo do que aquele praticado no mercado de origem. Ele provocará a competição. Além disso, a discriminação de preços no comércio internacional pode ser eficiente: um competidor que discrimina mercados pode conquistar mais consumidores do que aquele que não discrimina. ${ }^{395}$

Os economistas diferenciam a discriminação de preços, considerada procompetitiva, do preço predatório, considerado anticompetitivo. Nem toda discriminação de preços envolve um preço predatório, mas todo preço predatório praticado no mercado internacional é uma forma de discriminação de preços.

A predação no mercado internacional é a discriminação de preços entre o mercado doméstico e o mercado de exportação, com venda, no último, por um preço abaixo do preço de custo, com o objetivo de eliminar competidores e manter ou adquirir posição dominante no mercado. ${ }^{396}$ Os consumidores são beneficiados no curto prazo (preços menores), mas perderão no médio e longo prazo. O exportador apóia-se no mercado doméstico para recuperar o prejuízo contabilizado com a prática de preços abaixo do preço de custo (como um subsídio cruzado). ${ }^{397}$

Para o exercício de discriminação de preços no comércio internacional, alguns requisitos precisam ser observados. Em primeiro lugar, é

\footnotetext{
${ }^{395}$ NIELS, Gunnar; KATE, Adriaan. Op cit. p. 32.

${ }^{396}$ Gabrielle Marceau relata que nem sempre o custo definido pela autoridade investigadora corresponde ao custo efetivamente incorrido pela empresa, deturpando os resultados da investigação em prol de uma determinação positiva de preço predatório. A estrutura de custos também varia de acordo com as diferenças entre países, modelos de administração, métodos de contabilidade, instituições sociais, cultura, legislação, entre outros. Além disso, em empresas multinacionais, a identificação de tais custos é sempre mais arbitrária. Uma referência a um determinado custo deve sempre levar em consideração as diferenças nacionais. (MARCEAU, Gabrielle. Op. cit. P. 13).

${ }^{397}$ Ver AGGARWAL, Aradhna. Antidumping Law and practice: an Indian Perspective. Working Paper 85. Indian Council for Research on International Economic Relations, Abril 2002, p. 6 e Skyies A.O Antidumping and Antitrust: What problems does each address? In R.Z.Laurence. Brookings Trade Forum, 1998.
} 
necessário que os compradores domésticos do país de origem das importações não consigam adquirir os produtos que forem exportados. ${ }^{398} \mathrm{Em}$ segundo plano, deve ser imperfeita a concorrência no mercado de origem, sendo dominante a empresa exportadora e altas as barreiras à entrada de novos competidores. ${ }^{399}$ Desta forma, presentes estes elementos, a empresa exportadora estará em posição confortável para praticar uma discriminação de preços sem que seu poder no mercado de origem (que financia suas perdas no mercado externo) seja contestado.

Para a prática de dumping predatório, além das características acima mencionadas, é necessário que a empresa exportadora tenha suficiente poder no mercado mundial do produto em consideração. Se tal capacidade não existir, tão logo a empresa exportadora deseje praticar preços altos no mercado conquistado (importador), para recuperar os custos incorridos com a prática de dumping, produtores de terceiros mercados tentarão tomar-lhe o espaço ${ }^{400} \cdot 401$ Seus objetivos são, portanto, graves em relação aos objetivos da discriminação que tem potencial procompetitivo. O preço predatório tem o claro objetivo de eliminar o concorrente e dominar o mercado importador, eliminando as escolhas do consumidor para, no futuro próximo, aumentar seu preço.

Quais são os aspectos positivos trazidos pelo dumping não predatório ao país importador e ao país exportador? Marceau percorre este raciocínio, considerando, em primeiro lugar, o país importador. Com a prática de dumping, os produtores domésticos deixam de lucrar ou sofrem prejuízos. Os acionistas não vão

\footnotetext{
398 "Se uma empresa se aventura no mercado estrangeiro e mercado interno é aberto, o diferencial de preços vai induzir a reexportação do produto a preço de dumping para o mercado interno." VERMULST, Edwin. Competition and Anti-dumping: continued peaceful co-existence? Vermulst \& Waer, 24 de setembro de 1999.

${ }^{399}$ JOSKOW, Paul. KLEVORICK, Alvin. A framework for analyzing predatory pricing policy, Yale Law Journal, v. 28, n. 1, 1979, p. 213.

${ }^{400} \mathrm{Na}$ prática, a empresa pode imaginar que aquele mercado não é atrativo o bastante para outros competidores ou que os outros competidores não têm condições de lhe desafiar a recém-conquistada dominância no mercado importador. Além disso, ela pode praticar determinadas condutas como celebração de acordos de exclusividade com revendedores, garantindo, assim, a manutenção de sua posição dominante. Tal argumento, ou seja, a necessidade de segurança no mercado conquistado, é também defendido por Clarisse Morgan, Competition Policy and Anti-dumping: is it time for a reality check? Journal of World Trade. Vol. 30, n. 5, October 1996, p. 83.

${ }^{401}$ A vítima também deve estar localizada em um mercado com menor capacidade de obter recursos e em menor desenvolvimento, não conseguindo, desta forma, recuperar-se do dano provocado pelas importações e desafiar a ameaça estrangeira. AGGARWAL, Aradhna. Antidumping Law and practice: an Indian Perspective. Working Paper 85. Indian Council for Research on International Economic Relations, Abril 2002, p. 10.
} 
receber seus dividendos e os empregados podem ficar desempregados por algum tempo. Um mercado livre investe seus recursos onde eles são mais bem recompensados e no qual a concorrência induz um processo no qual as mais eficientes empresas são as vencedoras e as menos dinâmicas, as perdedoras. Por outro lado, preços baixos irão melhorar as condições e a economia dos usuários comerciais ${ }^{402}$ e consumidores. ${ }^{403} \mathrm{O}$ processo competitivo não pode existir sem perdedores. Por isso, proteger os perdedores durante este processo pode impactar negativamente na concorrência e, conseqüentemente, no mercado. ${ }^{404}$

Em muitos casos, está-se diante de um competidor nacional que não possui a habilidade necessária para competir com a inovação e os baixos custos do competidor estrangeiro. Uma autoridade investigadora legalista tenderá a reconhecer que, estando presente o dumping, ou seja, a empresa pratica um preço inferior ao preço que pratica em seu mercado doméstico, e estando a indústria doméstica em más condições, há boas razões para se concluir sobre o nexo causal e aplicar medidas. Contudo, grande parte deste reconhecido "dano" foi causada pela própria inabilidade da empresa. Nestas hipóteses, o dumping não predatório tende a ser procompetitivo, pois incentivará o investimento e a atualização da indústria doméstica, que deverá tomar providências para oferecer preços mais baixos.

Os efeitos sobre o mercado exportador também são relevantes. Se a demanda é menos elástica, condição para que o agente econômico possa praticar a discriminação, pode-se acreditar que os consumidores sofrem com altos preços e pouco incentivo. A ampliação do mercado do produtor no sentido da exportação pode significar um benefício aos consumidores nacionais, como possíveis quedas no custo

\footnotetext{
402 Marceau cita casos clássicos em que isto restou comprovado: a) a rápida expansão da indústria beneficiadora de açúcar na segunda metade do século XIX, devida ao dumping do açúcar de beterraba; b) a prosperidade da indústria náutica holandesa antes da Primeira Guerra Mundial, o que é atribuível parcialmente ao dumping do aço alemão. (MARCEAU, Gabrielle. Anti-Dumping and Anti-Trust: Issues in Free Trade Areas. Oxford: Clarendon Press, 1995, p. 18)

${ }^{403}$ MARCEAU, Gabrielle. Op cit. 17.

${ }^{404}$ NIELS, Gunnar; KATE, Adriaan. Trusting Antitrust to Dump Antidumping: abolishing antidumping in Free Trade Agreements without replacing it with Competition Law. Journal of World Trade, v. 31, n. 6, 1997, p. 32.
} 
(para maximizar ainda mais os lucros), investimentos em novos produtos, aumento da capacidade, entre outros. ${ }^{405}$

A discriminação (dumping não predatório) também será positiva para o país exportador se ela for o resultado da transição de uma situação de monopólio para um comportamento mais competitivo. Por exemplo, a discriminação pode ser uma fuga, para o mercado externo, de um competidor em colusão com outros competidores no mercado interno. A prática do preço discriminatório provocará alguma contestação no cartel, tendo em vista que aquele que discrimina conquistará maiores lucros que os demais. Além disso, a prática de discriminação de preços, mesmo que intermitente, elimina apenas o competidor ineficiente, o que é desejável pela sociedade. ${ }^{406}$

Para aqueles que defendem a distinção entre preço predatório e discriminação e a aplicação destes conceitos ao antidumping, apenas o primeiro merece a atenção da autoridade de defesa comercial e eventual aplicação de medida antidumping. ${ }^{407}$ A simples discriminação é bem-vinda, devido aos seus diversos efeitos positivos, causados ao mercado importador e exportador.

\subsection{A insuficiência da teoria concorrencial para a realização dos objetivos do antidumping}

Outros autores, entretanto, advertem que a proposta acima, de se reprimir apenas o dumping predatório, não é suficiente para a proteção da indústria doméstica, que é o grande objetivo do antidumping. Há os que defendem que o dumping predatório é raro, ou quase inexistente, e que a limitação à condenação deste dumping significaria deixar a indústria doméstica bastante desprotegida. Outros completam este raciocínio, lembrando que outros tipos de dumping - não apenas o

\footnotetext{
${ }^{405}$ MARCEAU, Gabrielle, Op. cit. p. 17-20.

${ }^{406}$ Se o exportador estiver maximizando seus lucros, o seu preço de exportação estará acima ou no mesmo nível de seu custo marginal. Se o produtor doméstico não consegue competir, vendendo produtos acima do custo marginal do exportador (já somados os custos de exportação), então ele pode ser considerado ineficiente. (DALE, Richard. Antidumping Law in a Liberal Trade Order. London: MacMillian, 1980, p. 156)

407 ARAÚJO Jr., José Tavares. As normas antidumping da ALCA e a agenda multilateral. Sistema de Informação sobre Comércio Exterior/Organização dos Estados Americanos - SICE/OEA, Dezembro de 2001, disponível em HTTP://www.sice.oas.org/compol/articles/cpant.asp, acessado em 27 julho de 2008.
} 
predatório - provocam efeitos nefastos à indústria doméstica, devendo também ser combatidos. $^{408}$

Para Niels e Kate, é muito difícil encontrar uma empresa que pratique preços predatórios e que tenha poder de mercado suficiente para forçar a eliminação de todos os produtores domésticos e dos outros exportadores. ${ }^{409}$ Mesmo que ele consiga fazer isso, dificilmente conseguirá manter seus preços de monopólio na fase posterior. ${ }^{410} \mathrm{Na}$ maioria dos casos em que uma medida antidumping é aplicada, não há uma real ameaça à concorrência no mercado investigador, mas isso não impede que exista um prejuízo grave à indústria doméstica. ${ }^{411}$

Leclerc contesta a probabilidade de um cenário de predação, no mercado internacional, para a formação de um monopólio. As barreiras para se estabelecer um monopólio internacional são significantes. Entre elas, está a dificuldade em evitar que os consumidores estoquem o produto durante a fase de predação, como também a necessidade de que existam altas barreiras de penetração em mercados

\footnotetext{
${ }^{408}$ Neste caso, negam a simples distinção entre dumping predatório e mera discriminação de preços. Entre as hipóteses de discriminação de preços, estariam várias outras espécies de dumping que podem causar efeitos negativos à indústria doméstica.

${ }^{409}$ Este entendimento foi confirmado em dois casos nos Estados Unidos, nos quais a Corte entendeu que a acusação de prática de cartel era infundada, "predatory pricing schemes are rarely tried, and even more rarely successful." (Matsushita Elec. Industry Co. v. Zenith Radio Corp. 475 U.S. 574 (1986) e Brooke Group Ltd. v. Brown \& Williamson Tobacco Corp. 509 U.S. 209 (1993).

${ }^{410}$ A Escola de Chicago defende que a predação não é sustentável em mercados contestáveis. O predador, mesmo que consiga eliminar empresas, não será capaz de recuperar as perdas que teve durante o período de predação e será sempre desafiado por um novo grupo de entrantes. Na visão de dois Conselheiros da Federal Trade Commission, que bem capturaram as definições chicagueanas em suas decisões, o preço predatório é um tigre branco, uma criatura extremamente rara, ou um unicórnio, um mito completo. $\mathrm{O}$ preço predatório é quase sempre irracional, improvável de acontecer. A recuperação dos prejuízos parece implausível porque os lucros esperados após a saída da "presa" do mercado precisam exceder substancialmente os prejuízos, considerando-se o valor temporal do dinheiro e o risco de que futuros lucros não sejam obtidos. (BAKER, Jonathan. Predatory pricing after Brooke Group: an economic perspective. Antitrust Law Journal. v. 62, 1993, p. 586-588.). Contrariando Chicago, as teorias posteriores acreditam que se a predação ocorre em um mercado, a recuperação pode ocorrer rapidamente e de forma lucrativa em vários outros mercados. Mesmo nos casos em que uma empresa participa de apenas um mercado, ela pode conseguir praticar preços predatórios e se recuperar posteriormente se o seu acesso a financiamento for melhor do que o da presa. Ele se apoiará nos seus "bolsos profundos" para eliminar a presa. Além disso, se as barreiras à entrada forem altas, a recuperação do preço predatório não é tão improvável assim. (BAKER, Op cit. P. 587). Ver também AREEDA, Philip. Predatory Pricing. Antitrust Law Journal, v. 49, 1980, p. 897; CALVANI, Terry, LYNCH, James. Predatory pricing under the Robinson-Patman and Sherman Acts: an introduction. Antitrust Law Journal. v. 51, 1982, p. 375. ${ }^{411}$ NIELS, Gunnar; KATE, Adriaan. Op cit. p. 32.
} 
estrangeiros (para evitar que outros contestem o poder adquirido) e altas barreiras nos próprios mercados domésticos. ${ }^{412}$

Trebilcock e Quinn completam o raciocínio. Para eles, o dumping predatório não é o único que causa efeitos negativos, devendo as autoridades se preocupar, também, com as demais espécies. O dumping esporádico também provoca efeitos danosos ao mercado importador. As constantes pausas nas fábricas da indústria doméstica e os ajustes necessários para competir temporariamente com as importações baratas causam ineficiências. A produtividade diminui pela deterioração das competências do trabalho e há dificuldade em manter e substituir equipamentos durantes os períodos de interrupção. A continuidade organizacional pode ser perdida, e a pesquisa e desenvolvimento de projetos podem ser reduzidas ou encerradas. ${ }^{413}$

Sandmo também completa os autores acima. Ele sugere que o custo de capital dos produtores domésticos pode aumentar, em resultado ao dumping cíclico e não predatório. O efeito negativo deste dumping esporádico é a possível formação de um monopólio ou duopólio, estruturas necessárias para que as empresas fiquem isentas dos riscos, não sofrendo com a demanda volátil. ${ }^{414}$

Como será exposto adiante ${ }^{415}$, acredita-se que antidumping e concorrência são políticas distintas, com objetivos diversos. Não é eficaz utilizar a teoria concorrencial, identificando-se práticas concorrências em práticas internacionais, como meio único de identificar quando a medida antidumping é desejável. Substituir antidumping por concorrência é não considerar a história e o motivo da existência do primeiro. O dumping não predatório também provoca efeitos negativos no mercado importador, que justificam uma restrição à concorrência quando a proteção à indústria doméstica se tornar preferencial.

Não há como se falar, na prática, em extinção do antidumping ou sua substituição. A boa defesa da concorrência, somada à análise, pela autoridade de defesa

\footnotetext{
${ }^{412}$ LECLERC, Jean-Marc. Reforming Anti-dumping Law: Balancing the Interests of Consumers and Domestic Industries. McGill Law Journal, v. 44, 1999, p. 116.

${ }^{413}$ Tradução literal de TREBILCOCK, M; QUINN, J. The Canadian Antidumping Act: A reaction to Professor Slayton. Canada-US Law Journal, 1979, p. 108.

${ }^{414}$ SANDMO, Agnar. On the Theory of the competitive firm under price uncertainty, American Economic Review, v. 61, n. 1, 1971, p. 65.

${ }^{415}$ Item 2.3.1.2.3.
} 
comercial, de alguns aspectos concorrenciais mínimos, são suficientes para melhorar e aproximar as duas práticas, mas será inevitável que estas se choquem, em alguns casos. Caberá à autoridade de defesa comercial - e não à autoridade concorrencial - realizar o balanço entre os efeitos negativos à concorrência e os efeitos positivos à indústria que deve ser protegida.

\subsection{A substituição do antidumping pela defesa da concorrência}

Por antidumping e concorrência estarem intimamente relacionados, alguns autores advogam que uma boa política concorrencial já seria o suficiente para a extinção da legislação antidumping. ${ }^{416}$ Uma política de defesa da concorrência eficiente e uma lei forte e completa poderiam reduzir os casos de dumping ${ }^{417}$, mas isso não significa que o antidumping seja um instrumento fadado à extinção. ${ }^{418}$ Antidumping e antitruste são instrumentos distintos em seus objetivos, origens, metodologias e finalidades. $^{419}$

\footnotetext{
${ }^{416}$ Sapir propõe que as alegações de dumping sejam primeiro investigadas pelas autoridades de defesa da concorrência do país importador e do país exportador. Para que se imponham medidas antidumping, as autoridades concorrenciais teriam que alcançar a conclusão que o mercado nacional da firma exportadora não é aberto à concorrência e que nenhum remédio é possível sob a aplicação do direito da concorrência. (SAPIR, André. Some ideas for reforming the Community Antidumping Instrument. Paper produced at the request of Commmissioner Mandelson for the Expert Seminar on Trade Defense Instuments, Bruxelas, 11 de julho de 2006, p. 2.)

${ }^{417}$ Evitar-se-ia o dumping provocado pela concentração indevida de poder econômico em alguns mercados e por infrações cometidas por agentes econômicos.

${ }^{418}$ Entre os fatores que possibilitam a prática de antidumping, citam-se quatro: i) mercados domésticos dos exportadores pouco competitivos; ii) práticas anticompetitivas no país exportador que permitem os preços baixos do exportador no mercado exterior; iii) subsídios governamentais à exportação; e iv) inexistência de economia de mercado. Como é possível depreender, apenas os dois primeiros aspectos poderiam ser investigados por uma autoridade antitruste, sendo mais numerosas as razões para o dumping. Sendo assim, não é possível falar em substituição. "A Administração aumenta os parâmetros globais na area do direito concorrencial e acredita que, com o sucesso deste esforço, a necessidade de invocar a lei antidumping será reduzida. Leis concorrenciais podem e trabalham efetivamente ao lado das leis antidumping, mas não são substitutas a estas últimas. Ainda são necessárias leis antidumping norteamericanas." (Garten, Jeffrey, New Challenges in the World Economy: the Antidumping Law and the U.S Trade Policy, in HOEKMAN, Bernard; MAVROIDIS, Petros, Dumping, Antidumping and Antitrust. p. 30)

419 “A lei antidumping e a lei antitruste vem da mesma árvore genealógica, mas dois galhos se divergiram profundamente. Na era moderna, o antitruste se concentrou na busca de eficiência econômica, concentrando-se em problemas relacionados ao poder econômico, inicialmente por meio de um processo
} 
Bierwagen discorre sobre os fatores que são observados pelos países que desejam, em um instrumento bilateral, substituir o antidumping pelos instrumentos de defesa da concorrência. Tais fatores nunca se mostraram viáveis em um contexto multilateral. Inicialmente, os governos identificam a competitividade no mercado relevante e tentam agir sobre comportamentos anticompetitivos em ambos os mercados (importador e exportador). Em segundo lugar, asseguram que as legislações dos dois países não criam barreiras entre o comércio nacional e internacional, acentuando o poder de mercado dos competidores internos em um dos dois negociadores. Por fim, lutam os governos para harmonizar as práticas dos países, no que se refere à concorrência, para que um país não condene o que o outro país entende como lícito. Esta última pode ser a tarefa mais difícil, ou seja, a harmonização das duas legislações, ou mesmo a adoção de uma delas para os dois países. ${ }^{420}$ Estes seriam, também, os obstáculos a serem superados para se alcançar uma boa legislação multilateral de direito da concorrência que possa substituir o antidumping. ${ }^{421}$

Direito antidumping e direito da concorrência são muito distintos para serem considerados substitutos. Em primeiro lugar, a metodologia usada é distinta, assim como a margem de discricionariedade de cada autoridade (de defesa comercial e concorrência). As autoridades de defesa comercial possuem uma maior margem de manobra na aplicação da lei antidumping, devendo interpretar diversos conceitos, como produto similar, além de certa liberdade na análise dos fatores que compõem o dano e o nexo causal (tais como nível de importações, competitividade, fluxo de caixa, etc.) ${ }^{422}$ As autoridades antitruste, ao contrário, já têm sua criatividade limitada por diversos regulamentos antitruste e pela jurisprudência. ${ }^{423}$ Há que se ressaltar, contudo, que esta realidade é visível em alguns Membros da OMC, especialmente na Comunidade Européia e nos Estados Unidos, mas não é verdadeira para todos eles, sobretudo aqueles

em Common Law que deixa aos tribunais a tarefa de delinear as práticas que violam a lei antitruste. Ao contrário, a lei antidumping objetivou criar uma forma politicamente popular de proteção contingencial, que não tem muito a ver com a prevenção de monopólios. A constituição política do antidumping não é uma constituição antimonopólio, mas sim visa proteger empresas em situação de fraqueza ou em declínio. (SYKES, Alan. Antidumping and Antitrust: what problems does each address? In Robert Z Lawrence. Brookings Trade Forum, 1998, Brookings Institutional Press, Washington D.C. p. 12)

${ }^{420}$ Conforme discutido no item 2.3.1.1.1.

${ }^{421}$ BIERWAGEN, Rainer. Op cit, p. 126-127.

${ }^{422}$ Por exemplo, o que uma autoridade entende como aumento nas importações pode ser entendido como estabilidade no volume de importações por outra autoridade.

${ }^{423}$ HOEKMAN, Bernard; MAVROIDIS, Petros. Dumping, Antidumping and Antitrust. p. 31. 
que editaram recentemente seus primeiros textos legais versando sobre concorrência. Ao contrário, ambas as autoridades estão diante de uma grande margem de discricionariedade, já que a autoridade concorrencial tem ampla liberdade para interpretar e definir, por exemplo, o mercado relevante, conceito que fundamental em sua análise. As apreciações são distintas, há liberdade sobre conceitos muito diferentes, não sendo possível atribuir às legislações antidumping e antitruste uma mesma metodologia.

Os objetivos do direito da concorrência e do direito antidumping são distintos. $\mathrm{O}$ antidumping é uma medida excepcional ao fluxo normal de comércio que permite ao país barrar importações que estejam causando dano à indústria doméstica. $\mathrm{O}$ direito da concorrência busca o bem-estar, a defesa das opções e melhores preços aos consumidores, assim como reduzir o poder de mercado das empresas e gerar eficiência. Algumas leis de concorrência têm objetivos específicos, como contribuir para o estabelecimento de um mercado comum, no caso da União Européia. ${ }^{424}$

Os valores do antidumping e do direito da concorrência são distintos. $\mathrm{O}$ primeiro condena a discriminação de preços e o preço predatório que causam dano à indústria doméstica. $\mathrm{O}$ direito da concorrência condena a discriminação e o preço predatório se estes causarem prejuízo à concorrência. Contudo, uma simples deslealdade ou injustiça praticada por uma empresa em suas exportações pode ser punida pelo antidumping, desde que reste comprovado que causou dano à indústria doméstica ou há uma ameaça crível. $\mathrm{Na}$ análise concorrencial, a preocupação não está centrada na deslealdade, na injustiça, mas sim na ação que pode provocar efeitos. Uma empresa que pratica preço predatório pode não ser punida se ela não tiver poder econômico. O que é injusto, desleal, para o antidumping, não é necessariamente intolerável para a concorrência. $\mathrm{O}$ direito da concorrência tende a ser mais tolerante e flexível do que o antidumping. ${ }^{425}$

\footnotetext{
${ }^{424}$ NIELS e KATE acentuam que os objetivos de defesa da concorrência são distintos em cada país e de acordo com a história de sua legislação. Por isso, é possível dizer que não há um único objetivo comum do direito da concorrência, tendo início neste ponto a dificuldade em se harmonizar as legislações e, posteriormente, substituir o antidumping. (NIELS, Gunnar; KATE, Adriaan. Op cit, p. 31.)

${ }^{425}$ NIELS, Gunnar; KATE, Adriaan. NIELS, Gunnar; KATE, Adriaan.Op cit. p. 32.
} 
Os remédios adotados pela legislação antitruste e antidumping são fundamentalmente distintos. $\mathrm{O}$ direito da concorrência protege o mercado, por meio de ações administrativas ou judiciais, combatendo preços e ações privadas. A legislação antidumping não impede que o exportador pratique preços baixos. Ele pode, por exemplo, recolher os direitos antidumping à autoridade devida e, após a entrada do produto no mercado doméstico, praticar novamente os preços baixos. ${ }^{426}$

Há, também, divergência no que se refere aos verdadeiros prejudicados pelo dumping e aqueles prejudicados pelas infrações concorrenciais. No direito antidumping, deve ficar claro quem são as "vítimas", os produtores que formam a indústria doméstica. No direito da concorrência, os prejudicados são toda a coletividade.

Outra diferença está relacionada aos investigados. O antidumping pode ser aplicado a qualquer ator, independente de seu poder de mercado em um determinado mercado. Assim, a Comissão Européia analisa as práticas de determinadas empresas, suas subsidiárias e exportadoras, sem que o poder de mercado ou eventual posição dominante sejam uma preocupação. No caso do antitruste, é essencial que a empresa investigada detenha posição dominante no Mercado Comum, não sendo aqueles que detêm posição dominante fora da União um motivo de questionamento.

A análise da similaridade do produto no antidumping é, por sua vez, distinta da comparação feita pelo direito concorrencial. No antidumping, além do conceito de similaridade, deve existir uma regra clara que defina a nomenclatura de comércio exterior para cada produto. Mas será que isso significa que os produtos contidos em uma mesma nomenclatura são fisicamente idênticos e competem entre sim? Certamente não. ${ }^{427}$ Além disso, na realidade comercial, tanto os produtos que são adequados à mesma utilidade, quanto os produtos que têm características físicas

\footnotetext{
${ }^{426}$ Isso pode acontecer de forma mais freqüente nos casos em que a investigação utiliza preços construídos ou preços de terceiros países, que muitas vezes são bem distintos dos preços praticados pelo exportador em seu mercado doméstico. Assim, eles podem se adaptar a estes preços artificiais.

${ }^{427}$ Por exemplo, de acordo com a Nomenclatura Comum do Mercosul, o produto "vidro temperado" está classificado sob o n. 70.07.1. São feitas duas subdivisões: 7007.11.00, para vidros de dimensões e formatos que permitem sua aplicação em automóveis, veículos aéreos ou outros veículos; e 7007.19.00, para outros tipos de vidro temperado. Contudo, nestes outros tipos de vidro temperado, certamente encontram-se vidros para diversas finalidades que não foram segmentadas, mas que não são necessariamente competidores entre si.
} 
semelhantes podem ser considerados competidores dos produtos importados. Muitos produtos que sofrem atualizações, desenvolvimentos e alterações podem deixar de ser similares (sob o ponto de vista do antidumping), mas ainda competirem com os produtos domésticos (sob o ponto de vista concorrencial).

Cabe criticar a sugestão do Projeto de Lei brasileiro n. 3.937/2004, que propõe a nova redação para a lei de defesa da concorrência no país. Segundo os comentários do autor do projeto, em seu relatório de setembro de 2007, a autoridade brasileira de defesa da concorrência (Conselho Administrativo de Defesa da Concorrência - CADE), em vários casos sob análise, "encontra barreiras alfandegárias ou não alfandegárias à competição de importações, que comprometem decisivamente o bem estar do consumidor pela falta de concorrência". Nestes casos, o CADE encaminha aos órgãos competentes, especialmente à CAMEX, ofícios com a indicação das referidas barreiras, para que, sobre elas, possam as autoridades de comércio se manifestar e refletir. Segundo o relatório, tais ofícios não são sequer respondidos. Por isso, propõe o projeto de lei que a CAMEX se posicione, obrigatoriamente, em relação aos ofícios. $^{428}$

Não cabe à autoridade de defesa da concorrência, totalmente alheia, na maioria dos casos, às necessidades do comércio internacional, determinar que a autoridade competente para a política de comércio internacional se posicione ou modifique seu entendimento em relação à aplicação de barreiras alfandegárias. Conforme defendido neste trabalho, as competências de cada autoridade devem ser respeitadas, tendo em vista que cada uma delas guarda relação estreita com a matéria à qual se ocupa, bem como conhece propriamente as necessidades de cada uma das políticas. Acredita-se ser possível somente a cooperação, contribuindo as autoridades de comércio para uma boa análise concorrencial nos casos devidos, assim como a autoridade de concorrência pode contribuir nas análises de comércio, fornecendo informações e auxiliando, quando solicitado, o entendimento das autoridades competentes.

Diante de todas as diferenças que separaram antidumping e antitruste, não é possível falar em substituição do primeiro pelo segundo. É viável, entretanto, a 
defesa da consideração, pelas autoridades de defesa comercial, de alguns aspectos concorrenciais. Isso não significa o envolvimento das autoridades de concorrência nas investigações, a menos que isso seja claramente solicitado pelas autoridades de defesa comercial. $^{429}$ Poder-se-ia realizar, por exemplo, o exame da competitividade na indústria doméstica, sendo o resultado elemento para o balanço a ser realizado no momento da conclusão sobre a aplicação de medidas antidumping e observância do interesse público. ${ }^{430}$

\subsubsection{A defesa da concorrência como interesse público no antidumping}

Os objetivos da defesa da concorrência são distintos dos objetivos da defesa comercial. A primeira tem como escopo a análise de concentrações e práticas de agentes econômicos, públicos ou privados, que possam trazer risco aos mercados afetados, ou, ao contrário, eficiências que devam ser preservadas. A finalidade do exame antidumping é decidir pela proteção desejada pela indústria doméstica, no caso de comprovação de dano, dumping e nexo causal. Não há qualquer relação preliminar entre o objetivo do antidumping e da defesa da concorrência. Entretanto, por serem os efeitos do antidumping, como visto, contrários aos objetivos da defesa da concorrência, sugere-se que a defesa da concorrência seja um dos interesses na balança do exame do interesse público nacional em relação à aplicação de medidas antidumping.

Para que a autoridade de defesa comercial possa concluir se a aplicação de medidas antidumping, em determinado caso, é uma medida que trará benefícios ao país investigador, sugere-se que ela observe se a restrição à concorrência no mercado da indústria doméstica, provocado pela restrição às importações, é interessante. Contudo, ao contrário das autoridades concorrenciais, não cabe à autoridade antidumping preocupar-se com a dinâmica do mercado, com o número de competidores adequado e esperado, com características intrínsecas ao mercado. Cabe à autoridade antidumping preocupar-se com o fato de que esta restrição na concorrência, com a diminuição do número de competidores (se existir), provocará prejuízos ao

\footnotetext{
${ }^{429}$ Como será explicado no item 2.3.1.4.

${ }^{430}$ SAPIR, André. Op. Cit. p. 3.
} 
consumidor intermediário e final, e se este prejuízo é maior do que os benefícios gerados à indústria doméstica.

Para que se permita esta análise, a autoridade antidumping deverá conhecer a relação entre concorrência e consumidor, bem como as diretrizes básicas da análise concorrencial. Compreender a concorrência como instrumento de política econômica permitirá concluir sobre os limites da ação concorrencial das autoridades de defesa comercial.

\subsection{O direito da concorrência como instrumento para implementar políticas}

A defesa da concorrência é uma forma de atuação interventora, mediata e unilateral, do Estado. O Estado não é um agente econômico, mas age como normatizador e regulador da atividade econômica. ${ }^{431}$ A intervenção ativa deve ser sempre uma exceção, e não a regra. Isso significa que deve haver liberdade plena ao agente privado, devendo intervir o Estado em situações pontuais, como no caso do abuso do poder econômico. ${ }^{432}$

Gerard Farjat enfatiza que a concentração capitalista leva a uma transformação da função do Estado e é um fator determinante para a intervenção. Para o autor, a concentração provoca a intervenção do Estado por três razões: i) há um desaparecimento relativo de mercado ou de concorrência livre; ii) o interesse econômico pode ser diferente do interesse geral; e iii) ela gera preocupações sociais. ${ }^{433}$

Não é possível, o que seria talvez incorreto, tentar delimitar os objetivos da ação do Estado sobre a concorrência. O direito da concorrência tem como uma de suas características inarredáveis o caráter dinâmico, o que significa que ele está vinculado ao momento e ao espaço de interpretação da lei e do mandamento do Estado.

\footnotetext{
${ }^{431}$ O que, no Brasil, se faz em consonância ao art. 174 da Constituição Federal de 1988. Este artigo dispõe que esta intervenção pode se dar nas modalidades de fiscalização, incentivo ou planejamento. Na modalidade fiscalizadora, o Estado atua verificando a observância, por seus agentes privados, da política econômica e das normas que a instrumentalizam.

${ }^{432}$ FARJAT, Gérard. Droit Economique. Paris: Presses Universitaires de France. 1971, p. 264.

${ }^{433}$ Op. Cit. p. 264.
} 
Paula Forgioni defende a possibilidade de traçar linhas gerais sobre as funções possíveis de uma lei antitruste, sem apresentar funções definidas, tidas como ótimas. Ela defende que as regras antitrustes são instrumentos que buscam objetos possíveis, mas que dependem dos princípios (corpo de normas que contém escolhas de valor e proibições de ordem geral). ${ }^{434}$ Deve-se, por isso, investigar cada país em cada tempo. Uma lei antitruste é um instrumento de determinada política econômica, possuindo, por consequiência, objetivos próprios, diversos das demais leis antitrustes. ${ }^{435}$

Para a compreensão desta dinamicidade, é imprescindível a apreensão do conceito de política econômica. A expressão política econômica significa a existência de uma ação do Estado abrangendo diversas variáveis econômicas, determinando maiores ou menores intervenções. ${ }^{436}$

Isabel Vaz conceitua política econômica como um conjunto de ações adequadas dirigidas racionalmente para a obtenção de determinados resultados de natureza econômica em uma comunidade. Quando o emissor destas diretrizes é o Estado, temos uma política econômica e social e poderíamos dizer, à maneira keynesiana, uma política macroeconômica. Para Isabel Vaz, a política econômica está estreitamente relacionada aos instrumentos legais previstos na ordem jurídica. ${ }^{437}$

No Brasil, tais normas foram dispostas a partir do art. 170 da Constituição Federal de 1988. São diretrizes da atividade econômica: i) a existência digna, conforme ditames da justiça social (instrumento para o alcance deste fim); ii)

\footnotetext{
434 "Mais do que objetivos, estamos falando de relação entre instrumentos e objetos possíveis. E, acima de tudo, estamos tratando com princípios." FORGIONI, Paula. Os fundamentos do antitruste. 2 ed. São Paulo: Editora Revista dos Tribunais, p. 164.

435 "A tutela da concorrência e a repressão aos abusos do poder econômico são objetivos de caráter múltiplo, inseridos no conjunto da política econômica de cada país, com o qual devem guardar necessária coerência. É por este motivo que se tem observado, ao longo da história econômica dos vários países, posições e atitudes diversas frente aos mesmos. Tal diversidade tem refletido menos diferenças de cunho doutrinário e ideológico e muito mais preocupações com as metas assinadas para a economia de cada país em determinados momentos históricos." (NUSDEO, Fábio. Abuso do Poder Econômico, Enciclopédia Saraiva do Direito, APUD FORGIONI, Paula. Fundamentos do Antitruste, cit. p. 164)

${ }^{436}$ A política econômica é o objeto imediato do Direito Econômico. Washington Peluso Albino de Souza define o Direito Econômico como sendo o ramo do Direito que tem por objeto a regulamentação da política econômica e por sujeito o agente que dela participe. Para ele, é um conjunto de normas de conteúdo econômico que assegura a defesa e a harmonia dos interesses individuais e coletivos, de acordo com a ideologia adotada na ordem jurídica. (SOUZA, Washington Peluso Albino de. Primeiras Linhas de Direito Econômico, 3 ed. São Paulo: LTR, 1994, p. 23.)

${ }^{437}$ VAZ, Isabel. Direito Econômico das Propriedades. Rio de Janeiro: Forense, 1993, p. 195.
} 
livre concorrência e livre iniciativa ${ }^{438}$ são instrumentos da promoção da dignidade humana (temos objetivos mais amplos do que, simplesmente, o livre mercado); iii) pleno emprego; iv) proteção ao consumidor; e v) desenvolvimento tecnológico. Como a estas diretrizes é atribuído o caráter de fundamento, não podem ser alteradas facilmente. Assim, a política econômica terá seus contornos balizados por estes preceitos. ${ }^{439}$

$\mathrm{Na}$ União Européia, tais diretrizes podem ser lidas no Tratado da União Européia. São princípios de uma economia de mercado e concorrência livre: i) promover o desenvolvimento harmonioso, ii) garantir o nível de emprego e proteção social; iii) igualdade entre os sexos; iv) crescimento durável e não inflacionário; v) alta competitividade; vi) proteção ao meio ambiente; vii) aumento do nível de qualidade de vida; e viii) solidariedade entre os membros. Para estes fins, segundo o art. 4, a ação dos Estados Membros e da União Européia implica a adoção de uma política econômica baseada na coordenação de políticas econômicas dos diversos Estados-Membros,

\footnotetext{
${ }^{438}$ Para Eros Roberto Grau, o princípio da livre iniciativa tem sua origem no Édito de Turgot, de 1976, cujo art. 7 determinava que, a partir daquele ano, qualquer pessoa é livre para realizar qualquer negócio ou exercer qualquer profissão, arte ou ofício que lhe aprouver, sendo obrigada a se munir previamente de uma patente (imposto direto), a pagar taxas exigíveis e a se sujeitar aos regulamentos de polícia aplicáveis. Para o autor, do princípio da liberdade de iniciativa decorre a livre concorrência. (GRAU, Eros Roberto. Princípio da Livre Concorrência - função regulamentar e função normativa. Revista Trimestral de Direito Público, n. 4, 1993, p. 124.) Em outra obra, Eros Grau enfatiza sua posição de que a livre iniciativa não é senão a projeção da liberdade individual no plano da produção, circulação e distribuição de riquezas, assegurando não somente a livre escolha das profissões e das atividades econômicas, mas também a autônoma eleição dos processos ou meios julgados mais adequados para os fins visados. Já o conceito de livre concorrência tem caráter instrumental, significando o princípio econômico segundo o qual a fixação dos preços das mercadorias e serviços não deve resultar de atos de autoridade, mas sim do livre jogo das forças em disputa de clientela na economia de mercado. (GRAU, Eros Roberto. A ordem econômica na Constituição de 1988.7 ed. São Paulo: Malheiros, 2002, p. 224.)

439 "Naturalmente, nem todos os dados, teoricamente à disposição dos responsáveis pela política econômica, poderão ser alterados, pelo menos dentro do horizonte estabelecido como limite para a aplicação de uma dada política. Assim, aqueles não-modificáveis descartar-se-ão como possíveis meios de ação. Podem ser de caráter físico (como as condições do solo), institucional (quando certas regras fundamentais dentro do contexto de valores vigente se tornam insuscetíveis legal ou sociologicamente de serem alteradas), ou mesmo psicológico (tais como a índole do povo, sua inclinação ao trabalho, ao ócio ou à poupança). O ponto importante a ser ressaltado é o de os dados fundamentalmente consistirem no conjunto institucional definidor do quadro jurídico dentro do qual opera o sistema. E este inclui tanto as normas relativas aos direitos de propriedade e obrigacionais, fulcro da atuação do mercado, quanto os preceitos e instituições que denotam a presença do Estado, inescapável como suporte e complementação daquele, no seu papel de corretor ou supridor das suas falhas operacionais." (NUSDEO, Fábio. Curso de Economia: Introdução ao Direito Econômico. 3 ed. São Paulo: Editora Revista dos Tribunais. 2001, p.
} 187). 
conduzida de acordo com o princípio da economia de mercado aberto e de livre concorrência. $^{440}$

Há uma diferença significativa neste ponto, conforme Spaake e Jaeger, sobre as leis nacionais dos países membros e as leis comunitárias. As leis nacionais têm o exclusivo propósito de proteger o consumidor e o interesse público. Elas são apoiadas em princípios econômicos e em raízes éticas de igualdade e liberdade, em linha com as aspirações de vida dos habitantes daquele país. A concorrência é, então, um fim em si mesmo, e as leis servem para atingir este fim. ${ }^{441}$

Quando é necessário introduzir esta lei em um contexto de mercado comum, entretanto, este processo é invertido. As regras da concorrência são definidas com antecedência, antes da formação do mercado comum. De nada adianta derrubar barreiras ao comércio, harmonizar economias e moedas, se as empresas e consumidores continuarem adstritos aos territórios nacionais. Deve haver incentivos à movimentação. Com o estabelecimento de um mercado comum como objetivo, a competição deixa de ser um fim em si mesma, mas um dos mais importantes instrumentos de política econômica objetivando a integração destes mercados. A competição foi escolhida como força motriz para a revolução econômica que é promover a interpenetração de diversas economias nacionais, prisioneiras por séculos de suas diferentes estruturas, diferentes

\footnotetext{
${ }^{440}$ Artigo $3^{\circ}$, item 3, Tratado da União Européia - Versão consolidada após Tratado de Lisboa. Jornal Oficial C 115 de 9 de Maio de 2008.

${ }^{441} \mathrm{O}$ direito da concorrência europeu filia-se à teoria da concorrência-instrumento. A concorrência não é um valor em si mesmo, não é um valor absoluto, mas um meio normal, eventualmente privilegiado, de obter o equilíbrio econômico. (FERREIRA ALVES, Jorge de Jesus. Direito da Concorrência nas Comunidades Européias. Coimbra: Coimbra Editora, 1989, p. 14.) Se a concorrência não é um valor em si mesmo, pode ser sacrificada em homenagem a outros valores. Por outro lado, não há ilicitude ou condenações automáticas, deve ser aplicada a regra da razão. Assim, uma concentração de empresas pode ser autorizada quando concorrer para o progresso econômico e social do país. (Leis francesas de 1953 e 1977, lei inglesa de 1956 e alemã de 1957). O direito comunitário aderiu a esta teoria, sendo a concorrência um instrumento da criação e do aperfeiçoamento do mercado comum. A teoria da concorrência-meio surgiu no direito europeu a partir da Primeira Guerra Mundial, afirmando-se a partir da segunda grande guerra, com as leis francesas de 1953 e 1977. Para a lei francesa, pode-se autorizar uma concentração de empresas quando concorrer para o progresso econômico e social do país. A concorrência, na Europa, é um instrumento de criação e aperfeiçoamento do mercado comum. Assim, o art. 85 (1) deve ser temperado pelo art. 85 (3). Permite-se, também, que sejam considerados interesses extra-comunitários.
} 
tradições e hábitos, e mergulhá-las em uma entidade econômica nova, o Mercado Comum Europeu. ${ }^{442}$

O direito da concorrência é um instrumento para a implementação de políticas públicas ${ }^{443}$, especialmente aquelas que usam o Estado para interferir sobre a economia. ${ }^{444}$ Ele serve, também, para oferecer um instrumento para que a administração pública possa orientar as decisões de grandes grupos para realizar o processo de desenvolvimento tido como desejável.

Diante destas conclusões, é importante compreender, para que esta compreensão possa auxiliar a autoridade de defesa comercial na deliminação do interesse público concorrencial no antidumping, quais são os possíveis objetivos do direito concorrencial.

\subsection{Os objetivos da defesa da concorrência}

Como mencionado no tópico anterior, há várias formas de explicar porque o Estado decide agir para proteger a concorrência. O Estado pode defender a concorrência como uma forma de buscar o progresso e o desenvolvimento ${ }^{445}$, assim como pode defender a concorrência como forma direta de proteger o consumidor, o

\footnotetext{
${ }^{442}$ Tradução livre e interpretação dos comentários de SPAAK, Fernand; JAEGER, Jean. The Rules of Competition within the European Commom Market. Law and Contemporary Problems. Vol. 26, n. 3. 1961, p. 485 e 486.

${ }^{443}$ Em conformidade com as diretrizes do ordenamento jurídico.

${ }^{444}$ Forgioni, Paula, Fundamentos do Antitruste. Cit. p. 193.

445 "O esforço que se observa nos países subdesenvolvidos no sentido de elevar rapidamente o nível de vida de suas populações vai fazer surgir uma legislação que procura fornecer os instrumentos normativos para favorecer rapidamente o processo de enriquecimento desses países." (VENANCIO FILHO, Alberto. A Intervenção do Estado no Domínio Econômico. Ed. Fac-similar a 1968. Rio de Janeiro: Renovar. 1998, p. 371.) Da mesma forma, o Estado pode intervir para eliminar a concorrência, sendo esta eliminação fonte esperada de progresso e desenvolvimento. Mário Shapiro lembra que o Brasil, entre as décadas de 30 e 80, realizou um esforço concentrado, no âmbito da política econômica, para fomentar a industrialização brasileira. As atuações do Estado de fomento industrial eram geridas em comunhão com os interesses macroeconômicos: as políticas fiscal, cambial, monetária e creditícia eram, por vezes, deixadas de lado pelas necessidades postas pela política industrial. O Estado agiu diretamente, como ator industrial ou patrocinador do capital privado, deixando-se a regulação de um ambiente concorrencial em segundo plano. Os diplomas da época estimulavam ou consentiam com a realização de operações societárias tendentes a uma concentração do poder econômico. (SCHAPIRO, Mário Gomes. Política Industrial e disciplina da Concorrência pós-reformas de mercado: uma avaliação institucional do ambiente de inovação tecnológica. Dissertação de mestrado apresentada ao Departamento de Direito Econômico e Financeiro da USP, São Paulo, 2005. p. 135-136.)
} 
emprego e impedir que o poder econômico concentrado nas mãos de poucos agentes econômicos seja uma ameaça ao bem-estar social. A defesa da concorrência é uma forma de intervir sobre a economia e garantir que a ação dos agentes econômicos esteja em consonância com o que se acredita ser uma forma de realização do bem-estar social. $^{446}$

Diversos mestres já se dedicaram ao debate dos objetivos da defesa da concorrência. Nos Estados Unidos, várias escolas ${ }^{447}$ se alternaram até o surgimento da Escola de Chicago, ou the law and economics. Esta última se dedicou ao estudo da ciência jurídica com a contribuição das ciências econômicas, abusando de seus instrumentos para a descoberta do sentido da defesa da concorrência.

Antes de Chicago, a Escola de Harvard, surgida nos anos 50, nos Estados Unidos, havia defendido que, nos mercados concentrados, em que são altas as barreiras à entrada ${ }^{448}$, as firmas participantes assumem determinados comportamentos, como a conduta concertada, causando o aumento dos preços e o comprometimento do desempenho econômico. ${ }^{449}$ Assim, é mais importante ao direito concorrencial o controle destas estruturas do que a ação sobre seu comportamento. Harvard defende, por meio da Teoria do Bloqueio de Mercado (chamada de "Market Foreclosure"), que as integrações verticais (entre os diversos degraus da cadeia econômica) têm como efeito a restrição da concorrência. ${ }^{450}$ Seus destacados autores Turner, Areeda, Sullivan, Blake, entre outros, defendem uma maior preocupação com a existência de concorrência na estrutura.

Desafiando a visão harvardiana, autores da Universidade de Chicago, como Bork, Bowman, Mac Gee e Posner, opinaram que o principal desafio das autoridades antitruste não são as estruturas, mas os comportamentos. A Escola de

\footnotetext{
${ }^{446}$ Segundo a Constituição Federal brasileira de 1988, em seu art. 174, "Como agente normativo e regulador da atividade econômica, o Estado exercerá, na forma da lei, as funções de fiscalização, incentivo e planejamento, sendo este determinante para o setor público e indicativo para o setor privado." ${ }^{447}$ Common Law, Rule of Reason, Monopolistic Competition, Workable Competition, Liberal School.

${ }^{448}$ As barreiras à entrada são fatores de um mercado que impedem firmas de fora dele de nele entrar. (HOVENKAMP, Herbert. $O p$ cit. p. 39) Alguns exemplos são custos irrecuperáveis, investimentos em propaganda, existência de barreiras artificiais como medidas antidumping.

${ }^{449}$ Segundo a leitura de SALGADO, Lúcia Helena. A Economia Política da Ação Antitruste. Rio de Janeiro: Singular, 1997, p. 26-80.

${ }^{450}$ Inicialmente, de forma radical, a Suprema Corte norte americana decidiu, com base nesta teoria, vetar os mais comezinhos casos de integração vertical, como ocorreu no caso Brown Shoe de 1962, envolvendo empresas com uma ínfima participação de mercado.
} 
Chicago influenciou fortemente as decisões norte-americanas na década de 80 , bem como as leis brasileira e européia sobre a defesa da concorrência. Chicago desafiou Harvard em alguns de seus pilares. Em primeiro lugar, demonstrou que as taxas de retorno do investimento, que segundo os autores de Harvard seriam maiores no caso de estruturas muito concentradas, poderiam ser fruto de estruturas eficientes, em que a concentração é necessária. Assim, os lucros monopolísticos derivados destas altas taxas de retorno não seriam fruto de preços supra-competitivos, mas da eficiência da concentração.

O modelo proposto pela Escola de Chicago entende que a eficiência é o único objetivo das leis antitruste. O Estado interfere minimamente na economia para garantir a realização desta eficiência. Mas Chicago, assim como suas antecessoras, sofreu várias críticas e foi acusada de propor objetivos cegos, que não teriam considerado outros fatores relevantes de influência sobre a decisão antitruste, tais como valores sociais.

Contudo, embora bastante criticada, Chicago tem seu mérito por discutir o valor da eficiência, especialmente alocativa, ou o bem-estar, criada pela ação do agente econômico. Um ato seria ineficiente quando diminui o bem-estar econômico, que é a soma do bem-estar do consumidor e do bem-estar do produtor. Seus críticos acrescentam que a política antitruste não pode deixar de observar as preocupações distributivas. $^{451}$ Este raciocínio será extremamente importante para que se possa compreender o antitruste como um dos objetos do interesse público no antidumping.

Chicago defendeu que o custo da ineficiência do mercado seria menor do que o custo da intervenção governamental, sendo melhor deixar o mercado ser guiado por suas forças. Os ideais desta escola levaram a uma redução do rigor das autoridades norte-americanas, tornando importante a análise das eficiências no exame das concentrações. $^{452}$

451 HOVENKAMP, Herbert. Distributive Justice and the Antitrust Laws, George Washington Law Review, v. 51, n. 1, 1982, p. 345 a 376. e HOVENKAMP, Herbert. Antitrust Policy after Chicago. Michigan Law Review, v. 84, n. 2, 1985, p. 213-284.

${ }^{452} \mathrm{O}$ que é bom para as grandes empresas é bom para o consumidor, sendo a solução dar o máximo de autonomia aos competidores privados. São as máximas de Chicago, na leitura de Hovemkamp: i) a eficiência econômica é o único objetivo das leis antitruste: a eficiência produtiva e a eficiência alocativa; 
Bork, um dos grandes expoentes da Escola de Chicago, defende a defesa da concorrência como meio de satisfação dos interesses dos consumidores. ${ }^{453}$ Para ele, não se pode desautorizar uma concentração geradora de bem-estar do consumidor, mesmo que ela prejudique os pequenos produtores. Segundo Bork, alguns juristas entendem que uma multiplicidade de objetivos é necessária, não questionando o fato de que um pode contradizer o outro. ${ }^{454}$ Ele crê que o único objetivo legítimo do antitruste é a maximização do bem estar do consumidor. ${ }^{455}$ Algumas vezes, o caso traz valores que podem ser conflitantes com o bem-estar do consumidor, e muitas vezes estes valores são também relevantes, mas o objetivo maior do antitruste deve sempre sobressair. Ele lembra que o Juiz Rufus Wheeler Peckham (em Trans-Missouri ${ }^{456}$ ) mencionou a existência do interesse dos pequenos produtores, "small dealers and worthy men", a expensas dos interesses dos consumidores. O Juiz Learned Hand, no

\footnotetext{
ii)a maioria dos mercados é competitiva, mesmo se eles contiverem relativamente poucos vendedores. É muito difícil um cartel ou oligopólio fechar qualquer possibilidade de competição, ex. melhoria dos serviços de atendimento aos consumidores; iii) o monopólio, quando existente, tende a ser autocorrigível: os altos lucros praticados pelo monopolista servirão para atrair firmas ao mercado; iv) as barreiras naturais à entrada nos mercados são mais imaginárias do que reais: investimentos vão ser feitos em qualquer mercado em que a taxa de retorno for alta (trata a entrada como fácil e instantânea); v) economias de escala são mais pervasivas que os economistas sabiam. Há economias de distribuição; vi) a firma geralmente maximiza seus lucros quando as firmas à jusante ou à montante se comportam competitivamente. Não há incentivos para que o monopolista queira criar/instigar um monopólio à justante ou à montante; vii) as firmas são maximadoras de lucro. As decisões são tomadas com base em ações que tornarão as empresas mais rentáveis do que qualquer outra alternativa. A integridade do mercado requer apenas poucas empresas maximadoras de lucro; viii) mesmo se os mercados forem imperfeitos, a intervenção do governo é justificada somente se os resultados forem uma melhora, levando-se em consideração os custos de uma intervenção; ix) a decisão de fazer do mercado eficiente é apolítica e é tomada apenas para maximizar o bem-estar da sociedade. Assim, se a prática produz maiores ganhos aos produtores do que perdas aos consumidores, ela é eficiente e não deve ser considerada ilegal. (HOVEMAKMP, Herbert. Op cit. p. 62).

${ }^{453} \mathrm{O}$ bem-estar do consumidor como sendo a soma do bem-estar dos consumidores e fornecedores, segundo a teoria de que os consumidores irão se beneficiar se os produtores ficarem mais ricos, porque os produtores vão investir seu dinheiro em coisas que os consumidores desejam. (BORK, Robert. The Antitrust Paradox, p. 90-117.)

${ }^{454} \mathrm{O}$ autor critica a forma como são discutidos os valores do antitruste. Seria o juiz antitruste guiado por um valor ou vários valores? Se vários, como ele deve decidir casos em que aparecem conflitos entre estes valores? Um resumo das opiniões antitruste dá a impressão de que o antitruste é uma árvore de valores sociais, todos vagos e indefinidos, mas sempre atrativos.

${ }^{455} \mathrm{O}$ economista de Chicago é enfático ao defender que "A linguagem dos textos legais do antitruste, suas histórias legislativas, as maiores características estruturais da lei antitruste, e as considerações de escopo, natureza, consistência indicam que a lei deve ser guiada somente pelo critério do bem-estar do consumidor." Op cit. p. 57.

${ }^{456}$ United States v. Trans-Missouri Freight Ass’n, 166 U.S 290, 1897
} 
caso Alcoa ${ }^{457}$, também discutiu o conflito do bem-estar do consumidor com outros valores.

Bork critica estes valores, que, para ele, fazem parte de uma tentada teoria dos propósitos sociais e políticos do antitruste. À Suprema Corte norte-americana teria sido atribuída a tarefa de proteger "viáveis, pequenos e locais senhores de negócios", mesmo que o resultado fosse um aumento ocasional de custos e preços ou a proteção a indústrias ineficientes. ${ }^{458}$ Bork lembra, ainda, Appalachian Coals ${ }^{459}$ e Brown Shoe ${ }^{460}$, duas decisões que revelam o grande conflito entre o bem-estar do consumidor e o bem-estar do pequeno produtor.

A proteção ao consumidor como objetivo do antitruste, para ele, está clara na história e na própria redação do Sherman Act. ${ }^{461}$ Os textos e políticas posteriores não dispõem com tanta clareza sobre o consumidor, mas agem na mesma direção. As principais características das leis antitruste foram definidas por idéias políticas e estas idéias não estão relacionadas senão a uma política de proteção ao consumidor. Também não parece, para Bork, que o Congresso norte-americano já desejou sacrificar o interesse do consumidor para favorecer qualquer outro. ${ }^{462}$

Desafiando Chicago, surge a Escola Ordo-liberal, para quem o funcionamento de uma economia de mercado depende da garantia de competição, o que só ocorre na existência de um aparato legal bem elaborado. O Direito, aqui sendo discutida sua importância, é o instrumento que garante a ordem privada e a auto-

\footnotetext{
${ }^{457}$ United States v. Aluminum Co. of America, 148 F. 2d 416, 428, 429 (2d Cir. 1945). A Corte de Apelação do Segundo Circuito julgou ilegal o grande poder de mercado no setor de alumínio da Aluminum Company of America. Nele, o Juiz julgou que uma das razões dos estatutos antitruste, para se condenar o monopólio, é preservar a organização de industriais em pequenas unidades que podem efetivamente competir uma com a outra (ou seja, valorizou o competidor e a concorrência entre os pequenos competidores acima de tudo).

${ }^{458}$ A crítica de Bork é dura: "O ponto aqui não é saber se estas idéias são políticas sociais duvidosas (que são), mas, ao contrário, como nossos estatutos prevêem, que elas fazem a lei antitruste impossível". (tradução livre, op. cit. p. 56)

${ }^{459}$ Neste caso, a corte permitiu a pequenos produtores restringir a concorrência, por meio de um cartel, auferindo lucros acima do nível competitivo. (Appalachian Coals, Inc. v. United States, 288 U.S 344 (1933).

${ }^{460}$ Neste caso, a corte impediu a produção de eficiências, com o objetivo de proteger pequenas empresas menos eficientes. (Brown Shoe Co. v. United States, 370 U.S 294 (1962).

${ }_{461}$ O Sherman Act declara ilegal dois tipos de contratos, pactos, acordos, trustes e combinações: i) feito para ou que pode impedir plena e livre competição; ii) feito para ou que tende a aumentar o custo para o consumidor.

${ }^{462}$ Op. Cit. p. 66.
} 
coordenação das forças do mercado. O direito de propriedade e direito das obrigações são fundamentais à garantia de competição em uma economia de mercado. Os ordoliberais criticam a eficiência com o único objetivo econômico predeterminado para a aprovação de uma concentração. Para seus autores, não é possível que a lei preveja tudo o que é desejado. A defesa dos interesses do consumidor deixa de ser o único alvo, lembrando-se, também, da defesa dos produtores e todos os agentes do mercado. Assim, não é essencial a existência de concorrência, bastando que seja possível e garantida pelo Estado. $^{463}$

Surge o Revisionismo Pós-Chicago ${ }^{464}$, com autores como Laurence Sullivan, Herbert Hovenkamp, Robert Steiner, Steven Salop, Eleanor Fox ${ }^{465}$, Robert Ptofsky, entre outros, com a crítica de que Chicago teria demasiado simplista. ${ }^{466}$ Utilizando alguns argumentos de Chicago - que em momento algum são julgados inúteis - indicam prejuízos de determinadas condutas. A eficiência pode não compensar a perda ou incentivo à entrada de novos concorrentes e pode não significar o que é melhor para os consumidores. Há, por exemplo, efeitos anticompetitivos nas concentrações verticais que não podem ser desprezados. ${ }^{467}$ Os críticos de Chicago não acreditam em eficiência natural dos atos de negócios. A real batalha, para Eleanor Fox, não concerne ao motivo econômico, mas está fundamentalmente ligada às diferentes visões concernentes ao direito e à sociedade. ${ }^{468}$

\footnotetext{
${ }^{463}$ Para os ordo-liberais, o poder econômico não foi enfraquecido, e isso restou claro na história da industrialização da Europa.Tal poder tende a se perpetuar e se tornar mais forte. $O$ direito da concorrência não pode deixar espaço à discricionariedade das autoridades, que devem se basear apenas em princípios fundamentais da constituição econômica. (GERBER, David. Constitutionalizing the Economy: German Neo-liberalism, Competition Law and the New Europe. American Journal of Comparative Law, n. 25, 1994, p. 78.)

${ }^{464}$ Ou New Coalition, conforme Eleanor Fox, in The Battle for the Soul of Antitrust. California Law Review, v. 75, n. 3, 1987, p. 917.

${ }^{465}$ A autora distingue Chicago, como sendo a escola que defende que a lei deve ser derivada da economia e por ela explicada, da chamada New Coalition, que acredita que o direito é essencialmente diferente da economia, a economia é um dos instrumentos usados para se cumprir o espírito do direito. A lei pode ser derivada de um texto, que contém suas bases legislativas e envolve construção judicial. (FOX, Eleanor. The Battle for the Soul of Antitrust. Cit. p. 917.)

${ }^{466}$ Ver Hovenkamp, Herbert. Antitrust Policy after Chicago, cit. ; Hovenkamp, Herbert. Chicago and its alternatives. Duke Law Journal, n. 6, 1986, p. 1014-1029; FOX, Eleanor. Consumer Beware Chicago. Cit. e WILEZ Jr. John Shepard. After Chicago: na exaggerated demise? Duke Law Journal, n. 6, 1986, p. 1003-1013. e BORK, Robert. BOWMAN, Ward. The Goals of Antitrust: A Dialogue on Policy. Columbia Law Review, v. 65, n. 3, 1965. p. 363-376.

${ }^{467}$ Leitura de FORGIONI, Paula. Os Fundamentos do Antitruste, São Paulo: Revista dos Tribunais, 2008, p. 181.

${ }^{468}$ FOX, Eleanor. The Battle for the Soul of Antitrust. Cit. p. 918.
} 
Embora desafiem Chicago, os autores do Revisionismo também enaltecem o consumidor como fim da defesa da concorrência.

Paula Forgioni lembra que uma das grandes críticas feitas à Escola de Chicago é o excesso de tecnicismo desprovido de qualquer remissão à opção política. ${ }^{469}$ As decisões a serem tomadas não derivariam de opções políticas, sendo racionais e neutras. Contudo, toda técnica implementa opção política, inexistindo tal neutralidade. ${ }^{470}$ De fato, a Escola de Chicago defende uma teoria pura do antitruste, segundo a qual não haveria qualquer influência da política sobre a economia, vista como principal instrumento deste ramo do direito. $\mathrm{O}$ direito que utiliza a economia, baseandose no indiscutível conceito de eficiência alocativa e produtiva ${ }^{471}$, é um direito mais puro. $^{472}$

Eleanor Fox desafia o conceito de eficiência, o cerne da teoria chicagueana. Ela conclui que a eficiência, definida como forma de realizar os interesses de longo prazo dos consumidores e implementada protegendo o processo competitivo, é o maior objetivo do antitruste, e que os valores básicos sócio-políticos do antitruste coincidem com a eficiência e guiam a política antitruste. Ela propõe um novo modelo, ou um novo equilíbrio, desta vez entre o abuso de poder (aparente e constante intuito da lei antitruste norte-americana), a preocupação com os consumidores e a necessidade de dar oportunidades aos empresários. A única forma de se encontrar este equilíbrio é preservar a competição como um processo. Se forças impessoais de concorrência, ao contrário do poder público ou privado, determinarem o comportamento do mercado e

\footnotetext{
${ }^{469}$ Para Hovenkamp, o antitruste tem sido extremamente vulnerável às mudanças políticas. "the danger, on the other hand, is that the assertion takes a particular policy out of the political process altogether which means, in the case of a democracy, that it is taken out of the democratic process." P. 67.

${ }^{470}$ A Professora cita Natalino Irti, em L'ordine giuridico Del mercato. FORGIONI, Paula. Op cit., p. 177.

${ }^{471}$ Eficiência alocativa está relacionada à distribuição de recursos na sociedade. É simplesmente determinar se os recursos estão empregados naquelas atividades que os consumidores mais apreciam ou necessitam. Eficiência produtiva relaciona-se ao efetivo uso dos recursos pelas empresas. (SALOMAO, Calixto. Direito Concorrencial: as estruturas. Cit. p. 177.)

${ }^{472}$ Paula Forgioni cita Ptofsky, para quem "Nunca houve um período comparável à década passada, quando economistas antitruste e advogados obtiveram tanto sucesso em persuadir cortes a adotar um conceito exclusivamente econômico para as questões antitruste. É história ruim, política ruim e direito ruim excluir alguns valores econômicos na interpretação das leis antitruste" (Sullivan e Hovenkamp, Antitrust Law, policy and procedure. in Forgioni, Paula, Os fundamentos do antitruste. 2008, p. 179.)
} 
seus resultados, o poder será dispersado, oportunidades e incentivos para as empresas sem poder de mercado vão aumentar e os resultados serão aceitáveis e justos. ${ }^{473}$

Defende-se, aqui, que não é possível falar em um direito puro, cego, desprovido de qualquer marca ideológica ou referência política. O consumidor é o fim mediato da defesa da concorrência, mas existem valores e premissas imediatas, que não podem ser descartadas. Assim, por exemplo, um Estado que elege a livre concorrência tem como ideal a promoção do bem-estar do consumidor (ex. preços mais baixos, mais opções de escolha, etc.). Contudo, para que este fim seja alcançado, há uma estrada, na qual a autoridade será chamada a analisar outros valores, tais como o valor do trabalho (trabalho para o consumo), o meio ambiente (como garantia de consumo), entre outros. Estes valores são também valores do mercado, tido, aqui, como sinônimo de concorrência.

\subsection{A concorrência e o consumidor}

Por que proteger o consumidor? A pergunta parece óbvia, sendo fácil responder que o consumidor é um agente frágil do mercado. Contudo, tal obviedade se obscurece quando se questiona: contra o quê se protege o consumidor? Há casos em que não há nenhum prejuízo ou ameaça flagrante e, mesmo assim, existe uma preocupação do Estado com a defesa do consumidor.

Parte-se das premissas da existência de desigualdade e pouco poder de barganha. ${ }^{474} \mathrm{O}$ consumidor é frágil porque não tem o mesmo poder econômico que o

\footnotetext{
${ }^{473}$ Para que isso seja possível, deve ser preservada a rivalidade entre numerosas empresas em um aberto e livre mercado, além de se proteger o acesso e a oportunidade a empresas sem poder de mercado. (FOX, Eleanor. The Modernization of Antitrust: a new Equilibrium. Cornell Law Review, n. 66, 1980, p. 1154.)

${ }^{474}$ Segundo a doutrina e jurisprudência brasileiras, são quatro, no mínimo, as formas de desigualdade dos consumidores em relação ao fornecedor de bens ou serviços: a desigualdade técnica, a desigualdade jurídica, a desigualdade informacional e a desigualdade socioeconômica. A desigualdade técnica ocorre quando o consumidor não conhece todos as características do produto ou serviço que está adquirindo, sendo presumida para o consumidor não profissional. A desigualdade jurídica ocorre quando o consumidor não tem conhecimentos jurídicos (entende-se para conhecimentos específicos, como o contábil) para se obrigar. A desigualdade informacional ocorre quando o consumidor não conhece a informação completa sobre o produto, sendo-lhe negado ou omitido certas características ou funções. Por fim, a desigualdade socioeconômica ocorre quando o consumidor não detém o mesmo poder econômico que o fornecedor, o que pode acontecer, por exemplo, se o produto for essencial. (MARQUES, Cláudia
} 
fornecedor, não tem a mesma capacidade jurídica (em sentido amplo) de interpretar todos os atos e contratos que assume e, principalmente, porque pode não ter acesso a todas as informações disponíveis. ${ }^{475}$

O bem-estar, por sua vez, é uma preocupação das Ciências Econômicas. A promoção do bem estar está relacionada à boa administração dos recursos, de maneira a proporcionar à sociedade e ao consumidor o melhor proveito destes. $^{476}$ Assim, para maximizar o bem-estar, deve-se buscar a melhor alocação de riquezas. A melhor alocação de riquezas, a mais eficiente, é aquela que proporciona maior grau de eficiência econômica, implicando a melhora da situação de um indivíduo sem piorar a de outro. ${ }^{477}$

A existência de alguma concorrência é fundamental para o bem-estar do consumidor. Mas o que é este bem-estar? Clark menciona a existência de valores que são aceitos como elementos de bem-estar. O bem-estar é concebido como uma lista de necessidades, ao invés de uma lista de desejos. Existem também o bem-estar do indivíduo, que é o bem-estar pessoal, e o bem-estar da sociedade. Conciliá-los implica uma liderança que reconheça a necessidade de desafios, somada à disposição das pessoas, em geral, para seguirem esta liderança. Assim, Clark se baseia na necessidade de democracia para a realização do bem-estar. Os padrões de bem-estar são um conjunto de valores socialmente aceitos e julgamentos de fato. Os consumidores decidem e, com o apoio da liderança democrática, identificam quais valores serão sobrepostos. ${ }^{478}$

É o Estado quem garante a existência desta liberdade. Este age direta ou indiretamente. Age diretamente quando ele mesmo fornece o produto escolhido para o bem-estar do consumidor. Age indiretamente quando controla a existência dos

Lima; BENJAMIN, Herman de Vasconcellos; MIRAGEM, Bruno. Comentários ao Código de Defesa do Consumidor. 2.ed. São Paulo: Editora Revista dos Tribunais, 2006, p. 256.)

${ }^{475}$ HARVEY, Brian; PARRY, Deborah. The Law of Consumer Protection and Fair Trading. Third edition. Londres: Butterworths, 1987, p. 45

${ }^{476}$ O Estado é o responsável por promover o bem-estar coletivo. Lembra-se do que já foi falado neste capítulo sobre Rousseau e Tocqueville, ambos estudiosos da vontade geral e do interesse público. Para Rousseau, o Estado, por meio do Contrato, deve realizar a vontade geral, que não é a soma das vontades individuais, mas possui corpo próprio. Tocqueville defende que o interesse público é garantido pela realização da democracia. Ambos estão discutindo o bem-estar da coletividade.

${ }^{477}$ MANSFIELD, Edwin. Microeconomia: teoria e aplicações. Tradução de José Edgard da Mota Freitas e Mario Fonseca Geille. 2 ed. Rio de Janeiro: Campus, 1980, p. 401.

${ }^{478}$ CLARK, John Maurice. Instituições econômicas e bem-estar social. Rio de Janeiro: Zahar Editores, 1967, p. 110-127. 
produtos não desejáveis, a exemplo da tributação sobre cigarros e bebidas. ${ }^{479}$ Uma das formas de ação deste Estado é a regulação da concorrência.

Se o mundo fosse guiado por um paradigma de competição perfeita ${ }^{480}$, segundo Viscusi, Vernon e Harrington, as políticas antitruste, assim como os demais esforços regulatórios, seriam desnecessários. Todos os mercados consistiriam em um grande número de competidores, com poucas externalidades presentes e os benefícios do mercado sendo distribuídos equitativamente. Os competidores exerceriam vigilância mútua, evitando que qualquer um deles abusasse de seu poder para falsear a concorrência ou prejudicar o consumidor. ${ }^{481}$ Assim, haveria liberdade dos produtores, segundo Clark, tornando viável a escolha do consumidor e, assim, seu bem-estar. Como esta concorrência perfeita não existe, surge a força do Estado, por sua intervenção, proporcionando um ambiente concorrencial praticável.

Carlston e Treece contestam a idéia de que mais produtores significa mais opções ao consumidor, da mesma forma com que contestam que mais competidores significa mais qualidade. Vários mercados se preocupam em contar o número de competidores, como se este número fosse um sinônimo de possibilidades ao consumidor e aumento de seu bem-estar. O volume de oportunidades de transação é um parâmetro melhor para se avaliar o funcionamento da competição no mercado do que a mera existência de competidores. Um cartel ilustra bem esta afirmativa, pois não oferece muitas opções ao consumidor, embora existam vários competidores. Da mesma forma, limitações físicas e temporais podem fazer com que o grande número de produtos oferecidos por diversos competidores só seja acessível por alguns poucos

\footnotetext{
${ }^{479}$ Age indiretamente sobre o bem-estar com sua ação reguladora. Sugere-se imaginar um típico trabalhador norte-americano que é acordado por seu rádio-despertador cujas estações tiveram suas regras dispostas pela Federal Communications Commission. Ao tomar seu café, ele abre uma caixa de cereal que contém alimento severamente monitorado pela Food and Drug Administration. O leite que irá despejar sobre o cereal é também controlado pelo U.S Department of Agriculture. Teste proposto por Viscusi e Vernon (VISCUSI, W. Kip; VERNON, John M. and HARRINGTON, Joseph. Economics of Regulation and Antitrust. Third Edition. Massachussetts: the MIT Press. p. 2.)

${ }^{480}$ A convergência entre proteção do consumidor e a proteção da concorrência surge do fato de que, para existir concorrência perfeita, é necessário que 1) haja liberdade de entrada e saída do mercado (livre iniciativa); 2) haja um número infinito de compradores no mercado; 3) o produto seja ser homogêneo; e 4) todos os consumidores tenham perfeito conhecimento e informação sobre os produtos competidores. Desta forma, consumidores com plena capacidade de entender e conhecer o mercado, sendo livres para escolher o produto ou serviço que mais se aproxima aos seus anseios, é um requisito para a existência de concorrência perfeita.

${ }^{481}$ Op. Cit. p. 3.
} 
consumidores. Por exemplo, sapatos são oferecidos por diversas empresas em todo o território de um país. Contudo, em determinada época, por razões ligadas ao transporte, somente um destes competidores consegue oferecer seus produtos aos consumidores, que não podem se deslocar até outras ofertas. Isso demonstra a invalidade do argumento de que a maior competição deve ser, em todos os casos, o modelo ideal para os objetivos de controle pelo Estado.

Assim, os autores encerram este paralelo entre competição e o bemestar dos consumidores defendendo que uma melhor ação de controle antitruste deve ter como diretrizes: i) prover meios aos consumidores de descobrir seus valores entre o maior número possível de produtos e serviços; ii) produtos e serviços sendo oferecidos pelos fornecedores em grande economia de meios e a preços determinados pela efetiva competição; e iii) a idéia de que o maior objetivo é o desenvolvimento do consumidor como um indivíduo e personalidade, ao invés de satisfazer os desejos marginais dos modelos econômicos abstratos de compra.

Além de sugerir as diretrizes, opinam sobre a análise e controle do antitruste, que deve se basear nos questionamentos: i) o relacionamento de mercado proposto ou investigado provê meios adequados para a realização dos valores dos consumidores como inovação, pesquisa de mercado, escolha de produtos ou serviços, uso eficiente dos meios e redução de preços correspondente à economia de custos? ii) existe competição suficiente para assegurar que este tipo de performance de mercado seja mantida? iii) Será que um movimento compulsório em direção a um maior número de concorrentes poderia resultar em melhorias de mercado de acordo com as diretrizes propostas nos parágrafos anteriores $?^{482}$

Como conclusão, é possível entender que a intervenção do Estado ${ }^{483}$ deve ser útil para garantir um número mínimo de competidores que hajam em liberdade, tornando viável a escolha do consumidor. O consumidor, por sua vez, deve ser capaz de

\footnotetext{
${ }^{482}$ CARLSTON, Kenneth; TREECE, James. Antitrust and the Consumer Interest. Michigan Law Review, v. 64, n. 5, 1966, p. 777-780.

${ }^{483}$ Entende-se por intervenção no domínio econômico a intromissão do Estado na ou sobre a atividade econômica, caracterizada por uma ação ou omissão, diante do contexto de uma política econômica e consoante o sistema econômico vigente. (CORDOVIL, Leonor. A intervenção estatal nas telecomunicações: a visão do Direito Econômico. Belo Horizonte: Editora Fórum, 2005, p. 64.)
} 
escolher entre um maior número de produtos e serviços, fornecidos a preços de competição, sendo tratado como indivíduo, não como massa.

\subsubsection{A análise concorrencial pelas autoridades de defesa comercial}

No início da década de 90, havia dois únicos processadores de cálciometal na Comunidade Européia: Pechiney e Extramet. A primeira era a única produtora do metal na Europa. A Pechiney se recusou a fornecer o metal à Extramet, que requereu a abertura de investigação, contra a Pechiney, por abuso de posição dominante. Diante da recusa de fornecimento, a Extramet iniciou suas importações de cálcio-metal da China e da União Soviética. Pechiney pediu a abertura de investigação antidumping contra o produto proveniente da China e da União Soviética. A Comissão Européia decidiu impor medidas antidumping. Extramet pediu a anulação da decisão de imposição de medidas ao Tribunal de Justiça, argumentando que a Comissão não analisou a possibilidade de outros fatores estarem provocando o dano à indústria doméstica: se a Pechiney tivesse fornecido o produto à Extramet, as importações teriam sido menores e não teria sido provocado nenhum dano à indústria doméstica. $\mathrm{O}$ Tribunal de Justiça decidiu anular a decisão da Comissão, argumentando que as práticas anticompetitivas não foram estudadas antes da aplicação das medidas antidumping. ${ }^{484}$

Como já discutido, é relevante a intercessão entre concorrência e comércio, mas são contrários os efeitos do antidumping, que restringe a concorrência entre produtores domésticos e importações. ${ }^{485}$ Por esta razão, a concorrência entre os produtores domésticos, assim como a concorrência entre produtores domésticos e

\footnotetext{
${ }^{484}$ Contudo, alguns meses depois, a Comissão reabriu o caso e aplicou margens de dumping seis vezes maiores do que as aplicadas no caso inicial, não levando em consideração qualquer questão anticompetitiva. Extramet Industry v. Council of the European Communities, N. C-358/89, Decisão de 11 de junho de 1992, comentada por HOEKMAN, Bernard; MAVROIDIS, Petros. Dumping, Antidumping and Antitrust.Journal of World Trade, v. 30, n. 1, February 1996, p. 48.

${ }^{485}$ Embora o objetivo do antidumping seja restabelecer a situação de concorrência leal, e não impedir que ela exista, o efeito é, em grande parte dos casos, a sua restrição. Isto porque, com a liberalização do comércio, tornam-se diversas as opções ao exportador. Se não há motivação para a exportação para o país investigador, ele irá transferir os produtos anteriormente exportados a este destino para outros países.
} 
importações e a concorrência entre os usuários industriais ${ }^{486}$, são relevantes para a análise do interesse público.

As leis antidumping existentes não tratam da fonte do dano, que pode ser o comportamento das empresas do mercado doméstico. Para Sykes, uma autêntica análise antidumping deveria se focar na estrutura dos mercados importador $\mathrm{e}$ exportador, com o objetivo de encontrar a causa do dumping e saber se as empresas que alegam o dumping são dominantes e, em conseqüência, estão clamando por pura proteção. $^{487}$

A investigação sobre a fonte do dano já é prevista no artigo 3.5 do Acordo Antidumping, que determina a observação de todos os fatores que podem terem sido causa do dano, que não o dumping praticado. Tal prática, em respeito ao Acordo Antidumping, deve ser revista e aperfeiçoada pelas autoridades nacionais, como foi visto no item 1.1.4.2. Contudo, caberá às autoridades de defesa comercial apenas observar a situação concorrencial no mercado importador, levando esta concorrência (sua possível redução pelo antidumping) à consideração quando do balanço dos fatores que compõem o interesse público do Membro investigador. Se a redução da concorrência for relevante, ${ }^{488}$ ela pode ser um peso grande a fundamentar a não aplicação de medidas antidumping, mas somente se este peso não for compensado pelos outros aspectos sugeridos neste trabalho (emprego e desenvolvimento).

Algumas autoridades nacionais, como a Comissão Européia, recusaram-se, durante muito tempo, a acreditar em redução das importações devido à aplicação de antidumping, e, com esta redução, a diminuição da competição interna. Ao contrário, estas autoridades enfatizaram a necessidade de que as medidas antidumping

\footnotetext{
486 Para ilustrar a importância da análise da competição entre usuários industriais, cita-se o caso Carbonato Dissódico, que será amplamente discutido adiante. Neste caso, a Comissão Européia entendeu que a indústria vidreira, usuária industrial, que temia a aplicação de medidas, possuía certo poder de mercado e era bastante concentrada. Desta forma, era improvável que a indústria de carbonato dissódico recusasse vender para a indústria vidreira, e, mesmo se isto ocorresse, a indústria vidreira teria poder suficiente para negociar com outros fornecedores fora da Comunidade Européia.

${ }^{487}$ Tradução livre da versão inglesa de SYKES, Alan. Antidumping and Antitrust: what problems does each address? In Robert Z Lawrence. Brookings Trade Forum, 1998, Brookings Institutional Press, Washington D.C.

${ }^{488}$ Se a imposição de medidas for permitir que a indústria doméstica monopolize o mercado, a adoção do antidumping tende a se afastar do interesse público. (Decisão da Comissão 1023/97, de 6 de junho de 1997, impondo medidas antidumping provisórias às importações de pallets de madeira originários da Polônia, J.O L 150/4.
} 
fossem consideradas como efetivo meio de restaurar a competição (leal). A revisão das práticas comunitárias sobre a consideração do interesse comunitário foi importante para a modificação desta visão, passando a autoridade a aceitar a verdadeira colisão entre as medidas antidumping e os objetivos concorrenciais. ${ }^{489}$ Assim, admite-se que, quando os produtores comunitários estiverem usando as medidas antidumping para eliminar importadores do mercado, ou quando o efeito das medidas for a criação ou reforço de posição dominante no mercado comum, a imposição de medidas pode não ser de interesse comunitário. ${ }^{490}$

No teste comunitário, a Comissão deve avaliar, inicialmente, o estado da competitividade da indústria, examinando sua estrutura e características. Uma indústria com um grande número de produtores independentes indica um grau de competição relativamente alto. ${ }^{491}$ Por outro lado, a existência de uma indústria formada por um monopólio ou duopólio indica competição fraca. Quando o mercado é composto por um maior número de produtores e a competição é intensa, a aplicação de medidas antidumping estará mais próxima ao desejo do interesse comunitário. ${ }^{492} \mathrm{Da}$ mesma forma, quando o grupo de usuários industriais dispõe de vários fornecedores na indústria comunitária, a imposição de medidas antidumping se aproxima mais do interesse comunitário, já que o impacto será menos perceptível devido à existência de várias fontes. ${ }^{493}$

Caso exista um menor número de competidores, maior atenção deve ser dada à aplicação de medidas antidumping. Entretanto, mesmo neste caso, nada impede que as medidas estejam no interesse do país. No caso Mecanismos de argolas para encadernação, na Comunidade Européia, a Comissão entendeu que, embora fosse

\footnotetext{
${ }^{489}$ MACLEAN, Robert; ECCLES, Richard. A change of style not substance: the Community's new approach towards the community interest test in anti-dumping and anti-subsidy law. Common Market Law Review, v. 36, 1999, p. 126-128.

${ }^{490}$ Decisão da Comissão de 15 de dezembro de 1990, relativa ao procedimento do artigo 85 do Tratado EEC, 1991 J.O L 152/1, que reconhece medidas antidumping como um fator de dominação de mercados. ${ }^{491}$ Bolsas. Decisão da Comissão 209/97, de 3 de fevereiro de 1997, J.O L 33/11.

492 Máquinas de fax. Decisão da Comissão n. 2140/97, de 30 de outubro de 1997, J.O L 297/61. Decidiuse que as medidas antidumping não teriam um impacto significativo no mercado devido ao grande número de competidores.

${ }^{493}$ Metal siliconado. Regulamento (EC) 2496/97, de 11 de dezembro de 1997, impondo medidas antidumping definitivas na importação de metal siliconado originário da República Popular da China J.O L 345/1. Nesta decisão, levou-se em consideração a presença de vários fornecedores para os usuários industriais, além de fontes alternativas como o Brasil, a Noruega, etc.
} 
pequeno o número de competidores (duopólio), as medidas poderiam ser um fator corretivo para os exportadores e elas não impediriam a entrada de exportadores de outras origens no mercado. ${ }^{494}$

Também não se pode descartar a possibilidade de que a indústria doméstica esteja agindo em colusão e que isso seja percebido em uma investigação antidumping. Algum histórico de práticas colusivas abusivas na indústria não pode ser desconsiderado. Contudo, para as autoridades de defesa comercial, somente a prática ocorrida no passado ou observada no presente é relevante. A maioria das autoridades de defesa comercial não dá importância às alegações de que as medidas antidumping podem facilitar uma colusão futura. Em geral, as autoridades de defesa comercial não entendem não ter competência para analisar a existência de práticas anticompetitivas. $\mathrm{Na}$ Comunidade Européia, por exemplo, a autoridade não pode sequer enviar dados ou chamar a atenção das autoridades competitivas para possíveis práticas que tenham sido descobertas no decorrer da investigação. ${ }^{495}$ No Brasil, ao contrário, não há qualquer impedimento legal a esta comunicação. ${ }^{496}$

Durante a investigação antidumping Fósforos com fins publicitários $^{497}$, um pedido formal de investigação foi protocolizado perante a DireçãoGeral de Concorrência contra o maior produtor na indústria comunitária. A empresa foi acusada de estar abusando de sua posição dominante no mercado comunitário por meio de práticas anticompetitivas, como preço predatório e a aquisição de competidores. A divisão de concorrência rejeitou o pedido, sendo este a motivação da divisão de comércio para não analisar a questão. Contudo, autores criticam a decisão da divisão de comércio, alegando que ela não deveria ter se apoiado na decisão concorrencial para

\footnotetext{
${ }^{494}$ Mecanismos de argolas para encadernação. Decisão da Comissão n. 1456/96, de 25 de julho de 1996, J.O L $187 / 47$.

495 Art. 19.5 e 19.6 do Regulamento Básico europeu. No caso Fósforos com fins publicitários. Regulamento 2025/97, de 15 de outubro de 1997, J.O L 284/57, um pedido formal de investigação foi protocolizado perante a Direção Geral de Competição contra o maior produtor na indústria comunitária. A empresa foi acusada de estar abusando de sua posição dominante no mercado comunitário por meio de práticas anticompetitivas, como preço predatório e a aquisição de competidores. O DG Competition rejeitou o pedido, sendo o argumento do DG Trade para não analisar a questão.

${ }^{496}$ A legislação brasileira não prevê expressamente a comunicação entre as autoridades, mas as informações sigilosas, trazendo indícios de violação concorrencial, podem ser comparadas às provas emprestadas, que devem ser submetidas ao contraditório e a um exame de pertinência pela autoridade.

${ }^{497}$ Regulamento 2025/97, de 15 de outubro de 1997, impondo medidas definitivas às importações de Fósforos com fins publicitários originárias do Japão, J.O L 284/57.
} 
simplesmente concluir que o comportamento da indústria doméstica não deveria interferir na aplicação de medidas antidumping. Além disso, parece que não foi sequer procedida investigação para avaliar a prática. Agindo desta forma, a Comissão está, para os críticos, repetindo o clássico erro de ignorar preocupações legítimas dos usuários industriais. Em vários outros casos, a Comissão rejeitou a alegação de prática anticompetitiva argumentando que a imposição de medidas antidumping, se trouxesse aumento dos preços, traria também competição de outras origens. ${ }^{498}$

No caso Castings - peças vazadas, os importadores alegaram que, com a aplicação de medidas, os exportadores iriam sair do mercado, deixando sozinha uma indústria doméstica muito concentrada. Além disso, outra investigação de abuso de posição dominante no passado já teria demonstrando que a indústria doméstica poderia voltar a abusar de posição favorecida. A Comissão entendeu, contudo, que era provável que os exportadores permanecessem no mercado, pois tinham forte posição. Além disso, havia um volume relevante de importações provenientes de outros países. Sobre as investigações concorrenciais, a Comissão entendeu que elas foram conduzidas fora do período de investigação antidumping e que não houve condenação. ${ }^{499}$

Em um segundo momento, deve a autoridade observar a existência de outros competidores - ou possíveis competidores - em outros mercados geográficos. Segundo a análise feita no item 2.3.1.1.2.2. deste trabalho, o antidumping provocará uma redução às importações, funcionando como uma barreira à entrada de competidores, mas esta redução está limitada ao país investigado. É possível a contestação desta situação competitiva por competidores provenientes de mercados não investigados, que encontrarão no país aplicador das medidas um interessante consumidor. Esta possibilidade deve ser investigada pelas autoridades antidumping. ${ }^{500}$

O exame dos aspectos concorrências não deve ser tão profundo a ponto de se transformar em um processo antitruste, nem tampouco é necessário que as autoridades concorrenciais participem do trabalho. Assim como o artigo 3.5 do acordo já permite que as autoridades de comércio adentrem superficialmente na análise da

\footnotetext{
${ }^{498}$ WELLHAUSEN, Marc. The Community Interest Test in Antidumping Proceedings of the European Union. American University International Law Review, v. 16, p. 1027.

${ }^{499}$ Regulamento (CE) n. 1212/2005 do Conselho, de 25 de julho de 2005, J.O L 199/1, de 29/07/2005.

${ }^{500}$ VERMULST, Edwin; DRIESSEN, Bart. Op cit. p. 156.
} 
concorrência existente na indústria, não parece haver nada, no texto do acordo ou em outros documentos da $\mathrm{OMC}$, que impeça às autoridades de defesa comercial de analisarem, superficialmente, os pontos expostos nos parágrafos anteriores.

Deve haver cooperação entre as autoridades de defesa comercial e concorrencial, mas esta colaboração deve existir a partir de uma demanda da primeira. Seria penoso exigir um parecer das autoridades concorrenciais em casos antidumping, aumentando demasiadamente o tempo de condução das investigações. Nos Estados Unidos, parece haver estreita relação entre as duas autoridades. ${ }^{501}$ Mesmo que não haja interferência expressa, a simples utilização de critérios concorrenciais pela autoridade de defesa comercial já é um fator que desencoraja o pedido de abertura de investigações em determinados setores. ${ }^{502}$

Como explicado, as análises concorrencial e de defesa comercial têm objetivos distintos: preservar a concorrência e, com ela, realizar diversas opções políticas, ou proteger a indústria doméstica. Acrescentando-se ao texto o elemento interesse público, a proteção à indústria doméstica ficará condicionada à concordância com o que é desejável ao país, segundo critérios definidos. A pura substituição do antidumping pela defesa da concorrência deixará a proteção à indústria doméstica manca, permitindo que outros objetivos, que podem estar acima da própria defesa da concorrência, não sejam realizados. Por outro lado, a defesa comercial pode desejar proteger a concorrência se isso significar o bem-estar do consumidor. Neste caso, defesa da concorrência e defesa comercial voltam a ser forças paralelas.

A autoridade antidumping, na apreciação do interesse público sob o ponto de vista concorrencial, deve verificar qual interesse merece ser privilegiado (o balanço): a proteção à indústria doméstica, dando-lhe oportunidade de se recuperar do prejuízo causado pelo dumping, ou garantir a existência de concorrentes no mercado da indústria doméstica, e, com isso, mais produtos, mais variedade, menores preços. Ao

\footnotetext{
501 “O envolvimento da divisão antitruste em alguns casos tem tido como efeito esfriar os interesses ou o aparecimento de algumas empresas domésticas. Em algumas ocasiões, o departamento antitruste elaborou seu próprio questionário a estas empresas domésticas, argüindo questões sobre preços e outros assuntos que foram justificados pela investigação antidumping. no caso de audiências, os advogados da divisão têm questionado as testemunhas da indústria doméstica com profundidade sobre questões antitruste sensíveis." (Applebaum, Harvey, The antidumping laws - impact on the competitive process. Antitrust Law Journal, v. 43, 1974, p. 590.)

${ }^{502}$ STEGEMANN, Kaus. Op cit. 471.
} 
contrário das autoridades concorrenciais, a quem caberia discutir, em caso parecido, se é interessante que o mercado seja concentrado, se esta concentração traz eficiências que são aplaudidas, à autoridade antidumping interessará a análise deste acúmulo de poder econômico sobre a oferta ao consumidor intermediário (usuário industrial) e ao consumidor final. Se houver ameaça ou prejuízo real à competição no mercado da indústria doméstica, e esta ameaça ou dano significarem menos ofertas e maiores preços aos consumidores, deve-se verificar se esta ameaça ou prejuízo é maior do que os benefícios gerados à indústria doméstica. Se a resposta for positiva, ou seja, se houver mais desvantagens aos consumidores do que vantagens à indústria doméstica, estar-se-á diante da resposta às autoridades antidumping: a aplicação de medidas não parece ser de interesse público. A defesa da concorrência não é uma das funções da autoridade de defesa comercial, a defesa da concorrência é apenas um dos aspectos a serem colocados na balança para verificar se as medidas antidumping são ou não interessantes. 


\subsection{A PROTEÇÃO AO EMPREGO COMO SEGUNDO ELEMENTO DO INTERESSE PÚBLICO NO ANTIDUMPING}

Um fator quase sempre considerado pelos Membros que já aplicam o teste do interesse público é a necessidade de proteger empregos, sejam eles da indústria doméstica, sejam das outras partes prejudicadas por uma investigação antidumping. Contudo, não é muito simples decidir entre qual emprego deverá ser protegido, se dos produtores nacionais, dos usuários industriais ou importadores. Na maioria dos casos, as autoridades nacionais tendem a proteger a indústria que emprega maior número de trabalhadores, mas é importante que as autoridades investiguem, também, se o alto preço destes trabalhadores já não é fruto de alguma proteção estatal (ou seja, com a aplicação, estar-se-á protegendo duas vezes, o que significa aumentando o custo duas vezes), ou se a proteção a esta indústria, baseando-se na proteção aos seus trabalhadores, não estará interrompendo um movimento natural de realocação de mãode-obra em setores economicamente mais interessantes.

Considerações como estas não invalidam o fato de que o emprego é, e deve continuar sendo, uma preocupação importante das autoridades nacionais e um elemento fundamental para a investigação do interesse público na aplicação de medidas antidumping. O objetivo deste capítulo é contribuir para a análise do emprego como um dos fatores da balança do interesse público.

\subsubsection{A relação entre comércio internacional e o emprego}

A proteção ao trabalho e a garantia do emprego sempre foram preocupações para os Membros da OMC. O assunto já esteve na pauta das discussões em diversas oportunidades, tanto nas discussões sobre o comércio em geral, quanto nas discussões estritamente relacionadas à defesa comercial, mas sofre a repulsa dos países em desenvolvimento, que acreditam que a questão social, se incluída nos temas de comércio, poderá servir como ótima desculpa, pelos países desenvolvidos, para impedir 
a entrada de seus produtos. ${ }^{503} \mathrm{~A}$ discussão sobre a inclusão do tema nas negociações comerciais não é simples, em parte porque é bastante difícil separar o que é moral do que é economia. Alguns aspectos, como a proibição do trabalho escravo e a exploração do trabalho infantil, são claramente aspectos morais, mas também podem trazer consequiências econômicas. O divisor de águas não é facilmente identificável, muito menos saber quem irá dividi-las. ${ }^{504}$

A inclusão do emprego como tema nas negociações de comércio internacional está ligada ao debate sobre a instituição de parâmetros multilaterais de proteção ao trabalhador. Discute-se o estabelecimento de regras internacionais de respeito ao trabalhador, como jornada máxima de trabalho, idade mínima para o trabalho, condições de trabalho, entre outros pontos. Os governos são pressionados a reduzir a proteção nacional ao trabalho para reduzir os custos com a mão de obra e não prejudicar as empresas domésticas que estão competindo no mercado internacional. Se tais regras forem instituídas igualmente por todos os países, haverá incentivos para um aumento do preço geral das mercadorias e, com isso, não haverá desequilíbrio na competição. $^{505}$

A proteção social no comércio internacional se faz por meio da realização do princípio de condicionamento social. Como condicionamento social no comércio internacional, entende-se a subordinação da adoção de determinadas medidas comerciais à garantia de certos direitos sociais no processo de produção das mercadorias importadas. As medidas comerciais podem ter um caráter liberalizante (o Membro irá conceder acesso ao seu mercado se o outro Membro respeitar os direitos sociais) ou restritivo (o Membro não irá conceder acesso ao seu mercado se o outro Membro não

\footnotetext{
503 “As maiores nações industriais querem o elo entre valores do trabalho e a estrutura da OMC. A grande maioria dos Membros da OMC é contra esta proposta, temendo o uso indevido deste elo para reprimir suas exportações. Este medo é justificado por alguma experiência e evidências. Então, se um país como os Estados Unidos querem o elo, mas insistem que seus motivos são sinceros, por que não assumem a responsabilidade de trazer uma proposta que possa aliviar o temor dos países pobres?" (JACKSON, John. International Economic Law in Times that are interesting. Journal of International Economic Law, 200, p. 13.

${ }^{504}$ DEADORFF, Alan; STERN, Robert. What you should know about globalization and the World Trade Organization. Review of International Economics, vol. 10, issue 3, 2002, p. 416.

${ }^{505}$ É importante notar que o país paga o preço da harmonização das regras do trabalho, com o aumento do preço do produto ao consumidor. (BROWN, Drusilla. Labor Standards: where do they belong on the International Trade Agenda? Journal of Economic Perspectives, n. 15, v. 3, 2001, p. 101.)
} 
respeitar os direitos sociais). As duas espécies são chamadas de condicionamento social positivo e negativo. ${ }^{506}$

De acordo com os defensores da harmonização das regras do trabalho, quando a proteção ao trabalhador ocorre em um determinado setor de um pequeno país, no qual os preços são fixados de acordo com o mercado internacional (e os produtores deste mercado competem diretamente com as importações), os produtores deste mercado não conseguirão repassar o custo da regulação aos seus consumidores, que preferirão os produtos importados. Se as regras forem impostas multilateralmente, e não apenas pelo governo deste pequeno país, todos os produtores mundiais tenderão a aumentar seus preços e haverá um novo equilíbrio. Contudo, há que se lembrar que o consumidor terá que arcar com parte deste aumento. Esta seria uma razão para justificar a harmonização da proteção ao trabalhador. ${ }^{507}$

A proteção ao trabalhador pode ser manipulada, assim como as barreiras tarifárias, para a realização de objetivos políticos. Da mesma maneira com que um país pode decidir elevar as barreiras à importação (como, por exemplo, impondo medidas antidumping), para o alívio dos produtores domésticos, que aumentarão seus preços na ausência ou redução das importações, um país pode decidir reduzir sua proteção ao trabalhador como meio de diminuir o custo do produtor. Com isso, o preço do bem nacional será reduzido e, assim, poder-se-á observar uma menor demanda por importações. Estes e outros exemplos podem ser citados na defesa da inclusão do tema do trabalho nas negociações de comércio internacional.

\footnotetext{
${ }^{506} \mathrm{Em}$ alguns países, tem-se observado a formação de grupos ou sindicatos especializados na defesa das condições de emprego em países terceiros. Algumas associações tem se convertido em defensoras dos direitos de outros trabalhadores, especialmente quando seu próprio emprego está em risco. Por esta razão, alguns países parecem estar interessados em adotar medidas unilaterais para pressionar países que não respeitam as condições de trabalho. Contudo, a prática unilateral traz vários problemas sob o ponto de vista do direito internacional. Algumas atuações podem constituir uma violação ao direito do outro Estado de eleger seu sistema econômico, político e social, outras atuações violam o princípio da não intervenção nos assuntos internos de outro Estado. As restrições comerciais negativas só poderiam ferir algum princípio se tomarem a forma de contramedidas a um ato ilícito cometido pelo outro Estado, devendo ser proporcionais à gravidade do primeiro ato. MARTÍNEZ, Luis Hinojosa. Comércio justo y derechos sociales. Madri, Editorial Tecnos. 2002, p. 36;

${ }^{507}$ BAGWELL, Kyle; STAIGER, Robert. The simple economics of Labor Standards and the GATT. National Bureau of Economic Research. Working Paper 6604, disponível em www.nber.org/papers/w6604.
} 
Bagwell e Staiger apresentam uma justificativa para a inclusão de temas concernentes às políticas domésticas em meio aos assuntos afetos à OMC. Para eles, quando os governos negociam tarifas, eles estão implicitamente aceitando um determinado nível de acesso aos mercados. De acordo com as regras do GATT (artigo XXIII), a nenhum país é dado o direito de mudar políticas domésticas que causam prejuízo ao compromisso de acesso aos mercados, mesmo que nenhuma regra do GATT seja violada. Assim, nenhum país seria capaz de se apropriar de vantagem estratégica, por meio da alteração de suas leis de proteção ao trabalho, sem dever concessões adicionais aos outros países que o reclamassem. Com isso, todos os países teriam que neutralizar as repercussões econômicas internacionais de suas decisões de política doméstica, mas isso significa que poderiam adotar certas políticas que lhe parecessem favoráveis, desde que fornecendo as respectivas concessões. ${ }^{508}$

Martinez critica este entendimento. Para ele, não é fácil para um Membro provar que o baixo nível de proteção ao trabalhador de outro Membro lhe causa prejuízo. Além disso, como os países em desenvolvimento gozam de tratamento mais favorecido, e são eles os mais acusados de violação às regras do trabalho, é bastante complexa a discussão de medidas em matéria de compensação ou suspensão de concessões. $^{509}$

O artigo 7 da Carta de Havana não deixa dúvidas acerca da inclusão do tema nas negociações de comércio internacional. Intitulado "Normas de trabalho equitativas", assinala que a "existência de condições de trabalho não equitativas, especialmente nos setores de produção destinados à exportação, cria dificuldades no intercâmbio internacional." O mesmo artigo previu a cooperação com a Organização Internacional do Trabalho e a possibilidade de se recorrer ao mecanismo de solução de controvérsias previsto pela Carta de Havana para a discussão das questões sociais. ${ }^{510}$

\footnotetext{
${ }^{508}$ Neste caso, de acordo com o art. XXIII.2 do GATT, o Grupo Especial e o Órgão de Apelação recomendarão ao Membro que realize um ajuste mutuamente satisfatório para as partes em conflito. BAGWELL, Kyle; STAIGER, Robert. Op cit. s/n. ${ }^{509}$ MARTINEZ, Luis. Op cit. p. 108.

510 “Artigo 7 da Carta de Havana 1) Os Estados Membros reconhecem que as medidas relacionadas ao emprego devem levar em conta os direitos dos trabalhadores, conforme as declarações, convênios e acordos intergovernamentais. Reconhecem, também, que todos os países têm um interesse comum no estabelecimento e manutenção de normas equitativas de trabalho em relação à produtividade da mão-deobra e, por conseguinte, na melhora dos salários e das condições de trabalho na medida em que permitam
} 
A leitura do GATT, contudo, permite concluir que não há qualquer disposição que se refira aos direitos sociais como condicionamento do comércio internacional. Apesar disso, não faltam aqueles que defendem que há várias disposições que podem justificar restrições ao comércio como reação ao dumping social. Os Membros da OMC que são também Membros da OIT devem se comportar de forma coerente com todos os compromissos internacionais. ${ }^{511}$ Todavia, a inexistência de referências expressas impede que a questão social seja vinculada aos compromissos assumidos em matéria comercial. ${ }^{512}$

Diversas discussões sobre a inclusão do tema antecederam a criação da $\mathrm{OMC}^{513}$, mas, ao final, nenhuma regra clara foi incluída na Ata Final de Marrakesh. Determinados textos resultantes da Rodada Uruguai trazem referências a objetivos de elevar o nível de vida e alcançar o pleno emprego de seus cidadãos. ${ }^{514}$ A mais importante referência se destaca pela sua localização: no preâmbulo do Acordo Constitutivo da OMC, que menciona que

\begin{abstract}
“as partes, pelo presente acordo, reconhecendo que suas relações na esfera comercial e econômica devem tender a elevar os níveis de vida, alcançar o pleno emprego e um volume considerável e em constante aumento de ingressos reais e demanda efetiva e a acrescentar a produção e o comércio de bens e serviços, permitindo, ao mesmo tempo, a utilização ótima dos recursos mundiais em conformidade com o objetivo de desenvolvimento sustentável e procurando proteger e preservar o meio ambiente, de maneira compativel com suas respectivas necessidades e interesses segundo os diferentes níveis de desenvolvimento econômico.”
\end{abstract}

a produtividade. Os Estados reconhecem que a existência de condições de trabalho não equitativas, especialmente nos setores destinados à exportação, cria dificuldades às trocas internacionais. Em conseqüência, cada Estado Membro adotará todas as medidas apropriadas e factíveis para fazer desaparecer estas condições em seus territórios. 2) os Membros que sejam também Membros da OIT colaborarão com esta Organização com o fim de colocar em prática este compromisso. 3) para todas as questões relativas às normas de trabalho que puderem ser submetidas conforme as disposições dos arts. 94 e 95, a Organização consultará e colaborará com a OIT.” (Tradução livre da versão em espanhol).

511 Entendimento ratificado pelo art. 31.3.c da Convenção de Viena de 1969, que dispõe como material que pode ajudar na interpretação de um tratado toda forma pertinente de direito internacional aplicável à relação entre as partes.

512 MARTINEZ, Luis. Op cit., p. 82.

${ }^{513}$ Proposta de reforma do artigo XXIII, feita em 1953, pelos Estados Unidos, nova tentativa de introduzir o tema na Declaração Ministerial de Punta del Este, nova tentativa do governo norte-americano de incluir o tema em 1987 e 1990. Ver mais em WILKINSON, R. The WTO in Crisis. Exploring the Dimensions of Institutional Inertia. Journal of World Trade, v. 35, issue 3, 2001, p. 408.

${ }^{514}$ Como a consideração de dados sobre salários e emprego como critério para averiguação de prejuízo grave (art. 6 do Acordo sobre Têxteis) e a consideração dos salários e do nível de emprego para avaliar o dano provocado à indústria doméstica pelas importações a preços de dumping (art. 3.4 do Acordo Antidumping). 
Pela leitura do referido preâmbulo, pode-se considerar que, embora não se tenha feito previsão específica do procedimento ou de negociações em direção a regras claras sobre a proteção ao trabalhador, o pleno emprego não deixou de ser uma preocupação multilateral, devendo ser observado quando das decisões unilaterais e quando das negociações como um importante pilar do comércio internacional.

\subsubsection{O emprego como preocupação no antidumping}

Nas negociações e nos textos acima mencionados, os Membros da OMC têm como objetivo construir regras de proteção às condições de trabalho, evitando que os países, para realizar os desejos egoístas dos agentes privados, reduzam os direitos sociais. No que concerne às medidas de defesa comercial, como o antidumping, a proteção ao trabalho é discutida sob outro ponto de vista. O objetivo do país investigador é proteger o nível de emprego e os salários pagos aos empregados de sua indústria, e não de um país terceiro. Trata-se de proteção ao emprego dentro do país.

A proteção ao emprego dentro do país pode ocorrer por duas razões. A primeira delas está intimamente relacionada à moral, sendo a vontade do país investigador proteger a indústria doméstica contra importações provenientes de países em que não há respeito às normas do trabalho. Neste caso, a proteção é vista como sinônimo de punição ao terceiro país que não respeita os direitos sociais e, ao mesmo tempo, como meio de salvaguardar os interesses sociais do próprio país. ${ }^{515}$ A segunda forma de proteção não está apoiada na moral, independente de o país investigado estar desrespeitando os direitos dos trabalhadores. Neste caso, a motivação do país investigador é claramente econômica, protege-se a indústria e o emprego de qualquer

\footnotetext{
${ }^{515}$ A possibilidade de proteção, por meio de medidas de defesa comercial, baseada em uma justificativa de caráter sócio-moral, não é ponto pacífico entre os Membros da OMC, mas também não há qualquer decisão do mecanismo de solução de controvérsias ou qualquer texto que impeça que esta seja a justificativa. O Regulamento CE n. 3286/94, por exemplo, permite que a Comunidade Européia adote medidas restritivas para eliminar o dano causado pelo comércio com países terceiros. Este documento parece permitir que sejam adotadas quaisquer medidas para eliminar um dano de natureza econômica a uma indústria da Comunidade, mesmo que a razão para a ação contra o terceiro país, ao lado do dano de natureza econômica provocado à indústria doméstica, seja a falta de respeito às normas do trabalho. (MARTÍNEZ, Luis Hinojosa. Op cit. p. 126).
} 
competição com a mão-de-obra barata (independente do respeito a direitos sociais). ${ }^{516}$ Qualquer uma das razões mencionadas exige, entretanto, que seja provocado um dano (ou ameaça de dano), de natureza econômica, à indústria doméstica.

Os próximos tópicos objetivam fornecer elementos para que as autoridades investigadoras e os países importadores possam mais bem avaliar o interesse público através de um dos seus três critérios: a proteção ao emprego.

\subsubsection{Por que não proteger os empregos da indústria doméstica}

Duas questões devem ser debatidas, antes de se aplicar medidas antidumping: i) será que o desemprego e a redução dos salários na indústria doméstica são sempre e somente ocasionados pelo aumento das importações? Os países investigadores têm como obrigação a investigação deste nexo de causalidade ${ }^{517}$, mas várias das causas não são verdadeiramente investigadas, tornando-se a perda de empregos e a redução dos salários na indústria doméstica instrumentos facilmente manipulados para a proteção indevida por meio do antidumping; ii) e mesmo quando este desemprego e redução da remuneração são causados pelo dumping, será a aplicação de medidas antidumping sempre justificável? Por vezes, o desemprego e a redução da remuneração são conseqüências de um movimento de alocação de funções entre parceiros comerciais, ou parte de um movimento em direção à igualdade entre estes parceiros. Além disso, ressalta Stegemann que o dumping pode não causar desemprego se os produtores domésticos estiverem preparados para reduzir sua margem de lucro e para aumentar a eficiência. ${ }^{518}$ Nestes casos, as medidas antidumping estarão em sentido contrário aos objetivos de liberalização comercial.

\footnotetext{
516 “A idéia de que a proteção tarifária gera emprego está ligada à noção popular de que o modo de vida do trabalhador norte-americano deve ser protegido contra a ruinosa competição com a mão de obra barata." (Stolper, Wolfgrang; SAMUELSON, Paul. Protection and real wages. Review of Economic Studies, v. 9, n. 1, Novembro, 1941, p. 58.)

${ }_{517}$ Art. 3.5 do Acordo Antidumping.

${ }^{518}$ STEGEMANN, Kaus. Op cit. p. 474. JAVELOT ressalta que não somente as empresas devem estar atentas e aptas a se adaptar a este movimento, como também o Estado deve ser um parceiro importante nesta adaptação. As economias devem ser capazes de organizar a regressão de setores em declínio e a progressão de outros setores em ascensão. A falta de capacidade de se adaptar de algumas economias
} 
Cabe responder ao primeiro questionamento com um exemplo. $\mathrm{Na}$ Comunidade Européia, diante da taxa de desemprego bastante expressiva ${ }^{519}$, foram elaborados diversos programas objetivando a criação de empregos e a proteção aos trabalhadores. Muitos destes programas envolvem pesados subsídios estatais, gerando um valor extraordinariamente alto para cada emprego. ${ }^{520}$ Com isso, observa-se um aumento do custo do produtor e, com isso, o desejo de reduzir progressivamente o número de vagas disponíveis. Não parece haver preocupação com a quantificação do valor de cada emprego que recebe a proteção estatal. ${ }^{521}$ Neste caso, a queda no nível de emprego será fruto de uma ação endógena, não de qualquer relação com o dumping do produto importado. Se a Comunidade Européia decidir, diante da comprovação de dumping, aplicar medidas, estará arcando, duas vezes, com o mesmo custo.

Responder-se-á, agora, ao segundo questionamento: a aplicação de medidas antidumping, com o objetivo de salvar empregos, que vai de encontro aos objetivos da liberalização comercial, é justificável? Ocorre um fenômeno inegável, no comércio internacional, de deslocamento da demanda de mão-de-obra dos países desenvolvidos em direção aos países em desenvolvimento. Contudo, esta alocação de empregos deve ser tratada como um fenômeno passageiro, que tende à igualdade de empregos em longo prazo. Cabe explicá-lo.

Não há dúvidas que os países em desenvolvimento ainda concentram a maior parte de sua mão-de-obra em indústrias que demandam maior número de empregados, ao passo que os países desenvolvidos concentram a maior parte das indústrias que demandam tecnologia, ao invés de trabalho (o chamado ciclo internacional do produto). ${ }^{522}$ Os países em desenvolvimento são também identificados

desenvolvidas impediu um ajuste rápido e encorajou os grupos afetados pelas novas condições de concorrência a procurar medidas de proteção. (JAVELOT, Sylvie. La loyauté dans le commerce international. Paris: Economica. 1998, p. 127.)

${ }^{519}$ Em agosto, o índice registrado foi de 8,4\% em 2007, de acordo com a Eurostat, agência de estatísticas européia, www.eurostat.ec.europa.eu.

${ }^{520}$ Muitos programas estão relacionados no sítio oficial da União Européia, na parte destinada ao "Emprego e Assuntos Sociais", em www.europa.eu.int.

${ }^{521}$ STANBROOK, Clive; BENTLEY, Philip. Dumping and subsidies: the Law and procedures governing the imposition of anti-dumping and countervailing duties in the European Community. 3 ed. Londres: Kluwer Law International. p. 154.

522 "Desenvolvido pela Apple na Califórnia, fabricado na China”. Com estes dizeres estampados na embalagem de seus iPods, a empresa americana deixa claro qual é a nova realidade da divisão do trabalho: alguns países tem as idéias, outros as executam. Quem ganha a maior fatia dos lucros? Aquele 
como aqueles em que a mão-de-obra é mal remunerada, sendo menores os custos do produtor. As consequiências do intercâmbio entre países em desenvolvimento e países desenvolvidos é o aumento do desemprego nestes últimos, gerando pedidos de proteção. ${ }^{523}$ Os países desenvolvidos ficam com o melhor resultado, mas os países em desenvolvimento podem mudar este quadro.

Com a terceirização da produção, dos países desenvolvidos para os países em desenvolvimento, é tendência natural que, em algum tempo, os países em desenvolvimento passem a desenvolver a tecnologia e não mais a importem, deixando de ser meros executores. Inicialmente, os países tecnologicamente avançados são imitados pelos países menos desenvolvidos, revelando a fragilidade da proteção à propriedade intelectual. Posteriormente, os países em desenvolvimento começarão a produzir conforme sua própria necessidade tecnológica, surgindo a inovação (através do fenômeno learning by doing, ou apprentissage par la pratique). ${ }^{524} \mathrm{Em}$ mais algum tempo, o movimento norte-sul poderá ser igualado pelo movimento sul-norte. Se forem impostas medidas antidumping nos países desenvolvidos, para proteger os trabalhadores da indústria doméstica da concorrência com trabalhadores de países menos desenvolvidos, bloqueando as importações provenientes destes países executores, ficará interrompido este ciclo considerado gerador de bem-estar e igualdade.

A relação entre aplicação de medidas antidumping e criação de empregos não é evidente. As medidas antidumping não parecem resolver o desemprego na Europa. No setor têxtil, por exemplo, uma grande parcela da produção de carpetes para aeroportos, grandes edifícios, casas, etc., é realizada na Europa, onde a produção

que teve a idéia, claro. Os Estados Unidos, o Japão, a Alemanha são alguns dos países que estão deixando para trás a condição de sociedades industriais para se tornar economias do conhecimento.(Tecnologia: Derrota na criatividade. Revista Veja, 3 de setembro de 2008, p. 99) "Hightech companies in particular are becoming increasingly global. For many such companies, there is an emerging international division of labor, in which coutries can specialize in the manufacture of individual components for complex products, rather than the entire product. Some companies, for example, have set up research facilities overseas with impressive results. Swiss and German scientists based in Switzerland but working for IBM, for example, made key breakthroughs on high-temperature superconductivity. Similarly, Texas Instruments' software has engineering laboratories in India, while Toyota has a major research center in southern California." (BARFIELD, Claude. High-tech protectionism: the irrationality of antidumping laws. Washington: The AEI Press, 2003, p. 9).

${ }^{523}$ Os testes para comprovar estas afirmações foram expostos nos três primeiros artigos de International Trade and Labour Markets, coordenado por Jitendralal Borkakoti e Chris Milner, que estudaram os mercados chileno, mexicano e do Reino Unido. BORKAKOTI, Jitendralal; MILNER, Chris. International Trade and Labour Markets. London: MacMillan Press, 1997, p. 1 a 90.

${ }^{524}$ OMC, Rapport sur le Commerce Mondial 2008: le commerce à 1'heure de la mondialisation. p. 73-76. 
altamente desenvolvida e computadorizada está disponível. Quanto maior o desenvolvimento neste setor, menor o número de empregados destas indústrias. Isso não tem nada a ver com a competição enfrentada pela indústria comunitária de produtos importados de terceiros países. Se a Comissão decide aplicar medidas antidumping, pode aumentar severamente os custos para o consumidor, sem que qualquer benefício seja percebido para os trabalhadores. ${ }^{525}$

Há também muita discussão no que se refere à proteção dos salários por meio da aplicação de medidas antidumping. Alguns economistas já desafiaram a afirmação de que os melhores salários são pagos por indústrias protegidas, tais como a indústria têxtil, vestuário e sapatos. ${ }^{526} \mathrm{Em}$ geral, estas indústrias tendem a empregar trabalhadores menos qualificados e menos remunerados do que as indústrias não protegidas. A clássica relação entre os efeitos da proteção e comércio sobre a remuneração (proteção reduz importações, e importações reduzidas aumentam a demanda por trabalho, que, por sua vez, aumenta a remuneração) é desafiada por modelos econômicos que buscam provar que o aumento da demanda por trabalho, no caso de redução de importações, gera mais vagas de trabalho, mas não aumento de remuneração. $^{527}$

Para Huang, o clássico argumento contra a proteção, mesmo no caso de desemprego, é que a medida estará impedindo que a mão-de-obra seja realocada naturalmente para setores diferentes e mais eficientes. Outro argumento é que a proteção para garantir o emprego é equivalente à exportação do desemprego resultando na perda de bem-estar mundial e nas dificuldades de outros países para exportarem. ${ }^{528}$ Mesmo se for possível aliviar o desemprego com as tarifas para tentar desviar a demanda agregada do exterior para os mercados domésticos, alguns economistas

\footnotetext{
${ }_{525}$ BERNERT, Peter. Op cit. p. 5.

526 GASTON, Noel; TREFLER, Daniel. Protection, Trade and Wages: Evidence from U.S. Manufacturing. Industrial and Labour Relations Review, v. 47, n. 4, julho 1994, p. 574.

${ }_{527}$ McDonald, Ian; SOLOW, Robert. Wage Bargaining and unemployment. American Economic Review, v. 71, n. 5, Dezembro de 1981, p. 896-908.

${ }^{528}$ HUANG, Thomas. Trade Remedies: Laws of dumping, subsidies and safeguards in China. London: Kluwer Law International, 2002, p. 19.
} 
acreditam que a melhor política é remover a causa da falha de mercado, criando suficientemente, mais demanda agregada e deixando o comércio livre. ${ }^{529}$

Nas hipóteses acima mencionadas, a aplicação de medidas antidumping, com o objetivo de salvar os empregos da indústria doméstica, não é desejável. Nestes casos, os prejuízos sociais ou causados a outros setores afetados poderão, facilmente, superar os benefícios obtidos pelos produtores nacionais. São estes exemplos proposições que devem ser observados pelas autoridades de defesa comercial no difícil balanço entre salvar empregos, preservar a concorrência ou incentivar o desenvolvimento industrial e tecnológico.

\subsubsection{Proteger quais empregos?}

Nos anos 40, a indústria de flores nos Estados Unidos concentrava sua produção nos Estados da Pensilvânia e Nova York, desenvolvendo-se velozmente de acordo com as melhorias no transporte aéreo no país. Um empresário norte-americano estudou a produção e descobriu que Bogotá, na Colômbia, era a melhor cidade do mundo para o crescimento das flores, além de oferecer um custo infinitamente menor do que o custo da produção nos Estados Unidos. Em 1989, a indústria colombiana de flores empregava, aproximadamente, 70.000 pessoas, $70 \%$ das quais mulheres, sendo responsáveis por outros 50.000 empregos em setores relacionados, tais como empacotamento e transporte. A indústria contribuiu para relevantes melhorias nas condições de vida do campo e nas cidades colombianas. As flores eram exportadas para Miami e, de lá, distribuídas para o restante do país, empregando 2.000 pessoas somente em Miami.

O sucesso das importações de flores fez com que os produtores norteamericanos pedissem restrições à sua entrada no País, sem a necessidade de comprovar que as importações eram injustas. Tal pedido foi recusado, entendendo a International Trade Commission que a indústria norte-americana não estava sofrendo prejuízo. A indústria doméstica insistiu, alegando que o sucesso das exportações colombianas

\footnotetext{
${ }^{529}$ Bhagwati, Jagdish. Free Trade Today. New Jersey: Princeton University Press, 2002.
} 
devia-se ao fato de que o governo daquele país subsidiava a produção. Além disso, os produtores se organizaram e enviaram petições diversas, elaboradas por produtores de diferentes flores, conseguindo, enfim, a proteção.

Este caso ilustra uma proteção cega em relação ao peticionário. Foram levados em consideração a redução das horas de trabalho dos empregados, a redução dos lucros e outros efeitos da importação. Não foram considerados os empregos dos 2.000 importadores de Miami, os 28 milhões de dólares pagos em tributos ou as 16.000 novas lojas abertas desde $1965 .^{530}$

Segundo o art. 3.4 do Acordo Antidumping, o exame do dano causado à indústria doméstica comportará a avaliação de todos os fatores econômicos e índices econômicos pertinentes, entre eles efeitos negativos, efetivos ou potenciais, sobre o emprego e os salários. Se o nível de emprego e os salários são critérios examinados na constatação do dano, são eles considerados importantes critérios econômicos na avaliação dos efeitos negativos a serem provocados às outras partes afetadas pela medida antidumping e ao interesse público (aqui incluídos o ganho de bem-estar e a diminuição dos custos).

Na aplicação da medida, estar-se-á protegendo a indústria doméstica, dando-lhe alívio para que possa se desenvolver e se recuperar de um dano. Por outro lado, estar-se-á aumentando o custo das importações, custo este que poderá ser arcado pelos importadores, se não for repassado aos usuários industriais ou aos consumidores finais. Aqueles que arcarem com os custos, sejam eles importadores ou usuários finais, poderão desejar reduzir outros custos, como emprego e salários. A questão posta para análise da autoridade investigadora é desvendar quais empregos e salários devem ser protegidos, se os da indústria doméstica, de seus fornecedores, dos importadores ou dos usuários comerciais.

Esta dúvida é trazida em quase todos os casos de análise de interesse público. A autoridade considera, em primeiro lugar, o fato de a indústria doméstica ter demitido empregados no período investigado, especialmente se o setor for demandante de mão-de-obra e se tiver havido grande investimento na criação de postos de trabalho.

${ }^{530}$ FINGER, Michael. Antidumping: How it works and Who gets hurt. Michigan: The University of Michigan Press, 1993, p. 40. 
As medidas antidumping recebem ainda maior apoio se os estabelecimentos industriais forem localizados em áreas econômicas menos favorecidas.

A questão foi desafiada pela Comunidade Européia em alguns casos. ${ }^{531}$ No caso LORS (disc-chargers), a baixa demanda da indústria doméstica por empregos, devido à natureza da atividade, foi considerada como aspecto importante para avaliar que o emprego não seria um dos benefícios da aplicação de medidas. ${ }^{532}$ No caso das Fotocopiadoras, a única representante da indústria doméstica foi considerada como demandante de mão-de-obra, o que seria mais um argumento para a sua proteção, mesmo que prejudicando os interesses dos consumidores em um curto prazo. Este entendimento foi confirmado pelo Tribunal de Justiça. ${ }^{533}$ No caso Lâmpadas, a Comissão considerou que a proteção ao grande número de empregados (várias centenas) da indústria doméstica era uma das justificativas para a aplicação da medida antidumping. Além disso, um dos fornecedores da indústria doméstica cooperou com a investigação, pedindo a continuidade da aplicação das medidas, sendo uma das principais razões a necessidade de assegurar o trabalho a centenas de trabalhadores localizados em vários pontos da Comunidade (Alemanha, Espanha, Itália, Eslováquia e Hungria). ${ }^{534}$ Por fim, cabe mencionar o caso Bolsas da China, no qual indústria comunitária foi considerada como importante empregadora na Comunidade Européia e o fato de que os dois produtores estavam localizados em áreas carentes, empregando nesta região, foi considerado relevante. ${ }^{535}$

É possível depreender, na análise das decisões acima, que o critério adotado pela Comissão Européia é a proteção ao maior gerador de empregos. ${ }^{536} \mathrm{~A}$

\footnotetext{
${ }^{531} \mathrm{Na}$ União Européia, estão entre os objetivos do bloco a promoção do desenvolvimento harmonioso, equilibrado e sustentável das atividades econômicas e elevado nível de emprego e proteção social (Art. 2 do Tratado que Institui a Comunidade Européia). Para tanto, entre outras missões, ela deve: i) promover uma coordenação entre as políticas de emprego dos Estados-Membros, com o objetivo de reforçar a sua eficácia, mediante a elaboração de uma estratégia coordenada em matéria de emprego; (...) (art. 3, inciso 1 , letra i).

532 Sistema de leitura ótica para carros. Regulamento (EU) n 1999/55. 21 de dezembro de 1998, O.J. L18, 23/01/1999, p. 62.

533 Julgamento da Corte de 14 de março de 1990, Gestetner Holdings v. Council and Commission of the European Communities, case C-156/87. European Court reports, 1990, p. I-00781.

${ }^{534}$ Lâmpadas. Regulamento (EU) n 1470/2001, de 16 de julho de 2001, OJ L 195 19/07/2001, p. 8.

535 Bolsas. Decisão da Comissão 209/97, de 3 de fevereiro de 1997, J.O L 33/11.

${ }^{536}$ Esta proteção ao emprego será dosada e balanceada por outros critérios, tais como os custos arcados por cada interessado, o impacto sobre a produção e o valor da produção dos usuários industriais, a diminuição das opções aos consumidores, entre outros. (Decisão no caso Peças Vazadas confirma este
} 
leitura de algumas decisões na Comunidade Européia permite concluir que as indústrias que empregam maior número de pessoas são também aquelas que têm maior força de pressão sobre as autoridades dos países, que, por sua vez, pressionam o Conselho Europeu para uma decisão em seu favor. ${ }^{537}$

No que concerne à prática norte-americana, Hansen e Park buscaram evidências de que os setores protegidos pelas decisões antidumping sempre foram aqueles que demandam maior número de trabalhadores. No caso, os economistas explicam este fenômeno pelo fato de que estas indústrias são capazes de produzir mais lucros, maior organização, mais influência e, conseqüientemente, mais votos. ${ }^{538}$

No Brasil, nos poucos casos em que o interesse público foi, de alguma forma, justificativa para a não aplicação de medidas, não há manifestações expressas sobre o emprego. $\mathrm{O}$ valor do trabalho humano foi incluído na Constituição Federal brasileira como princípio. Este valor deve orientar toda e qualquer intervenção econômica, sendo um importante elemento na análise precedente à aplicação de direitos antidumping. 539

De fato, a proteção à indústria que emprega o maior número de trabalhadores parece ser um bom critério. Contudo, ele não pode ser um critério único. A autoridade de defesa comercial deve observar, também, os elementos descritos no tópico anterior, tais como: i) se o desemprego em uma das indústrias observadas e balanceadas significará realocação desta mão de obra para setores mais produtivos e interessantes à economia nacional; ii) se a perda do emprego em uma das indústrias já é

entendimento, Peças Vazadas - Regulamento (CE) n. 1212/2005 de 25 de julho de 2005, J.O L 199/1, de 29/07/2005.)

${ }^{537}$ No caso Televisão a cores (Cathode-ray Color Television Picture Tubes), o emprego foi um dos principais fatores de desempate entre a indústria doméstica e os importadores e consumidores. Como os produtores domésticos empregavam milhares de pessoas em vários países da Comunidade Européia, esta preocupação prevaleceu sobre os empregos dos importadores ou mesmo os prejuízos causados aos consumidores com a aplicação de medidas (Televisão a cores. Decisão da Comissão 837/00, de 19 de abril de 2000, J.O L 102/15).

${ }^{538}$ HANSEN, Wendy e PARK, Kee. Nation-State and Pluralistic Decision Making in Trade Policy: The case of the International Trade Administration. International Studies Quarterly, v. 39, 1995, p. 195.

539 Para José Afonso da Silva, a circunstância de a Constituição declarar que a ordem econômica é fundada na valorização do trabalho humano e na iniciativa privada, consagra uma economia de mercado, de natureza capitalista, pois a iniciativa privada é um princípio básico da ordem capitalista, mas, embora capitalista, a ordem econômica dá prioridades ao valor do trabalho humano sobre todos os demais valores da economia de mercado. (AFONSO DA SILVA, José. Curso de Direito Constitucional Positivo, 18 ed., São Paulo: Malheiros, 2000, p. 274.) 
consequiência do alto custo da mão de obra provocado pela proteção estatal já existente; iii) se há indícios de que a proteção gerará mais empregos (o que depende do possível desenvolvimento da indústria, que será discutido adiante); e iv) se há indícios de que a proteção ao emprego trará um real aumento aos salários. 


\subsection{O DESENVOLVIMENTO TECNOLÓGICO E INDUSTRIAL COMO TERCEIRO ELEMENTO DO INTERESSE PÚBLICO NO ANTIDUMPING}

São comuns os casos em que a autoridade nacional decide iniciar uma investigação antidumping, ou aplicar medidas definitivas, baseando-se no fato de que a indústria doméstica é estratégica ao desenvolvimento industrial e tecnológico do país. Este é um requisito essencial, pois está economicamente ligado ao interesse público e ao desenvolvimento econômico do setor que busca a proteção. Contudo, em alguns casos, a prática tem demonstrado que a escolha de uma indústria com base em sua importância estratégica pode ser uma decisão errada.

Em outros casos, a autoridade investigadora decide proteger a indústria doméstica, ou qualquer das partes afetadas pela aplicação de medidas antidumping, com base na necessidade de incentivar o seu desenvolvimento, mesmo que ela não seja estratégica. Contudo, a decisão pode se tornar um erro se a autoridade investigadora não for capaz de concluir sobre a possibilidade de desenvolvimento desta indústria, ou seja, a possibilidade e capacidade da própria indústria de atingir os objetivos traçados pela política que motivou a decisão antidumping. O setor protegido pode não ser mais interessante à economia do país, ou pode ser um setor que não tende a se desenvolver, pela própria natureza da atividade. ${ }^{540}$

Por isso, alguns pontos podem ser lembrados pela autoridade quando a investigação do interesse público para a aplicação de medidas for baseada na possibilidade de desenvolvimento industrial e tecnológico futuro, da indústria doméstica ou de qualquer indústria examinada. São alguns dos pontos a capacidade de desenvolvimento da indústria, a capacidade de investimento, o interesse nacional pelo desenvolvimento da indústria.

\footnotetext{
${ }^{540}$ Como no caso LORS, na Comunidade Européia, em que a Comissão concluiu que o parco crescimento alcançado pela indústria nos últimos anos parecia demonstrar que não eram grandes as chances de desenvolvimento do setor no futuro. Sistemas de leitura ótica a laser para carros, Regulamento (EU) n 1999/55. 21 de dezembro de 1998, O.J. L18, 23/01/1999, p. 62.
} 


\subsubsection{A relação entre comércio internacional e desenvolvimento tecnológico e industrial}

A globalização provocou sensíveis mudanças nos padrões de industrialização. Até mesmo as pequenas empresas encontraram um interessante elo com empresas transnacionais, celebrando acordos como franquia, joint venture, licenciamento e subcontratação.

A integração da produção e distribuição de bens e serviços não é um fenômeno novo. Após a Segunda Guerra Mundial, a desregulação gradual dos mercados, a abolição de tarifas em vários países e a privatização de empresas criaram uma nova estrutura de intercâmbio entre países e empresas. A globalização, neste contexto, é a resposta das empresas às mudanças no ambiente comercial internacional, processo derivado de mudanças nas políticas, com a liberalização dos mercados e do fluxo de capitais, e da aceleração do progresso tecnológico e alocação de empresas em diferentes e antes inimagináveis territórios. ${ }^{541}$

As empresas e governos que se recusaram a se adaptar a estas mudanças tentam se proteger da ameaça da competição com os novos parceiros, mas arcam com o alto custo de serem colocados de lado. Não somente não são considerados como parceiros, como têm seus raros investimentos mal vistos pelos países competidores. Além disso, provocam certa desconfiança dos investidores estrangeiros, na realização de seus investimentos diretos e indiretos.

Os países que participam, com sucesso, do movimento de globalização, possuem duas características em comum: i) trabalhadores bem educados, capazes de competir com a mão de obra das demais economias; ii) políticas que contribuem para a atração e permanência de investimentos industriais, especialmente o investimento direto. ${ }^{542}$

\footnotetext{
${ }^{541}$ UNITED NATIONS INDUSTRIAL DEVELOPMENT ORGANIZATION, The Globalization of Industry: implications for developing countries beyond 2000. Viena, Dezembro 1996, p. 35.

${ }^{542}$ UNITED NATIONS INDUSTRIAL DEVELOPMENT ORGANIZATION, cit. p. 39.
} 
O aumento do comércio entre os países gera ou aumenta a concorrência entre as empresas. A concorrência entre as empresas gera uma busca ao desenvolvimento de seus produtos, à qualidade, à diversificação das ofertas, e à redução dos custos. Os competidores capazes de reduzir seus custos e, mesmo assim, aumentar a qualidade de seus produtos, são aqueles que desenvolvem sua capacidade de alocar recursos para utilizações mais produtivas. Estas empresas geralmente alcançam fatias maiores do mercado e têm desempenho superior, provocado por uma habilidade maior para a inovação. ${ }^{543}$

Contudo, se o ambiente concorrencial que gerou o crescimento do agente econômico for, de alguma forma, abalado, restarão ameaçadas a melhor alocação de recursos e a inovação. Por esta razão, é essencial que os mercados estejam abertos aos competidores eficientes e que não existam barreiras artificiais à competição. ${ }^{544}$ Logo, as barreiras tarifárias e não tarifárias são as principais ameaças ao desenvolvimento e à inovação.

A melhor alocação de recursos e a transformação desta alocação em mais incentivos ao desenvolvimento, crescimento e inovação, podem ser resultado de diversas iniciativas dos países, que não a proteção. Aliás, não há comprovação de que a proteção favorece o desenvolvimento, como se verá no tópico seguinte. O desenvolvimento está ligado a aspectos que não estão relacionados à proteção, tais como marketing, logística, pesquisa e desenvolvimento, trabalho, busca de novas fontes de capital e verticalização. Os resultados também dependem da organização dos recursos humanos empregados no trabalho e do conhecimento sobre as necessidades dos consumidores. Contudo, a imitação das experiências de outros países nem sempre é positiva, devido às particularidades e os recursos de cada país competidor. Assim, na

\footnotetext{
${ }^{543}$ Economistas chamam este movimento de adaptação ao comércio de "hipótese de disciplina à importação". Para eles, uma grande abertura do comércio faz com que os produtores nacionais, até este momento protegidos, reajam de uma maneira que aumenta a eficiência ou o bem-estar. Estas empresas estavam pouco expostas à concorrência (em razão, por exemplo, de seu caráter monopolístico ou da existência de colusões), o que as permitia praticar preços mais elevados em relação aos seus custos marginais. A produtividade das empresas tende a melhorar, também, por diversas razões, notadamente pelo efeito da concorrência que incentiva a trabalhar e inovar, a liberalização que dá acesso às tecnologias e a novos produtos.(ORGANIZAÇÃO MUNDIAL DO COMÉRCIO, Rapport sur le commerce mondial 2008: Le commerce à 1 'heure de la mondialisation. Genebra: WTO, 2008, p. 146.)

${ }^{544}$ METCALF, J. RAMLOGAN, R, UYARRA, E. Competition, innovation and economic development: the instituted connection. In Leading issues in competition, regulation and development. Cheltenham: Elgar, p. 75.
} 
China, por exemplo, são comuns as organizações de menor tamanho, centralizadas e que buscam a redução de custos. Na Coréia, outro exemplo, desenvolvem-se de forma mais intensa as empresas que conseguem manter estreita relação entre si e entre empresas do setor público.

\subsubsection{O desenvolvimento tecnológico e industrial como interesse público no antidumping}

Não raro, as autoridades antidumping, ao realizarem as verificações nas empresas, deparam-se com parques industriais completamente ultrapassados, com maquinário obsoleto e incapaz de competir com os parques industriais dos exportadores. A resposta imediata dos produtores domésticos, nestes casos, é acusar o dumping como razão pela qual não puderam investir na modernização de suas plantas. A proteção oferecida pela medida antidumping seria, como fundamentam, a única forma de trazer alívio a esta indústria, permitindo a realização dos investimentos necessários em tecnologia e na ampliação do parque industrial. Esta é, pelo menos, a justificativa de quase todos os produtores domésticos que se encontram nesta situação.

Será que a indústria doméstica está obsoleta e não tem capacidade de fazer investimentos por causa da concorrência desleal com o dumping, ou será que a indústria doméstica não consegue concorrer com qualquer outra empresa porque ela não está obsoleta e não fez, no passado, os investimentos devidos em ampliação e em tecnologia? Caberá à autoridade, com base no art. 3.5 do Acordo Antidumping, verificar se a desatualização da empresa frente à tecnologia contribuiu para o dano.

A discussão que mais interessa a este trabalho refere-se à consideração da necessidade de desenvolvimento tecnológico e industrial como interesse público na aplicação do antidumping. Ao lado dos fatores concorrência (consumidor) e emprego, a busca pelo desenvolvimento da indústria doméstica aparece, com freqüência, na motivação das autoridades nacionais. ${ }^{545}$ Este argumento deve ser examinado sob dois

\footnotetext{
545 No caso DRAMs, o fato de a indústria doméstica ser considerada estratégica foi considerado importante para a aplicação de medidas antidumping. (DRAMs. Regulamento (EU) n. 1480/2003, de 11 de agosto de 2003, OJ L 21/2, 22/08/2003, p. 1.)
} 
pontos de vista: i) a proteção, por meio do antidumping, leva ao desenvolvimento industrial? ii) diante de um importante mercado usuário do produto, deve-se privilegiar o desenvolvimento da indústria doméstica, ou deste usuário?

Para que as autoridades nacionais consigam responder a estes dois quesitonamentos, o que só é possível no caso concreto, fornecer-se-ão, nos próximos tópicos, elementos para a consideração do desenvolvimento tecnológico e industrial na decisão de aplicar medidas antidumping ou não, caso o interesse público assim determinar.

2.5.2.1 A indevida proteção dos setores estratégicos

Defende-se que a proteção pelo antidumping apresenta melhores resultados quando aplicada para favorecer setores estratégicos, que necessitam se desenvolver para alcançar níveis mundiais ou mesmo garantir a segurança nacional. Barfield apresenta sua contribuição a esta discussão, baseando-se no estudo das medidas antidumping aplicadas, e seus efeitos, em quatro setores norte-americanos considerados estratégicos: supercomputadores, telas planas, DRAM-semicondutores e aço. ${ }^{546}$

A proteção à indústria doméstica considerada erroneamente como estratégica pode gerar as conseqüências desastrosas: i) impactos negativos em outras indústrias, consumidores e trabalhadores; ii) intervenção política exacerbada; iii) ações antidumping baseadas em previsões históricas erradas de que a competitividade seria protegida ao se proteger uma indústria estratégica; e iv) o surgimento de novas tecnologias que tornam irrelevantes as primeiras medidas aplicadas.

A primeira conseqüência desastrosa é fruto do erro cometido pela autoridade investigadora no balanço (ou na falta de balanço) entre os interesses da indústria doméstica e de outras indústrias envolvidas ou seus consumidores. Nos casos DRAM-semicondutores, telas planas e aço, preferiu-se proteger a indústria doméstica "estratégica", em busca de seu desenvolvimento, do que se preocupar com as indústrias que dependiam da indústria doméstica, que empregavam um grande número de pessoas. 
A autoridade errou ao não observar que não havia nenhuma garantia de que a indústria doméstica iria se desenvolver ou era realmente estratégica.

Uma das principais características do mercado de semicondutores é a sua vida cíclica. A indústria observava lucros espetaculares e, menos de três anos depois, sofria contrações expressivas na demanda. Neste setor, mesmo durante os períodos de crise, os produtores não podem deixar de investir em pesquisa e desenvolvimento, já que o produto se torna obsoleto em meses.

Não foi o que fizeram os produtores norte-americanos, deixando que os produtores japoneses os superassem. Em 1985, diante de uma forte crise, produtores de semicondutores americanos decidiram exercer pressão sobre o governo do país, que determinou a abertura de investigação. Em 1986, os governos do Japão e Estados Unidos assinaram o acordo STA (Semiconductor Trade Agreement), no qual o Japão se comprometia a impedir a prática de dumping de suas empresas e a apresentar relações mensais de preços ao governo norte-americano. Contudo, não obstante o acordo, os Estados Unidos impuseram barreiras tarifárias de cerca de $100 \%$ no ano posterior. As indústrias japonesas foram obrigadas, pelo STA, a realizar lucros astronômicos (já que eram obrigadas a praticar preços mais altos) e o governo japonês abriu espaço para que estas empresas se cartelizassem (na tentativa de dividir o mercado e diminuir a produção, para cumprir o STA). Estes atos significaram a transferência direta de um custo equivalente a quatro bilhões de dólares para os usuários americanos e consumidores finais. A indústria norte-americana de semicondutores não se desenvolveu (devido à falta de investimento em tecnologia) e quase todos os produtores domésticos deixaram o mercado em menos de dez anos (falta de incentivo à competição, falta de incentivo à inovação, entre outras causas). Os preços altos praticados pelos japoneses atraíram a indústria coreana, que entrou no mercado norteamericano e alcançou relevante fatia de participação. ${ }^{547}$

\footnotetext{
${ }^{547}$ A única sobrevivente produtora norte-americana foi a empresa Micron, que alcançou certo progresso a partir de 1995. Em 1998, a empresa pediu abertura de investigação antidumping contra Taiwan. Imediatamente e como claro meio de retaliação, o governo taiwanês abriu investigação contra os Estados Unidos. Posteriormente, o governo norte-americano decidiu que não havia dano, encerrando a investigação sem a aplicação de medidas. O governo taiwanês procedeu da mesma forma. (BARFIELD, Claude. Op cit. p. 25-38)
} 
A segunda hipótese, intervenção política exacerbada em defesa do desenvolvimento e da manutenção da indústria doméstica a qualquer preço, é ilustrada pelo caso dos supercomputadores.

Desde os anos 80, o governo norte-americano busca fortalecer sua indústria de telas planas, seja por meio de medidas antidumping, seja por subsídio direto. As indústrias do país, que eram as únicas produtoras no mundo, foram substituídas pelas indústrias japonesas, que dominam $90 \%$ do mercado mundial. No início da década de 90, o governo, com o objetivo de recuperar a liderança em um setor tecnológico considerado estratégico (produtos eletrônicos de alta tecnologia), chegou a incentivar as indústrias do país a pedir a aplicação de medidas antidumping contra os produtos do Japão. As autoridades investigadoras ignoraram diferenças extremas entre os produtos dos dois países, que eliminaria a existência de similaridade, bem como não consideraram algumas manifestações recebidas alertando para as desvantagens aos usuários industriais, trabalhadores e consumidores finais. Apesar de todos os esforços do governo, os produtores norte-americanos não conseguiram suprir a demanda e se modernizar.

A terceira hipótese - a proteção apoiada em conceitos ultrapassados sobre o desenvolvimento e segurança nacional - é facilmente ilustrada pelo caso do aço, nos Estados Unidos, setor que foi protegido por medidas antidumping e medidas compensatórias por três décadas. A vontade de salvar a obsoleta indústria do aço impediu o surgimento de indústrias de alta tecnologia, que poderiam competir em diversos mercados relacionados ao aço.

A indústria norte-americana do aço foi especialmente beneficiada pelo governo no pós-guerra. Para poder enfrentar a grande demanda, os produtores industriais adotaram duas estratégias: insistir em fornos já obsoletos e tentar aplicar tecnologia mais avançada nos já ultrapassados fornos, alguns do século anterior. A indústria gozou de certa vantagem durante alguns anos, com a prática de cartel e pouco investimento, até a descoberta, em 1970, de jazidas de ferro de alta qualidade em países como Brasil e Austrália. As facilidades no transporte e os investimentos em tecnologia efetuados pelas empresas japonesas foram decisivos para a redução da competitividade das empresas americanas. As importações no mercado norte-americano cresceram, 
passando a representar $25 \%$ do consumo. Observando este fato, os produtores decidiram investir em outra tecnologia. Contudo, apesar dos novos investimentos, já estava formada a idéia de que as importações estavam contribuindo para o dano das empresas e que elas eram um vilão a ser combatido. O governo iniciou, então, ações que se alternavam entre proteção e subsídios. Foram iniciadas dezenove investigações antidumping e foi estabelecido um mecanismo de preços mínimos, segundo o qual o governo fixava o preço mínimo do aço importado. Quando este mecanismo foi extinto, os produtores responderam com mais de cem petições requerendo investigações. $\mathrm{O}$ governo decidiu adotar um sistema de quotas "voluntárias". Desde então, os Estados Unidos acompanham momentos em que se alternam restrições voluntárias e medidas antidumping, caracterizando uma perpétua proteção governamental, que sempre desestimulou o progresso tecnológico. ${ }^{548}$

Deste caso, Barfield tira conclusões interessantes, como i) nem a proteção, nem os subsídios, são capazes de remediar o atraso tecnológico; ii) os custos da proteção do aço para a economia norte-americana e para os consumidores foram certamente maiores do que os benefícios obtidos pela indústria doméstica ${ }^{549}$; iii) os Estados Unidos continuam insistindo que a proteção ao aço é essencial para a segurança nacional, apoiando-se em um velho conceito, sem qualquer comprovação científica. ${ }^{550}$

A quarta e última hipótese, a rápida substituição do produto por outro mais avançado, tornando o esforço e os custos da proteção estatal inúteis, pode ser depreendida do caso dos supercomputadores.

Em 1996, uma agência norte-americana (UCAR) fundada pela Fundação Norte-americana de Ciência (NSF), publicou sua intenção de fechar um acordo de grande importância econômica, para a produção de sistemas de supercomputadores, com uma empresa japonesa (NEC). Imediatamente, a Cray, líder no mercado de supercomputadores norte-americano, pressionou o governo para a abertura de uma investigação antidumping, alegando que a NEC estava praticando dumping para

\footnotetext{
548 ADAMS, Walter. Import Restraints and Industrial Performance: The Dilemma of Protectionism. In Antidumping Law: Policy and Implementation. Ann Arbor: The University of Michigan Press, 1979, p. 35 .

${ }^{549}$ Custos repassados aos consumidores estimados em 46 milhões a 76 milhões de dólares.

${ }^{550} \mathrm{O}$ autor se baseia nas alegações de que o apoio aos produtores de aço é essencial, o que teria ficado ainda mais visível depois dos atentados em 11 de setembro de 2001, nos Estados Unidos.
} 
forçar a saída das empresas norte-americanas do mercado. Dois eventos políticos se sucederam. Em primeiro lugar, o Congresso introduziu uma lei que garantia o pagamento de salários aos empregados da NSF se o contrato fosse assinado. Ao mesmo tempo, a investigação antidumping foi concluída, determinando a aplicação de medidas com base em uma margem de 454\%. Mesmo assim, o NSF decidiu prosseguir, acreditando que a NEC não estava praticando dumping e que ela apresentaria uma proposta alta. Em uma audiência, o responsável pela concorrência chegou a afirmar que a Cray só respondia a um dos quatro critérios técnicos do contrato, sendo a NEC muito superior em termos de desempenho. A NEC japonesa recusou-se a colaborar com a investigação e interpôs recursos administrativos e judiciais contra a decisão de aplicação de antidumping. Contudo, ela perdeu todos os processos.

O caso dos supercomputadores demonstra a atitude protecionista do governo investigador, com o claro objetivo de proteger cegamente a indústria doméstica. Contudo, não houve qualquer análise da viabilidade tecnológica da indústria doméstica e, mesmo diante de sérios indícios de que ela não alcançava o nível técnico do competidor estrangeiro, optou-se por protegê-la. Posteriormente, o mercado sofreu mudanças sensíveis, e o produto examinado deixou de ser importante. Restaram somente os custos da intervenção governamental, sem qualquer benefício obtido com a proteção. $^{551}$

\subsubsection{Como conjugar desenvolvimento e interesse público no antidumping}

Acredita-se que grande parte dos Membros da OMC tenha, em suas legislações, a previsão do desenvolvimento industrial e tecnológico como um princípio a ser seguido. ${ }^{552} \mathrm{O}$ desenvolvimento industrial e tecnológico é um dos fatores considerados de interesse público e deve ser avaliado, ao lado da concorrência e do

\footnotetext{
${ }_{551}^{551}$ Op cit. p. $13-17$.

552 No caso do Brasil, ele está no capítulo IV da Constituição Federal de 1988, que versa sobre a promoção e incentivo ao desenvolvimento técnico, científico e tecnológico, bem como ao apoio e estímulo às empresas que investirem em desenvolvimento no País. Na União Européia, estão entre os objetivos do bloco a promoção do desenvolvimento harmonioso, equilibrado e sustentável das atividades econômicas e elevado nível de emprego e proteção social (art. 2 do Tratado da União Européia). Para tanto, ela deve: $\mathrm{m}$ ) reforçar a capacidade concorrencial da indústria da Comunidade (art. 3 , inciso 1 , letras i e m).
} 
emprego. Contudo, há que se observar a forma pela qual será alcançado este desenvolvimento, que não pode ser pela intervenção cega do governo ou da autoridade de defesa comercial, como nos casos vistos acima. A proteção direta às empresas, sem qualquer exigência de contrapartida, pode dar margem a comportamentos oportunistas, já que a ação do governo contra os competidores internacionais é o meio mais fácil ${ }^{553}$, para as indústrias locais, de permanecer no mercado, mesmo que não queiram ou não possam investir no seu próprio desenvolvimento. ${ }^{554}$

E o que fazer diante do pedido de proteção de uma indústria que, caso concedido, irá certamente afetar outro produtor doméstico, que depende do produto da indústria protegida? A resposta também surge da análise dos quatro casos acima. A autoridade deve avaliar i) a importância das duas indústrias examinadas para a economia e defesa nacionais; ii) qual das indústrias examinadas irá certamente se desenvolver se for protegida, de forma a compensar as desvantagens que a outra, não privilegiada, irá sofrer; iii) se algum dos produtos finais a ser privilegiado (produção da indústria doméstica ou produção do consumidor usuário da indústria doméstica) poderá ser facilmente substituído em um futuro próximo, tornando inútil a sua proteção neste momento; iv) qual o investimento feito nos últimos anos pelas indústrias e v) o crescimento desta indústria, em termos de participação de mercado. ${ }^{555}$

\footnotetext{
${ }^{553}$ Cada vez mais, parece que as empresas não estão buscando vitória competitiva no comércio, mas sim nos corredores da justiça e dos reguladores. Elas são assistidas por governos que exibem sua extraordinária ingenuidade em impor novas restrições para salvar indústrias vulneráveis da competição. (CZINKOTA, Michael; KOTABE, Masaaki. A marketing perspective of the US International Trade Commission's Antidumping Actions - an empirical inquiry. Journal of World Business, v. 32, i. 2, 1997, p. 171). Alguns autores tem defendido que as leis antidumping norte-americanas são as responsáveis pela criação de um sistema de proteção administrada, que tem se transformado em uma nova avenida à proteção industrial. A forma mais rápida de revisão administrativa do protecionismo é o antidumping. (CUMBY, R; MORAN, T. Testing models of the trade poliy process: the case of antidumping in the Uruguay Round. Georgetown University, in CZINKOTA, Michael; KOTABE, Masaaki. Op cit, p. 172)

${ }^{554}$ Cabe mencionar decisão contrária a este entendimento, bastante criticada. No caso europeu Máquinas de Escrever, o Tribunal de Justiça europeu rejeitou o argumento de que não seria de interesse comunitário proteger produtores ineficientes. Segundo a corte, o fato de um produtor comunitário estar encontrando dificuldades atribuíveis, em parte, a causas outras que não o dumping, não é razão para negar a este produtor a proteção contra o dano causado pelo dumping. (Canon v. Council. Casos 277/85 e 300/85, julgamento em 5 de outubro de 1988).

${ }_{555}$ Com este último teste, a autoridade poderá identificar uma indústria embrionária, ou seja, aquela que poderia ter se desenvolvido mais nos últimos anos, mas não o fez por fatores não relacionados ao dumping, verificando se há qualquer indício de que esta indústria irá se desenvolver, se irá atrair os consumidores ou se será capaz de suprir a demanda do mercado.
} 


\subsection{CONCLUSÃO DA SEGUNDA PARTE}

A escolha e a imposição, pelo Acordo Antidumping, de critérios para a definição do interesse público é fundamental. Sem estes critérios, há duas possíveis conseqüências, uma no âmbito multilateral, outra no âmbito nacional. No primeiro, são grandes os riscos de uma aplicação do teste de maneira discriminatória. No nível nacional, as incertezas provocadas por um teste extremamente amplo e sem critérios desmotivarão a participação, na investigação, de importadores, usuários industriais, consumidores, e mesmo da indústria doméstica.

Três critérios são frequentemente observados pelos Membros que já aplicam o teste do interesse público e conseguem espelhar os interesses econômicos envolvidos em uma investigação antidumping. Concorrência, tendo como fim último a proteção ao consumidor, o trabalho e o desenvolvimento industrial e tecnológico são aspectos que traduzem as vantagens e desvantagens na aplicação de medidas antidumping.

A imposição de uma medida pode provocar restrição à concorrência. Isso ocorre porque os objetivos do antidumping e do antitruste são distintos em si: o antidumping tem como fim último conceder proteção à indústria nacional, ao passo que o antitruste tem vários possíveis objetos, entre eles, a preservação da concorrência necessária ao bem-estar do consumidor. Não cabe às autoridades de defesa comercial fazer uma profunda análise dos efeitos das medidas antidumping sobre a concorrência, mas cabe ao Estado, titular das duas atividades (antidumping e antitruste), zelar para que elas sejam menos contraditórias. Isso é possível por meio de uma boa aplicação da política da concorrência e por meio de uma prática concorrencial que observe o contexto internacional. Por outro lado, podem as autoridades de defesa comercial observar, embora superficialmente, se a restrição causada à concorrência é compensada por outras vantagens geradas pela aplicação do antidumping.

Salvar empregos da indústria doméstica é preocupação de toda investigação antidumping. Entretanto, preservar os empregos dos produtores domésticos 
pode significar a perda dos empregos de importadores e usuários industriais do produto. Como balancear estas duas prováveis perdas? Na maior parte das decisões analisadas, os Membros preferiram salvar a indústria que mais empregava ou demandava trabalho. Alguns atos podem ser praticados pela autoridade nacional na busca da solução. Pode-se investigar, por exemplo, se a perda dos empregos em determinada atividade econômica não significará a migração destes trabalhadores para outros setores economicamente mais interessantes ou necessários, em um movimento que já poderia ser esperado mesmo que não houvesse qualquer discussão de dumping naquela indústria. É importante determinar, além disso, a relação entre a proteção pelo antidumping, a criação de empregos e o aumento dos salários.

O desenvolvimento industrial e tecnológico é, também, motivo de inquietação. Aqui, pode o Membro se questionar se a proteção irá trazer o desenvolvimento da indústria doméstica e se este desenvolvimento é interessante ao país importador, considerando-se o custo da proteção.

Embora a observância destes critérios deva ser obrigatória, a partir daí, não caberá à OMC dizer o que cada Membro deve considerar mais relevante no balanço, ou a forma com que cada um entenderá cada um destes critérios. Os diversos sistemas jurídicos dos Membros trazem diversas concepções do que seja o objetivo concorrencial, o bem-estar do consumidor, a proteção ao trabalho ou qual o valor atribuído ao desenvolvimento industrial e tecnológico. A definição destes três critérios busca delimitar o âmbito de discricionariedade das autoridades nacionais, impedindo que critérios não econômicos sejam considerados em uma análise que deve ser estritamente econômica. 


\section{QUESTÕES PROCESSUAIS RELACIONADAS À ANÁliSE DO INTERESSE PÚBLICO NO ANTIDUMPING}

Além de ser fundamental a definição de critérios substantivos para a análise do interesse público, reduzindo a ampla margem de discricionariedade das autoridades nacionais, é importante que sejam estabelecidas regras procedimentais a serem observadas nas investigações de interesse público.

Inicialmente, cabe discutir quais partes podem submeter suas considerações a respeito do interesse público. Algumas autoridades nacionais aceitam informações fornecidas pelos exportadores, mesmo não sendo eles considerados partes "nacionais". Outras autoridades, contudo, negam qualquer dado ou argumento trazido por estes interessados. Geralmente, são aceitas contribuições da indústria doméstica, dos importadores, dos usuários e consumidores. Neste capítulo, dissertar-se-á sobre as vantagens e desvantagens em se aceitar a manifestação de cada possível interessado.

Outro ponto também bastante interessante para a reflexão é a definição do momento em que cada autoridade nacional deverá realizar o teste do interesse público. Debater-se-á se este exame pode ser feito antes da abertura da investigação, antes da aplicação de medidas provisórias, antes da aplicação de medidas definitivas, caso a indústria doméstica desista da investigação, na revisão e na celebração de compromissos de preço.

Qual deve ser a autoridade responsável pelo estudo do interesse público? A independência dos decisores é fundamental para que a escolha da solução a ser adotada seja baseada em aspectos objetivos, e não em aspectos meramente políticos. 


\subsection{QUEM SÃO AS PARTES INTERESSADAS EM SUBMETER CONSIDERAÇÕES DE INTERESSE PÚBLICO}

O artigo 6.1 do Acordo Antidumping estabelece que deve ser dado conhecimento da abertura de uma investigação a todas as partes interessadas, que gozam de ampla oportunidade para apresentar ou questionar, por escrito, todas as provas e fatos relevantes na investigação em questão. $\mathrm{O}$ artigo $6.11^{556}$ define que serão partes interessadas o exportador ou produtor estrangeiro do bem objeto de investigação, a associação de comércio que represente a maioria dos produtores domésticos, o governo do país exportador e o produtor do bem similar no país importador, ou associação de comércio que represente a maioria dos produtores domésticos. $\mathrm{O}$ termo "partes interessadas" também inclui importadores do produto, que podem ser afetados pelas medidas antidumping. Além disso, o mesmo artigo menciona, claramente, que não há impedimento para que o Membro permita a participação de outras partes domésticas ou estrangeiras além das mencionadas acima, como os fornecedores da indústria doméstica ou mesmo dos usuários industriais.

O artigo 6.2 ressalta, ainda, que deve ser dada ampla oportunidade para que as partes interessadas defendam seus interesses. Isso inclui a possibilidade de discutir seus argumentos com aqueles que possuem opiniões opostas, incluindo o acesso aos documentos e manifestações de outras partes e da própria autoridade. A redação atual do acordo também dispõe que os usuários industriais do produto e organizações representativas de consumidores podem se manifestar durante a investigação (neste último caso, a hipótese deve ser limitada aos casos em que o produto é vendido ao varejo).

Embora existam as previsões acima, nenhuma disposição obriga as autoridades a considerarem as informações apresentadas pelas partes interessadas. A

\footnotetext{
${ }^{556}$ Art. 6.11. Para as finalidades deste Acordo considerar-se-ão "partes interessadas": (a) exportadores ou produtores estrangeiros ou importadores de um produto objeto de investigação, ou associação comercial ou empresarial, das quais a maioria dos membros seja de produtores, exportadores ou importadores de tal produto; (b) o Governo do Membro exportador; e (c) o produtor do similar nacional no Membro importador, ou associação comercial ou empresarial na qual a maioria dos membros produz o similar nacional no território do Membro importador.
} 
obrigação limita-se à concessão de oportunidades de manifestação, mas não dispõe acerca do tratamento concedido a essas informações e argumentos.

A finalidade da previsão de uma cláusula de interesse público é fazer a justiça econômico-social entre as diversamente afetadas pela investigação. ${ }^{557}$ Isso não será possível se elas não tiverem, da mesma maneira que as demais partes interessadas na investigação, acesso ao processo e à defesa de seus argumentos.

As partes consideradas interessadas na análise do interesse público deverão colaborar ativamente com a investigação, fornecendo provas de seus argumentos. Nos países que já observam o interesse público no antidumping, os interessados obedecem aos procedimentos delimitados e têm obrigações perante a análise. ${ }^{558} \mathrm{~A}$ autoridade do país investigador pode ou não formular questões específicas a serem respondidas pelas partes.

Conforme já discutido neste trabalho, o interesse público não é simplesmente a soma dos interesses individuais, mas sim um terceiro interesse, que pode coincidir com a soma ou ser maior do que ela. A autoridade deve realizar o balanço entre os interesses existentes, mas, como resultado deste balanço, pode encontrar um terceiro interesse, que não coincide com o interesse de nenhuma das partes. ${ }^{559}$ Para que este balanço seja bem feito, precisam ser consideradas as informações trazidas por todas as partes interessadas, observados alguns limites a serem discutidos abaixo, manifestando-se a autoridade sobre estas informações, em um debate democrático.

\subsubsection{O interesse individual formador do interesse público no antidumping}

\footnotetext{
${ }^{557}$ Opinião defendida em AGGARWAL, Aradhna. The WTO Anti-dumping Agreement: possible reform through the inclusion of a public interest clause. Working Paper n. 142, Indian Council for Research on International Economic Relations, Setembro 2004, p. 5.

${ }^{558}$ SINNAEVE, Adinda. Op cit, p. 159.

${ }^{559}$ Não se coaduna, aqui, com a defesa de alguns autores de que "o interesse público nacional seria uma simples soma de todos os interesses privados da nação." (FINGER, M. and ZLATE. A. WTO Rules that allow new trade restrictions: the public interest is a bastard child. Paper prepared for the U.N Millenium Project Task Force on Trade, coordinated by Ernesto Zedillo and Patrick Messerlin. Abril 2003)
} 
Uma investigação antidumping tem como origem, na maioria das vezes, o interesse de uma empresa ou grupo de empresas. ${ }^{560}$ Antes de descobrir o peso deste interesse sobre os demais interesses em jogo nas investigações, é importante inquirir aspectos como a ética e os objetivos reais destas empresas. Além disso, é necessário desvendar a atual situação destas empresas diante da globalização, que as tornou empresas sem vinculação afetiva com nenhum país.

\subsubsection{Interesses das empresas em uma investigação antidumping}

Todos os Membros da OMC que promovem investigações antidumping com certa freqüência conhecem os efeitos da pressão de um determinado grupo econômico, empresa ou associação. ${ }^{561}$ Se não há um grupo ou uma associação representante dos interesses da indústria nacional no lado dos peticionários, há sempre esta associação ou grupo ao lado dos importadores ou consumidores. Estas associações são engrenagens movimentadas pela força de empresas, que vêem na união uma força maior do que a sua participação individual. ${ }^{562}$ Pouco se escreveu, até hoje, sobre os interesses das empresas que participam de uma investigação. Quais seriam as razões para que algumas empresas desejem participar de investigações, apoiando ou não a autoridade investigadora? E porque outras empresas decidem se abster, não participar? Seria somente a proteção à competitividade a motivação destas firmas?

Robin e Sawyer escreveram um artigo sensível a estas questões, trabalhando o conceito de ética nas petições antidumping. Segundo eles, há boas e éticas razões para que as empresas protocolem um pedido de investigação antidumping, assim

\footnotetext{
560 De acordo com o art. 5.1 do Acordo Antidumping, uma investigação deve começar com a manifestação da indústria doméstica. A única exceção está prevista no art. 5.6 do mesmo acordo, segundo o qual as autoridades de um país podem abrir a investigação sem o requerimento das partes, mas somente quando já existirem indícios suficientes de dano, dumping e nexo causal. Estes casos são, entretanto, muito raros.

${ }_{561}^{56}$ Como base desta discussão, antecedeu-a, neste trabalho, o debate de pressões do item 1.3.4.

562 Grande parte das investigações nos Estados Unidos são abertas após pedido de indústrias que concentram poucas empresas. Quando há várias empresas de pequeno porte, elas se organizam, em todos os casos, por meio de uma associação. A autoridade norte-americana tende a aplicar medidas antidumping mais facilmente em casos em que há poucas e grandes indústrias representando os produtores domésticos. (CZINKOTA, Michael; KOTABE, Masaaki. A marketing perspective of the US International Trade Commission's Antidumping Actions - an empirical inquiry. Journal of World Business, v. 32, i. 2, 1997, p. 175)
} 
como existem razões antiéticas. No segundo caso, são maiores as possibilidades de se afetar o bem-estar. A pergunta central é: é razoável acreditar que a empresa está pedindo a abertura de uma investigação buscando na lealdade uma oportunidade de ser mais competitiva? Se a resposta for positiva, passa-se na primeira fase do teste, já que o intuito do antidumping, para os autores, é maximizar as boas consequiências e ajudar a sociedade a cumprir a obrigação de manter a competitividade. A motivação de evitar a competição é antiética e não passa no teste. ${ }^{563}$

Os autores trazem dois exemplos, um ético e outro antiético. O primeiro caso é o pedido da Vaughn Beals of Harley-Davidson de abertura de uma ação antidumping, nos Estados Unidos, contra as importações de motocicletas provenientes do Japão. A International Trade Commission (ITC) decidiu que as vendas de motocicleta pela Harley-Davidson não estavam sendo afetadas e que não deveria ser imposta nenhuma sanção. Contudo, a Harley-Davidson provocou politicamente a ajuda do Governo dos Estados Unidos contra a prática que chamou de "prática de estoque excessivo". No ano seguinte, 1983, o presidente dos Estados Unidos concedeu a ajuda solicitada. Ele determinou a imposição de uma medida antidumping a ser progressivamente reduzida, em cinco anos, contra a totalidade das motocicletas, provenientes do Japão, que competissem com a Harley-Davidson. As medidas antidumping começaram em $45 \%$ e terminaram em $10 \%$. Os resultados foram diversos, já que as empresas japonesas detinham fábricas nos EUA e, por vezes, transferiam parte de sua produção para aquele país. Por outro lado, a Harley-Davidson ganhou certo fôlego para corrigir algumas imperfeições em sua produção, de forma a se tornar mais competitiva. Um ano antes de expiradas as medidas, a empresa demonstrou que elas não eram mais necessárias, o que levou à sua extinção.

Os autores examinam, então, os efeitos desta medida para todos os envolvidos. A empresa claramente precisava de ajuda e tempo para sobreviver no mercado. Os resultados mostraram que ela se tornou mais competitiva. A medida antidumping provou ser necessária para o mercado e condizente com os níveis suportados pela indústria japonesa. Todos aqueles que dependiam da sobrevivência da

${ }^{563}$ ROBIN, Donald; SAWYER, Charles. The ethics of antidumping petitions. Journal of World Business, v. 33, n. 3, 1998, p. 315-316. 
Harley-Davidson foram beneficiados no longo prazo, como trabalhadores, revendedores, consumidores finais. Os consumidores tiveram que pagar mais caro, durante quatro anos, para adquirir o produto, mas foram beneficiados com a variedade de opções de compra no longo prazo. A petição, na avaliação dos autores, foi ética. ${ }^{564}$

O segundo caso traz uma ação antiética deflagrada pela empresa Union Camp, a maior produtora de materiais feitos de madeira, tais como papel, produtos de embalagem, assim como alguns produtos químicos. Um de seus produtos mais famosos era um ácido usado na produção de PVC (cloreto de polivinila). Seus maiores competidores eram indústrias chinesas. O maquinário utilizado pela Union Camp estava ultrapassado e a empresa usava uma técnica menos eficiente, de menor qualidade, que demandava menores gastos. Ao contrário, as indústrias chinesas produziam em altíssima qualidade. Seria necessário um investimento de vinte milhões de dólares para construir uma nova planta para a Union Camp. Alguns chineses não se defenderam, tendo como resultado uma margem de dumping de $243 \%$. Aqueles que se defenderam, alcançaram uma margem de, aproximadamente, $45 \%$. O ITC entendeu que o Union Camp teria sofrido dano provocado pelas importações chinesas. Estava bastante visível o interesse da Union Camp, no caso, de provocar a aplicação de antidumping para não ter que investir na melhoria de sua planta e conseqüente aumento da competitividade. Com a aplicação, ela se tornou uma monopolista no mercado norteamericano. Os chineses sofreram prejuízos. Ironicamente, a própria Union Camp adquiria produtos dos chineses, sofrendo, como resultado, um aumento no seu custo. Mas as piores consequiências foram sofridas pelos consumidores industriais. Uma das empresas demitiu, imediatamente, 50 empregados. Outra preferiu fechar sua planta e se mudar para a Bélgica. A Union Camp poderia ter sobrevivido sem a aplicação de medidas e seria obrigada a se tornar mais competitiva. A petição foi claramente antiética. $^{565}$

Mesmo as investigações que são suspensas, retiradas pelas partes ou encerradas sem a aplicação de medidas podem produzir conseqüências negativas no

\footnotetext{
${ }^{564}$ U.S. International Trade Commission (ITC) publication 1342. (1983). Heavyweight motorcycle, and engines and power train subassemblies. Investigation n. TA 201-47, February.

${ }^{565}$ U.S. International Trade Commission (ITC) publication 2793 (1994) Sebacid Acid from the People's Republic of China. Investigation n. 731-TA-653, Final, July.
} 
mercado. Há dois tipos de empresas peticionarias: aquelas que querem a aplicação das medidas, e aquelas que querem obter um aumento de preços independentemente da aplicação da medida. Algumas parecem usar o processo antidumping como uma estratégia de negócios, o que deve ser bem avaliado pela autoridade antidumping. Prusa foi o autor que melhor avaliou esta questão. ${ }^{566}$

Prusa apresenta os benefícios da estratégia das empresas que fazem pedidos de investigação e depois desistem destes pedidos. Até mesmo petições com poucas chances de sucesso já conferem ganhos significativos para as indústrias domésticas e estrangeiras. Muitas investigações antidumping são abertas nos Estados Unidos e poucas medidas são aplicadas. Entre as investigações em que não são aplicadas medidas, estão vários casos em que a indústria doméstica desistiu de seu pedido. Há indícios de que, em alguns, a indústria doméstica fez um acordo com os produtores estrangeiros, sem passar pelo crivo e sem o conhecimento das autoridades. ${ }^{567}$ Segundo o autor, estes acordos criam mais distorções do que aquelas associadas à simples imposição de medidas antidumping. ${ }^{568}$

566 PRUSA, Thomas. Why are so many antidumping petitions withdrawn? Journal of International Economics, n. 33 (1992), p. 1-20.

567 Ou seja, não seria o caso de um acordo de preços em consonância com o art. 8 do Acordo Antidumping. Christopher Taylor alerta para o fato de que uma indústria doméstica pode ameaçar fazer uso das medidas antidumping para celebrar um acordo com um competidor internacional. Ele menciona dois casos em que isso teria acontecido e que o fato teria se tornado público. Um deles ocorreu em 1989, quando os maiores produtores de ferro-silício dos Estados Unidos formaram um cartel, determinaram o preço, e repeliram os compradores, que passaram a comprar o produto importado. Então, utilizaram a queda nas vendas para provar o dano sofrido pelo dumping. Foram impostas medidas antidumping em 1993 contra cinco origens, ficando as empresas livres para praticar o cartel. Quando as importações começaram a entrar no país por outra fonte não investigada, o Brasil, as empresas tentaram fazer um acordo com o exportador brasileiro, que se recusou. A existência do cartel foi descoberta e os membros foram condenados. (caso USITC, 1999 ${ }^{a}$, mencionado por PIERCE, Richard. Antidumping Law as Means of Facilitating Cartelization. Public Law and Legal Theory, Working Paper 002, George Washington University Law School, 1999, p. 4). Outro caso não menos dramático aconteceu em 1995. Segundo a empresa estrangeira, a empresa doméstica teria tentado fazer um acordo. Assim que a empresa estrangeira recusou, a indústria doméstica peticionou requerendo a abertura da investigação. (caso Music Center v. Prestini Musical Instrument Company, 874 F. Supp. 543 E.D NY 1995). (TAYLOR, Christopher. The economic effects of withdrawn antidumping investigations: is there evidence of collusive agreements? Journal of International Economics, v. 62, 2004, p. 296.

${ }^{568}$ Para PRUSA, há dúvida se este acordo celebrado entre as empresas é ilegal. TAYLOR defende a sua ilegalidade. Para Taylor, as empresas não estariam sob a proteção da doutrina norte americana conhecida como Noerr-Pennington, que permite que as empresas troquem informações competitivas se o objetivo for se unir para desafiar alguma decisão governamental ou pressionar, de alguma forma, o governo (lobby). Todavia, no caso dos acordos entre empresas em uma investigação antidumping, não está presente o desejo de influenciar o governo, mas sim de conseguir um benefício especial e privado. 
No Brasil, não há casos relatados em que isso tenha acontecido. Contudo, acredita-se que esta idéia - provocar uma investigação antidumping para obter um acordo, com a intermediação ou não do governo, com os produtores estrangeiros já tenha sido considerada por vários produtores brasileiros. Um acordo entre produtores domésticos e estrangeiros pode ser considerado ilegal no Brasil, independente do envolvimento do próprio governo. Há uma diferença bastante clara, na prática e na legislação, entre a celebração de acordos entre concorrentes e a celebração do chamado compromisso de preços, previsto no art. 35 do Decreto n. $1.602 / 95^{569}$.

O compromisso de preços, no Brasil, é sempre celebrado entre o governo, a autoridade investigadora, e os exportadores. Não é necessária nem prevista a interferência da indústria doméstica. Tende a ser ilegal, no direito brasileiro, a celebração de acordo ou qualquer tratativa entre indústria doméstica e exportadores, ou entre exportadores. A Lei n. 8.884/94, a Lei de Defesa da Concorrência, prevê, em seu art. $21, \mathrm{I}^{570}$, que pode ser considerada uma infração à ordem econômica os acordos de preços e condições de venda entre concorrentes. Se este acordo existe com o objetivo de prejudicar a livre concorrência (art. 20, I, da mesma lei ${ }^{571}$ ), provocar ou ameaçar provocar efeitos em território do país investigador, mesmo que aparentemente justificado pela existência de uma investigação antidumping, ele pode ser considerado um cartel, punível em âmbito administrativo e criminal.

Nada impede que as empresas estejam interessadas na abertura de uma investigação antidumping para a criação de um ambiente propício à celebração de um cartel. Este é mais um dos interesses possíveis de uma empresa ou grupos de empresas, que deve ser amplamente investigado e, se descoberto, punido pela autoridade de defesa da concorrência do país afetado.

\footnotetext{
569 "Art. 35. Poderão ser suspensos os procedimentos sem prosseguimento de investigação e sem aplicação de medidas antidumping provisórias ou direitos antidumping se o exportador assumir voluntariamente compromissos satisfatórios de revisão dos preços ou de cessação das exportações a preços de dumping, destinadas ao Brasil, desde que as autoridades referidas no art. $2^{\circ}$ fiquem convencidas de que o mencionado compromisso elimina o efeito prejudicial decorrente do dumping."

570 "Art. 21. As seguintes condutas, além de outras, na medida em que configurem hipótese prevista no art. 20 e seus incisos, caracterizam infração da ordem econômica: I - fixar ou praticar, em acordo com concorrente, sob qualquer forma, preços e condições de venda de bens ou de prestação de serviços."

571 "Art. 20. Constituem infração da ordem econômica, independentemente de culpa, os atos sob qualquer forma manifestados, que tenham por objeto ou possam produzir os seguintes efeitos, ainda que não sejam alcançados: I - limitar, falsear ou de qualquer forma prejudicar a livre concorrência ou a livre iniciativa."
} 
Por fim, cabe lembrar que, em alguns países, são tantas as dificuldades para que as empresas estrangeiras colaborem com a investigação, que a indústria doméstica tem incentivos a mais para pedir a abertura de investigações. Nos Estados Unidos, por exemplo, os enormes questionários, informações extremamente precisas, bem como prazos inflexíveis, fazem com que as empresas exportadoras e importadoras enfrentem vários obstáculos para cumprir o determinado nos procedimentos. E, com frequiência, neste país, as autoridades tendem a desconsiderar toda a informação fornecida pelas partes interessadas (exportadores e importadores) se consideram que o material fornecido está incompleto. ${ }^{572}$ De certa forma, já sabendo das dificuldades que os estrangeiros enfrentarão, há grande incentivo aos pedidos de investigações pela indústria doméstica, mesmo quando estas não estão certas sobre a força de seus argumentos. ${ }^{573}$

\subsubsection{A globalização das partes interessadas}

As empresas não estão mais presas a um só território e, com freqüência, terceirizam sua produção, ou parte dela, a empresas do mesmo grupo econômico localizadas em outros países que oferecem maiores benefícios econômicos. São raras as empresas que se identificam, hoje, com uma só nação ou cultura. Este novo contexto permite questionar o tripé "indústria doméstica, importador, exportador". Será que a indústria doméstica ainda é aquela que concentra sua produção no território importador? Será que os importadores são empresas localizadas apenas nos países investigadores, que atraem a produção externa que será revendida ou utilizada em indústrias nacionais? Será que o exportador ainda é aquele que fabrica seu produto no país investigado e que tem localizados, neste país, todos os fatores de produção?

Esta aparente novidade no comércio internacional não é tão nova assim. Tem se chamado atenção, há várias décadas, para uma realidade em que a empresa transcende os limites de seu território para alcançar mão-de-obra, insumos, impostos e outros fatores mais benéficos à sua produção. $\mathrm{O}$ par de tênis importado pelo

\footnotetext{
572 Já discutido no item 1.1.4.3.

573 MOORE, Michael. Facts available dumping allegations: when will foreign firms cooperate in antidumping petitions? European Journal of Political Economy. Vol. 21, 2005, p, 186.
} 
país A não é mais produzido, em sua totalidade, no país B. O país B produz apenas a sola, e importa, dos países C e D, o cadarço e o couro. Cada um destes elementos é fabricado pela mão de obra local, ou seja, dos países B, C e D. Como definir os custos incorridos nesta produção?

A queda das fronteiras também afeta a indústria doméstica. Ela não mais tem sua produção totalmente concentrada no país investigador. Mas como definir o interesse desta empresa em relação ao seu país? Deve um Membro da OMC se preocupar em conferir proteção a uma empresa localizada em seu território, mas cuja matriz está localizada na França, para onde são remetidos seus lucros?

Em 1979, Ehrenhaft já chamava atenção para o problema: "empresas que antigamente se intitulavam americanas assumiram, agora, uma dimensão global”. Teorias tradicionais do comércio internacional previam que as mercadorias deveriam ser produzidas onde está o capital, trabalho, materiais, administração, energia, e um ambiente regulatório propício. Estes elementos não necessariamente precisam estar, hoje, sobre o mesmo território. ${ }^{574}$

Em alguns casos, uma empresa chega a ter interesses contrários aos de outra empresa do mesmo grupo econômico localizada em outro país. Por exemplo, em 1969, empresas americanas produtoras de potássio clorídrico alegaram a prática de dumping nas importações do produto proveniente do Canadá, curiosamente produzido e exportado, também no Canadá, por empresas do mesmo grupo econômico. Outra investigação americana, concernente a automóveis europeus, tinha entre as empresas exportadoras, produtoras européias, a Ford, empresa de origem americana. ${ }^{575}$

Ehrenhaft elenca alguns fatores que levaram à perda da nacionalidade pelas empresas: i) uma empresa multinacional pode ter como donos nacionais de outros países que não aquele de seu imediato interesse; ii) o governo de cada país com o qual a multinacional possui uma significante relação pode questionar direitos e obrigações

\footnotetext{
${ }^{574}$ EHRENHAFT, Peter. Multinational Enterprises and the Antidumping Law. Harvard International Law Journal, vol. 20, n. 2, 1979.

575 Potassium Chloride, Otherwise Known as Muriate of Potash, from Canada, 34 Fed. Reg. 19,2003 (1969) (Determination of Sales at Less than Fair Value); 34 Fed. Reg 13,670 (1969) (Tariff Commission Determination of Injury) e Automobiles from West Germany, 41 Fed. Reg. 34,989 (1976) (Discontinuance of Antidumping Investigation). Ambos os casos foram mencionados por EHRENHAFT, Peter. Op cit. p. 278.
} 
referentes à sua atuação; iii) as multinacionais se tornaram capazes de produzir, vender e conseguir recursos de fontes diversas, atingindo vantagens comparativas maiores do que se estivessem limitadas a uma só jurisdição; iv) as multinacionais são ágeis em lidar com diferentes moedas e taxas de cambio, o que lhes permite lidar com a instabilidade cambial em algumas regiões.

A existência destas empresas torna ainda mais difícil a ação das autoridades investigadoras. Os conceitos de "doméstica", "terceiro país" e "local" tornam-se contestáveis. Quando da comparação dos preços, é necessário fazer um exercício para considerar as vendas entre empresas do mesmo grupo e as vendas aos primeiros compradores independentes. Outra dúvida nestes casos é a possibilidade de a empresa investigada como exportadora apoiar-se seu prejuízo em outra empresa, do mesmo grupo, localizada em país não investigado. Com isso, ela conseguirá praticar preços baixos e compensar suas perdas com os lucros obtidos em outros mercados. Trata-se de uma forma de subsídio cruzado. Esta prática também pode estar presente quando a empresa recebe algum benefício do governo de outro país (País C), sob a forma de subsídio, e extrai o benefício praticando preços mais baixos no País B, que é o exportador para o País A, o investigador. ${ }^{576}$

A solução para tais problemas é a condução de uma investigação que leva em consideração todo o grupo econômico da empresa, não somente aquela unidade exportadora.

Também não são raras as investigações antidumping no Brasil em que os importadores e exportadores clamam que a autoridade, aplicando medidas, estará protegendo empresas que não são nacionais. Isto ocorre quando a indústria doméstica é composta por uma empresa com origem em outro país. Seria este argumento relevante? Aqui se coloca o problema da multinacionalidade da indústria doméstica. Como deve ser o tratamento conferido à indústria doméstica que apenas produz no país, mas que remete seus lucros ao exterior?

Vários pontos podem ser mencionados ao se responder a esta questão. O primeiro deles concerne aos empregos gerados por estas empresas multinacionais.

${ }^{576}$ EHRENHAFT, Peter. Op cit. p. 281. 
Embora sua sede esteja localizada em outro país, esta empresa está, geralmente, há vários anos no país investigador, ou pelo menos os anos necessários para que se possa investigar o dano. ${ }^{577}$ Com frequiência, esta empresa recebe incentivos fiscais do governo para permanecer no território, incentivos que geralmente são concedidos por um longo prazo. Preocupada com a reputação e dedicada às políticas de governança corporativa e assistencialismo, são normais investimentos de grande valor nas comunidades em que se estabelecem. Assim, esta empresa fixa suas raízes naquele território, não havendo mais motivos para que seja considerada estrangeira. $\mathrm{O}$ argumento contrário dos importadores e exportadores é que não é difícil, para esta empresa, desistir da produção no território, fechar fábricas e se mudar para outro país. Este argumento é frágil, diante dos motivos já expostos e das dificuldades geralmente observadas para a instalação da empresa em um novo território. Estas empresas firmam, geralmente, um compromisso de longo prazo com o país no qual se estabelecem.

Ao contrário, a abertura de uma investigação antidumping provoca maiores incentivos ao investimento no território investigador do que o inverso. Belderbos lembra que, em época de globalização, as medidas antidumping têm desempenhado um papel impensável há alguns anos, que é o de incentivar o investimento direto estrangeiro (ou seja, a instalação de unidades fabris no território). Isto porque, se a empresa exportadora encontra no antidumping um grande desestímulo à venda para aquele país, ela pode optar por se instalar naquele país, transferir parte de sua unidade produtiva para o país investigador, de tal forma a não precisar mais exportar seus produtos, que serão vendidas no mercado doméstico como produtos nacionais. $^{578}$

\subsubsection{As partes interessadas}

O acordo antidumping, na nova redação que está sendo negociada pelos Membros, deve prever quais são as partes interessadas no teste do interesse

\footnotetext{
${ }^{577}$ Período nunca inferior a três anos no Brasil, de acordo com o art. 25, §2º , do Decreto n. 1.602/95.

${ }^{578}$ BELDERBOS, René. Antidumping and Tariff Jumping: Japanese firms DFI in the European Union and the United States. The WTO and Anti-dumping, Volume II, Cheltenham: Elgar Reference Collection, 2005, p. 63-100.
} 
público. Não se pode deixar a critério do Membro elegê-las, sob pena de aumentar a insegurança e a falta de previsibilidade já discutidas em diversos momentos neste trabalho.

\subsubsection{Indústria doméstica}

Em primeiro lugar, cabe criticar o entendimento de que as investigações antidumping se prestam somente a proteger a indústria doméstica. Embora este seja um dos objetivos, não é o único. $\mathrm{O}$ dumping produz consequiências negativas para o interesse destas empresas, razão pela qual elas pedem, ao governo do país, que abra investigações para analisar a existência de práticas desleais de comércio. Contudo, o objetivo das investigações antidumping não é somente proteger estas indústrias, mas sim investigar a existência de dumping, dano e nexo causal. ${ }^{579}$

Quando uma indústria doméstica é aparentemente beneficiada pela imposição de medidas antidumping, ela pode estar sendo, na verdade, prejudicada. $\mathrm{O}$ bloqueio às importações a preço de dumping, fazendo com que os exportadores aumentem os preços oferecidos ao mercado, pode ser uma ótima oportunidade para que a indústria doméstica conquiste os consumidores anteriormente clientes dos exportadores. Contudo, por outro lado, a indústria doméstica pode ser prejudicada pela imposição de medidas, embora os efeitos prejudiciais não sejam tão visíveis. A imposição das medidas pode representar um falso conforto aos produtores domésticos, que, se não tiverem investido em tecnologia e no desenvolvimento da própria capacidade, podem sofrer no futuro, de forma ainda pior, quando estas medidas deixarem de existir. Isso ocorre porque, durante o período em que são aplicados os direitos antidumping, os produtores nacionais tendem a se acomodar, deixando de investir. Posteriormente, quando os direitos não forem mais aplicados, as exportações para este país serão retomadas pelos produtores estrangeiros, que virão com o desejo de reconquistar o mercado, com produtos de boa qualidade e preços baixos, além de um ótimo conhecimento prévio sobre seus antigos clientes.

\footnotetext{
${ }^{579}$ Opinião defendida em AGGARWAL, Aradhna. Op. Cit. p. 5.
} 
Por estas razões, deve-se considerar, também, os efeitos da imposição de medidas também para a indústria doméstica, que é parte do interesse público a ser considerado. Para uma boa análise dos efeitos das medidas, deve-se identificar qual a conduta esperada dos produtores domésticos após a aplicação do antidumping.

Avalia-se, por exemplo, se é possível o aumento de sua participação de mercado. Em certos casos, a indústria doméstica é de tal forma embrionária que não é possível prever seu crescimento durante o período de aplicação das medidas. ${ }^{580}$ Além disso, ela pode estar de tal forma abalada (pelo dumping ou por outros fatores) que mesmo a aplicação de medidas não será suficiente para a sua recuperação. Pode-se, também, considerar que a indústria doméstica não é mais viável, seja porque não poderá se recuperar, seja porque o produto não é mais interessante ao país. ${ }^{581}$ Por fim, se parte do dano foi causado pelo desinteresse da indústria doméstica em investir em novas tecnologias e se adequar às demandas do mercado consumidor, é possível que esta situação permaneça, mesmo com a aplicação de medidas antidumping. ${ }^{582}$ Verifica-se, também, se a indústria doméstica será capaz de suprir a demanda interna, ou se as importações investigadas serão apenas substituídas por importações de outras origens. Para tanto, analisa-se algum investimento feito pela indústria doméstica em aumento da capacidade de produção, por exemplo, ou se há algum excedente de produção ou capacidade maior do que a produção nos últimos anos. ${ }^{583}$ Nestes exemplos, os benefícios da proteção podem ser reduzidos, sendo inferiores às desvantagens sofridas pelas outras partes consideradas na análise do interesse público.

\subsubsection{Importadores}

\footnotetext{
${ }^{580}$ Argumento para a não aplicação de medidas no caso Discos Versáteis Digitais Regraváveis (DVD +/R), Decisão da Comissão n. 713/2006 de 20 de outubro de 2006, J.O L. 293/07, 14/10/2006. .

${ }^{581}$ A viabilidade da indústria doméstica foi analisada no caso europeu das Escovas de Cabelo, Decisão da Comissão 967/00, de 8 de maio de 2000, J.O L 111/4.

${ }^{582} \mathrm{O}$ investimento tecnológico passado e a atuação da indústria doméstica foram elementos importantes no caso europeu DRAMs, Decisão da Comissão 967/00, de 8 de maio de 2000, J.O L 111/4.

${ }_{583}$ No caso europeu Bolsas de couro e bolsas sem couro, os importadores argumentaram que a indústria doméstica não era capaz de suprir a demanda, o que foi rechaçado pela Comissão, segundo a qual os produtores domésticos haviam investido grande quantia em tecnologia, aumentando sua capacidade. (Decisão da Comissão n. 1567/97, de 1 de agosto de 1997, J.O L 208/31.
} 
Há algum preconceito na consideração dos argumentos dos importadores em investigações de interesse público, pois são raros os importadores que revendem apenas o produto investigado. Usualmente, os importadores oferecem uma gama variada de produtos, sendo possível desviar seus esforços, anteriormente despendidos com o produto sob investigação, para outros produtos não investigados. Também são os importadores responsáveis pela entrada do produto no mercado, criando uma demanda que não existia ou trazendo ao usuário industrial a possibilidade de compra a um preço que este último não conhecia. Assim, muitas vezes, não é o usuário industrial aquele que se interessa pelo produto, aquele que descobre a origem e demanda o produto, mas o importador. Contudo, não se pode esquecer que os importadores podem ser, ao mesmo tempo, usuários industriais, importando o produto para consumo cativo, não para a revenda. ${ }^{584}$

A Comissão Européia utiliza três critérios para a análise dos prejuízos causados aos importadores com a aplicação das medidas: i) a importância dos importadores nas vendas e distribuição do produto; ii) a sua habilidade para absorver as medidas antidumping (e não repassá-las); e iii) o efeito das medidas na sua viabilidade futura. No primeiro caso, são avaliados a importância dos importadores como facilitadores de importações, seu papel como empregadores e sua contribuição para o bom funcionamento do mercado. Também é relevante o fato de os importadores venderem outros produtos. ${ }^{585} \mathrm{O}$ número de importadores e sua pequena importância econômica marginalizam a sua relevância frente aos interesses da indústria doméstica. $^{586}$

\footnotetext{
${ }^{584}$ CZINKOTA, Michael; KOTABE, Masaaki. A marketing perspective of the US International Trade Commission’s Antidumping Actions - an empirical inquiry. Journal of World Business, v. 32, i. 2, 1997, pp. 170 .

${ }^{585}$ No caso Corda de Fibra Sintética, o impacto causado aos importadores foi considerado menor pelo fato destes comercializarem produtos de outros mercados e ainda serem fornecedores do produto doméstico. (Corda de Fibra Sintética. Decisão da Comissão n. 18/98, de 7 de janeiro de 1998, J.O L $4 / 28$ ).

${ }^{586}$ No caso europeu Aço Inox, ficou caracterizado que a distribuição do produto era feita por um grande número de importadores que operavam entre os produtores e os usuários do produto, e seu comportamento influenciava a formação dos preços do produto. Ficou também claro que a indústria doméstica possuía apenas um pequeno contato com os usuários industriais e precisava de sua rede de distribuição. Concluiu a Comissão que a situação dos importadores iria piorar depois da aplicação das medidas. (Aço inoxidável. Decisão da Comissão n. 1732/97, de 4 de setembro de 1997, J.O L 243/17)
} 
A sua habilidade para absorver as medidas dependerá dos lucros computados pelos importadores. Quanto maiores os lucros, mais facilmente irão absorver o custo das medidas. Também, neste ponto, a Comissão analisa se o importador será capaz de repassar estes custos. Este resultado dependerá da concorrência no mercado do importador, ou seja, quanto menor a concorrência, mais facilmente estes custos serão repassados aos usuários industriais e consumidores.

Por fim, analisa-se a viabilidade futura dos importadores. Esta viabilidade pode ser verificada utilizando-se os mesmos critérios aplicados na análise do dano, obviamente aqueles que forem aplicáveis, tais como análise do fluxo de caixa, lucratividade, participação de mercado, etc.. ${ }^{587}$ Estimando-se a margem de dumping e, com isso, o antidumping a ser aplicado, poderá a autoridade analisar se os importadores conseguirão arcar com os valores, ou repassá-los aos consumidores.

As alegações dos importadores tendem a ser analisadas com mais cautela quando eles são parte do grupo econômico do exportador. No caso Ball Bearings, a partir da manifestação do Advogado Geral, o Tribunal de Justiça entendeu prudente se fazer a distinção entre os importadores independentes e os importadores que são empresas subsidiárias dos exportadores. Para a autoridade, não há diferença entre importadores independentes, já que todos serão afetados da mesma forma pelas medidas antidumping, mas esta diferença existe em relação àqueles que estão ligados aos exportadores, que serão mais afetados, mas, ao mesmo tempo, representam diretamente o interesse dos exportadores, o que deve ser visto com cautela. ${ }^{588}$

\subsubsection{Usuários industriais}

Economicamente, os usuários são a indústria mais prejudicada pela aplicação de medidas antidumping. ${ }^{589}$ O usuário é o responsável pela encomenda do produto ao importador ou ao exportador. Se aplicada uma medida antidumping, a não

\footnotetext{
${ }^{587}$ Assim procedeu a Comissão no caso Permanganato de Potássio, Decisão da Comissão n. 467/98 de 23 de fevereiro de 1998, J.O L 60/1.

588 GIANNAKOPOULOS, Themistoklis. Safeguarding Companies' Rights in Competition and Antidumping/Antisubsidies Proceedings. London: Kluwer Law International, p. 312.

${ }^{589}$ Sendo ele o importador ou comprando do importador.
} 
ser que o importador absorva o aumento do custo, caberá ao usuário aborvê-lo ou repassá-lo ao consumidor final do produto transformado. Por exemplo, um fabricante de filmes de polipropileno biorientado decidirá se repassará o aumento do custo derivado da aplicação de medida antidumping sobre o polipropileno que importa (ou que compra do importador) ao consumidor do filme.

O objetivo da medida antidumping, na esfera do usuário industrial, é compeli-lo a considerar o produto da indústria doméstica como uma opção privilegiada, pela facilidade de compra, rapidez da entrega (visto que a indústria doméstica não corre o risco de demora na entrega derivado de condições de transporte internacional, por exemplo) e outras economias de transação. Assim, se uma medida é aplicada e o preço do produto oferecido pela origem investigada se igualar ao preço vendido pelo produtor doméstico, não haverá mais razão para a aquisição do produto importado. Privilegiar-seá o mercado doméstico e, com isso, observar-se-á o crescimento da participação de mercado da indústria peticionária e o aumento da procura do produto nacional pelo usuário industrial.

Caberá à autoridade investigadora, inicialmente, delinear as indústrias que são usuárias do produto. Devem ser enviados questionários e ser concedido o tempo necessário para que todas as possíveis indústrias prejudicadas manifestem sua opinião. ${ }^{590}$ É na análise dos efeitos das medidas aos usuários industriais que os países geralmente encontram a maior ação de grupos de pressão. Se o bem investigado representa boa parte dos custos de produção destes usuários industriais, tais usuários tendem a se unir e atuar perante a autoridade investigadora. ${ }^{591}$

Três aspectos são relevantes para a consideração das autoridades ${ }^{592}$ : i) a concorrência no mercado interno e a oferta aos usuários; ii) a influência do produto

\footnotetext{
${ }^{590}$ No caso europeu Glicina, a Comissão Européia investigou as indústrias de comida animal, agroquímica e farmacêuticas, prováveis afetadas pelas medidas antidumping. (Glicina. Decisão da Comissão n. 1043/00 de 18 de maio de 2000, impondo medidas provisórias às importações de glicina originárias da República Popular da China (J.O L 118/6).

${ }^{591}$ Deve-se lembrar, entretanto, que o número de usuários industriais é geralmente bem maior do que o número de produtores do produto investigado na indústria doméstica. Desta forma, a união e a defesa de seus interesses são geralmente mais difíceis do que a união e defesa de interesses dos produtores. A autoridade de defesa comercial deve levar este aspecto em consideração.

${ }^{592}$ Seguindo-se, aqui, novamente o exemplo da Comunidade Européia, exposto por Wellhausen, op cit., p. 1069.
} 
investigado sobre os custos do usuário industrial; e iii) as respostas possíveis dos usuários industriais.

A primeira questão a ser analisada é controversa. Aparentemente, a imposição de medidas antidumping reduz a competição no mercado do produto investigado e as opções de compra dos usuários industriais. Contudo, alguns argumentam que o aumento dos preços ao mercado doméstico, causado pela aplicação das medidas antidumping, aumenta a concorrência, atraindo produtores de outras origens e entrantes no próprio mercado local. Além disso, acreditam que a aplicação de medidas tem como objetivo o retorno à situação natural de competição, assumindo-se que os usuários estavam sendo beneficiados, anteriormente, por preços artificialmente suprimidos. ${ }^{593}$ Para que este argumento seja válido, é importante que não sejam expressivas as barreiras à entrada e que existam produtores em outras origens.

Sobre a possibilidade de aquisição de outras origens ou de produtores no mercado doméstico, considera-se: i) outros produtores da própria indústria doméstica que não tenham aumentando sua produção ou capacidade devido ao parco retorno financeiro afetado pelo dumping; ii) possíveis fornecedores domésticos que aparecerão quando o dumping for neutralizado; e iii) fornecedores de outras origens não acusados de dumping. ${ }^{594}$

A análise dos custos visa descobrir quanto do produto final, vendido pelo usuário, é representado pelo produto objeto da investigação. Os resultados deste teste, na Comunidade Européia, têm sido utilizados como bom argumento para a aplicação das medidas. Imagine-se que o produto investigado representa 10,8\% do custo do produto final do usuário industrial. Se a medida antidumping aplicada for de $12 \%$ sobre o valor final do produto investigado, ela representará um acréscimo de apenas

\footnotetext{
${ }^{593}$ STANBROOK, Clive; BENTLEY, Philip. Dumping and subsidies: the Law and procedures governing the imposition of anti-dumping and countervailing duties in the European Community. London: Kluwer Law International, 1996, p. 153. Também ver Wellhausen, op cit., p. 1070.

${ }^{594}$ Wellhausen afirma que estas hipóteses estão distantes da realidade verificada. O que ocorre, na prática, é o reforço de duopólios, poucos entrantes, e produtores em outras origens temerosos de que sua entrada neste mercado significará a abertura de investigação contra eles (já que os produtores locais já terão percorrido metade do caminho para a aplicação de uma medida antidumping contra estes novos competidores).
} 
1,3\% no custo do usuário industrial. ${ }^{595}$ Wellhausen critica este entendimento, utilizando três bons argumentos: i) este raciocínio não considera o efeito inflacionário pósaplicação de medidas: quando as medidas são aplicadas, a indústria doméstica tende a aumentar seus preços, aumentando os custos do usuário industrial; ii) a aplicação das medidas pode levar à falta do produto, especialmente quando há poucos fabricantes. Os usuários industriais tendem a ficar extremamente dependentes da indústria doméstica; iii) muitos usuários industriais competem no mercado internacional. Um pequeno aumento no custo já provoca a desestabilização da concorrência nestes mercados. ${ }^{596}$

Entre as respostas possíveis dos usuários industriais, estão a absorção dos custos das medidas (neste caso, passa-se a avaliar se esta absorção tem efeitos sobre a viabilidade da indústria usuária), ou o repasse destes custos aos consumidores de seus produtos. Se a absorção implicar a demissão de empregados ou a redução dos salários, passa-se à consideração do segundo elemento - o emprego.

Deve-se lembrar, também, que os usuários industriais têm certo receio em defender seus interesses em investigações antidumping. O grande medo destas partes é que seu nome seja visto como um apoio às indústrias que praticam dumping, $\mathrm{o}$ que pode afetar sua reputação nos negócios futuros, sobretudo se este futuro trouxer a escassez do produto, gerando situação de extrema dependência destes usuários em relação ao produtor doméstico. ${ }^{597}$

\subsubsection{Consumidores e suas associações}

A participação das associações de consumidores e dos consumidores industriais é fundamental nas investigações, porque eles podem fornecer uma visão realista da oferta, vista sob o ponto de vista da demanda. Somente estas associações e os consumidores industriais serão capazes de relatar as dificuldades encontradas no mercado do produto final, uma eventual existência de práticas abusivas, infrações ao

\footnotetext{
595 Cálculo realizado no caso Mecanismos de argola para encadernação. Decisão da Comissão n. 1456/96, de 25 de julho de 1996, OJ L 187/47, 26/07/1996.

${ }_{596}^{596}$ Wellhausen, Marc. Op cit, p. 1071.

597 STEGEMANN, Klaus. Anti-dumping policy and the consumer. Journal of World Trade Law, v. 19, n. 5, 1985, p. 469.
} 
direito do consumidor, ou mesmo uma inaptidão da indústria doméstica em fornecer o produto. Os usuários industriais desempenham papel semelhante, mas encontram maiores dificuldades, visto que, na maioria dos casos, eles não querem se indispor com a indústria doméstica.

No Canadá, Membro que faz o teste do interesse público, o interesse dos consumidores é considerado relevante. Nos casos Prepared Baby Food ${ }^{598}$ e Contrast Media ${ }^{599}$, o Tribunal (CITT) se manifestou favoravelmente ao interesse dos consumidores. No primeiro caso, expressou a preocupação de que a perda da competitividade levaria a um aumento de preços, o que afetaria a saúde financeira das famílias e suas crianças. No caso Contrast Media, os alegados aumentos de preços e falta de opção aos radiologistas foram decisivos para a aplicação de um direito menor.

Entretanto, no mesmo Membro, há casos em que o interesse da indústria doméstica prevaleceu sobre o dos consumidores. No caso Grain $\operatorname{Corn}^{600}$, a autoridade canadense entendeu que o interesse dos consumidores não estava em igualdade com o interesse dos produtores domésticos, devendo ser o interesse dos consumidores considerado quando "circunstâncias especiais e justificantes" estiverem presentes. $^{601}$

O impacto das medidas para os consumidores deve ser avaliado, ou seja, deve-se investigar se os usuários ou importadores irão repassar o aumento do custo para o consumidor. Contudo, mesmo nos casos em que não haverá repasse, ainda

\footnotetext{
${ }^{598}$ Décision définitive - Aliments pour bébés. 30 mars 1998 4237-83 AD/1180.

599 Certains opacifiants iodés originaires ou exportés des états-unis d'amérique (y compris le commonwealth de porto rico) Enquête no : nq-99-003.

${ }^{600}$ Maïs-grain à l'état brut Enquête no NQ-2005-001

${ }^{601}$ No caso Courvecles de disques et de bocaux, o CITT recebeu várias manifestações da autoridade concorrencial alertando para o impacto ao consumidor provocado pela redução da competição na aplicação das medidas antidumping. Entretanto, negou o Tribunal a tese de que os interesses dos consumidores e da concorrência devam ser considerados mais importantes do que o interesse da indústria doméstica. O CITT entendeu, além disso, que não havia risco de monopolização do mercado, já que os produtores estrangeiros eram fortes e os consumidores poderiam migrar para outros mercados no caso da alta dos preços. (Couvercles, de disques et de bocaux destinés à la mise en conserve domestique, importés soit séparément ou conditionnés ensemble, originaires ou exportés des états-unis d'amérique Renvoi no : RE-94-002.)
} 
prevalece a possibilidade de diminuição da oferta, ou da diminuição de opções ao consumidor. $^{602}$

Discute-se se a recusa da participação de associação de consumidores ou consumidores industriais pode ser interpretada como desinteresse e, com isso, autorização para aplicar medidas. É preciso lembrar que há uma limitação de recursos financeiros e de pessoal para que estas associações possam participar das investigações e fornecer as informações necessárias. Os consumidores enfrentam problemas de diversidade e coordenação, para responder aos questionamentos da autoridade. Além disso, há dificuldades em comprovar que o efeito, que parece pequeno para um consumidor individual, pode ser enorme se considerado o grupo de consumidores. $\mathrm{Na}$ maioria das vezes, a própria associação de consumidores desconhece o tamanho deste impacto. ${ }^{603}$ Diante de todas estas dificuldades, não pode a autoridade depreender que a falta de manifestação dos consumidores significa que não serão prejudicados com a aplicação de medidas antidumping. As autoridades, ao contrário, precisam usar todo o tipo de informação disponível para tratar dos interesses dos consumidores. ${ }^{604}$

\subsubsection{Exportadores}

Os países que já aplicam o teste do interesse público não consideram, geralmente, a manifestação dos exportadores sobre interesse público. A justificativa é que estas empresas não estão localizadas no território e não estão preocupadas com os desejos e necessidades locais. Este entendimento tende a mudar. Com a já relatada globalização das partes interessadas, não é raro que os exportadores sejam filiais da indústria doméstica do país investigador ou empresas contratadas como resultado de terceirização da produção no próprio país investigador. ${ }^{605}$ Nestes casos, estas empresas

\footnotetext{
${ }^{602}$ Utilizado, com sucesso, no caso Disc Chargers, Regulamento (EU) n 1999/55. 21 de dezembro de 1998, O.J. L18, 23/01/1999, p. 62.

${ }^{603}$ KEMPTON, Jeremy. Anti-dumping policy and the consumer interest. Consumer Policy Review, nov/dez 2000, p. 5.

${ }^{604}$ STEVENSON, Cliff. Evaluation of EC Trade Defence Instruments. Cit. p. 29.

${ }^{605}$ Este ponto tem sido muito discutido na Comunidade Européia, após o caso Sapatos de Couro (Regulamento (EU) n . 1472/2006, de 4 de outubro de 2006, J.O L. 275/34 6/10/2006). Em várias investigações, os exportadores são empresas subsidiárias ou filiais de empresas européias, possuindo, também, o que se pode conceber como "interesse comunitário”. (BERNERT, Peter. Op cit. p. 2)
} 
possuem um elo forte de interesse com o mercado importador, existindo, muitas vezes, para satisfazer as necessidades exclusivas daquele mercado.

Por isso, não se deve dispensar a manifestação dos exportadores, mas eles são considerados como partes que têm como principal interesse vender no país investigador. $^{606}$ Os exportadores são os maiores interessados, depois da indústria doméstica, em contribuir com a investigação. Eles são a parte que mais se dispõe a investir na defesa de seus argumentos, contratando consultores, publicações especializadas e todo tipo de ajuda cujo custo seja proporcional ao que podem perder se forem aplicadas medidas. Por isso, podem as autoridades investigadoras obter interessantes informações destas partes, que, na maioria dos casos, não seriam trazidas por nenhuma outra parte.

Por fim, cabe lembrar que os exportadores já são considerados partes interessadas no processo, tendo acesso a todos os dados não confidenciais, audiências e às autoridades. Por isso, sua participação na discussão do interesse público não representaria um ônus maior para os investigadores.

${ }^{606}$ Vyboldina defende que, independentemente de ser o exportador uma subsidiária de produtores domésticos, como vem acontecendo em casos recentes, ele continua sendo uma parte apoiada em interesses a curto prazo, que são vender pelo menor preço possível. Este interesse se choca com o interesse maior, a longo prazo, que é assegurar que o produto estará sempre disponível por um preço justo, mesma qualidade, e que o usuário possa sempre escolher livremente entre produtos importados e produtos nacionais. (VYBOLDINA, Elena. The Green Paper on Trade Defence Instruments: AntiDumping. Global Trade and Customs Journal, v. 2, i. 11, 2007, p. 413) 


\subsection{DIREITOS E DEVERES PROCESSUAIS DAS PARTES INTERESSADAS}

O respeito ao direito de acesso ao processo, ao direito de manifestação, ao direito de audiência e à transparência das decisões da autoridade investigadora são fundamentais para que uma parte decida participar de uma investigação. A sua violação durante um procedimento de análise do interesse público provoca resultados ainda mais negativos do que em uma investigação simples, tendo em vista que a motivação das partes interessadas na pesquisa do interesse público, para a participação neste processo, é ainda menor do que a vontade daqueles que são diretamente afetados pela medida.

A participação em um processo antidumping exige o pagamento de um preço. Em muitos casos, estas empresas contratam profissionais aptos a entender o procedimento e melhor expressarem suas opiniões. Além disso, não são raros os casos em que as partes são obrigadas a designar pessoas dedicadas exclusivamente à coleta e organização de dados a serem apresentados. Se estas partes interessadas sabem que não terão acesso a todos os documentos disponibilizados no processo ou sabem que não poderão requerer ou participar de reuniões, haverá menos incentivos para arcar com os custos da participação.

Os artigos 6.2 e 6.4 do Acordo Antidumping dispõem que às partes interessadas serão concedidas amplas oportunidades de defender seus interesses, o que significa participar de audiências, apresentar seus argumentos, bem como ter acesso a toda a informação disponível, de caráter não confidencial. Não há limites em relação ao conteúdo discutido, ou seja, as partes interessadas podem se manifestar sobre qualquer parte ou informação disponível no processo. Direito semelhante deve ser concedido às partes interessadas na discussão do interesse público na investigação, com a exceção sobre o conteúdo. No caso dos interessados na discussão do interesse público, não há razões para permitir que estes possam discutir, também, elementos como dumping, dano 
ou nexo causal. ${ }^{607}$ Sua participação deve se restringir à defesa de seus interesses. $\mathrm{O}$ objetivo desta restrição é evitar que a investigação do interesse público possa provocar efeitos negativos sobre a celeridade processual.

As partes que possam contribuir para a conclusão sobre o interesse público terão pleno acesso a todas as informações não confidenciais relativas ao processo e que possam ser úteis à defesa de seus interesses. Da mesma forma, deve lhes ser garantido o direito de manifestação sobre os elementos que possam contribuir para a demonstração de seu interesse. $\mathrm{O}$ direito de acesso e de manifestação deve incluir o momento da revelação dos fatos essenciais, previsto pelo artigo 6.9 do Acordo Antidumping: às partes interessadas deve ser dado conhecimento sobre os fatores que contribuíram para a conclusão das autoridades sobre a aplicação dos direitos. ${ }^{608}$

Deve ser assegurado, da mesma forma como é garantido às partes interessadas desde o início do procedimento, o direito de audiência, que é a chance de encontrar aqueles que investigam, expor seus argumentos oralmente, bem como confrontar as demais partes e interesses contrários. Caberá ao Membro, de acordo com o procedimento que já aplica em suas investigações, definir as formalidades relativas à audiência (ex. comunicação prévia, comunicação às outras partes, etc.).

A autoridade deve zelar pela transparência dos atos relativos à investigação do interesse público, dando publicidade aos prazos, acesso a informações apresentadas por outras partes, às reuniões realizadas, entre outros atos. ${ }^{609}$

A autoridade antidumping deve revelar os motivos que fundamentaram sua decisão. A motivação é uma obrigação de qualquer juiz, um dever que corresponde aos princípios fundamentais de equidade e regularidade do processo, mas também um direito daquele que perde de entender os argumentos e fatos sobre os quais este juiz se apóia. ${ }^{610} \mathrm{Na} \mathrm{OMC}$, assim como nas decisões nacionais, a motivação

\footnotetext{
${ }^{607}$ A não ser quando expressamente admitido pelas autoridades nacionais, em observância ao artigo 6.12 do Acordo Antidumping.

${ }^{608}$ 6.9. Antes de formular juízo definitivo, as autoridades deverão informar todas as partes interessadas sobre os fatos essenciais sob julgamento que formam a base para a decisão de aplicar ou não medidas definitivas. Tal informação deverá ocorrer com antecipação suficiente para que as partes possam defender seus interesses.

${ }^{609}$ Conforme já discutido no item 1.1.4.4.

${ }^{610}$ Mexique. Sirop de mais, WT/DS132/AB/RW, para. 107.
} 
oscila entre um monólogo e um diálogo. Situada em uma decisão que pode ser compreendida como um ato unilateral, a motivação é antes de tudo monólogo, mesmo que ela se dirija a certos destinatários. Ela pode ser vista, também, como um elemento do diálogo que se desenvolve no contraditório. Para a formação deste contraditório, intercalar-se-ão consultas às partes. ${ }^{611}$

${ }^{611}$ RUIZ FABRI, Hélène. La motivation des décisions dans le règlement des différends de l'OMC. La motivation des décisions des jurisdictions internationales. Paris : Pedone, 2008, p. 106. 


\subsection{QUAL O MOMENTO DA CONSIDERAÇÃO DO INTERESSE PÚBLICO}

Alguns autores defendem que o Acordo Antidumping deve permitir que os Membros considerem o interesse público antes de iniciar investigações antidumping e, novamente, antes de aplicar as medidas definitivas, quando as partes interessadas já tiverem se manifestado a respeito. ${ }^{612}$

A análise não deve ser feita no início da investigação. Este procedimento demandaria tempo, atrasaria o início das investigações, além de não haver informações suficientes, nesta fase, sobre concorrência, emprego e desenvolvimento da indústria. Por razões semelhantes, o exame não deve ser feito antes da aplicação de medidas provisórias. Embora o teste do interesse público possa evitar uma investigação e, assim, as consequiências negativas por ela causadas, os riscos de que este teste seja mal feito - pela falta de dados e do contraditório - são grandes. Os momentos apropriados para o exame do interesse público são: i) antes de aplicar medidas definitivas; ii) em um procedimento de revisão, antes da decisão final; e iii) durante a negociação de um compromisso de preços.

\subsubsection{Antes da abertura da investigação}

O mercado do produto sofre prejuízos a partir da abertura da investigação. ${ }^{613}$ Em alguns casos, os exportadores deixam de vender seus produtos neste mercado logo quando tomam conhecimento da aplicação das medidas, seja porque temem que medidas provisórias sejam aplicadas ${ }^{614}$, seja por preferirem investir, desde já, em outros mercados. Além disso, os usuários industriais receiam que os exportadores, sabendo da investigação, prefiram outros mercados nos quais não sofrem ameaça, o que pode ocasionar um desabastecimento do mercado investigado e a quebra

\footnotetext{
${ }^{612}$ AGGARWAL, Aradhna. The WTO Anti-dumping Agreement: possible reform through the inclusion of a public interest clause. Working Paper n. 142, Indian Council for Research on International Economic Relations, Setembro 2004, p. 7.

${ }^{613}$ Como discutido em 3.1.1.1.

${ }^{614}$ No Brasil, as medidas provisórias podem atingir mercadorias já embarcadas e a caminho do país importador, conforme art. 7, parágrafo 2, da Lei n. 9.019/95.
} 
dos compromissos de entrega do produto. ${ }^{615}$ Em outros casos, os exportadores preferem "desovar" seus produtos no mercado investigador, antes que uma medida antidumping seja imposta. Devido à produção prematura destes efeitos, deve-se fazer uma profunda reflexão sobre a aplicação do teste do interesse público antes da abertura do procedimento.

Por estas razões, para Aggarwal, o artigo 5.8 do Acordo Antidumping $^{616}$ deve ser modificado para permitir que o interesse público seja considerado pela autoridade antes da abertura da investigação. Para o autor, "uma investigação não deve ser iniciada se as autoridades estão convencidas de que não é do interesse público a imposição de tais medidas.",617

Singapura defende a possibilidade de se analisar o interesse público antes da abertura da investigação. Depois de recebida a petição de abertura, caberá ao Ministro do Comércio e Indústria avaliar se há provas suficientes de que não é do interesse público a aplicação da medida antidumping final. A investigação só será aberta após a conclusão de que ela é de interesse público. ${ }^{618}$

É bastante difícil avaliar a existência do interesse público que impeça a aplicação de medidas antidumping antes do início da investigação, já que, nesta fase, as partes interessadas ainda não se manifestaram a respeito, a autoridade tem apenas parcial compreensão sobre a existência de dumping, dano e nexo causal. ${ }^{619}$ Esta compreensão parcial tem como objetivo justificar a abertura da investigação, mas não é uma análise completa ou tampouco profunda.

\footnotetext{
${ }^{615}$ A investigação ela mesma tende a diminuir as importações, devido aos altos custos administrativos gastos pelos importadores e usuários domésticos na defesa de seus interesses e a insegurança em relação aos mercados. (FINGER, Michael. Safeguards. In HOEKMAN, Bernard et al. Development, Trade and the WTO: A Handbook. Washington: The World Bank, 2002.

${ }^{616}$ Art. 5.8.A petição de abertura (questionário) deve ser rejeitado e uma investigação deve ser terminada assim que as autoridades ficarem satisfeitas de que não há indícios suficientes de dumping ou dano.

${ }^{617}$ AGGARWAL, Aradhna. The WTO Anti-dumping Agreement: possible reform through the inclusion of a public interest clause. Working Paper n. 142, Indian Council for Research on International Economic Relations, Setembro 2004, p. 8.

${ }^{618}$ Proposed Elements for a Framework for Negotiation, principles and objectives for antidumping rules, communication for the delegation of Singapore, GATT Doc, n. MTN, GNG/NG8/W/55 (13 de outubro de 1989), p. 3.

619 "Parece evidente que a Comissão não estaria em posição de decidir sobre os interesses comunitários para a imposição das medidas antidumping/anti-subsídios se não conduzirem uma investigação formal antes disso, que concluiria, em primeiro lugar, pela existência de dumping ou subsídios, dano e nexo causal." (GIANNAKOPOULOS, Themistoklis. Op cit. p. 436.)
} 
Para que a autoridade de defesa comercial seja capaz de realizar o balanço entre os interesses da indústria doméstica, de um lado, importadores, usuários e consumidores, de outro, ela deve conhecer a real situação da indústria doméstica, e, como mencionado, sua viabilidade, investimentos realizados, potencial de crescimento, entre outros fatores. Se ela não conhece sequer a situação da indústria doméstica, mas dispõe apenas de provas iniciais, ela não poderá realizar este balanço de forma coerente. Além disso, a decisão sobre a existência de interesse público para a abertura da investigação pode influenciar as decisões futuras sobre o interesse público (quando da aplicação de medidas provisórias e definitivas).

Além disso, caso seja feita a análise do interesse público antes da abertura da investigação, será necessário modificar o artigo 5.5 do Acordo Antidumping, que cabe às autoridadees evitar qualquer publicidade sobre a petição requerendo o início da investigação, a não ser que a decisão de abertura do procedimento já tenha sido tomada. ${ }^{620} \mathrm{O}$ objetivo deste artigo é evitar os efeitos acima mencionados, provocados sobre o mercado afetado, que podem ser causados pela simples petição pedindo a abertura da investigação.

Não pode haver decisão sobre o interesse público se não houver contraditório. Aproveitando-se da idéia tocqueviliana de formação do interesse público, ${ }^{621}$ é importante que as partes interessadas possam participar ativamente do processo, e não somente vislumbrarem no Estado o ente que pode definir o que é melhor para o destino de todos. A adoção de um procedimento de análise de interesse público para a abertura das investigações pode aumentar a arbitrariedade, permitindo que a autoridade sofra pressões da indústria doméstica e de outros interesses que sequer serão conhecidos pelos usuários domésticos, importadores e consumidores.

A aplicação do teste do interesse público antes da abertura da investigação pode provocar um retardamento injustificado ao início do procedimento,

\footnotetext{
${ }^{620}$ Art. 5.5. A menos que se tenha tomado a decisão de iniciar a investigação, as autoridades evitarão divulgar a petição que solicita início de investigação. Após receber petição devidamente documentada, porém, e antes de proceder ao inicio da investigação, as autoridades deverão notificar o Governo do Membro exportador respectivo. (Na prática, este artigo não tem impedido que os exportadores e outros interessados tenham conhecimento da provável abertura de investigação. O mais comum é que os próprios governos exportadores, quando notificados pela autoridade importadora, comuniquem a notificação aos seus produtores domésticos.)

${ }^{621}$ Discutida no item 1.3.1.2.
} 
trazendo prejuízos ainda maiores à indústria doméstica, além de encarecer o procedimento e os custos da investigação, arcados pelo país investigador.

\subsubsection{Na aplicação de medidas provisórias}

O Acordo Antidumping, em seu artigo $7.5^{622}$, dispõe que, na aplicação de medidas provisórias, serão observadas as disposições do artigo $9^{\circ}$, que prevê regras para a imposição e cobrança de direitos antidumping. Este último menciona a possibilidade de não aplicação das medidas (margem para a aplicação do teste do interesse público) e a sugestão de aplicação de um direito mínimo. Se o artigo $9^{\circ}$ for modificado para a inclusão de um teste mandatório de interesse público, será necessário decidir se o artigo 7.5 sofrerá modificação, ou seja, se a cláusula do interesse público será aplicada no caso de medidas provisórias.

As dificuldades na aplicação do teste do interesse público na fase que antecede a aplicação de direito provisório são as mesmas observadas no exame feito antes da abertura da investigação: as autoridades dispõem de poucos recursos financeiros e não existem, ainda, informações suficientemente precisas ou verificadas, pelas autoridades, sobre a posição dos importadores, usuários e consumidores. A aplicação de direito provisório, segundo a redação atual do Acordo Antidumping, se faz quando a autoridade, decorridos, no mínimo, sessenta dias do início das investigações, já seja capaz de determinar, preliminarmente, a existência de dano e dumping. ${ }^{623}$

Geralmente, após sessenta dias do início da investigação, a autoridade já recebeu todos os questionários das partes interessadas, mas ainda não os analisou com profundidade ou não teve ainda tempo hábil para verificar, in loco, nenhuma informação apresentada. Algumas autoridades, como é o caso da brasileira, têm preferido concluir sobre a medida provisória depois de realizadas as verificações in loco. Contudo, não há nenhuma regra no acordo que obrigue esta prática.

\footnotetext{
${ }^{622}$ Art. 5.7. Na aplicação de medidas provisórias, serão observadas as disposições pertinentes do Artigo 9. ${ }^{623}$ Artigo 7 do Acordo Antidumping.
} 
Na Comunidade Européia, a análise do interesse comunitário pode ser feita antes da aplicação dos direitos provisórios. No caso do Carbonato Dissódico, o exemplo de exame feito antes da aplicação de medidas provisórias, mas a Comissão já havia verificado, naquele momento, grande parte das informações do processo. ${ }^{624}$

Essa não é a realidade da maioria das investigações, em especial quando são feitas em países em desenvolvimento. Um erro neste momento, uma avaliação inadequada da situação dos importadores, consumidores e usuários industriais, pode causar um prejuízo muito grande à indústria doméstica, privando-a da proteção imediata, que é o objetivo das medidas provisórias. É bastante improvável que os prejuízos imediatos às outras partes afetadas pelo antidumping sejam tão rapidamente sentidos quanto o são os prejuízos à indústria doméstica (que já sofre dano há anos).

Por estas razões, não é recomendável que se faça a análise do interesse público neste momento da investigação.

\subsubsection{Na desistência do peticionário}

De acordo com o artigo 9.1 do Regulamento Básico europeu, o processo de investigação será sempre encerrado quando for retirado o pedido da indústria doméstica, a não ser que esse encerramento não seja do interesse da Comunidade. Como "retirada da denúncia", tem-se entendido não somente a desistência formal, como também a aparente falta de interesse no prosseguimento do processo.

\footnotetext{
${ }^{624}$ A Comissão Européia decidiu aplicar medidas provisórias, mesmo diante do argumento de que esta aplicação não seria de interesse comunitário. Foram argumentos a questão concorrencial, o nível de emprego, o desenvolvimento e viabilidade da indústria vidreira, principal usuária do produto. ${ }^{624}$ Anteriormente à abertura desta investigação, a Comissão Européia investigou e puniu práticas discriminatórias da indústria de carbonato dissódico, como a celebração de acordos de repartição de mercado, bem como práticas de desconto anticompetitivas. A indústria vidreira alegou que estas práticas haviam contribuído para o dano alegado pela indústria doméstica. Contudo, entendeu a Comissão que as práticas foram extintas à época da punição e que a competitividade neste mercado estaria sendo observada com atenção, não se podendo falar em risco concorrencial. Argumentou a indústria vidreira, também, que os direitos antidumping ameaçariam sua viabilidade e competitividade, obrigando os produtores a reduzir seus custos, a começar pelos empregados. A Comissão avaliou o impacto das medidas sobre os usuários industriais, concluindo que os efeitos eram mínimos ( $0,3 \%$ sobre o preço do vidro). Além disso, entendeu a Comissão que a indústria vidreira possuía um considerável poder negocial, sendo composta por vários grupos multinacionais, que detinham suficiente poder de barganha para negociar seus contratos. Carbonato Dissódico. Regulamento (CE) n. 823/95 da Comissão de 10 de abril de 1995. JO L 83/8, de 13/04/1995.
} 
A investigação de antidumping nas importações do produto Sistemas de Leitura Ótica a Laser para carros (LORS), provenientes do Japão, Coréia, Malásia, China e Taiwan ${ }^{625}$ houve desistência. Neste caso, a Comissão considerou que o produto investigado deveria ser subdivido em três produtos (tocadores, disc chargers e rádios) e que cada um deveria ser investigado separadamente. Para os rádios de carro, entendeu que não havia interesse comunitário para que a investigação continuasse, já que não houve pedido formal das partes.

A indústria doméstica é o principal motor de uma investigação antidumping, embora seja a autoridade investigadora a responsável pela busca da verdade e pelo exame preciso dos fatos apresentados por todas as partes interessadas. Para que a aplicação de medidas antidumping seja autorizada, de acordo com a proposta deste trabalho, é importante que seja feito o balanço entre as vantagens e desvantagens provocadas pelo antidumping. Se a indústria doméstica não tem mais interesse na investigação, é porque não são consideráveis os benefícios da aplicação de medidas. Assim, serão maiores as desvantagens para outras partes. Além disso, o prosseguimento da investigação sem o apoio destes produtores tornará muito difícil a tarefa da autoridade investigadora. Por isso, sustenta-se que a desistência do peticionário deve ser motivo para o encerramento da investigação, independentemente do interesse público. ${ }^{626}$

No mesmo caso mencionado no tópico anterior, envolvendo a importação de Carbonato Dissódico, dois anos após a aplicação das medidas definitivas, decidiu a Comissão proceder à revisão do antidumping. Contudo, não obteve o apoio, nesta revisão, de quatro produtores nacionais, que representavam $80 \%$ da produção doméstica. Por esta razão, discutiu-se se o prosseguimento da revisão, no caso de falta de interesse do peticionário, é do interesse comunitário. O outro produtor, representando

\footnotetext{
${ }^{625}$ J.O. L18/62 de 23 de janeiro de 1999.

${ }^{626}$ Como ilustração, menciona-se o estudo de Gallaway sobre os efeitos da desistência do peticionário, da revogação da medida antidumping ou do fim de sua aplicação, para partes diversamente afetadas pela imposição do antidumping. Após estudar vários mercados nos Estados Unidos, como telefones, aço, têxtil, computadores e outros, o autor chegou à conclusão de que o fim de medidas antidumping pode ser traduzido em queda imediata dos preços na maioria destas indústrias, ganhos de bem-estar para os usuários industriais e consumidores, substituição, pela demanda, do produto doméstico pelo produto importado, entre outros efeitos. (GALLAWAY; Michael. BLONIGEN, Bruce; FLYNN, Joseph. Welfare costs of US antidumping and countervailing duty laws. Journal of International economics, v. 49, 1999, p. 211-244.)
} 
o restante da produção doméstica, argumentou que o prosseguimento da investigação era necessário para garantir que a indústria comunitária não ficasse sem proteção caso os produtores americanos decidissem insistir, esporadicamente, na prática de antidumping. Contudo, este argumento não foi considerado suficientemente relevante para o prosseguimento da investigação, devido à falta de interesse dos demais produtores. $^{627}$

\subsubsection{Na aplicação de medidas definitivas}

Segundo a atual redação do artigo $9^{\circ}$ do Acordo Antidumping, a decisão de aplicar ou não um direito antidumping definitivo, nos casos em que tenham sido respeitados todos os requisitos para a sua aplicação, assim como a decisão de fixar um valor em nível igual ou inferior à totalidade da margem de dumping, cabe à autoridade do Membro importador. É desejável que o estabelecimento do direito antidumping seja facultativo no território de todos os Membros e que o direito seja inferior à margem de dumping se for suficiente para eliminar o dano.

O interesse público, verificado com base nos critérios da concorrência, emprego e desenvolvimento tecnológico e industrial, deve ser a razão para a não aplicação das medidas definitivas, ou a sua aplicação por um período inferior a cinco anos. Serão analisados, como é a proposta deste trabalho, os interesses dos importadores, dos usuários industriais, dos consumidores e da indústria doméstica, pondendo se considerar manifestações dos exportadores. Seus interesses serão verificados por meio de respostas ao questionário - que pode ser um questionário elaborado especificamente para esta finalidade, ou, no caso dos importadores e da indústria doméstica, perguntas adicionadas ao questionário já enviado na investigação. Há tempo suficiente, durante a investigação, para que se faça este estudo.

Quando da aplicação de medidas definitivas, já terá transcorrido tempo suficiente para a realização de audiências. É desejável que, no caso de discussão

${ }^{627}$ Carbonato dissódico. Regulamento (CE) n. 1991/97 do Conselho de 13 de outubro de 1997. J.O L 282, de 15/10/1997. 
de interesse público, estas audiências sejam obrigatórias, tornando o procedimento mais transparente e abrindo espaço para a discussão oral entre as partes interessadas.

\subsubsection{Na celebração de compromissos de preços}

De acordo com o artigo $8^{\circ}$ do Acordo Antidumping ${ }^{628}$, a investigação antidumping pode ser suspendida ou encerrada sem imposição de direitos se o exportador assumir voluntariamente compromissos satisfatórios de revisar seus preços e por fim à prática de dumping, de modo que as autoridades fiquem convencidas de que se elimina o efeito prejudicial do dumping. A autoridade não é obrigada a aceitar os compromissos se considerarem que esta aceitação seria ineficaz, como no caso de um número muito grande de exportadores, ou por motivos de política geral. As autoridades deverão expor seus motivos para a não aceitação do compromisso e dar oportunidade para que o exportador se manifeste. Mesmo diante de um compromisso, o exportador pode solicitar que a investigação sobre a existência de dumping e dano seja conduzida até a apuração final. Se não for encontrado dumping ou dano, o compromisso se extinguirá automaticamente.

As autoridades gozam de grande discricionariedade para aceitar compromissos apresentados pelos exportadores. ${ }^{629}$ Há certa discussão acerca da publicidade destes compromissos. Na Europa, eles não são publicados. No Brasil, a publicação é obrigatória. ${ }^{630} \mathrm{~A}$ sua não publicação impede que outros interessados possam comentar ou discutir o entendimento. Como apenas a publicação das razões da

\footnotetext{
${ }^{628}$ Art. 8. Poderão suspender-se ou dar-se por encerrados os procedimentos sem imposição de medidas provisórias ou direitos anti-dumping se qualquer exportador comunica sua disposição de assumir voluntariamente compromisso satisfatório no sentido de rever seus preços ou de cessar as exportações a preços de dumping destinadas à região em apreço, de forma a que as autoridades fiquem convencidas de que o efeito danoso do dumping será eliminado. Os aumentos de preço que se realizem sob tais compromissos não deverão ser mais altos do que o necessário para eliminar a margem de dumping. Seria desejável que o aumento de preço fosse menor do que a margem de dumping, caso esse aumento seja suficiente para cessar o dano causado à indústria doméstica.

${ }^{629}$ No caso europeu Ball Bearings, o exportador apelou ao Tribunal de Justiça alegando que a decisão da Comissão de não aceitar o compromisso, baseando-se em experiências passadas que indicariam que o compromisso não tinha sido suficiente, não era satisfatória. Caso 240/84 NTN Toyo Bearing Co. Ltd v EC Coucil, Julgamento de 7 de maio de 1987, ECR 1809.

${ }^{630}$ Decreto n. 1602/95, Art. 36. Aceito o compromisso de preços, o ato que contenha a decisão de homologação de tal compromisso será publicado no Diário Oficial da União e conterá, conforme o caso, decisão quanto ao prosseguimento ou suspensão da investigação, notificando-se às partes interessadas.
} 
recusa da aceitação do compromisso é obrigatória, segundo o Acordo Antidumping ${ }^{631}$, é muito difícil saber que fatores contribuem para a satisfação da autoridade investigadora em cada caso. ${ }^{632}$ Por isso, caso seja aceita a proposta de interesse público e a celebração do compromisso seja um dos momentos considerados para o exame, deve-se modificar também o artigo $8^{\circ}$, obrigando a autoridade a motivar, também, a decisão de aprovação do acordo de preços.

Diante deste quadro de incertezas, cabe questionar se seria viável a aplicação do teste do interesse público quando da decisão de aceitação de compromissos de preços pela autoridade investigadora. Quais seriam as vantagens e desvantagens, para indústria doméstica e para os exportadores, da aceitação de um compromisso de preços? As mais significantes vantagens da celebração de um compromisso de preços são obtidas pelos exportadores. A maior delas é o fato de que o excedente a ser definido sobre os preços será convertido em lucro para os próprios exportadores (permanecerá em seus bolsos), ao passo que uma medida antidumping seria recolhida aos cofres públicos. A segunda vantagem é o encerramento da pendenga, de forma rápida, para que o mercado possa voltar a adquirir seus produtos. ${ }^{633}$

Para o importador, a celebração de um compromisso de preços não parece ser tão interessante, pois ele verá o aumento do preço do produto e não recebe qualquer contrapartida sobre este aumento (a não ser que exista um acordo entre exportador e importador para divisão do excesso determinado pelo compromisso). Em muitos casos, o exportador pode até mesmo obrigar que o importador revenda o produto por um valor menor do que o valor que importou. Esta prática é freqüente nos casos de empresas de um mesmo grupo econômico, em que há outras formas de compensação.

Para os usuários industriais e consumidores, as desvantagens são percebidas sob a forma de aumento de preços, a não ser que, como visto no parágrafo

\footnotetext{
${ }^{631}$ Artigo 8.3 do Acordo Antidumping.

${ }^{632}$ Em alguns casos, o entendimento da mesma autoridade, em dois casos, é distinto. Isso ocorreu na Europa, nos casos (Fotocopiadoras. Regulamento (CE) n. 535/87 do Conselho de 23 de fevereiro de 1987, J.O L 54/12, 24.2.1987) e no caso (Motores multifásicos elétricos Regulamento (CEE) n. 724/82 da Comissão de 30 de março de 1982, J.O L 85/9, 31/03/1982). No primeiro, a autoridade recusou a apresentação de compromissos pelos importadores, entendendo que a aplicação e controle deste compromisso seria muito difícil. No segundo caso, porém, o acordo oferecido por vários importadores foi aceito pela Comissão.

${ }^{633}$ VAN BAEL, Ivo; BELLIS, Jean-François. Antidumping and other trade protection laws of the EEC. Bruxelas: CCH Editions Limited, 1990, p. 407.
} 
anterior, o importador decida absorver o impacto sobre o preço, com o objetivo de preservar sua participação de mercado.

A indústria doméstica tem sua pretensão, de certa forma, vitoriosa, já que o objetivo do compromisso de preços é fazer com que o aumento do preço permita a recuperação da indústria doméstica. Contudo, há que se acrescentar que não há nenhuma disposição legal no regulamento multilateral que obrigue à autoridade dar conhecimento ou pedir a avaliação da indústria doméstica sobre o compromisso celebrado ou a ser celebrado. Se a autoridade não publicar o compromisso, ou mesmo se ele for celebrado sem qualquer contribuição da indústria doméstica, pode ser que este compromisso não seja suficiente para cumprir seus objetivos, ou seja inapropriado para aquele tipo de indústria. ${ }^{634}$

Sobre os três aspectos considerados como elementos do interesse público, cabe fazer uma breve análise de sua satisfação na celebração do compromisso. Neste ponto, estes elementos, com a exceção da análise concorrencial, são parecidos à forma de análise proposta para a aplicação de medidas definitivas, já que a investigação pode ser encerrada neste momento.

Em primeiro lugar, para a aceitação do compromisso, é importante que a autoridade investigadora já esteja suficientemente convencida sobre a viabilidade de recuperação e desenvolvimento da indústria doméstica. Para isso, sob o aspecto do interesse público, ela deverá observar os investimentos passados e previsões de investimento em tecnologia e desenvolvimento. Se houver dúvida em relação a estes pontos, pode haver mais desvantagens, na aceitação do compromisso, do que vantagens, impondo sério ônus aos importadores, usuários industriais e consumidores.

Em segundo lugar, deve-se observar, da mesma forma sugerida para a determinação final da autoridade, a capacidade da indústria doméstica de recuperar e preservar seus empregos. Deve-se investigar se a celebração do compromisso põe em risco empregos oferecidos pelos importadores e usuários industriais, comparando-se este risco aos benefícios obtidos pela indústria doméstica.

\footnotetext{
${ }^{634}$ Isso pode ocorrer, por exemplo, na determinação dos índices de correção do preço durante o período de validade do compromisso. Estes índices ou fatores de correção podem não ser os mais apropriados à natureza da indústria.
} 
Por fim, cabe fazer a análise dos mesmos aspectos concorrenciais sugeridos para a aplicação definitiva de medidas. Qual a situação competitiva da indústria doméstica? Pode ser a ausência de competição e certa posição dominante uma reforçada pelo compromisso de preços?

Além dos três critérios, outro exame deve ser feito no caso do compromisso, ainda sob o ponto de vista concorrencial. Para que aceite um compromisso oferecido por vários exportadores, a autoridade investigadora deverá verificar: i) se os preços oferecidos por estes exportadores são mais ou menos parecidos; ii) se a indústria doméstica pode aumentar seus preços ou pelo menos mantê-los, ao invés de reduzi-los para competir com as importações. Quando da primeira análise, ou seja, sobre a linearidade dos preços entre os exportadores, estaria a autoridade investigadora agindo corretamente ao buscar esta harmonização dos preços entre concorrentes em um mesmo mercado? No caso Glicina, a Comissão Européia não aceitou o compromisso de preços oferecido pelos vários exportadores por acreditar que, no caso, a celebração dos acordos poderia causar impactos negativos no mercado do produto. ${ }^{635}$ No caso Castings - peças vazadas, a Comissão não aceitou o compromisso de preços proposto em 2005, sob o argumento de vários competidores e pequenos operadores econômicos praticando preços similares reduziria, de forma inadequada, a concorrência no mercado. Posteriormente, a decisão foi reformada, aceitando-se o compromisso proposto, mas sem se retomar a questão concorrencial. ${ }^{636}$

\subsubsection{Na revisão}

Há quatro tipos possíveis de revisão a ser feita por um país investigador: a revisão intermediária, a revisão de novo exportador, revisão dos 5 anos, e a revisão quando existem provas de que as medidas estão sendo absorvidas. A primeira hipótese, a revisão intercalar, pode ocorrer a qualquer momento, desde que transcorrido um ano do início da aplicação das medidas. São enviados novos questionários às partes interessadas e é novamente investigado o dano. O segundo tipo

\footnotetext{
${ }^{635}$ Glicina, Regulamento (CEE) n. 2322/85 do Conselho, de 12 de agosto de 1985, J.O L 218/1.

${ }^{636}$ Peças vazadas. Regulamento (CE) n. 268/2006 do Conselho, de 14 de fevereiro de 2006, J.O L 47/3, de $17 / 02 / 2006$.
} 
de revisão é a revisão do novo exportador, aplicável à pessoa jurídica que não exportou ou produziu durante o período investigado. A revisão procederá ao cálculo da margem de dumping aplicada a este exportador. Ele pode requerer que o dano seja novamente investigado, mas deve provar a mudança nas circunstâncias que justifique o novo exame. O terceiro caso é o de revisão após cinco anos de aplicação da medida. A parte que a solicitar deve comprovar que i) há dumping e dano; ii) a recuperação parcial ou total do dano só foi possível pela existência de medidas antidumping; iii) é provável que o exportador continue praticando dumping. A quarta e última possível revisão é realizada sempre que houver indícios de que o exportador está absorvendo o custo das medidas antidumping, não o repassando aos importadores. Ele pode fazer isso de diversas formais, tais como contratos com o importador ou redução do valor da exportação.

Toda revisão que comporta análise do dano pode analisar o interesse público. Mais importante ainda, a revisão do interesse público poderá considerar, desta vez, situações reais, observadas com a aplicação das medidas. ${ }^{637}$

Além disso, sendo o interesse público alçado à categoria de um quarto e último elemento a ser pesquisado na investigação antidumping, nada impede que seja aberta investigação se existirem motivos para se acreditar que o interesse público observado à época da primeira aplicação não mais existe. Se for caracterizado que o teste do interesse público merece ser refeito, ele pode ser a causa de nova revisão.

\subsubsection{Consideração do interesse público para a aplicação de um direito mais flexível}

Discute-se, também, a consideração do interesse público para tornar a aplicação de medidas antidumping mais flexível. Pode-se examinar a vontade geral para definir modalidades específicas de medidas antidumping, além da aplicação de medidas em valores mais baixos. Desta forma, alcançar-se-ia uma imposição mais balanceada e

${ }^{637}$ SINNAEVE, Adinda. Op cit., p. 161. 
justa de medidas antidumping, aproximando-se a decisão dos interesses das várias partes interessadas. ${ }^{638}$

Uma maior flexibilidade seria bem-vinda, especialmente nos casos em que o balanço entre os interesses não é tão simples nem fornece resultados conclusivos. A medida pode ser fixada, por exemplo, em um valor mais baixo, que represente o menor direito suficiente para neutralizar o dumping (ou um direito menor do que a margem cheia) e permitir a recuperação da indústria doméstica. ${ }^{639}$

Sinnaeve entende importante o estudo da questão, mas reconhece que a falta de critérios e métodos específicos poderia trazer riscos e insegurança às investigações. Perder-se-ia o interesse pelo trabalho extenso e complexo das autoridades, que é o cálculo da margem de dumping e dano, para dar lugar a uma terceira margem fixada ao bel prazer. Além disso, seria muito difícil alcançar equilíbrio, já que o balanço entre os interesses conflitantes não é facilmente expressado em uma equação quantitativa. ${ }^{640}$

O Canadá utiliza o interesse público para conferir esta flexibilidade à aplicação da medida. O CITT pode recomendar a flexibilização do nível da medida e a investigação do efeito da sua redução. Se a redução for suficiente para os produtores domésticos e houver outros argumentos que a justifiquem, o CITT pode recomendá-la. Contudo, não há uma metodologia clara, sendo a redução fruto de uma apreciação discricionária.

No Brasil, não há previsão expressa para a utilização do interesse público com os fins de permitir maior flexibilidade à aplicação das medidas. Contudo, a construção de decisões mais flexíveis não é estranha à prática brasileira. No caso PVC, contra Estados Unidos e México, o DECOM decidiu pela aplicação de direitos antidumping sempre revisados, baseados na construção de um valor mínimo. Calculase, trimestralmente, o valor praticado pelo mercado mundial, considerado como um

\footnotetext{
${ }^{638}$ SAPIR, André. Op cit. p. 3.

${ }^{639}$ Aplicando-se, neste caso, a regra do direito menor defendida por alguns Membros, discutida no item 1.2.1.4.

${ }^{640}$ SINNAEVE, Adinda. Op cit. p. 177.
} 
valor normal razoável, e as importações cujos preços forem inferiores a este valor normal razoável são acrescidas da diferença. ${ }^{641}$

Na Comunidade Européia, esta flexibilidade não está prevista em lei e não é aplicada pelas autoridades, no que se refere ao valor do direito antidumping aplicado. Contudo, é aceita, quando o interesse público o autorizar, para a redução do tempo de aplicação da medida a um prazo menor do que cinco anos. ${ }^{642}$ Esta flexibilidade é desejada para proteger, da melhor forma, os diferentes interesses. ${ }^{643}$

${ }^{641}$ Processo MDIC/SECEX RJ-52100.027088/2003-33, Resolução n. 18, de 29 de junho de 2005.

${ }^{642}$ No caso Calçados a parte superior em couro, entendeu pela aplicação de medidas antidumping. Contudo, devido à forte pressão dos usuários industriais perante a França, o país propôs ao Conselho que as medidas só fossem aplicadas por dois anos, o que foi aprovado. Calçados a parte superior em em couro. Regulamento do Conselho de 5 de outubro de 2006, J.O L 275/1 de 6 de outubro de 2006.

${ }^{643}$ GRAAFSMA, Folkert; CORNELIS, Joris. The EC's Green Paper on Trade Defence Instruments: Guillotine on Anti-dumping or smokescreen for more basic predicaments? Global Trade and Customs Journal, v. 2, i. 7, 2007, p. 259. 


\subsection{A AUTORIDADE COMPETENTE PARA A ANÁLISE DO INTERESSE PÚBLICO}

Alguns Membros da OMC, como é o caso dos Amigos do Antidumping, questionam, nas discussões perante o Grupo de Negociações em Regras, se o Acordo Antidumping deve sugerir, ou mesmo apontar, qual a autoridade competente para a verificação do interesse público em cada país. ${ }^{644}$

A decisão deve ser deixada ao Membro, embora se possam fazer sugestões acadêmicas ou mesmo incluir, no texto do Acordo Antidumping, uma recomendação. Assim como cabe aos Membros escolher quais as autoridades são competentes para a análise do dano e do dumping, sendo-lhes permitido escolher e modificar seus sistemas a qualquer tempo, de acordo com a viabilidade financeira e conveniência, deve ser deixada, também, à escolha dos Membros, a autoridade que irá analisar o interesse público.

$\mathrm{O}$ sistema de defesa comercial dos Membros da $\mathrm{OMC}$, aqui entendido como as autoridades competentes e suas competências, varia, sensivelmente, de um país a outro. Grande parte deles possui duas autoridades, uma encarregada das investigações de dumping e dano (autoridade investigadora), e outra a quem cabe decidir sobre a aplicação da medida antidumping.

Em alguns Membros, a única autoridade investigadora possui dois departamentos, um responsável pelo dano e nexo, outro pelo dumping (ou seja, não são as mesmas pessoas as responsáveis pelos exames, embora estejam vinculadas a um mesmo órgão). ${ }^{645} \mathrm{Em}$ outros, há uma só autoridade e somente um corpo técnico, que realiza todo o trabalho investigatório. ${ }^{646}$

Cada um dos modelos escolhidos possui vantagens e desvantagens. A maior desvantagem para a escolha de apenas uma autoridade é a falta de independência

\footnotetext{
${ }^{644}$ Economic Effects of Anti-dumping Measures: paper from Hong Kong, China, and the Separate Customs Territory of Taiwan, Penghu, Kinmen e Matsu, TN/RL/GEN/142, 6 de junho de 2006.

${ }^{645}$ Este é o caso da Comunidade Européia.

${ }^{646}$ Este é o caso do Brasil e da África do Sul.
} 
entre as análises. Após reconhecer a existência de dumping, o corpo técnico responsável pela investigação tende a acreditar que o dano, quando existente, foi causado por este dumping. Ao mesmo tempo, a análise por uma só autoridade é vantajosa, já que permite uma visão global da indústria e, ao mesmo tempo, dos preços praticados no mercado estudado. Além disso, diminui-se o gasto com a máquina administrativa, o número de documentos solicitados e de audiências realizadas (já que é feita uma audiência una). ${ }^{647}$

Para que se possa compreender a sugestão apresentada por este trabalho, três diferentes sistemas foram escolhidos para estudo: o modelo europeu, o canadense e o brasileiro.

Na Comunidade Européia, há apenas uma autoridade investigatória (Comissão Européia), segmentada em dois departamentos. Certamente, não se pode dizer que são duas autoridades distintas, já que só haverá uma decisão final e pode existir certa comunicação entre elas. As funções são divididas entre a Direção-Geral I.C, que investiga o antidumping, e a Direção-Geral I.E., que investiga o dano e o interesse comunitário. O objetivo desta divisão, que existe desde 1995, é reduzir o tempo de análise e aumentar a objetividade das decisões. Outras Direções-Gerais podem ser envolvidas no processo, caso necessário, como Concorrência (Direção-Geral IV). ${ }^{648}$ Após a recomendação de ambas as Direções-Gerais sobre a existência de dumping e dano, decidirá a Comissão pela aplicação de medidas provisórias ou medidas definitivas. No caso das medidas provisórias, a decisão pode ser tomada pela própria Comissão, a não ser que o Conselho, deliberando por maioria qualificada, decida contrariamente. $^{649} \mathrm{Na}$ aplicação definitiva, assim que receber os comunicados de existência de dumping e dano, bem como a confirmação de que o interesse comunitário é favorável à aplicação de medidas, cabe ao Conselho, deliberando por maioria simples, criar o direito. ${ }^{650}$

No Canadá, há duas autoridades distintas. A aplicação do SIMA (Special Import Measures Act) cabe, conjuntamente, ao Department of National

\footnotetext{
${ }^{647}$ VERMULST, E; WAER, P. E.C. Antidumping Law and Practice. London: Sweet \& Maxwell, 1996, p. 282.

${ }^{648}$ MOEN, Paul. Op cit., p.52.

${ }^{649}$ Art. 7.6 do Regulamento Básico europeu.

${ }^{650}$ Art. 9.4 do Regulamento Básico europeu.
} 
Revenue (Revenue Canada) e ao CITT. Revenue Canada é o órgão responsável pela investigação de dumping. ${ }^{651}$ Ao CITT compete iniciar a investigação se a aplicação lhe parecer de interesse público, bem como analisar o dano e do nexo causal. ${ }^{652}$

O CITT pode iniciar um procedimento especial para apuração do interesse público no antidumping se houver indícios suficientes de que a imposição de medidas pode não ser o desejo público. O primeiro passo desta avaliação é a sua publicação em jornal oficial. Quem se interessar por este exame poderá apresentar sua opinião, oralmente ou por escrito. O CITT poderá decidir pela redução das medidas antidumping recomendadas pelo Revenue Canada ou especificar o valor adequado para eliminar o dano ou ameaça de dano à indústria doméstica. ${ }^{653}$

No Brasil, compete ao DECOM a investigação de dumping, de dano, bem como a conclusão sobre o nexo causal. ${ }^{654}$ Segundo o art. $2^{\text {o }}$ do Decreto n. 1.602/95, compete aos Ministros de Estado da Indústria, Comércio, Turismo e Fazenda a decisão de aplicar, em conjunto, medidas provisórias e direitos definitivos, bem como homologar compromissos, com base em parecer da Secretaria de Comércio Exterior (SECEX), comprovando a existência de dumping e de dano. O mesmo corpo técnico responsável pela investigação de dano é responsável pela condução da investigação de dumping e pela conclusão sobre o nexo causal. As mesmas pessoas realizam as verificações nas empresas, quando elas ocorrem. As audiências, segundo o artigo 31 do mesmo instrumento jurídico, quando solicitadas, são realizadas (é prática das autoridades brasileiras realizar audiências em todas as investigações antidumping). Dispõe o artigo 64 , parágrafo $3^{\circ}$, que cabe às autoridades do artigo $2^{\circ}$ decidir pela suspensão do direito, não homologação de compromisso de preços ou pela aplicação da

\footnotetext{
${ }^{651}$ No caso do Canadá, ao contrário da Comunidade Européia, há, de fato, duas autoridades separadas. Contudo, como comenta Moen, as análises não são tão independentes quanto parece. Cabe ao Revenue Canada opinar pela existência de dumping para a abertura da investigação. Contudo, o CIIT pode ser chamado a opinar em três hipóteses: i) se o Revenue Canada decidir não iniciar a investigação por falta de indício de dano (tanto o Revenue Canada, quanto a parte interessada, podem pedir segunda opinião ao CITT); ii) a investigação de dano é conduzida pelo Revenue Canada, mas qualquer parte interessada pode pedir ao CITT que manifeste sua opinião, contrária ou favorável, à condução da investigação pelo Revenue Canada no que concerne ao dano; iii) após o entendimento do Revenue Canada sobre o dano, esta decisão pode ser revista pelo CITT. Por estas possíveis revisões, o autor atribui a função quasejudicial ao CITT. (Op. Cit. p. 63.)

${ }^{652}$ Art. 45 do SIMA.

${ }^{653}$ Art. 45 do SIMA.

${ }^{654}$ Art. $3^{\circ}$ do Decreto 1.602/95.
} 
medida definitiva em valor diferente do recomendado, se esta decisão for baseada em razões de interesse nacional.

Diante das três diferentes experiências acima narradas, pode-se concluir que há três possíveis autoridades competentes para a análise do interesse público: i) a autoridade responsável pela análise de dano (ou seja, que irá estudar a situação do mercado investigador); ii) a autoridade responsável pela decisão final sobre a aplicação de direito antidumping (que analise dano e dumping); iii) uma autoridade

parcialmente independente da investigação de dumping e dano. É possível dizer que há uma autoridade mais adequada a este exame?

\subsubsection{A autoridade concorrencial}

Antes de analisar qual autoridade de defesa comercial, ou modelo, é mais adequado à análise do interesse público, vale dissertar sobre a participação das autoridades concorrenciais em exames antidumping.

Como comentado, ${ }^{65}$ alguns autores sugerem que uma boa análise concorrencial, feita por um bom sistema de defesa da concorrência, já seria capaz de evitar que as empresas praticassem dumping em outros mercados. As medidas antidumping teriam como efeitos, segundo esta opinião, a redução da competição no mercado investigador, e, com isso, a diminuição da oferta de produtos, preços mais altos, bem como o eventual aumento de poder econômico da indústria doméstica. Por esta razão, seria útil uma cooperação - e até mesmo substituição - entre as autoridades de defesa comercial e as autoridades de defesa da concorrência. ${ }^{656}$

Cooperação é diferente de substituição. A função de defesa da concorrência é diferente da função de defesa comercial. Elas são consideradas, inclusive, conflitantes. A atividade da autoridade da concorrência será sempre baseada na necessidade de se preservar o mercado e as opções ao consumidor, a preços que não

\footnotetext{
${ }^{655}$ Capítulo 2.3.1.2.3.

${ }^{656}$ MONTEIRO, Carmen Diva Beltrão; GALVÃO, Letícia Andreoli. Interesse público: critérios para a consideração em processos de investigação antidumping. SEAE/MF Documento de trabalho $\mathrm{n}$. SEAE/MF Documento de trabalho n. 44, Dezembro de 2006, citada no item 1.2.2.2.
} 
sejam de monopólio. Uma autoridade de defesa comercial tem, inevitavelmente, a função oposta de conceder proteção ao competidor doméstico, que deve estar sofrendo com a competição que esta autoridade considera desleal.

Como enfatizado, as atividades podem ser complementares se a boa regulação da concorrência evitar a formação de concentrações econômicas e, com elas, a prática de dumping no mercado internacional, mas a atividade da autoridade concorrencial termina neste momento. Em alguns casos, ela não conseguirá evitar a concentração, se esta for necessária ao desenvolvimento da indústria, por exemplo, sendo possível que as empresas concentradas pratiquem dumping em outro país, o que não é punível per se. ${ }^{657}$ A atividade da autoridade de defesa comercial será estudar tais importações, concluir se elas estão causando dano à indústria deste outro país e, em caso de resposta positiva, conceder a proteção esperada pelos produtores domésticos.

As atividades são também complementares no sentido de que caberá à autoridade de defesa comercial observar, como defendido no capítulo dedicado à concorrência, a situação concorrencial provocada pela aplicação de medidas. Caso exista a possibilidade de que a indústria doméstica pratique, no futuro, preços de monopólio ou a redução da oferta, esta possibilidade só serve, à autoridade de defesa comercial, como um dos argumentos para o lado da balança relativo a não aplicação das medidas. ${ }^{658}$

Nos Estados Unidos, é freqüente o contato entre as autoridades de defesa da concorrência e de comércio internacional. O objetivo deste contato, segundo a manifestação do Advogado Geral dos Estados Unidos, em 1977, é "assegurar que o alívio perante a competição estrangeira é autorizado apenas quando os critérios

\footnotetext{
${ }^{657}$ Kennedy ressalta que, em pequenas economias, para que a indústria possa atingir economias de escala, pode ser necessário tolerar uma grande concentração de poder de mercado, que não seria admitido, talvez, em um grande país. Até mesmo cartéis podem ser tolerados. Por exemplo, a legislação concorrencial da Coréia dispõe que, em caso de indústrias crescentes ou indústrias em dificuldades, pode ser permitido que estas indústrias celebrem acordos verticais, como forma de racionalização. (Kennedy, Kevin. Op. cit. p. 247.)

${ }^{658}$ Capítulo 2.3.1.4.
} 
definidos para esta proteção são encontrados e quando não existe nenhuma outra medida proposta, com efeitos menos negativos para o consumidor e para a competição."659

No Canadá, um dos quatro casos em que foi usado o interesse público como argumento para a não aplicação ou diminuição das medidas antidumping aplicadas, teve a autoridade concorrencial como coautora da decisão. No caso Korean Cars, o diretor de investigação e pesquisa do Departamento de Política Concorrencial apresentou duas manifestações escritas no procedimento antidumping, argumentando que a Hyundai, acusada de praticar dumping, exercia uma influência positiva sobre a competição no País, propiciando maior competitividade e mais opções de escolha. Ele citou a crescente demanda, do mercado mundial, por veículos de passageiros e a preferência dos consumidores por carros melhores. ${ }^{660}$

Na Comunidade Européia, como mencionado acima, é possível a colaboração entre autoridades de defesa comercial e autoridades concorrenciais. Esta cooperação, entretanto, é limitada pelas disposições do artigo 19.5 e 19.6, que impedem a comunicação de dados e informações, pela autoridade antidumping, a outras autoridades, e reza que as informações recebidas em investigações antidumping só podem ser utilizadas para o fim para o qual foram solicitadas. Contudo, há casos em que, mesmo que não haja transmissão ou apreciação de informação concedida para outro propósito, já existe investigação de prática econômica restritiva pela autoridade concorrencial, em curso ou finalizada, no mesmo mercado investigado pela autoridade antidumping. Nestes casos, é natural e legal que exista comunicação entre as autoridades. ${ }^{661}$

A não colaboração entre as autoridades de defesa da concorrência e defesa comercial traz, por vezes, contradições. Há casos em que a autoridade de defesa da concorrência acredita poder contar com as importações como fonte de contestação no mercado examinado, sem saber que outras autoridades, desta vez de defesa comercial,

\footnotetext{
${ }^{659}$ Annual Report of the Attorney General of the United States, 1977, in Anti-dumping policy and the consumer. P. 470.

${ }^{660}$ DUTZ, Mark. Enforcement of Canadian Trade Remedies Laws: the case for competition policies as na antidote for protection. FINGER, Michael. Antidumping: how it works and who gets hurt. Cit, p. 216.

661 Houve profunda cooperação entre as autoridades de defesa comercial e concorrencial no caso Extramet, já citado no capítulo 3.3.3.2.
} 
estão investigando este mercado e poderão aplicar medidas antidumping que inviabilizarão estas importações.

Por estas razões, não se defende, aqui, que a autoridade concorrencial seja a responsável pela investigação de interesse público, ou possa, de qualquer forma, exercer influência relevante sobre o resultado desta análise. Ao contrário, aceita-se a cooperação entre estas autoridades como uma forma de melhoria na qualidade das investigações e, principalmente, na avaliação dos efeitos a serem provocados pela decisão.

\subsubsection{A autoridade de defesa comercial}

Como descrito na introdução deste capítulo, há vários modelos de autoridade de defesa comercial. Alguns Membros adotam o sistema em que há uma só autoridade investigatória, outros possuem autoridades distintas para o exame do dumping e do dano.

Nos Membros que já aplicam o teste do interesse público, como no Canadá, a mesma autoridade responsável pela análise do dano é a autoridade responsável pela análise do interesse público. Este modelo parece perfeito, desde que a autoridade que procede à verificação do dano possua total independência em relação à aplicação final da medida. Na Comunidade Européia, por exemplo, o exame do dano e do interesse público são feitos pela mesma autoridade, quase simultaneamente, mas não é esta autoridade a responsável pela decisão final, que cabe ao Conselho. Por esta razão, embora a Comissão tenha liberdade para ouvir o interesse das partes que podem contribuir com a investigação do melhor resultado para a Comunidade, será do Conselho a última palavra em relação ao assunto, o que permite, certamente, a interferência política que pode comprometer, em alguns casos, a análise objetiva e imparcial sobre a questão. ${ }^{662}$

\footnotetext{
662 "O principal canal pelo qual lobbies e os eleitores influenciam a Comunidade Européia é o governo dos Estados Membros, via Conselho de Ministros. Os comissários são geralmente políticos por formação. Além disso, não é suficientemente claro que a Secretaria é uma agência política inteligente cuja função não é chegar à raiz dos problemas e mapear soluções, mas sim percorrer um complexo sistema de comitês
} 
O modelo brasileiro não é adequado à análise do interesse público. A CAMEX, responsável pela decisão, é uma Câmara composta por Ministros de Estado ${ }^{663}$ de diversas áreas de interesse nacional, mas que, por vezes, não conhecem os objetivos do instrumento antidumping e a sua origem histórica. Embora a CAMEX tenha por objetivo a formulação, adoção, implementação e coordenação de políticas relativas ao comércio exterior de bens e serviços ${ }^{664}$, ela também comporta funções como definir procedimentos relativos à implementação da política de comércio exterior, estabelecer diretrizes para negociação de pactos bilaterais, regionais ou multilaterais e formular diretrizes para a política tarifária de importação e exportação. Estas políticas não podem afetar a decisão sobre a aplicação de medidas antidumping, de natureza econômica, que comporta, no máximo, a avaliação das conseqüências da medida para as partes afetadas. $^{665}$

Além disso, não há qualquer previsão legal de contato entre as autoridades que realizaram a investigação (DECOM) e os Ministros da CAMEX. Não havendo contato da CAMEX com as partes ou com a investigação, restará prejudicado o entendimento da câmara no que diz respeito à consideração do interesse público. Como, no Brasil, é a Câmara a única responsável, nos termos do art. 46, parágrafo $3^{\circ}$ pela decisão de não aplicar medidas em caso de interesse público, não fazendo os investigadores qualquer juízo de valor sobre a matéria, tem-se uma distância muito grande entre o órgão decisor (CAMEX) e as pessoas que realmente compreenderam as características da indústria, suas necessidades e os efeitos destas medidas para possíveis partes afetadas.

\footnotetext{
e grupos de trabalho, com a função básica é manter a Comissão em contato próximo com os governos dos Estados Membros. Também não é reconhecido a medida pela qual importantes decisões são influenciadas por contatos pessoais entre comissários ou seus assessores e políticos influentes, servidores civis, homens de negócios e sindicatos." (Tradução livre de VERREYDT, Eric; WAELBROECK, Jean. European Community Protection against Manufactured Imports from Developing Countries: A case study in the political economy of protection. In Import, Competition and Response, Chicago: National Bureau of Economic Research, 1982, p. 377.)

${ }^{663}$ O Ministro do Desenvolvimento, Indústria e Comércio Exterior, Ministro da Casa Civil da Presidência da República, Ministro das Relações Exteriores, Ministro da Agricultura, Ministro da Fazenda, Ministro do Planejamento, Orçamento e Gestão, e Ministro do Desenvolvimento Agrário.

${ }^{664}$ Art. $1^{\circ}$ do Decreto 4.732, de 10 de junho de 2003.

${ }^{665}$ Esta é a opinião do Senador brasileiro Francisco Dornelles, que propôs, em 2007, um Projeto de Lei (PLS 715/07) para a criação de um Conselho de Defesa Comercial no País. Para ele, a CAMEX não tem a independência suficiente à análise antidumping e o sistema atual de aprovação das decisões do DECOM é lento e impede que sejam aplicadas medidas provisórias. (ver mais em www.senado.gov.br).
} 


\subsubsection{A necessária independência da autoridade}

Diante das experiências narradas, embora o objetivo deste trabalho não seja sugerir que o Acordo Antidumping imponha aos Membros a autoridade que deva investigar o interesse público, mas apenas fazer sugestões acerca das características desta autoridade, é desejável que ela goze de autonomia e distanciamento das decisões de natureza política do país. Ao mesmo tempo, é desejável que ela tenha perfeito conhecimento da indústria analisada, que tenha acompanhado a análise de dano à indústria doméstica, para que seja capaz de encontrar o equilíbrio necessário entre os anseios dos produtores nacionais e dos outros agentes afetados pela aplicação de medidas antidumping. ${ }^{666}$

Este ponto tem sido alvo de debate na Comunidade Européia. Os estudos que precederam a elaboração do Livro Verde ${ }^{667}$ lembraram que, na Europa, é enorme a possibilidade de interferência política nas decisões sobre aplicação de medidas de proteção comercial. Para alguns, a decisão deve ser puramente técnica, mas, como os Estados Membros podem manifestar suas opiniões sobre as conseqüências das medidas em seus territórios, este tecnicismo é comprometido.

Para Stevenson, a interferência dos Membros é importante: eles estão mais próximos à sua realidade do que os operadores de Bruxelas. Entretanto, uma decisão totalmente política e individualista de um Membro é condenável. ${ }^{668}$ Para isso, o mecanismo de voto permite que cada Membro possua seu peso sobre as decisões e que um interesse estritamente político não consiga prevalecer. Parece impossível que o

\footnotetext{
${ }^{666}$ No caso do (Algodão. Regulamento (EU) n. 2208/96 de 18 de novembro de 1996), oito Estados Membros recusaram a aplicação de medidas que havia sido recomendada pela Comissão, após longo estudo sobre a existência de interesse público. Há críticas de que, neste caso, os usuários industriais, entendendo que não foram ouvidos suficientemente pela Comissão, acusando-a de adotar um procedimento não transparente, decidiram exercer pressão sobre vários Estados Membros. O resultado foi o entendimento totalmente contrário à decisão técnica. (FIEBIGER, Gernot. The Community Interest Test in EC Antidumping Law: Recent developments. Master Thesis Executive M.B.L, supervised by Jacques Bourgeois, St. Gallen, 2001, p 30.)

${ }^{667}$ Discutido no tópico 1.2.2.1.1

668 "Embora os Estados Membros conheçam claramente os impactos das medidas sobre seus territórios, uma decisão de um Membro votando em nome de seu interesse nacional seria ilegal. Cada Membro deve definir o que está no interesse comunitário. O Conselho perderia um recurso perante o Tribunal Europeu se a motivação para a rejeição de uma medida fosse baseada no argumento de 13 interesses nacionais negativos." (STEVENSON, Cliff. Op. Cit.p. 31)
} 
interesse político ou econômico particular de um Membro seja vitorioso se não for este o interesse comunitário. ${ }^{669}$

$\overline{{ }^{669} \text { STEVENSON, Cliff. Op cit. p. } 31 .}$ 


\subsection{A POSSIBILIDADE DE REVISÃO DA DECISÃO ADMINISTRATIVA}

O último texto proposto pelo Grupo de Negociações em Regras, como comentado em capítulo dedicado a este tema ${ }^{670}$, sugere a modificação do art. 9.1, para incluir um teste de interesse público obrigatório. ${ }^{671}$ Contudo, um dos pontos principais, alvo de muitos comentários dos Membros, é a proibição de revisão da decisão da autoridade pelo mecanismo de solução de controvérsias da OMC e pelo Poder Judiciário.

Para os Membros que se manifestaram expressamente sobre este assunto, a observância do procedimento na aplicação da cláusula deve estar sujeita à revisão, que não deve alcançar, entretanto, o conceito de interesse público, ou seja, o que o Membro define como interesse público. ${ }^{672}$

\subsubsection{Revisão pelo Poder Judiciário}

O Acordo Antidumping determina, em seu art. 13, que os Membros mantenham tribunais ou procedimentos judiciais ou arbitrais para a revisão das medidas administrativas vinculadas a determinações definitivas ou provisórias de direito antidumping. Estes tribunais serão independentes das autoridades investigadoras.

Como discutido anteriormente, é recomendável que os tribunais responsáveis pelo julgamento de casos antidumping sejam especializados, devido à complexidade da matéria. ${ }^{673} \mathrm{Se}$ isso não for possível, é desejável, pelo menos, que estes

\footnotetext{
${ }^{670}$ Item 1.2.1.3.

${ }^{671}$ Art. 9.1 (proposta) Cada Membro que possui legislação antidumping deve estabelecer procedimentos em sua lei ou regulamento que permita que suas autoridades, ao tomar as decisões descritas no artigo 5 levem em consideração a representação feita pelas partes domésticas interessada ${ }^{671} s$ que podem ter seu interesse afetado pela imposição de medida antidumping. A aplicação destes procedimentos, $e$ as decisões tomadas em relação a ele, não devem ser sujeitas ao mecanismo de solução de controvérsias, ao art. 17 deste Acordo ou qualquer outra previsão de acordo da OMC. (TN/RL/W/213, 2007)

${ }^{672}$ Public Interest: Communication from Colombia, Hong Kong, China, Israel, Japan, Norway, Singapore, Switzerland, the Separate Customs Territory of Taiwan, Penghu, Kinmen and Matsu, and Thailand. 12 de março de 2008.

${ }^{673}$ Tópico 1.1.3.2.
} 
tribunais sejam especializados em revisão de decisões administrativas, como acontece na França, para que os juízes estejam familiarizados com os desafios da administração pelo Poder Executivo. ${ }^{674}$

Alguns Membros, como é o caso do Brasil, adotam o princípio da inafastabilidade do Poder Judiciário ${ }^{675}$, o que significa que nenhuma decisão, nenhum conflito, pode ser afastado da apreciação pelo Poder Judiciário.

$\mathrm{Na}$ Comunidade Européia, podem ser revisados todos os atos administrativos que objetivem ter força de lei. No caso do antidumping, são entendidos como sendo tais atos: i) decisões da Comissão sobre a não abertura da investigação; ii) decisões sobre imposição de medidas provisórias; iii) decisões do Conselho determinando o recolhimento definitivo de direitos assegurados por meio de medidas provisórias; iv) determinações sobre imposição de medidas definitivas; v) decisões determinando o encerramento do procedimento. Contudo, tal revisão é limitada à verificação do respeito às regras processuais, verificação de erro óbvio de avaliação dos fatos e casos de abuso de poder. ${ }^{676}$ As irregularidades na rejeição de uma proposta de compromisso de preços podem ser questionadas na hipótese iv. Da mesma forma, a aceitação de um compromisso pode ser questionada por meio da alternativa v. Ainda na Comunidade Européia, para provocar a revisão, a parte deverá demonstrar: i) incompetência do órgão decisor; ii) violação a procedimento; iii) violação ao Tratado ou a alguma lei relativa à sua aplicação; iv) abuso de poder. ${ }^{677}$

Na Comunidade Européia, podem postular a revisão da decisão antidumping, pelo Poder Judiciário, os Estados Membros ${ }^{678}$, a própria Comissão ou o Conselho, o Parlamento e o Banco Central Europeu. ${ }^{679}$ Qualquer outro interessado

\footnotetext{
${ }^{674}$ BENITAH, Mark.The Law of Subsidies under GATT/WTO Systems, London: Kluwer Law. 2001, p. 198.

${ }^{675}$ Art. 5, inciso XXXV, da Constituição Federal brasileira.

${ }^{676}$ Decisão no caso C-156/87 Gestetner, parágrafo 63. No caso C-179/87, Sharp Corporation, parágrafo 59, o Tribunal de Justiça avaliou a decisão do Conselho, que determinou a aplicação de medidas antidumping sobre a importação de fotocopiadoras do Japão, diante do argumento de empresas japonesas estavam adquirindo empresas européias em dificuldades financeiras. O Tribunal se limitou a dizer que, como não houve nenhum erro óbvio de avaliação dos fatos, o entendimento da Comissão não poderia ser modificado.

${ }^{677}$ STANBROOK, Clive; BENTLEY, Philip. Op cit. p. 209-210.

${ }_{678}^{678}$ Caso 129/86, Hellenic Republic v. Council and Commission (1987) ECR 1189.

${ }^{679}$ Art. 263 (ex-artigo 230 do Tratado que institui a Comunidade Européia) O Tribunal de Justiça da União Européia fiscaliza a legalidade dos atos legislativos, dos atos do Conselho, da Comissão e do
} 
deverá demonstrar que a medida lhe foi endereçada, ou que a medida, direta e individualmente, afeta-lhe. ${ }^{680}$

Diante destas considerações e exemplos, cabe questionar: i) se uma decisão administrativa sobre o interesse público pode ser revista pelo Poder Judiciário; ii) quem seriam as partes legítimas para contestá-la.

\subsubsection{A revisão da decisão de interesse público pelo Poder Judiciário}

A resposta ao primeiro questionamento é simples. A OMC é uma organização cujos Membros adotam diferentes sistemas jurídicos, diferentes formas de sanção e diferentes regras procedimentais. Muitos destes Membros possuem regras sobre o que deve ser levado ao conhecimento do Poder Judiciário. Alguns deles optam por uma intervenção abrangente ${ }^{681}$, outros optam por uma intervenção limitada. ${ }^{682}$ Por estas divergências entre os Membros, afastar qualquer possibilidade de análise do conteúdo de uma decisão administrativa, por meio de um acordo internacional, não parece ser uma alternativa viável. Além disso, o tema do interesse público está

\footnotetext{
Banco Central Europeu, que não sejam recomendações ou pareceres, e dos atos do Parlamento Europeu e do Conselho Europeu destinados a produzir efeitos jurídicos em relação a terceiros. O tribunal fiscaliza também a legalidade dos atos dos órgãos ou organismos da União destinados a produzir efeitos jurídicos em relação a terceiros. Para o efeito, o Tribunal é competente para conhecer dos recursos com fundamento em incompetência, violação de formalidades essenciais, violação de Tratados ou de qualquer norma jurídica relativa à sua aplicação, ou em desvio de poder, interpostos por um Estado-Membro, pelo Parlamento Europeu, pelo Conselho ou pela Comissão. O Tribunal é competente, nas mesmas condições, para conhecer dos recursos interpostos pelo Tribunal de Contas, pelo Banco Central Europeu e pelo Comitê das Regiões com o objetivo de salvaguardar as respectivas prerrogativas.

${ }^{680}$ ADAMANTOPOULOS, Konstantinos; PEREYRA, María. EU Anti-subsidy Law \& Practice. 2 ed. London: Sweet \& Maxwell. 2007, p. 464.

${ }^{681} \mathrm{Na}$ Comunidade Européia, o Poder Judiciário do Membro pode analisar todo o fundamento da decisão antidumping, não somente os aspectos formais. (Caso C-216/91 - Rima Eletrometalurgia), em que o exportador solicitou ao Tribunal a revisão da decisão do Conselho que determinou a aplicação de medidas antidumping. A corte reexaminou o mérito da decisão do Conselho, no que se referia à prova e aos valores para o cálculo do dumping.)

${ }^{682}$ Nos Estados Unidos, a indústria doméstica não pode pedir a revisão, pelo Poder Judiciário, da decisão administrativa que nega a aplicação de medidas antidumping, embora os importadores possam pedir a revisão de decisões que impõem medidas. (STYN, Ronald. The Antidumping Act: Problems of Administration and Proposals for Change. Stanford Law Review, v. 17, n. 4, 1965, p. 745.)
} 
intimamente relacionado às necessidades e interpretações nacionais, estipuladas pelos governantes. ${ }^{683}$

Impedir que o Poder Judiciário revise uma decisão relativa à vontade nacional pode motivar decisões admistrativas extremamente arbitrárias. Por fim, é muito mais razoável, para a maioria dos interessados, o recurso local, aos seus próprios juízes, do que convencer o país exportador a recorrer ao mecanismo de solução de controvérsias da OMC. Impedir este acesso é limitar, de forma perversa, a defesa dos interesses destas partes.

Segundo Jaffe, um indivíduo que tem seu interesse afetado por uma ação administrativa tem o direito, em algum ponto, a uma determinação judicial sobre a sua validade. ${ }^{684}$ A revisão judicial de decisões administrativas i) corrige um eventual exercício arbitrário de poder; ii) estimula ações oficiais responsáveis com fundamento na possibilidade de análise judicial e anulação; iii) aumenta a credibilidade do público diante do processo administrativo; iv) preserva o devido processo legal. ${ }^{685}$

Embora seja recomendável a obrigatória análise judicial das decisões sobre interesse público, nada garante que este exame será isento de qualquer consideração política. Os tribunais desempenham um importante papel na implementação de políticas e, quando o assunto é o interesse público, não se pode esperar resultado diferente. Haverá sempre a possibilidade de uma pouco técnica, mesmo quando emitida pelo Poder Judiciário. Autores ressaltam que este risco é maior ainda no caso de uma corte especializada, como é recomendável para os casos de antidumping. Unah promoveu um estudo econômico que demonstra, claramente, que, nos Estados Unidos, as decisões judiciais tendem à proteção da indústria doméstica. ${ }^{686}$ No caso de discussão de interesse público, é importante que os juízes conheçam os preceitos esperados para a análise, principalmente o necessário equilíbrio entre todas as partes envolvidas e afetadas.

\footnotetext{
${ }^{683}$ Como discutido no item 1.3.1.

${ }^{684}$ JAFFE, The Right of Judicial Review, Harvard Law Review, n. 71, 1958, p. 408.

685 STYN, Ronald. The Antidumping Act: Problems of Administration and Proposals for Change. Stanford Law Review, v. 17, n. 4, 1965, p. 748.

${ }^{686}$ UNAH, Isaac. Specialized Courts of Appeals' Review of Bureaucartic Actions and the Politics of Protectionism. Political Research Quarterly, v. 50, n. 4, 1997, p. 851-878.
} 
3.5.1.2 A legitimidade ativa para recorrer ao Poder Judiciário no caso de conflito sobre o interesse público

Se os Membros considerarem, como partes interessadas, a indústria doméstica, seus fornecedores, os usuários industriais, importadores, e associações de consumidores, é desejável que estes mesmos personagens sejam considerados partes legítimas no pólo ativo de ações judiciais. As razões são as mesmas do próprio sentido da revisão judicial: se eles são partes obrigatórias na investigação de interesse público, a apreciação pelo Poder Judiciário conferirá credibilidade, tornará as decisões mais elaboradas, preservará o devido processo legal e estimulará ações responsáveis pelas autoridades.

Há que se ressaltar que a revisão judicial, neste caso, deve se limitar à análise da decisão sobre o interesse público. Desta forma, restringe-se o interesse destes personagens à parte da decisão para a qual contribuíram ou são diretamente afetadas, impedindo que possam discutir elementos da investigação que são de interesse restrito das partes consideradas interessadas referidas no art. 6.11.

Atualmente, como não existe obrigatoriedade na aplicação do teste do interesse público, cada Membro tem autonomia para, caso decida pela utilização do teste, determinar quais serão as partes interessadas e como serão colhidas e consideradas suas informações. Caso seja aprovado um teste obrigatório, deve o Acordo Antidumping determinar quais são estas partes. A partir deste momento, não é desejável que estas partes determinadas tenham seu direito à revisão da decisão, pelo Poder Judiciário, negado pela legislação nacional. Contudo, o Acordo Antidumping não poderá impor esta consideração, mas apenas recomendá-la, como faz o art. 13 em relação à própria revisão. Isto porque, conforme mencionado acima, a determinação da competência judicial deve ficar a critério do Membro.

Na Comunidade Européia, o entendimento do Tribunal de Justiça sobre a legitimidade dos interessados para recorrer, judicialmente, de decisão antidumping, é errático. No caso Bureau Européen des Unions de Consommateurs v. 
Commission, a associação de consumidores reclamou, perante o Tribunal de Justiça europeu, o fato de não ter tido acesso aos documentos não confidenciais em uma investigação antidumping, o que lhe foi negado por meio de um ofício enviado pela Comissão. Entendeu a corte que o recurso judicial promovido pelo Bureau era legítimo, já que a carta afetava seus interesses. ${ }^{687}$ No caso Ball Bearings, o recurso do importador foi considerado legítimo, mas ficou claro, pelas palavras do Advogado Geral, que não teria sido aceito se este importador não pertencesse ao mesmo grupo econômico do exportador (parte interessada). ${ }^{68}$ No caso Extramet, o Tribunal aceitou o recurso promovido pelos distribuidores (traders), mas restou claro que a legitimidade só seria reconhecida em circunstâncias específicas, em que sua participação na investigação tivesse sido realmente decisiva. ${ }^{689}$

\subsubsection{Pelo mecanismo de solução de controvérsias da OMC}

Há polêmica, nas negociações sobre regras, a respeito da possibilidade de revisão, pelo órgão de solução de controvérsias, de decisões nacionais sobre interesse público. Conforme descrito no tópico dedicado ao tema ${ }^{690}$, é opinião da maioria dos Membros que a revisão não deve ser permitida pelo novo texto do acordo, sob pena de ferir a soberania de cada um e o direito individual de definir o que seja interesse público.

Este trabalho propõe critérios substantivos para a análise do interesse público, baseados na experiência de algumas autoridades nacionais que já realizam o teste e nas propostas dos Membros. A simples discriminação dos critérios já invalida o argumento de que a definição do conceito do interesse público deve ser feito, no caso-acaso, pelos Membros, no exercício de sua soberania.

\footnotetext{
687 Decidiu a corte que o procedimento antidumping e as decisões adotadas não resultam em conseqüências para estes consumidores, não há nenhuma alegação contra eles. Entendeu a corte, também, que o fato de certo acesso ser concedido a consumidores, em alguns casos, não torna este acesso obrigatório em todos os procedimentos. A decisão sobre as partes afetadas ou não pela investigação é discricionária e cabe somente à Comissão. (Caso C-170/89, 28 de novembro de 1991.)

${ }^{688}$ Opinião do Advogado Geral no caso Ball Bearings, op cit, p. 1244.

${ }^{689}$ Extramet, op cit.

${ }^{690}$ Tópico 1.2.1.3.
} 
Para que se possa concluir sobre a viabilidade do exame de decisão sobre interesse público, pelo órgão de solução de controvérsias da OMC, propõem-se três etapas: i) o estudo dos critérios para exame, pelo órgão de solução de controvérsias, nas disputas antidumping; ii) a análise teórica e jurisprudencial de entendimentos sobre a intervenção do órgão de solução de controvérsias em decisões de conteúdo aparentemente soberano; iii) a conclusão sobre a possibilidade de revisão, pela OMC, de decisões nacionais sobre interesse público.

3.5.2.1 Critério de exame pelo órgão de solução de controvérsias da OMC

A liberalização do comércio internacional trouxe novas regras a serem respeitadas pelos Membros da OMC, e, com estas regras, a chance de violação ou erro de interpretação. Para sanar tais erros e impedir abusos, foi assinado o Acordo de Solução de Controvérsias, estabelecendo a competência de um grupo de experts e de um órgão de apelação para a análise da conduta dos Membros perante os acordos firmados.

Um dos maiores temores dos Membros, de uma forma geral, é a ingerência exagerada, por este grupo de experts ou pelo Órgão de Apelação, nas decisões que são, por sua natureza, relacionadas ao interesse nacional e à soberania. A palavra soberania causa polêmica no que se refere ao relacionamento entre as regras internacionais e as instituições nacionais. Contudo, há que se lembrar que a função principal do órgão de solução de controvérsias não é rever o entendimento das autoridades nacionais, mas sim avaliar a conformidade deste entendimento com as regras multilaterais e torná-las efetivas, adicionando uma medida de previsibilidade e efetividade a um sistema orientado por normas que, de outra forma, seriam fracas. ${ }^{691}$

Para assegurar o principal objetivo do mecanismo de solução de controvérsias, ou seja, a efetividade dos compromissos multilaterais, é fundamental que sejam claramente delimitadas as funções deste órgão. Caso contrário, há um enorme

${ }^{691}$ CROLEY, Steven; JACKSON, John. WTO Dispute Procedures, standard of review, and deference to national governments. American Journal of International Law, v. 90, 1996, p. 193. 
risco de que ele ultrapasse sua competência e invada a esfera de competência nacional. ${ }^{692}$

A assinatura dos acordos da OMC foi comemorada como forma de reprimir a análise pelo mecanismo de disputas do GATT, considerada invasiva. ${ }^{693}$ Dispõe o artigo 17.6 do Acordo Antidumping que o grupo especial, ao examinar a matéria objeto do artigo 17.5. (declaração escrita do Membro reclamante ou fato comunicado pela autoridade do Membro importador), deverá determinar i) se a autoridade investigadora, ao analisar os fatos, estabeleceu-os adequadamente; ii) se a sua avaliação foi imparcial; e iii) se a sua avaliação foi objetiva ${ }^{694}$. Se forem trilhados estes passos, mesmo que o órgão de revisão alcance conclusão diversa, não considerará inválida a avaliação da autoridade. As disposições do Acordo Antidumping serão compreendidas segundo as regras consuetudinárias de interpretação do direito internacional público. Se mais de uma interpretação for aceitável, o Grupo Especial deve declarar se as medidas estão em conformidade com o Acordo, se elas encontram respaldo em uma das interpretações possíveis. Em resumo, a autoridade deve proceder aos seguintes testes: a) verificar a propriedade; b) verificar imparcialidade; c) verificar a objetividade; d) verificar a possibilidade de mais de uma interpretação; e) verificar se a decisão condiz com alguma das interpretações. ${ }^{695}$

\footnotetext{
${ }^{692}$ Mesmo com a definição rígida das funções do órgão de solução de controvérsias, há várias criticas sobre possíveis abusos nas análises. Ver: DAVEY, William. Has the WTO Dispute Settlement System Exceeded its Authority? A consideration of deference shown by the system to members government decisions and its use of issue-avoidance techniques. Journal of International Economic Law, n. 4.(1), 2006, p. 79-110.

${ }^{693}$ CROLEY, Steven; JACKSON, John. WTO Dispute Procedures, standard of review, and deference to national governments. American Journal of International Law, v. 90, 1996, p. 196.

${ }^{694}$ Cabe lembrar, aqui, que as investigações antidumping são enormemente influenciadas pelos fatos trazidos à análise. Por esta razão, o estabelecimento correto destes fatos já é a metade do trabalho a caminho da conclusão. (VERMULST, Edwin; KOMURO, Norio. Anti-dumping disputes in the GATT/WTO: Navigating Dire Straits. Journal of World Trade. V. 31, n. 1, 1997, p. 7.)

${ }^{695} \mathrm{Se}$ o procedimento seguido pela autoridade nacional foi estabelecido de forma correta e a avaliação foi feita de forma imparcial e objetiva, o Grupo Especial eventualmente constituído no mecanismo de solução de controvérsias confirmará os resultados. Isso significa que não há revisão do juízo de oportunidade das medidas antidumping decididas com toda objetividade e imparcialidade pelas autoridades nacionais. este entendimento confirma, segundo Carreau e Juillard, o fato de que existe um controle independente dos procedimentos nacionais seguidos. Seria delicado e pouco aceitável discutir, em uma organização não jurisdicional, como o mecanismo de solução de controvérsias da OMC, as decisões de justiça nacional revestidas de autoridade de coisa julgada. (CARREAU, Dominique; JUILLARD, Patrick. Droit International Economique. Paris : Dalloz, 2003, p. 199.)
} 
Há diferença entre o conteúdo dos pontos i. e ii. do artigo 17.6 do Acordo Antidumping. $\mathrm{O}$ artigo 17.6.i exclui a possibilidade de uma segunda análise nos casos em que a autoridade tenha estabelecido corretamente os fatos, tenha sido imparcial e objetiva. Neste caso, mesmo que o Grupo Especial discorde do entendimento, não poderá revê-lo. ${ }^{696}$ Contudo, se mesmo estabelecidos os fatos corretamente, mesmo sendo imparcial e objetiva, a autoridade comete erros de interpretação do acordo, passa-se ao artigo 17.6.ii. O art. 17.6.ii dispõe que a análise da conformidade da decisão será feita segundo as regras consuetudinárias de interpretação do direito internacional público. ${ }^{697}$

Foi o caso Guatemala - Cimento II o primeiro a discutir o âmbito da revisão internacional da decisão da autoridade nacional sobre antidumping. Nele, o Grupo Especial entendeu que não é seu papel proceder a um reexame dos indícios sobre os quais se apoiaram as autoridades domésticas. $\mathrm{O}$ artigo 17 deixa claro que a tarefa do Grupo Especial é revisar o texto da determinação das autoridades. Especificamente, o grupo deve determinar se os fatos foram estabelecidos corretamente e a sua avaliação foi imparcial e objetiva. Em outras palavras, o Grupo Especial deve determinar se uma autoridade investigadora, de forma imparcial e objetiva, baseando-se nas mesmas provas, poderia ter entendido daquela forma. Em primeiro lugar, deve o Grupo Especial analisar as provas consideradas pela autoridade. Em segundo lugar, este exame é limitado aos fatos apresentados à autoridade (o que significa que não deve haver análise de fatos novos). ${ }^{698}$

No caso posterior, Tailândia-ferro e aço, o Órgão de Apelação interpretou "estabelecimento correto dos fatos" como sendo demonstração dos fatos e a

\footnotetext{
696 "Este grau de deferência aos fatos requer que as autoridades conduzam uma justa e substancial investigação (por exemplo, não impondo diferentes ônus da prova aos produtores domésticos e exportadores) e uma justa avaliação dos fatos (por exemplo, não criando presunções irrefutáveis)." (HORLICK; CLARKE, P. Standards for panels reviewing anti-dumping determinations under the GATT and the WTO, in PETERSMANN, International Trade Law and the GATT/WTO Dispute Settlement System. London: Kluwer Law International, 1997, p. 6.)

${ }^{697}$ Invocação direta às normas da Convenção de Viena sobre o Direito dos Tratados, segundo Croley e Jackson. A Convenção de Viena estabelece, em seu artigo 31, a Regra Geral de Interpretação, segundo a qual o tratado deve ser interpretado de acordo com seu sentido ordinário a ser conferido segundo o contexto e seus objetivos. $\mathrm{O}$ artigo 32 estabelece meios suplementares de interpretação, como o recurso aos trabalhos preparatórios do tratado e às circunstâncias de sua conclusão. (Op cit. p. 200-201)

698 Guatemala-Enquête antidumping concernant le ciment Portland em provenance du Mexique. W/DS60/R e W/DS60/AB, 1998.
} 
sua prova. Entendeu o Órgão de Apelação que a sua função é evitar uma segunda análise da decisão da autoridade nacional pelo Grupo Especial quando os fatos forem estabelecidos corretamente e a sua avaliação for imparcial e objetiva. O Órgão de Apelação também esclareceu que a discussão sobre se as provas ou entendimentos foram colocados à disposição das partes interessadas é uma questão de procedimento e devido processo, discutida em outros artigos, especialmente 6 e 12, do Acordo Antidumping e, em conseqüência, à luz do artigo 17.6.ii do mesmo instrumento. ${ }^{699}$

No caso US-Aço inoxidável, o Grupo Especial esclareceu o alcance da análise dos fatos. Os Estados Unidos entenderam que a questão de saber se as vendas foram feitas em dólar ou em won é uma questão de fato e, por esta razão, pode ser avaliada segundo o art. 17.6.i., ou seja, não deve ser feito reexame se a autoridade procedeu ao exame dos fatos corretamente, e sua avaliação foi imparcial e objetiva. A Coréia argumentou que a determinação em questão não era uma determinação de fato, pois não havia controvérsia de fato (o artigo 17.6.i não seria aplicável que não para certos fatos fundamentais objetivamente verificáveis, ex. as faturas apresentadas tinham valores em dólar ou won?). Entendeu o Grupo Especial que o critério de exame depende da natureza da questão posta em análise.

O critério pertinente a ser aplicado a questões de fato, ou seja, para a interpretação do Acordo Antidumping, está estabelecido no artigo 17.6.ii. Segundo o Grupo Especial, no mesmo caso, este artigo aplica-se não somente ao estabelecimento dos fatos, mas também à sua valoração. O grupo de experts não deve somente verificar se as autoridades nacionais estabeleceram corretamente os fatos pertinentes, mas também verificar o valor ou o peso acordado a estes fatos e se esta valoração foi feita de forma imparcial e objetiva (vai além de uma avaliação jurídica). Assim, a determinação feita pela autoridade sobre a forma pela qual as vendas foram efetuadas em won é uma determinação de fato, já que representa uma determinação formulada sobre a base da avaliação de certos fatos e que não implica em interpretação do Acordo Antidumping. Cabe ao Grupo Especial, então, analisar se uma autoridade imparcial e objetiva, tendo

${ }^{699}$ Droits antidumping sur les profilés en fer ou en aciers non alliés et les poutres en $\mathrm{H}$ en provenance de Pologne. WT/DS122, 2001. 
em mãos os elementos que ela dispunha, poderia determinar que as vendas locais foram efetuadas em won e não em dólar. ${ }^{700}$

No caso Estados Unidos-Ácido Laminado, o Órgão de Apelação esclareceu que o artigo 17.6 é dividido em dois sub-artigos, cada um deles aplicável a um diferente aspecto de exame pelo Grupo Especial. O primeiro se refere ao estabelecimento dos fatos pelo grupo especial, e o segundo se refere à interpretação das previsões relevantes. $\mathrm{O}$ art. 17.6 faz uma clara distinção entre o estabelecimento dos fatos e a interpretação legal do Acordo Antidumping. Em um parágrafo seguinte, esclarece o Órgão de Apelação que o Grupo Especial deve interpretar as disposições do Acordo Antidumping de acordo com as regras costumeiras de interpretação do direito internacional público, remetendo-se, diretamente, aos artigos 31 e 32 da Convenção de Viena sobre a Interpretação dos Tratados. Se encontrar mais de uma interpretação, ambas estão corretas, e a medida será considerada em conformidade com o Acordo Antidumping. ${ }^{701}$

Em conclusão, o critério de exame de atos praticados por autoridades nacionais, em investigações antidumping, é determinado pelo artigo 17.6. Este artigo prevê duas hipóteses de análise: i) análise fática - verificação sobre a propriedade, imparcialidade e objetividade e, ii) análise legal - interpretação segundo o texto do Acordo Antidumping. Até este momento, não há qualquer impedimento ou mudança que seja necessária para adequar a proposta deste trabalho aos já existentes critérios de exame. Desta forma, caberá ao órgão de solução de controvérsias i) analisar se a autoridade considerou corretamente os fatos apresentados sobre o interesse público, verificando-os de forma imparcial e objetiva e; ii) analisar a conformidade da decisão com o Acordo Antidumping.

3.5.2.2 Competência do órgão de solução de controvérsias para a análise de decisões nacionais de caráter político

\footnotetext{
${ }^{700}$ Para 6.18 e seguintes.

701 États-Unis - mesures antidumping appliquées à certains produits en acier laminés à chaud en provenance du Japon. WT/DS184/AB/R para. 54.
} 
A resistência dos Membros, durante as negociações sobre interesse público, no que diz respeito à revisão pelo órgão de solução de controvérsias, é justificada pelo desejo de soberania em relação à definição do que seja este interesse. Esta razão é apoiada na afirmação de que a decisão de interesse público é uma decisão política, que não está apoiada em critérios legais, cabendo ao Membro escolha da política nacional. Por esta razão, cabe revisitar o entendimento do órgão de solução de controvérsias da OMC sobre decisões políticas dos Membros.

Para este estudo, são as decisões envolvendo o artigo XX do GATT bastante úteis. Este artigo dispõe que certas medidas podem ser consideradas exceções às regras multilaterais, desde que não constituam discriminação arbitrária ou injustificada no comércio internacional. ${ }^{702}$

No caso da Coréia-Carne de Boi, entendeu o Órgão de Apelação que a determinação da necessidade de uma medida, de acordo com o artigo XX, $\mathrm{d}^{703}$, depende do peso e do balanço de uma série de fatores entre os quais figura, em primeiro plano, o respeito à lei ou regulamento em questão, a importância do interesse comum ou dos valores comuns protegidos por esta lei ou regulamento e a incidência concomitante da lei ou regulamento sobre as exportações e importações. ${ }^{704}$ Nesta decisão, sendo a necessidade avaliada pelo respeito à lei e a importância dos valores comuns e do interesse protegidos por ela, admite-se que o órgão de solução de controvérsias vá, de alguma forma, examinar esta lei e tais valores.

No caso Brasil-Pneus recicláveis, o Grupo Especial foi chamado a examinar se a medida adotada pelo Brasil, visando impedir a importação de pneus reciclados, poderia ser considerada como uma das dez exceções do artigo XX do GATT. Em outras palavras, deveria o Grupo Especial examinar se o objetivo da política

\footnotetext{
702 Art. XX. Desde que tais medidas não sejam aplicadas de forma a constituírem um meio de discriminação arbitrária ou injustificável entre os países em que as mesmas condições existirem ou uma restrição disfarçada no comércio internacional, nada no presente Acordo deve ser interpretado como impedindo a adoção ou aplicação, por todas as partes contratantes, das medidas: (elenco).

$\left.{ }^{703} \mathrm{~d}\right)$ necessárias para assegurar o respeito às leis e regras que não sejam incompatíveis com as disposições do presente Acordo, como, por exemplo, leis ou regras que estiverem relacionadas à aplicação de medidas aduaneiras, ou vigência de monopólios administrativos conforme o parágrafo 4 do artigo II e ao artigo XVII, à proteção de patentes, marcas de fabricação e direitos de autor e de reprodução, e às medidas próprias para impedir práticas de natureza a induzir a erro;

704 Corée-Mesures affectant les importations de viande de bouef fraîche, réfrigérée et congelée, WT/DS161/AB/R, parágrafo 164.
} 
geral da medida brasileira (uma lei) se enquadrava no elenco de políticas dispostas nas alíneas do artigo $\mathrm{XX} .^{705}$

O Órgão de Apelação enfatizou que não há dúvida sobre o direito dos Membros de definir seus objetivos em matéria de saúde pública e meio-ambiente ${ }^{706}$ e o nível de proteção que desejou obter com a medida ou política que decidiu adotar. ${ }^{707}$ Ao invés disso, o órgão de solução de controvérsias deve considerar se as medidas são necessárias, interpretado como indispensáveis e inevitáveis para os objetivos propostos. Para avaliar o significado de "necessárias", a decisão mencionou o caso Estados Unidos-jogos, em que o Órgão de Apelação esclareceu que, para definir o conceito de necessidade, a autoridade deve realizar três testes, sendo eles i) uma avaliação da importância relativa dos interesses e valores promovidos pela medida contestada, ii) uma avaliação da contribuição da medida para a realização dos objetivos que ela persegue e, por fim, iii) uma avaliação da restrição que a medida impõe ao comércio internacional. ${ }^{708}$ Não há dúvidas que o órgão de solução de controvérsias possa revisitas as duas últimas questões.

Pela análise das decisões acima, é possível depreender que há espaço para que o Grupo Especial examine as medidas adotadas pelo Membro para a realização de suas políticas. Não cabe ao Membro julgar a política do Membro, mas sim a conformidade da providência adotada para a realização desta política com os acordos.

Outra menção à existência de políticas internas e interesses comuns no país está no Relatório de 1987, sobre os Arenques e Salmão, citado pelo Grupo Especial no caso Gasolina ${ }^{709}$. É o parágrafo 4.6 da decisão: “como indica o preâmbulo do art. $\mathrm{XX}$, a inclusão do artigo $\mathrm{XX}, \mathrm{g}^{710}$, no Acordo Geral não tinha como objetivo alargar o âmbito do artigo em relação às medidas tomadas com fins de política comercial, mas

\footnotetext{
${ }^{705}$ WT/DS332/AB/R, para. 139 e nota de rodapé n. 215.

706 Apoio no documento États-Unis-Normes concernant à l'essence nouvelle et ancienne formules, WT/DS52/AB/R, p. 33.

${ }^{707}$ Apoio no documento Relatório do Órgão de Apelação no caso Coréia - medidas afetando a carne de boi, para. 161.

${ }^{708}$ États-Unis-Mesures visant la fourniture transfrontières de services de jeux et paris. WT/DS285/AB/R Para. 306

${ }^{709}$ États-Unis-Normes concernant à l'essence nouvelle et ancienne formules, WT/DS52/AB/R, p. 33.

${ }^{710} \mathrm{XX}, \mathrm{g}$. Relacionados à conservação de recursos naturais exauríveis, se estas medidas forem aplicadas conjuntamente com as restrições à produção ou ao consumo nacionais.
} 
simplesmente assegurar que os compromissos a título do Acordo Geral não impeçam a aplicação das políticas visando à conservação dos recursos naturais esgotáveis. ${ }^{711}$

Sobre a análise de aspectos políticos pelo órgão de solução de controvérsias, Davey lembra que alguns países, como é o caso dos Estados Unidos, têm em suas legislações previsões que impedem que o Poder Judiciário interfira em decisões que tenham um caráter eminentemente político. Trata-se da "political question doctrine”. Esta é, segundo ele, a principal razão pela qual os Estados Unidos rejeitem qualquer decisão que tenha por objetivo analisar entendimentos políticos dos governos e autoridades.

Davey defende que não se deve criar regras que obriguem o Grupo Especial e o Órgão de Apelação a rejeitar o caso de imediato. O escopo fundamental do órgão de solução de controvérsias é garantir segurança e previsibilidade ao sistema multilateral de comércio. Ele não poderá fazer isso se algumas decisões nacionais forem consideradas muito políticas para serem revistas pelo órgão de controvérsias. Ele pode considerar válida a decisão do Membro quando baseada em política (exemplo o artigo $\mathrm{XX}$ do GATT), mas não deve ser obrigado a rejeitar os pedidos de plano. $\mathrm{O}$ autor completa, ainda, que é favorável à análise, pelo órgão de solução de controvérsias, mesmo em casos em que a segurança nacional for a razão da prática adotada (exceção do artigo $\mathrm{XXI}^{712}$ ). Segundo ele, é esperado que o Grupo Especial e Órgão de Apelação garantam certa margem de discricionariedade à autoridade, mas a possibilidade de uma revisão para prevenir abusos é também apropriada. ${ }^{713}$

No mesmo sentido, Oesch recorda que há algumas áreas, como saúde e meio-ambiente, que, embora estejam relacionadas a outras políticas que não o comércio, estão intimamente ligadas a ele. As medidas nacionais nestas áreas podem, em algumas ocasiões, violar regras aceitas perante a OMC e o acesso aos mercados a

\footnotetext{
${ }^{711}$ Canada - Mesures affectant l'exportation de harengs et de saumons non préparés, IBDD, S35/106, para. 4.6, citado na página 20 do relatório do Órgão de Apelação em WT/DS2/AB /R, Estados Unidos normas referentes à essência nova e antigas fórmulas, 26 de abril de 1996.

${ }^{712}$ Exceções relacionadas à segurança.

${ }^{713}$ DAVEY, William. Has the WTO Dispute Settlement System Exceeded its authority? A consideration of deference shown by the system to member government decisions and its use of issue-avoidance techniques. In COTTIER, Thomas; MAVROIDIS, Petros. The Role of the Judge in International Trade Regulation: Experience and Lessons for the WTO. Ann Arbor: The University of Michigan Press, 2003, p. 67.
} 
outros parceiros comerciais. Revisões insensíveis e muito invasivas destas medidas nacionais podem interferir nas preferências das políticas nacionais e causar preocupações sérias de que a soberania nacional está em risco. Em princípio, os níveis apropriados de proteção do meio-ambiente, por exemplo, são estabelecidos domesticamente e pertencem ao domínio reservado do poder e da soberania nacionais. Contudo, estas políticas e medidas devem, inquestionavelmente, estar de acordo com os acordos da OMC. ${ }^{714}$ Neste ponto, o autor se apóia na decisão do caso Estados Unidos Gasolina reformulada, mencionando a passagem:

Os Membros da OMC têm uma larga margem de autonomia para determinar suas próprias políticas em meio-ambiente (incluindo sua relação com o comércio), seus objetivos ambientais e sua legislação ambiental. Ao que concerne à OMC, esta autonomia está circunscrita apenas à necessidade de respeitar a conformidade com o Acordo Geral e os outros acordos. ${ }^{715}$

Oesch discute se o principio da soberania nacional é um argumento legalmente relevante para ser invocado em uma disputa. A OMC é um sistema basicamente contratual e intergovernamental, que não tem natureza constitucional em nenhum sentido. O papel dos julgadores na OMC é contratual, diferentemente do papel atribuído a um juiz nacional pela constituição, consistindo em um exame mecânico sobre a concordância da ação do Membro com as obrigações que ele assumiu. Considerações de separação e balanço de poderes, que seriam critérios de revisão nacionais, não têm espaço na OMC. A interpretação das regras à luz de princípios constitucionais encontrados em sistemas domésticos é limitada. Assim, a soberania nacional não limita, de plano, uma análise da medida adotada pelo Membro. $\mathrm{O}$ autor cita o entendimento no caso Japão-Bebidas Alcóolicas:

O Acordo da OMC é um tratado - internacionalmente equivalente a um contrato. No exercício de sua soberania e na busca de seus interesses nacionais, os Membros da OMC fizeram uma barganha. Em troca dos benefícios que esperam como Membros da OMC, eles acordaram em exercer sua soberania de acordo com os compromissos que assumiram no Acordo da OMC. ${ }^{716}$

\footnotetext{
${ }^{714}$ OESCH, Matthias. Standards of Review in WTO Dispute Resolution. Oxford: Oxford University Press, 2003 , p. 27.

${ }^{715}$ Tradução livre da versão em inglês de États-Unis-Normes concernant à l'essence nouvelle et ancienne formules, WT/DS52/AB/R, p. 30.

${ }^{716}$ Tradução livre do trecho da decisão, na página 15, conforme mencionada por OSCH, Matthias. Op cit. P. 30.
} 
Enquanto está claro no texto do Acordo de Solução de Controvérsias $^{717}$ que não se pode aumentar a obrigação das partes, por meio da jurisprudência, está também claro que desvios na conduta nacional frente a obrigações e compromissos assumidos precisam ser meticulosamente examinados, sem ser necessário excessivo cuidado com a soberania nacional dos Membros. Por esta razão, argumentos apoiados na soberania nacional são considerados particularmente perigosos no contexto de tratados multilaterais. Termina o autor afirmando que "os ganhos da coordenação econômica internacional e da escolha de regras só podem ser realizados se o protecionismo desleal e ilegítimo for condenado sem restrições sobre quando o ato respeita o princípio da soberania de um país ou não."718

O objetivo final das discussões é encontrar um equilíbrio entre os interesses dos Membros de proteger sua soberania e um interesse mais geral de uniformidade do Direito da OMC e sua aplicação consistente. Em apenas alguns casos se permite que valores soberanos prevaleçam. Em algumas decisões sobre aspectos políticos sensíveis, o Grupo Especial e Órgão de Apelação concedem especial deferência à decisão do Membro. Nestas hipóteses limitadas, não cabe ao órgão priorizar política diversa e valores diferentes, mas sim aceitar os valores estabelecidos pelo Membro. Contudo, mesmo nestes casos, dever-se-á fazer a análise sobre a decisão tomada ou medida adotada pelo Membro, se ela é proporcional e está pode garantir a realização dos objetivos desejados. ${ }^{719}$

3.5.2.3 Exame da decisão nacional sobre interesse público

O Acordo de Soluções de Controvérsias é um importante progresso alcançado pelas Partes Contratantes do GATT, após anos de experiência na negociação de temas controversos e no julgamento de controvérsias entre os países signatários. A maior função dos procedimentos ali dispostos é dar maior efetividade às regras elaboradas.

\footnotetext{
${ }_{717}$ Art. 3.2 do Acordo de Solução de Controvérsias.

${ }^{718}$ Op cit. p. 30.

${ }^{719}$ Osche, Matthias. Op cit. p. 31.
} 
A proposta deste trabalho é a sugestão de critérios que desencorajam a aplicação de medidas antidumping, em nome do interesse público. Estes critérios devem ser apostos no texto do acordo como mandatórios, não somente sugestivos, sendo sua violação razão para análise do órgão de solução de controvérsias, nos termos do art. 17.6.

As discussões sobre interesse público nas negociações, conforme comentado no segundo capítulo, englobam o debate sobre a possível revisão das decisões nacionais pela OMC. O último texto sugerido pelo presidente do Grupo de Negociações em Regras, em $1997^{720}$, prevê que a decisão do país investigador não poderá ser revista no contexto multilateral. A grande razão para a sua exclusão entre as matérias a serem discutidas pelo Grupo Especial é que a expressão interesse público está estritamente relacionada ao conceito de soberania. Se o conceito de soberania ainda é o cerne das dúvidas existentes entre o relacionamento das regras internacionais e instituições nacionais, e o papel de cada um na regulação do comportamento econômico que cruza as fronteiras nacionais ${ }^{721}$, pode-se imaginar o quanto não será motivo de discussão sobre o interesse público, que não cruza estas fronteiras.

Surge, então, a dúvida. Se o interesse público não cruza as fronteiras, seria ele um problema de direito internacional, ou seja, caberia à OMC a análise da decisão da autoridade nacional que analisou este interesse para a aplicação de uma medida antidumping? Reflete-se, também, que este interesse público, quando o resultado do teste for negativo, será motivo para a não aplicação de medidas antidumping e, com isso, não haverá ação contrária à liberalização do comércio internacional.

Contudo, haverá situações em que a análise deste interesse público servirá de desculpa para a violação de regras respeitadas pelos Membros da OMC. Por exemplo, este interesse poderá determinar a não aplicação de medidas antidumping na importação de sapatos proveniente da Argentina, mas poderá ser considerado a favor da imposição de medidas antidumping contra os mesmos sapatos provenientes da China. $\mathrm{O}$ interesse público pode ser, então, ótima saída para a discriminação condenada pelo

\footnotetext{
$720 \mathrm{TN} / \mathrm{RL} / \mathrm{W} / 213,2007$

${ }^{721}$ CROLEY, Steven; JACKSON, John. Op cit. p. 104.
} 
artigo 9.2 $2^{722}$ do Acordo Antidumping ${ }^{723}$. O Membro poderá entender, também, que a aplicação de medidas antidumping nas importações de pneus da Tailândia condiz com o interesse público, que é preservar o meio ambiente e a saúde, mas não aplicar qualquer medida contra os pneus fabricados internamente, que podem poluir ainda mais.

Em um exercício de imaginação, cabe pensar se a Comunidade Européia, no caso Lâmpadas, já explicado neste trabalho, decidisse acatar o argumento dos importadores de que a aplicação de medidas antidumping elevaria o preço das lâmpadas, fazendo com que os consumidores voltassem a consumir lâmpadas mais baratas - e que consomem mais energia. Neste caso, poderia argumentar o Membro da OMC que o interesse público encontra-se fundamentado na política de meio-ambiente da Comunidade. Contudo, com a aplicação das medidas, o único produtor nacional aumentou seus preços, em uma posição monopolista bastante confortável. Com o aumento dos preços, os consumidores passaram a consumir lâmpadas mais baratas, que são as que consomem mais energia. Neste caso, é possível imaginar a abertura de consultas, pelo Membro exportador, contestando uma violação ao artigo III: $4^{724}$ do GATT, que determina que o Membro não pode conferir tratamento mais favorecido aos produtos nacionais do que aos produtos importados. Poder-se-á argumentar que o país importador impediu a importação, realizando seu interesse público de defender o meio

\footnotetext{
${ }^{722} 9.2$ Assim que uma medida for imposta em relação a um produto determinado, este direito, que terá montantes apropriados a cada caso, será cobrado sem discriminação sobre as importações deste produto, de qualquer fonte que forem provenientes, se for constatado que são objeto de dumping e que causam um dano.

${ }^{723}$ Caso muito parecido foi discutido no procedimento de consultas, sem que o demandante pedisse a abertura de contencioso posterior. Trata-se de caso Comunidade Européia - medidas antidumping contra ferro e aço. $\mathrm{O}$ demandado havia decidido aplicar medidas antidumping contra a Índia, após investigação que entendeu pela presença de dumping, dano e nexo causal, mas não aplicou medidas antidumping contra Egito, Eslováquia e Turquia, embora também estivessem presentes, na investigação contra os três países, os três elementos que autorizam a aplicação de medidas antidumping. Após o procedimento de consultas, as partes chegaram a uma solução, decidindo a Comunidade Européia não mais aplicar as medidas antidumping (Communautés Européenes - droits antidumping visant certains produits laminés plats, en fer ou en aciers non alliés, en provenance d'Inde. WT/DS313/1, G/ADP/D55/1, 8 de Julho de 2004 e Communautés Européennes-droits antidumping visant certains produits laminés plats, en fer ou en acier non alliés, en provenance d'Inde WT/DS313/2, 27 de outubro de 2004).

${ }^{724}$ Art. III.4. Os produtos do território de todas as partes contratantes importados ao território de todas as outras partes contratantes não serão submetidos a um tratamento menos favorável do que o tratamento concedido aos produtos similares de origem nacional no que se refere a leis, regras, condições de venda, colocação à venda, compra, transporte, distribuição e utilização destes produtos no mercado interno. As disposições do presente parágrafo não impedirão a aplicação de tarifas diferentes para o transporte interior, fundadas exclusivamente na utilização econômica dos meios de transporte e não na origem dos produtos.
} 
ambiente, mas, ao mesmo tempo, não se preocupou com o mesmo efeito sendo provocado internamente.

No caso narrado, uma discussão seria inviável se a análise do interesse público, tal como sugerida pelos Membros negociadores, sem a possibilidade de revisão pelo mecanismo de solução de controvérsias. A parte reclamante poderia contestar a violação ao artigo III:4 do GATT, mas o país reclamado poderia argumentar que não buscou uma das exceções do artigo $\mathrm{XX}$ ou qualquer outro, mas sim se apoiou na cláusula do interesse público, que está "imune" à qualquer apreciação do órgão de solução de controvérsias.

Como também analisado, em diversas oportunidades, a OMC teve a oportunidade de analisar aspectos relacionados ao interesse do Membro. É certo que, em nenhum destes momentos, este interesse recebeu o complexo predicado de "interesse público", mas nada impede que os interesses já discutidos possam ser assim considerados.

Não há consenso entre os Membros sobre a possibilidade de revisão das decisões pelo órgão de solução de controvérsias. O grupo que defendia a revisão, os Amigos do Antidumping, apresentou propostas conflitantes. Em uma reunião do Grupo de Negociações sobre Regras, em 2005, eles defenderam a apreciação pelo órgão, que não seria distinta de nenhuma outra avaliação econômica já realizada. ${ }^{725} \mathrm{Em}$ outro documento, apresentado em março de 2008, o grupo diz concordar com outros numerosos Membros sobre o fato de que cabe a cada Membro determinar se e em que o interesse público é respeitado. Defendem estes Membros que a decisão de mérito da autoridade nacional não pode ser revista pelo órgão de solução de controvérsias, podendo haver apenas uma decisão sobre o procedimento.

Entretanto, as propostas dos Membros são extremamente amplas no que diz respeito ao conteúdo do interesse público. Se o objetivo é limitá-lo, impedindo que seja um instrumento de discriminação, estará determinado o que o Membro pode

${ }^{725}$ Rapport Résumé de la Réunion tenue les 11, 13 et 15 Avril 2005, TN/RL/M/26, DE 11 de maio de 2005, p.2. 
considerar como interesse público, no antidumping, cabendo, então, a revisão pelo órgão de solução de controvérsias.

Os limites estipulados pelo artigo 17.6. servem exatamente aos propósitos de uma revisão esperada sob o âmbito do interesse público. O objetivo de uma primeira análise (17.6.i) deverá ser descobrir se a autoridade considerou corretamente os fatos, não decidiu sob influência de pressões políticas, comuns, como já mencionado, em investigações antidumping, se avaliou os dados postos à sua análise e fundamentou, de forma objetiva, suas conclusões sobre estes dados. A segunda análise (17.6.ii) permitirá a apreciação da conformidade da decisão sobre interesse público co ma nova redação do artigo 9.1, que deverá englobar os critérios a serem apreciados. Desta forma, uma autoridade severamente influenciada pela vontade de um grupo de pressão teria mais forças para reagir e decidir imparcialmente, sabendo que seu entendimento poderia ser revisado por um órgão independente, em um contexto multilateral. Seriam, também, menores os riscos de uma decisão judicial influenciada, conforme mencionado no tópico dedicado à análise judicial.

Para responder à questão de soberania, pode-se aplicar, para o interesse público, o mesmo raciocínio desenvolvido no tópico anterior. Os Membros da OMC, ao assinarem o Acordo Antidumping, assumiram compromissos específicos diante de um organismo multilateral, obtendo vantagens em troca. Neste momento, os Membros abriram mão de parte de sua soberania, abandonando antigas restrições e largas possibilidades de ação em nome destes benefícios. A possibilidade de não aplicar medidas antidumping já existe desde a assinatura do Acordo Antidumping, não é algo novo. Por isso, o objetivo da aposição de uma cláusula de interesse público obrigatória não é abrir espaço ao livre-arbítrio do Membro, mas sim vinculá-lo a uma análise mais justa e menos protecionista, tornando o instrumento antidumping mais racional. Com isso, não pode estar no livre-arbítrio dos Membros a decisão sobre quais serão os critérios adequados para não aplicar a medida antidumping.

Deve haver critérios também obrigatórios, já que o objetivo da cláusula será compelir os usuários do antidumping à sua utilização racional. Assim, não pode restar ao livre-arbítrio dos Membros a definição ou interpretação destes critérios, a não ser que este exercício seja feito de forma imparcial e objetiva, analisando todos os 
fatos corretamente e não violando qualquer das disposições do Acordo Antidumping (começando pelos critérios definidos para a análise do interesse público). Nesta nova estrutura, não há espaço para brigas de soberania. Se o objetivo da cláusula fosse dar aos Membros o direito irrestrito de aplicar ou não medidas antidumping, não haveria qualquer necessidade de mudança em relação à redação atual do Acordo.

Critérios claros e pontuais a serem observados não geram espaço à discussão de soberania, a não ser que o Membro comprove que analisou corretamente os critérios, os fatos, de forma imparcial e objetiva. Neste caso, e não havendo outra violação ao Acordo Antidumping, não caberá intervenção pelo órgão de solução de controvérsias.

\subsection{CONCLUSÃO DA TERCEIRA PARTE}

A proposição de critérios não é suficiente para eliminar a incerteza nas investigações que discutem o interesse público. O Acordo Antidumping deve estabelecer quais partes serão ouvidas como interessadas, motivando uma ampla pesquisa das razões que podem justificar a não aplicação de medidas. Neste sentido, serão considerados os interesses da indústria doméstica (não somente aqueles manifestados, mas os reais efeitos da proteção sobre estes produtores), dos importadores (considerando-se que eles podem, em alguns casos, explorar outra atividade econômica), dos usuários industriais, dos consumidores e suas associações. Podem ser ouvidos, também, os fornecedores da indústria doméstica e os exportadores. Estes últimos, embora não sejam produtores nacionais, podem trazer relevantes informações ao processo, pois são os maiores interessados na não aplicação das medidas.

O Acordo Antidumping deve permitir que o teste do interesse público seja usado em momentos outros que a aplicação de medidas definitivas: a celebração de compromissos de preços e a revisão de medidas já aplicadas podem ter o mesmo efeito, sobre o mercado, de uma imposição definitiva e inicial, clamando pela análise do interesse público. 
A autoridade competente para aplicar o teste deve ser a autoridade de defesa comercial que realiza a investigação. Somente ela é capaz de tracejar a figura completa da indústria sob exame e de suas necessidades. É essencial que esta autoridade esteja distante de pressões de grupos e do próprio governo, não técnicas, que se afastem da consideração dos três aspectos sugeridos neste trabalho. Se for estabelecido e seguido um procedimento detalhado para o bom exame deste interesse público, não haverá razão para que estes grupos se aproximem da autoridade investigadora, ou da autoridade que lhe é superior, visando modificar a decisão técnica.

A decisão da autoridade de defesa comercial deve estar sujeita à revisão pelo Poder Judiciário. Neste sentido, o Acordo deve prever, assim como faz o artigo 13, a existência de procedimentos judiciais para a revisão de interesse público. É desejável que as partes ouvidas para a formação deste interesse possam recorrer ao Poder Judiciário e que o Membro tenha juízes especializados para o julgamento de tais questões, nos países em que isto for viável.

Deve ser possível a revisão da decisão de interesse público pelo órgão de solução de controvérsias da OMC. Se os Membros acatarem os três critérios sugeridos nesta proposta, estarão abrindo mão de sua soberania na indicação do que seja interesse público no antidumping, em nome da efetividade e da segurança na prática multilateral. Contudo, esta avaliação deve se limitar à revisão da observância, pelos Membros, destes critérios. O valor atribuído por cada um a estes fatores, bem como a sua relevância e sobreposição aos demais, já fazem parte da soberania nacional. 


\section{CONCLUSÃO FINAL}

Não são raras as críticas à prática antidumping dos Membros da OMC. Na maioria dos casos, as falhas são a consequiência de interpretações erradas do texto do Acordo Antidumping, ou de suas lacunas. Todas as críticas têm um só fundamento: a utilização indevida do instrumento antidumping como peneira para barrar importações decorrentes do aumento do fluxo do comércio internacional. Os Membros da OMC celebram concessões, reduzem tarifas, mas, por outro lado, aumentam a proteção por meio do antidumping.

O uso indevido ou excessivo do instrumento antidumping provoca discussões que ultrapassam os corredores da OMC para se encontrar nos corredores das autoridades nacionais. Não somente os países exportadores - cujos produtos foram alvo de antidumping - buscam modificações na prática, mas também há celeuma dentro das fronteiras do país importador. Uma aplicação indevida provoca conseqüências sensíveis no mercado internacional, tais como o conflito entre países parceiros comerciais, a falta de credibilidade e o afastamento de investimentos, mas provoca, sobretudo, conseqüências nem sempre positivas ao próprio país investigador, como o aumento do custo do importador, a possível escassez do produto, entre outras.

Uma forma de frear a aplicação indevida do antidumping é observar se as medidas trarão benefícios ao país que as impõe. Para isso, deve-se fazer um balanço das vantagens e desvantagens que elas provocam, encontrando-se dois possíveis resultados: se as desvantagens ao país são maiores do que as vantagens, não se aplica o antidumping, ou se aplica por menor período ou em menor valor.

A possibilidade de realizar este balanço já existe no Acordo Antidumping vigente. Os Membros são livres para não aplicar medidas antidumping mesmo encontrando provas de dumping, dano e nexo causal. Contudo, a não aplicação será uma liberalidade do país investigador, não há nada que o obrigue a não aplicar. Diversos Membros da OMC vêm propondo que os países investigadores sempre façam a análise do que é interessante aos diversos afetados por uma investigação antidumping, sendo esta análise fundamental para a decisão de aplicar ou não medidas. A este exame tem sido dado o nome de interesse público. 
Imagine-se que todos os Membros da OMC, respeitando a nova redação do Acordo Antidumping, passem a observar se a aplicação de medidas é de interesse público. Contudo, se a redação aprovada for a última redação negociada, critérios não serão propostos. Assim, o Membro ficará livre, por exemplo, para não aplicar medidas contra importações de um país que lhe é preferido, ou que lhe faz também concessões relevantes. Seria muito mais interessante e proveitoso se o Membro se resumisse a observar razões econômicas - mesma natureza do antidumping - que estivessem diretamente relacionadas à finalidade do instrumento.

Para tanto, o interesse público deve ter natureza econômica. Entretanto, mesmo definindo-lhe a natureza, os Membros ainda gozarão de ampla discricionariedade, podendo escolher razões não tão apropriadas para a não aplicação do antidumping.

Observando-se a prática dos países que já realizam o teste do interesse público, bem como conhecendo o desejo de alguns Membros nas mais diversas negociações sobre o assunto, percebe-se que três aspectos são recorrentes e são a expressão do que é o desejo público em uma investigação antidumping. Estes critérios são os parâmetros mais adequados para se permitir a correta comparação entre as vantagens e desvantagens para as diversas partes envolvidas na discussão. Verificandose o interesse público a partir destes critérios, estar-se-á aproximando de uma imposição de medidas que tende a ser mais apropriada às necessidades do país, ao verdadeiro desejo do Membro de proteção frente à importação.

A concorrência é o primeiro destes critérios. Um país pode defender a concorrência de várias formas: i) como um fim em si, evitando estruturas que possam comprometer o funcionamento de uma economia livre e ii) defender a concorrência como meio de realizar outras políticas, tais como o desenvolvimento, a proteção ao meio ambiente e a proteção ao direito do consumidor. Uma autoridade antidumping sabe que toda medida antidumping provoca um efeito anticoncorrencial. Mesmo que ela não retire os exportadores (competidores) do mercado, algum temor ela provocará. Por isso, um dos critérios a serem utilizados para saber se a medida antidumping é interessante ao país é a concorrência (ou sua possível redução). Contudo, não se deve achar que a proteção à concorrência deve ser um fim do direito antidumping. 
Concorrência e antidumping são, e devem permanecer sendo, instrumentos com objetivos quase opostos.

O segundo critério é a proteção ao emprego. Todo país que almeja aplicar medidas o faz sob pressão de grupos ligados à indústria doméstica, sejam os próprios produtores, sejam fornecedores desta indústria. Por outro lado, a aplicação de medidas provoca aumento do custo dos importadores e usuários industriais, que poderão encontrar na demissão de seus empregados um meio rápido e eficaz de reduzi-lo. Não é simples balancear estes dois interesses: proteger os empregados da indústria doméstica ou proteger os empregados dos usuários e importadores do produto investigado? Cada país responderá este questionamento diante de um caso concreto, sendo impossível conceber uma fórmula pronta. Contudo, é essencial que este critério - a proteção ao emprego - seja avaliado como interesse público do país.

Por fim, a aplicação de medidas antidumping pode ser benéfica a uma indústria que deseja desenvolver-se, comprar máquinas, expandir seu parque industrial. Entretanto, este objetivo não será realizado se a indústria, por sua própria natureza ou ineficiência, não conseguir aproveitar a proteção derivada da aplicação destas medidas. Se isso acontecer, prejuízos maiores do que benefícios serão gerados a importadores, usuários industriais e consumidores. O desenvolvimento da indústria doméstica deve ser observado pela autoridade investigadora.

Criar critérios para a interpretação do interesse público é uma forma de garantir que o trabalho das autoridades investigadoras não ultrapasse a razão de ser do antidumping. Se há requisitos claros para que o antidumping seja aplicado, deve haver motivos claros para que ele não seja aplicado. Contudo, o resultado da interpretação e julgamento pelo Membro não deve ser imposto pelo Acordo Antidumping. Concorrência, emprego e desenvolvimento são conceitos também indefinidos, que têm significados definidos pelo tempo e pela política econômica de um país. Pode-se apenas sugerir formas de leitura destes critérios, o que fez este trabalho, mas o balanço caberá ao Membro, que deve ser transparente e respeitar requisitos processuais na condução de seu exame. 
Como requisitos processuais que podem garantir a melhor análise, estão a observância do princípio da transparência, a concessão de amplas oportunidades para todos os interessados se manifestarem e a realização do teste do interesse público nos momentos mais apropriados da investigação. A autoridade responsável pela análise deve ser a autoridade que conduziu a investigação, com a mínima interferência de autoridades sujeitas a orientações políticas: trata-se de um instrumento econômico, com fins muito específicos. Por fim, deve ser possível a revisão da decisão pelo Poder Judiciário e pelo órgão de solução de controvérsias da OMC (limitada, esta última, à verificação da aplicação dos três critérios e dos procedimentos).

A partir do último texto proposto pelo Presidente do Grupo de Negociações em Regras da OMC para o artigo 9.1 do Acordo Antidumping, propõe-se a seguinte redação, contemplando o interesse público na forma sugerida por este trabalho:

9.1 Antes de aplicar medidas antidumping, ao celebrar compromisso de preços e ao proceder à revisão descrita no artigo 11, a autoridade investigadora deve observar se a imposição de medidas antidumping está em consonância com o interesse público do Membro. A observação do interesse público pode ter como resultado a aplicação de medidas, a não aplicação, ou a flexibilização da aplicação, tendo esta seu prazo de vigência reduzido ou sendo reduzido o valor das medidas.

9.1.1 Para a definição deste interesse público, deve a autoridade examinar as vantagens e desvantagens provocadas pela aplicação das medidas, observando o interesse das partes interessadas, em relação aos seguintes aspectos:

(i) a concorrência no mercado nacional ou regional do produto sob consideração, bem como os efeitos de uma possível restrição à concorrência para o consumidor, no que se refere à oferta, aos preços e às opções. As autoridades investigadoras podem solicitar opiniões às autoridades concorrenciais, se julgarem necessário.

(ii) o emprego no mercado doméstico, compreendido como os efeitos da aplicação de medidas sobre as condições de emprego na indústria doméstica, em seus fornecedores, nos usuários industriais e nos importadores. Para tanto, a autoridade pode avaliar os efeitos sobre das medidas sobre salários, criação de novos empregos e outros custos estritamente relacionados ao trabalho. As autoridades devem observar, também, se a perda do emprego em uma indústria pode significar a realocação destes empregados em outros setores.

(iii)o desenvolvimento tecnológico e industrial, compreendido como a possibilidade de melhoria tecnológica e ampliação da indústria doméstica. As autoridades devem observar a importância econômica da indústria para o desenvolvimento nacional, se a indústria é capaz de se desenvolver e se a indústria pode se tornar ultrapassada e desinteressante no curto e médio prazo. 
9.1.2 As autoridades devem dar ampla oportunidade para que as partes interessadas possam se manifestar a respeito do interesse público. Para este fim, as autoridades devem publicar e enviar notificações para todas as partes interessadas conhecidas, bem como dar a estas partes () dias para se manifestar. Como partes interessadas, considerar-se-ão a indústria doméstica, seus fornecedores, os importadores, os usuários industriais, consumidores e suas associações. Não deverão ser desconsiderados imediatamente elementos e informações trazidos pelos exportadores.

9.1.3 A decisão da autoridade investigadora pode ser revisada pelo Poder Judiciário nacional, bem como pelo mecanismo de solução de controvérsias da OMC. Neste último caso, a revisão deve ser limitada à análise da observância, pelas autoridades nacionais, dos critérios e procedimentos estabelecidos neste artigo. A decisão final sobre o interesse público, se concluído que as autoridades observaram os critérios e procedimentos, não estará sujeita a revisão pelo mecanismo de solução de controvérsias da OMC. 


\section{ANEXO 01 - PROPOSTAS DOS MEMBROS SOBRE INTERESSE PÚBLICO NO ANTIDUMPING}

\begin{tabular}{|c|c|c|}
\hline MEMBROS & PROPOSTA & CONSIDERAÇÕES \\
\hline \multicolumn{3}{|l|}{ GATT } \\
\hline Hong Kong & MTN.GNG/NG8/W/46 1989 & $\begin{array}{l}\text { - } \quad \text { Desejo de entender melhor a racionalidade do antidumping no GATT; } \\
\text { - Remover ambigüidades; } \\
\text { - } \quad \text { Detalhamento e precisão em certos pontos; } \\
\text { - Transparência e critérios mais rígidos. }\end{array}$ \\
\hline Hong Kong & MTN.GNG/NG8/W51 1989 & $\begin{array}{l}\text { - } \quad \text { Os produtores não podem ser as únicas preocupações dos investigadores; } \\
\text { - } \quad \text { Consideração do interesse dos importadores e dos custos. }\end{array}$ \\
\hline Singapura & MTN.GNG/NG8/W/55 1989 & $\begin{array}{l}\text { - } \quad \text { Consideração dos interesses de usuários industriais e consumidores no inicio da investigação; } \\
\text { - } \quad \text { Interesses públicos mais amplos; } \\
\text { - } \quad \text { As leis antitruste protegem a indústria doméstica, prejudicando consumidores; } \\
\text { - Custos da intervenção precisam ser estudados. }\end{array}$ \\
\hline Canadá & MTN.GNG.NG8/W/65 1989 & $\begin{array}{l}\text { - } \quad \text { Avaliação do dano em contexto mais amplo; } \\
\text { - } \quad \text { Consideração de fatores econômicos maiores; } \\
\text { - } \quad \text { Efeitos sobre consumidores, indústrias e economia em geral; } \\
\text { - } \quad \text { Consideração após determinação do dano. }\end{array}$ \\
\hline Coréia & $\begin{array}{l}\text { MTN.GNG/NG8/2/40.Add } 2 \\
1989\end{array}$ & $\begin{array}{l}\text { - Algumas indústrias domésticas ganham com importação abaixo do preço; } \\
\text { - } \quad \text { Devem ser considerados produção, competitividade e lucro dos importadores; } \\
\text { - } \quad \text { Consumidores e grau de concentração da indústria doméstica. }\end{array}$ \\
\hline Japão & $\begin{array}{l}\text { MTN.GNG/NG8/W/48/Add.1 } \\
1990\end{array}$ & $\begin{array}{l}\text { - As medidas afetam consumidores; } \\
\text { - Sugestão de rodapé do art. 8.1: "antes de impor medidas antidumping, as autoridades devem levar em } \\
\text { consideração seus impactos sobre toda a economia nacional." }\end{array}$ \\
\hline Estados Unidos & MTN.GNG/NG8/15 1990 & $\begin{array}{l}\text { - } \quad \text { Deve ser decidido domesticamente, não multilateralmente; } \\
\text { - } \quad \text { Pode abrir espaço para lobby e interferência na análise objetiva; } \\
\text { - Em alguns países, cabe à autoridade administrativa definir o momento de consideração; } \\
\text { - O teste pode dar menos atenção a aspectos técnicos e macular a objetividade esperada. }\end{array}$ \\
\hline Países Nórdicos & MTN.GNG/NG8/2/276 1990 & $\begin{array}{l}\text { - Proposta de texto: consideração na abertura, aplicação de medidas definitivas e provisórias; } \\
\text { - Observar situação competitiva, consumidores, usuários industriais e outras circunstâncias econômicas } \\
\text { relevantes. }\end{array}$ \\
\hline Coréia & ADP/W/287 1991 & $\begin{array}{l}\text { - Os fatores devem ser considerados na aplicação de medidas definitivas, mas podem ser aplicadas em outras } \\
\text { fases. }\end{array}$ \\
\hline
\end{tabular}




\begin{tabular}{|c|c|c|}
\hline MEMBROS & PROPOSTA & CONSIDERAÇÕES \\
\hline & & $\begin{array}{l}\text { - Aspectos: preços domésticos, impacto sobre importações, impacto sobre outras industrias, etc. } \\
\text { - } \quad \text { governo coreano nunca aplicou na abertura ou nas medidas provisórias, mas isso é permitido. }\end{array}$ \\
\hline \multicolumn{3}{|r|}{ ( } \\
\hline Canadá & TN/RL/W/1 2002 & - Deve ser considerado o interesse público nas negociações de regras; \\
\hline $\begin{array}{l}\text { FANS (Brasil, Chile, } \\
\text { Colômbia, costa rica, } \\
\text { Hong Kong, China, } \\
\text { Israel, Japão, Coréia, } \\
\text { México, Noruega, } \\
\text { Singapura, Suíça, } \\
\text { Tailândia, Turquia) }\end{array}$ & TN/RL/W/6 2002 & - Mencionam um exemplo (importadores que perderão empregados). \\
\hline Comunidade Européia & TN/RL/W/13 2002 & $\begin{array}{l}\text { - Exame do impacto sobre operadores econômicos; } \\
\text { - O teste é, por natureza, discricionário, mas é capaz de fornecer larga análise sobre a situação do mercado } \\
\text { doméstico importador. }\end{array}$ \\
\hline Comunidade Européia & TN/RL/W/20 2002 & $\begin{array}{ll}- & \text { Questionamentos ao Grupo: } \\
\checkmark & \text { O que é o interesse público? } \\
\checkmark & \text { Deve ser um requisito procedimental para conseguir informações ou um teste com critérios substantivos } \\
\checkmark & \text { Quais seriam estes critérios }\end{array}$ \\
\hline $\begin{array}{l}\text { FANS (Brasil, Chile, } \\
\text { Colômbia, costa rica, } \\
\text { Hong Kong, China, } \\
\text { Israel, Japão, Coréia, } \\
\text { México, Noruega, } \\
\text { Singapura, Suíça, } \\
\text { Tailândia, Turquia) }\end{array}$ & TN/RL/W/45 2003 & $\begin{array}{l}\text { - O art. } 6.12 \text { deve ser aperfeiçoado, incluindo-se critério substantivo; } \\
\text { - Deve-se diminuir ou eliminar medidas em nome de um interesse publico mais amplo; } \\
\text { - Examinar outros interesses como consumidores, importadores, etc; } \\
\text { - Há vários momentos nos quais estes interessados devem se manifestar; } \\
\text { - Os objetivos dos países devem se resumir a melhorar o bem-estar coletivo por meio do comércio e sua } \\
\text { disciplina. Se a aplicação do antidumping é contrária a esta idéia, não se deve aplicar. }\end{array}$ \\
\hline Austrália & TN/RL/W/22 2002 & $\begin{array}{l}\text { - Não considera que um teste deva ser incluído no acordo, pois ele deve ficar a critério de cada país; } \\
\text { - Defende a lesser duty rule. }\end{array}$ \\
\hline Estados Unidos & TN/RL/W/34 2002 & $\begin{array}{ll}- & \text { Questões à União Européia: } \\
\checkmark & \text { O Membro é livre para determinar os critérios? A autoridade faz isso no caso-a-caso? } \\
\checkmark & \text { Qual a metodologia aplicada? } \\
\checkmark & \text { O teste é sujeito à revisão judicial? } \\
\checkmark & \text { Quais são os resultados desta revisão? }\end{array}$ \\
\hline Canadá & TN/RL/W/47 2003 & $\begin{array}{l}\text { - O interesse público pode limitar medidas inconsistentes, algumas vezes ilegais; } \\
\text { - O art. } 6.12 \text { permite manifestação de partes interessadas sobre dumping, dano e nexo, mas algums membros }\end{array}$ \\
\hline
\end{tabular}




\begin{tabular}{|c|c|c|}
\hline MEMBROS & PROPOSTA & CONSIDERAÇÕES \\
\hline & & $\begin{array}{l}\text { teriam tomado medidas para ampliar este escopo; } \\
\text { - } \quad \text { Exemplos: incapacidade de fornecimento, aumento dos preços para usuários, preocupação concorrencial; } \\
\text { - Conseqüências para economia, comércio e concorrência. }\end{array}$ \\
\hline Estados Unidos & TN/RL/W/54 2003 & - Todos os países devem usar os mesmos critérios? \\
\hline Canadá & TN/RL/W/47 2003 & $\begin{array}{l}\text { - Comentou a proposta australiana de que os países devem ser livres, enfatizando necessidade de } \\
\text { previsibilidade, transparência e respeito ao devido processo. }\end{array}$ \\
\hline Egito & TN/RL/W/79 2003 & - A decisão de aplicar deve ser deixada ao Membro. \\
\hline Egito & TN/RL/W/101 2003 & $\begin{array}{l}\text { - Deve-se manter o acordo na forma atual, no que se refere ao interesse público. o teste é uma opção política; } \\
\text { - A decisão demanda uma complexa análise de todos os fatores envolvidos, o que pode significar tempo e } \\
\text { recurso. }\end{array}$ \\
\hline Estados Unidos & TN/RL/W/103 2004 & $\begin{array}{l}\text { - Será que o acordo, tal como está, já não permite a consideração de aspectos econômicos, de comércio e de } \\
\text { competição? }\end{array}$ \\
\hline Canadá & TN/RL/W/134 2004 & - $\quad$ O acordo não proíbe tais considerações, mas deve ser obrigatório. \\
\hline Comitê - resumo & TN/RL/W/143 2004 & $\begin{array}{l}\text { - Esclarecimento das disciplinas e regras relacionadas à consideração do interesse público; } \\
\text { - Reforçar regras para garantir que informações mais relevantes sejam consideradas; } \\
\text { - Debater quando devem ser consideradas as informações; } \\
\text { - O teste deve ser obrigatório ou apenas sugerido; } \\
\text { - Examinar os efeitos indesejados do antidumping e esforços para considerar a economia como um todo. }\end{array}$ \\
\hline $\begin{array}{l}\text { FAN (Costa rica, Hong } \\
\text { Kong, China, Israel, } \\
\text { Japão, Coréia, Noruega, } \\
\text { Suíça, Tailândia, } \\
\text { Taiwan, Penghu, Matsu) }\end{array}$ & TN/RL/W/174 2005 & $\begin{array}{l}\text { - Manifestação exclusiva sobre interesse público; } \\
\text { - Medida afeta fluxo de comércio, e seu custo é suportado por todos, inclusive pelo contribuinte; } \\
\text { - O acordo não obriga o Membro a considerar os efeitos diversos; } \\
\text { - A medida pode ter uma boa base econômica; } \\
\text { - Direito de manifestação de qualquer interessado; } \\
\text { - Transparência: as autoridades devem publicar suas conclusões sobre o interesse público. }\end{array}$ \\
\hline Reunião abril 2005 & TN/RL/M/26 2005 & $\begin{array}{l}\text { - } \quad \text { Conceito de interesse público seria muito subjetivo; } \\
\text { - A proposta permitiria a consideração de aspectos não econômicos? } \\
\text { - Preocupações com o cumprimento da obrigação de não discriminação; } \\
\text { - O teste consome tempo, é custoso e demandante; } \\
\text { - Não seria a mesma coisa que a lesser duty? } \\
\text { - Não haveria sobreposição da autoridade concorrencial e antidumping? } \\
\text { - Porque não somente diretrizes? } \\
\text { - Até que ponto o DSB poderia revisar? }\end{array}$ \\
\hline
\end{tabular}




\begin{tabular}{|c|c|c|}
\hline MEMBROS & PROPOSTA & CONSIDERAÇÕES \\
\hline Reunião abril 2005 & TN/RL/M/26 2005 & $\begin{array}{l}\text { FANS se manifestaram: } \\
\text { - O teste teria natureza econômica e não seria difícil; } \\
\text { - A controvérsia deve ser analisada pelo DSB como qualquer outra; } \\
\text { - É diferente da lesser duty. Ela define até que ponto a medida é adequada. O interesse público define efeitos } \\
\text { para outros setores. }\end{array}$ \\
\hline Africa do Sul & TN/RL/GEN/137 2006 & $\begin{array}{l}\text { - Defendeu a importância, mas temeu custos; } \\
\text { - A inclusão deve ser prerrogativa do membro, especialmente se país em desenvolvimento. }\end{array}$ \\
\hline FANs (Sem Brasil) & TN/RL/GEN/53 2005 & $\begin{array}{l}\text { Proposta de claúsula (texto): } \\
\text { - Antes de aplicar a medida; } \\
\text { - A autoridade deve mandar notificações aos agentes conhecidos, dando x dias para manifestação; } \\
\text { - Agentes podem se manifestar sobre: custos, competição, disponibilidade do produto, lucratividade e } \\
\text { competitividade; } \\
\text { - Os comentários devem ser recebidos em uma análise objetiva e imparcial. Se a informação for incompleta, a } \\
\text { autoridade deve buscá-la em fontes publicas. }\end{array}$ \\
\hline Jamaica & TN/RL/W/188 2005 & $\begin{array}{l}\text { - } \quad \text { pede pela obrigatoriedade, mas não sugere critérios. Nova insegurança; } \\
\text { - Critica os FANs, dizendo que eles não estão defendendo um interesse público nacional, mas a consideração } \\
\text { de fatores mais amplos. }\end{array}$ \\
\hline Hong Kong & TN/RL/W/194 2005 & $\begin{array}{l}\text { - A proposta dos FANs coaduna com as regras de boa governança e transparência; } \\
\text { - Os membros serão obrigados a discutir os benefícios do antidumping; } \\
\text { - O acordo permite que as medidas não sejam aplicadas; } \\
\text { - Critica a Jamaica, respondendo que os fans não querem considerar outros aspectos não econômicos; } \\
\text { - A definição da autoridade ficaria a critério do membro; } \\
\text { - Propõe a utilização de critérios quantitativos. }\end{array}$ \\
\hline Canada & TN/RL/GEN/85 2005 & $\begin{array}{l}\text { - Deve-se tentar acomodar os interesses dos diversos membros; } \\
\text { - As decisões não poderiam ser analisadas pelo órgão de solução de controvérsias; } \\
\text { - Deve-se estipular a obrigatoriedade na observação, mas não fixar modalidades precisas de implementação; } \\
\text { - A autoridade deve considerar representações das "partes domésticas", como, por exemplo, organizações de } \\
\text { consumidores, usuários industriais e autoridades de concorrência do Membro;. } \\
\text { Devem ser considerados: } \\
\text { 1. Se os produtos similares aos produtos em consideração são realmente disponíveis em outras origens que não } \\
\text { sofrerão medidas; } \\
\text { 2. Se a medida deve ser aplicada em quantidade máxima porque } \\
\text { i) elimina ou reduz a competição; } \\
\text { ii) causa ou pode causar dano substancial aos produtores domésticos que usam o produto; }\end{array}$ \\
\hline
\end{tabular}




\begin{tabular}{|c|c|c|}
\hline MEMBROS & PROPOSTA & CONSIDERAÇÕES \\
\hline & & $\begin{array}{l}\text { iii) prejudica ou pode prejudicar a concorrência por: a) limitar acesso aos produtos que são usados como } \\
\text { insumos para a produção de outros produtos; b) limitar o acesso à tecnologia. } \\
\text { iv) Restringe ou pode restringir a escolha ou disponibilidade dos produtos, ou de outra forma causar prejuízos ao } \\
\text { consumidor } \\
\text { 3. Quando a imposição ou não imposição pode causar dano aos produtores domésticos de insumos, incluindo } \\
\text { commodities primárias, manufatura doméstica ou produção de produtos similares. } \\
\text { Outros fatores relevantes em determinadas circunstâncias }\end{array}$ \\
\hline $\begin{array}{l}\text { Hong Kong, China, } \\
\text { Taiwan, Penghu, } \\
\text { Kimmen e Matsu }\end{array}$ & TN/RL/GEN/142 2006 & $\begin{array}{l}\text { - Lembram que o teste deverá ser aplicado nas revisões, quando o dano estiver novamente sendo verificado; } \\
\text { - } \quad \text { As autoridades devem ser determinadas pelo Membro investigador. }\end{array}$ \\
\hline $\begin{array}{l}\text { Presidente do Grupo de } \\
\text { Negociações em regras }\end{array}$ & TN/RL/W/213 2007 & $\begin{array}{l}\text { - Ressalta que os Membros, em Doha, acordaram negociar para "clarify and improving" as disciplinas dos } \\
\text { acordos antidumping e subsídios; } \\
\text { • Propõe nova redação para todo o acordo. A cláusula } 9.1 \text { trata de interesse público: } \\
\text { "Cada Membro que possui legislação antidumping deve estabelecer procedimentos em sua lei ou regulamento que } \\
\text { permita que suas autoridades, ao tomar as decisões descritas no artigo } 5 \text { [initiation and subsequent investigation] } \\
\text { levem em consideração a representação feita pelas partes domésticas interessadas que podem ter seu interesse } \\
\text { afetado pela imposição de medida antidumping. A aplicação destes procedimentos, e as decisões tomadas em relação } \\
\text { a ele, não devem ser sujeitas ao mecanismo de solução de controvérsias, ao art. } 17 \text { deste Acordo [revisão judicial] } \\
\text { ou qualquer outra previsão de acordo da OMC." (tradução literal da versão inglesa). } \\
\text { • Partes domésticas interessadas são consideradas, segundo o rodapé sugerido, como usuários industriais do } \\
\text { produto importado ou do produto similar doméstico, fornecedores da indústria doméstica e, se o produto for } \\
\text { vendido no varejo, organizações representativas de consumidores. }\end{array}$ \\
\hline FANs (sem Brasil) & TN/RL/W/222 2008 & $\begin{array}{l}\text { - Fazem críticas ao texto apresentado pelo presidente do comitê de negociações. Para eles, a proposta foi muito } \\
\text { - Eimples; } \\
\text { É importante, mais do que permitir que as autoridades levem em consideração os comentários das partes } \\
\text { domésticas, obrigá-las a fazê-lo e a considerar tais informações; } \\
\text { - O conceito de partes domésticas seria muito limitado, deixando de fora os consumidores finais; } \\
\text { - Deveria haver possibilidade de revisão judicial e revisão pelo mecanismo de solução de controvérsias da } \\
\text { OMC. }\end{array}$ \\
\hline $\begin{array}{l}\text { Presidente do Grupo de } \\
\text { Negociações em Regras }\end{array}$ & TN/RL/W/232 2008 & $\begin{array}{l}\text { - Apresenta versão consolidada com comentários de vários membros e tentativa de harmonização das } \\
\text { propostas. O texto foi dividido em i) consolidação da proposta dos Membros; ii) texto do diretor; iii) } \\
\text { comentário dos Membros. }\end{array}$ \\
\hline
\end{tabular}




\section{ANEXO 02 - DECISÕES RELEVANTES, NA COMUNIDADE EUROPÉIA, SOBRE INTERESSE COMUNITÁRIO}

\begin{tabular}{|c|c|c|c|}
\hline & Decisão & Referência & Considerações \\
\hline 1. & $\begin{array}{c}\text { Carbonato dissódico (Soda } \\
\text { ash) }\end{array}$ & $\begin{array}{l}\text { Regulamento (EU) n. } 2.381 / 95 \text {, de } \\
10 \text { de outubro de } 1995, \text { OJ. L } \\
244 / 32\end{array}$ & $\begin{array}{l}\text { - A indústria de vidros, principal usuária do produto investigado, exerceu grande pressão (lobby) } \\
\text { - Osobre os seus próprios Estados Membros para impedir a adoção de medidas definitivas; } \\
\text { Os prejuízos para a indústria de vidro seriam o aumento dos custos e a menor competitividade } \\
\text { - O internacional; } \\
\text { - } 7 \text { Menha sido suficiente para a não aplicação destes direitos. } \\
\text { - Foi discutida a difícil definição de interesse da comunidade: seria a soma dos interesses da } \\
\text { maioria? }\end{array}$ \\
\hline 2. & $\begin{array}{c}\text { Pallets de Madeira } \\
\text { (palettes simples, en bois) }\end{array}$ & $\begin{array}{c}\text { Decisão da Comissão 1023/97, de } 6 \\
\text { de junho de 1997, OJ L 150/4. } \\
\text { 06/06/1997. }\end{array}$ & $\begin{array}{l}\text { - A competição entre produtores domésticos e exportadores também foi considerada relevante para } \\
\text { - a análise do interesse público. } \\
\text { mercado dos produtores domésticos for muito baixa, importações de terceiros países serão sempre } \\
\text { necessárias; } \\
\text { - Se a imposição de medidas permitir que a indústria doméstica monopolize o mercado, a adoção } \\
\text { do antidumping tende a se afastar do interesse público. }\end{array}$ \\
\hline 3. & $\begin{array}{c}\text { Fósforos com fins } \\
\text { publicitários (allumettes } \\
\text { publicitaires) }\end{array}$ & $\begin{array}{c}\text { Regulamento } 2025 / 97 \text {, de } 15 \text { de } \\
\text { outubro de 1997, OJ L 284/57, } \\
16 / 10 / 1997 .\end{array}$ & $\begin{array}{l}\text { - A empresa foi acusada de estar abusando de sua posição dominante no mercado comunitário por } \\
\text { meio de práticas anticompetitivas, como preço predatório e a aquisição de competidores; } \\
\text { - A divisão de concorrência rejeitou o pedido, sendo este a motivação da divisão de comércio para } \\
\text { não analisar a questão. }\end{array}$ \\
\hline
\end{tabular}




\begin{tabular}{|c|c|c|c|}
\hline 4. & $\begin{array}{l}\text { Peças Vazadas (pièces de } \\
\text { voirie) }\end{array}$ & $\begin{array}{l}\text { Regulamento (CE) n. 1212/2005 de } \\
25 \text { de julho de 2005, OJ L 199/1, de } \\
\text { 29/07/2005. }\end{array}$ & $\begin{array}{l}\text { - Os importadores alegaram que, com a aplicação de medidas, os exportadores iriam sair do } \\
\text { mercado, deixando sozinha uma indústria doméstica muito concentrada; } \\
\text { - Além disso, outra investigação de abuso de posição dominante no passado já teria demonstrando } \\
\text { que a indústria doméstica poderia voltar a abusar de posição favorecida; } \\
\text { - A Comissão entendeu que era provável que os exportadores permanecessem no mercado, pois } \\
\text { tinham forte posição. Além disso, havia um volume relevante de importações provenientes de } \\
\text { outros países; } \\
\text { Sobre as investigações concorrenciais, a Comissão entendeu que elas foram conduzidas fora do } \\
\text { período de investigação e que não houve condenação. }\end{array}$ \\
\hline 5. & $\begin{array}{l}\text { Mecanismos de argolas } \\
\text { para encadernação } \\
\text { (mécanismes pour reliure } \\
\text { à anneaux) }\end{array}$ & $\begin{array}{c}\text { Decisão da Comissão n. 1456/96, } \\
\text { de } 25 \text { de julho de 1996, OJ L } \\
187 / 47,26 / 07 / 1996 .\end{array}$ & $\begin{array}{l}\text { - A Comissão entendeu que, embora fosse pequeno o número de competidores (duopólio), as } \\
\text { medidas poderiam ser um fator corretivo e elas não impediriam a entrada de exportadores de } \\
\text { outras origens no mercado; }\end{array}$ \\
\hline 6. & $\begin{array}{l}\text { Fotocopiadoras } \\
\text { (photocopieurs) }\end{array}$ & $\begin{array}{l}\text { Regulamento (CE) n. 535/87 do } \\
\text { Conselho de } 23 \text { de fevereiro de } \\
\text { 1987, J.O L 54/12, 24.2.1987 }\end{array}$ & $\begin{array}{l}\text { - A única representante da indústria doméstica foi considerada como demandante de mão-de-obra, } \\
\text { o que seria mais um argumento para a sua proteção, mesmo que prejudicando os interesses dos } \\
\text { consumidores em um curto prazo; } \\
\text { O Tribunal de Justiça avaliou a decisão do Conselho, que determinou a aplicação de medidas } \\
\text { antidumping sobre a importação de fotocopiadoras do Japão, diante do argumento de empresas } \\
\text { japonesas estavam adquirindo empresas européias em dificuldades financeiras; } \\
\text { - O Tribunal se limitou a dizer que, como não houve nenhum erro óbvio de avaliação dos fatos, o } \\
\text { entendimento da Comissão não poderia ser modificado. }\end{array}$ \\
\hline 7. & $\begin{array}{l}\text { Motores elétricos } \\
\text { multifásicos (moteurs } \\
\text { électriques polyphasés } \\
\text { normalisés d' une } \\
\text { puissance de plus de } 0,75 \\
\text { à } 75 \text { kilowatts inclus) }\end{array}$ & $\begin{array}{l}\text { Regulamento (CEE) n. 724/82 da } \\
\text { Comissão de } 30 \text { de março de } 1982 \text {, } \\
\text { J.O L 85/9, 31/03/1982. }\end{array}$ & $\begin{array}{l}\text { - Um dos fatores para a aceitação de Compromisso de Preços foi o fato de os exportadores serem } \\
\text { empresas de países em desenvolvimento. }\end{array}$ \\
\hline 8. & Uréia (urée) & $\begin{array}{l}\text { Regulamento (CEE) n. 3339/87 do } \\
\text { Conselho de } 4 \text { de novembro de } \\
\text { 1987, J.O L 317/1, 07/11/1987. }\end{array}$ & $\begin{array}{l}\text { - Um dos fatores para a aceitação de Compromisso de Preços foi o fato de os exportadores serem } \\
\text { empresas de países em desenvolvimento. }\end{array}$ \\
\hline
\end{tabular}




\begin{tabular}{|c|c|c|c|}
\hline 9. & $\begin{array}{l}\text { Motores Propulsores } \\
\text { (propulseurs spéciaux du } \\
\text { type hors-bord) }\end{array}$ & $\begin{array}{l}\text { Regulamento (CEE) n. 1305/87 do } \\
\text { Conselho de } 11 \text { de maio de } 1987 \text {, } \\
\text { J.O L 124/1, 13/05/1987. }\end{array}$ & - A Comissão aceitou a celebração de Compromisso de Preços por vários exportadores. \\
\hline 10. & Glicina (Glycine) & $\begin{array}{l}\text { Glycine, Regulamento (CEE) n. } \\
\text { 2322/85 do Conselho, de } 12 \text { de } \\
\text { agosto de } 1985, \text { OJ L } 218 / 1 .\end{array}$ & $\begin{array}{l}\text { - Decisão discutiu quem seriam os usuários industriais. A Comissão Européia investigou as } \\
\text { indústrias de comida animal, agroquímica e farmacêuticas, prováveis afetadas pelas medidas } \\
\text { antidumping. }\end{array}$ \\
\hline 11. & Algodão & $\begin{array}{l}\text { Regulamento (EU) n. } 2208 / 96 \text { de } \\
18 \text { de novembro de } 1996 .\end{array}$ & $\begin{array}{l}\text { - Volume de importações teria crescido } 12,5 \% \text { nos últimos anos; } \\
\text { - As importações representavam } 40 \% \text { do volume comercializado; } \\
\text { A aplicação de medidas colidia com os interesses da importante indústria de têxteis localizada no } \\
\text { norte da Europa; } \\
\text { - E Estados Membros foram contra a aplicação das medidas, sobre o argumento de que o custo } \\
\text { adicional para os usuários industriais era desproporcional ao benefício gerado à indústria } \\
\text { doméstica; } \\
\text { A não consideração dos interesses deste grupo de produtores têxteis gerou enorme discussão e } \\
\text { pressão política. Levou à revisão, pela Comissão de seus procedimentos na análise do interesse } \\
\text { público. }\end{array}$ \\
\hline 12. & Charmotas Refratárias & $\begin{array}{l}\text { Decisão da Comissão } 137 / 96 \text { de } 22 \\
\text { de janeiro de } 1996, \text { OJ L 21/1 }\end{array}$ & $\begin{array}{l}\text { - Rejeitou o argumento que as medidas antidumping poderiam criar um monopólio no mercado de } \\
\text { charmotas. }\end{array}$ \\
\hline 13. & $\begin{array}{l}\text { Bolsas de plástico ou de } \\
\text { material têxtil }\end{array}$ & $\begin{array}{l}\text { Regulamento (EU) n. 1.567/97, O.J } \\
\text { L 20/8 de } 2 \text { de agosto de } 1997 .\end{array}$ & $\begin{array}{l}\text { - O produtor tinha apenas } 2 \% \text { do mercado, sendo o restante suprido por importações; } \\
\text { - } \quad \text { As vantagens para o produtor seriam menores do que as desvantagens para o importador; } \\
\text { - } \quad \text { Medio risco de desabastecimento no mercado local; }\end{array}$ \\
\hline 14. & $\begin{array}{l}\text { Bolsas originárias da } \\
\text { China (bolsas de couro) }\end{array}$ & $\begin{array}{l}\text { Decisão da Comissão 209/97, de } 3 \\
\text { de fevereiro de } 1997 \text { OJ L 33/11. }\end{array}$ & $\begin{array}{l}\text { - Procedeu-se à avaliação do impacto econômico das bolsas da China sobre a competitividade do } \\
\text { mercado europeu de bolsas. }\end{array}$ \\
\hline 15. & Ferro-silico-manganes & $\begin{array}{l}\text { Decisão da Comissão n. 1778/97, } \\
\text { de } 12 \text { de setembro de } 1997 \text { OJ L } \\
\text { 252/6. }\end{array}$ & $\begin{array}{l}\text { - A imposição de medidas antidumping foi entendida como a melhor solução diante da inexistência } \\
\text { de manifestações representativas de usuários do produto, sendo poucos os questionários } \\
\text { preenchidos; }\end{array}$ \\
\hline
\end{tabular}




\begin{tabular}{|c|c|c|c|}
\hline 16. & Aço Inoxidável & $\begin{array}{l}\text { Decisão da Comissão n. 1732/97, } \\
\text { de } 4 \text { de setembro de } 1997, \text { OJ L } \\
243 / 17\end{array}$ & $\begin{array}{l}\text { - A distribuição do produto era feita por um grande número de importadores que operavam entre os } \\
\text { produtores e os usuários do produto; } \\
\text { - Seu comportamento influenciava a formação dos preços do produto. Ficou também claro que a } \\
\text { indústria doméstica possuía apenas um pequeno contato com os usuários industriais e precisava } \\
\text { de sua rede de distribuição; } \\
\text { - Concluiu a Comissão que a situação dos importadores não iria piorar depois da aplicação das } \\
\text { medidas. }\end{array}$ \\
\hline 17. & Corda de Fibra Sintética & $\begin{array}{l}\text { Decisão da Comissão n. 18/98, de } 7 \\
\text { de janeiro de } 1998 \text {, OJ L 4/28 }\end{array}$ & $\begin{array}{l}\text { - O impacto causado aos importadores foi considerado menor pelo fato destes comercializarem } \\
\text { produtos de outros mercados e ainda serem fornecedores do produto doméstico. }\end{array}$ \\
\hline 18. & $\begin{array}{l}\text { Sistemas de Leitura Ótica } \\
\text { a Laser para carros } \\
\text { (LORS) }\end{array}$ & $\begin{array}{l}\text { Regulamento (EU) n 1999/55. } 21 \\
\text { de dezembro de 1998, O.J. L18, } \\
\text { 23/01/1999, p. } 62 .\end{array}$ & $\begin{array}{l}\text { - Redefinição do produto em consideração; } \\
\text { - A participação dos produtores domésticos no mercado local havia crescido pouco, de } 0 \% \text { a } 1,4 \% \text {; } \\
\text { - Altas barreiras à entrada (tributo alto); } \\
\text { - A Comissão considerou o nível do emprego afetado, sendo muito mais grave para os } \\
\text { importadores do que para a indústria doméstica; } \\
\text { - Medidas não aplicadas. }\end{array}$ \\
\hline 19. & Escovas de cabelo & $\begin{array}{c}\text { Decisão da Comissão 967/00, de } 8 \\
\text { de maio de 2000, OJ L 111/4. }\end{array}$ & $\begin{array}{l}\text { - Analisou a viabilidade da indústria doméstica; } \\
\text { - Análise do ambiente de competição entre os produtores domésticos, assim como entre os } \\
\text { produtores domésticos e os exportadores. }\end{array}$ \\
\hline 20. & $\begin{array}{l}\text { Discos Versáteis Digitais } \\
\text { Regraváveis (DVD +/- R) }\end{array}$ & $\begin{array}{l}\text { Decisão da Comissão n. } 713 / 2006 \\
\text { de } 20 \text { de outubro de } 2006 \text {, OJ L. } \\
\text { 293/07, 14/10/2006. }\end{array}$ & $\begin{array}{l}\text { - Indústria embrionária; } \\
\text { - A parcela afetada pelo dumping seria substituída por importações de outras origens; } \\
\text { - } \quad \text { Dumping, dano e nexo causado não foram analisados; } \\
\text { - Foi alegado que o dano da indústria doméstica era fruto de sua decisão de aumentar os preços, } \\
\text { - gozando de posição dominante. Esta afirmação não foi considerada; } \\
\text { - As medidas não foram aplicadas }\end{array}$ \\
\hline
\end{tabular}




\begin{tabular}{|c|c|c|c|}
\hline 21. & $\begin{array}{l}\text { Sapatos de couro (leather } \\
\text { footwear) }\end{array}$ & $\begin{array}{l}\text { Regulamento (EU) n . 1472/2006, } \\
\text { de } 4 \text { de outubro de 2006, OJ L. } \\
\text { 275/34 6/10/2006. }\end{array}$ & $\begin{array}{l}\text { - Foram argumentos: i) a produção doméstica era insuficiente; ii) o dano não foi causado pelo } \\
\text { dumping, mas sim por outros fatores que não relacionados a ele; iii) as medidas vão limitar a } \\
\text { escolha dos consumidores, alguns sapatos só são produzidos na China e Vietnã; iv) o Vietnã é um } \\
\text { país em desenvolvimento e precisa exportar. O prejuízo gerado a um país em desenvolvimento é } \\
\text { contrário aos objetivos da União Européia; } \\
\text { - Interesse dos consumidores: não houve representações de entidades ou organizações que } \\
\text { - } \quad \text { Os imporem trazer elementos substantivos sobre o prejuízo dos consumidores; } \\
\text { - A Comissão esclareceu que as manifestações dos exportadores são consideradas na investigação } \\
\text { de forma geral; } \\
\text { - Não se conseguiu apurar os efeitos para os distribuidores, por falta de dados fornecidos por eles. } \\
\text { - As medidas foram aplicadas. }\end{array}$ \\
\hline 22. & Lâmpadas & $\begin{array}{l}\text { Regulamento (EU) n } 1470 / 2001 \\
\text { de } 16 \text { de julho de } 2001 \text {, OJ L } 195 \\
19 / 07 / 2001, \text { p. } 8 \text {. }\end{array}$ & $\begin{array}{l}\text { - Caso de revisão, com mudanças da época da aplicação; } \\
\text { - Importante participação dos fornecedores da indústria doméstica; } \\
\text { - A aplicação seria contrária à política de meio ambiente da União Européia, já que os } \\
\text { - consumidores voltariam a comprar lâmpadas mais baratas, que consomem mais energia; } \\
\text { - A Comissão entendeu que a indústria doméstica não conseguia suprir a demanda doméstica; } \\
\text { - } \quad \text { O arguns produtores domésticos eram contra a aplicação; } \\
\text { - Medidas não aplicadas. }\end{array}$ \\
\hline 23. & $\begin{array}{c}\text { PSF (Fibras Sintéticas de } \\
\text { Poliéster }\end{array}$ & $\begin{array}{l}\text { Regulamento (EU) n . 428/2005 de } \\
10 \text { de março de } 2005 \text {, OJ L 71, } \\
\text { 17/03/2005, p. } 1 .\end{array}$ & $\begin{array}{l}\text { - As desvantagens para os consumidores e importadores seriam maiores do que as vantagens para a } \\
\text { indústria doméstica; } \\
\text { - A indústria doméstica oferecia apenas um volume reduzido e pouca variedade; } \\
\text { - Aumento certo nos preços dos consumidores; } \\
\text { - Medidas não aplicadas. }\end{array}$ \\
\hline 24. & Carbonato de Bário & $\begin{array}{l}\text { Regulamento (EU) n } 1175 / 2005 \text { de } \\
18 \text { de julho de } 2005 \text {, OJ L } 189 \text {, } \\
\text { 21/07/2005, p. } 15\end{array}$ & $\begin{array}{l}\text { - Discute a importância da manifestação dos consumidores, mas ressalta que eles normalmente não } \\
\text { enviam suas manifestações, ou enviam já em fase avançada das investigações; } \\
\text { - Houve manifestação de usuários industriais. A Comissão analisou qual a proporção do produto } \\
\text { investigado no custo dos usuários industriais. }\end{array}$ \\
\hline 25. & Roupa de cama & $\begin{array}{l}\text { Regulamento (EU) n. } 397 / 2004 \text {, of } \\
2 \text { March 2004, OJ L } 66,4 / 03 / 2004 \text {, } \\
\text { p. } 1\end{array}$ & $\begin{array}{l}\text { - Foi analisada a capacidade de suprir a demanda pela indústria doméstica; } \\
\text { - Medidas aplicadas. }\end{array}$ \\
\hline
\end{tabular}




\begin{tabular}{|c|c|c|c|}
\hline 26. & Bicicletas & $\begin{array}{c}\text { Regulamento (EU) n. 1095/2005, } \\
\text { de } 12 \text { de julho de 2005, OJ L 183, } \\
\text { 14/07/2005, P. } 1 .\end{array}$ & $\begin{array}{l}\text { - } \quad \text { A Comissão entendeu que a indústria doméstica era competitiva em condições leais de comércio; } \\
\text { - O fato de vários produtores já terem saído do mercado comprova que as medidas são urgente; } \\
\text { - Há grandes vantagens, para a indústria doméstica, na imposição de medidas; } \\
\text { - Medidas impostas. }\end{array}$ \\
\hline 27. & DRAMs & $\begin{array}{l}\text { Regulamento (EU) n. 1480/2003, } \\
\text { de } 11 \text { de agosto de } 2003 \text {, OJ L 21/2, } \\
22 / 08 / 2003, \text { p. } 1\end{array}$ & $\begin{array}{l}\text { - Foram analisados os investimentos tecnológicos feitos pelos produtores e foi constatado que eles } \\
\text { eram competitivos; } \\
\text { - A indústria emprega mais de } 10.000 \text { pessoas e é considerada estratégica; } \\
\text { - } \quad \text { Foram analisadas barreiras à entrada: os custos de entrada são altos e a reentrada é improvável; } \\
\text { - Medidas aplicadas. }\end{array}$ \\
\hline 28. & Ferro-silicone & $\begin{array}{l}\text { Decisão da Comissão de } 21 \text { de } \\
\text { fevereiro de 2001, OJ L 84, } \\
\text { 23/03/2001 }\end{array}$ & $\begin{array}{l}\text { - Análise do interesse comunitário em procedimento de revisão; } \\
\text { - Ficou demonstrado que a indústria comunitária não foi capaz de se beneficiar das medidas } \\
\text { impostas, não foi capaz de manter sua participação de mercado, fechou fábricas e demitiu } \\
\text { empregados, mesmo as importações tendo desaparecido; } \\
\text { - Não está claro que a manutenção das medidas vá trazer algum benefício à indústria doméstica, } \\
\text { apenas impactará a indústria do aço; } \\
\text { - Medidas não mantidas. }\end{array}$ \\
\hline 29. & Glifosato & $\begin{array}{l}\text { Regulamento (EU) n. 1683/2004, } \\
\text { de } 24 \text { de setembro de } 2004 \text {, OJ L } \\
303,30 / 09 / 2004, \text { p. } 1\end{array}$ & $\begin{array}{l}\text { - Reavaliação do interesse em revisão antidumping; } \\
\text { - A Europa importa glifosato de ácido ou de sal, que é vendido formulado. A indústria que faz esta } \\
\text { formulação também foi considerada interessada; } \\
\text { - Os importadores não sofreriam tanto com a manutenção das medidas, já que eles importam outros } \\
\text { produtos; } \\
\text { - Os distribuidores independentes apresentaram provas de que a indústria comunitária praticaria } \\
\text { ações prejudiciais para sua atividade (dos distribuidores independentes); } \\
\text { A obtenção do registro de importação do glifosato é onerosa, mas isso não parece ser obstáculo } \\
\text { grave; } \\
\text { - Os distribuidores alegaram práticas anticompetitivas (cartel) promovidas pela indústria } \\
\text { doméstica, mas os elementos de prova não foram considerados suficientes; } \\
\text { - O efeito para os importadores é menor do que o benefício para a indústria doméstica; } \\
\text { - Medidas aplicadas. }\end{array}$ \\
\hline
\end{tabular}




\begin{tabular}{|c|c|c|c|}
\hline 30. & Resinas de Goma & $\begin{array}{l}\text { Decisão da Comissão de } 10 \text { de } \\
\text { janeiro de 1994, OJ L } 41 \\
\text { 12/02/1994, p. } 50 .\end{array}$ & 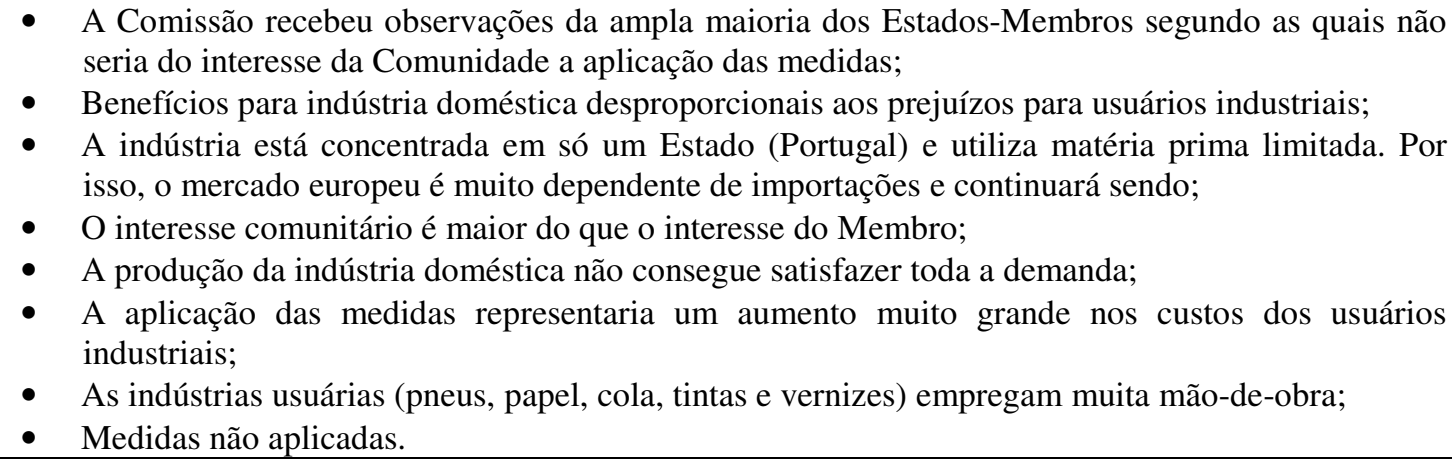 \\
\hline 31. & Acido Sulfânico & $\begin{array}{l}\text { Regulamento (EU) n. 1339/2002, } \\
\text { de } 22 \text { de julho de 2002, OJ L 196, } \\
\text { 25/07/2002, p. } 11 .\end{array}$ & $\begin{array}{l}\text { - A indústria comunitária comprovou que tem condições de crescer sua capacidade de produção } \\
\text { para satisfazer à crescente demanda; } \\
\text { - A imposição de medidas vai permitir o crescimento da indústria doméstica; } \\
\text { - Medidas impostas. }\end{array}$ \\
\hline 32. & $\begin{array}{l}\text { Balanças electrónicas } \\
\text { (balances électroniques) }\end{array}$ & $\begin{array}{l}\text { Regulamento (CE) n. } .^{\circ} 692 / 2005 \text { do } \\
\text { Conselho, de } 28 \text { de Abril de } 2005 \text {, } \\
\text { que altera o Regulamento (CE) } \\
\text { n. } 2605 / 2000 \text { do Conselho, JO L } \\
112 \text { de 3.5.2005, }\end{array}$ & $\begin{array}{l}\text { - O desenvolvimento tecnológico foi discutido como um motivo para a aplicação de medidas } \\
\text { antidumping. }\end{array}$ \\
\hline 33. & Sapatos de Segurança & $\begin{array}{l}\text { Decisão da Comissão de } 28 \text { de } \\
\text { agosto de 2006, OJ L 234/33, } \\
\text { 29/08/2006.. } \\
\end{array}$ & $\begin{array}{l}\text { - A indústria comunitária desistiu do pedido de aplicação de medidas antidumping quando } \\
\text { conheceu o entendimento da Comissão de que havia dúvidas sobre o dano; } \\
\text { - Não foram aplicadas medidas. }\end{array}$ \\
\hline 34. & $\begin{array}{l}\text { Calçado com a parte } \\
\text { superior de couro natural }\end{array}$ & $\begin{array}{l}\text { Regulamento do Conselho n. } \\
1472 / 2006 \\
\text { de } 5 \text { de outubro de } 2006 \text {, JO L } \\
275 / 1 \text { de } 6 / 10 / 2006 \\
\end{array}$ & $\begin{array}{l}\text { - A Comissão decidiu pela aplicação de medidas antidumping; } \\
\text { - A pressão política sobre o Conselho foi enorme, propondo a França que a medida fosse aplicada, } \\
\text { então, somente por dois anos. }\end{array}$ \\
\hline 35. & Mercúrio & $\begin{array}{l}\text { Regulamento CEE de } 8 \text { de } \\
\text { dezembro de 1987, OJ L 346, de } \\
\text { 10/12/1987. }\end{array}$ & $\begin{array}{l}\text { - O mercúrio foi considerado como produto estratégico para a Comunidade Européia, justificando a } \\
\text { aplicação de medidas antidumping com o intuito de preservar o único competidor europeu contra } \\
\text { importações da Rússia. }\end{array}$ \\
\hline
\end{tabular}

Fonte: Site oficial da União Européia, www.europa.eu.int. 


\section{ANEXO 03 - DECISÕES RELEVANTES, NO BRASIL, SOBRE O INTERESSE PÚBLICO}

\begin{tabular}{|c|c|c|c|}
\hline & Decisão & Referência & Considerações \\
\hline 36. & $\begin{array}{l}\text { Barrilhas (Carbonato } \\
\text { dissódico) }\end{array}$ & $\begin{array}{l}\text { Processo MDIC/SECEX 52100- } \\
\text { 000016/1996-11, Circular n. 23, de } \\
29 \text { de junho de 1998, publicada no } \\
\text { D.O.U em 30.06.98. }\end{array}$ & $\begin{array}{l}\text { - A imposição de medidas poderia afetar drasticamente as indústrias de vidro e de limpeza, } \\
\text { dependentes de importações; } \\
\text { - Medidas não foram impostas; } \\
\text { - Indústria doméstica faliu. }\end{array}$ \\
\hline 37. & Ferro cromo & $\begin{array}{l}\text { Ferro cromo. Processo } \\
\text { MDIC/SECEX 52100- } \\
\text { 017966/2003-11, Resolução } \\
\text { CAMEX n 31, de 05 de outubro de } \\
\text { 2004, publicada no D.O.U. de } 11 \text { de } \\
\text { outubro de 2004. }\end{array}$ & $\begin{array}{l}\text { - Indústria doméstica extremamente concentrada; } \\
\text { - } \quad \text { Aplicação poderia levar ao aumento de poder econômico; } \\
\text { - Necessidade de preservar o interesse do país e a estabilidade de preços no setor siderúrgico; } \\
\text { - Medidas foram suspensas, devendo-se monitorar o setor; } \\
\text { - Posteriormente, foram aplicadas medidas contra a África do Sul. }\end{array}$ \\
\hline 38. & Escovas de cabelo & $\begin{array}{l}\text { Processo MIDIC/SECEX } \\
\text { 52500.012357/2006-38, Circular n. } \\
\text { 62, de } 14 \text { de setembro de } 2006 \\
\text { publicada no D.O.U em } \\
\text { 15.09.2006. }\end{array}$ & - Discutiu a difícil caracterização do produto similar. \\
\hline 39. & Policloreto de vinila. & $\begin{array}{l}\text { Processo MDIC/SECEX RJ- } \\
\text { 52100.027088/2003-33, Resolução } \\
\text { n. 18, de } 29 \text { de junho de } 2005, \\
\text { publicada no D.O.U em } 01.07 .05 \text {. }\end{array}$ & $\begin{array}{l}\text { - O DECOM entendeu que não restou evidenciada causalidade entre o dano e a prática de dumping. } \\
\text { A indústria doméstica havia importado um volume relevante da Argentina, a preços inferiores do } \\
\text { que os preços das demais origens investigadas. }\end{array}$ \\
\hline 40. & Nitrato de amônio & $\begin{array}{l}\text { Processo MDIC/SECEX/RJ } \\
\text { 52500.017967/2007-78, Resolução } \\
\text { n. } 71 \text {, de } 4 \text { de novembro de } 2008 \\
\text { publicada no D.O.U em } 07.11 .08 \text {. }\end{array}$ & $\begin{array}{l}\text { - } \quad \text { Continuidade na aplicação por mais um ano; } \\
\text { - Imediata suspensão da aplicação. } \\
\text { - Interesse do país em preservar a estabilidade dos preços do produto e sua importância nas } \\
\text { principais culturas brasileiras }\end{array}$ \\
\hline 41. & Cimento portland & $\begin{array}{l}\text { Processo MDIC/SECEX } \\
\text { 52500.007154/2005-16, Resolução } \\
\text { CAMEX n. 36, de 22 de novembro } \\
\text { de 2006, publicada no D.O.U em } \\
\text { 27.11.06. }\end{array}$ & $\begin{array}{l}\text { - Suspensão da aplicação para o cimento destinado ao Estado de Roraima - explicação problema } \\
\text { concorrencial. }\end{array}$ \\
\hline 42. & $\begin{array}{c}\text { Pneus novos para } \\
\text { bicicletas }\end{array}$ & $\begin{array}{c}\text { Processo MDIC/SECEX } \\
\text { 52100.085489/2002-27, Resolução } \\
\text { CAMEX n. 37, de } 11 \text { de dezembro }\end{array}$ & $\begin{array}{l}\text { - Conteúdo político da decisão que suspendeu o direito contra a China, porque não } 320 \text { ra interessante } \\
\text { ao país. }\end{array}$ \\
\hline
\end{tabular}


de 2003, publicada no D.O.U em

$$
\text { 19.12.03. }
$$

Fonte: DECOM (www.mdic.gov.br) e base de dados de Mauro Grinberg, advogado (coletânea de jurisprudência). 


\section{BIBLIOGRAFIA}

\section{Obras Gerais : Tratados, Manuais}

ABREU DALLARI, Dalmo. Elementos de Teoria Geral do Estado, 16 ed. Saraiva, São Paulo, 1991.

ADAMANTOPOULOS, Konstantinos; PEREYRA, María. EU Anti-subsidy Law \& Practice. 2 ed. London: Sweet \& Maxwell. 2007.

ADAMS, Walter. Import Restraints and Industrial Performance: The Dilemma of Protectionism. In Antidumping Law: Policy and Implementation. Ann Arbor: The University of Michigan Press, 1979.

AFONSO DA SILVA, José. Curso de Direito Constitucional Positivo, 18 ed., São Paulo: Malheiros, 2000.

ARAGÃO, Murillo. Grupos de pressão no Congresso Nacional: como a sociedade pode defender licitamente seus direitos no Poder Legislativo. São Paulo: Maltese, 1994.

ARISTÓTELES, Política, Universidade de Brasília, Trad. Mario da Gama Kury, 1997.

BANDEIRA DE MELlO, Celso Antonio. Curso de Direito Administrativo. 11 ed. São Paulo: Malheiros, 1999.

BANDEIRA DE MELLO, Celso Antonio. Elementos de Direito Administrativo, 2 ed. São Paulo: Revista dos Tribunais, 1981.

BAPTISTA, Luiz Olavo. Empresa Transnacional e Direito. São Paulo: Editora Revista dos Tribunais, 1987.

BARFIELD, Claude. High-tech protectionism: the irrationality of antidumping laws. Washington: The AEI Press, 2003.

BARRAL, Welber. Dumping e Comercio Internacional: A regulamentação antidumping após a Rodada do Uruguai. Rio de Janeiro: Forense, 2000.

BARROSO, Luís Roberto. Prefácio à obra Interesses públicos $x$ interesses privados: desconstruindo o princípio da supremacia do interesse público. Rio de Janeiro: Lúmen Júris, 2005.

BASTOS, Celso Ribeiro. Curso de Direito Constitucional, 11 ed. Saraiva, 1989. 
BELDERBOS, René. Antidumping and Tariff Jumping: Japanese firms DFI in the European Union and the United States. The WTO and Anti-dumping, Volume II, Cheltenham: Elgar Reference Collection, 2005.

BENITAH, Mark.The Law of Subsidies under GATT/WTO Systems, London: Kluwer Law. 2001.

BHAGWATI, Jagdish. Free Trade Today. New Jersey: Princeton University Press, 2002.

BHAGWATI, Jagdish. Protectionism. Massachusetts: The MIT Press, 1988.

BORGES, Alice Gonzáles. Temas do Direito Administrativo Atual. Belo Horizonte: Editora Fórum, 2004.

BORK, Robert. The Antitrust Paradox. New York: Free Press, 1978.

BORKAKOTI, Jitendralal; MILNER, Chris. International Trade and Labour Markets. London: MacMillan Press, 1997.

CARREAU, Dominique; JUILLARD, Patrick. Droit International Economique. Paris : Dalloz, 2003.

CLAMOUR, Guylain, Intérêt Général et concurrence, Dalloz, Nouvelle Bibliothèque de Thèses, 2007.

CLARK, John Maurice. Instituições econômicas e bem-estar social. Rio de Janeiro: Zahar Editores, 1967.

CORDEN. W. The revival of protectionism. Occasional papers. New York: Group of Thirty, 1984.

CORDOVIL, Leonor. A intervenção estatal nas telecomunicações: a visão do Direito Econômico. Belo Horizonte: Editora Fórum, 2005.

COTTIER, Thomas; MAVROIDIS, Petros. The Role of the Judge in International Trade Regulation: Experience and Lessons for the WTO. Ann Arbor: The University of Michigan Press, 2003.

ESCOLA, Hector. El interes público como fundamento del derecho administrativo. Buenos Aires: Depalma, 1989.

F. BADIA. Grupos de Interesse e de promoção e pressão. Brasília: Instituto Tancredo Neves, 1987.

FARJAT, Gérard. Droit Economique. Paris: Presses Universitaires de France, 1971. 
FERNANDEZ, Marta. Los Derechos antidumping em el derecho comunitário. Valladolid : Lex Nova, 1999.

FERREIRA ALVES, Jorge de Jesus. Direito da Concorrência nas Comunidades Européias. Coimbra: Coimbra Editora, 1989.

FINGER, Michael. Antidumping: How it works and Who gets hurt. Michigan: The University of Michigan Press, 1993.

FINGER, Michael. Safeguards. In HOEKMAN, Bernard et al. Development, Trade and the WTO: A Handbook. Washington: The World Bank, 2002.

FORGIONI, Paula. Os Fundamentos do Antitruste, São Paulo: Revista dos Tribunais, 2008.

GALBRAITH, John Kenneth. A cultura do contentamento. São Paulo: Pioneira, 1992.

GELLHORN, Ernest; KOVACIC, William; CALKINS, Stephen. Antitrust Law and Economics in a nutshell. Saint Paul: Thompson West, 1994.

GIANNAKOPOULOS, Themistoklis. Safeguarding Companies' Rights in Competition and Antidumping/Antisubsidies Proceedings. London: Kluwer Law International, 2006.

GRAU, Eros Roberto. A ordem econômica na Constituição de 1988. 7 ed. São Paulo: Malheiros, 2002.

GRAU, Eros Roberto. Direito, Conceitos e Normas Jurídicas. São Paulo: Editora RT, 1988.

HAMONIAUX, Thibau. L'intérêt general et le juge communautaire, Paris, LGDJ, Systèmes, 2001.

HARVEY, Brian; PARRY, Deborah. The Law of Consumer Protection and Fair Trading. Third edition. Londres: Butterworths, 1987.

HINDLEY, Brian. MESSERLIN, Patrick. Antidumping Industrial Policy: legalized protectionism in the WTO and what to do about it. Washington: The AEI Press, 1996.

BAIN. Barriers to New Competition: Their Character and Consequences in Manufacturing Industries In HOVENKAMP, Herbert. Federal Antitrust Policy: the Law of Competition and its Practice. Second Edition. Saint Paul: West Group, 1999.

JAVELOT, Sylvie. La loyauté dans le commerce international. Paris: Economica, 1998. 
JENNY, Frédéric. Competition, Trade and Development Before and After Cancun. International Antitrust Law \& Policy: Fordham Corporate Law, 2003.

JOHANNPETER, Guilherme Chagas Gerdau. Antidumping - prática desleal no comércio internacional. Porto Alegre: Livraria do Advogado, 1996.

KENNEDY, Kevin. Competition Law and the World Trade Organisation: the limits of multilateralism. Londres: Sweet \& Maxwell, 2001.

KRONSTEIN, Heinrich. The Law of International Cartels. London: Cornell University Press, 1973.

LAFAY, Gérard. Peut-on se proteger de la crise? Le protectionnisme. Paris: Economica, 1985.

LINOTTE, Didier; MESTRE, Achille. Services Publics et Droit Public Économique. Paris: Librairies Techniques, 1982.

LONG, Olivier. Public Scrutiny of Protection: domestic policy transparency and trade liberalization. Special report n. 7, Londres: Trade Policy Research Centre. 1989.

MARCEAU, Gabrielle. Anti-Dumping and Anti-Trust: Issues in Free Trade Areas. Oxford: Clarendon Press, 1995.

MANSFIELD, Edwin. Microeconomia: teoria e aplicações. Tradução de José Edgard da Mota Freitas e Mario Fonseca Geille. 2 ed. Rio de Janeiro: Campus, 1980 .

MARQUES, Cláudia Lima; BENJAMIN, Herman de Vasconcellos; MIRAGEM, Bruno. Comentários ao Código de Defesa do Consumidor. 2.ed. São Paulo: Editora Revista dos Tribunais, 2006.

MARSDEN, Philip. A competition policy for the WTO. Londres: Cameron May, 2003.

MARTINEZ, Luis. Comercio Justo y Derechos Sociales: la condicionalidad social en El comercio internacional. Granada: Tecnos, 2002.

MATSUSHITA, Mitsuo; SCHOENBAUM, Thomas e MAVROIDIS, Petros. The World Trade Organization: Law, Practice and Policy, The Oxford International Law Library, 2003.

MATTOS, César (org.). A Revolução do Antitruste no Brasil. São Paulo: Editora Singular, 2003. 
MEDAUAR, Odete. O Direito Administrativo em Evolução, São Paulo, Revista dos Tribunais, 1992.

MEDEIROS, Evan. Chasing the dragon: assessing China's system of export controls for WMD-related goods and technologies. Santa Monica: Rand, 2005, 112 p. CHAN, Thomas. China's export miracle: origins, results and prospects. London: McMillan, 1999.

METCALF, J. RAMLOGAN, R, UYARRA, E. Competition, innovation and economic development: the instituted connection. In Leading issues in competition, regulation and development. Cheltenham: Elgar, 2005.

MEYNAUD, Jean. Les Groupes de Pression. Presses Universitaires de France. Que sais-je? n. 985, 1965.

NUSDEO, Fábio. Curso de Economia: Introdução ao Direito Econômico. 3 ed. São Paulo: Editora Revista dos Tribunais. 2001.

OESCH, Matthias. Standards of Review in WTO Dispute Resolution. Oxford: Oxford University Press, 2003.

OLIVEIRA, José Roberto Pimenta. Os princípios da razoabilidade e da proporcionalidade no Direito Administrativo Brasileiro. São Paulo: Malheiros, 2006.

PETERSMANN, International Trade Law and the GATT/WTO Dispute Settlement System. London: Kluwer Law International, 1997.

PONTES DE MIRANDA, Comentários à Constituição de 1967, Tomo I, São Paulo: Ed. Revista dos Tribunais, 1969.

RANGEON, François. L'ideologie de l'intérêt général. Paris : Economica,1986.

ROCHA, Carmen Lucia Antunes. Princípios Constitucionais da Administração Pública, Belo Horizonte: Del Rey, 1994.

ROUSSEAU, Jean-Jacques. Do Contrato Social: Princípios do Direito Político. Trad. J. Cretella Jr. e Agnes Cretella. São Paulo: Editora Revista dos Tribunais, 2002.

SAlGADO, Lúcia Helena. A Economia Política da Ação Antitruste. Rio de Janeiro: Singular, 1997.

SALOMÃO, Calixto. Direito Concorrencial: as estruturas. 2 ed. São Paulo: Malheiros, 2002.

SANTOS, António; GONÇALVES, Maria Eduarda; LEITÃO MARQUES, Maria Manuel. Direito Económico. Coimbra: Almedina, 1997. 
SIMON, Denys. Le système juridique communautaire, Paris, PUF, 2001.

SOUZA, Washington Peluso Albino de. Primeiras Linhas de Direito Econômico, 3 ed. São Paulo: LTR, 1994.

STANBROOK, Clive; BENTLEY, Philip. Dumping and subsidies: the Law and procedures governing the imposition of anti-dumping and countervailing duties in the European Community. 3 ed. Londres: Kluwer Law International.

STANBROOK, Clive; BENTLEY, Philip. Dumping and subsidies: the Law and procedures governing the imposition of anti-dumping and countervailing duties in the European Community. London: Kluwer Law International, 1996.

TOCQUEVILlE, Alexis de. A Democracia na América. T.1. São Paulo: Martins Fontes, 2005.

TOCQUEVILlE, Alexis de. O antigo regime e a revolução. Brasília: Edunb. 1982.

VALLE FIGUEIREDO, Maria Lúcia. Curso de Direito Administrativo. São Paulo: Ed. Malheiros.

VAN BAEL, Ivo; BELLIS, Jean-François. Antidumping and other trade protection laws of the EEC. Bruxelas: CCH Editions Limited, 1990.

VAZ, Isabel. Direito Econômico das Propriedades. Rio de Janeiro: Forense, 1993.

VENANCIO FILHO, Alberto. A Intervenção do Estado no Domínio Econômico. Ed. Fac-similar a 1968. Rio de Janeiro: Renovar. 1998.

VERMULST, E; WAER, P. E.C. Antidumping Law and Practice. London: Sweet \& Maxwell, 1996.

VIDIGAL, Geraldo de Camargo. Teoria Geral do Direito Econômico. São Paulo: Revista dos Tribunais, 1977.

VINER, Jacob: Dumping: a problem in international Trade. Chicago: The University of Chicago Press, 1923.

VISCUSI, W. Kip; VERNON, John M. and HARRINGTON, Joseph. Economics of Regulation and Antitrust. Third Edition. Massachussetts: the MIT Press. 


\section{Obras Especiais : Teses e Monografias}

FIEBIGER, Gernot. The Community Interest Test in EC Antidumping Law: Recent developments. Master Thesis Executive M.B.L, supervised by Jacques Bourgeois, St. Gallen, 2001.

MOEN, Paul. Public interest issues in international and domestic Anti-dumping Law: the WTO, European Communities and Canada. Genebra: Intitut Universitaire de Hautes Etudes Internationales, 1998.

SCHAPIRO, Mário Gomes. Política Industrial e disciplina da Concorrência pósreformas de mercado: uma avaliação institucional do ambiente de inovação tecnológica. Dissertação de mestrado apresentada ao Departamento de Direito Econômico e Financeiro da USP, São Paulo, 2005.

\section{Artigos, Relatórios, Crônicas}

AGGARWAL, Aradhna. Antidumping Law and practice: an Indian Perspective. Working Paper 85. Indian Council for Research on International Economic Relations, 2002.

AGGARWAL, Aradhna. The WTO Anti-dumping Agreement: possible reform through the inclusion of a public interest clause. Working Paper n. 142, Indian Council for Research on International Economic Relations, 2004.

AGGARWAL, Aradhna. The WTO Antidumping Code: issues for review in postDoha negotiations. Working Paper n. 99, New Delhi: Indian Council for Research on International Economic Relations. 2003.

AGGARWAL, Aradhna. Macro Economic Determinants of Antidumping: A comparative analysis of developed and developing countries. World Development, v. 32, n. 6, 2004.

ALMEIDA, João Gabriel Assis. A aplicação extraterritorial do direito da concorrência brasileiro. Revista do Ibrac, vol. 8, número 3, 2001.

ANDERSON, James. Strategic Lobbying and Antidumping. Journal of Economic Integration, v. 9, n. 2, 1994.

ANDERSON, Keith. Antidumping Laws in the United States: use and welfare consequences. Journal of World Trade, v. 27. n 2, 1993.

APPLEBAUM, Harvey, The antidumping laws - impact on the competitive process. Antitrust Law Journal, v. 43, 1974.

ARAÚJO Jr., José Tavares. As normas antidumping da ALCA e a agenda multilateral. Sistema de Informação sobre Comércio Exterior/Organização dos 
Estados Americanos - SICE/OEA, Dezembro de 2001, disponível em HTTP://www.sice.oas.org/compol/articles/cpant.asp, acessado em 27 julho de 2008.

AREEDA, Philip. Predatory Pricing. Antitrust Law Journal, v. 49, 1980.

ÁVILA, Humberto Bergmann. Repensando o princípio da supremacia do interesse público sobre o particular. Revista Trimestral de Direito Público, n. 24, 1998.

BAGWELL, Kyle; STAIGER, Robert. The simple economics of Labor Standards and the GATT. National Bureau of Economic Research. Working Paper 6604, disponível em www.nber.org/papers/w6604.

BAKER, Jonathan. Predatory pricing after Brooke Group: an economic perspective. Antitrust Law Journal. v. 62, 1993.

BALDWIN, Robert. Inefficacy of protection in promoting social goals. World Economy, v. 8, n. 2, 1985.

BERNERT, Peter. Thoughts in response to the list of issues considered by the Commission. Eurocommerce: Preparatory Paper for the Seminar on Trade Defence Instruments, 2006.

BERRY, Jeffrey. Citizen Groups and the Changing Nature of Interest Groups Politics in América. Annals of The American Academy of Political and Social Science, v. 528, 1993.

BETHKE, R. Note concerning a short written contribution with regard to the EU trade defence instruments and its application in a globalized economy. Issues under reflection. 11 de julho de 2006.

BLIN, Olivier. La stratégie communautaire dans l'Organisation Mondiale du Commerce. Journal du Droit International, janvier-fevrier-mars 2006, n. 1, 2006.

BORGES, Alice Gonzáles. Interesse Público: um conceito a determinar. Revista de Direito Administrativo, Rio de Janeiro, v. 205, jul/set. 1996.

BORGES, Alice Gonzáles. Supremacia do Interesse Público: desconstrução ou reconstrução? Interesse Público. v. 37, ano 2006.

BORIN, Jair. O lobby na imprensa: tipificação e formas de atuação. Cadernos de jornalismo e Editoração, São Paulo, n. 22, 1998.

BORK, Robert. BOWMAN, Ward. The Goals of Antitrust: A Dialogue on Policy. Columbia Law Review, v. 65, n. 3, 1965. 
BROEK, Naboth. Legal Persuasion, political realism, and legitimacy: The European Court's recent treatment of the effect of WTO Agreements in the EC legal order. Journal of International Economic Law, v 4, n 2, 2001.

BRONCKERS, Marco. Rehabilitating Antidumping and other Trade Remedies through cost-benefit analyses. Journal of World Trade, v. 30, n. 5, 1996.

BROWN, Drusilla. Labor Standards: where do they belong on the International Trade Agenda? Journal of Economic Perspectives, n. 15, v. 3, 2001.

CALVANI, Terry, LYNCH, James. Predatory pricing under the RobinsonPatman and Sherman Acts: an introduction. Antitrust Law Journal. v. 51, 1982.

CAPITULA, Sueli Solange. Interesse Público - Princípio Constitucional Implícito. Cadernos de Direito Constitucional e Ciência Política. Revista dos Tribunais, ano 5, n. 17, out/dez 1996.

CARLSTON, Kenneth; TREECE, James. Antitrust and the Consumer Interest. Michigan Law Review, v. 64, n. 5, 1966.

CARRACEDO, Jose Rubio. Democracia y legitimacion del poder em Rousseau. Revista de Estudios Politicos, n. 58, Outubro-dezembro, 1987.

CLOSE, Patricia. The ABCs of discretion in antidumping injury decisions. International Trade and Regulation, v. 13, n. 5, 2007.

CORDEN. W. The revival of protectionism. Occasional papers. New York: Group of Thirty. 1984.

CROLEY, Steven; JACKSON, John. WTO Dispute Procedures, standard of review, and deference to national governments. American Journal of International Law, v. 90, 1996.

CZINKOTA, Michael; KOTABE, Masaaki. A marketing perspective of the US International Trade Commission's Antidumping Actions - an empirical inquiry. Journal of World Business, v. 32, i. 2, 1997.

DAVEY, William. Has the WTO Dispute Settlement System Exceeded its authority? A consideration of deference shown by the system to member government decisions and its use of issue-avoidance techniques. In COTTIER, Thomas; MAVROIDIS, Petros. The Role of the Judge in International Trade Regulation: Experience and Lessons for the WTO. Ann Arbor: The University of Michigan Press, 2003.

DEADORFF, Alan; STERN, Robert. What you should know about globalization and the World Trade Organization. Review of International Economics, vol. 10, issue 3, 2002. 
DIDIER, Pierre. The WTO Anti-Dumping Code and EC Practice: issues for review in trade negotiations. Journal of World Trade, vol. 35, n. 1, 2001.

EHRENHAFT, Peter. Multinational Enterprises and the Antidumping Law. Harvard International Law Journal, vol. 20, n. 2, 1979.

FARIA, José Ângelo Estrella. Aplicação Extraterritorial do Direito da Concorrência. Revista Informação Legislativa. A. 27, n. 105, Jan/mar, 1990.

FERREIRA ALVES, Jorge de Jesus. Direito da Concorrência nas Comunidades Européias. Coimbra: Coimbra Editora, 1989.

FINGER, M. and ZLATE. A. WTO Rules that allow new trade restrictions: the public interest is a bastard child. Paper prepared for the U.N Millenium Project Task Force on Trade, coordinated by Ernesto Zedillo and Patrick Messerlin. Abril 2003.

FOX, Eleanor. Competition Law and the Millennium Round. Journal of International Economic Law, v. 2, n. 4, 1999.

FOX, Eleanor. Consumer Beware Chicago. The Michigan Law Review, v. 84, n. 8, 1986.

FOX, Eleanor. International Antitrust and the Doha Dome. Virginia Journal of International Law, v. 43, 2003.

FOX, Eleanor, The Battle for the Soul of Antitrust. California Law Review, v. 75, n. 3, 1987.

FOX, Eleanor. The Modernization of Antitrust: a new Equilibrium. Cornell Law Review, n. 66, 1980.

FREY, Klaus. Descentralização e Poder Local em Alexis de Tocqueville. Revista de Sociologia Política, Curitiba, n. 15, 2000.

FUKUNAGA, Yuka. A Effect-Based Approach to Anti-Dumping: why should we introduce a mandatory lesser duty rule? Journal of World Trade, v. 38, n. 3, 2004.

GALLAWAY; Michael. BLONIGEN, Bruce; FLYNN, Joseph. Welfare costs of US antidumping and countervailing duty laws. Journal of International economics, v. 49, 1999.

GASTON, Noel; TREFLER, Daniel. Protection, Trade and Wages: Evidence from U.S. Manufacturing. Industrial and Labour Relations Review, v. 47, n. 4, julho 1994. 
GERBER, David. Constitutionalizing the Economy: German Neo-liberalism, Competition Law and the New Europe. American Journal of Comparative Law, n. 25, 1994.

GOCO, Jonell. Non discrimination, Likeness, and Market Definition in World Trade Organization Jurisprudence. Journal of World Trade, v. 40, n. 2, 2006.

GOMES, Carlos Jacques Vieira. Os Escopos Sociais do Direito Antitruste. Revista do IBRAC, v. 11, n. 2, 2004.

GRAAFSMA, Folkert; CORNELIS, Joris. The EC's Green Paper on Trade Defence Instruments: Guillotine on Anti-dumping or smokescreen for more basic predicaments? Global Trade and Customs Journal, v. 2, i. 7, 2007.

GRAU, Eros Roberto. Princípio da Livre Concorrência - função regulamentar e função normativa. Revista Trimestral de Direito Público, n. 4, 1993.

GRAZIANO, Luigi. O lobby e o interesse público. Revista Brasileira de Ciências Sociais. v. 12, n. 35, fev. 1997.

GROSSMAN, Emiliano. Les groupes d'intérêt économiques face à l'intégration européenne: Le cas Du secteur bancaire. Revue Française de science politique, v. 53, n. 5, 2003.

HANSEN, Wendy e PARK, Kee. Nation-State and Pluralistic Decision Making in Trade Policy: The case of the International Trade Administration. International Studies Quarterly, v. 39, 1995.

HINDLEY, Brian. The Green Paper on Trade Defence Instruments: Antidumping. Global Trade and Customs Journal, v. 2, n. 10, 2007.

HOEKMAN, Bernard; Leidy Michael. Spurious injury as indirect rent seeking: free trade under the prospect of protection. Economics and Politics, v. 3, n. 2, 1991.

HOEKMAN, Bernard; LEIDY, Michael. Dumping, Antidumping and Emergency Protection. Journal of World Trade. v. 23, n. 5, Outubro 1989.

HOEKMAN, Bernard; MAVROIDIS, Petros. Dumping, Antidumping and Antitrust. Journal of World Trade, v. 30, n. 1, 1996.

HORLICK, Gary e SHEA, Eleanor. The World Trade Organization Anti-dumping Agreement. Journal of World Trade, v. 29, n. 1, 1995.

HOVENKAMP, Herbert. Antitrust Policy after Chicago. Michigan Law Review, v. 84, n. 2, 1985. 
HOVENKAMP, Herbert. Chicago and its alternatives. Duke Law Journal, n. 6, 1986.

HOVENKAMP, Herbert. Distributive Justice and the Antitrust Laws, George Washington Law Review, v. 51, n. 1, 1982.

IRWIN, Douglas. The rise of U.S. antidumping activity in historical perspective. IMF Working Paper: Research Department, WP/05/31, 2005.

JACKSON, John. International Economic Law in Times that are interesting. Journal of International Economic Law, v. 3, n. 1, 2000.

JAFFE, The Right of Judicial Review, Harvard Law Review, n. 71, 1958.

JOSKOW, Paul. KLEVORICK, Alvin. A framework for analyzing predatory pricing policy, Yale Law Journal, v. 28, n. 1, 1979.

JUSTEN FILHO, Marçal. Conceito de Interesse Público e a personalização do direito administrativo. Revista Trimestral de Direito Público, v. 26, 1999.

JUSTEN FILHO, Marçal. O Direito Administrativo Reescrito: problemas do passado e temas atuais. Revista Negócios Públicos, ano II, n. 6, 2005.

KEMPTON, Jeremy. Anti-dumping policy and the consumer interest. Consumer Policy Review, nov/dez 2000.

KINDLENBERGER, Charles Poor. Group Behavior and International Trade. In Protectionism in the World Economy. Londres: Elgar Publish. Co. 1992, p. 46-62.

KOMMERSKOLLEGIUM, National Board of Trade of Sweden, The use of antidumping in Brazil, China, India, South Africa, - rules, trends and causes. p. 11, disponível em http://www.kommers.se/upload/Analysarkiv/Arbetsomr\%C3\%A5den/Antidumpning/National_Bo ard_of_Trade-_Antidumping_in_Four_Developing_Countries.pdf, disponível em 20 de janeiro de 2008.

LECLERC, Jean-Marc. Reforming Anti-dumping Law: Balancing the Interests of Consumers and Domestic Industries. McGill Law Journal, v. 44, 1999.

LONG, Olivier. Public Scrutiny of Protection: domestic policy transparency and trade liberalization. Special report n. 7, Londres: Trade Policy Research Centre. 1989.

MACLEAN, Robert; ECCLES, Richard. A change of style not substance: the Community's new approach towards the community interest test in anti-dumping and anti-subsidy law. Common Market Law Review, v. 36, 1999. 
MAGALHÃES, Fernando. O passado ameaça o futuro: Tocqueville e a perspectiva da democracia individualista. Tempo Social, Revista de Sociologia da USP, São Paulo, 12 (1), 2000.

MARINHO, Josaphat. Grupos de Pressão na Sociedade. Revista Trimestral de Direito Público, n. 1, 1993.

McDonald, Ian; SOLOW, Robert. Wage Bargaining and unemployment. American Economic Review, v. 71, n. 5, Dezembro de 1981.

MONTEIRO, Carmen Diva Beltrão; GALVÃO, Letícia Andreoli. Interesse público: critérios para a consideração em processos de investigação antidumping. SEAE/MF, 2005.

MOORE, Michael. Facts available dumping allegations: when will foreign firms cooperate in antidumping petitions? European Journal of Political Economy. v. 21. 2005.

MORGAN, Clarisse. Competition Policy and Anti-dumping: is it time for a reality check? Journal of World Trade. Vol. 30, n. 5, October 1996.

NARAYANAN, Prakash. Anti-dumping in India - present state and future prospects. Journal of World Trade, v. 40, n. 6, 2006.

NELSON, Douglas. The political economy of antidumping: a survey. European Journal of Political Economy, v. 22, 2006.

NIELS, Gunnar; KATE, Adriaan. Trusting Antitrust to Dump Antidumping: abolishing antidumping in Free Trade Agreements without replacing it with Competition Law. Journal of World Trade, v. 31, n. 6, 1997.

OLIVEIRA, Andréa Cristina de Jesus. As muitas faces do lobbying no Brasil: corrupção, tráfico de influência ou um instrumento democrático de representação de interesses? Revista Espaço Acadêmico. N. 47, Abril 2005.

OLIVEIRA, Andréa Cristina de Jesus. Breve histórico sobre o desenvolvimento do lobbying no Brasil. Revista de Informação Legislativa. Brasília: Senado Federal, ano 42, n. 168, Outubro/Dezembro 2005.

PALMETER, David. A commentary on the WTO Anti-Dumping Code, Journal of World Trade, v. 30, n. 4, 1996.

PANAGANYA, Arvind. Cost of protection: where do stand. American Economic Review, v. 92, n. 2, 2002.

PANAGARIYA, Arvind. Anti-dumping: Let us not shoot ourselves in the foot. Economic Times, June 30, 1999. 
PIERCE, Richard. Antidumping Law as Means of Facilitating Cartelization. Public Law and Legal Theory, Working Paper 002, George Washington University Law School, 1999.

PINCUS, J. J. Pressure Groups and the Pattern of Tariffs. Journal of Political Economy. n. 4, 1983.

PRUSA, Thomas. On the Spread and Impact of Antidumping. NBER Working Paper Series, Working Paper 7404, 1999, disponível em www.nber.org/papers/w7404)

PRUSA, Thomas. Why are antidumping petitions withdrawn? Journal of International Economics, v. 33, 1992.

PRUSA, Thomas; SKEATH, Susan. The Economic and Strategic Motives for Antidumping Filings. NBER Working Paper Series, Working Paper 8424, 2001.

RIDEAU, Joël. Les Groupes d'intérêt dans le système institutionnel communauaire. Revue des Affaires Européennes. n. 3. LGDJ, 1993.

ROBIN, Donald; SAWYER, Charles. The ethics of antidumping petitions. Journal of World Business, v. 33, n. 3, 1998.

RUIZ FABRI, Hélène; MONNIER, Pierre. Chronique du règlement des différends 2005-2006. Journal du Droit International, juilet-aout-septembre, 2006.

RUIZ FABRI, Hélène. La motivation des décisions dans le règlement des différends de l'OMC. La motivation des décisions des jurisdictions internationales. Paris : Pedone, 2008.

SANDMO, Agnar. On the Theory of the competitive firm under price uncertainty, American Economic Review, v. 61, n. 1, 1971.

SAPIR, André. Some ideas for reforming the Community Antidumping Instrument. Paper produced at the request of Commmissioner Mandelson for the Expert Seminar on Trade Defense Instuments, Bruxelas, 11 de julho de 2006.

SCHYMURA, Luiz Guilherme. Barreiras à entrada: o caso do setor de creme dental brasileiro. MATTOS, César (org.). A Revolução do Antitruste no Brasil. São Paulo: Editora Singular, 2003.

SINNAEVE, Adinda. The Community Interest Test in Anti-dumping Investigations: time for reform? Global Trade and Customs Journal, v. 2, n. 4, 2007.

SPAAK, Fernand; JAEGER, Jean. The Rules of Competition within the European Commom Market. Law and Contemporary Problems. Vol. 26, n. 3. 1961. 
STEGEMANN, Klaus. Anti-dumping policy and the consumer. Journal of World Trade Law, v. 19, n. 5, 1985.

STEVENSON, Cliff. Mayer, Brown, Rowe \& Maw LLP. Evaluation of EC Trade Defence Instruments. December 2005.

STOLPER, Wolfgrang; SAMUELSON, Paul. Protection and real wages. Review of Economic Studies, v. 9, n. 1, Novembro, 1941.

STYN, Ronald. The Antidumping Act: Problems of Administration and Proposals for Change. Stanford Law Review, v. 17, n. 4, 1965.

SYKES, Alan. Antidumping and Antitrust: what problems does each address? In Robert Z Lawrence. Brookings Trade Forum, Brookings Institutional Press, Washington D.C, 1998.

TAYLOR, Christopher. The economic effects of withdrawn antidumping investigations: is there evidence of collusive agreements? Journal of International Economics, v. 62, 2004.

TREBILCOCK, M; QUINN, J. The Canadian Antidumping Act: A reaction to Professor Slayton. Canada-US Law Journal, 1979.

UNAH, Isaac. Specialized Courts of Appeals' Review of Bureaucartic Actions and the Politics of Protectionism. Political Research Quarterly, v. 50, n. 4, 1997.

USATEGUI, Elisa. Comunidad y Género em Alexis de Tocqueville. Revista de Estudios Políticos, n. 121, Julio-Septiembre, 2003.

VAZ, Isabel. Legislação de Defesa da Concorrência e Extraterritorialidade. Revista do IBRAC, vol. 4, número 6, 1997.

VELASCO, Demetrio. Tocqueville (1805-1859), dos siglos despues. Estudios de Deusto. Revista de La Universidad de Deusto. v. 53/1, Janeiro-junho 2005. Bilbao: Deusto, 2005.

VERMULST, Edwin. Adopting and Implementing Anti-Dumping Laws: some suggestions for developing countries. Journal of World Trade, v. 31, n. 2, 1997.

VERMULST, Edwin. The 10 Major Problems with the Anti-Dumping Instrument in the European Community. Journal of World Trade, v. 39, n. 1, 2005.

VERMULST, Edwin; DRIESSEN, Bart. New Battles in the Anti-dumping War: recent movements on the European Front. Journal of World Trade, v. 31, n. 3, 1997.

VERMULST, Edwin; KOMURO, Norio. Anti-dumping disputes in the GATT/WTO: Navigating Dire Straits. Journal of World Trade. V. 31, n. 1, 1997. 
VERREYDT, Eric; WAELBROECK, Jean. European Community Protection against Manufactured Imports from Developing Countries: A case study in the political economy of protection. In Import, Competition and Response, Chicago: National Bureau of Economic Research, 1982.

VIEGAS, Isabel; JANK, Marcos; MIRANDA, Silvia. Barreiras não-tarifárias dos Estados Unidos e União Européia sobre as exportações agrícolas brasileiras. Informações Econômicas, v. 37, n. 3, março 2007.

VYBOLDINA, Elena. The Green Paper on Trade Defence Instruments: AntiDumping. Global Trade and Customs Journal, v. 2, i. 11, 2007.

WELLHAUSEN, Marc. The Community Interest Test in Antidumping Proceedings of the European Union. American University International Law Review, v. 16, 2001.

WELLHAUSEN, Marc. The Community Interest Test in Antidumping Proceedings of the European Union. American University International Law Review, v. 16.

WENIG, Harald. The European Community's Antidumping System: Salient Features. Journal of World Trade, v. 39, n. 4, 2005.

WILEZ Jr. John Shepard. After Chicago: na exaggerated demise? Duke Law Journal, n. 6, 1986.

WILKINSON, R. The WTO in Crisis. Exploring the Dimensions of Institutional Inertia. Journal of World Trade, v. 35, issue 3, 2001.

YU, Tian. The 10 Major Problems with the Anti-Dumping instrument in the People's Republic of China. Journal of World Trade, v. 39, n. 1, 2005.

\section{Documentos de negociação na OMC}

Access to non-confidential information: paper from the United States. TN/RL/GEN/90, 17 de novembro de 2005.

Access to non-confidential information: paper from the United States. TN/RL/GEN/90, 17 de novembro de 2005.

Amendments to the Anti-dumping Code - Submission by Canada. MTN.GNG/NG8/W/65, 22 dezembro de 1989.

Amendments to the Antidumping Code, Communication from the Delegation of Hong Kong, MTN. GNG/NG8/W51 12 September 1989. 
Anti-Dumping: illustrative major issues, TN/RL/W6, 26 de abril de 2002.

Comments by Jamaica on Proposals to the Negotiating Group on Rules discussed at the Group's Meeting on 26-30 September 2005. TN/RL/W/188, 10 de outubro de 2005.

Comments from Australia on Canada's submission on the antidumping agreement. (DOCUMENT TN/RL/W/47), TN/RL/W/62, 11 de fevereiro de 2003.

Comments on Document TN/RL/W/6 on Anti-Dumping Measures, Paper from Australia, TN/RL/W/22, 15 de outubro de 2002.

Draft Consolidated Chair Texts of the ADA and SCM Agreements TN/RL/W/213, 30 de novembro de 2007.

Drafting proposals of the Nordic Countries Regarding Amendments of the Antidumping Code. GATT Doc. N. MTN.GNG/NG8/2/76.(11 de abril de 1990).

Economic Effects of Anti-dumping Measures: paper from Hong Kong, China, and the Separate Customs Territory of Taiwan, Penghu, Kinmen e Matsu, TN/RL/GEN/142, 6 de junho de 2006.

Egyptian paper containing replies to questions posed by Australia in document number TN/RL/W/73, TN/RL/W/101, de 6 de maio de 2003.

Fourth set of questions from the United States on paper submitted to the Rules Negotiation Group, TN/RL/W/103, 6 de maio de 2003.

Further Explanation of the Public Interest Proposal: Paper from Hong Kong, China. TN/RL/W/194, 17 de novembro de 2005.

Further Submission on Public Interest: communication from Hong Kong, China, Israel, Japan, Korea, Norway, Switzerland, Separate Customs Territory of Taiwan, Penghu, Kinmen and Matsu and Thailand, TN/RL/GEN/53, 1 de julho de 2005.

General Contribution to Discussion of Negotiating Group on Rules on Antidumping Measures, Paper from Brazil, Chile, Colombia, Costa Rica, Hong Kong, China, Israel, Japan, Korea, Mexico, Norway, Singapore, Switzerland, Thailand and Turkey, TN/RL/W/28/Rev.1, 22 de novembro de 2002.

Illustrative Major Issues, Paper from Brazil, Chile, Colombia, Costa Rica, Hong Kong, China, Israel, Japan, Korea, Mexico, Norway, Singapore, Switzerland, Thailand and Turkey, TN/RL/W/6, 26 de abril de 2002.

Improved Disciplines under the Agreement on Subsidies and Countervailing Measures and the Anti-Dumping Agreement, TN/RL/W/1, 15 de abril de 2002. 
Lesser Duty Rule, Communication from Brazil, Chile, Colombia, Costa Rica, Hong Kong, China, Israel, Japan, Korea, Norway, Singapore, Switzerland, Taiwan, Penghu, Kinmen and Matsu and Thailand, TN/RL/W/224,12 de março de 2008.

Meetings of January 31 - February 2 and February 19-20, 1990, GATT Doc n. MTN.GNG/NG8/15, 19 de março de 1990.

Negotiating Group on Rules - Questions from the European Communities on Documents TN/RL/W/6 and TN/RL/W/10, TN/RL/W/20, 10 de outubro de 2002. Negotiating Group on Rules - Working Document from the Chairman, TN/RL/W232, 28 de maio de 2005.

Negotiating Group on Rules: note by the Chairman. TN/RL/W/143, 22 de agosto de 2003.

Preliminary comments and questions by the Arab Republic of Egypt on the contributions submitted in the framework of the Doha Negotiations on the antidumping agreement and on the agreement on subsidies and countervailing measures, TN/RL/W/79, 24 de março de 2003.

Principles and Purposes of Anti-dumping provisions: communication from the delegation of Hong Kong, MTN.GNG/NG8/W/46, 3 de julho de 1989.

Proposals on issues relating to the anti-dumping agreement: paper from South Africa. TN/RL/GEN/137, 29 de maio de 2006.

Proposed Elements for a Framework for Negotiation, principles and objectives for antidumping rules, communication for the delegation of Singapore, GATT Doc, $\mathrm{n}$. MTN, GNG/NG8/W/55, 13 de outubro de 1989.

Public Interest - Paper from Canada, TN/RL/GEN/85, 17 de novembro de 2005.

Public Interest: Communication from Colombia, Hong Kong, China, Israel, Japan, Norway, Singapore, Switzerland, the Separate Customs Territory of Taiwan, Penghu, Kinmen and Matsu, and Thailand. 12 de março de 2008.

Public Interest: paper from Chile, Costa Rica, Hong Kong, China, Israel, Japan, Korea, Norway, Switzerland, Separate Customs Territory of Taiwan, Penghu, Kinmen and Matsu and Thailand. TN/RL/W/174, 29 de março de 2005.

Questions from the European Communities on Documents TN/RL/W/6 AND TN/RL/W/10, de 10 de outubro de 2002.

Replies to questions to our first contribution (TN/RL/W/6), Paper from Brazil, Chile, Colombia, Costa Rica, Hong Kong, China, Israel, Japan, Korea, Norway, Singapore, Switzerland and Thailand, TN/RL/W/45, 27 de janeiro de 2003. 
Reply from Canada to Questions Posed by the United States in TN/RL/W/103, TN/RL/W/134, 14 de julho de 2003.

Responses by the Republic of Korea to Questions Raised by the European Commission, GATT Doc. N. ADP/W/287, de 17 de abril de 1991.

Second set of questions from the United States on papers submitted to the Rules Negotiation Group, TN/RL/W/34, 2 de dezembro de 2002.

Submission by the Republic of Korea on the Antidumping Code, Addendum, MTN. GNG/NG8/2/40/Add.2, 20 de dezembro 1989.

Submission from Canada respecting the Agreement on Implementation of Article VI of the GATT 1994 (The Antidumping Agreement), TN/RL/W/47, 28 de janeiro de 2003.

Submission from the European Communities concerning the Agreement on Implementation of Article VI of GATT 1994, TN/RL/W/13, 8 de julho de 2002.

Submission of Japan on the Amendments to the Antidumping Code, MTN.GNG/NG8/W/48/Add.1, 29 de janeiro de 1990.

Summary Report of the Meeting held on 11, 13 \& 16 April 2005, TN/RL/M/26, 11 de maio de 2005.

Summary Report of the Meeting Held on 8 and 10 July 2002, TN/RL/M/3, 1 de agosto de 2002.

Third set of questions from the United States on papers submitted to the Rules Negotiation Group, TN/RL/W/54, 6 de fevereiro de 2003.

Transparency on antidumping activity: submission from the European Communities. TN/RL/GEN/110, 20 de abril de 2006.

\section{Jurisprudência brasileira}

Escovas de cabelo. Processo MIDIC/SECEX 52500.012357/2006-38, Circular n. 62, de 14 de setembro de 2006, publicada no D.O.U em 15.09.2006.

Carbonato dissódico. Processo MDIC/SECEX 52100-000016/1996-11, Circular n. 23, de 29 de junho de 1998, publicada no D.O.U em 30.06.98.

Policloreto de vinila. Processo MDIC/SECEX RJ-52100.027088/2003-33, Resolução n. 18, de 29 de junho de 2005, publicada no D.O.U em 01.07.05.

Nitrato de amônio. Processo MDIC/SECEX/RJ 52500.017967/2007-78, Resolução n. 71, de 4 de novembro de 2008, publicada no D.O.U em 07.11.08. 
Cimento portland. Processo MDIC/SECEX 52500.007154/2005-16, Resolução CAMEX n. 36, de 22 de novembro de 2006, publicada no D.O.U em 27.11.06.

Pneus novos para bicicletas. Processo MDIC/SECEX 52100.085489/2002-27, Resolução CAMEX n. 37, de 11 de dezembro de 2003, publicada no D.O.U em 19.12.03.

Ferro cromo. Processo MDIC/SECEX 52100-017966/2003-11, Resolução CAMEX n 31, de 05 de outubro de 2004, publicada no D.O.U. de 11 de outubro de 2004.

Sadia/Perdigão, Conselho Administrativo de Defesa Econômica, Ato de Concentração n. 08012.003123/2001-64.

Petroquímica União, Conselho Administrativo de Defesa Econômica, Ato de Concentração n. 08012.014599/2007-16

\section{Jurisprudência européia}

\section{Comissão Européia}

Acido Sulfânico. Regulamento (EU) n. 1339/2002, de 22 de julho de 2002, J.O. L 196/11, 25.07.2002.

Aço Inoxidável. Decisão da Comissão n. 1732/97, de 4 de setembro de 1997, J.O. L 243/17.

Algodão. Regulamento (EU) n. 2208/96 de 18 de novembro de 1996. J.O. L 295 de 20.11.1996.

Balanças eletrônicas. Regulamento (CE) n. ${ }^{\circ} 692 / 2005$ do Conselho, de 28 de Abril de 2005, que altera o Regulamento (CE) n. ${ }^{\circ}$ 2605/2000 do Conselho, J.O. L 112 de 3.5.2005.

Bicicletas. Regulamento (EU) n. 1095/2005, de 12 de julho de 2005, J.O. L $183 / 1,14 / 07 / 2005$.

Bolsas de plástico ou de material têxtil. Regulamento (EU) n. 1.567/97, J.O. L 20/8 de 2 de agosto de 1997.

Bolsas originárias da China (bolsas de couro). Decisão da Comissão 209/97, de 3 de fevereiro de 1997 J.O. L 33/11.

Calçado com a parte superior de couro natural. Regulamento do Conselho n. 1472/2006, de 5 de outubro de 2006, J.O. L 275/1 de 6/10/2006. 
Calçados a parte superior em couro. Regulamento (EU) de 5 de outubro de 2006, J.O L 275/1 de 6 de outubro de 2006.

Carbonato de Bário. Regulamento (EU) n 1175/2005 de 18 de julho de 2005, J.O. L 189/15, 21/07/2005.

Carbonato dissódico (Soda ash). Regulamento (EU) n. 2.381/95, de 10 de outubro de 1995, J.O.. L 244/32.

Charmotas Refratárias. Decisão da Comissão 137/96 de 22 de janeiro de 1996, J.O. L 21/1.

Corda de Fibra Sintética. Decisão da Comissão n. 18/98, de 7 de janeiro de 1998, J.O. L $4 / 28$.

Discos Versáteis Digitais Regraváveis (DVD +/- R). Decisão da Comissão $\mathrm{n}$. 713/2006 de 20 de outubro de 2006, J.O. L. 293/07, 14/10/2006.

DRAMs. Regulamento (EU) n. 1480/2003, de 11 de agosto de 2003, J.O. L 21/2, 22/08/2003.

Escovas de cabelo. Decisão da Comissão 967/00, de 8 de maio de 2000, J.O. L $111 / 4$.

Ferro-silico-manganes. Decisão da Comissão n. 1778/97, de 12 de setembro de 1997 J.O. L 252/6.

Ferro-silicone. Decisão da Comissão de 21 de fevereiro de 2001, J.O. L 84, 23/03/2001.

Fósforos com fins publicitários. Regulamento 2025/97, de 15 de outubro de 1997, J.O. L 284/57, 16/10/1997.

Fotocopiadoras. Regulamento (CE) n. 535/87 do Conselho de 23 de fevereiro de 1987, J.O. L 54/12, 24.2.1987.

Glicina, Regulamento (CEE) n. 2322/85 do Conselho, de 12 de agosto de 1985, J.O. L 218/1.

Glifosato. Regulamento (EU) n. 1683/2004, de 24 de setembro de 2004, J.O. L 303/1, 30/09/2004.

Lâmpadas. Regulamento (EU) n 1470/2001, de 16 de julho de 2001, J.O. L 195/8 19/07/2001.

Mecanismos de argolas para encadernação. Decisão da Comissão n. 1456/96, de 25 de julho de 1996, J.O. L 187/47, 26/07/1996. 
Mercúrio. Regulamento CEE de 8 de dezembro de 1987, J.O. L 346, de 10/12/1987.

Motores elétricos multifásicos (moteurs électriques polyphasés normalisés d' une puissance de plus de 0,75 à 75 kilowatts inclus). Regulamento (CEE) n. 724/82 da Comissão de 30 de março de 1982, J.O. L 85/9, 31/03/1982.

Motores Propulsores (propulseurs spéciaux du type hors-bord). Regulamento (CEE) n. 1305/87 do Conselho de 11 de maio de 1987, J.O L 124/1, 13/05/1987.

Pallets de Madeira. Decisão da Comissão 1023/97, de 6 de junho de 1997, J.O. L 150/4. 06/06/1997.

Peças Vazadas (pièces de voirie). Regulamento (CE) n. 1212/2005 de 25 de julho de 2005, J.O. L 199/1, de 29/07/2005.

PSF (Fibras Sintéticas de Poliéster. Regulamento (EU) n . 428/2005 de 10 de março de 2005, J.O. L 71/1, 17/03/2005.

Resinas de Goma. Decisão da Comissão de 10 de janeiro de 1994, J.O. L 41/50, $12 / 02 / 1994$.

Roupa de cama. Regulamento (EU) n. 397/2004, of 2 março 2004, J.O. L 66/1, 4/03/2004.

Sapatos de couro. Regulamento (EU) n . 1472/2006, de 4 de outubro de 2006, J.O. L. 275/34 6/10/2006.

Sapatos de Segurança. Decisão da Comissão de 28 de agosto de 2006, J.O. L 234/33, 29/08/2006.

Sistemas de Leitura Ótica a Laser para carros (LORS). Regulamento (EU) n 1999/55. 21 de dezembro de 1998, J.O.. L18, 23/01/1999.

Uréia. Regulamento (CEE) n. 3339/87 do Conselho de 4 de novembro de 1987, J.O. L 317/1, 07/11/1987.

\section{Decisões judiciais na União Européia}

Béguilin Import v. S.A.G.L Export. Arrêt de la Cour du 25 novembre 1971, affaire $22-71$

Bureau Europeen des Unions de Consommateurs v. Commission. [1991] 170/89, E.C.R I-5709. 
Canon v. Council. Casos 277/85 e 300/85, Decisão de 5 de outubro de 1988.

Commission v Italy. Court of Justice of the European Communities. Case 184/85.

E.C.R. 2013, 1987.

Euroalliages et. al. v. Commission Case T-132/2001. [2003] ECR II - 2359 (90).

Euroalliages v. Commission. Judgment of the Court of First Instance [2003] T188/99.

Extramet Industry v. Council of the European Communities, N. C-358/89, Decisão de 11 de junho de 1992.

Gestetner Holdings v. Council and Commission [1990], C-156/87. I-00781.

Hellenic Republic v. Council and Commission [1987] Caso 129/86, ECR 1189.

Toyo Bearing Co. Ltd v EC Council. Caso 240/84 NTN, [1987] ECR 1809.

United Brands v. Commission of the European Communities. Court of Justice of the European Communities. Case 27/76, E.C.R 207, 1978.

\section{Jurisprudência OMC}

Brésil - Mesures visant l'importation de pneumatiques rechapés (Plaignant: Communautés européennes), WT/DS332/AB/R, 3 Decembre 2007.

Brésil - Programme de financement des exportations pour les aéronefs (Plaignant: Canada), WTO/DS46/ARB, 28 Août 2000.

Communautés européennes - Mesures affectant l'amiante et les produits en contenant (Plaignant: Canada), WT/DS135/AB/R, 12 Mars 2001.

Corée - Droits antidumping sur les importations de certains papiers en provenance d'Indonésie (Plaignant: Indonésie), WT/DS312/R, 28 Novembre 2005.

Corée - Mesures affectant les importations de viande de bœuf fraîche, réfrigérée et congelée (Plaignant: Etats-Unis), WT/DS161/AB/R, 31 Juillet 2000.

Corée - Taxes sur les boissons alcooliques (Plaignant: Communautés européennes), WT/DS75/R, 2 avril 1997.

Corée - Taxes sur les boissons alcooliques (Plaignant: Etats-Unis), WT/DS84/R, 17 septembre 1998. 
Etats-Unis - Enquête de la Commission du commerce international dans l'affaire concernant certains bois d'œuvre résineux en provenance du Canada (Plaignant: Canada), WT/DS277/AB/RW, 13 Avril 2006.

Etats-Unis - Mesures antidumping appliquées à certains produits en acier laminés à chaud en provenance du Japon (Plaignant: Japon), WT/DS184/AB/R, 19 Fevrier 2002.

Etats-Unis - Mesures visant la fourniture transfrontières de services de jeux et paris (Plaignant: Antigua-et-Barbuda), WT/DS285/AB/R, 30 Mars 2007.

Etats-Unis - Normes concernant l'essence nouvelle et ancienne formules (Plaignant: Brésil), WT/DS4/AB/R, 10 Avril 1995.

Etats-Unis — Loi antidumping de 1916 (Plaignant: Communautés européennes), WT/DS136/AB/R, 4 juin 1998.

Etats-Unis - Loi antidumping de 1916 (Plaignant: Japon), WT/DS162/AB/R, 10 février 1999.

Etats-Unis - Normes concernant l'essence nouvelle et ancienne formules (Plaignant: Venezuela)WT/DS2/AB /R, 26 Avril 1996.

Guatemala - Enquête antidumping concernant le ciment Portland en provenance $\mathrm{du}$ Mexique (Plaignant: Mexique),W/DS60/R e W/DS60/AB, 19 Juin et 2 Novembre 1998.

Japon - Mesures affectant les pellicules et papiers photographiques destinés aux consommateurs (Plaignant : États Unis), W/DS/44/R, 13 juin 1996.

Mexique - Enquête antidumping concernant le sirop de maïs à haute teneur en fructose en provenance des Etats-Unis (Plaignant: Etats-Unis), WT/DS132/R, 22 Juin 2001.

Mexique - Mesures visant les services de télécommunication (Plaignant: EtatsUnis), WT/DS204/4, 17 août 2000.

Thaïlande - Droits antidumping sur les profilés en fer ou en aciers non alliés et poutrelles profilées en $\mathrm{H}$ en provenance de Pologne (Plaignant: Pologne), WT/DS122/AB, 12 Mars 2001. 